UNIVERSIDADE DE SÃO PAULO

FACULDADE DE FILOSOFIA, LETRAS E CIÊNCIAS HUMANAS

DEPARTAMENTO DE GEOGRAFIA

PROGRAMA DE PÓS-GRADUAÇÃO EM GEOGRAFIA FÍSICA

THEREZA CHRISTINA COSTA MEDEIROS

Padrões de Campo Sujo Seco na paisagem da bacia hidrográfica do ribeirão Taquaruçu Grande no município de Palmas - TO

(Versão Corrigida) 
THEREZA CHRISTINA COSTA MEDEIROS

\section{Padrões de Campo Sujo Seco na paisagem da bacia hidrográfica do ribeirão Taquaruçu Grande no município de Palmas - TO}

Tese apresentada ao Programa de Pós-Graduação em Geografia Física, do Departamento de Geografia da Faculdade de Filosofia, Letras e Ciências Humanas da Universidade de São Paulo, para a obtenção do título de doutor em Geografia Física.

Área de Concentração: Geografia Física

Orientador: Prof. Dr. Yuri Tavares Rocha

São Paulo 
Autorizo a reprodução e divulgação total ou parcial deste trabalho, por qualquer meio convencional ou eletrônico, para fins de estudo e pesquisa, desde que citada a fonte.

Catalogação na Publicação

Serviço de Biblioteca e Documentação

Faculdade de Filosofia, Letras e Ciências Humanas da Universidade de São Paulo

M488p

Medeiros, Thereza Christina Costa

Padrões de Campo Sujo Seco na paisagem da bacia

hidrográfica do ribeirão Taquaruçu Grande no município de Palmas - TO / Thereza Christina Costa Medeiros ; orientador Yuri Tavares Rocha. - São Paulo, 2013. $268 \mathrm{f}$.

Tese (Doutorado)- Faculdade de Filosofia, Letras e Ciências Humanas da Universidade de São Paulo. Departamento de Geografia. Área de concentração: Geografia Física.

1. Campo Sujo. 2. Padrões florísticos e fitogeográficos. 3. Vellozia seubertiana. 4. Vochysia cinnamomea. 5. Byrsonima subterranea. I. Rocha, Yuri Tavares, orient. II. Título. 


\section{FOLHA DE APROVAÇÃO}

Thereza Christina Costa Medeiros

Padrões de Campo Sujo Seco na paisagem da bacia

hidrográfica do ribeirão Taquaruçu Grande no

município de Palmas - TO

Tese apresentada ao Programa de Pós-Graduação em

Geografia Física, do Departamento de Geografia da

Faculdade de Filosofia, Letras e Ciências Humanas da Universidade de São Paulo, para a obtenção do título de doutor em Geografia Física.

Aprovada em:

$$
\text { Banca Examinadora }
$$

Prof. Dr. __ Yuri Tavares Rocha

Instituição:

FFLCH - USP

Assinatura:

Prof. Dr. ___ Jose Bueno Conti

Instituição: FFLCH - USP

Assinatura:

Prof. Dra.__Fabiana de Gois Aquino

Instituição:__EMBRAPA/Cerrados

Assinatura:

Prof. Dr.__ José Roberto Rodrigues Pinto

Instituição:_Universidade de Brasília

Assinatura:

Prof. Dr._Ana Maria Marques Camargo Marangoni

Instituição: FFLCH - USP

Assinatura: 
Aos meus pais, Mário e Tereza,

e aos meus irmãos,

Emanuella Thereza

Marcelo

Nemésio

Maria Clotilde

$e$

Mário Júnior,

Dedico. 


\section{AGRADECIMENTOS}

Ao Professor Dr. Yuri Tavares Rocha, mestre e amigo, pela orientação, compreensão e confiança a mim depositada, ao longo da trajetória da realização desta tese.

Ao Curso de Doutorado em Geografia Física do Programa de Pós-Graduação em Geografia, do Instituto de Filosofia, Letras e Ciências Humanas (FFLCH) da Universidade de São Paulo (USP), pela oportunidade da realização da presente tese.

À Universidade Federal do Tocantins (UFT) e ao Colegiado de Geografia/Porto Nacional, pelo afastamento concedido para a realização do curso de doutorado.

Ao Conselho Nacional de Pesquisa e Tecnologia (CNPq), pelo apoio financeiro e concessão da bolsa de estudo.

À Direção do Campus de Porto Nacional (UFT), na pessoa da Professora Dra. Jucéia Aparecida V. Garbelini, pela valiosa contribuição na disponibilização de transporte no início das atividades de campo.

Ao Prof. Msc. Rodney Haulien Oliveira Viana Curador do Herbário HTO, do Núcleo de Estudos Ambientais (NEAMB)/UFT/Porto Nacional, e ao Wagner e Davi (técnicos do Herbário), pelo uso das instalações, estufa, e apoio no uso de exsicatas no processo de identificação de plantas e no tratamento e encaminhamentos do material botânico para especialistas.

Ao Professor Dr. Renato de Mello Silva Curador do Herbário SPF da Universidade de são Paulo pela determinação da espécie Vellozia seubertiana Goethart \& henrard.

À Dra.Maria Cândida Henrique Mamede Curadora do Herbário SP do Instituto de Botânica de São Paulo e ao Prof. Dr. Tarciso Filgeiras pelo recebimento de material botânico para determinação. 
Ao Professor, Dr. Everardo Valadares se Sá Barretto Sampaio da Universidade Federal de Pernambuco por esclarecimentos estatísticos.

Aos Professores Dr. Fernando de Moraes e Dr. Lucas Barbosa Coordenadores do Laboratório de Análise Geo-Ambiental, do Curso de Geografia (UFT/Proto Nacional) pelo uso de equipamentos.

Aos professores Dr. Sandro Sidinei Vargas de Cristo e Dr. Emerson Figueiredo Leite Coordenadores do Laboratório de Geoprocessamento, do Curso de Geografia (UFT/Porto Nacional) pelo uso de equipamentos e contribuições com os mapas.

Ao professor MSc. Maurício Alves da Silva Coordenador do Laboratório de Cartografia, do Curso de Geografia (UFT/Porto Nacional) pelo uso de equipamentos.

Ao Laboratório de Biogeografia do Departamento de Geografia (FFLCH/USP) pelo uso das instalações e equipamentos.

Ao Setor de Transporte da UFT/Porto Nacional, e aos motoristas Sr. José Florentino, Sr. Carlos e Sr. João, pela colaboração nos trabalhos de campo.

À todos da Secretaria da Pós-Graduação do Departamento de Geografia/FFLCH/USP.

Aos Proprietários das Fazendas: BR (área 1), Dom Emanuel (área 2), Brejo do Meio (área 3), do Senhor Maurício (área 4), e Estância Cantilenas (área 5), pela permissão do acesso às suas propriedades para realização do trabalhos de campo e fitossociológico.

Ao Leandro Alves da Silva (graduando do Curso de Ciências Biológicas da UFT/Porto Nacional), à Maria Oneide S. Bofim Caraíba (ex-aluna do Curso de Geografia Bacharelado da UFT/Porto Nacional) e Josenir Alves Ferreira de Souza (aluna do Curso de Geografia Bacharelado da UFT/Porto Nacional) pelas valiosas e imprescindíveis contribuições nas atividades de campo.

À minha família presente em todos os momentos da minha vida. 
Ao meu irmão Marcelo pelas contribuições diagramáticas.

Ao Ari Fonseca, pela calorosa acolhida e importante apoio à minha chegada em São Paulo para a realização do Curso.

À amiga Eliza Segvhenian e Família, pelo companheirismo, contribuições e apoio em São Paulo.

Aos amigos que estiveram presentes e me acompanharam nessa trajetória.

À Deus, todo poderoso, toda honra e toda glória. 
"A natureza é o reino da liberdade e para pintar vivamente as concepções e os prazeres que faz nascer um sentimento profundo da natureza é preciso que o pensamento possa se revestir livremente assim dessas formas e dessa elevação da linguagem, que são dignas da grandeza e da majestade da criação”. 


\section{RESUMO}

MEDEIROS, T. C. C. Padrões de Campo Sujo Seco na paisagem da bacia hidrográfica do ribeirão Taquaruçu Grande no município de Palmas (TO). 2013. 252 f. Tese (Doutorado). Faculdade de Filosofia, Letras e Ciências Humanas, Universidade de São Paulo, 2013.

O presente trabalho visou compreender os padrões florísticos e fitogeográficos de Campo Sujo Seco na bacia hidrográfica do ribeirão Taquaruçu Grande, no município de Palmas (TO). A análise de sua paisagem baseou-se na produção de mapas de vegetação; localização e medição da área de distribuição; caracterização fitossociológica e florística, buscando identificar padrões de Campo Sujo Seco; e, verificação da influência dos solos e do relevo na formação de tais padrões. O trabalho foi realizado em etapas de laboratório e campo. O mapeamento foi feito com base na carta da Diretoria do Serviço Geográfico (DSG) do Ministério do Exercito e IBGE de 1979 e imagens LANDSAT de 2011. Utilizou-se o software SPRING 5.1.8 (INPE). A caracterização pedológica foi feita por meio de delineamento em blocos casualizados, com aplicação do teste "T" e análise de variância com comparação das médias pelo teste de Tukey, usando o software Bio Estat 5.0. A caracterização da vegetação foi feita pelo método de parcelas e os parâmetros biométricos medidos foram diâmetro a altura do solo e altura de arbustos e árvores. Os parâmetros fitossociológicos analisados foram densidade, frequência, dominância absolutas e relativas e valor de importância específica. Foram calculados índices de similaridade de Sørensen, de diversidade de Shannon-Wiener e de uniformidade de Pielou. A análise de agrupamento entre áreas foi feita pela classificação UPGMA, pelo índice de Jaccard e e ordenação por Análise em Componentes Principais, utilizando-se o software Fitopac 2, e pelo método Twinspan, com o software WinTWIN. A paisagem da bacia do ribeirão Taquaruçu Grande é composta pelos geofácies Mata de Galeria, Mata Ciliar, Mata Seca, Cerradão, Cerrado Sentido Restrito, Babaçual, Vereda, Campo Sujo Seco, Campo Limpo Úmido, Campo Rupestre, Lago, ribeirões, córregos e brejos, Área Urbana e Agropecuária/Silvicultura. O Campo Sujo Seco teve uma área de 7.478,82 ha (16,2\% da bacia hidrográfica), localiza-se nos planaltos e chapadas da serra do Lageado e nas planícies secas da depressão do Tocantins. Os solos são do tipo Plintossolos Pétricos e se caracterizaram como bem drenados e com baixo teor de água, ácidos, distróficos, álicos com altos teores de ferro e de textura média. A flora pertence à divisão Magnoliophyta (angiospermas) é, predominantemente, da classe Magnoliopsida, com 39 famílias, 82 gêneros e 121 espécies. A densidade total foi de 2.761,47 indivíduos.ha ${ }^{-1}$; a dominância de $5,64 \mathrm{~m}^{2}$. ha ${ }^{-1}$; o diâmetro média de $4,61 \mathrm{~cm}$ e a altura média de $1,12 \mathrm{~m}$. Existe alta similaridade florística entre topo e encosta $(0,79)$ e alta diversidade alfa $(3,533$ nats.indivíduo ${ }^{-1}$ ). De acordo com a densidade de plantas, há padrões de campos sujos secos densos, típicos e ralos em relevos de topos e encostas. Pelos métodos de agrupamento UPGMA, Coordenadas Principais e Twinspan, há padrões florísicos representados, principalmente, pelas espécies Vochysia cinnamomea, Byrsonima subterranea e Vellozia seubertina. Os campos de $V$. cinnamomea localizam-se no sul da bacia, os de $B$. subterranea no norte e os de $V$. seubertiana no centro-norte, que constituíram os geótopos do geofácie Campo Sujo Seco. Existem padrões estruturais, florísticos e fitogeográficos diversos de campo sujo seco na bacia hidrográfica do ribeirão Taquaruçu Grande e as condições ambientais de relevo e edáficas tiveram influência na formação desses padrões.

Palavras-chave: Campo Sujo. Padrões florísticos e fitogeográficos. Vellozia seubertiana. Vochysia cinnamomea. Byrsonima subterranean. 


\section{ABSTRACT}

MEDEIROS, T. C. C. Field patterns in the landscape of Campo Sujo Seco River watershed Taquaruçu Grande in the municipality of Palmas (TO). 2013. $252 \mathrm{f}$. Tese (Doutorado). Faculdade de Filosofia, Letras e Ciências Humanas, Universidade de São Paulo, 2013.

The present work aimed to understand the patterns floristic and phytogeographical countryside of campo sujo in River watershed Taquaruçu Grande, municipality of Palmas (TO). The analysis of the landscape was based on the production of vegetation maps, location and measurement range; floristic and phytosociological characterization, seeking to identify patterns of Campo Sujo Seco; and check the influence of soils and relief in the formation of such patterns. The work was carried out in steps of laboratory and field. The mapping was done based on the letter from the Board of Geographic Service (DSG) of the Brazilian Army (EB) and IBGE 1979 and digital images were used LANDSAT 2011. The software used was the SPRING 5.1.8 (INPE). The pedological characterization was made by means of a randomized block design, with application of the " $t$ " test and analysis of variance for comparison of means by Tukey's test, using the software Bio Stat 5.0. The vegetation characterization was done by the method of plots and biophysical parameters measured were diameter at ground height and height of shrubs and trees. The phytosociological parameters analyzed were density, frequency, dominance of absolute and relative amount of specific importance. Sørensen's similarity indices were calculated, as well as the Shannon-Wiener Diversity Index and the Equitability of Pielou. Cluster analysis between areas was done by UPGMA classification, the Jaccard index and ranking by Principal Component Analysis, using the software Fitopac 2, and the method Twinspan with software WinTWIN. The landscape of the basin of the Taquaruçu Grande comprises the geofacies Gallery Forests, Riparian Forests, Dry Forests, Cerradão, Cerrado Sensu Stricto, Babaçual, Veredas, Campo Sujo Seco, Campo Limpo Úmido, Campo Rupestre, lake, creeks, streams and swamps, Urban area and Agricultural area. The Campo Sujo Seco with patches of cerrado sensu stricto had an area of $7.478,82$ ha $(16,2 \%$ of the watershed), located in the highlands and plateaus of the Serra do Lageado and the dry plains of depression Tocantins. Soils are the type Petric Plinthosols and were charactrized as well-drained, low water content, acidic, dystrophic, alic with high levels of iron and medium textured. The flora belongs to the division Magnoliophyta (angiosperms) is predominately class Magnoliopsida, with 39 families, 82 genera and 121 species. The total density was 2761.47 individuals.ha ${ }^{-1}$, the dominance of 5.64 $\mathrm{m}^{2}$. ha $\mathrm{h}^{-1}$, the mean diameter of $4.61 \mathrm{~cm}$ and height of $1.12 \mathrm{~m}$. There is high floristic similarity between top and slope (0.79) and high alpha diversity (3,533 nats.individual $\left.{ }^{-1}\right)$. According to the density of plants, there are patterns of Campo Sujo Seco dense and sparse typical reliefs on the tops and slopes. By cluster UPGMA, Principal Coordinates and Twinspan, there are florisics patterns represented mainly by species Vochysia cinnamomea, Byrsonima subterranea and Vellozia seubertina. The V. Cinnamomea fields located in the southern basin, the $B$. subterranean in the north and those of $V$. seubertiana in north-central, which constituted the geotopes the geofacie Campo Seco Seco. There are structural patterns, floristic and phytogeographical various Campo Sujo Seco in River watershed Taquaruçu Grande and environmental conditions of relevant and soil influenced the formation of these patterns.

Keywords: Campo sujo. Patterns floristic and phytogeographical. Vellozia seubertiana. Vochysia cinnamomea. Byrsonima subterrânea. 


\section{LISTA DE ILUSTRAÇÕES}

Figura 2.1 - Sub-regiões da região Neotropical: 1, Caribenha; 2, Amazônica, 3, Chaquenha; e 4, Paranaense (a); e as Províncias da sub-região Chaquenha: 1, Caatinga;

2, Cerrado; 3, Chaco; 4, Pampa; e 5, Monte (b). Fonte: Morrone (2001)...........................

Figura 2.2 - Mapa Fitogeográfico do Brasil, elaborado por Karl Friedrich Philipp von Martius, em 1858. Fonte: Henriques (2008)..................................................................

Figura 2.3 - Floresta Ombrófila Densa. Adaptado de Veloso et al. (1991)...................... 62

Figura 2.4 - Floresta Ombrófila Aberta (Faciação da Floresta Ombrófila Densa).

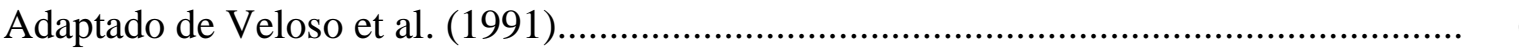

Figura 2.5 - Floresta Ombrófila Mista. Adaptado de Veloso et al. (1991)....................... 63

Figura 2.6 - Floresta Estacional Semidecidual. Adaptado de Veloso et al. (1991).......... 63

Figura 2.7 - Floresta Estacional Decidual. Adaptado de Veloso et al. (1991)................. 64

Figura 2.8 - Campinarana. Adaptado de Veloso et al. (1991).......................................... 64

Figura 2.9 - Savana. Adaptado de Veloso et al. (1991)..................................................... 64

Figura 2.10 - Savana Estépica. Adaptado de Veloso et al. (1991).................................... 65

Figura 2.11 - Estepe. Adaptado de Veloso et al. (1991).................................................... 66

Figura 2.12 - Formações Pioneiras. Adaptado de Veloso et al. (1991)............................ 66

Figura 2.13 - Domínios morfoclimáticos brasileiros. Fonte: Ab’ Saber, 2003................ 70

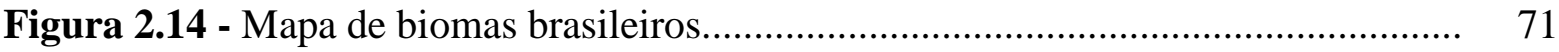

Figura 2.15 - Mapa da ecorregiões do Cerrado. Fonte: Arruda et al. (2008).................... 72

Figura 2.16 - Ecorregiões no Cerrado contínuo. Fonte: Pinheiro et al.

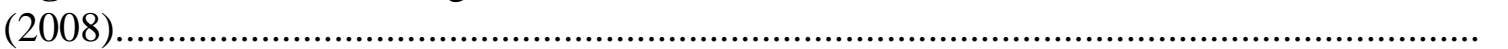

Figura 2.17 - Regiões fitoecológicas do Estado de Tocantins. Fonte: SEPLAN (2012).

Figura 3.1 - Localização da bacia hidrográfica do ribeirão Taquaruçu Grande no município de Palmas e no Estado do Tocantins. (Autores do Mapa:Thereza C. C. Medeiros e Adriano Dias Souza Andrade). 
Figura 3.2 - Diagrama climático para a estação meteorológica de Palmas - TO, segundo a metodologia proposta por Walter e Lieth (1967). Fonte: Instituto Nacional de Meteorologia (INMET), (Organização: T. C. C. Medeiros).

Figura 3.3 - Vista parcial da Serra do Lageado, município de Palmas (TO) (Fotografia por Y. T. Rocha, 2012).

Figura 3.4 - Demonstração da coleta de solo sob vegetação de Campo Sujo Seco, na bacia hidrográfica do ribeirão Taquaruçu Grande, Palmas - TO (Fotografias por: T. C. C. Medeiros, 2012)

Figura 3.5 - Pontos de amostragem fitossociológica e florística do geótopo Campo Sujo da bacia do ribeirão Taquaruçu Grande, Palmas (TO).

Figura 3.6 - Desenho esquemático da disposição das parcelas no relevo de topo e de vertente, no Campo Sujo Seco, na bacia hidrográfica do ribeirão Taquaruçu Grande, Palmas - TO.

Figura 3.7 - Demonstração de aspectos da amostragem da caracterização florísticoestrutural com a disposição das parcelas de $100 \mathrm{~m}^{2}$ e sub-parcelas de $1 \mathrm{~m}^{2}$ na posição mediana da vertente (a); sub-parcela de $1 \mathrm{~m}^{2}$ para caracterização do estrato herbáceosubarbustivo (b); medida de altura (c) e circunferência de base de plantas (d), da vegetação de Campo Sujo Seco, na bacia do ribeirão Taquaruçu Grande, Palmas - TO. Fotografia de T.C.C. Medeiros em 2011).

Figura 3.8 - Mata Ciliar representada em um diagrama de perfil (1) e cobertura arbórea (2) em uma faixa de $80 \mathrm{~m}$ de comprimento por $4 \mathrm{~m}$ de largura, nos períodos seco e chuvoso. Fonte: Ribeiro e Walter (2008).

Figura 3.9 - Mata de Galeria não inundável representada em um diagrama de perfil (1) e cobertura arbórea (2) em uma faixa de $80 \mathrm{~m}$ de comprimento por $10 \mathrm{~m}$ de largura. Fonte: Ribeiro e Walter (2008).

Figura 3.10 - Mata Seca representada em um diagrama de perfil (1) e cobertura arbórea (2) em uma faixa de $80 \mathrm{~m}$ de comprimento por $10 \mathrm{~m}$ de largura, em diferentes épocas chuvosa e seca, onde: $\mathrm{Ca}=$ cobertura arbórea; $\mathrm{A}=$ Mata Seca Sempre-Verde, B = Mata Seca Semidecídua, C = Mata Seca Decídua com afloramento de rocha. Fonte: Ribeiro e Walter (2008).

Figura 3.11 - Cerradão representado em um diagrama de perfil (1) e cobertura arbórea (2) em uma faixa de $40 \mathrm{~m}$ de comprimento por $10 \mathrm{~m}$ de largura. Fonte: Ribeiro e Walter (2008)

Figura 3.12 - Cerrado Denso (a), Típico (b) e Ralo (c) representado em um diagrama de perfil (1) e cobertura arbórea (2) em uma faixa de $40 \mathrm{~m}$ de comprimento por $10 \mathrm{~m}$ de largura. Fonte: Ribeiro e Walter (2008).

Figura 3.13 - Tipos de Palmeirais (Guerobal, Babaçual e Buritizal) representados em um diagrama de perfil (1) e cobertura arbórea (2) em uma faixa de $40 \mathrm{~m}$ de comprimento por $10 \mathrm{~m}$ de largura. Fonte: Ribeiro e Walter (2008). 
Figura 3.14 - Veredas representada em um diagrama de perfil (1) e cobertura arbórea (2) em uma faixa de $40 \mathrm{~m}$ de comprimento por $10 \mathrm{~m}$ de largura. Fonte: Ribeiro e Walter (2008)

Figura 3.15 - Campo Sujo representado em um diagrama de perfil (1) e cobertura arbórea (2) em uma faixa de $40 \mathrm{~m}$ de comprimento por $10 \mathrm{~m}$ de largura. Fonte: Ribeiro e Walter (2008).

Figura 3.16 - Campo Limpo representado em um diagrama de perfil (1) e cobertura arbórea (2) em uma faixa de $40 \mathrm{~m}$ de comprimento por $10 \mathrm{~m}$ de largura. Fonte: Ribeiro e Walter (2008).

Figura 3.17 - Campo Rupestre representado pelo diagrama de perfil (1) e cobertura arbórea (2) em uma faixa de $40 \mathrm{~m}$ de comprimento por $10 \mathrm{~m}$ de largura. Fonte: Ribeiro e Walter (2008).....

Figura 4.1 - Unidades da paisagem da bacia hidrográfica do ribeirão Taquaruçu Grande, Palmas - TO.

Figura 4.2 - Mapa da bacia hidrográfica do ribeirão Taquaruçu Grande, Palmas (TO), com base na Carta da DSG, de 1979.

Figura 4.3 - Figura 4.3 - Mapa da bacia hidrográfica do ribeirão Taquaruçu Grande, Palmas (TO), com base na Carta da Diretoria do Serviço Geográfico, Ministério do Exército e IBGE (1979)

Figura 4.4 - Figura 4.4 - Mapa da bacia hidrográfica do ribeirão Taquaruçu Grande, Palmas (TO), com base na Carta da Diretoria do Serviço Geográfico, Ministério do Exército e IBGE (1979) e imagem Landsat 2011

Figura 4.5 - Mapa Topográfico da bacia hidrográfica do ribeirão Taquaruçu Grande, Palmas (TO), com base na Carta da DSG, de 1979.

Figura 4.6 - Imagem mostrando o relevo com planícies, vales, encostas, cânions, chapadas e planaltos na bacia hidrográfica do ribeirão Taquaruçu Grande, Palmas - TO (Organização: T.C.C. Medeiros e S.S.V. de Cristo)

Figura 4.7 - Mapa de unidades de paisagem da bacia hidrográfica do ribeirão Taquaruçu Grande, Palmas - TO.

Figura 4.8 -Mata Ciliar no ribeirão Taquaruçuzinho, na bacia hidrográfica do ribeirão Taquaruçu Grande, Palmas (TO). Fonte: Projeto Taquaruçu. Disponível em: $<$ www.projetotaquarussu.com.br $>$ Acesso em 08 dez. 2013

Figura 4.9- Matas de Galeria do Brejo da Lagoa, na bacia hidrográfica do ribeirão Taquaruçu Grande, Palmas (TO). Fotografia: T. C. C. Medeiros, 2010.

Figura 4.10 - Matas de Galeria inundável do ribeirão Taquaruçuzinho, na bacia hidrográfica do ribeirão Taquaruçu Grande, Palmas (TO). Fotografia: T. C. C. Medeiros, 2010. 
Figura 4.11 - Mata Seca em vertentes à margem direita do córrego Mutum, na bacia hidrográfica do ribeirão Taquaruçu Grande, Palmas (TO). Fotografia: T. C. C. Medeiros, 2011

Figura 4.12 - Cerradão em área de chapada entre o vale do ribeirão Taquaruçuzinho e o ribeirão Taquaruçu Grande, na bacia hidrográfica do ribeirão Taquaruçu Grande, Palmas (TO). Fotografia por T. C. C. Medeiros, 2011.

Figura 4.13 - Cerrado Sentido Restrito em área de chapada entre o vale do ribeirão Taquaruçuzinho e o ribeirão Taquaruçu Grande, na bacia hidrográfica do ribeirão Taquaruçu Grande, Palmas (TO). Fotografia: T. C. C. Medeiros, 2011.

Figura 4.14 - Cerrado Rupestre, no vale do Vai Quem Quer, na bacia hidrográfica do ribeirão Taquaruçu Grande, Palmas (TO). Fotografia: T. C. C. Medeiros, 2011

Figura 4.15 - Vereda em área adjacente ao vale de tributário do córrego Mutum, na bacia hidrográfica do ribeirão Taquaruçu Grande, Palmas (TO). Fotografia por T. C. C. Medeiros, 2011

Figura 4.16 - Campo Sujo Seco em área de topo e encostas suavemente onduladas de chapadas, na bacia hidrográfica do ribeirão Taquaruçu Grande, Palmas (TO). Fotografia por T. C. C. Medeiros, 2011.

Figuras 4.17 - Fósseis de Crinóides em Campo Sujo Seco em chapada, na bacia hidrográfica do ribeirão Taquaruçu Grande, Palmas (TO). Fotografia por T. C. C. Medeiros, 2011.

Figura 4.18 - Campo limpo úmido em área de baixadas suavemente onduladas, na bacia hidrográfica do ribeirão Taquaruçu Grande, Palmas (TO). Fotografia por T. C. C. Medeiros, 2013.

Figura 4.19 - Campo Rupestre em vertente íngreme de morro à margem esquerda do Brejo da Lagoa, na bacia hidrográfica do ribeirão Taquaruçu Grande, Palmas (TO). Fotografia: T. C. C. Medeiros, 2011

Figura 4.20 - Babaçual em área de chapada entre o vale do ribeirão Taquaruçuzinho e o córrego Mutum, na bacia hidrográfica do ribeirão Taquaruçu Grande, Palmas (TO). Fotografia por T. C. C. Medeiros, 2011 .....

Figura 4.21 - Aspecto da área urbana da cidade de Palmas (Palácio dos Girassóis e Assembléia Legislativa), município de Palmas (TO). Fotografia: T. C. C. Medeiros, 2013

Figura 4.22 - Aspecto da área urbana do distrito de Taquaruçu, na bacia hidrográfica do ribeirão Taquaruçu Grande, município de Palmas (TO). Fotografia: T. C. C. Medeiros, 2013.

Figura 4.23 - Aspecto da área urbana de Palmas (TO), onde se observa fragmentos florestais e savânicos, na bacia hidrográfica do ribeirão Taquaruçu Grande, município de Palmas (TO). Fotografia: Google Earth, 2013. 
Figura 4.24 - Atividades Agropecuárias/Silvicultura como reflorestamento de Eucalyptus sp. (a), e desmatamento (b), na bacia do ribeirão Taquaruçu Grande, município de Palmas (TO). Fotografia: T. C. C. Medeiros, 2011/2013.

Figura 4.25 - Atividades Agropecuárias/Silvicultura, com aspectos da agricultura (a) e da pecuária (b), na bacia do ribeirão Taquaruçu Grande, município de Palmas (TO). Fotografia disponível em: 〈www.portalnorte.com.br $\rangle$; 〈www.memorialduke.com.br $\rangle$. Acesso em 08 dez. 2013.

Figura 4.26 - Lago e ribeirão Taquaruçuzinho, na bacia hidrográfica do ribeirão Taquaruçu Grande, município de Palmas (TO). Fotografia: T. C. C. Medeiros, 2013

Figura 4.27 - Cachoeira da Roncadeira, na borda de chapadão, no Brejo da Lagoa, na bacia hidrográfica do ribeirão Taquaruçu Grande, município de Palmas (TO). Fotografia: Y. T. Rocha, 2012

Figura 4.28 - Altitude dos Campos Sujos Secos em relevos de topo e vertente, na bacia hidrográfica do ribeirão Taquaruçu Grande, Palmas (TO).

Figura 4.29 - Aspectos da paisagem mostrando a variação de altitude de topos em relação a vertentes, em área de Campo Sujo Seco (A4), em planalto com relevo ondulado, na bacia hidrográfica do ribeirão Taquaruçu Grande, Palmas (TO).

Figura 4.30 - Aspectos do Plintossolo sob vegetação de Campo Sujo Seco em corte vertical de topo (a), em corte vertical em vertente (b), em superficie de topo (c) e em superfície de vertente (d), na bacia hidrográfica do ribeirão Taquaruçu Grande, Palmas (TO).

Figura 4.31 - Água presente no solo do Campo Sujo Seco nos meses de fevereiro (fev), março (mar), abril (abr), junho (jun) e agosto (ago) de 2013, em áreas de topo e vertente, na bacia hidrográfica do ribeirão Taquaruçu Grande, Palmas (TO)......

Figura 4.32 - Percentuais médios de água presente no solo do Campo Sujo Seco, relativos aos meses de fevereiro, março, abril, junho e agosto de 2013, em áreas de topo e vertente, na bacia hidrográfica do ribeirão Taquaruçu Grande, Palmas (TO)

Figura 4.33 - Relações entre teores de M.O. (\%) com CTC Total e CTC Efetiva $\left(\mathrm{cmol}_{\mathrm{C}} / \mathrm{dm}^{3}\right)$ em solos de Campo Sujo Seco, em 2012, na bacia hidrográfica do ribeirão Taquaruçu Grande, Palmas (TO)

Figura 4.34 - Síntese da sistemática da comunidade de plantas do campo sujo seco, da bacia hidrográfica do ribeirão Taquaruçu Grande, Palmas (TO).

Figura 4.35 - Formas de vida das espécies da comunidade de plantas do campo sujo seco, na bacia hidrográfica do ribeirão Taquaruçu Grande, Palmas (TO). 
Figura 4.36 - Distribuição do número de espécies, por famílias com $\geq 2$ espécies, da comunidade de plantas do campo sujo seco, na bacia hidrográfica do ribeirão Taquaruçu Grande, Palmas (TO).

Figura 4.37 - Número de espécies, gêneros e famílias de alguns estudos em áreas de campo sujo do Cerrado brasileiro e do campo sujo seco, na bacia hidrográfica do ribeirão Taquaruçu Grande, Palmas (TO).

Figura 4.38 - Distribuição do número de espécies, por famílias do estrato subarbustivo-arbustivo-arbóreo, da comunidade de plantas do campo sujo seco, na bacia hidrográfica do ribeirão Taquaruçu Grande, Palmas (TO).

Figura 4.39 - Distribuição do número de plantas, por espécie com $\geq 10$ indíviduos.ha $^{-}$ 1, no campo sujo seco, na bacia hidrográfica do ribeirão Taquaruçu Grande, Palmas (TO)

Figura 4.40 - Distribuição das espécies com índice de valor de importância (IVI) acima de 7\%, da comunidade de plantas do campo sujo seco (A1E; A1T; A2E; A2T; A3E; A3T; 4E; A4T; A5E; A5T), na bacia hidrográfica do ribeirão Taquaruçu Grande, Palmas (TO).

Figura 4.41 - Distribuição do número de espécies, por famílias do estrato subarbustivo-arbustivo-arbóreo, da comunidade de plantas do campo sujo seco (topo), na bacia hidrográfica do ribeirão Taquaruçu Grande, Palmas (TO)

Figura 4.42 - Distribuição do número de plantas, por espécie com $\geq 10$ indíviduos, no campo sujo seco, na bacia hidrográfica do ribeirão Taquaruçu Grande, Palmas (TO).....

Figura 4.43 - Distribuição das espécies com índice de valor de importância (IVI) acima de $7 \%$, da comunidade de plantas do campo sujo seco, na bacia hidrográfica do ribeirão Taquaruçu Grande, Palmas (TO)....

Figura 4.44 - Distribuição do número de espécies, por famílias do estrato subarbustivo-arbustivo-arbóreo, da comunidade de plantas do campo sujo seco (encosta), na bacia hidrográfica do ribeirão Taquaruçu Grande, Palmas (TO)

Figura 4.45 - Distribuição do número de plantas, por espécie com $\geq 10$ indíviduos, no campo sujo seco (encosta), na bacia hidrográfica do ribeirão Taquaruçu Grande, Palmas (TO)

Figura 4.46 - Distribuição das espécies com índice de valor de importância (IVI) acima de 7, da comunidade de plantas do campo sujo seco (A1E; A2E; A3E; A4E; A5E), na bacia hidrográfica do ribeirão Taquaruçu Grande, Palmas (TO)....

Figura 4.47 - Distribuição do número de espécies, por famílias do estrato hebáceosubarbustivo, da comunidade de plantas do campo sujo seco, na bacia hidrográfica do ribeirão Taquaruçu Grande, Palmas (TO). 
Figura 4.48 - Índice de cobertura do solo das espécies do estrato herbáceosubarbustivo do campo sujo seco, por áreas do topo (A1T; A2T; A3T; A4T; A5T), na bacia hidrográfica do ribeirão Taquaruçu Grande, Palmas (TO).

Figura 4.49 - Índice de cobertura do solo das espécies do estrato herbáceosubarbustivo do campo sujo seco, por áreas da encosta (A1E; A2E; A3E; A4E; A5E), na bacia hidrográfica do ribeirão Taquaruçu Grande, Palmas (TO).

Figura 4.50 - Dendograma de similaridade de Jaccard das comunidades de plantas do campo sujo seco, em cinco áreas de relevo de topo $(\mathrm{T})$ e encosta $(\mathrm{E})$, na bacia hidrográfica do ribeirão Taquaruçu Grande, Palmas (TO), com ligação dos grupos pela média não ponderada (UPGMA).

Figura 4.51 - Grupo 1 (área 3- topo e encosta), por número de indivíduos das espécies, das comunidades de plantas do campo sujo seco, na bacia hidrográfica do ribeirão Taquaruçu Grande, Palmas (TO).

Figura 4.52 - Grupo 1 (área 3 - encosta), com Vochysia cinnamomea, em campo sujo seco, na bacia hidrográfica do ribeirão Taquaruçu Grande, Palmas (TO). Fotografia por T.C.C. Medeiros (2012).

Figura 4.53 - Grupo 2 (área 1 - topo e encosta), por número de espécies, das comunidades de plantas do campo sujo seco, na bacia hidrográfica do ribeirão Taquaruçu Grande, Palmas (TO).

Figura 4.54 - Grupo 2 (área 1- topo), com Vellozia seubertiana, em campo sujo, na bacia hidrográfica do ribeirão Taquaruçu Grande, Palmas (TO). Fotografia por T.C.C. Medeiros (2012)

Figura 4.55 - Grupo 3 (área 5 - topo e encosta), por número de espécies, das comunidades de plantas do campo sujo seco, na bacia hidrográfica do ribeirão Taquaruçu Grande, Palmas (TO)

Figura 4.56 - Grupo 3 (área 5 - topo), com Byrsonima subterranea, em campo sujo seco, na bacia hidrográfica do ribeirão Taquaruçu Grande, Palmas (TO). Fotografia por T.C.C. Medeiros (2012).

Figura 4.57 - Grupo 4 (área 2 - topo), por número de plantas das comunidades do campo sujo seco, na bacia hidrográfica do ribeirão Taquaruçu Grande, Palmas (TO)....

Figura 4.58 - Grupo 4 (área 2 - topo), com V. seubertiana, S. comosa e outras espécies, em campo sujo seco, na bacia hidrográfica do ribeirão Taquaruçu Grande, Palmas (TO). Fotografia por T.C.C. Medeiros (2012).

Figura 4.59 - Grupos 5 (área 4 - topo) por número de plantas da comunidade do campo sujo seco, na bacia hidrográfica do ribeirão Taquaruçu Grande, Palmas (TO).... 
Figura 4.60 - Grupos 6 (área 5 - encosta), por número de plantas da comunidades do campo sujo seco, na bacia hidrográfica do ribeirão Taquaruçu Grande, Palmas (TO)...

Figura 4.61 - Grupos 5 (A - topo) e Grupo 6 (B - encosta) representados pela área 4, com Vellozia seubertiana, em campo sujo seco, na bacia hidrográfica do ribeirão Taquaruçu Grande, Palmas (TO). Fotografia por T.C.C. Medeiros (2012)

Figura 4.62 - Dendograma da classificação Twinspan (até o $4^{\circ}$ nível de divisão) das comunidades de plantas do campo sujo seco, na bacia hidrográfica do ribeirão Taquaruçu Grande, Palmas (TO)

Figura 4.63 - Análise de Coordenadas Principais (PCO) das comunidades de plantas do campo sujo seco, na bacia hidrográfica do ribeirão Taquaruçu Grande, Palmas (TO).

Figura 4.64 - Densidade de plantas registrada no Campo Sujo Seco, por área de topo (T) e de vertente (V), na bacia hidrográfica do ribeirão Taquaruçu Grande, Palmas (TO).

Figura 4.65 - Correlação entre grau de inclinação da encosta e número de espécie (número de espécies/ha), das comunidades de plantas do campo sujo seco, na bacia hidrográfica do ribeirão Taquaruçu Grande, Palmas (TO).

Figura 4.66 - Correlação entre grau de inclinação da encosta e número de indivíduos (número de ind./ha), das comunidades de plantas do campo sujo seco, na bacia hidrográfica do ribeirão Taquaruçu Grande, Palmas (TO)....

Figura 4.67 - Correlação entre grau de inclinação da encosta e dominância absoluta das espécies $\left(\mathrm{m}^{2} / \mathrm{ha}\right)$, das comunidades de plantas do campo sujo seco, na bacia hidrográfica do ribeirão Taquaruçu Grande, Palmas (TO)

Figura 4.68 - Correlação entre grau de inclinação da encosta e número de espécies herbáceas-subarbustivas, das comunidades de plantas do campo sujo seco, na bacia hidrográfica do ribeirão Taquaruçu Grande, Palmas (TO). 


\section{LISTA DE TABELAS}

Tabela 2.1 - Valores de áreas para tipos de formação vegetal para o Estado do Tocantins segundo fontes diferentes

Tabela 3.1 - Principais aplicações potenciais das bandas espectrais do Landsat 5 TM. Fonte: SANO (1987)

Tabela 3.2 - Coordenadas das áreas de amostragem no campo sujo da bacia hidrográfica do ribeirão Taquaruçu Grande, Palmas (TO).

Tabela 4.1 - Classificação da paisagem com base nos Geóopos na bacia hidrográfica do ribeirão Taquaruçu Grande, Palmas (TO), para o ano de 2011.

Tabela 4.2 - Índices das classes temáticas de diversos mapeamentos da paisagem da bacia hidrográfica do ribeirão Taquaruçu Grande, Palmas - TO

Tabela 4.3 - Água (\% de água/1 kg de solo) presente em solos do campo sujo seco, na bacia hidrográfica do ribeirão Taquaruçu Grande, Palmas (TO).

Tabela 4.4 - Teores médios de água (\% de água/1 kg de solo) presente em áreas de solos de Campo Sujo Seco, na bacia hidrográfica do ribeirão Taquaruçu Grande, Palmas (TO) ao longo do período de fevereiro a agosto de 2013.

Tabela 4.5 - Propriedades químicas do solo sob vegetação de Campo Sujo Seco, em área de topo (T) e de vertente (V), na bacia hidrográfica do ribeirão Taquaruçu Grande, Palmas (TO).

Tabela 4.6 - Teores médios de $\mathrm{Ca}\left(\mathrm{cmol}_{\mathrm{d}} / \mathrm{dm}^{3}\right)$, para áreas (blocos), em solos de Campo Sujo Seco, na bacia hidrográfica do ribeirão Taquaruçu Grande, Palmas (TO)

Tabela 4.7 - Teores médios de $\mathrm{Mg}\left(\mathrm{cmol}_{\mathrm{c}} / \mathrm{dm}^{3}\right)$, para áreas (blocos), em solos de Campo Sujo Seco, na bacia hidrográfica do ribeirão Taquaruçu Grande, Palmas (TO).

Tabela 4.8 - Teores médios de H+Al (\%), para áreas, em solos de Campo Sujo Seco, na bacia hidrográfica do ribeirão Taquaruçu Grande, Palmas (TO)

Tabela 4.9 - Teores médios de Saturação por Bases (V\%) para áreas (blocos), em solos de Campo Sujo Seco, na bacia hidrográfica do ribeirão Taquaruçu Grande, Palmas (TO)

Tabela 4.10 - Espécies vivas do campo sujo seco (A1E; A1T; A2E; A2T; A3E; A: A4E; A4T; A5E; A5T), na bacia hidrográfica do ribeirão Taquaruçu Grande, Palmas (T( com densidade absoluta (AbsDe); densidade relativa (RelDe); freqüência absoluta (AbsF frequência relativa (RelFr); dominância absoluta (AbsDo); dominância relativa (RelD em ordem decrescente de índice de valor de importância (IVI) 
Tabela 4.11 - Parâmetros fitossociológicos da comunidade subarbustiva-arbustivoarbórea do campo sujo seco, na bacia hidrográfica do ribeirão Taquaruçu Grande, Palmas (TO), com informações de densidade, dominância, diâmetro médio e altura média relacionados às parcelas de amostragem de topo e de encosta, com respectivos percentuais totais de plantas vivas e mortas.

Tabela 4.12 - Parâmetros fitossociológicos (densidade, área basal e altura média) para campo sujo de diversas localidades do Cerrado brasileiro e da bacia hidrográfiaca do ribeirão Taquaruçu Grande, Palmas (TO).

Tabela 4.13 - Espécies do campo sujo seco (topo), na bacia hidrográfica do ribeirão Taquaruçu Grande, Palmas (TO), com área de ocorrência, densidade absoluta (AbsDe); densidade relativa (RelDe); freqüência absoluta (AbsFr); frequência relativa (RelFr); dominância absoluta (AbsDo); dominância relativa (RelDo); em ordem decrescente de índice de valor de importância (IVI).

Tabela 4.14 - Número de famílias, gêneros e espécies, da comunidade de plantas do campo sujo seco, por área, na bacia hidrográfica do ribeirão Taquaruçu Grande, Palmas (TO).

Tabela 4.15 - Densidade absoluta (AbsDe), dominância absoluta (AbsDo), diâmetro (média) e altura (média) da comunidade de plantas do campo sujo seco, por área, na bacia hidrográfica do ribeirão Taquaruçu Grande, Palmas (TO).

Tabela 4.16 - Espécies do campo sujo seco (encosta), na bacia hidrográfica do ribeirão Taquaruçu Grande, Palmas (TO), com densidade absoluta (AbsDe); densidade relativa (RelDe); frequiência absoluta (AbsFr); frequência relativa (RelFr); dominância absoluta (AbsDo); dominância relativa (RelDo); em ordem decrescente de índice de valor de importância (IVI)

Tabela 4.17 - Número de famílias, gêneros e espécies, da comunidade de plantas do campo sujo seco, por área, na bacia hidrográfica do ribeirão Taquaruçu Grande, Palmas (TO).

Tabela 4.18 - Densidade absoluta (AbsDe), dominância absoluta (AbsDo), diâmetro (médio) e altura (média) da comunidade de plantas do campo sujo seco, por área, na bacia hidrográfica do ribeirão Taquaruçu Grande, Palmas (TO).

Tabela 4.19 - Espécies do campo sujo seco (topo e encosta), do estrato herbáceosubarbustivo, na bacia hidrográfica do ribeirão Taquaruçu Grande, Palmas (TO), em ordem alfabética, com respectivos índices de cobertura do solo

Tabela 4.20 - Diversidade de espécies pelo índice de Shannon-Wiener (H') e eqüitabilidade de Pielou (J'), em relevo de topo (A1T; A2T; A3T; A4T; A5T), e encosta (A1E; A2E; A3E; A4E; A5E), da comunidade de plantas do campo sujo seco, na bacia hidrográfica do ribeirão Taquaruçu Grande, Palmas (TO). 
Tabela 4.21 - Índices de diversidade de Shannon $\left(\mathrm{H}^{\prime}\right)$ nats.indivíduo ${ }^{-1}$ e eqüitabilidade de Pielou (J') em diversas fitofisionomias no campo sujo e no campo sujo seco da bacia hidrográfica do ribeirão Taquaruçu Grande, Palmas

Tabela 4.22 -Parâmetros fitossociológicos e de diversidade florística para o campo sujo seco (topo e encosta), na bacia hidrográfica do ribeirão Taquaruçu Grande, Palmas (TO). 


\section{LISTA DE QUADROS}

Quadro 2.1 - Sistema de classificação de fitogeografia brasileira de Lima (1966).

Quadro 2.2 - Sistema de classificação de Veloso (1966)

Quadro 2.3 - Classificação fitogeográfica do Projeto Radambrasil (BRASIL, 1981)

Quadro 3.1 - Síntese dos procedimentos técnicos e metodológicos da pesquisa......

Quadro 3.1 - Esquematização da análise sintética da paisagem segundo Bertrand (2004).

Quadro 4.1 - Unidades da paisagem e respectivas categorias da bacia do ribeirão Taquaruçu Grande, Palmas (TO).

Quadro 4.2 - Florística da comunidade de plantas do campo sujo seco, na bacia hidrográfica do ribeirão Taquaruçu Grande, Palmas (TO), com espécies da classe Magnoliopsida, segundo a ordem, família, gênero, ambiente de ocorrência e distribuição geográfica.

Quadro 4.3 - Florística da comunidade de plantas do campo sujo seco, na bacia hidrográfica do ribeirão Taquaruçu Grande, Palmas (TO), com espécies da classe Liliopsida, segundo a ordem, família, gênero, ambiente de ocorrência e distribuição geográfica..

Quadro 4.4 - Espécies da comunidade de plantas do campo sujo seco (topo e encosta), na bacia hidrográfica do ribeirão Taquaruçu Grande, Palmas (TO), com formas de vida (Fan = Fanerófitas; Hem = Hemicriptófitas; Cam = Caméfitas; Ter $=$ Terófitas; Geo $=$ Geófitas.

Quadro 4.5 - Espécies preferenciais e não preferenciais das divisões estabelecidadas pelo método Twinspan, das comunidades de plantas do campo sujo seco, na bacia hidrográfica do ribeirão Taquaruçu Grande, Palmas (TO)...................

Quadro 4.6 - Similaridade florística entre campos sujos de várias localidades do Cerrado e o campo sujo seco da bacia hidrográfica do ribeirão Taquaruçu Grande, Palmas (TO).

Quadro 4.7 - Distribuição de espécies no topo em grupos de predominância baixa, média, alta, e exclusivas, de acordo com a sua respectiva densidade em relevo de topo ou encosta no campo sujo seco, na bacia hidrográfica do ribeirão Taquaruçu Grande, Palmas (TO)

Quadro 4.8 - Distribuição de espécies na encosta em grupos de predominância baixa, média, alta, e exclusivas, de acordo com a sua respectiva densidade em relevo de topo ou encosta no campo sujo seco, na bacia hidrográfica do ribeirão Taquaruçu Grande, Palmas (TO). 


\section{SUMÁRIO}

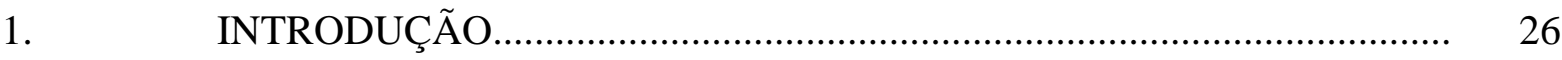

2. FUNDAMENTAÇÃO TEÓRICA......................................................... 30

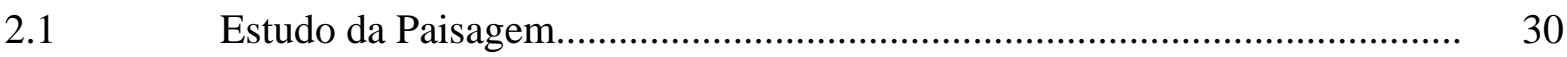

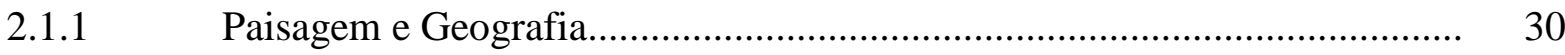

2.1.2 Ecologia da Paisagem e a Abordagem Sistêmica na Geografia .................. 39

2.2 Sistemática Fitogeográfica e o Cerrado...................................................... 44

2.2.1 Fitogeografia Mundial e da América Latina............................................. 44

2.2.2 Fitogeografia Brasileira............................................................... 51

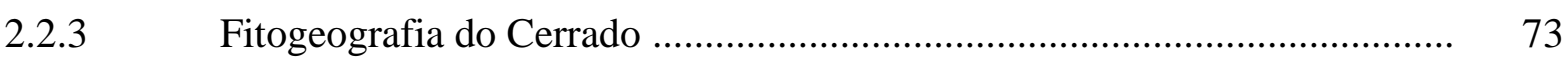

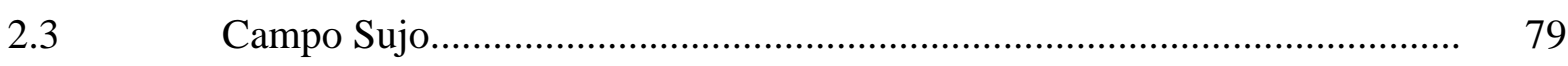

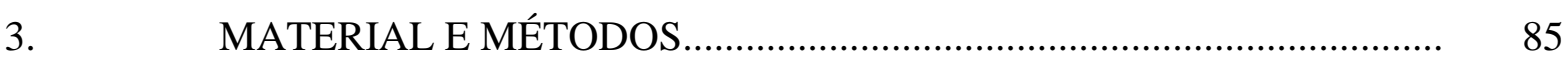

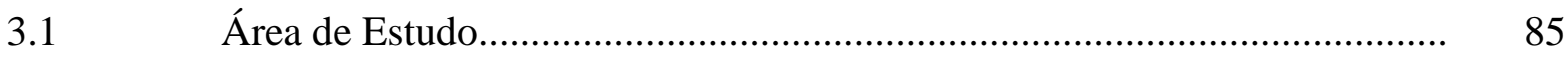

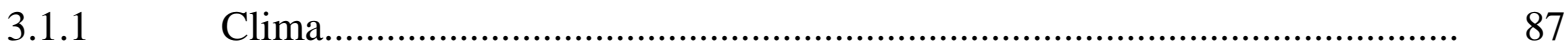

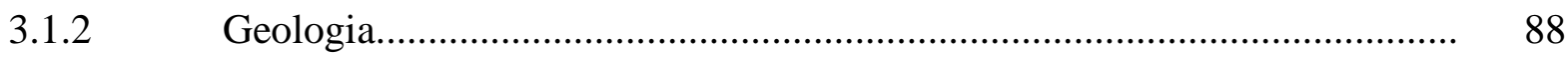

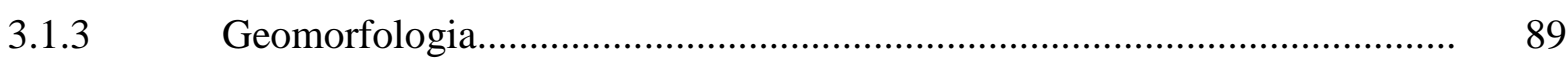

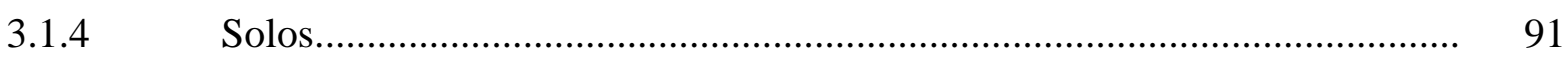

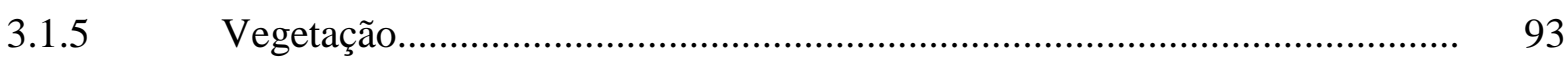

Procedimentos Metodológicos............................................................... 95

3.2.1 3.2.1. Primeira Etapa: Levantamento, Produção e Processamento de 95

3.2.1.1 Levantamentos bibliográfico, cartográfico e de imagens de sensores 95

3.2.1.2 Levantamento, produção e processamento de dados.................................. 96

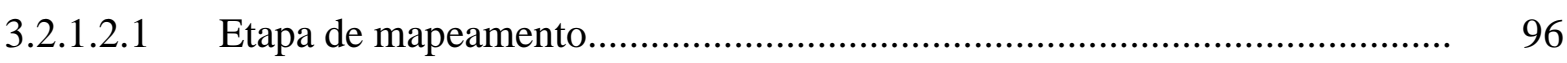

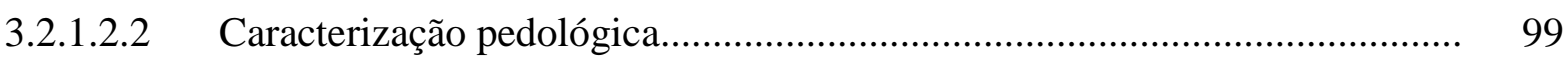

3.2.1.2.3 Caracterização da vegetação...................................................................... 101

3.2.1.2.4 Análise da Paisagem......................................................................... 108

3.2.1.2.4.1 Caracterização dos Geofácies................................................................ 110

S.3 Segunda Etapa: Correlações das Informações ......................................... 119

3.4 Terceira Etapa: Análise e Interpretação das Variáveis que Estruturam a 119

3.5 Quarta Etapa: Concepção da Evolução da Paisagem..................................... 119 
4.1 Análise sintética da paisagem da bacia do ribeirão Taquaruçu Grande,

Palmas (TO).

Altitude 156

4.2.1.2

Relevo.

4.2.1.3.2 Atributos químicos do solo

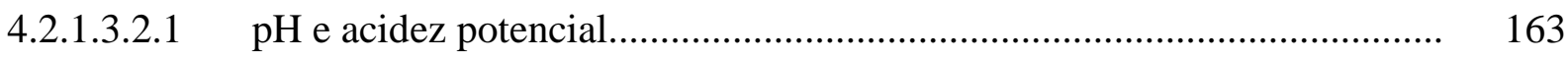

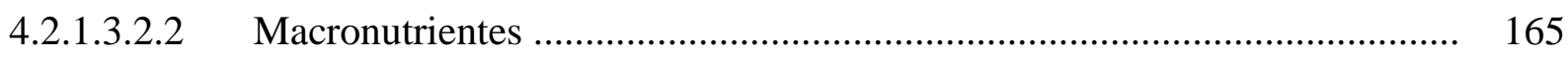

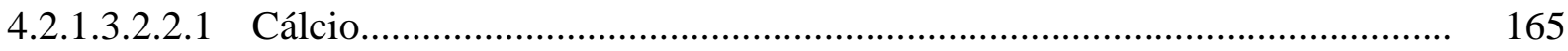

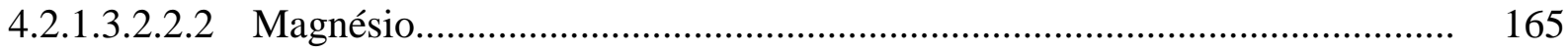

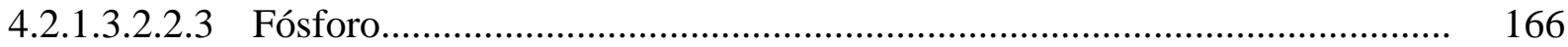

4.2.1.3.2.2.4 Potássio .......................................................................................... 167

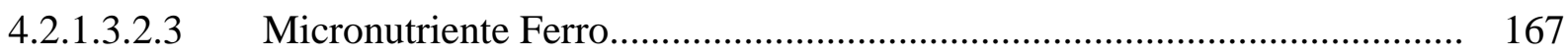

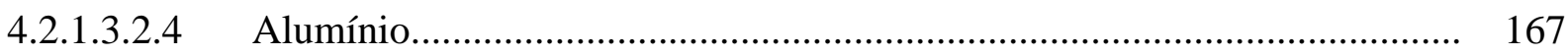

4.2.1.3.2.5 Matéria Orgânica.................................................................................. 168

4.2.1.3.2.6 Capacidade de Troca Catiônica ................................................................. 168

4.2.1.3.2.7 Saturação por Bases............................................................................. 171

4.2.1.3.3 Atributos físicos do solo......................................................................... 172

4.2.1.3.4 Caracterização geral dos solos............................................................ 173

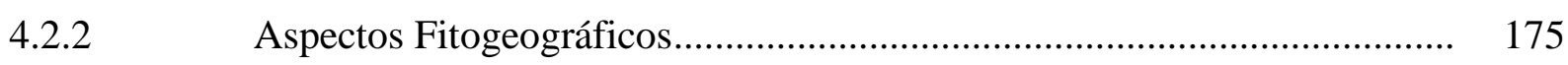

4.2.2.1 Sistemática e distribuição geográfica ................................................... 175

4.2.2.3 Formas de vida vegetal.................................................................. 190

4.2.2.3 Florística e fitossociologia................................................................... 195

4.2.2.3.1 Estrato subarbustivo-arbustivo-arbóreo do Campo Sujo Seco.................... 197

4.2.2.3.1.1 Estrato subarbustiva-arbustivo-arbórea do Campo Sujo Seco: topo........... 204

4.2.2.3.1.2 Estrato subarbustivo-arbustivo-arbóreo do Campo Sujo Seco: encosta...... 209

4.2.2.3.2 Estrato herbáceo-subarbustivo do Campo Sujo Seco................................ 213

4.2.2.3.3 Diversidade e similaridade florística do Campo Sujo Seco........................ 218

4.2.2.3.3.1 Índice de Diversidade de Shannon-Wiener............................................. 218 
4.2.2.3.3.2 Análise de Agrupamento ................................................................... 219

4.2.2.3.3.3 Análise de Ordenação...................................................................... 235

4.2.2.3.3.4 Análise de variações estruturais......................................................... 236

4.2.2.3.3.5 Similaridade florística com outros campos sujos................................. 237

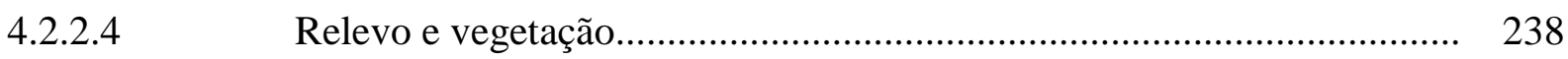

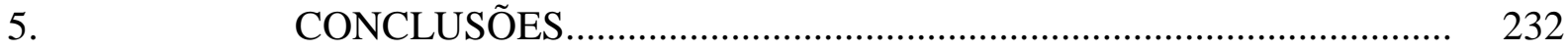

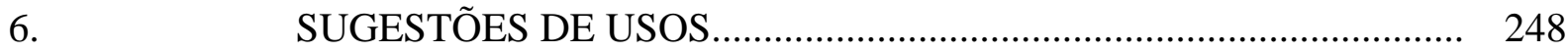

7. REFERÊNCIAS BIBLIOGRÁFICAS ........................................... 251 


\section{INTRODUÇÃO}

O Cerrado está localizado na região do Brasil Central e ocupava desde aproximadamente seis mil anos até o presente uma área com cerca de $2.000 .000 \mathrm{~km}^{2}$ (MACHADO et al., 2004). È considerado um domínio muito antigo, pois edafologicamente os solos do Planalto Central estão entre os mais velhos do mundo e sendo intemperizados desde o Cretáceo, há 100 milhões de anos (GOODLAND, 1971). Segundo Ab’ Saber (1971), a vegetação dos cerrados se adaptou e se desenvolveu em algum momento do Quaternário (ou mesmo nos fins do Terciário) e esta estrutura de paisagens, de planaltos interiorizados, dotados de solos lateríticos, é certamente um dos quadros de vegetação mais arcaicos do país.

Levando em consideração o tempo geológico e evolutivo, as dimensões do domínio do Cerrado modificaram-se refletindo as pulsações climáticas em nosso planeta (AB`SABER, 2003). Atualmente, a ampla ocorrência do Cerrado no território central brasileiro, estendendose de $5^{\circ}$ a $20^{\circ}$ de latitude Sul e de $45^{\circ}$ a $60^{\circ}$ de longitude Oeste (ALHO; MARTINS, 1995), em altitudes variadas, ocupando diferentes bacias hidrográficas (Amazonas, Tocantins, Paraná, Paraguai, São Francisco e Parnaíba) e exibindo grande diversidade de solos e climas, levam a uma diversificada biota (FELFILI et al., 2007). Há um consenso entre os estudiosos que essa biodiversidade constitui padrões fitogeográficos que integram formações florestais, savânicas e campestres (EITEN 1994; RIBEIRO; WALTER, 1998; 2008; WALTER, 2006).

O Cerrado é considerado o representante do bioma das savanas de maior biodiversidade e estudos realizados por Machado et al. (2004), Sano (2007) e MMA/IBAMA (2011) têm demonstrado a redução da sua área, fato que resulta em ameaças à biodiversidade. Tal situação colocou o Cerrado entre as áreas prioritárias para conservação, fazendo parte do hotspot de biodiversidade do mundo (MYERS et al., 2002, SILVA; BATES, 2002). Embora seja o segundo maior bioma da América do Sul, o Cerrado possui a menor porcentagem de áreas com proteção integral. Atualmente, apenas 8,21\% do Cerrado estão protegidos pelas unidades de conservação, uma das razões que fazem do Cerrado o bioma brasileiro que mais sofreu alterações com a ação humana ${ }^{1}$. Nestes anos de fragmentação e degradação das formações naturais, foram poupadas apenas as regiões serranas, por serem impróprias para práticas agrícolas. Dentre os territórios desmatados que se destacaram nos mapeamentos

\footnotetext{
${ }^{1}$ Disponível em: http://www.icmbio.gov.br/portal/biodiversidade/unidades-de-conservacao/biomas-brasileiros/cerrado.html . Acesso em 20 nov. 2013.
} 
realizados por Machado et al. (2004), Sano (2007) e MMA/IBAMA (2011) está o Estado do Tocantins. Porém, a bacia hidrográfica do ribeirão Taquaruçu Grande, município de Palmas, por abranger a região dos planaltos residuais do Tocantins (serra do Lageado), ainda tem fragmentos preservados de Cerrado nas regiões serranas.

As informações sobre vegetação no Estado do Tocantins têm sido produzidas, principalmente, em macroescala com a delimitação de unidades fitogeográficas e diferentes padrões de riqueza de espécies que apontam para uma diferenciação entre as florestas tocantinenses, podendo-se citar SEPLAN (2012) e Haidar et al. (2013).

Verifica-se que há poucas informações básicas como, por exemplo, a composição florística e a estrutura dos estratos herbáceo, arbustivo e arbóreo que compõem as formações savânicas e campestres. Estas informações florísticas e estruturais, assim como dados sobre a riqueza de espécies, refletem não só fatores evolutivos e biogeográficos, como também o histórico de perturbação natural ou antrópica (GENTRY, 1992; HUBBELL; FOSTER, 1986).

No âmbito do Cerrado, ainda são poucos os trabalhos que vêm sendo desenvolvidos com o objetivo de compreender melhor a sua estrutura, florística e funcionamento e estes têm se concentrado na região do Distrito Federal e têm enfocado especialmente duas fitofisionomias, o Cerrado e o Cerrado Sentido Restrito (CASTRO, 1987; CASTRO, 1994; CASTRO et al., 1999; MANTOVANI; MARTINS, 1993; DURIGAM et al., 1994; BATALHA et al., 1997; BATALHA; MANTOVANI, 2001; BRANDO; SAPARETTI, 2003; DURIGAN, 2004; ASSUNÇÃO; FELFILI, 2004; FONSECA; SILVA JÚNIOR, 2004; AMARALet al., 2006; LÍBANO; FELFILI, 2006; MIRANDA et al., 2006; ROSSATO et al., 2008; PINTO et al., 2009).

No Estado do Tocantins, estudos que focalizam o campo sujo, uma das fitofisionomias do Cerrado, são inexistentes. Considerando outros aspectos, a bacia do ribeirão Taquaruçu Grande, no município de Palmas (TO), algumas pesquisas já foram realizadas:

- Camargo (2005) estudou a aplicação de indicadores perceptivos para análise das paisagens cênicas do trajeto entre o distrito de Taquaruçu, Polo Ecoturístico deste Município;

- Souza (2006) realizou estudos a respeito da dinâmica da paisagem na bacia do ribeirão Taquaruçu Grande, mapeando o uso e a cobertura vegetal para construir os cenários ambientais tendenciais e normativos;

- Guarda (2006) pesquisou a expansão urbana do entorno do lago do reservatório da usina hidrelétrica Luís Eduardo Magalhães, também localizado no município de Palmas, nos anos 
de 1990, 1993, 1999, 2002 e 2005, fazendo um acompanhamento por dados de sensoriamento remoto do LANDSAT e CBERS;

- Gama Junior (2008) pesquisou os braquiópodes da Formação Pimenteiras (Devoniano Médio/Superior), na região sudoeste da bacia sedimentar do Parnaíba, no também em Palmas; - Martins e Martins (2008) estudaram a quantificação e qualificação dos problemas ambientais por atores sociais na bacia do ribeirão Taquaruçu Grande;

- Milagres (2009) pesquisou a percepção da paisagem por parte da comunidade local do distrito de Taquaruçu, no que se refere às paisagens mais agradáveis e desagradáveis com finalidades turísticas;

- Marques (2011) fez uma avaliação da qualidade da água da bacia do ribeirão Taquaruçu Grande e da área de sua influência no reservatório da Usina Hidroelétrica Luis Eduardo Magalhães, no médio curso do rio Tocantins.

- Ferreira (2011) em estudo a respeito do planejamento sistemático das unidades de conservação do Estado do Tocantins apontou dentre as áreas de maior diversidade e relevância para a conservação, a porção central do rio Tocantins, que inclui o Parque Estadual do Lageado e a parte da Área de Proteção Ambiental da Serra do Lageado, que está ao sul do referido Parque, dentro da bacia hidrográfica do ribeirão Taquaruçu Grande, é destacada.

- e Martins e Monteiro (2013) investigaram o uso de geotecnologia para análise de fragmentação do cerrado na paisagem da bacia do ribeirão Taquaruçu Grande.

Apesar dos estudos realizados que trabalharam a paisagem na referida bacia hidrográfica, estes trataram enfaticamente das ações antrópicas como fator de redução das áreas de Cerrado pela degradação e ocupação com fins diversos, e não há um foco relacionado à fitogeografia.

A bacia hidrográfica do ribeirão Taquaruçu Grande no município de Palmas constituise uma unidade importante de pesquisa por ser, em área geográfica, a maior bacia do município, sendo responsável por $65 \%$ do seu abastecimento público de água e abrigar uns dos últimos remanescentes do Cerrado do Tocantins, além de possuir um papel importante no ecoturismo do Estado.

Tendo em vista tais aspectos, levantaram-se as seguintes hipóteses:

1- A bacia hidrográfica do ribeirão Taquaruçu Grande apresenta uma diversidade de fitofisionomias do Cerrado.

2- Os Campos Sujos Secos localizam-se nos topos nos planaltos. 
3- O solo e o relevo são fatores ambientais que influenciam a diversidade dos tipos de Campo Sujo.

4- Existe mais de um tipo de campo sujo.

5- A composição e a diversidade florística, são os fatores de diferenciação entre tipos de campos sujos.

Assim, o presente estudo objetivou analisar a paisagem e o geofácie Campo Sujo Seco, verificar a influência dos solos e do relevo em relação a este geofácie com o intuito de compreender a fitogeografia e os padrões de Campo Sujo Seco, na bacia hidrográfica do ribeirão Taquaruçu Grande, no município de Palmas (TO). 


\section{FUNDAMENTAÇÃO TEÓRICA}

\subsection{Estudo da Paisagem}

\subsubsection{Paisagem e Geografia}

O termo paisagem, nas línguas latinas, é derivado do termo pagus, que significa país, traduzindo o sentido de lugar e unidade territorial, do qual derivou várias formas: paisaje (castellano), paysage (francês), paesaggio (italiano). Nas línguas germânica, landschaft, inglesa, landscape (BOLÓS I CAPDEVILA, 1992) e portuguesa, paisagem, também derivam do latim.

A paisagem corresponde ao material clássico de estudo do geógrafo e é fundamental na Geografia. Qualquer parte da superfície terrestre constitui uma paisagem (DELPOX, 1974). Pelo fato da geografia consistir em localizar fatos, ou apreender as diferenças do espaço terrestre e em comparar conjuntos desvendando seu dinamismo interno e suas relações recíprocas, além de estudar paisagens morfológicas, vegetais, agrárias, urbanas, etc., a geografia está no âmago da ciência da paisagem (ROUGERIE, 1969). Na história da paisagem na geografia, podem ser identificadas quatro principais escolas: Alemã, RussoSoviética, Anglo-Saxônica e Francesa.

Escola Alemã

Tem como um dos primeiros contribuidores A. Hommeyerem, que introduziu o conceito de paisagem na Geografia, no século XIX, mediante a forma landschaft, significando o conjunto de elementos observáveis desde um ponto alto, podendo esta ser classificada como paisagem morfológica, de vegetação, agrária, urbana, cultural, etc. (BÓLOS I CAPDEVILA, 1992). A ciência da paisagem é uma realidade antiga e foi criada a partir dos relatos de viajantes e exploradores cientistas do século XVIII, em especial Alexander Von Humboldt, ao qual é atribuído, no âmbito científico, o emprego do termo paisagem no início do século XIX (BÓLOS I CAPDEVILA, 1992). Humboldt apresentou, de forma coerente, a estrutura da superfície terrestre em suas duas obras consideradas fundamentais: Viaje a las regiones equinocciales del Nuevo Mundo e El Cosmos (BÓLOS I CAPDEVILA, 1992; BERNALDEZ, 1981). Nesse sentido, Humboldt é considerado o fundador da Geografia moderna pelo pioneirismo do estudo da natureza sob a ótica geográfica, valorizando os princípios da 
causalidade e da comparação, enfatizando a ideia de paisagem por uma concepção holística (CONTI, 1998).

$\mathrm{Na}$ segunda metade do século XIX e na primeira metade do século XX, são estabelecidas a concepção científica e a maior parte das bases teóricas da ciência da paisagem. A ideia de unidade e complexidade da superfície terrestre de interconexão das três esferas: atmosfera, litosfera e hidrosfera, gerando a quarta esfera, a biosfera, lançada por Humboldt, tem continuidade com seus discípulos (BÓLOS I CAPDEVILA, 1992).

Outra figura de destaque é Siegfried Passarge pelos seus estudos na África, sendo o primeiro autor que dedicou um livro à paisagem, dando origem a uma ciência que no início se considerou um ramo da Geografia e que recebeu o nome de "Geografia da paisagem". Carl Troll, por sua vez, teve uma importância ligada ao conceito de paisagem vinculada à ecologia; foi quem definiu "ecotopo" como a extensão do conceito de "biótopo", desenhando, dessa maneira, o futuro conceito de geossistema (BÓLOS I CAPDEVILA, 1992). A expressão paisagem ecológica ou ecologia da paisagem foi introduzida por ele (ODUM; BARRET, 2011), no fim da década de 1930, quando observou que todos os métodos de ciência natural estão aprisionados na área da ciência da paisagem, definindo a ecologia da paisagem de acordo com o conceito de ecossistema de Tansley, em 1935: “A ecologia da paisagem é o estudo do complexo inteiro da rede de causa-efeito entre as comunidades vivas e suas condições ambientais que predominam em um setor da paisagem" (ODUM; BARRET, 2011, p. 375). Posteriormente, a ecologia da paisagem foi denominada "Geoecologia" por Carl Troll (BÓLOS I CAPDEVILA, 1992).

Segundo Boesch e Carol (1956), os geógrafos alemães utilizavam a palavra Landschaf ou paisagem para designar o objetivo da geografia. Para esses autores, Hettner, geógrafo alemão utilizou o termo paisagem na concepção de "partes do mundo, países, paisagens e localidades" para uma unidade de caráter específico. Na década de 1950, a maioria dos geógrafos alemães entendia como paisagem as áreas homogêneas definidas, mormente regiões naturais (BOESCH; CAROL, 1968).

Na década de 1920, foram lançadas as bases da Teoria Geral de Sistemas pelo biólogo alemão Ludwig Von Bertalanffy e o conceito de "sistemas" invadiu todos os campos da ciência e, desde então, tem penetrado no pensamento e na fala populares e nos meios de comunicação de massas (BERTALANFFY, 2003). Portanto, na Alemanha surgiram as primeiras ideias a cerca da paisagem do ponto de vista científico, a partir do século XIX e início do século XX. 
Na escola alemã, seguindo a linha da globalidade da paisagem, também se destacou J. Schmithüsen, orientando seu trabalho para os aspectos dinâmicos da paisagem. Ele se propôs a distinguir entre os conceitos de paisagem (Landschaft) e região (Länder), argumentando que na paisagem interessa definir as relações causais, ou seja, aquilo que se acha sujeito a normas e a leis gerais, enquanto que o conceito de região, embora utilize métodos e resultados iguais ou parecidos aos da linha da paisagem, não interessam as leis gerais como objetivo específico, mas se baseia no particular e único de cada uma delas (BÓLOS I CAPDEVILA, 1992).

Outro alemão de destaque foi $O$. Schluter, que definiu a visão fisionômica da paisagem como a primeira aproximação junto à realidade estudada. A partir da ciência ecológica, o conceito de sistema ficou plenamente incorporado aos estudos da paisagem, passando também a inserir o papel da sociedade humana. Nessa nova abordagem dos estudos da paisagem, as figuras de destaque na Alemanha passaram a ser E. Neef e G. Haase (BÓLOS I CAPDEVILA, 1992).

Na primeira metade do século XX, também aparecem as contribuições das escolas de paisagem russo-soviética e anglo-saxônica. Nas décadas de 1930 e 1940, a humanidade começa a ter clareza de que também é parte integrante do complexo conjunto "Natureza" e como consequência se popularizou a problemática de conservação da paisagem (BÓLOS I CAPDEVILA, 1992). Para compreensão desse fato, no âmbito da Geografia, faz-se necessário buscar acontecimentos históricos de maior destaque de forma a mostrar a evolução do pensamento geográfico em relação à paisagem, que teve seus fundamentos lançados pela escola alemã, principalmente na figura de Humboldt e seus discípulos, mas também uma grande participação da escola russo-soviética.

\section{Escola Russo-Soviética}

Nesta escola, a ciência da paisagem tem início no final do século XIX com o nome de Geografia física complexa e tem suas origens conectadas com as concepções da escola alemã (BÓLOS I CAPDEVILA, 1992). A primeira metade do século XX marca uma grande ruptura na visão da paisagem pelos geógrafos e naturalistas russos. A geografia russa desenvolveu-se pela necessidade de colonização dos vastos espaços próximos (Ural, Cáucaso, Sibéria) durante o século XIX. Nesta época, a geografia estava junto às práticas de explorações militares, experiências de viagens e descrições estatísticas, firmando-se como disciplina universitária. Fruto da investigação de meios eficazes de gestão do seu imenso espaço e a criação rápida de mapas do vasto território, a geografia russa, assim como na Alemanha, tenta substituir o estudo das relações funcionais pelos dados fisionômicos (ROUGERIE, 1991 apud 
FROVOLA, 2007, p. 160) ${ }^{1}$. Os cientistas russos, com base na investigação geográfica proposta por Humboldt, continuam a refletir sobre a paisagem como objeto específico do estudo geográfico que tem um caráter abrangente na relação universal entre os diversos componentes do meio e a sua subordinação no espaço (FRÓVOLA, 2007).

No século XIX, são estabelecidas as bases da nova ciência geográfica que, no século $\mathrm{XX}$, passou a ser chamada pelos cientistas russos de Landschaftovedinie ou ciência da paisagem. Entretanto, no início do século XX, a paisagem dos geógrafos russos se distancia da representação sensível da paisagem e passa a ser, sobretudo, influenciada pela doutrina marxista que domina a Rússia a partir de 1917. Com isso, passa a haver uma contradição no âmago da noção de paisagem, que vai provocar discussões contínuas entre os geógrafos a respeito da morfologia, da sua estrutura e os seus métodos de estudo (FRÓVOLA, 2007).

A geografia russa teve muita influência das escolas geográficas de Anoutchine e de Dokoutchaev, formadas no fim do século XIX, que propuseram métodos de investigação mais concretos e definiram a paisagem como objeto investigador da geografia. Anoutchine utilizou muito o método da comparação geográfica (concepções da geografia alemã), dando, ao mesmo tempo, uma atenção específica à história da formação dos objetos e dos fenômenos naturais, e aposta nos seus relatórios de causalidade. Dokoutchaev apoia suas reflexões na ideia filosófica espalhada no século XIX de que a natureza é única, contínua e indivisível e na análise da prática agrária que o conduz a propor questões sobre o papel do solo nos sistemas territoriais, que considera pela primeira vez como corpus natural específico. Com Dokoutchaev, a ideia de que o solo é, ao mesmo tempo, um corpo natural e histórico, cada zona geográfica representa uma região genética, seria necessário estudá-lo sob o ponto de vista da variabilidade da natureza no tempo e no espaço. Essa nova abordagem fortaleceu as interações entre a vegetação, o relevo, a geologia, o clima e a atividade humana e orientou a geografia russa para a análise sintética da paisagem e a história da sua formação. Suas ideias foram integradas no século XX não somente nos trabalhos de seus discípulos, mas também em qualquer investigação físico-geográfica na Rússia (FRÓVOLA, 2007).

Sob a influência das ideias de Dokoutchaev e de Hetter, outro importante geógrafo russo, Berg, discípulo de Anoutchine, propôs no início do século XX, como objeto de estudo geográfico, as unidades espaciais de escalas diferentes (da paisagem à zona geográfica), tendo a geografia como objeto a paisagem e o seu método a regionalização. Berg definiu a paisagem como uma região na qual as particularidades do relevo, do clima, das águas, do solo, da

\footnotetext{
1 ROUGERIE, G.; BEROUTCHACHVILI N. Geosistmas et paysages.Bilans et méthodes. Paris:Armand Colin, 1991, 302 p.
} 
vegetação e da atividade antrópica são organizadas em um conjunto geográfico harmonioso. Porém, questionou “qual lugar é necessário atribuir ao homem na paisagem?" Ele considerou o homem como uma força externa à paisagem. No decorrer do século XX, os geógrafos da paisagem irão hesitar entre a abordagem que totaliza o homem como parte da paisagem e a abordagem dualista, ou seja, o homem como força externa à paisagem (FRÓVOLA, 2007).

Nos anos 1930 e 1940, a ciência da paisagem afirmou-se definitivamente na Rússia como um ramo da geografia, assim como também a geomorfologia, a biogeografia e a pedologia, mas, embora se apresentando como uma ciência com seus próprios objetos, seus métodos de análise continuavam descritivos. As mudanças do capitalismo para o socialismo na sociedade russa promoveram importantes reflexos nas ciências, tendo em vista a nacionalização da terra e dos seus recursos (água, florestas, solos, etc.), o que também levou a uma mudança radical nas relações da sociedade russa com o meio. No que se refere à geografia da paisagem, o seu aspecto de investigação mais importante era o aspecto utilitário, ou seja, a aplicabilidade prática, sendo a finalidade nessa época, dos estudos geográficos, a mudança racional do meio geográfico em conformidade com os objetivos da construção socialista. As mudanças que o novo regime político impôs à análise geográfica da paisagem requereram da Geografia novos métodos de análise como modelo qualitativo e quantitativo, de modo a permitir o controle do meio geográfico e a abordagem quantitativa se firmou rapidamente (FRÓVOLA, 2007).

Verificou-se uma evolução no pensamento geográfico quando Grigoriev, em seu artigo "Estudo físico-geográfico da URSS" publicado em 1931 (ABRAMOV, 1972 apud FRÓVOLA, 2007, p. 166) ${ }^{2}$, escreveu que o método descritivo e qualitativo não podia mais conservar sua importância na geografia. Ele colocou a esfera geográfica ou geosfera no centro dos estudos geográficos, composta por suas massas aéreas, águas e a base litológica que, sob a influência da energia solar, levam ao aparecimento dos solos, dos vegetais e animais, cuja expressão dos processos físico-geográficos é a paisagem. Segundo Grigoriev, é “impossível estudar a fisionomia da paisagem sem analisar seu conteúdo material que pode ser exprimido em fórmulas e equações" (FRÓVOLA, 2007, p.166).

Da mesma forma, essa evolução do pensamento geográfico é expressa quando outro geógrafo soviético, Armand (1949 apud FRÓVOLA, 2007, p. 167) 3 afirmou que o mapa não

\footnotetext{
2 ABRAMOV, L. S. Descriptions naturalistes de notre pays: Développement de l'approche physico-géographique. АБРАМОВ Л. С. Описания природы нашей страны: Развитиефизико-географических характеристик: Moscou: Myisl, 1972. $277 \mathrm{p}$.

3 ARMAND, D. L. Relations fonctionnelles et corrélatives en géographie physique: Mémoires de la Société géographique de
} 
pode ser mais um objetivo principal da investigação geográfica, que a informação do mapa deve ser completada por um gráfico ou um quadro que represente o dinamismo temporal do fator geográfico estudado. A nova concepção da investigação geográfica alcançou seu auge na década de 1960, quando a geografia moderna não é apenas uma ciência descritiva, mas deve oferecer uma base científica completa a trabalho da humanidade. Dessa forma, a base teórica e metodológica em relação à paisagem não se aplica mais a essas novas esferas (FRÓVOLA, 2007). De acordo com Guérassimov (1966 apud FRÓVOLA, 2007, p. 167) ${ }^{4}$, "a ciência da paisagem não resolveu os problemas metodológicos ligados à investigação e à elaboração dos métodos objetivos e precisos de divulgação e descrição científica dos seus objetos de investigação".

Na segunda metade do século XX, nos anos 1960-1970, surge a doutrina do geossistema. Sotchava, membro do Instituto de Geografia da Sibéria, em 1962, introduziu o termo geossistema na ciência soviética (CRUZ, 1985), cuja nova concepção visava resolver os problemas metodológicos de estudo da paisagem. Porém, apesar do conceito de geossitema ter nascido na escola soviética, é resultado da influência dos pressupostos teóricos lançados por Humboldt, da escola alemã, que tinha uma orientação naturalista e que por sua vez influenciou o pedólogo Dokoutchaev (VICENTE; PEREZ FILHO, 2003; FRÓVOLA, 2007). Sotchatva definiu o geossistema como:

\footnotetext{
"um sistema natural, de nível local, regional ou global, no qual o substrato mineral, o solo, as comunidades de seres vivos, a água e as massas de ar, particulares às diversas subdivisões da superfície terrestre, são interconectadas por trocas de matéria e de energia, em só um conjunto" (ROUGERIE; BEROUTCHACHVILI, 1991 apud FRÓVOLA, 2007, p. 167) 1 .
}

Para Sotchava, o geossistema inclui todos os elementos da paisagem como um modelo global, territorial e dinâmico aplicável a qualquer paisagem (BÓLOS I CAPDEVILA, 1992). A partir de então, o que passa a interessar aos geógrafos da paisagem são as dinâmicas espaciais e temporais das paisagens e seu funcionamento (FRÓVOLA, 2007).

O geossistema, assim como o ecossistema, é um modelo teórico aplicável a qualquer paisagem de qualquer tamanho (BÓLOS I CAPDEVILA, 1992). Apesar disso, a nova doutrina do geossistema gerava questionamentos entre os geógrafos russos, que enfrentavam conflituosos direcionamentos de metodologias no estudo do geossistema no que se refere, por

\footnotetext{
l'URSS APMAHД Д. Л. “Функциональные и коррелятивные отношения в физической географии “ в Известия Всес. Геогр. о-ва. v. 81, n. 1, p. 81-94, 1949.

4 GUIERASSIMOV, I. P. Géographie constructive: buts, méthodes, résultats. Mémoires de la Société Géographique de l’URSS (ГЕРАСИМОВ И. П. “Конструктивная география: цели, методы, результаты “ в Известия Всесоюзного Географического общества), v. 98, n. 5, p. 389-403, 1966. (en russe).
} 
exemplo, à inclusão ou não dos feitos humanos como integrantes do geossistema (FRÓVOLA, 2007).

\section{Escola Francesa}

Esta escola está representada por um conjunto de centros universitários e trouxe também importantes contribuições, particularmente metodológicas, para a ciência da paisagem (BÓLOS I CAPDEVILA, 1992). Os estudos da paisagem iniciaram com Vidal De La Blache, para o qual esta é uma fisionomia do espaço, algo que se vê e se descreve como combinação dos feitos físicos, biológicos e humanos, cujo estudo teria seu marco adequado na região, sem deixar de mostrar sua profunda raiz com o meio natural, mostrava também a capacidade humana em dominar o meio, dando início a uma abertura da geografia para as ciências sociais, mas sem perder a tradição naturalista (MARTINEZ, 1979). Também Martinez (1979) questionou uma possível ruptura "postvidaliana" com os estudos da paisagem que se seguiram com Bertrand, chamando atenção de que Vidal De La Blache aparece cada vez menos como pai do conceito paisagístico que a geografia regional francesa ia por em prática.

O estudo da paisagem, na França, em linhas gerais seguiu as diretrizes da geografia alemã e soviética, tendo como um dos centros de estudos da paisagem a Universidade de Toulouse-Le Mirail, com o professor Georges Bertrand (BÓLOS I CAPDEVILA, 1992), que definiu a paisagem como:

\footnotetext{
"uma determinada porção do espaço, o resultado da combinação dinâmica, portanto instável, dos elementos físicos, biológicos e antrópicos que, reagindo dialeticamente uns sobre os outros, fazem da paisagem um conjunto único e indissociável, em perpétua evolução" (BERTRAND, 2004, p. 141).
}

Bertrand (2004) afirmou que estudar uma paisagem é antes de tudo apresentar um problema de método; a paisagem total integra a paisagem natural e as implicações das ações antrópicas; e, ainda, as paisagens fortemente urbanizadas, alguns dos seus aspectos são estudados por métodos análogos. Ele fez críticas à análise da paisagem de modo fragmentado, pois, a paisagem é um todo, isto é, uma entidade global e estabeleceu uma taxonomia para seu estudo, cujas unidades de paisagem da maior para a menor são: Zona, Domínio, Região Natural, Geossistema, Geofácies e Geótopo. Entretanto, mencionou que é na escala do geossistema que se situa a maior parte dos fenômenos de interferência entre os elementos da paisagem que envolve as combinações dialéticas mais interessantes para o geógrafo.

Dentre outros pesquisadores de universidades francesas, G. Cabussel também é um nome concreto no estudo das paisagens, que concebeu a paisagem como uma forma de 
adaptação-fisionômica-estrutural do conjunto formado pela vegetação natural e é transformada pela ação do homem (BÓLOS I CAPDEVILA, 1992).

No estudo da paisagem dentro da Universidade de Paris, destaca-se G. Rougerie, cuja tese de doutorado tratou do significado da evolução dos solos na paisagem, especialmente na Costa de Marfil; G. Soutadé, da Universidade de Paris X, com estudos da paisagem a grande escala em meios de alta montanha; na Universidade de Estrasburgo, destacaram-se J. Tricart que representa a tendência de estudos de paisagem aplicada a partir da geomorfologia, e M. Phipps, G. Allaire, J.C. Weiber e D. Marthieu, com estudos de aplicação especialmente para a agricultura. Destacam-se também F. Moraud, seguindo a escola soviética com estudo a cerca de geossistema, e A. Dauphiné, dedicado a estudos de potencialidade da paisagem e planificação territorial, dentre outros (BÓLOS I CAPDEVILA, 1992).

Escola Anglo-Saxônica

A escola anglo-saxônica teve como berço os Estados Unidos e se difundiu rapidamente pelo mundo na década de 1960 (MOREIRA, 1981). Representa uma segunda fase na formação da ciência da paisagem. Recebeu influências das escolas germânica e russa, cujo conhecimento gerado por tais escolas foram utilizados e necessários para elaborar a teoria da paisagem integrada e permitiram uma concepção científica melhor estruturada (BÓLOS I CAPDEVILA, 1992).

Do ponto de vista da ciência da paisagem, esta escola despontou na primeira metade do século XX com o surgimento da doutrina do "holismo". Smuts, anglo-saxão, foi o criador desta doutrina com sua obra Holism and evolution em 1926, que tem uma abordagem a cerca das características dos conjuntos ou unidades que se formam na superfície terrestre. Segundo essa doutrina, o universo e suas partes constituintes têm tendência a originar unidades que formam um todo (hólos) de complicação crescente. Nelas participam a matéria inerte, a matéria viva e a matéria pensante (o homem). Após as teorias de Smuts, as concepções holísticas se fizeram patentes e foram profundamente consideradas, generalizando-se a ideia de que os conjuntos constituintes da superfície terrestre apresentam tamanhos e complicação crescente (BÓLOS I CAPDEVILA, 1992).

Seguindo seu caráter revolucionário, a partir da década de 1960, a escola anglosaxônica introduziu mudanças principalmente no plano do método, sendo este uma combinação do método quantitativo com a teoria dos sistemas e a teoria dos modelos, isto é, representando um salto da geografia descritiva (fase pré-científica) para a fase da cientificidade, o que significou uma revolução na geografia, passando-se assim, da descrição 
da paisagem à matematização da paisagem, da descrição da morfologia da paisagem à rigorosa tipologia de padrões espaciais, da descrição subjetiva à objetividade descritiva da linguagem matemática. Dentre seus produtores, incluem-se geógrafos de todos os países, com menor difusão entre os franceses, pelo fato dessa escola apresentar a "geografia quantitativa e teorética" como uma "nova geografia", contraposta à geografia de origem europeia, a "velha geografia" (MOREIRA, 1981).

Dentro da escola anglo-saxônica, distinguem-se linhas de estudo como "paisagem e geomorfologia", na qual se destacam Strhaler e Power, e, a linha do Commonwealth Scientific and Industrial Research Organisation (C.S.I.R.O), ou método australiano como também se denomina, que teve início durante a segunda guerra mundial, entre 1943 e 1945, e se baseia no uso sistemático da fotointerpretação do meio natural. Por se basear em fotografias aéreas, as unidades obtidas são basicamente fisionômicas e só se definem tipos de paisagem com a ajuda de transectos sobre o terreno, pelos quais se pode obter informações complementares como o conhecimento das principais espécies vegetais, tipos de rochas, de solos, etc. O trabalho completa-se com o estudo de mapas e trabalhos já existentes. Existem outras linhas que atualmente trabalham no estudo global do território com caráter aplicado voltado para o uso da terra (BÓLOS I CAPDEVILA, 1992).

\section{Paisagem e Geografia no Brasil}

No Brasil, segundo Conti (2011), os estudos geográficos e da paisagem surgem na Universidade de São Paulo (USP) com a implantação do curso de Geografia como ensino superior, seguindo a orientação metodológica de tradição francesa e cita entre os grandes mestres que lançaram as bases da Geografia brasileira em 1935, Pierre Deffontaines, que deixou vários trabalhos, entre os quais "Regiões e paisagens do Estado de São Paulo"; Pierre Monbeig que permaneceu por 11 anos (1935-1946) no Departamento de Geografia da Faculdade de Filosofia, Ciências e Letras (FFLCH) da USP, que muito contribuiu com orientações de tese de doutorado a respeito da geografia paulista. Tamanho avanço era notado que o Boletim Paulista de Geografia, lançado em 1949, teve frequentes publicações de Ab’Saber, Azevedo, França, Muller e Penteado, na década de 1950, quando a geografia no Brasil se iniciava (CONTI, 2011).

Outros nomes de destaque trabalhando a geografia e a paisagem foram citados por Conti (2011), como Carlos Augusto de Figueiredo Monteiro, Percy Lau, Dora do Amarante Romariz, Lindalvo Bezerra dos Santos, Lúcio de Castro Soares, Elza Coelho de Souza Keller, José Veríssimo da Costa Pereira, Fábio de Macedo Soares Guimarães e Ney Strauch. 
Também é destacada por Conti (2011) a tese de doutoramento do Prof. Adilson Avansi de Abreu, de 1973, que se intitulou "Introdução ao Estudo das Paisagens do Médio Vale do Jaguari-Mirim“,ressaltando a importância do estudo pelo fato de, pela primeira vez, ser analisado o papel fundamental da geomorfologia na organização paisagística regional.

Os avanços do estudo da paisagem no Brasil são também registrados pela introdução de a "Fisiologia da Paisagem" como disciplina curricular na USP, em 1968, no currículo de bacharelado do curso de Geografia da FFLC/USP, de autoria do Prof. Aziz Nacib Ab'Saber (CONTI, 2011). Outra contribuição de destaque de Aziz Ab'Saber foi “Um Conceito de Geomorfologia a Serviço das Pesquisas sobre o Quaternário” em 1969 (CONTI, 1998).

Ab'Saber possui outras obras de relevância dentro do estudo das paisagens, e algumas que contemplam o Cerrado, como “O Relevo Brasileiro e Seus Problemas” (AB'SABER, 1964); “Domínios Morfoclimáticos e Províncias Fitogeográficas no Brasil”, (AB’SABER, 1967); “Os Domínios Morfoclimáticos da América do Sul” (AB’SABER, 1977); “Contribuição à Geomorfologia da área do Cerrado" (AB'SABER, 1982); O Pantanal Matogrossense e a Teoria dos Refúgios' (AB'SABER, 1990); "Cerrados e Mandacarus" (AB’SABER, 2002); e, “Os Domínios de Natureza no Brasil: Potencialidades Paisagísticas” (AB'SABER, 2003).

\subsubsection{Ecologia da Paisagem e a Abordagem Sistêmica na Geografia}

A Ecologia da Paisagem, segundo Odum e Barrett (2007), é uma ciência emergente que tem como pedra angular o estudo das causas e consequiências dos padrões espaciais na paisagem. Ela considera o desenvolvimento e a heterogeneidade espacial, as interações temporais e espaciais e trocas por meio de paisagens heterogêneas, as influências da heterogeneidade espacial nos processos bióticos e abióticos e o manejo da heterogeneidade espacial para o benefício e a sobrevivência da sociedade Risser et al., 1984 (apud ODUM; BARRETT, 2007) ${ }^{5}$.

Estes aspectos são também relacionados por Turner (1989), que descreve a Ecologia da Paisagem como uma ciência que dá ênfase a amplas escalas espaciais e aos efeitos ecológicos da produção de padrões espaciais nos ecossistemas, considerando especificamente o desenvolvimento e a dinâmica da heterogeneidade espacial, interações e intercâmbio ao

\footnotetext{
${ }^{5}$ RISSER, P. G.; KARR, J. R.; FORMAN, R. T. T. Landscape ecology: Directionand approaches. Champaign, III.: Natural Histoy Survy, Number 2. 1984.
} 
longo de paisagens heterogêneas, influências da heterogeneidade espacial nos processos bióticos e abióticos e o manejo da heterogeneidade espacial.

A ecologia da paisagem, de acordo com Odum e Barrett (2007), teve início na América do Norte na década de 1980, quando Gary W. Barrett (Diretor do Programa de Ecologia da Fundação Nacional da Ciência) recomendou fundos para um seminário realizado em Allerton Park, no município de Piatt, Illinois, em abril de 1983. Essa reunião serviu como elemento catalisador para as reuniões anuais da Associação Internacional da Ecologia da Paisagem dos Estados Unidos (IALE).

Apesar de ser uma ciência nova, segundo Turner (1989) a expressão "Ecologia da Paisagem" foi usada pela primeira vez por Troll (1939 apud TURNER, 1989) ${ }^{6}$, tendo surgido de tradições européias de geografia regional e de ciência vegetal. Várias disciplinas contribuíram para o recente desenvolvimento da Ecologia da Paisagem, como por exemplo, economistas e geógrafos desenvolveram muitas técnicas para ligar padrões e processos em amplas escalas tais como o desenvolvimento de modelos espaciais para abordar problemas de geografia humana. Também está integrada com o planejamento e tomada de decisão em relação ao uso da terra, na Europa. A Ecologia da Paisagem também se desenvolveu em caminhos mais teóricos de pesquisa e muitas aplicações práticas simultaneamente, enfatizando os processos ecológicos (TURNER, 1989).

Segundo Bernaldez (1981), se nos interessássemos pelos tipos de processos que ocorrem na paisagem natural e que são responsáveis pela manutenção do seu aspecto ou fisionomias características, iríamos obter um catálogo notável. O estudo em torno de uma paisagem concreta pode nos proporcionar a matéria para um amplo curso de ciências do meio ambiente. Para esse autor, em alguns livros como o de Strahler e Strahler, dedicados a ciências do ambiente há um excelente compêndio sistemático dos tipos de processos cujo conhecimento é mais necessário na interpretação das paisagens. Ele considerou como o mais importante a possibilidade de conceber o conjunto de mecanismos subjacentes ao fenômeno "paisagem" como um sistema de interações. E refere que a Geografia e a Ecologia têm chamado a atenção sobre a necessidade de estudar a natureza não em forma analítica ou setorial, descobrindo processos isolados e sem conexão, mas enfocando visões de conjunto.

Metzger (2001) se refere à Ecologia da Paisagem como uma disciplina holística, integradora das ciências sociais (sociologia, geografia humana), geo-físicas (geografia física, geologia, geomorfologia) e biológicas (ecologia, fitossociologia, biogeografia) que visa em

\footnotetext{
${ }^{6}$ TROLL, C. Luftbildplan and okologische Bodenforschung. Z. Ges. Erdkunde, Berlin, p. 241-98. 1939.
} 
particular a compreensão global da paisagem (essencialmente cultural) e o ordenamento territorial.

A Ecologia da Paisagem tem duas abordagens. A abordagem geográfica (ecologia humana de paisagens), centrada nas interações do homem com seu ambiente, onde a paisagem é vista como o fruto da interação da sociedade com a natureza, e a abordagem ecológica (ecologia espacial de paisagens), particularmente preocupada na compreensão das consequiências do padrão espacial nos processos ecológicos. Mas, reconhece que essas abordagens não são tão distintas quanto parecem, e aponta como sendo um dos principais desafios da sociedade internacional de ecologia de paisagem a unificação dos conceitos básicos e o estabelecimento de um sólido arcabouço teórico comum (METZGER, 2001).

A Geografia é uma ciência com abrangência interdisciplinar. De acordo com Mendonça (1998) o tratamento dos aspectos sociais e naturais dentro de uma mesma ciência, a Geografia, constitui-se em um dos seus grandes problemas desde sua origem, o que significa por em evidência a velha questão dicotômica da Geografia: Geografia Humana versus Geografia Física (referida apenas para mostrar essas duas abordagens da Geografia).

Segundo Christofoletti (1981), no contexto científico do século XIX, a focalização geográfica era global, sintética. A Geografia surgia como disciplina posicionada no entremeio das ciências humanas e das ciências da natureza, objetivando o estudo global do ambiente humano. Vidal de La Blache (1922 apud CHRISTOFOLITTI, 1981) ${ }^{7}$ ofereceu exposição clara dessa perspectiva. Entretanto, embora usufruindo conceitualmente o direito de estudar globalmente o ambiente natural, os geógrafos também promoveram o aprofundamento de questões particulares sobre determinados conjuntos de fenômenos. Tal perspectiva integravase no processo de especialização reinante no transcurso da primeira metade do século XX. Os geógrafos contribuíram de modo decisivo para o desenvolvimento dos estudos tópicos, setoriais. A expansão dos trabalhos relacionados com a Climatologia, Biogeografia, Geomorfologia, Hidrologia e Pedologia criou condições para que se individualizassem como ciências autônomas (CHRISTOFOLITTI, 1981).

Mendonça (1998) fala a respeito do surgimento da Geografia Física, tendo este ocorrido sequenciadamente à Escola Possibilista com o desenvolvimento dos ramos específicos de estudo e pesquisas científicos da Geografia Física, como a Climatologia, Geomorfologia, Biogeografia, Hidrologia, etc... que se baseando em outras ciências como a Meteorologia, Geologia e Biologia etc... influenciaram o conhecimento geográfico produzido

\footnotetext{
${ }^{7}$ Blache, B. V. de La. Principes de Géographie Humaine. Librairie Armand Colin, Paris. 1922.
} 
a partir de então, chegando à atualidade (MENDONÇA, 1998). Assim, a Geografia Física, não é uma abordagem apenas das ciências da terra, mas também das ciências biológica através dos aspectos ecológicos e da Biogeografia, abordagem esta que fica expressa na a lei que regulamenta a profissão do geógrafo:

\begin{abstract}
Decreto $\mathrm{N}^{\circ}$ 85.138, DE 15 SET 1980 que regulamenta a Lei $\mathrm{n}^{\circ} 6.664$, de 26 JUN 1979. Lei $\mathrm{N}^{\circ} 7.399$, de 4 de novembro de 1985 que altera a redação da Lei 6.664, e Decreto $\mathrm{N}^{\circ}$ 92.290, de 10 de janeiro de 1986, que regulamenta a Lei n. 7.399, de 4 de novembro de1985, disciplina a profissão de Geógrafo, e dá outras providências [...] Art. $3^{\circ}$ - É da competência do Geógrafo o exercício das seguintes atividades e funções a cargo da União, dos Estados, dos Territórios e dos Municípios, das entidades autárquicas ou de economia mista e particulares: I - reconhecimentos, levantamentos, estudos e pesquisas de caráter físico-geográfico, biogeográfico, antropogeográfico e geoconômico e as realizadas nos campos gerais e especiais da Geografia, que se fizerem necessárias: [...] f) na caracterização ecológica e etológica da paisagem geográfica e problemas conexos ${ }^{8}$.
\end{abstract}

Brown (1977) define Geografia Física como: terra, ar, água, plantas e animais, e solos. Para ele, é de se esperar que a ênfase relativa dada pelos geógrafos físicos a esses cinco elementos depende do tipo de abordagem centrada na paisagem.

Vale (2012) em uma análise da abordagem sistêmica na Geografia Fisica, fez referência a Moraes (1983 apud Vale, 2012) ${ }^{9}$, para o qual a perspectiva de fisiologia da paisagem se fundamenta na Biologia, em particular na ideia de organismo. A paisagem seria um organismo, com funções vitais e elementos que interagem. Caberia à Geografia conhecer as inter-relações entre fenômenos de qualidades distintas que coabitam numa determinada porção do espaço terrestre. Para Vale (2012) esta perspectiva introduz a Ecologia no domínio geográfico. Ela comenta que, dentro da Geografia, o interesse conceitual da Ecologia ficou mais restrito aos biogeógrafos. A influência dos conceitos biológicos ou ecológicos na Geografia foi mais profunda do que se pode supor, pois vários termos e conceitos foram e ainda são utilizados de forma corrente, principalmente na Biogeografia.

A fronteira entre Ecologia e Geografia nunca foi clara porque ambas lidam com a paisagem (FRIEDRICHS, 1958 apud VALE, 2012) ${ }^{10}$. A Ecologia da Paisagem trabalha com o conceito de ecossistema tanto quanto a Geografia, não obstante as críticas ao conceito feitas posteriormente à criação do mesmo, principalmente pelos geógrafos russos e franceses, principalmente pela carência de unidade espacial (VALE, 2012).

\footnotetext{
${ }^{8}$ Disponível em <http://normativos.confea.org.br/ementas/visualiza.asp?idEmenta=6 >. Acesso em 25/nov/2013.

${ }^{9}$ MORAES, A. C. R. Geografia: pequena história crítica. São Paulo: Editora HUCITEC, 1983.

${ }^{10}$ FRIEDERICHS, K. A Definition of Ecology and Some Thoughts About Basic Concepts. Ecology 39:154-159. 1958.
} 
A acusação de que o estudo dos ecossistemas "não é geografia" repousa no fato, presumivelmente, de que a definição de eco-sistema não define explicitamente a superfície da terra como campo de operação. "A ecologia é o estudo das relações ambientais; a geografia é o estudo das relações do espaço", declara Davies (1961, p.415), mas continua acrescentando que "o que não está claro é onde acaba uma e começa a outra (CHORLEY; HAGGETT, 1974, p. 86 apud VALE, 2012, p. 99) ${ }^{11}$.

O termo "Ecologia da Paisagem" cunhado por Troll é fruto da influência que a Ecologia exerceu sobre a Geografia, cujos princípios repousam na visão horizontal do geógrafo somada à visão vertical do ecólogo, vindo a ser uma referência aos estudos, sobretudo biogeográficos, visando entender as relações sociedade-natureza. Carl Troll também utilizou o termo geoecologia. Para ele, o nascimento da Ecologia da Paisagem significou a ligação mais importante entre Geografia (paisagem) e Biologia (ecologia). A perspectiva dos geógrafos incluía, além das paisagens naturais, as paisagens antrópicas (VALE, 2012).

A proposta do estudo das paisagens por Bertrad (2004), da Escola Francesa de Geografia, em "Paisagem e Geografia Física Global” contempla a abordagem ecológica nos estudos da paisagem pelos geógrafos, pois o geossistema se define a partir dos dados ecologicamente estáveis e resulta da combinação de fatores geomorfológicos (natureza das rochas e dos mantos superficiais, valor do declive, dinâmica das vertentes...), climáticos (precipitações, temperatura...) e hidrológicos (lençóis freáticos, epidérmicos, e nascentes, pH das águas, tempo de ressecamento do solo...) que correspondem ao potencial ecológico do geossistema. O geossitema se define também por certo tipo de exploração biológica (vegetação, solo e fauna), além da ação antrópica, estando em clímax quando há equilíbrio entre o potencial ecológico e a exploração biológica (BERTRAND, 2004).

A abordagem ecológica no estudo das paisagens na Geografia não é recente, pode-se observar essa tendência a partir de estudos de Hunboldt e DeCandolle no século XIX, por exemplo, quando estes relacionaram seus estudos botânicos com as influências do ambiente (comentados a seguir), e ao longo do histórico do estudo da paisagem na Geografia (comentado anteriormente), cuja abordagem ecológica foi se aprofundando à medida que as bases científicas desse estudo foram se tornando mais sólidas, se definindo, acompanhando o avanço cientifico de cada época. Atualmente, os estudos da paisagem pelos geógrafos não possuem apenas aspectos humanos, mas também biogeográficos e ecológicos.

\footnotetext{
${ }^{11}$ CHORLEY, J. R.; HAGGET, P. Modelos físicos e de informações em Geografia. São Paulo: Editora da USP, Rio de Janeiro: Livros Técnicos e Científicos Editora, 1974.
} 


\subsection{Sistemática Fitogeográfica e o Cerrado}

\subsubsection{Fitogeografia Mundial e da América do Sul}

Desde o século XIX aos dias atuais, são inúmeras as contribuições dos biogeógrafos no traçado das regionalizações fitogeográficas. Tem-se uma sistematização de informações que se iniciou em uma escala macro com grandes regiões fitogeográficas ou reinos florísticos, em termos mundiais, para uma escala de mais detalhes com classificações fitofisionômicas de áreas com dimensões regionais.

Dentre os primeiros biogeógrafos que contribuíram com conhecimentos a respeito da geografia das plantas, pode-se citar Humboldt (1805), com sua obra "Essay on the Geography of Plants", na qual já visualizava a distribuição dos seres vivos no planeta (especialmente os vegetais) sob a influência dos parâmetros físico-ambientais; ele mencionou que a "geografia de plantas" considera as plantas pelas relações de suas associações locais em diferentes climas. A geografia das plantas não só organiza as plantas de acordo com as zonas e as altitudes em que elas são encontradas, mas distingue hábitats entre plantas (HUMBOLDT, 1805), reconhecendo a relação entre a latitude e altitude na distribuição dos vegetais.

De Candolle (1820), em sua obra "Essai Élémentaire de Geoography of Plants", comentou que a geografia das plantas nos faz conhecer a distribuição atual de plantas na terra e nas águas, e atribuiu ao seu crescimento as causas externas como o clima, a temperatura, a elevação do solo acima da superfície do mar, e a distância do equador, condições químicas do solo, geomorfologia e as circunstâncias acidentais externas que operam sobre a produção de plantas. Ele expôs com muitos exemplos e comparações as diferenças das floras entre hemisférios e regiões, possibilitando uma visualização da fitogeografia regional.

Este mesmo autor relatou a respeito do grande número de plantas que pertenciam exclusivamente aos trópicos, que nunca passavam além deles, sendo encontradas também na Ásia e África, na América e as ilhas dos Mares do Sul, e mesmo em Nova Holanda como muito famílias como Palmae, Sapindaceae e Annonaceae, dentre outras. Para De Candolle (1820), havia muitas exceções a esta regra, no entanto, dependia das circunstâncias. Em primeiro lugar, os países que estão acostumados a compartilhar suas floras com as regiões vizinhas, em particular as ilhas situadas sob a mesma latitude, como os Açores possuem as floras da Europa e do norte da África, em vez das da América, porque elas são escassas (ou dificilmente encontradas aí), e também Malta, possui uma flora composta por aquelas do sul da Europa e o norte da África. O mesmo grau de latitude, no hemisfério sul e norte, é 
conectado com temperaturas muito diferentes e produz uma vegetação completamente diferente. Isso, porém, deve ser entendido pelo fato do verão ser mais curto no hemisfério sul, porque o movimento da terra em seu perigeu é mais rápido. No verão, há também mais frio porque a grande quantidade de gelo sobre a vasta extensão de mar exige mais calor para dissolvê-la, como também, porque os raios solares não são refletidos em tal quantidade a partir da superfície clara da água mar, para proporcionar o grau apropriado de calor. E, portanto, no hemisfério sul, a flora do polo se estende mais perto do equador, que no norte. Sob o grau 53 e 54 de latitude sul, são encontradas plantas que correspondem com a flora ártica. Na Terra de Magalhães, e na Terra do Fogo, Betula antartica corresponde com Betula nana na Lapónia; Empetrum nigrum, - Arnica montana - Genum magellanicum com Genu rivale, na Inglaterra, - Sxifraga magellanica com Saxifraga rivularis, em Finmark (DE CANDOLLE, 1820).

Do mesmo modo que Humboldt, De Candole destacou a importância das condições físicas na distribuição das floras mundiais. Mas, apesar dessas grandes contribuições, segundo Cox e Moore (2009), foi o botânico alemão Adolf Engler o primeiro a produzir, em 1879, um planisfério detalhado e compreensível com limites da distribuição de floras regionais distintas; seu mapa também apresentava diferentes tipos de vegetação em cada das grandes áreas. Ele identificou quatro grandes regiões florais ou domínios botânicos mundiais: Domínio boreal extratropical (América do Norte, Europa e Ásia), Domínio Paleotropical (da África às Índias Orientais), Domínio sul-americano e Domínio do Velho Oceano (da costa chilena, via sul da África, ilhas do Atlântico sul e Oceano Índico até Austrália e parte da Nova Zelândia), tendo observado também algumas famílias de plantas ou gêneros que eram dominantes ou característicos de cada domínio, exceto por modificações comparativamente pequenas. O sistema de plantas aceito atualmente com base em Good e Tarktajan é muito similar ao de Engler (COX; MOORE, 2009).

Em outra contribuição a respeito da flora mundial, Udivardy (1975), em sua obra " $A$ classification of the Biogeographical Provinces of the World", propôs um sistema biogeográfico unificado (flora e fauna), principalmente para fins de conservação com oito reinos: Paleártico, Neártico, Áfricotropical, Indomalasico, Oceânico, Australiano e Neotropical. No que se refere à flora, assim como Cox e Moore (2009), Udvardy (1975) comentou que todos os esquemas florísticos são baseados em Engler, dentre estes ele também destaca as classificações de Good e Takhtajan. Nesta classificação de Edvardy (1975) o reino Neotropical é composto de 47 províncias e o Brasil tem seu território dentro de 15 destas 
províncias que são: 4 (Guiana); 5 (Amazônia); 6 (Madeira); 7 (Serra do Mar); 8 (Floresta Úmida Brasileira); 9 (Planalto Brasileiro); 20 (Caatinga); 21 (Gran Chaco); 27 (Llanos); 28 (Campos Limpos); 29 (Babaçu); 30 (Campos Cerrados); 31 (Pampas Argentinos); 45 (Ilha Fernando de Noronha) e 46 (Ilha Trindade Sul). Nota-se que o Cerrado constitui uma província independente.

Por sua vez Takhtajan (1986), autor de uma das regionalizações da flora mundial atualmente aceita, estabeleceu seis reinos florísticos, seguindo uma hierarquia de sub-reinos, região, e províncias. Os reinos estabelecidos foram: Holártico, Paleotropical, Neotropical, Cape, Australiano, e Holantártico.

O reino Neotropical ocupa a parte tropical da Península da Flórida, parte das terras baixas e costeiras do México, toda a América Central, ilhas das Antilhas e grande parte da América do Sul. Contém famílias endêmicas e subendêmicas: Hymenophyllopsidaceae, Stylocerataceae, Caryocaraceae, Pelliceraceae, Lissocarpaceae, Brunelliaceae, Thurniaceae, dentre outras. A flora neotropical tem uma origem comum com a Paleotropical e é assumido que, pelo menos para as plantas com flores, que estas tiveram seu núcleo inicial no reino Paleotropical. São muitas as famílias com distribuição pantropical, que inclui ambos os trópicos do Velho e Novo Mundo, como por exemplo, as famílias Annonaceae, Canellaceae, Myristicaceae, Lauraceae, Piperaceae, Ochnaceae, Sapotaceae, Bombacaceae, dentre outras. Um considerável número de gêneros é encontrado nos trópicos de ambos os hemisférios, provavelmente não menos que 450. O número total de gêneros não é conhecido, mas são estimados aproximadamente de 3.000 a 3.600 gêneros neotropicais. Subdivide-se em cinco regiões: Caribenha, de Terras Altas das Guianas, Amazônica, Brasileira e Andina (TAKHTAJAN, 1986). A região Brasileira subdivide-se em província Caatinga, Planalto do Brasil Central, Chaco, Atlântica e Paraná.

Existem outras regionalizações ou classificações fitogeográficas, em escala mundial, com enfoques não florísticos, mas fisionômicos. Nas primeiras décadas do século XX, surgiu o termo "formação" que, segundo Coutinho (2006), foi empregado por Griesebach, cuja origem seria uma derivação da palavra alemã vegetationsform utilizada por Martius. No Congresso de Botânica de 1910 (Bruxelas), sua Comissão de Nomenclatura estabeleceu que uma formação "se compõe de associações que se diferenciam em sua composição florística, mas coinidem, em primeiro lugar, nas condições estacionais e, em segundo lugar, nas suas formas biológicas". A partir de então, vários conceitos monoclimáticos foram propostos por Weaver e Clements, Clements, Mueller-Dombois e Ellemberg, e Colinvaux (COUTINHO, 
2006). Posteriormente, surgiu o termo "bioma" que Clements (1949 apud COUTINHO, 2006, p. 15) ${ }^{12}$ descreveu como: "Biome - A community of plants and animals, usually of the rank of a formation: a biotc comunity". Segundo Coutinho (2006), o que diferenciou "formação" de bioma foi a inclusão da fauna no novo termo; entretanto, a fisionomia permite reconhecer os diferentes biomas.

Há várias classificações de biomas, como a de Cailleux (1953), que contribuiu para o entendimento das floras mundiais com a delimitação fisionômica das grandes formações naturais em que reconheceu oito principais formações naturais terrestres: tundra, floresta subártica e temperada, durisilva, savana, floresta tropical de folhas caducas, estepe e pradarias, semidesertos e desertos, e floresta equatorial.

Odum e Barrett (2011): citaram as tundras ártica e alpina, Calota de gelo dos polos e dos picos de montanhas, Florestas de coníferas boreais, florestas decíduas temperadas, campos temperados,campos tropicais e savanas, chaparrais, desertos, florestas tropicais semidecíduas, e florestas úmidas tropicais sempre-verdes. Cox e Moore (2009) citaram os desertos, tundra gelada de altas latitudes e grandes altitudes, floresta boreal de coníferas ou taiga, floresta temperada, floresta tropical úmida, grassland temperada, e chaparral. Brow e Lomolino (2006) consideraram tundra e gelo, floresta boreal, Floresta temperada decídua e floresta subtropical de sempre-vivas, pradarias temperadas, desertos e semidesertos, floresta tropical decídua e savana, floresta tropical úmida, e tundra alpina; dentre outras classificações, mas todas evidenciam o forte vínculo dos biomas com o clima, e a percepção dessa relação do clima com as zonas de vegetação do mundo vem desce os primeiros biogeógrafos.

Segundo Cox e Moore (2009), existe um zoneamento geral dos biomas em função da latitude ou altitude. Nesse sentido, Walter e Leith (1960 apud COUTINHO, 2006, p. 16) ${ }^{13}$ elaboraram uma classificação dos climas do mundo em nove zonas climáticas distribuídas como zonas latitudinais da Terra, representando cada zona uma grande unidade ecológica da geobiosfera, que eles denominaram de zonobioma, que foram posteriormente publicados em Walter (1986):

Zonobioma I - Florestas pluviais tropicais sempre verdes

Zonobioma II - Florestas tropicais estacionais ou savanas

Zonobioma III - Desertos quentes

\footnotetext{
12 CLEMENTS, F.E. Dynamics of Vegetation. New York, The H.W. Wilson Co. 1949.

13 Walter, H.; Lieth, H. Klimadiagramm-Weltatlas. Veb. Gustav Fischer Verlag, Jena. 1960.
} 
Zonobioma IV - Vegetação esclerofila (chaparral, maqui)

Zonobioma V - Florestas subtropicais sempre verdes

Zonobioma VI - Florestas temperadas subcaducifólias

Zonobioma VII - Estepes ou desertos

Zonobioma VIII - Floresta de coníferas (Taiga)

Zonobioma IX - Tundras

Tendo em vista a atual crise da biodiversidade, que exige ações para conter a perda da biodiversidade, Olson et al. (2001) estabeleceram um novo mapa da vida na Terra por meio do traçado de ecorregiões terrestres com o objetivo de subsidiar a discussão sobre estratégias de conservação da biodiversidade terrestre.

A regionalização proposta por Udvardy (1975), que teve um cunho conservacionista, serviu de base para a delimitação das ecozonas e ecorregiões por Olson et al. (2001), que afirmaram: "as Ecoregiões refletem a distribuição de espécies e comunidades com mais eficiência do que as Unidades baseadas em modelos globais e regionais derivados apenas dos dados biofísicos, tais como chuva e temperatura" (OLSON et al., 2001, p. 933). Eles subdividiram o mundo terrestre em 14 biomas: Florestas tropical e subtropical úmidas latifoliadas; Florestas tropical e subtropical secas latifoliadas; Florestas tropical e subtropical latifoliadas de coníferas; Florestas temperadas e mistas latifoliadas; Floresta temperadas de coníferas; Floresta Boreal/Taiga; Campos tropicais e subtropicais, savanas e arbustos; Campos temperados, savanas e arbustos; Campos úmidos e savanas, Campos montanhosos e arbustivos; Tundra; Florestas Mediterrâneas, lenhosas e arbustivas; Desertos e xéricas arbustivas; e Maguezais; e, em oito reinos biogeográficos: Neártico, Paleártico, Neotropical, Afrotropical, Indo-Malásico, Australiano, Oceânico, e Antártico, que abrigam 867 ecorregiões.

Para Olson et al. (2001), o modelo de ecorregião oferece funcionalidades que melhoram a sua utilidade para o planejamento da conservação em escalas globais e regionais por ter abrangente cobertura, uma estrutura de classificação que se baseia na conhecimento biogeográfico existente e um nível detalhado de resolução biogeográfica. Estes autores consideram que a nova regionalização é aproximadamente um aumento de quatro vezes na resolução sobre as 198 províncias bióticas de Dasmann (1973) e 193 unidades de Udvardy (1975). 
Em todas as classificações fitogeográficas em nível mundial, o reino Neotropical manteve-se, significando a individualidade de sua flora. Para a América do Sul, que compõe grande parte desse reino, existem várias classificações ou regionalizações biogeográficas estabelecidas, dentre elas a de Cabrera e Willink (1973), Ab’Saber (1977) e Morrone (2001), que contemplam aspectos fitogeográficos.

Cabrera e Willink (1973) estabeleceram uma classificação de táxons animais e vegetais para a América do Sul, estando esta representada em quatro grandes regiões biogeográficas: Região Holártica (pequena porção do norte da península da Baixa Califórnia); Região Neotropical (ocupa quase todo o México, América Central, e a maior parte da América do Sul); Região Antártica (cobre a cordilheira austral desde os $37^{\circ}$ de latitude sul até o cabo de Hornos, as ilhas Malvinas, as ilhas de Juan Fernándes e a Antártica); e a Região Oceânica (nos mares costeiros).

Na proposta de regionalização de Cabrera e Willink (1973), o continente sulamericano compõe-se de cinco domínios pertencentes à Região Neotropical: Domínio Caribe (Províncias Guajira, das Ilhas Galápagos), Domínio Amazônico (Províncias Amazônica, Pacífica, Yungas, Venezuelana, do Cerrado, Paranaense, da Savana, Atlântica, e Páramo), Domínio Guiano, Domínio Chaqueño (Províncias Caatinga, Chaquenha, Espinal, Prepunenha, do Monte, e Pampeana), e Domínio Andino-Patagônico (Províncias Altoandina, Punenha, do Deserto, Chilena Central, Patagônica); e um pertencente à Região Antártica, o Domínio Subantártico (é um domínio sul-americano que faz parte das regiões Antártica e Oceânica, ao qual pertencem as províncias Subantártica, Insular e de Juan Fernández). O Cerrado, neste sistema de regionalização, é uma província do Domínio Amazônico e chega a adentrar o leste paraguaio, da mesma forma que a Província do Chaco também chega a adentrar o sudoeste do Estado do Mato Grosso do Sul.

Ab’Saber (1977) propôs uma regionalização da América do Sul com base em critérios climáticos, geomorfológicos, fitogeográficos e ecológicos, com 23 domínios: Domínios Equatorial Amazônico, Equatorial Pacífico, Tropical Atlântico, dos Cerrados, RorraimoGuianense, Intermontano Subequatorial, dos Andes Equatoriais, das Caatingas, do Chaco Central, dos Desertos Costeiros Pacíficos, das Punas e Desertos de Cordilheira dos Andes Centrais, dos Planaltos Sub-brasileiros com Araucárias, Andino Subtropical com Araucárias, das Pradarias Mistas Subtropicais, Pampa Úmida, Páramos, do Monte, do Monte Estético, Patagônico, dos Andes Subantárticos, de Finisterra Subúmida das Terras Patagônicas e Magalhânicas, e das Tundras Subantárticas; e, com quatro paisagens diferentes: das Serras 
Úmidas e Piemontes da Faixa Tucano-Boliviana, Rochosas, de Glaciais Residuais: sul dos Andes, de Encraves Glaciários de Altura. Nesta regionalização da América do Sul, o Cerrado constitui um domínio independente.

Morrone (2001), em sua obra "Biogeografía de América Latina y El Caribe", estabeleceu uma classificação biogeográfica composta de regiões, sub-regiões e províncias, determinando nesta classificação as regiões Neártica, Neotropical e Andina para a América Latina e o Caribe. A região Neotropical compreende a região dos trópicos americanos, desde o norte do México até o centro da Argentina; entretanto, existem evidências de que a biota sul-americana da região Neotropical se expandiu mais para o sul em tempos pré-quaternários, chegando até a Patagônia (Figura 2.1). Esta região integra o reino Holotropical, juntamente com as regiões Afrotropical ou Etiópica, Oriental e Australiana Tropical e compõe-se das subregiões: Caribenha, Amazônica, Chaqueña e Paranaense (MORRONE, 2001).

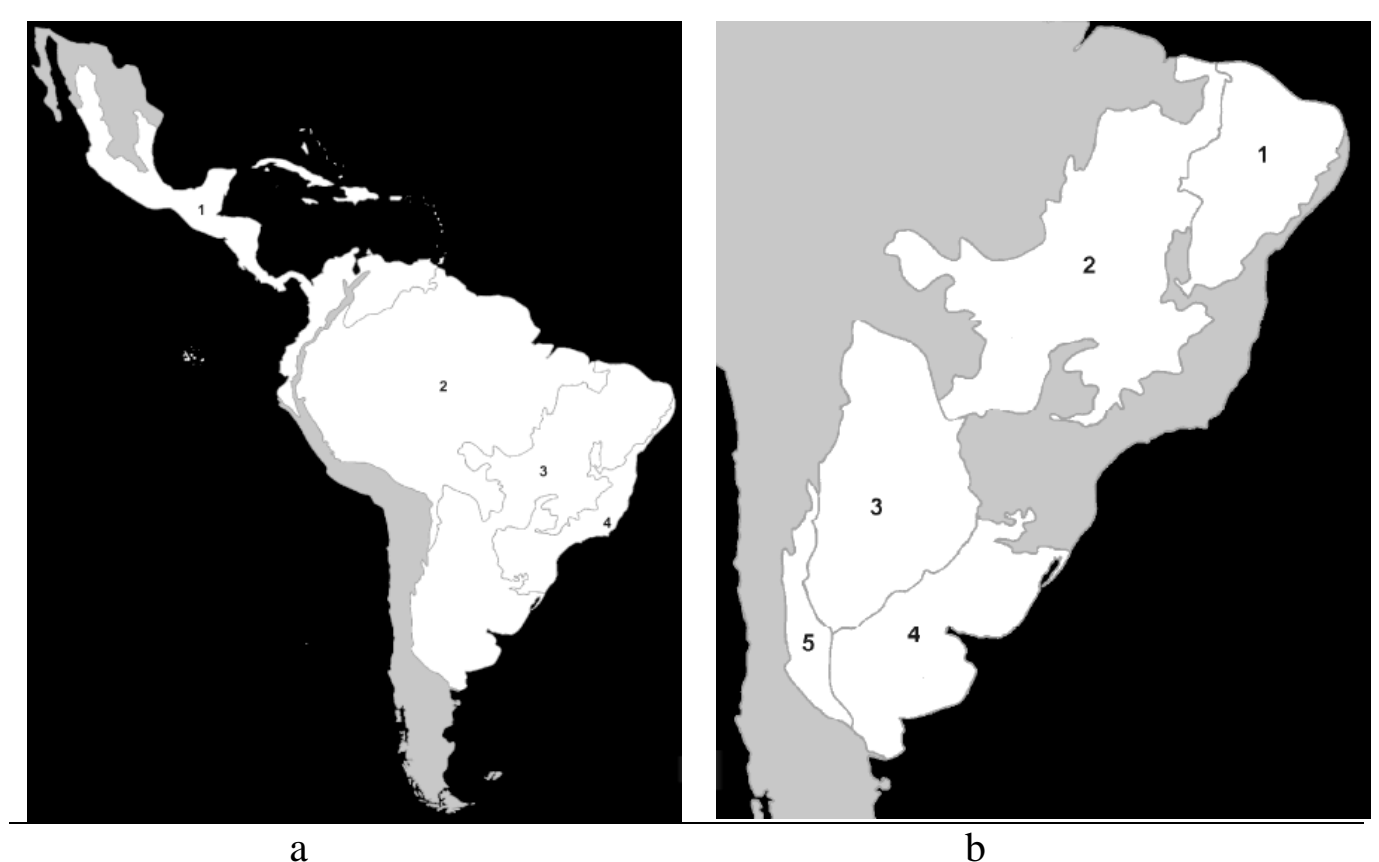

Figura 2.1 - Sub-regiões Neotropicais: 1, Caribenha; 2, Amazônica, 3, Chaquenha; e 4, Paranaense (a); e as Províncias da sub-região Chaquenha: 1, Caatinga; 2, Cerrado; 3, Chaco; 4, Pampa; e 5, Monte (b). Fonte: Morrone (2001)

A sub-região Chaquenha estabelecida por Morrone (2001) ocupa o norte e o centro da Argentina, sul da Bolívia, oeste e centro do Paraguai, e centro e noroeste do Brasil. Equivale ao "corredor de savana" de Schmidt e Inger (1951) e à "diagonal de formações abertas" de Vanzolini (1963), revisados por Prado e Gibbs (1963), também segundo Morrone (2001).

Morrone (2001) reconheceu cinco províncias na sub-região Chaquenha (Figura 2.1): Caatinga, Cerrado, Chaco, Pampa e Monte. Considerando-se a flora, os traços individuais de 
Enterolobium contortisiliqum, Astronium urundeuva e Aramigus são característicos desta subregião, como também os táxons de angiospermas: Copernicia e Trithrinax (Arecaceae), Bromelia e Dyckya (Bromeliaceae), Holocheilus e Panphalea (Asteraceae), Opuntia, Quiabentia e Trichocereus (Cactaceae), Gymnosporia e Schaefferia (Celastraceae), Pouteria gardneriana (Sapotaceae), Acacia, Amburana cearensis, Caesalpinia, Enterolobium contortisiliqum, Hymenaea martiana, Nachaerium acutifolium e Pterogyne nitens (Fabaceae), Aspidosperma pyrifolium e Vallesia (Apocynaceae), Combretum leprosum (Combretaceae), Acanthosyris e Jodina (Santalaceae), Astronium urunbeuva (Anacardiaceae), Bulnesia, Larrea e Plectrocarpa (Zygophyllaceae) e Celtis (Ulmaceae).

Para a América Latina, além destas regionalizações expostas anteriormente, também foi estabelecida uma classificação em ecorregiões com fins conservacionistas. Pelo planejamento ecorregional da América Latina e do Caribe, há um consenso atual que existem 18 ecorregiões terrestres, 77 ecorregiões de água doce e 42 ecorregiões marinhas; estas ecorregiões têm se convertido nas unidades básicas de planejamento e conservação (THE NATURE CONSERVANCY, 2007).

Em todos os sistemas de regionalização com o objetivo de classificar as floras ou fitofisionomias, quer seja em nível de reinos, regiões, províncias, ou ecorregiões o Cerrado tem sido individualizado dentro destas classificações, embora apareça às vezes com a denominação de Planalto Brasileiro ou Planalto Central do Brasil e, em outras, com o próprio nome Cerrado.

\subsubsection{Fitogeografia Brasileira}

No Brasil, a primeira regionalização fitogeográfica foi feita pelo botânico alemão Karl Friedrich Philipp von Martius, que veio ao Brasil fazendo parte da Missão Austríaca, que integrava a comitiva da arquiduquesa Leopoldina na vinda ao Brasil para se casar com D. Pedro, época em que o Brasil era colônia do Reino de Portugal, Brasil e Algarve. A viagem de Martius de três anos (1817-1820) resultou em muitas publicações e importantes obras como a monumental "Flora Brasiliensis",

Martius, ao produzir mapa fitogeográfico do Brasil no século XIX (Figura 2.2), utilizou um sistema de classificação baseado em divindades gregas: Nayades - ninfas dos lagos, rios, fontes; Oreades - ninfas das montanhas, companheiras de Diana, deusa grega da

\footnotetext{
${ }^{14}$ Disponível em: <www.fapesp.br/publicações/flora > Acesso: DATA: 20/10/2011.
} 
caça; Hamadryades - ninfas que ressuscitam e protegem bosques e árvores; Dryades - ninfas protetoras dos bosques e árvores; Napaeae - ninfas protetoras dos vales e prados (HENRIQUES, 2008), que representam Amazônia, Cerrado, Caatinga, Mata Atlântica, Campos e Florestas Meridionais, respectivamente. Em 1958, o mapa fitogeográfico de Martius foi anexado ao volume XXI da Flora Brasiliensis (VELLOSO et al., 1991).

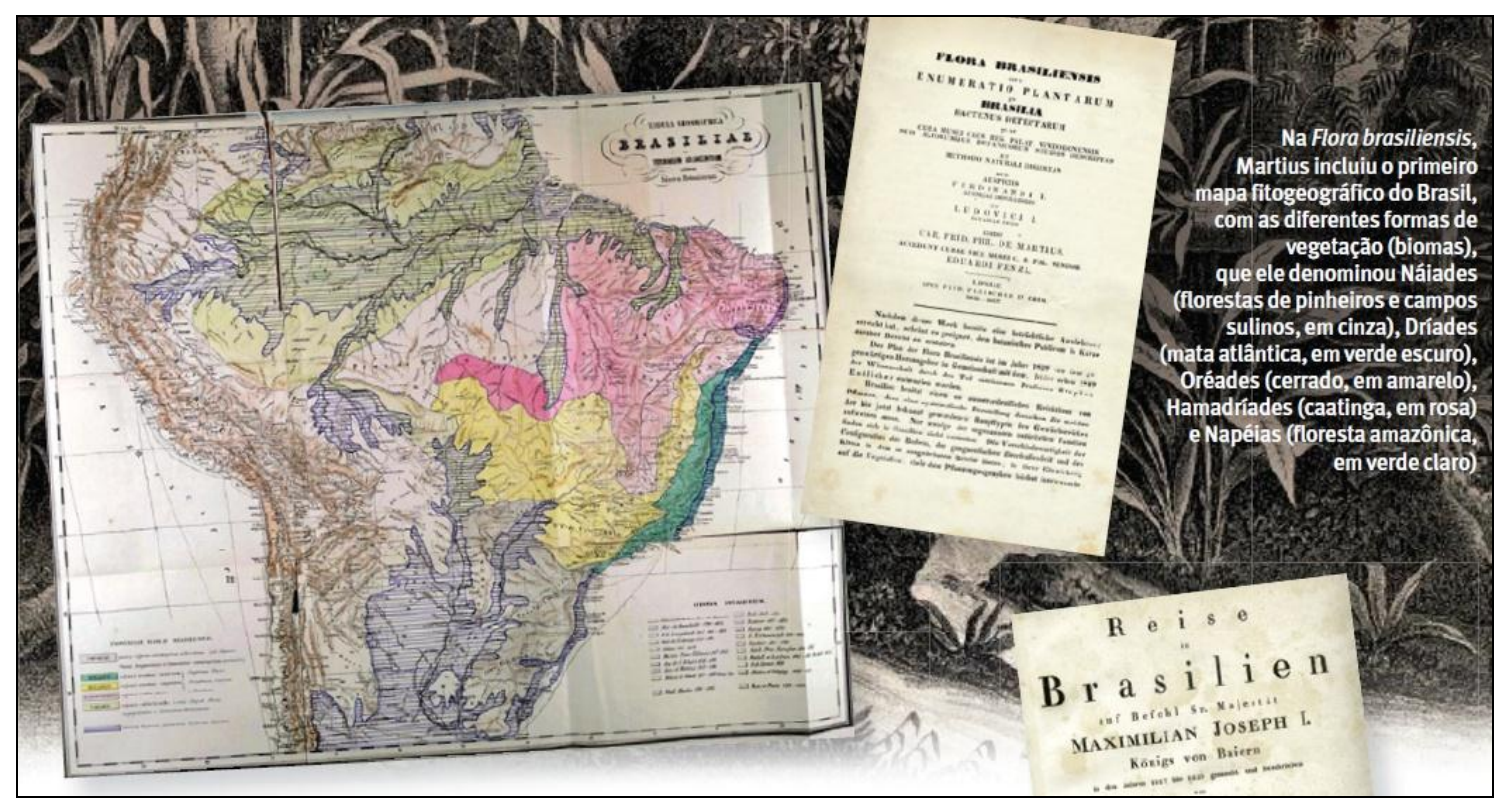

Figura 2.2 - Mapa Fitogeográfico do Brasil, elaborado por Karl Friedrich Philipp von Martius, em 1858. Fonte: Henriques (2008)

Após Martius, mais de meio século depois, no início do século $\mathrm{XX}$, uma nova classificação fitogeográfica brasileira foi estabelecida por Gonzaga de Campos em 1912.

A classificação de Campos tinha cunho fitofisionômico estrutural e incluiu como grandes divisões: Matas; Campos; Caatingas; Vegetação Costeira; e, Pantanal.

I - Matas: nesta categoria ele estabeleceu as seguintes subdivisões:

A - Florestas da Zona Equatorial (Hileia Amazônica), compondo-se de:

a) Matas de Aluviões Marítimas (ou manguezais)

b) Matas de Aluviões Fluviais (ou das várzeas)

c) Matas de Terra Firme

B - Floresta da Encosta Atlântica (desde a altura do cabo de São Roque, na latitude $5^{\circ}, 5$ Sul até o Rio Grande do Sul, na latitude de $30^{\circ}$. Subdivide-se em:

a) Floresta de Encosta

b) Pinheirais (Araucárias)

\section{C - Matas Pluviais do Interior}


Campos (1912) justificou a inclusão dos Pinheirais na categoria "Matas", tendo em vista ocorrerem conjuntamente com espécies da floresta atlântica, a exemplo do Paraná, os pinheirais ocorrem com grandes quantidades de embuias, tapinhoans, canelas, araçás, guaraiuvas, guaynviras e outras árvores de grande porte.

Outro aspecto que aqui merece esclarecimento é que as Matas Pluviais do Interior, a que Campos (1912) se refere, ocorrem em uma zona que no geral é megatérmica, porém com chuvas reduzidas e estacionais, concentradas em curto prazo, de modo que as secas prolongadas dão a certas zonas o caráter dos climas xerófilos com ocorrência de Cerradões, Catanduvas $^{15}$, Faxinas $^{16}$, Campos Cerrados, Campos Limpos, e Quissassas ${ }^{17}$.

Mas não são essas as Matas Pluviais do interior, e sim aquelas decorrentes de fatores geomorfológicos como grandes formas do relevo como serras, cordilheiras, encostas dos planaltos que, como degraus para o interior do país, se sobrepõem ao planalto da borda atlântica, juntando-se a outros tantos fatores de condensação, produzindo florestas de grande porte por áreas extensas, mas que na realidade representam apenas manchas locais dentro do ambiente de Cerrado. Como por exemplo, em Minas, Campos (1912) cita as matas da serra das Vertentes, que revestem o curso superior do Paraopeba, rios Pará, Boa Vista e Itapecerica; das encostas orientais da serra da Canastra e da Mata da Corda que revestem as cabeceiras do rio São Francisco; em Goiás, a serra do Duro, o chapadão de Tabatinga, chapadão da Mangabeira que representam o último divisor prolongado a norte, oferece, principalmente, nas escarpas de oeste, zonas de condensação cobertas de matas. As vertentes mais orientais do Paranã, do rio Palmas, do Manoel Alves de Natividade, do rio do Sono constituem-se de largas manchas de boas matas (CAMPOS, 1912).

O divisor entre o Paraná e o Tocantins-Araguaia, orientado a nordeste, oferece nas duas encostas os mesmos resultados de uma condensação mais abundante: matas das cabeceiras do Descoberto, do Areias, dos afluentes mais meridionais do Corumbá, cabeceiras do Maranhão, do rio das Almas, vertentes do rio Vermelho, do rio Claro, Cayapozinho, Bonito e Caiapó Grande (CAMPOS, 1912).

Em Mato Grosso, o mesmo prolongamento do mesmo divisor avança até as raias do Paraguai e por ele ocorrem algumas manchas de matas nas cabeceiras dos afluentes setentrionais do Botas e de outros afluentes ocidentais do rio Pardo e pelas cabeceiras do

\footnotetext{
${ }^{15}$ Matas ralas de árvores esguias e ramos tortos, com solos secos e arenosos. Às vezes com tapete de capim.

${ }^{16}$ Catanduvas do sul. Denominação mais ao sul de São Paulo e daí para Estados do sul.

${ }^{17}$ Cerrado sujo.
} 
Anhanduhy e do Vacaria aparecem matas na encosta sul do divisor; para o norte, ocupa as vertentes do Taquary e do Coxim, do Tabôco e do Aquidauana; mais ao norte, as matas ocupam uma faixa quase contínua circundando a grande depressão ou Pantanal do Paraguai (CAMPOS, 1912).

\section{D - Matas Ciliares}

Mata que se limita à faixa que acompanha os rios e seus afluentes. No Amazonas, é a vegetação das "pestanas" dos rios. Atendendo à origem e em correspondência à denominação empregada de "matas pluviais", poderiam ser chamadas de "matas de condensação". No Brasil, tem sido usado o termo "mata de anteparo"; Os botânicos europeus adotam "matas em galeria” (CAMPOS, 1912).

\section{E - Capoeirões, Capoeiras}

Corresponde às matas que não se encontram no estado primitivo; já não são matas virgens, são de segundo crescimento ou capoeirões (CAMPOS, 1912).

\section{F - Pastos}

Este grupo é formado pelos locais em que os traços de mata têm desaparecido quase totalmente; onde a mata é derrubada, queimada para plantar capim para criação ou as espécies mais vigorosas de capim e outras plantas se alastram e dominam vastas áreas onde a mata foi devastada, a exemplo das pastagens com capim Gordura, Jaraguá e Provisório em Goiás, Mato Grosso e Noroeste de São Paulo (CAMPOS, 1912).

II - Campos: este grupo corresponde a áreas com predomínio de vegetação de gramíneas e plantas herbáceas e subdivide-se em:

a) Campinas (campos de várzea e estão presentes nos grupos A; B; C; D);

b) Campos do Sul (campos paleáceos, de vacaria, gerais, em parque, arbóreos e subarbustivos);

c) Campos Cerrados (característicos dos planaltos interiores, ocorrendo em chapadas e tabuleiros).

d) Campos Alpinos (característicos de grandes altitudes e ocorrem de modo acentuado em Minas, na serra do Espinhaço, da Canastra e nos Gerais da Bahia; as plantas que dão cunho alpino são as Velloziáceas com seus gêneros Vellozia e Barbacenia; onde estas ocorrem a altitude é superior a $1000 \mathrm{~m}$ e chegam a ter até de 20 a $30 \mathrm{~cm}$ de diâmetro e até 3 a $4 \mathrm{~m}$ de altura; em Goiás a formação alpina tem grande desenvolvimento na área das chapadas divisoras das bacias do Paranaíba e do Tocantins; de Bomfim 
a Pirenópolis existe uma verdadeira transição de campos cerrados para os campos alpinos e um dos elementos citados é a canela d'ema (CAMPOS, 1912).

\section{III - Caatingas}

Tipo de vegetação especial do nordeste brasileiro e que melhor se caracteriza na parte setentrional da bacia do São Francisco ao norte do paralelo de $10^{\circ}$. Segundo Campos (1912), tanto Martius quanto Warming, ao se referir às características da Caatinga, destacaram a perda de folhas como proteção às secas prolongadas; a caatinga está presente nas Florestas Tropicais e nos Campos Cerrados e é uma mata verde na estação chuvosa (CAMPOS, 1912).

\section{IV - Vegetação Costeira}

Corresponde ao grupo complexo de praias de areia e dunas e da região baixa mais ou menos embrejada que se estende terra adentro por trás das praias cobertas de uma vegetação especial chamada restinga (CAMPOS, 1912).

\section{V - Pantanal}

Vasta depressão com altitudes que variam de 100 a $200 \mathrm{~m}$, cuja zona mais característica está em Mato Grosso, como parte de uma entidade muito maior: o Gran Chaco. Apesar de ser uma zona tipicamente de campo, o Pantanal possui muitas formações vegetais, como a de florestas onde o "carandasal" é muito abundante, perto das margens do rio Paraguai; parques de "paratudal", mais afastados do rio, formados por paratudo (Tecoma caraiba Mart.); nas partes mais embrejadas ocorre a palmeira Mauritia vinifera, porém os buritizais localizam-se mais para o norte, nos pantanais do Miranda, do rio Negro e do Taquari; o "pajoal” é um tipo dos campos paleáceos (campos do sul) que aparecem em volta das depressões; o "espinhal" correspondem às fitas de vegetação seca e espinhenta que aparecem pela orla da baixada e mesmo ao longo de alguns rios; no Pantanal, acham-se representados todos os tipos de vegetação do país, das diversas regiões, exceto os campos alpinos (CAMPOS, 1912).

Depois de Campos (1912), surge a classificação fitogeográfica brasileira de Alberto J. de Sampaio, em 1938. É uma classificação florística com base no sistema geobotânico de Engler. De acordo com Sampaio (1938), a flora brasileira estava dividida em duas grandes Províncias, Amazônica e Extra Amazônica, que podem ser subdivididas:

I - Flora Amazônica ou Hileia Brasileira:

1 - Zona do Baixo Amazônas (da boca do rio Negro ao litoral)

1. Sub-zona sul 
2. Sub-zona norte

2 - Zona do Alto Amazonas (da boca do rio Negro ao Acre)

1. Sub-zona sul

2. Sub-zona norte

II - Flora Extra Amazônica ou Flora Geral (ocupava maior extensão do nosso país e mesmo na Hileia tinha repercussão em campos ali inclusos). Esta flora era composta por:

1- Zona dos Cocais

2- Zona das Caatingas

3- Zona das Florestas Orientais (ou das matas costeiras)

4- Zona dos Pinhais ou Sul Brasileira da Araucária

5- Zona dos Campos

6- Zona Marítima

a. Vegetação Halófila ou do Litoral

b. Flora Insular

1. Das Ilhas Afastadas

2. Das Ilhas Costeiras

c. O Phytoplancton ou flora flutuante

Segundo Sampaio (1938), a flora Amazônica é parte da chamada "Hyleae" de Humboldt, ou seja, desta grande floresta equatorial, que partindo das vertentes orientais dos Andes, estende-se pelo vale do Amazonas e de seus numerosos afluentes, prosseguindo ao norte, na zona do Orenoco e Guianas (SAMPAIO, 1938).

No Brasil a flora Amazônica não se restringe à Amazônia (Acre, Amazonas e Pará), mas, estende-se até às cabeceiras dos afluentes do Amazonas nos Estados do Mato Grosso e de Goiás, e penetra o Maranhão até Imperatriz e, provavelmente, nos médios cursos dos rios Pindaré e Grajaú (SAMPAIO, 1938). Este autor ainda comentou que na flora brasileira, assim como na América do Sul, domina a vegetação campestre, que está presente tanto na Flora Amazônica como em todas as zonas da Flora Geral; entretanto sua área principal é no Brasil Central, ou seja, a zona dos "Campos" e "zona Oreades" de Martius, mas não se restringe ao Brasil Central, uma vez que os campos ocorrem desde o norte da Amazônia ao Arroio Chuí.

Após a classificação de Sampaio (1938), pode-se citar a de Lindalvo Bezerra dos Santos em 1943. Segundo Santos (1943) a paisagem brasileira diversifica-se em grandes 
quadros típicos, tanto pelo seu aspecto da vegetação, quanto pela sua flora; estes quadros podem ser de zonas ou regiões fitogeográficas que no Brasil possuem oito aspectos gerais principais: florestas tropicais, pinhais, cerrados, campinas, caatingas, babaçuais, vegetação litorânea, complexo do Pantanal.

A classificação de Santos (1943) inclui:

\section{I - Florestas Tropicais}

Este quadro é representado por três formações: floresta Amazônica ou Hiléia brasileira, floresta de encosta Atlântica e floresta do vale do rio Paraná.

\section{II - Pinhais}

Os Pinhais de Araucaria angustifolia representam uma grande ocorrência florestal na região dos campos gerais.

\section{III - Cerrados}

As formações campestres revestem, em maior extensão, o planalto brasileiro. O campo é a vegetação dominante na América do Sul e característico do Brasil Centro-Oeste. Tem uma larga dispersão, campos do Alto Rio Branco, campos de Marajó, campos do norte do rio Amazonas (no Pará), na região das Caatingas e no Planalto Meridional (campos Gerais), sendo encontrado no Brasil desde as latitudes setentrionais do Rio Branco até as planícies sulrio-grandenses, assim como afirmou Sampaio (1938). Estas formações campestres apresentam-se sob dois aspectos principais: Cerrados, semelhantes a savanas tropicais, sendo que este é o tipo predominante no Planalto. É comum em Mato Grosso, Goiás e grande parte de Minas, ocorrendo também de modo considerável no Maranhão, Piauí, Bahia, São Paulo, em regiões de clima semiúmido tropical, com estacionalidade climática (SANTOS, 1943).

\section{IV - Campinas}

Ocorrem em áreas com clima dos Cerrados, mas de forma mais extensa em regiões de clima subtropical semiúmido com chuvas distribuídas uniformemente. Estas são soberbamente representadas pelos campos sul-rio-grandenses e constituem a Campanha Gaúcha. No altiplano, ocorrem os campos Gerais com larga ocorrência dispersa no Paraná. No sudeste catarinense, é bem representado pelos campos de Lages e se prolongam pelo nordeste do Rio Grande do Sul com os campos de Vacaria (SANTOS, 1943).

Extensas áreas de campinas também ocorrem no planalto brasileiro entre 10 e $15^{\circ} \mathrm{Sul}$. Esta ocorrência se dá na chapada do divisor de águas Tocantins/São Francisco. No sul de Mato Grosso, destacam-se os campos de Vacaria (SANTOS, 1943). Este autor enfatiza que 
dentro dos Cerrados e das Campinas ocorrem as florestas beira-rio (ciliares ou em galeria) e os capões (ilhas de mata em meio aos campos).

\section{V - Caatingas}

Vegetação de árvores pequenas, arbusto e grande número de cactáceas que compõem um conjunto com aspecto de mato xerófilo, refletindo as condições climáticas. A área de ocorrência das Caatingas é o bloco norte oriental do planalto brasileiro (sertões dos estados nordestinos) A Caatinga possui diversos tipos e, nesta zona, ocorre também a carnaúba (SANTOS, 1943).

\section{VI - Babaçuais}

Superfície de ocorrência predominante da palmeira babaçu que se apresenta em agrupamentos adensados. Os babaçuais ocorrem de modo intercalado entre a floresta Amazônica e a região semiárida das Caatingas nordestinas; entretanto, os maiores adensamentos desses palmeirais estão na planície maranhense, entre o litoral e o planalto, no sentido noroeste/sudeste (SANTOS, 1943).

\section{VII - Vegetação Litorânea}

Estreita faixa de vegetação "beira-oceano", condicionada às particularidades climáticas e dos solos litorâneos; também fazem parte desta zona: os coqueirais, a vegetação de restinga e os mangues (SANTOS, 1943).

\section{VIII - Complexo do Pantanal}

Baixada mato-grossense, entre a borda ocidental do grande planalto e o sulco do rio Paraguai. Do ponto de vista da vegetação, é um complexo com ocorrência de florestas amazônicas, matas de encosta, palmeirais, cerrados, campinas, matas beira-rio, vegetação dos alagados, vegetação aquática, etc. Entretanto, o aspecto mais geral é o campestre, com vários matizes (SANTOS, 1943).

De acordo com Veloso et al. (1991), Santos (1943) pode ser considerado como precursor da fitogeografia fitofisionômica no Brasil, cujas três divisões maiores por ele determinadas (formações florestais, campestres e complexas) foram seguidas pelo Projeto RADAMBRASIL no início da década de 1970. Foi o primeiro a conceituar, de modo correto, o termo "formação", de acordo com seu criador Grisebach. Almeida (2009) considerou que, no campo biogeográfico, foi o primeiro trabalho classificatório da vegetação brasileira.

Em 1963, Carlos Toledo Rizzini estabeleceu uma divisão fitogeográfica baseada nos métodos de Braun-Blanquet que admite, dentro de um reino florístico, quatro categorias de 
territórios regionais (região ${ }^{18}$, província $^{19}$ setor $^{20}$ e distrito ${ }^{21}$ ). Esta divisão considerou o aspecto florístico-vegetacional e foi estruturada em três províncias geobotânicas: Amazônica, Atlântica e Central. Tais províncias se subdividem em sub-províncias e setores. A Província Atlântica composta pelas subprovíncias Nordestina (Agreste, Sertão, Seridó, e Ilha de Fernando de Noronha) e Astro-Oriental (Litoral, Cordilheira, Pinheiral, e Ilha da Trindade); Província Central (Subprovíncia do Planalto Central, Subprovíncia da Depressão Matogrossense, Subprovíncia do Meio Norte); e Província Amazônica (Subprovíncia do Alto Rio Branco, Subprovíncia do Jari-Trombetas, Subprovíncia do Rio Negro, e Subprovíncia da Planície Terciária com cinco setores: Oceânico, Suleste, Setor Sul, Oeste, Sudoeste ou Acre). Esta divisão fitogeográfica foi reafirmada em Rizzini (1997).

Na década de 1960, outros sistemas de classificação fitogeográficos, para o território brasileiro, foram realizados, como o de Lima (1966), com nomenclatura fitogeográficafisionômica e regional, e o de Velloso (1966). Lima (1966) estabeleceu 24 categorias incluindo florestas, campos, dentre outros (Quadro 2.1). Já Veloso (1966)estabeleceu duas grandes categorias (classes de formação e tipos de vegetação), ambas com subdivisões (Quadro 2.2). Tanto no sistema de classificação de Lima (1966) quanto no de Veloso (1966), o Cerrado constituiu uma categoria extra à de campo.

Quadro 2.1 - Sistema de classificação fitogeográfica brasileira de Lima (1966)

\begin{tabular}{|l|l|}
\hline \multicolumn{2}{|c|}{ Categorias fitogeográficas-fitofisionômicas } \\
\hline 1. Floresta de terra firme do baixo Amazonas & $\begin{array}{l}\text { 13. Florestas esclerófilas, caatingas amazônicas e } \\
\text { floresta de restinga }\end{array}$ \\
3. Floresta de terra firme do alto Amazonas & $\begin{array}{l}\text { 14. Floresta xerófila; cerradão } \\
\text { 4. Fapó }\end{array}$ \\
$\begin{array}{l}\text { 15. Cerrados } \\
\text { 5. Hileia bahiana }\end{array}$ & $\begin{array}{l}\text { 16. Mangues } \\
\text { 6. Floresta sub-tropical }\end{array}$ \\
7. Floresta de araucária & 18. Caatinga arbórea densa e Agreste \\
8. Floresta costeira & 19. Caatinga arbustiva densa \\
9. Floresta mesófila & 20. Caatinga arbustiva esparsa \\
10. Floresta de babaçu & 21. Campinas de várzea \\
11. Floresta ciliar de carnaúba & 22. Campos limpos e Pampas \\
12. Floresta serrana & 24. Complexo do Pantanal \\
\hline
\end{tabular}

\footnotetext{
${ }^{18}$ Com várias formações climáticas e endemismos de alto nível, como famílias, tribos e grupos afins.

${ }^{19}$ Distingue-se pela posse de pelo menos uma formação-clímax e gêneros e espécies peculiares.

${ }^{20}$ Definido pela ausência de gêneros endêmicos e presenças de espécies notáveis.

${ }^{21}$ Caracteriza-se por apresentar comunidades raras ou ausentes nas áreas circunvizinhas (serve para designar inclusões de uma vegetação dentro de outra mais ampla).
} 
Quadro 2.2 - Sistema de classificação fitogeográfica brasileira de Veloso (1966)

\begin{tabular}{|l|l|}
\hline \multicolumn{2}{|c|}{ Categorias fitogeográficas-fitofisionômicas } \\
\hline I - Classes de formação & - Floresta pluvial subtropical \\
- Floresta pluvial tropical & 11. Montana de Laureles (Laurel Rainforest) \\
1. Perenifólia Amazônica de várzea & 12. Mista e Coniferales \\
2. Perenifólia Amazônica de planície & \\
3. Semicaducifólia amazônica e perenifólia sul bahiana & II - Tipos de vegetação \\
- Floresta pluvial estacional & 13. Caatinga \\
4. Perenifólia da encosta atlântica do Nordeste & 14. Cerrado \\
5. Perenifólia da encosta atlântica do leste-sul & 15. Campo limpo do planalto Centro-Sul \\
6. Perenifólia da encosta atlântica mista de palmales & 16. Campo limpo da Campanha gaúcha \\
7. Perenifólia do planalto centro-sul & 17. Campo inundável (overflow of praire) \\
- Floresta caducifólia tropical & 18. Campo de altitude (meadow) \\
8. do Nordeste & - Tipos edáficos \\
9. do planalto Centro-Oeste & 19. Mangues-Dunas \\
10. da baixada do Paraguai & 20. Pantanal matogrossense \\
\hline
\end{tabular}

Na década de 1970, foi publicada a obra "Aspectos da vegetação do Brasil” de autoria de Romariz (1974). Nesta publicação, a autora forneceu uma visão mais global da distribuição das principais formações vegetais brasileiras e estabeleceu quatro formações vegetais para o território nacional: formações florestais (floresta latifoliada equatorial, floresta latifoliada tropical, floresta latifoliada tropical úmida da encosta, e mata de Araucária), formações herbáceas (ampos), formações complexas (cerrado, caatinga e complexo do Pantanal) e formações litorâneas (vegetação do litoral).

Nas décadas de 1970 e 1980, a fitogeográfica brasileira teve outra contribuição com a classificação produzida delo Projeto Radambrasil (BRASIL, 1981), que estabeleceu um sistema fitogeográfico fitofisionômico-ecológico brasileiro com 12 categorias, sob a orientação de Henrique Pimenta Veloso e Luis Góes-Filho (Quadro 2.3).

Quadro 2.3 - Classificação fitogeográfica brasileira do Projeto Radambrasil (BRASIL, 1981)

\begin{tabular}{|ll|ll|}
\hline \multicolumn{2}{|c|}{ Categorias fitofisionômico-ecológicas } \\
\hline 1. & Savana (Cerrado e Campos Gerais) & 7. & Floresta Ombrófila Mista \\
2. & Estepe (Caatinga e Campanha Gaúcha) & 8. Floresta Estacional Semidecidual \\
3. Savana Estépica & 9. Floresta Estacional Decidual \\
4. & Vegetação Lenhosa Oligotrófica dos Planaltos & 10. Área das Formações Pioneiras \\
5. & Floresta Ombrófila Densa & 11. Área de Tensão Ecológica \\
6. & 12. Refúgios Ecológicos \\
\hline
\end{tabular}

Veloso e Góes-Filho (1982), a partir da classificação do Radambrasil, apresentaram a "Classificação fisionômica ecológica das formações neotropicais", adaptada ao sistema universal, que incluiu as seguintes categorias:

1- Região ecológica da savana (Cerrado e Campo)

2- Região ecológica da estepe (Caatinga e Campanha Gaúcha) 
3- Região ecológica da savana estépica (vegetação de Roraima)

4- Região ecológica da vegetação lenhosa oligotrófica pantanosa tropica

5- Região ecológicada floresta ombrófila densa (Floresta pluvial tropical) Sendo da 1 à 5 com a subdivisão:

a - Arbórea densa

b - Arbórea aberta

c-Parque

d - Gramíneo-lenhosa

6- Região ecológica da floresta ombrófila Aberta (4 fácies da Floresta Densa) a - Das terras baixas

b - Submontana

c-Montana

7- Região ecológica da floresta ombrófila mista (Floresta das Araucárias)

a - Aluvial

$\mathrm{b}-$ Submontana

c - Montana

d - Alto montana

8- Região ecológica da floresta estacional semidecidual (Floresta Subcaducifólia)

9- Região ecológica da floresta estacional decidual (Floresta Caducifólia)

Da 8 à 9 com as subdiviões:

a - Aluvial

$\mathrm{b}-$ Das terras baixas

c-Submontana

d - Montana

10- Áreas das formações pioneiras

a - Com influência marinha

b - Com influência fluviomarinha

c - Com influência fluvial

11- Áreas de tensão ecológica (contato entre regiões)

11.1 - Com misturas florísticas;

11.2 - Com encraves florísticos

12- Refúgios ecológicos

13- Disjunções ecológicas 
Na década de 1990, Veloso et al. (1991) estabeleceram uma nova classificação da vegetação brasileira, considerando seis sistemas:

\section{I - Sistema fisionômico ecológico, com nove divisões:}

1. Floresta ombrófila densa (Floresta Pluvial Tropical)

O termo "ombrófila densa" foi criado por Ellemberg e Miller Dombois (1965/66) e substituiu "pluvial" (de origem latina) por ombrófila (de origem grega), mas com o mesmo significado "amigo das chuvas" (VELOSO et al., 1991). É um tipo de vegetação caracterizado por fanerófitos (macro e mesofanerófitos), além de lianas e epífitos em abundância. Este tipo vegetacional foi dividido em cinco formações: Formação Aluvial; Formação de Terras Baixas; Formação Submontana; Formação Montana; e Formação Alto Montana (Figura 2.3).

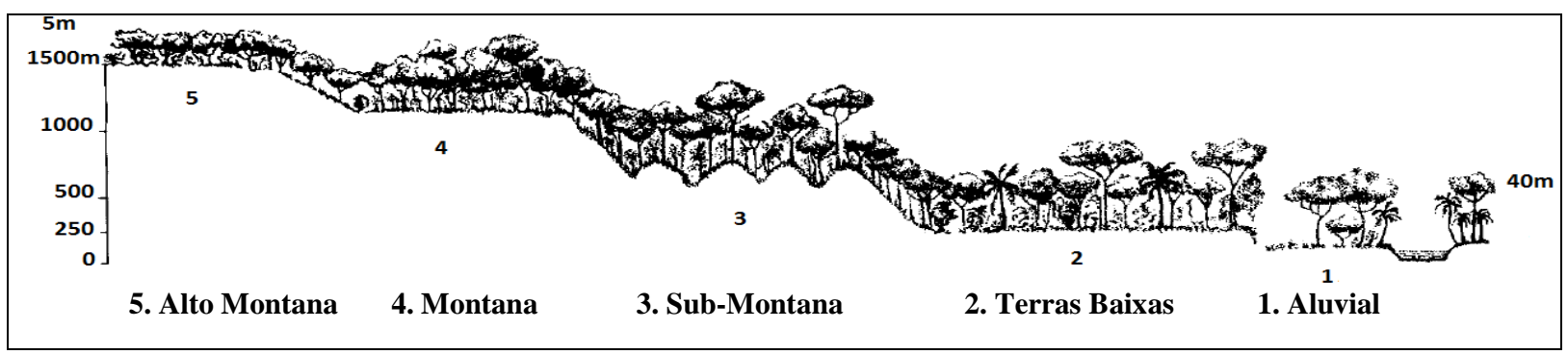

Figura 2.3 - Floresta Ombrófila Densa. Fonte: Adaptado de Veloso et al. (1991)

\section{Floresta Ombrófila Aberta (Faciação da Floresta Ombrófila Densa)}

Antes considerada como transição entre a floresta Amazônica e áreas extraamazônicas. Possui quatro faciações florísticas: com cipó, com palmeira, com bambu e com sororoca (Figura 2.4).

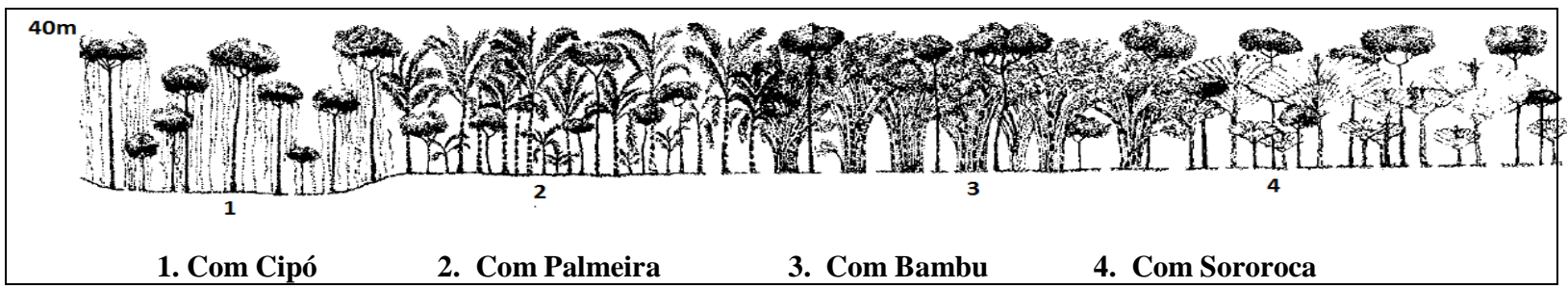

Figura 2.4 - Floresta Ombrófila Aberta (Faciação da Floresta Ombrófila Densa). Fonte: Adaptado de Veloso et al. (1991)

3. Floresta Ombrófila Mista (Floresta de Araucária)

Conhecida como "Mata de Araucária ou Pinheiral", é característica do planalto meridional e apresenta disjunções em refúgios nas serras do Mar e Mantiqueira. A 
composição florística é dominada por Drymis, Araucaria e Padocarpus. Apresenta quatro formações distintas (Figura 2.5): Floresta Ombrófila Mista Aluvial, Floresta Ombrófila SubMontana, Floresta Ombrófila Montana e Floresta Alto Montana (VELOSO et al., 1991).

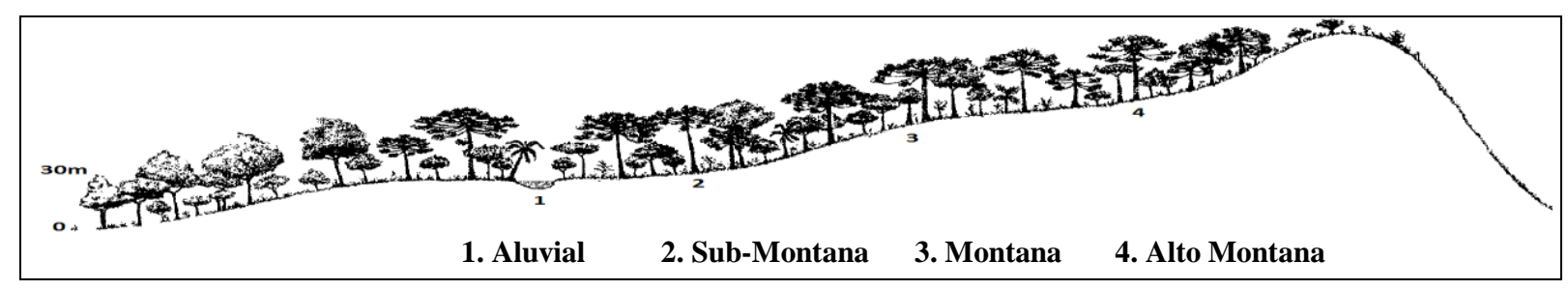

Figura 2.5 - Floresta Ombrófila Mista. Fonte: Adaptado de Veloso et al. (1991)

4. Floresta Estacional Semidecidual (Floresta Tropical Subcaducifólia)

Vegetação condicionada pela dupla estacionalidade climática: uma com intensas chuvas de verão seguidas por estiagens acentuadas e outra subtropical sem período seco, mas com seca fisiológica resultante do intenso frio do inverno com temperaturas médias inferiores a $15^{\circ} \mathrm{C}$, com quatro formações (Figura 2.6): Aluvial, Terras Baixas, Sub-Montana e Montana (VELOSO et al., 1991).

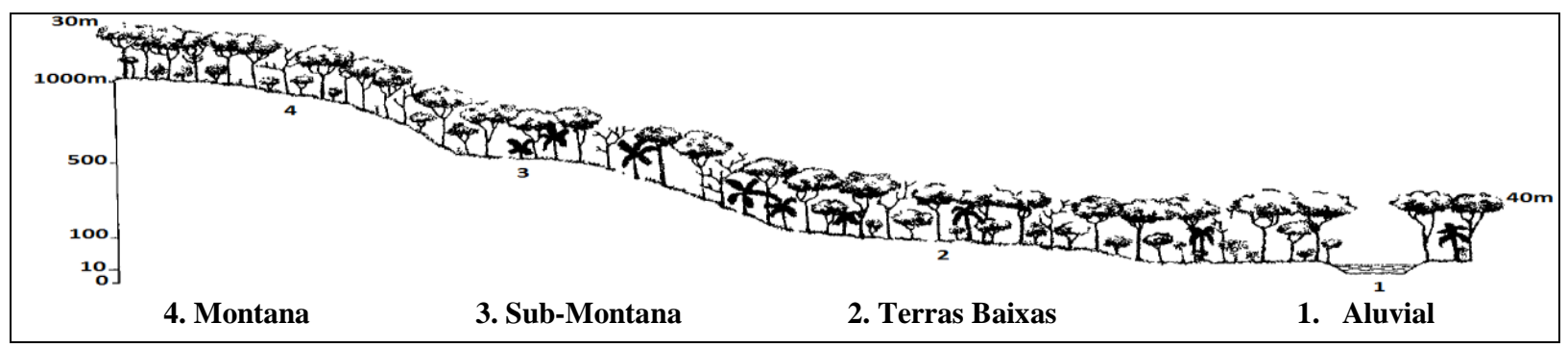

Figura 2.6 - Floresta Estacional Semidecidual. Fonte: Adaptado de Veloso et al. (1991)

\section{Floresta Estacional Decidual (Floresta Tropical Caducifólia)}

Caracterizada por duas estações climáticas bem marcadas: uma chuvosa seguida por um longo período biologicamente seco. Ocorre em forma de disjunções florestais, predominantemente caducifólias com mais de 50\% dos indivíduos sem folhagem no período desfavorável e possui quatro formações (Figura 2.7): Aluvial, Terras Baixas, Sub-Montana e Montana (VELOSO et al., 1991). 


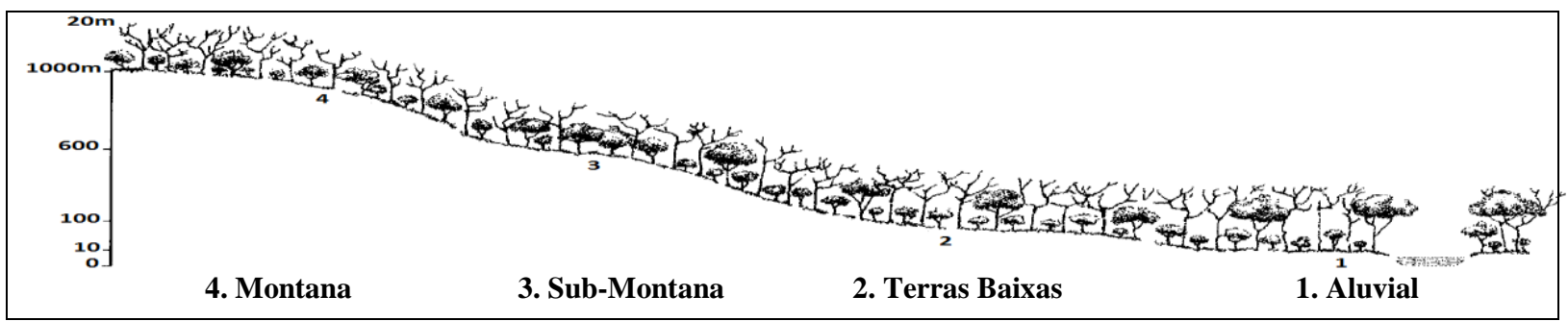

Figura 2.7 - Floresta Estacional Decidual. Fonte: Adaptado de Veloso et al. (1991)

\section{Campinarana (Campina)}

Vegetação típica das bacias dos rios Negro, Orenoco e Branco. Região ecológica que ocorre nos solos Podzol Hidromórfico ${ }^{22}$ e Areias Quartzosa ${ }^{23}$, com predominância florística de ecotipos amazônicos raquíticos com pelo menos um gênero monotípico endêmico, como por exemplo a Barcella odora, da família Palmae, de dispersão pantropical. Esta classe está dividida em três subgrupos de formação (Figura 2.8): Arbórea Densa ou Florestada, Arbórea Aberta ou Arborizada e Gramíneo-Lenhosa (VELOSO et al., 1991).

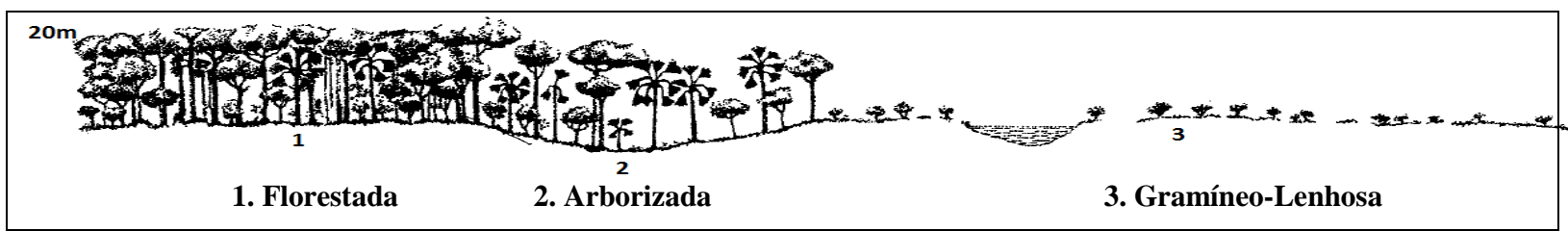

Figura 2.8 - Campinarana. Fonte: Adaptado de Veloso et al. (1991)

\section{Savana (Cerrado)}

Vegetação xeromórfa, preferencialmente de clima estacional com mais ou menos seis meses secos, podendo, não obstante, ser encontrada também em clima ombrófilo. Foi dividida em quatro subgrupos de formação (Figura 2.9): Florestada, Arborizada, Parque e GramíneoLenhosa (VELOSO et al., 1991).

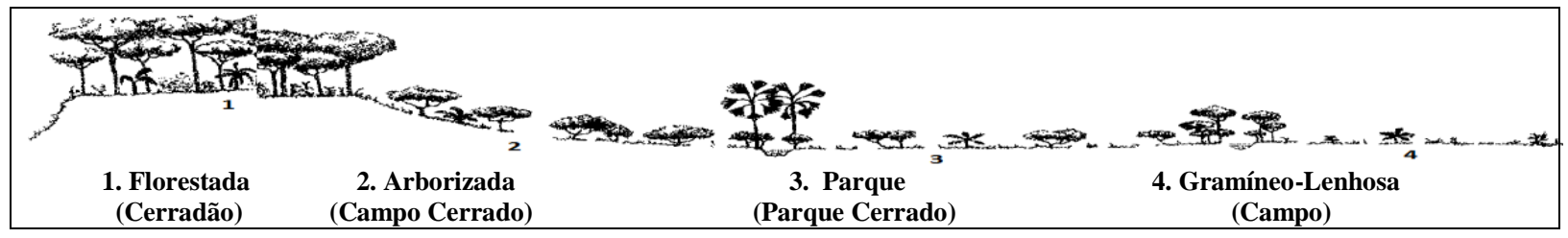

Figura 2.9 - Savana. Fonte: Adaptado de Veloso et al. (1991)

\footnotetext{
${ }^{22}$ No sistema atual de solos EMBRAPA (SANTOS et al., 2006) Podzol Hidromórfico é Espodossolo.

${ }^{23}$ No sistema atual de solos EMBRAPA (SANTOS et al., 2006) Areias Quartzosas é Neossolo Quartzarênico.
} 
8. Savana Estépica (Savana seca e/ou úmidas: Caatinga do sertão árido, Campos de Roraima, Chaco sul-matogrossensegrandense e Parque de espinilho da barra do rio Quari).

O termo foi empregado para denominar a área do "sertão árido nordestino", com dupla estacinalidade climática, sendo uma área disjunta no norte do Estado de Roraima e duas outras áreas chaquenhas disjuntas (uma no extremo sul de Mato Grosso do Sul e outra na barra do rio Quari no Rio Grande do Sul). A Savana Estépica foi subdividida em quatro subgrupos de formação (Figura 2.10): Florestada, Arborizada, Parque, e Gramíneo-Lenhosa (VELOSO et al., 1991).

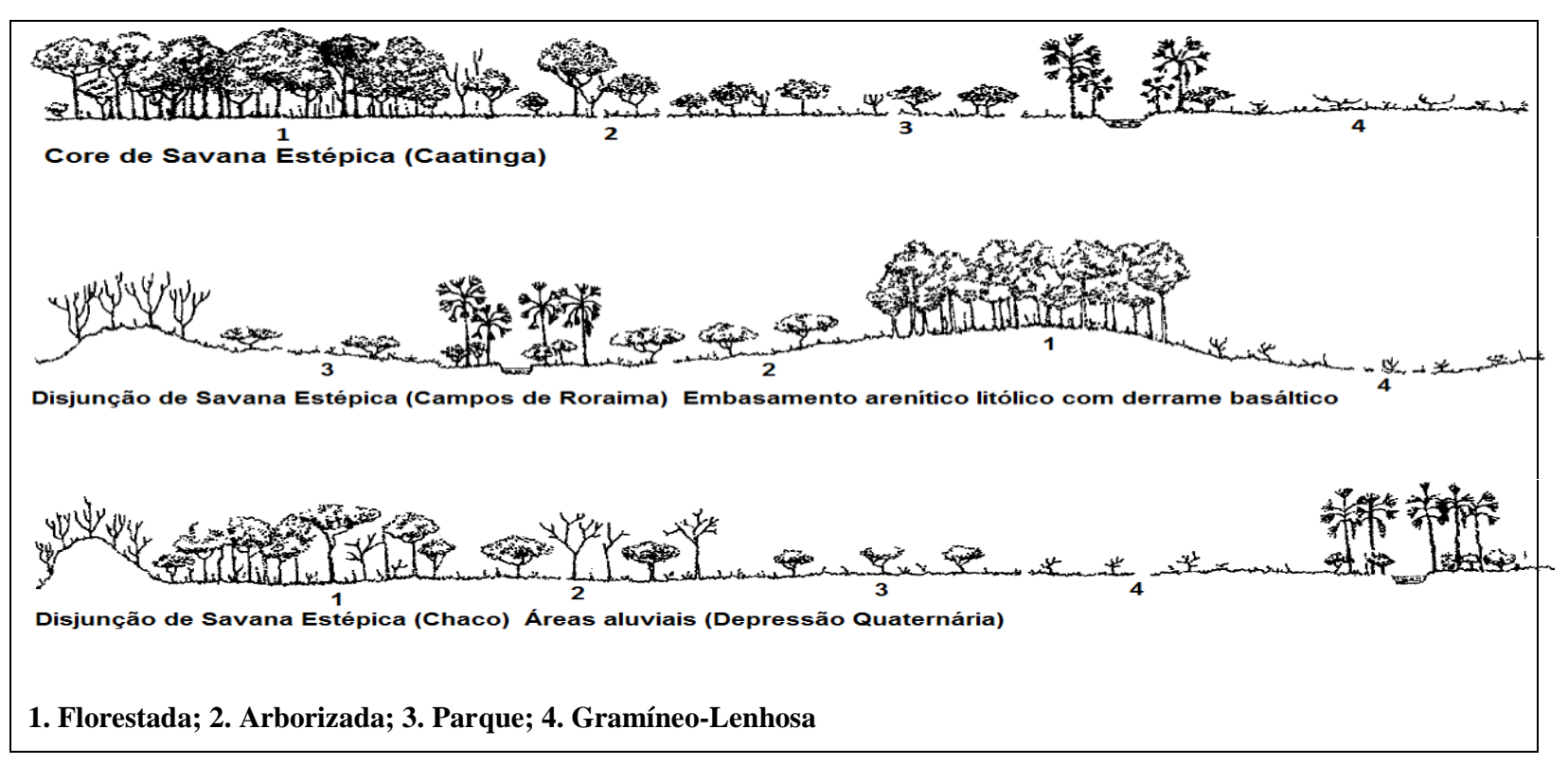

Figura 2.10 - Savana Estépica. Fonte: Adaptado de Veloso et al. (1991)

\section{Estepe (Campos Gerais Planálticos e Campanha Gaúcha)}

Área subtropical onde as plantas são submetidas à dupla estacionalidade climática (uma fisiológica devido ao frio e outra seca com déficit hídrico). Foi dividida em três subgrupos de formação em dois tipos de relevo (Figura 2.11): o pediplano gaúcho e o planalto meridional: Arborizada, Parque, e Garmíneo-Lenhosa (VELOSO et al., 1991). 


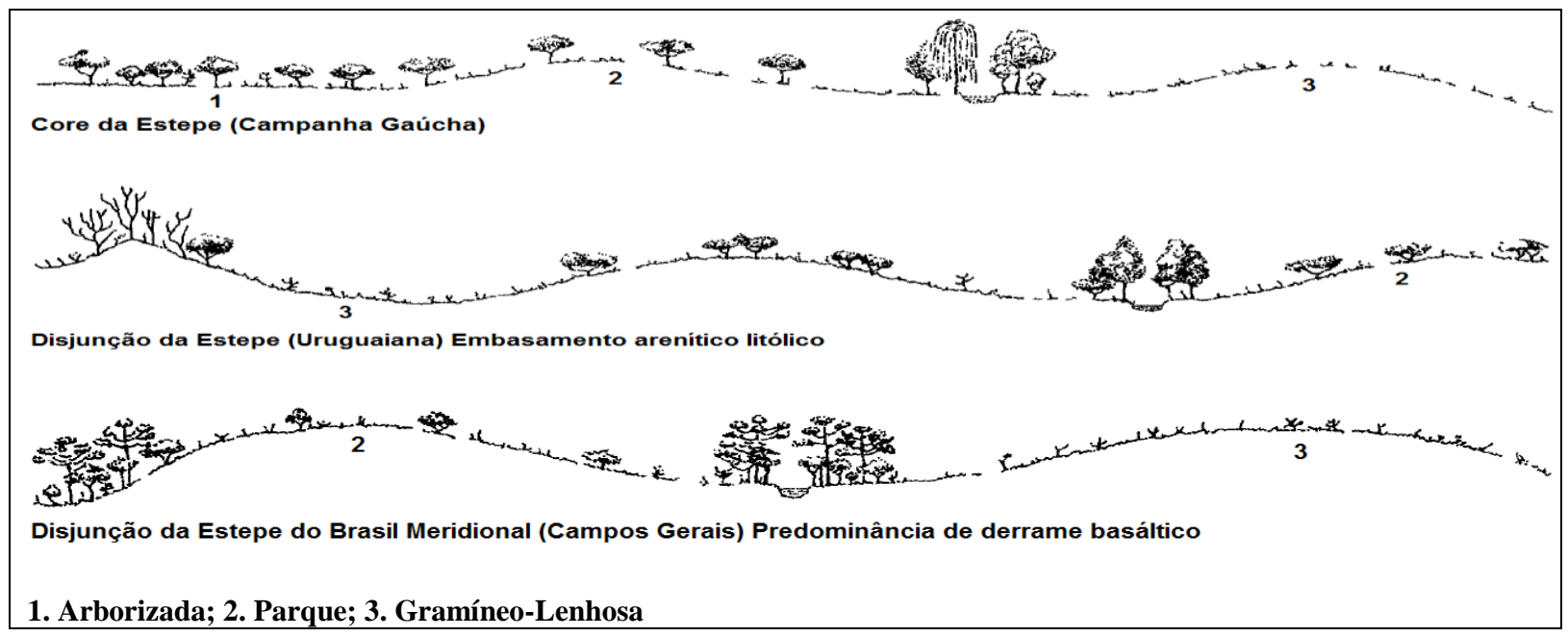

Figura 2.11 - Estepe. Fonte: Adaptado de Veloso et al. (1991)

\section{II - Sistema Edáfico de Primeira Ocupação (Formações Pioneiras)}

São comunidades vegetais consideradas de primeira ocupação de carater edáfico que ocupa terrenos rejuvenecidos pelas seguidas deposições de areias marinhas nas praias e restingas, os aluviões flúviomarinhos nas embocaduras dos rios e os solos aluviais e lacustres. As comunidades pioneiras são (Figura 2.12): comunidades de influência marinha (restinga), podendo estas serem herbáceas, arbustivas e arbóreas; comunidades de influência flúviomarinha, podendo ser herbáceas e arbóreas (mangue); e, comunidades de influência fluvial podendo ser herbáceas, arbustivas e buritizal (VELOSO et al., 1991).

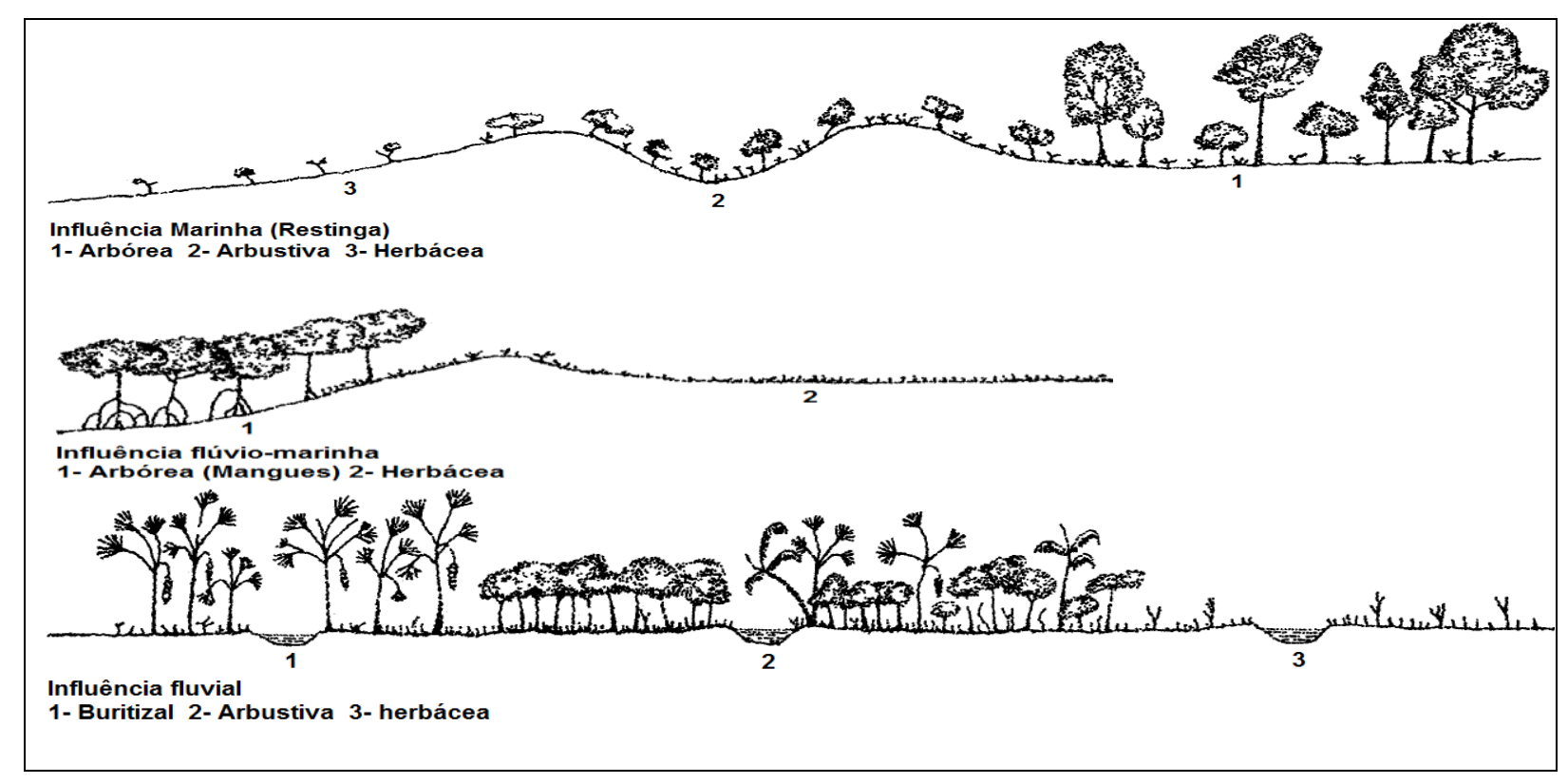

Figura 2.12 - Formações Pioneiras. Fonte: Adaptado de Veloso et al. (1991) 


\section{III - Sistema de Transição (Tensão Ecológica)}

Entre duas ou mais regiões ecológicas ou tipos de vegetação. São comunidades indiferenciadas, onde as floras se interpenetram constituindo as transições florísticas ou contatos edáficos. Constituem ecótonos, que são uma mistura florística entre tipos de vegetação, e encraves, que são áreas disjuntas que se contactam (VELOSO et al., 1991).

\section{IV - Sistema de Refúgios Vegetacionais (Relíquias)}

Toda e qualquer vegetação floristicamente diferente e fisionômico-ecológica também diferente do contexto geral da flora dominante na região ecológica ou no tipo de vegetação. Muitas vezes, os refúgios constituem uma vegetação relíquia, como é o caso das comunidades localizadas acima de $1.800 \mathrm{~m}$ de altitude (VELOSO et al., 1991).

\section{V - Sistema da Vegetação Disjunta}

Diferente de refúgio, disjunções são repetições, em escala menor, de um outro tipo de vegetação próximo que se insere no contexto da região ecológica dominante. Como por exemplo, duas vegetações são ecologicamente disjuntas, sendo uma por influência paleoclimática, como por exemplo as disjunções da floresta mista situadas nas serras da Mantiqueira e da Bocaina), e outra por influência pedológica, como por exemplo a savana cerrado - dos tabuleiros costeiros do Nordeste e do vale do Paraíba do Sul (VELOSO et al., 1991).

\section{VI - Sistema de Vegetação Secundária (tratos Antrópicos)}

Inclui todas as comunidades secundárias brasileiras como:

1) Sucessão natural de várias fases: primeira da sucessão natural, segunda, terceira, quarta e quinta;

2) Uso da terra para a agropecuária tem várias finalidades como: agricultura, pecuária e reflorestamento e/ou florestamento (VELOSO et al., 1991).

Em 1992, o Instituto Brasileiro de Geografia e Estatística (IBGE) lançou o Manual Técnico da Vegetação Brasileira (IBGE, 1992), que estabeleceu o sistema de classificação fitogeográfica vigente, cuja primeira meta foi o sistema de classificação fisionômicoecológica e como segunda meta o sistema de classificação florística. Estabeleceu um sistema 
primário e um sistema secundário. Pode-se dizer que é totalmente baseado no sistema de classificação de Veloso et al. (1991).

O sistema primário (ou natural) inclui todos os tipos de vegetação que estão organizadas em quatro grandes temas, ou seja, Regiões Fitoecológicas Brasileiras, Formações Pioneiras, Refúgios Vegetacionais e Faixas de Tensão Ecológica (IBGE, 1992), como se segue:

1 - Regiões Fitoecológicas

1.1 Floresta Ombrófila Densa (Floresta Pluvial Tropical)

1.2 Floresta Ombrófila Aberta

1.3 Floresta Ombrófila Mista (Floresta de Araucária)

1.4 Floresta Estacional Semidecidual (Floresta Tropical Subcaducifólia)

1.5 Floresta Estacional Decidual (Floresta Tropical Caducifólia)

a) Floresta Estacional Decidual Aluvial

b) Floresta Estacional Decidual das Terras Baixas

c) Floresta Estacional Decidual Submontana

d) Floresta Estacional Decidual Montana

1.6 Campinarana (Campinas)

a) Florestada

b) Arborizada

c) Gramíneo-Lenhosa

1.7 Savana (Cerrado)

a) Savana Florestada

b) Savana Arborizada (campo cerrado)

c) Savana Parque

d) Savana Gramíneo-Lenhosa

1.8 Savana Estépica (Caatinga)

a) Savana Estépica Florestada

b) Savana Estépica arborizada

c) Savana Estépica Parque

d) Savana Estépica Gramíneo-Lenhosa

1.9 Estepe (Campos Gerais Planálticos e Campanha Gaúcha)

a) Estepe Arborizada

b) Estepe Parque 


\author{
c) Estepe Gramíneo-Lenhosa
}

2. Áreas de Formações Pioneiras

2.1 Vegetação com influência marinha (restinga)

2.2 Vegetação com influência flúvio marinha (manguezal e campo salino)

2.3 Vegetação com influência fluvial (comunidades aluviais) ao longo do litoral como nas planícies fluviais e ao redor das depressões aluvionares em terrenos instáveis cobertos de vegetação em constante sucessão. Trata-se de uma vegetação de primeira ocupação de carater edáfico.

3. Áreas de Tensão Ecológica (vegetação de transição)

3.1 Ecotonos (mistura florística entre tipos de vegetação)

3.2 Encraves (áreas disjuntas que se contactam)

4. Refúgios Vegetacionais (comunidades relíquias): toda e qualquer vegetação floristicamente diferente, como o caso de comunidades localizadas em altitudes acima de $1800 \mathrm{~m}$.

O sistema secundário (ou antrópico) inclui todas as comunidades secundárias brasileiras, isto é, são as áreas nas quais houve intervenções humanas para o uso da terra com finalidades diversas como mineração, agricultura, pecuária e descaracterização da vegetação primária. Estas áreas, após serem abandonadas do uso antrópico, reagem de acordo com o tempo e o uso, mas a vegetação que surge sempre reflete os parâmetros ecológicos do ambiente por meio do processo de sucessão ecológica natural. Tal processo tem várias fases (primeira, segunda, terceira, quarta e quinta fases).

Além da sucessão ecológica natural, existem os usos da terra pela agropecuária que incluem agricultura e pecuária (pastagem) e pelo reflorestamento, como por exemplo de Eucalyptus e de Pinus (IBGE, 1992).

Outras classificações com o sentido de regionalização do território brasileiro podem ser citadas por terem como um dos seus critérios de estabelecimento a vegetação, como é o caso dos Domínios Morfoclimátios (AB’ SABER, 1971; 2003), Biomas (IBAMA, 2012) e Ecorregiões (DINNERSTEIN, 1995).

Percebe-se que não há um consenso para a nomenclatura regional do Cerrado na literatura científica, que ora é considerado domínio, ora bioma, e mais recentemente ecorregião. A esse respeito já existem discussões na literatura científica e as principais discussões giram em torno dos termos domínio e bioma, tendo sido realizadas por Coutinho (2006) e Batalha (2011), que consideram o Cerrado como um domínio. 
Segundo Ab'Saber (1971, 2003), o território brasileiro, tendo em vista a sua magnitude espacial, comporta um mostruário bastante completo das principais paisagens e ecologias do mundo tropical. Ele reconheceu seis grandes domínios paisagísticos e macroecológicos em nosso país, quais sejam, Amazônico (domínio das terras florestadas da Amazônia), Cerrado (chapadões tropicais interiores com cerrados e florestas-galeria), Mares de Morros (áreas mamelonares tropicais-atlânticas florestadas), Caatingas (depressões intermontanas e interplanálticas semiáridas), Araucárias (planaltos subtropicais com araucárias) e Pradarias (coxilhas subtropicais com pradarias mistas), existindo entre estes, as faixas de transição (Figura 2.13).

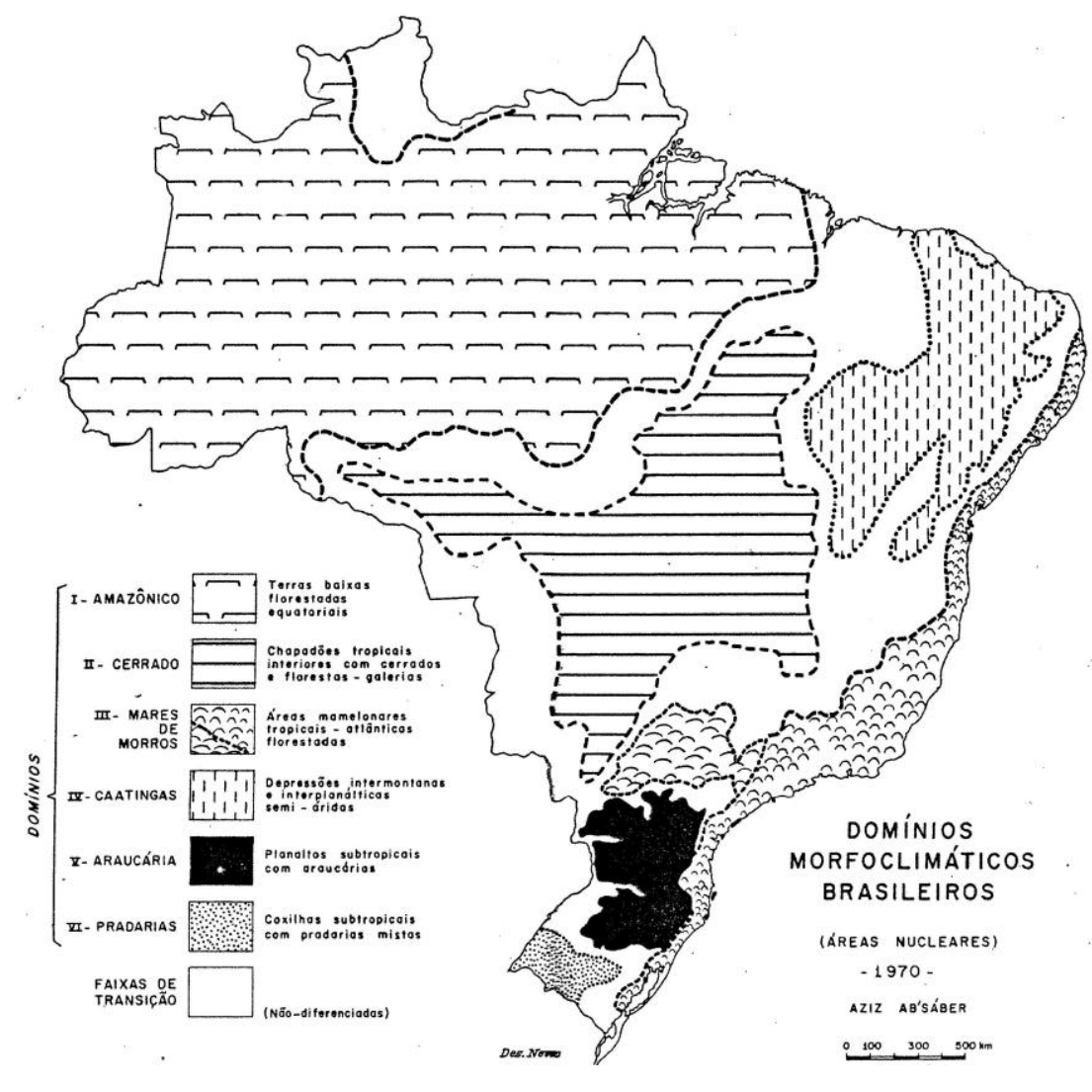

Figura 2.13 - Domínios morfoclimáticos brasileiros. Fonte: Ab’ Saber, 2003

Estes grandes domínios foram definidos pelos principais quadros de vegetação e por feições morfoclimáticas de grande extensão e generalidade. Cada um deles apresenta padrões de paisagens, de caráter sub-regional e eventuais enclaves de paisagens exóticas, sob a forma de recorrência de paisagens vegetais relacionadas a outros domínios de paisagem vegetal (AB'SABER, 1971). 
Considerando escalas regionais, outra classificação foi estabelecida pelo Instituto Brasileiro do Meio Ambiente e dos Recursos Naturais Renováveis (IBAMA), resultando no Mapa de Biomas do Brasil como produto do termo de cooperação assinado entre o IBGE e o Ministério do Meio Ambiente em agosto de 2003. Os biomas brasileiros são: Amazônia, Mata Atlântica, Caatinga, Cerrado, Pantanal e Pampa (Figura 2.14).

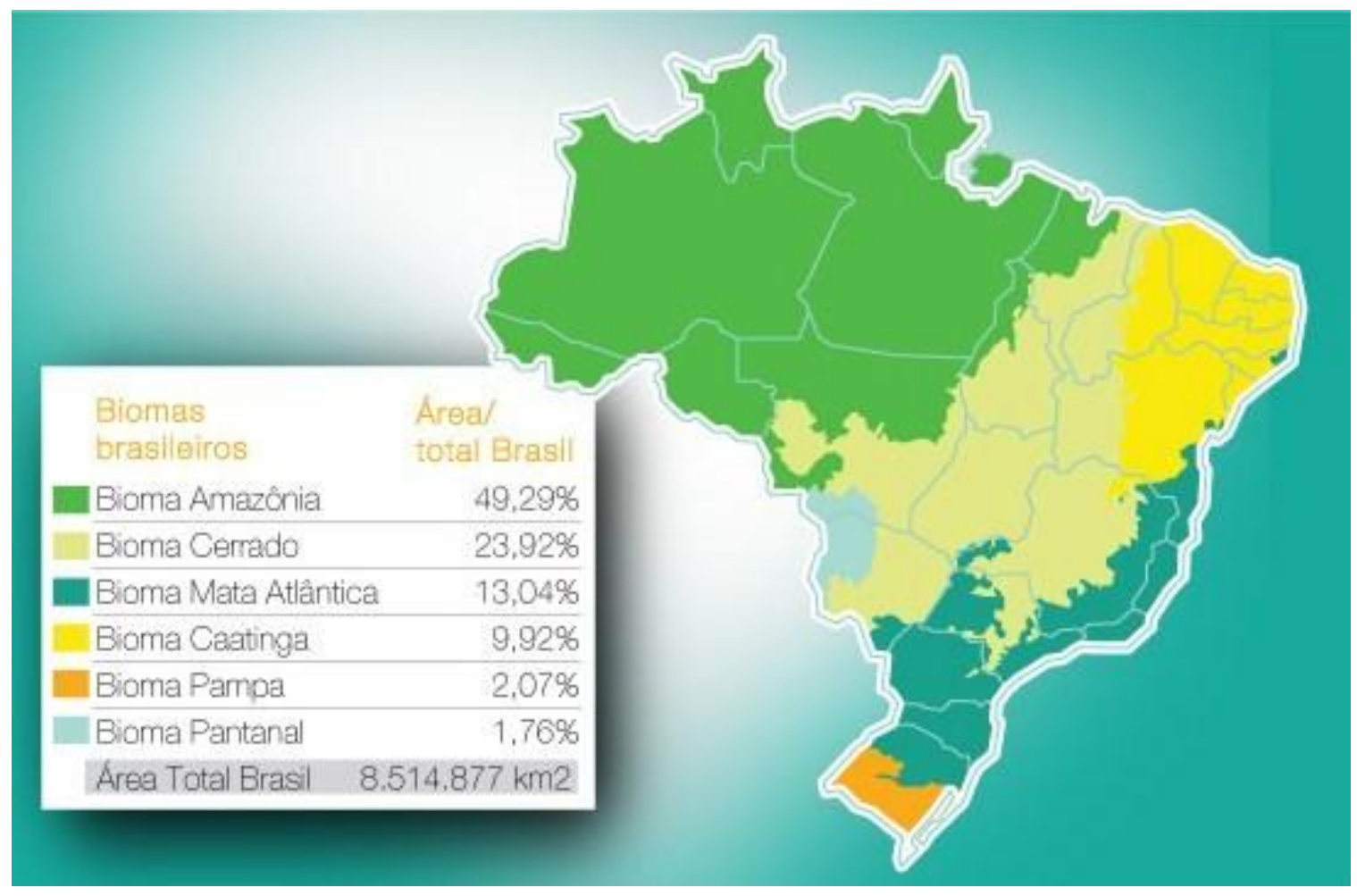

Figura 2.14 - Mapa de biomas brasileiros. Fonte:

http://www.brasil.gov.br/infograficos/biomas-brasileiros/image_galeria5. (Acesso: 22 jul. 2013)

Bioma é conceituado como um "conjunto de vida vegetal e animal, constituído pelo agrupamento de tipos de vegetação contíguos e que podem ser identificados a nível regional, com condições de geologia e clima semelhantes e que, historicamente, sofreram os mesmos processos de formação da paisagem, resultando em uma diversidade de flora e fauna própria" 24 .

Segundo Arruda et al. (2008) e com o objetivo de conservação da biodiversidade brasileira, uma ação conjunta em 1998 do IBAMA, Ministério do Meio Ambiente (MMA) e as principais organizações não governamentais (ONGs) de cunho conservacionista e atuantes no Brasil (World Wildlife Fund - WWF, The Nature Conservance - TNC, Conservation

\footnotetext{
${ }^{24}$ Disponível em: < http://7a12.ibge.gov.br/vamos-conhecer-o-brasil/nosso-territorio/biomas $>$. Acesso em 22 jul. 2013.
} 
International - CI - e Biodiversitas) resultou na divisão dos biomas brasileiros em 33 ecorregiões $^{25}$, tendo como base a metodologia de Dinerstein et al. (1995). Depois, outro estudo de 2003, também coordenado pelo IBAMA, sugeriu a divisão dos mesmos biomas em 74 ecorregiões, sendo o Cerrado subdividido em 22 ecorregiões.

Também de acordo com Arruda et al. (2008), o Cerrado pode ser subdividido em 22 ecorregiões, o que mostra uma grande diversidade de ambientes físicos (Figura 2.15).

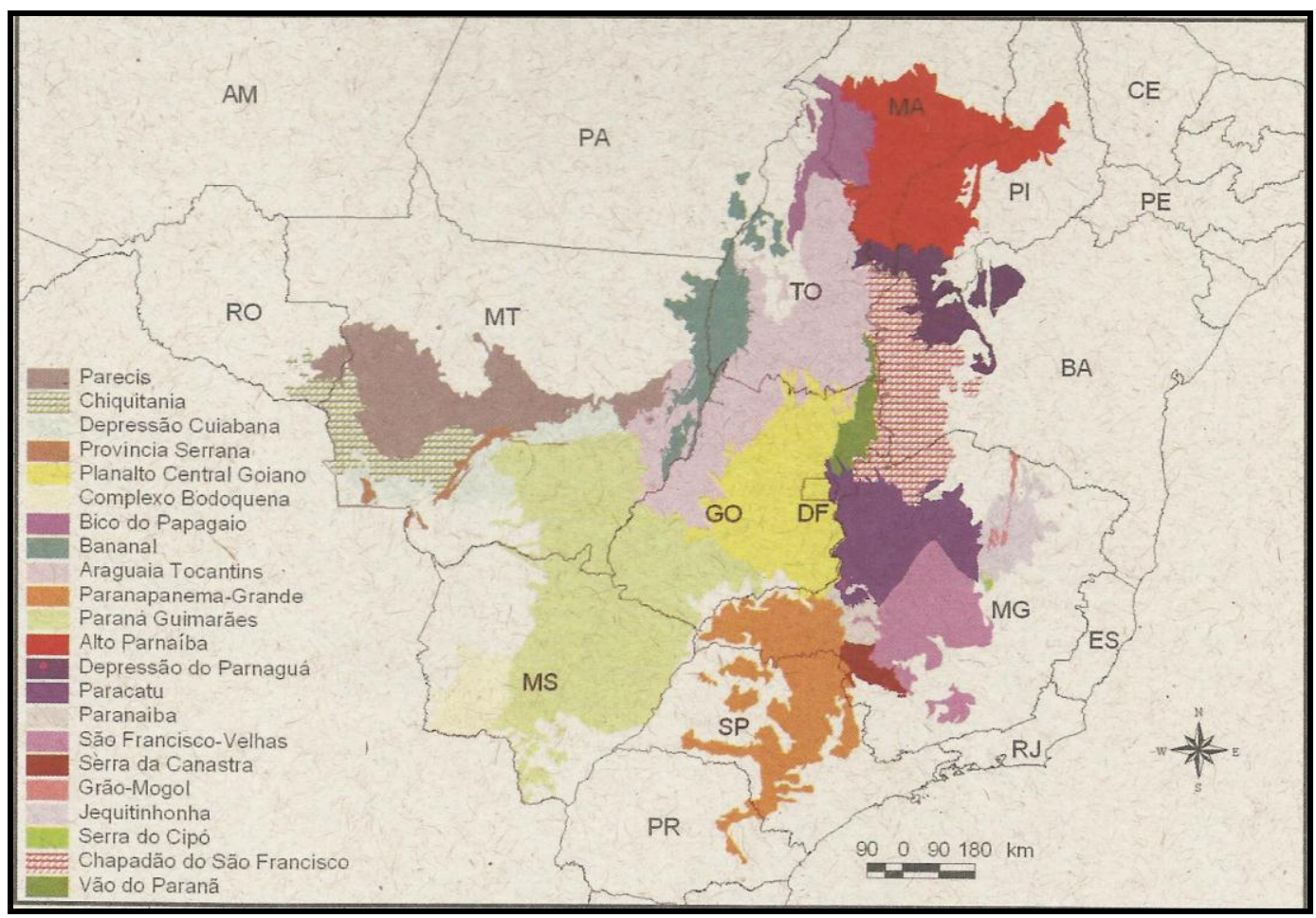

Figura 2.15- Mapa das 22 ecorregiões do Cerrado. Fonte: Arruda et al. (2008)

Em estudo específico para apenas a área contínua do Cerrado, Pinheiro et al. (2008) sugeriram 21 ecorregiões (Figura 2.16).

\footnotetext{
${ }^{25}$ Ecorregião: "Um conjunto de comunidades naturais, geograficamente distintas, que compartilham a maioria das suas espécies, dinâmicas e processos ecológicos, e condições ambientais similares, nas quais as interações ecológicas são críticas para sua sobrevivência em longo prazo"(DINERSTEIN ET al., 1995).
} 


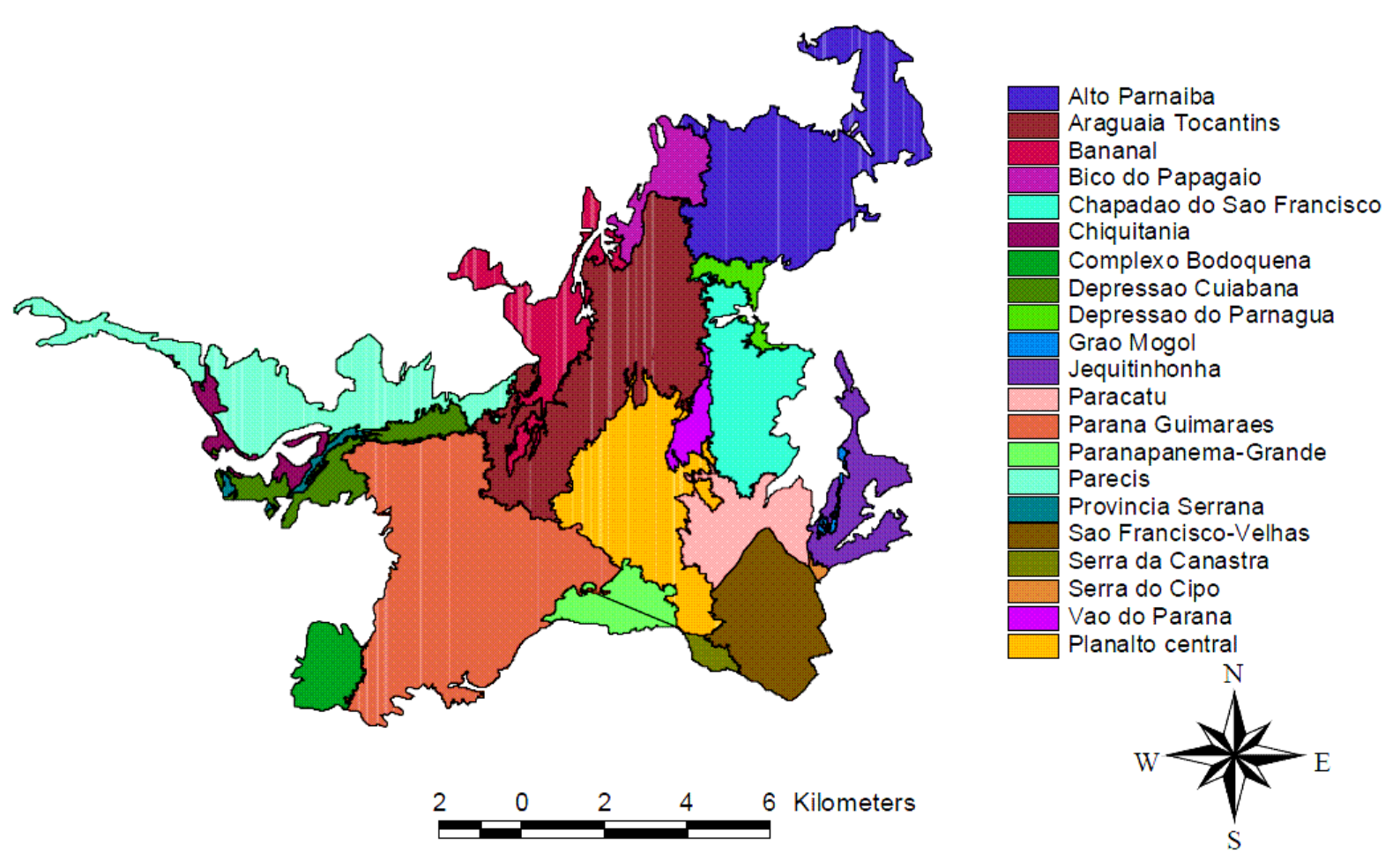

Figura 2.16 - Ecorregiões no Cerrado contínuo. Fonte: Pinheiro et al. (2008)

Como se pôde constatar, somente a partir de meados do século XX, com Santos (1943), o Cerrado estabeleceu-se nos sistemas de classificação das floras do Brasil, com a denominação de "Cerrado", evidenciando o avanço e a ampliação da visão dos geobotânicos do país, nas suas propostas de regionalização fitogeográfica, pois antes dessa época estava sempre inserido em uma divisão espacialmente mais abrangente, na categoria campestre, o que é uma herança dos naturalistas do século XIX que, em suas descrições de viagens ao Brasil Central, o Cerrado era concebido como campo por se tratar de uma vegetação mais aberta, diferente da Mata Atlântica (primeira impressão da vegetação brasileira aos estrangeiros que chegavam ao Brasil); o termo Cerrado apareceu nas descrições dos campos quando estes se apresentavam mais fechados, a exemplo dos escritos de Warming : "A três ou quatro dias de Lagoa Santa, a vegetação tornou-se mais abundante e, em volta de Lagoa Santa, havia muitos campos cerrados, isto é, sobretudo campos fechados" (KLEIN, 2002, p. 69).

\subsubsection{Fitogeografia do Cerrado}

O Cerrado constitui um dos domínios morfoclimáticos na classificação de Ab'Saber (1971; 2003) e conta com muitos estudos que estabeleceram classificações fitofisionômicas. 
Dentre os viajantes naturalistas que adentraram o Brasil Central, somente com Löfgren (1898 apud WALTER, 2006, p.69) ${ }^{26}$ é que o termo "Cerrado" passou a ser empregado como fisionomia, havendo, portanto, a primeira adoção formal da palavra "cerrado", com o sentido fitofisionômico, que se mantém até hoje, e o estabelecimento da primeira sequência clássica em uso atual: Cerradão (caatanduva), Cerrado (propriamente dito) e Campo Cerrado (caatininga) como se pode observar nos seus escritos:

\begin{abstract}
"Os Cerrados pouco se distingue dos Cerradões, e suas principais differenças consistem no porte menor das arvores que são alli mais contorcidas; no augmento dos vegetais de casca suberosa e folhas coriaceas e na maior quantidade de plantas herbaceas. Formam a tansição para o Campo Cerrado, ou caatininga, onde há ainda maior quantidade de plantas herbáceas, árvores mais baixas e contorcidas ainda tornando-se cada vez mais espaçada a vegetação alta, começando pouco a pouco, a predominância dos vegetais sublenhosos até transformar-se na vegetação particular e característica do Campo Limpo". (LÖFGREN,1898 apud WALTER, 2006, Capítulo 2, p. 69$)^{15}$.
\end{abstract}

No século XIX, além de Löfgren, Warming $(1973)^{27}$ deu importantes contribuições para o conhecimento a respeito da flora do Cerrado com seus estudos em Lagoa Santa (MG). Parte da sua obra é relacionada aos campos, cujos estudos deveriam ser em três degraus: a) a vegetação herbácea e subarbustos; b) os arbustos; c) as árvores. Foi o primeiro a relacionar o termo savana ao Cerrado: "Os brasileiros chamam essa paisagem de Campo, isto é, campo de gramíneas; os espanhóis a chamam Savana” (KLEIN, 2002, p. 67).

Após isso, existiram outras tentativas de estabelecer uma classificação fitofisionômica para o Cerrado brasileiro, dentre elas a de Eiten (1993), que estabeleceu tipos de interflúvio com ocorrência de cerrado (cerradão, cerrado sentido restrito, campo cerrado, campo sujo, e campo limpo), floresta mesofítica de interflúvio, campo rupestre, campos litossólicos miscelâneos, vegetação de afloramento de rocha maciça; e tipos associados a cursos d'água como florestas galeria e florestas de encosta associadas, buritizais e veredas, campo úmido, brejos permanentes, pantanal, e plantas aquáticas e brejeiras.

Ferri (1977) distinguiu diferentes tipos de cerrado no território brasileiro, estando estes agrupados em duas principais áreas, a área core, essencialmente de cerrados no Planalto Central (Estados de Mato Grosso, Goiás, Distrito Federal, e Minas Gerais), e a área periférica no Norte (região Amazônica), no Nordeste (região das caatingas) e no Sul, ocorrendo seus últimos vestígios no Paraná. Ferri reconheceu também áreas reduzidas de cerrado em Rondônia, Paraíba e Pernambuco. Ele descreveu a vegetação de cerrado em três grupos: o das

\footnotetext{
${ }^{26}$ Löfgren, A. Ensaio para uma distribuição dos vegetais nos diversos grupos florísticos no estado de São Paulo. São Paulo, 1898.

${ }^{27}$ Obra reeditada a partir do original de 1892.
} 
plantas permanentes, que reúne todas as árvores e muitos arbustos que possuem sistemas radiculares profundos (Anacardium pumilum e Andira humilis); o das espécies efêmeras composto pelas plantas herbáceas (Ipomoea procumbens, Gomphrena prostata, Vernonia grandiflora); e o grupo das gramíneas que podem ser permanentes ou efêmeras, dependendo da duração do seu ciclo de vida.

Ferri (1977) também descreveu a vegetação arbustivo-arbórea do cerrado com características bem peculiares, como a presença de galhos tortuosos, casca grossa, folhas coriáceas, de superfície brilhante, com aspectos de envernizadas ou revertidas por pelos ou escamas, e de viverem em um ambiente com escassez de água. Mas, igualmente chamou atenção para a existência de espécies que não possuem características de adaptação às condições de seca, como é o caso de Tocoyena formosa, Kielmeyera coriacea, dentre outras; Dimorphandra mollis e Stryphnodendron barbadetinam, por exemplo, que possuem um limbo enorme, dividido e subdividido em folíolos mais ou menos numeroso; e, ao fato de muitas espécies produzirem muitas flores e brotos vegetativos em plena estação seca, antes das chuvas.

Coutinho (1978) considerou o cerrado lato sensu como um complexo de formações oreádicas, que inclui três biócoros: biócoro de campo composto pelas formações campestres (campo limpo); biócoro de savana composto pelas formações savânicas ecotonais (campo sujo, campo cerrado, cerrado stricto sensu); e biócoro de floresta com formação florestal (cerradão).

Rizzini (1979), tratando da vegetação brasileira, ao se referir à área do cerrado, mencionou matas secas, cerradão, savana (termo análogo para o cerrado), reconhecendo quatro tipos de savanas, com: estrato arborescente com 8-20 m de altura e cobertura arbórea raramente de 40\%; estrato arbustivo com 2-7 m, mais denso, podendo alcançar $60 \%$ de cobertura; estrato herbáceo superior, até $2,5 \mathrm{~m}$, com gramíneas, subarbustos e arbustos pequenos, chegando a 100\% de cobertura na estação favorável; e, estrato herbáceo inferior, chegando a $1 \mathrm{~m}$ de altura, dominado por gramíneas, ciperáceas e leguminosas. Este mesmo autor também reconhecer a existência de campo limpo da área central ou campos centrais de ocorrência em Minas e Goiás ou da periferia (Matogrosso, São Paulo e Bahia), distinguindo cinco tipos: a) campo ferruginoso que inclui campo de canga couraçada e campo de canga nodular; b) campo quartzítico, sendo campo quartzítico com gramíneas, campo quartzítico com gramíneas e subarbustos, e campo quartzítico das afloramentos; c) campos gerais, campo planáltico; d) campo arbustivo. 
Ribeiro et al. (1983) consideraram as fisionomias de mata de galeria, mata mesofítica, cerradão, cerrado (cerrado denso, cerrado típico, errado ralo, parque cerrado, e vegetação rupestre de altitude), campo sujo campo limpo e vereda, cujos parâmetros para diferenciação entre as fitofisionomias foram: a estrutura da vegetação (altura, estratificação, percentagem de cobertura arbórea) e as características do solo (grau de umidade, profundidade e afloramento de rochas).

Radambrasil, publicado em Veloso et al. (1991), estabeleceu uma Região Ecológica da Savana, incluindo Cerrado e Campo com fisionomias arbórea densa, arbórea aberta, parque e gramíneo-lenhosa. Veloso et al. (1991) e IBGE (1992) adotaram também o termo Savana para o Cerrado, com a seguinte classificação: Savana florestada (cerradão), Savana arborizada (campo cerrado), Savana parque (parque cerrado) e Savana gramíneo-lenhosa (campo), como já descrito anteriormente.

Mais recentemente, Ribeiro e Walter (1998; 2008) adotaram e ampliaram a classificação definida por Ribeiro et al. (1983), que utilizou uma nomenclatura mais simples e termos regionais consagrados, em que os critérios adotados para diferenciar os tipos fitofisionômicos foram baseados na fisionomia (forma), que é definida pela estrutura, pelas formas de crescimento dominantes e por possíveis mudanças estacionais. Este autores também consideraram os aspectos do ambiente (fatores edáficos) e a composição florística, descrevendo 11 tipos fitofisionômicos gerais inclusos em: formações florestais (mata ciliar, mata galeria, matas secas e cerradão); formações savânicas (cerrado sentido restrito, parque cerrado, palmeirais e veredas); e, em formações campestres (campo sujo, campo limpo e campo rupestre). Muitos dos tipos gerais apresentam subtipos.

Haidar et al. (2013) reconheceram apenas três regiões fitoecológicas para o Estado do Tocantins (Florestas, Savanas e Formações Pioneiras), com cerca de 20 tipos de vegetação (fitofisionomias), e destacam a dominância do Cerrado Stricto Sensu, além de encraves e ecótonos.

1- Florestas:

1.1 - Floresta Estacional Semidecidual (Aluvial; Terras Baixas, Submontana; Montana);

1.2 - Floresta Estacional Decidual (Submontana; Montana)

2- Savana (Cerrado):

2.1 - Savana Florestada (Cerradão)

2.2 - Savana Arborizada

- Cerrado Denso com Mata de Galeria e Cerrado Denso sem Mata de Galeria 
- Cerrado Típico com Mata de Galeria e Cerrado Típico sem Mata de Galeria

- Cerrado Rupestre com Mata de Galeria e Cerrado Rupestre sem Mata de Galeria

- Cerrado Inundável com Mata de Galeria e Cerrado Inundável sem Mata de Galeria

2.3 - Savana Parque

- Parque Cerrado Inundável com Murundu

- Campo Sujo Seco e Campo Sujo Úmido

- Cerrado Ralo com Mata de Galeria e Cerrado Ralo sem Mata de Galeria

2.4 - Savana Gramíneo-lenhosa

-Campo Limpo Seco, Campo Limpo Úmido e Campo Limpo com Murundu

3 - Formação Pioneira

3.1 - Formação Fluvial Lacustre

4 - Áreas de Contato (Encrave)

- Cerrado/ Floresta Estacional

5- Áreas de Contato (Ecótono)

- Floresta Estacional/Floresta Ombrófila

O Cerrado no Estado do Tocantins está dentre as regiões fitoecológicas na regionalização estabelecida por SEPLAN (2012) e ocupa maior área do Estado (181.092,423 $\left.\mathrm{km}^{2}-65,23 \%\right)$ seguido pela Floresta Estacional $\left(36.350,441 \mathrm{~km}^{2}-13,09 \%\right)$, Encrave Cerrado/Floresta Estacional $\left(21.460,361 \mathrm{~km}^{2}-7,73 \%\right)$, Ecótono Floresta Estacional/Floresta Ombrófila (19.638,205 km² -7,07\%), Floresta Ombrófila (14.706,479 km² - 5,30\%), e Encrave Cerrado/Floresta Ombrófila (616,232 km² - 0,22\%) (Figura 2.18).

Em termos comparativos com outros trabalhos que quantificam áreas para a vegetação do Tocantins, utilizou-se SEPLAN (2012) para esta comparação (Figura 2.17; Tabela 2.1). 


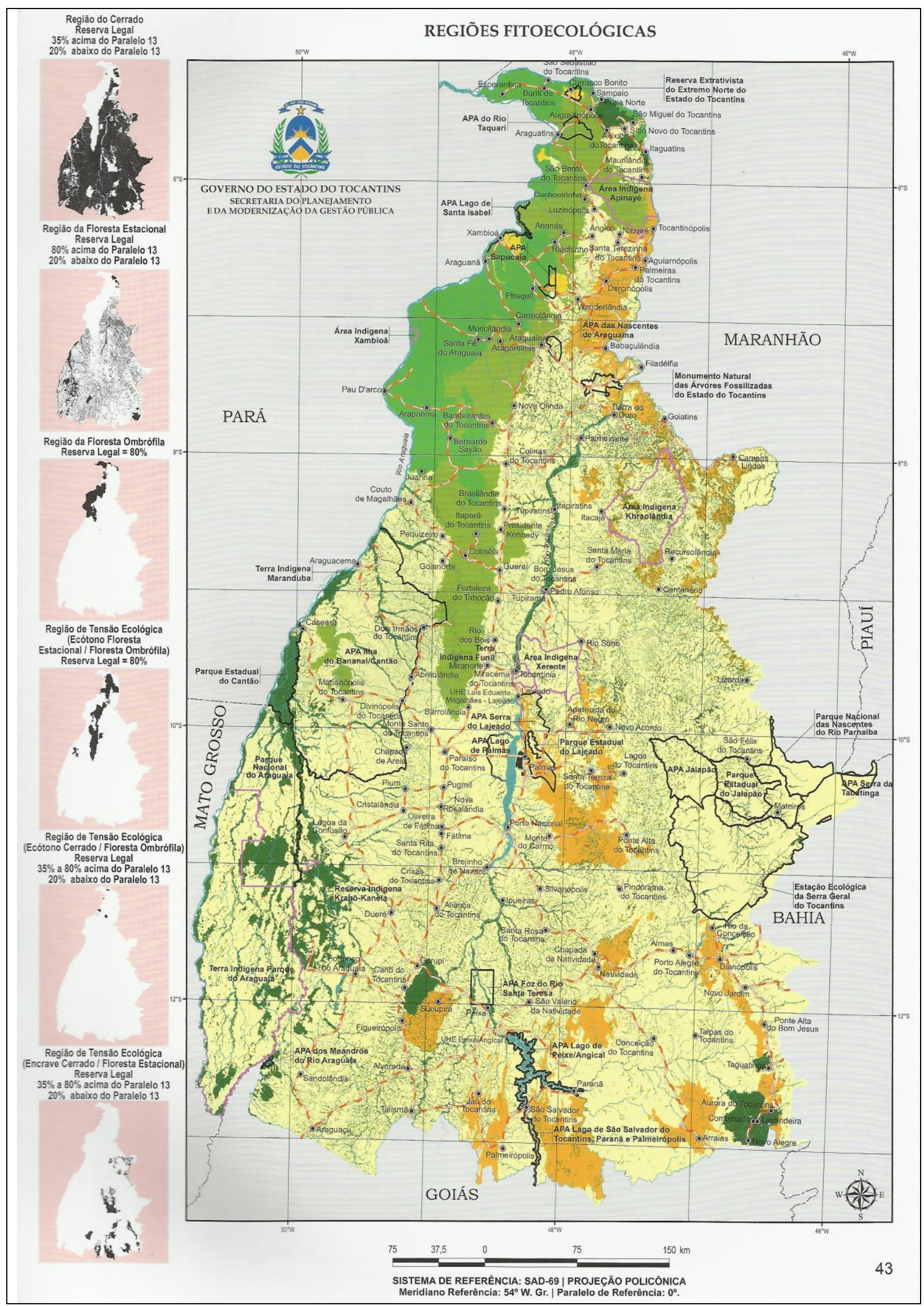

Figura 2.17 - Regiões fitoecológicas do Estado de Tocantins. Fonte: SEPLAN (2012) 
Trabalhos envolvendo mapeamentos do Cerrado atribuem outros valores de áreas para tipos de formação vegetal para o Estado do Tocantins, como por exemplo, Machado et al. (2004) e Sano et al. (2007), como pode ser visto na Tabela 2.1.

Tabela 2.1 - Tipos de formação vegetal para o Estado do Tocantins segundo fontes diferentes.

\begin{tabular}{|c|c|c|c|c|c|c|c|c|}
\hline \multicolumn{3}{|c|}{ Machado et al. (2004) } & \multicolumn{3}{|c|}{ Sano et al. (2007) } & \multicolumn{3}{|c|}{ SEPLAN (2012) } \\
\hline Tipo & Área & $\%$ & Tipo & Área & $\%$ & Tipo & Área & $\%$ \\
\hline A & $25.057,9 \mathrm{~km}^{2}$ & $9 \%$ & $\mathrm{FF}$ & $50.115,73 \mathrm{~km}^{2}$ & $18 \%$ & $\mathrm{C}$ & $181.092,423 \mathrm{~km}^{2}$ & $65 \%$ \\
\hline $\mathrm{C}$ & $253.362,8 \mathrm{~km}^{2}$ & $91 \%$ & FS & $144.778,76 \mathrm{~km}^{2}$ & $52 \%$ & FE & $36.350,441 \mathrm{~km}^{2}$ & $13 \%$ \\
\hline & & & FC & $25.057,86 \mathrm{~km}^{2}$ & $9 \%$ & $\mathrm{EC} / \mathrm{FE}$ & $21.460,361 \mathrm{~km}^{2}$ & $8 \%$ \\
\hline & & & $\mathrm{CA}$ & $58.468,35 \mathrm{~km}^{2}$ & $21 \%$ & $\mathrm{EFE} / \mathrm{O}$ & $19.638,205 \mathrm{~km}^{2}$ & $7 \%$ \\
\hline & & & & & & FO & $14.706,479 \mathrm{~km}^{2}$ & $5 \%$ \\
\hline & & & & & & $\mathrm{EC} / \mathrm{FO}$ & $616,232 \mathrm{~km}^{2}$ & $0,2 \%$ \\
\hline Total & $278.420,7 \mathrm{~km}^{2}$ & $100 \%$ & & $278.420,7 \mathrm{~km}^{2}$ & $100 \%$ & & $273.864,141 \mathrm{~km}^{2}$ & $100 \%$ \\
\hline
\end{tabular}

Obs.: A=Amazônia; C=Cerrado; FF=Formação Florestal; FS=Formação Savânica; FC=Formação Campestre; $\mathrm{CA}=$ Cobertura Antrópica; $\mathrm{FE}=$ Floresta Estacional 1; $\mathrm{EC} / \mathrm{FE}=$ Encrave Cerrado/ Floresta Estacional; EFE/O=Ecótono Floresta Estacional/Floresta Ombrófila; FO=Floresta Ombrófila; EC/FO=Encrave Cerrado/Floresta Ombrófila).

Com relação a essas divergências entre áreas apresentadas por Machado et al. (2004) e Sano et al. (2007), estes últimos explicaram que é necessário considerar que as propostas possuem critérios e sistemas de classificação regionais diferentes. Outro fator a considerar é a escala e a data das imagens orbitais utilizadas no mapeamento, assim como o sensor gerador dessas imagens. O mesmo pode-se justificar em relação à SEPLAN (2012).

Considerando o exposto a repeito das regionalizações nas diversas escalas, os esboços de regionalização são bastante diversos e, ao longo do tempo, mostraram mudanças acompanhando a evolução científica e tecnológica e de ocupação humana, passando de estudos de fitogeografia com focos florísticos e ou fisionômicos em escalas mundiais, que tiveram início no século XVIII, a estudos fitogeográficos regionais, atualmente, mais detalhados com categorias fitofisionômicas em uma escala de paisagem. Em se tratando do Cerrado, considerando-se o avanço da fitogeografia brasileira, as classificações atuais têm mostrado cada vez mais a riqueza de padrões florísticos e estruturais desse domínio, província, bioma ou ecorregião.

\subsection{Campo Sujo}

Como exposto anteriormente, Sampaio (1932) comentou que na flora brasileira, assim como na América do Sul, domina a vegetação campestre, que no Brasil está presente desde o 
norte da Amazônia ao Arroio Chuí; porém sua área principal é no Brasil Central, ou seja, a zona dos "Campos" e "zona Oreades" de Martius.

Barbosa et al. (1993), ao estudarem elementos da paleogeografia no que se refere à oscilação climática e a presença do homem pré-histórico no sudoeste de Goiás, delinearam subsistemas do passado e destacaram o grande significado dos campos no período mais antigo da ocupação humana. Para esses autores, no final do Pleistoceno e início do Holoceno, os campos deveriam abranger uma área maior que a atual, de modo a ter se expandido pelas áreas hoje ocupadas pelo cerrado. Eles acreditam que na evolução paisagística, os campos sejam mais antigos, que foram gradativamente invadidos pela vegetação de arbustos maiores e pelo cerrado, e que a parte de campos hoje existente deve estar condicionada a microclimas atuais que não se refizeram totalmente das agressões climáticas do Quaternário, sendo vestígios de áreas que ocuparam espaços maiores e dominantes na paisagem final do Pleistoceno.

No Brasil Central, ocorrem campos sujos, campos limpos e campos rupestres (RIBEIRO; WALTER, 2008). O campo sujo, objeto desta tese, tem sido pouco estudado e os trabalhos realizados, em geral, têm uma abordagem florística, fenológica ou estrutural e se concentram na região Sudeste e no Distrito Federal.

Oliveira-Filho e Fluminhan-Filho (1999) estudaram a ecologia da vegetação do Parque Florestal Quedas do Rio Bonito, sul de Minas Gerais, com o propósito de classificar, mapear e descrever os tipos fisionômicos da vegetação, dentro de uma abordagem interpretativa, na qual as variações da vegetação são associadas a variações ambientais. Estes autores reconheceram cinco tipos fisionômicos: floresta, candeal, cerrado, campo de altitude e campo rupestre; também verificaram que a distribuição dos mesmos na paisagem obedece basicamente à conjunção de dois fatores: o regime de água nos solos e a frequência de incêndios.

Munhoz (2003) estudou os padrões de distribuição sazonal e espacial das espécies do estrato herbáceo- subarbustivo em comunidades de campo limpo úmido e de campo sujo com o objetivo de analisar a florística, a fitossociologia, a fenologia e o relacionamento entre a composição da comunidade e as variáveis ambientais. O estudo de campo sujo foi realizado na Fazenda Água Limpo (Brasília - DF) e de campo limpo, na Fazenda Água Fria (Alto Paraíso de Goiás - GO). O campo sujo apresentou uma grande riqueza florística de 264 espécies distribuídas em 141 gêneros e 45 famílias, sendo Asteraceae, Poaceae, Leguminosae e Rubiaceae as que apresentaram maior número de espécies. No campo limpo úmido, foram 
encontradas 190 espécies em 95 gêneros e 37 famílias, sendo que as famílias de maior número de espécies foram: Poaceae, Cyperaceae, Asteraceae e Polygalaceae. A maioria dos gêneros amostrados apresentou ema única espécie, sugerindo uma alta diversidade genérica nessas fisionomias. Quanto à fenologia, a floração no campo limpo úmido apresentou a distribuição apenas na estação chuvosa; a produção de frutos foi também maior no período chuvoso. No campo sujo, a floração ocorreu distribuída por todo o período estudado (abril de 2000 a março de 2001), com concentração das espécies florescendo na estação chuvosa. Segundo a autora, são necessários mais estudos da camada rasteira de cerrado para ampliar o conhecimento sobre a distribuição de suas espécies e dos fatores ambientais determinantes de seus padrões de distribuição espaciais e sazonal.

Tannus e Assis (2004) estudaram a composição de espécies vasculares de campo sujo e campo úmido em área de cerrado em Itirapina (SP). Eles amostraram 384 espécies, 211 gêneros e 76 famílias de plantas vasculares. Do total de espécies, 255 foram consideradas exclusivas do campo sujo e 114 do campo úmido. Apenas 10 espécies tiveram ocorrência comum entre as duas fisionomias. Dentre as famílias mais ricas do campo sujo, destacaramse: Asteraceae, Leguminosae e Poaceae. No campo úmido, as famílias mais ricas foram: Cyperaceae, Poaceae, Lentibulariaceae e Eriocaulaceae. No campo sujo, o componente herbáceo-subarbustivo prevaleceu sobre o arbustivo-arbóreo numa proporção de 3,6:1. No campo úmido, foram encontradas apenas espécies herbáceo-subarbustivas. O estudo revelou acentuadas distinções florísticas entre o campo sujo e o campo úmido, tendo em vista o reduzido número de espécies compartilhadas.

Tannus et al. (2006) estudaram a fenologia reprodutiva em campo sujo e campo úmido em uma área de cerrado em Itirapina (SP). As espécies vegetais do Cerrado apresentaram variações periódicas nos padrões de crescimento e reprodução, fortemente relacionados com a sazonalidade climática. Em ambas as fitofisionomias, os padrões fenológicos foram, em geral, significativamente sazonais, usualmente com pico na estação úmida, mas diferiram de acordo com o hábito e modo de dispersão. Tais diferenças foram relacionadas às características ambientais de cada fisionomia, especialmente ao regime hídrico dos solos. O hábito das espécies mostrou grande influência nos padrões fenológicos observados e os padrões de frutificação nem sempre se relacionaram aos modos de dispersão, como observado em outras fisionomias do Cerrado, ressaltando a importância do desenvolvimento de estudos fenológicos detalhados em campo sujo e campo úmido. 
Munhoz e Felfili (2006) investigaram a fenologia do estrato herbáceo-subarbustivo de uma comunidade de campo sujo na Fazenda Água Limpa (Brasília - DF), com o objetivo de avaliar a influência das mudanças sazonais sobre a fenologia vegetativa (foliação) e reprodutiva (floração e frutificação) do componente herbáceo. A floração na comunidade apresentou-se distribuída por todo o período de um ano estudado (nov./1999 a dez./2000), com concentração na estação chuvosa. O período de produção de frutos foi similar ao de produção de flores e a maioria das espécies amadureceu seus diásporos do meio da estação chuvosa até o fim da seca. Na estação seca, houve grande percentagem de espécies com folhas secas. No entanto, nem todas as espécies secaram completamente suas folhas nesse período, sendo que $3,2 \%$ produziram folhas novas e $31 \%$ mantiveram suas folhas verdes. Os eventos vegetativos e reprodutivos das plantas da camada herbáceo-subarbustiva mostraram-se dependentes da pluviosidade.

Também Munhoz e Felfili (2006) estudaram a fitossociologia do estrato herbáceosubarbustivo de uma área de campo sujo na Fazenda Água Limpa (Brasília - DF) em diferentes períodos de amostragem. Foram amostradas 163 espécies, incluídas em 78 gêneros e 39 famílias. As famílias mais importantes foram: Poaceae (25), Asteraceae (22), Fabaceae (18), Rubiaceae (11), Lamiaceae (9) e Myrtaceae (9), somando 57,67\% das espécies amostradas. As famílias com maiores porcentagens de cobertura foram: Poaceae, Myrtaceae, Asteraceae, Fabaceae e Euphorbiaceae. A família mais importante foi Poaceae, com 67,04\% de cobertura. Andropogon leucostachyus, Arthropogon villosus, Baccharis humilis, Echinolaena inflexa e Leptocoryphium lanatum estiveram entre as dez principais espécies em porcentagem de cobertura nesta família. A similaridade de Sørensen foi alta, entre 0,60 e 0,69, provavelmente devido à homogeneidade do solo da área. A similaridade entre os cinco períodos de inventário também foi alta, pois as espécies mais importantes variam pouco em suas taxas de cobertura ao longo do ano.

Amaral (2008) estudou as mudanças estruturais e florísticas do estrato herbáceoarbustivo em campo sujo e campo limpo úmido na fazenda Água Limpa (Brasília - DF) entre 2000 e 2007. Foram registradas 509 espécies em 220 gêneros e 64 famílias para as duas comunidades no levantamento florístico. No inventário fitossociológico, foram amostradas, para as mesmas comunidades, 253 espécies em 150 gêneros e 46 famílias. No campo sujo, foram registradas 295 espécies em 153 gêneros e 46 famílias. As famílias de maior ocorrência foram: Asteraceae (57), Poaceae (40), Fabaceae (34), Myrtaceae (16), Rubiaceae (14), Malpighiaceae (12), Melastomataceae (11), e Lamiaceae (10). Foi constatada a redução de $9 \%$ 
nas espécies herbáceas e um aumento de $16 \%$ nos subarbustos. A similaridade florística pelo índice de Sørensen entre os dois períodos foi alta (60\%). A autora concluiu que a lenta substituição na composição das espécies sugere que as espécies de campo sujo estão sob influência das alterações ocorridas, devido à falta da frequência de distúrbios com o fogo ocorrido no primeiro levantamento.

Araújo et al. (2012) estudaram a composição florística e estrutura fitossociológica de áreas de campo sujo e cerrado sentido restrito na Floresta Nacional de Silvânia (GO), com o objetivo de analisar a estrutura fitossociológica das vegetações de cerrado sentido restrito e campo sujo da unidade de conservação. Foram registradas 60 espécies em 46 gêneros distribuídas em 28 famílias, sendo 52 espécies no cerrado sentido restrito e 27 no campo sujo. As famílias que apresentaram mais espécies foram: Malpighiaceae (7), Fabaceae (6) e Vochysiaceae (5). As espécies com maior Índice de Valor de Importância foram: Qualea grandiflora, Kielmeyera coriacea e Styrax ferrugineus para o sentido restrito, e S. ferrugineus, Piptocarpha rotundifolia e Erythroxylum deciduum para o campo sujo. No cerrado sentido restrito, a densidade e área basal foram de 1125 indivíduos/ha e 5,32 $\mathrm{m}^{2} / \mathrm{ha}$ respectivamente. Já no campo sujo, foram 730 indivíduos/ha e 1,96 m²/ha. O índice de Shannon $\left(\mathrm{H}^{\prime}\right)$ encontrado para o cerrado sentido restrito foi de 3,48, e para o campo sujo 2,91, valores que evidenciam uma alta diversidade de espécies para a área em estudo.

Giácomo et al. (2013) estudaram a florística e a fitossociologia em áreas de campo sujo e cerrado stricto sensu com o objetivo de caracterizar a florística e calcular os parâmetros fitossociológicos das espécies presentes nestas duas áreas na Estação Ecológica de Pirapitinga (Morada Nova de Minas - MG). Nas duas áreas de estudo, foram amostrados um total de 3.224 indivíduos distribuídos em 81 espécies, 70 gêneros e 40 famílias. As famílias mais ricas foram Fabaceae e Vochysiaceae. O cerrado foi a formação vegetal com maior riqueza de espécies (81) e maior densidade (2.257 ind $\mathrm{ha}^{-1}$ ). Na área de campo sujo, a densidade absoluta foi de aproximadamente 926 ind $\mathrm{ha}^{-1}$. As espécies com as maiores densidades absolutas foram: Miconia burchellii, Qualea parviflora, Heteropterys byrsonimifolia, Salvertia convallariaeodora, com 91,25, 78,75, 77,50, 62,50 ind. ha ${ }^{-1}$, respectivamente. As dez espécies com os maiores valores de importância (VI) foram: Qualea parviflora, Salvertia convallariaeodora, Miconia burchellii, Heteropterys byrsonimifolia, Byrsonima coccolobifolia, Bowdichia virgilioides, Miconia ferruginata, Acosmium dasycarpum, Curatella americana e Vatairea macrocarpa, representando 55,40 \% do total do VI encontrado. Ambas as áreas estudadas apresentaram alta diversidade e baixa dominância 
ecológica e possuem distribuição diamétrica em forma de J-invertido, indicando o predomínio de indivíduos jovens.

Esta informação teórica levantada que perpassa pela história da paisagem na Geografia, a sistemática fitogeográfica e o Cerrado, e o Campo Sujo tem a finalidade de fundamentar cientificamente este trabalho, que faz uma análise da paisagem e do Campo Sujo Seco (um tipo de vegetação do Cerrado), com uma abordagem biogeográfica, e dará suporte às etapas seguintes do trabalho como a caracterização da área de estudo, os procedimentos metodológicos e a discussão dos resultados. 


\section{MATERIAL E MÉTODOS}

\section{1 Área de Estudo}

A bacia hidrográfica do ribeirão Taquaruçu Grande, localiza-se no município de Palmas - TO. A capital Palmas foi implantada em 1990 logo após a criação do Estado do Tocantins pela Constituição de 1988 (BRASIL, 1988), em uma área de $1.056,10 \mathrm{~km}^{2}$ (0,29\% do Estado) do recém-emancipado, na época, município de Taquaruçu, passando este à condição de distrito de Palmas. O seu nome foi escolhido em homenagem a Comarca de São João da Palma, sede do primeiro movimento separatista da região, instalada em 1809 na barra do Rio Palma com o Rio Paranã. Outro fator que influenciou o nome foi a grande quantidade de palmeiras na região (MIRANDA, 2007).

O povoamento do Tocantins, embora só Estado a partir de 1988, é um processo que se iniciou entre 1633 e 1658 com a chegada dos jesuítas (MIRANDA, 2007). A mineração aurífera do século XVIII fez surgir vários arraiais mineradores que deram origem às cidades de Natividade (1734); Pontal (1738), arraial que está na origem do arraial de Porto Real do Pontal, época do Reinado, depois Porto Imperial, época do Brasil Monárquico e, finalmente Porto Nacional, a partir da proclamação da República no Brasil; Arraias (1730); Arraial do Carmo, hoje cidade de Monte do Carmo (1746), além de outras cidades tocantinenses que se tornaram históricas (MIRANDA, 2007). Nos fins do século XIX a ocupação do norte de Goiás, hoje Tocantins, adquiriu um caráter mais sistemático, iniciando a história dos conflitos pela posse da terra. Esse processo de ocupação foi acentuado no início do século XX e se intensificou com a implantação de grandes projetos, principalmente com a construção da rodovia Belém-Brasília. Após muitos anos de luta do povo em busca da autonomia do Tocantins (CAVALCANTE, 2003), Palmas surge de um descampado no meio do Cerrado (MIRANDA, 2007).

A bacia hidrográfica do ribeirão Taquaruçu Grande pertencente à bacia do rio Tocantins, está localizada na região centro-sul do município de Palmas (Figura 3.1), entre as coordenadas geográficas de $10^{\circ} 10^{\prime} 33^{\prime \prime}$ e $10^{\circ} 25^{\prime} 18^{\prime \prime}$ de latitude sul e $48^{\circ} 03^{\prime} 57^{\prime \prime}$ e $48^{\circ} 23^{\prime} 03^{\prime \prime}$ de longitude oeste. Possui uma área de $46.177,47$ hectares, o que representa $20 \%$ da área total do município, sendo 73,67\% da Área de Proteção Ambiental (APA) Serra do Lajeado. Esta APA foi criada pela Lei n. 906, de 20 de maio de 1997, constituindo-se de uma gleba de terras com 121.417,7659 hectares, situada nos municípios de Palmas, Aparecida do Rio Negro, 
Tocantínia e Lajeado do Tocantins, incluindo a Serra do Lajeado, o vale do ribeirão Lajeado e a Serra do Carmo (UNITINS, 1999).

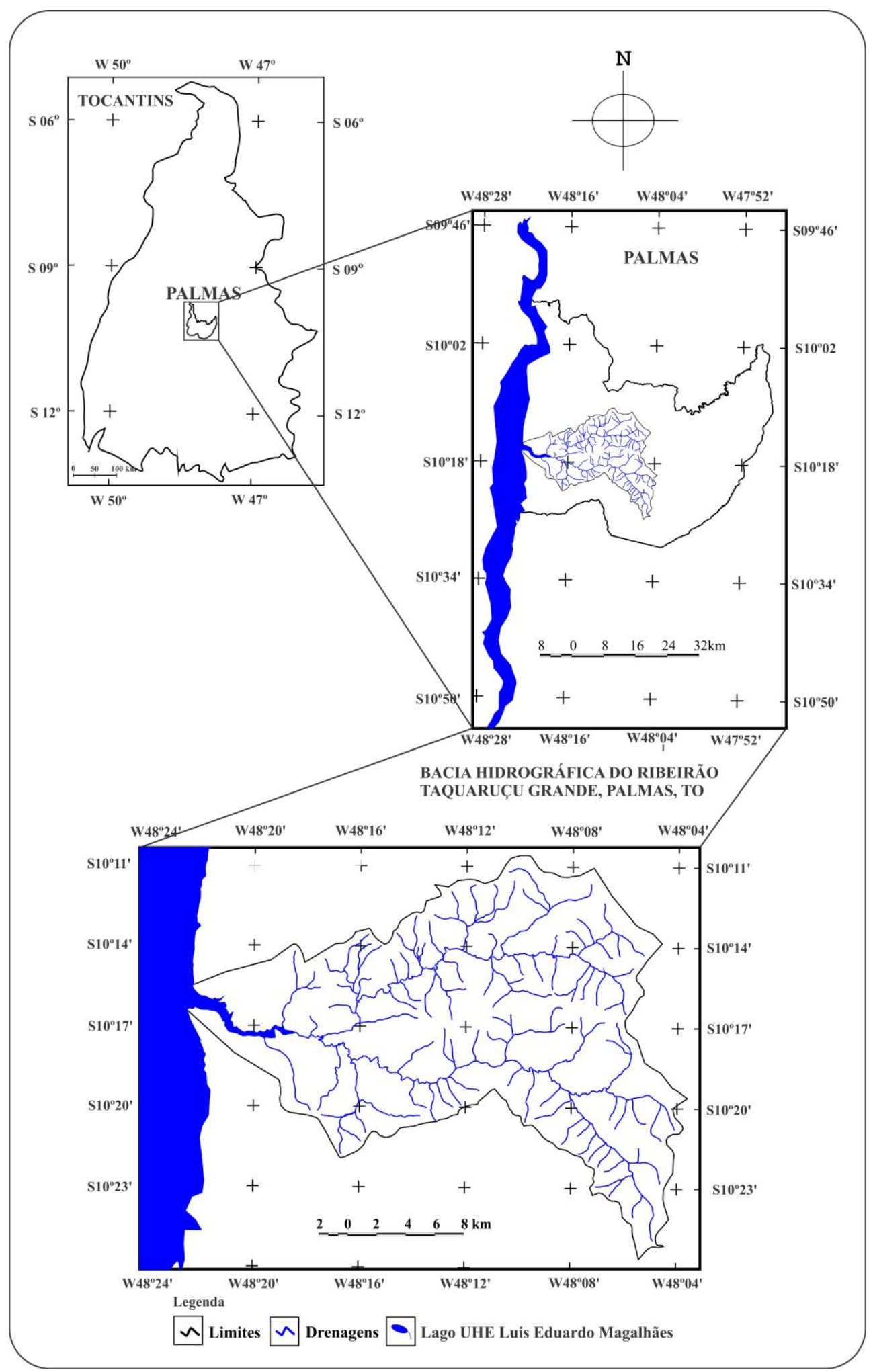

Figura 3.1 - Localização da bacia hidrográfica do ribeirão Taquaruçu Grande no município de Palmas e no Estado do Tocantins (Organização: T. C. C. Medeiros e A. D. S. Andrade) 


\subsubsection{Clima}

Pelo método de Thornthwaite, a regionalização climática Estado do Tocantins inclui os tipos climáticos (SEPLAN, 2012):

- úmido: B1wA'a', clima úmido com moderada deficiência hídrica, e B1wA'a', clima úmido com pequena ou nula deficiência hídrica;

- úmido subúmido: C2r2A'a', clima úmido subúmido com pequena deficiência hídrica, e C2wA'a', clima úmido subúmido com moderada deficiência hídrica.

A bacia do ribeirão Taquaruçu Grande está dentro da faixa de clima úmido subúmido, tipo C2 $\mathrm{wA}^{\prime} \mathrm{a}^{\prime \prime}$, clima úmido subúmido com moderada deficiência hídrica (SEPLAN, 2012).

$\mathrm{O}$ clima $\mathrm{C} 2 \mathrm{wA}^{\prime} \mathrm{a}^{\prime \prime}$ é um clima úmido subúmido com moderada deficiência hídrica no inverno. A evapotranspiração potencial média anual é de $1.500 \mathrm{~mm}$, distribuindo-se no verão em torno de $420 \mathrm{~mm}$ ao longo de três meses consecutivos com temperatura mais elevada. A precipitação média anual é de 1.700 a $1.800 \mathrm{~mm}$ e a temperatura do ar média anual é de $28^{\circ} \mathrm{C}$ (SEPLAN, 2012).

O diagrama climático para a estação meteorológica de Palmas - TO, a $280 \mathrm{~m}$ de altitude, com base nos dados climáticos de temperatura e precipitação para uma série temporal de 19 anos (INMET) ${ }^{1}$, mostra o clima com estacionalidade definida, início da estação chuvosa em setembro e início da estação seca entre maio e junho (Figura 3.2), que perdura por todo inverno. As chuvas mais intensas ocorrem no período de outubro a abril com índices pluviométricos acima de $100 \mathrm{~mm}$. Janeiro, fevereiro e março são os meses mais chuvosos (chuvas de verão), quando a pluviosidade atinge valores em torno de $200 \mathrm{~mm}$, com média anual de $1648 \mathrm{~mm}$.

A temperatura média anual foi de $26,7^{\circ} \mathrm{C}$, com temperaturas mais frias nos meses mais chuvosos e nos meses de junho e julho por influência do inverno no hemisfério sul. A temperatura mínima absoluta do período foi $15^{\circ} \mathrm{C}$ (médias das temperaturas mínimas, $21,1^{\circ} \mathrm{C}$ ), e a temperatura máxima absoluta $38,6^{\circ} \mathrm{C}$ (média das máximas, $32,8^{\circ} \mathrm{C}$ ) (Figura 3.2).

\footnotetext{
${ }^{1}$ Disponível em < www.inmet.gov.br $>$. Acesso em: 20/12/2012.
} 


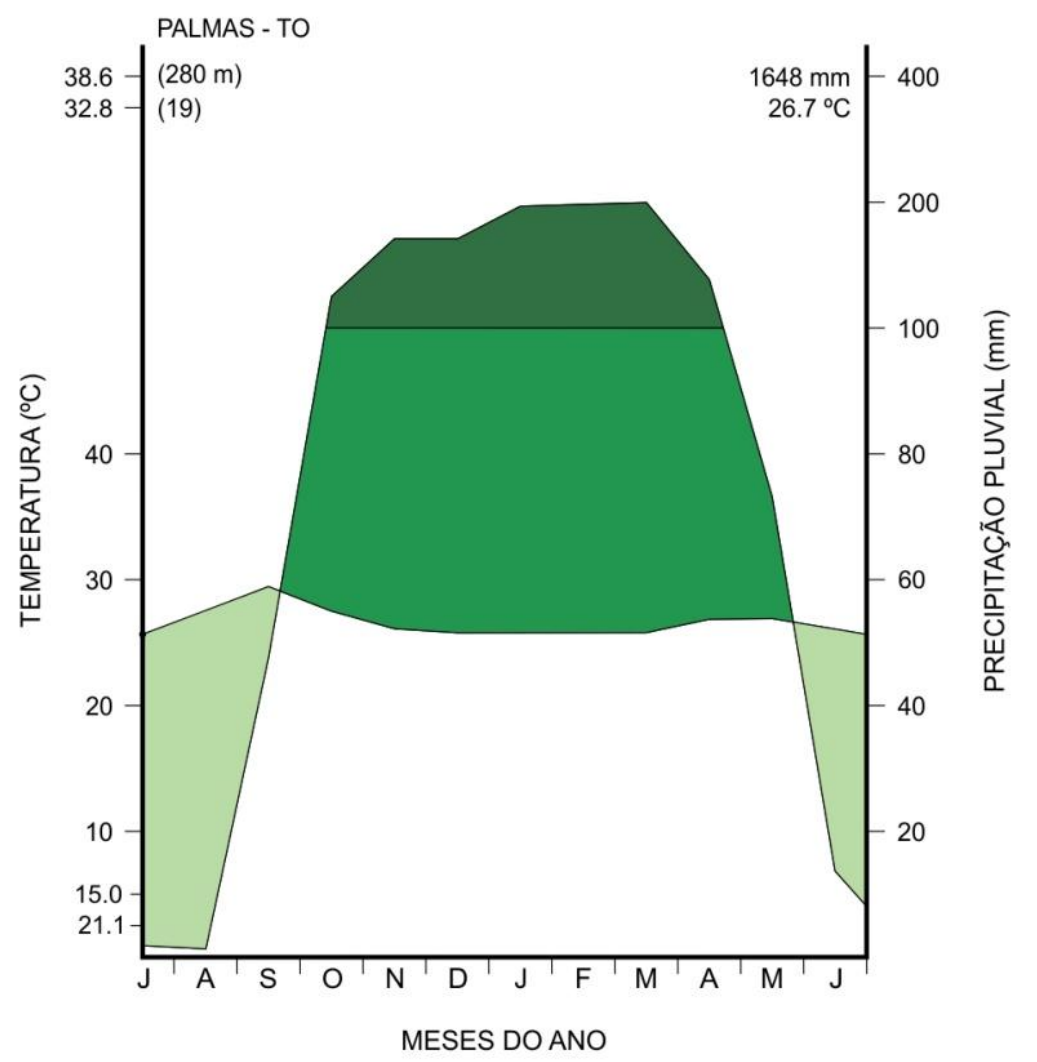

Estação chuvosa com pluviosidade $>100 \mathrm{~mm}$

Estação chuvosa com pluviosidade $<100 \mathrm{~mm}$

Estação seca

Figura 3.2 - Diagrama climático para a estação meteorológica de Palmas - TO, segundo a metodologia proposta por Walter e Lieth (1967). Fonte: Instituto Nacional de Meteorologia (INMET) ${ }^{2}$, (Organização: T. C. C. Medeiros).

\subsubsection{Geologia}

O Estado do Tocantins possui os seguintes ambientes geológicos: depósitos sedimentares inconsolidados, bacias sedimentares, faixas orogênicas, sequência metavulcanosedimentares e embasamentos de estilos complexos (SEPLAN, 2012). Dentre estes, estão presentes na bacia do ribeirão Taquaruçu Grande, os terrenos da bacia sedimentar do Parnaíba (SEPLAN, 2008) e de embasamentos de estilos complexos que, segundo Seplan (2008), correspondem aos complexos metamórficos do Arqueano e Proterozóico inferior.

\footnotetext{
${ }^{2}$ Disponível em < www.inmet.gov.br $>$. Acesso em: 20/12/2012.
} 


\subsubsection{Geomorfologia}

O relevo tocantinense apresenta Formas Estruturais, Formas Erosivas, Tipos de Dissecação e Formas de Acumulação. Na bacia do ribeirão Taquaruçu Grande, ocorrem relevos do tipo Formas Estruturais com superfícies tabulares estruturais e patamares estruturais e Formas Erosivas com superfícies tabulares erosivas, superfícies de pediplanos, inselbergs e terraços fluviais (SEPLAN, 2008).

A Depressão do Tocantins, que faz parte da compartimentação de Formas Erosivas, corresponde ao corredor deprimido do vale do rio Tocantins com altitudes entre 200 e 300 metros, relevos de dissecação suave e o predomínio de formas tabulares, com grande diversidade de expressão areolar. Também ocorrem em escala menor, trechos com relevos aplanados ainda conservados. As seções de aplanamento bordejam áreas serranas ou trechos marginais do rio Tocantins. Nesta área, com superfície rebaixada, emergem blocos de relevos residuais, denominados regionalmente de serras do Lajeado, da Malhada Alta, Maria Antonia, Santo Antônio, Manuel do Carmo, que fazem parte do Planalto Residual do Tocantins (BRASIL, 1981).

Nesta unidade geomorfológica, os processos que atuaram quando da elaboração das depressões foram as mesmas e ocorreram de forma simultânea que a da depressão do Araguaia que ocorreu em duas fases distintas: a) fase climática com período seco prolongado, elaborando a superfície por processo de pediplanação; b) fase de clima de savana, com retomada de erosão recente. Assim, a paisagem atual é explicada pela conjugação dessas fases climáticas e pela proximidade do nível de base (BRASIL, 1981).

As concreções superficiais de aspecto glomerular ocorrem em diversos tipos de terreno e de compartimento do relevo. A presença generalizada de concreções ferruginosas na superfície do terreno e acompanhando a topografia, levou a duas hipóteses principais: a) as concreções estariam se formando ou se reelaborando sob o clima atual, devido à ascensão por capilaridade das soluções até o nível da superfície onde ocorre a evaporação; b) as concreções teriam se formado ao longo do perfil do solo e foram expostas pela ablação dos níveis superiores (BRASIL,1981).

Em se tratando da Depressão Tocantins, existe alguns pontos específicos que merecem ser relatados, como a presença de concreções de forma constante, dentre eles, de Porto Nacional até Tocantínia (sentido S-N), trecho em que se situa a bacia do ribeirão Taquaruçu Grande. Estes registros sugerem que a área foi submetida a processos erosivos típicos de fases 
climáticas agressivas (semiárida) que resultaria em pediplanação, cuja idade foi considerada plio-pliestocênica por Barbosa et al. (1973 apud BRASIL, 1981, p. 224) ${ }^{3}$.

O Planalto Residual do Tocantins, que corresponde às Formas Estruturais, é representado por três unidades de relevo regionalmente denominadas de serra do Lageado e do Carmo, Malhada Alta e Maria Antônia, com cota média de 500 m, atingindo 600 m nas bordas ocidentais do planalto. O Planalto é individualizado pela presença de escarpas abruptas, sob a forma de frente de "cuestas" e por superfícies estruturais tabulares e foi esculpido em litologias constituídas de folhelho, siltitos e arenitos que fazem parte da borda sudoeste da bacia sedimentar do Parnaíba e que são datadas como devonianas da Formação Pimenteiras (BRASIL, 1981).

O fato de haver superfícies alteradas com altitudes variando de 450 a $750 \mathrm{~m}$, elas foram consideradas por Brasil (1981) como superfícies elevadas com nível de cimeira regional, que se encontram interpenetradas por amplos corredores rebaixados. Esses relevos compõem o Planalto Residual do Tocantins e constituem os trechos mais elevados do Planalto do Interflúvio Araguaia-Tocantins, considerados de idade pliocênica de aplanamento. A similaridade altimétrica com o Planalto Dissecado do Sul do Pará e o Planalto do Interflúvio Araguaia-Tocantins levou Brasil (1981) inferir que estes relevos estiveram submetidos ao mesmo processo de pediplanação que truncaram o topo desses planaltos. Boaventura (1974 apud BRASIL, 1981, p. 222) ${ }^{4}$, analisando esse nível de aplanamento, considerou-o de idade pliocênica.

A serra do Lageado (Figura 3.3) compõe o bloco mais compacto do Planalto Residual do Tocantins, juntamente com a serra do Carmo. Neste bloco, a escarpa oeste, de direção norte-sul, voltada para o rio Tocantins é denominada serra do Lageado, uma frente de "cuestas" com escarpas abruptas que revelam a estrutura sub-horizontal da Formação Pimenteiras. O reverso tem mergulho suave para leste com formas tabulares amplas. A frente de "cuestas" da serra do Lageado possui restos de superfícies estruturais tabulares, sobre as quais há cobertura arenosa.

\footnotetext{
3 BARbOSA, G.V.; BOAVENTURA, R.S.; PINTO, M.N. Geomorfologia. In: BRASIL. Departamento Nacional da Produção Mineral. Projeto RADAM. Parte das Folhas SC 23 Rio São Francisco e SC 24 Aracaju. Rio de Janeiro, 1973 (Levantamento de Recursos Naturais, 1).

${ }^{4}$ BOAVENTURA, R.S. Geomorfologia. In: BRASIL. Departamento Nacional da Produção Mineral. Projeto RADAM Folhas SB 22 Araguaia e parte da Folha SC 22 Tocantins. Rio de Janeiro, 1974 (Levantamento de Recursos Naturais, 4).
} 


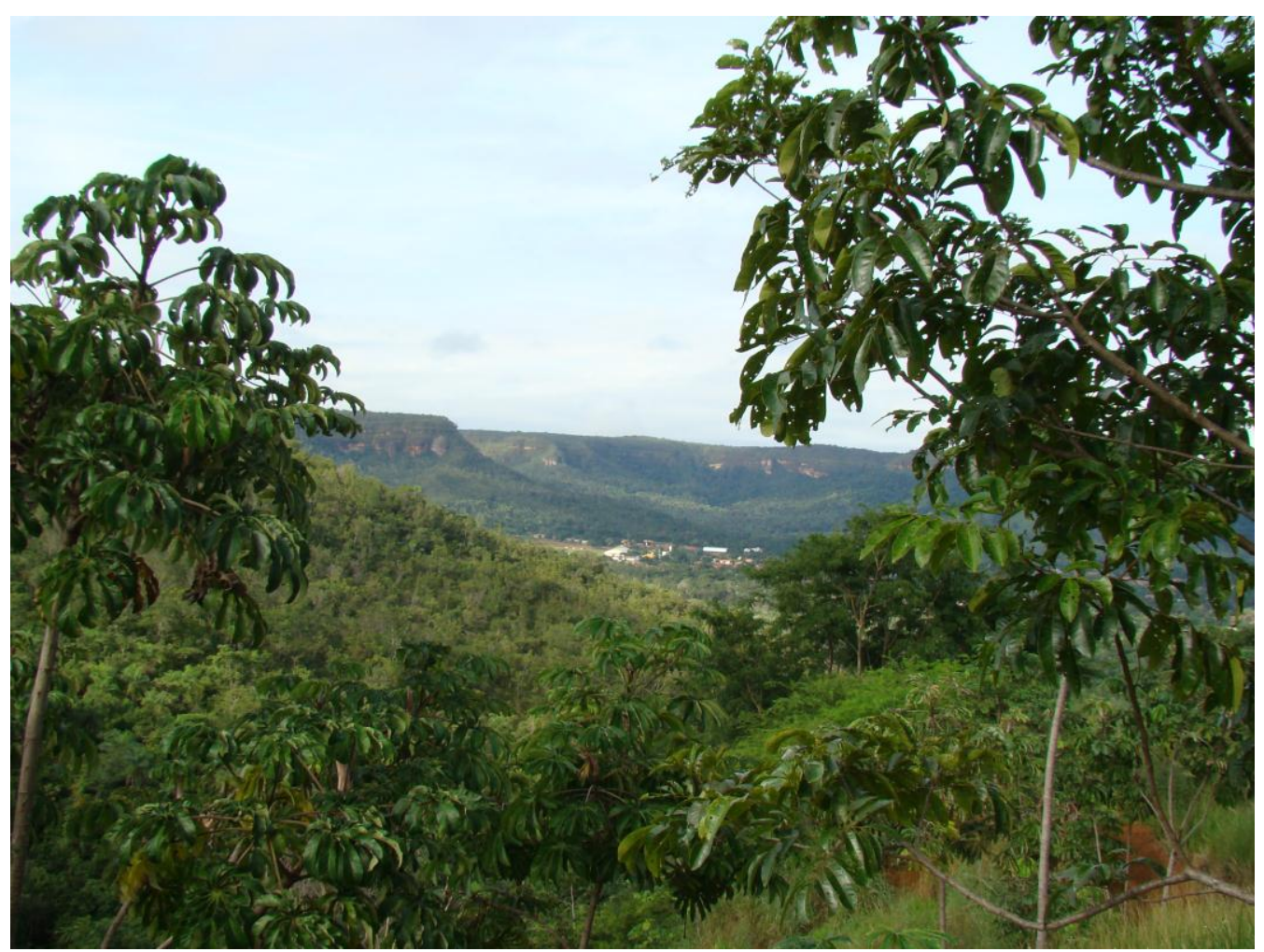

Figura 3.3 - Vista parcial da Serra do Lageado, município de Palmas - TO (Fotografia por Y. T. Rocha, 2012)

Esta serra é marcada por três feições dominantes: 1) extensa chapada de topo suavemente ondulado do Lageado, pertencente à orográfica faixa que se prolonga desde a altura de Monte do Carmo até as margens do rio Tocantins, próximo à cidade de Tocantinia; 2) a segunda feição contrasta fortemente com os topos aplainados, é a zona entalhada e dissecada a partir dessa superfície, que se apresenta acidentada, declivosa e localmente escarpada; 3) a terceira estende-se pelo piemonte ocidental do Lageado, correspondendo à calha do rio Tocantins. A articulação da superfície do topo com a superfície baixa se faz por meio de pedimentos em morfogêneses de Cerrado (BRASIL, 1981). A serra do Lageado exerce a função de divisor de águas entre o rio Tocantins e o rio Sono (BRASIL,1981). O ribeirão Taquaruçu Grande faz parte dessa divisão de águas tendo suas nascentes nesta serra e sendo afluente da margem direita do rio Tocantins.

\subsubsection{Solos}

Os solos encontrados no Estado do Tocantins são os seguintes: Argissolos, Cambissolos, Chernossolos, Neossolos, Planossolos, Gleissolos, Latossolos, Luvissolos, Nitossolos e Plintossolos (SEPLAN, 2012). 
Reatto et al., (2008) em estudo dos solos do Cerrado, citaram para o Estado do Tocantins, Latossolo, Argissolo, Neosolo Quartzarênico, Plintossolo, Plintossolo Pétrico, Neossolo Litólico, Gleissolo, Nitossolo, Cambissolo, onde os quatro primeiros tipos de solos dominam em percentual de ocorrência no Cerrado e no Estado (Tabela 3.1). Na bacia do ribeirão Taquaruçu Grande ocorrem Latossolos e Plintossolos, com predominância dos Plintossolos (SEPLAN, 2012).

Tabela 3.1 - Solos do Tocantins: percentual em relação ao Cerrado e ao Estado (Fonte: REATTO, et al., 2008)

\begin{tabular}{lcc}
\hline \multicolumn{1}{c}{ Solo } & \% no Cerrado & \% no Estado \\
\hline Latossolo & 2,89 & 21,85 \\
Argissolo & 2,33 & 17,56 \\
Neosolo Quartzarênico & 1,97 & 14,89 \\
Plintossolo & 1,69 & 12,73 \\
Plintossolo Pétrico & 0,89 & 6,75 \\
Neossolo Litólico & 066 & 5,01 \\
Gleissolo & 0,46 & 3,47 \\
Nitossolo & 0,23 & 1,76 \\
Cambissolo & 0,04 & 0,33 \\
\hline
\end{tabular}

De acordo com Santos et al. (2006), os Latossolos são constituídos por material mineral com horizonte B latossólico, sendo solos em avançado estágio de intemperização, muito evoluídos, destituídos de minerais primários ou secundários menos resistentes ao intemperismo; variam de fortemente a bem drenados e são normalmente muito profundos, sendo a espessura do solum raramente inferior a $1 \mathrm{~m}$; têm sequência de horizontes pouco diferenciada e são, em geral, fortemente ácidos, com baixa saturação por bases, podendo ser distróficos a alumínicos. São típicos das regiões equatoriais e tropicais, mas ocorrem também em zonas subtropicais, distribuídos por amplas e antigas superfícies de erosão, pedimentos ou terraços fluviais antigos em relevo plano a suave ondulado, apesar de ocorrer em relevo acidentado montanhoso. Originam-se dos mais variados tipos de rochas, sob as mais diversas condições climáticas e tipos de vegetação.

Os Plintossolos são solos constituídos por material mineral, que apresentam horizonte plíntico ou litoplíntico ou concrecionário, que podem iniciar dentro de $40 \mathrm{~cm}$ da superfície; ou dentro de $200 \mathrm{~cm}$ da superfície quando precedidos de horizonte glei, ou imediatamente abaixo do horizonte $\mathrm{A}$, ou $\mathrm{E}$, ou de outro horizonte que apresente cores pálidas, variegadas ou com mosqueados em quantidade abundante (SANTOS et al., 2006). Quando precedidos de horizonte ou camada de coloração pálida (acinzentadas, pálidas ou amarelado claras), estas 
cores deverão ter matizes e cromas (a: matiz 5Y; ou b: matizes 7,5YR, 10YR ou 2,5Y com croma menor ou igual a 4), podendo ocorrer ou não mosqueados de coloração desde avermelhadas até amareladas. Quando precedidos de horizontes ou camadas de coloração variegada, pelo menos uma das cores deve satisfazer as condições dos itens "a" e "b" definidos anteriormente. Quando precedidos de horizontes ou camadas com mosqueados, estes deverão ocorrer em quantidade abundante (> $20 \%$ em volume), numa matriz de coloração avermelhada ou amarelada e deverão apresentar matizes e cromas conforme ítens “a" e "b" definidos anteriormente (SANTOS et al., 2006).

\subsubsection{Vegetação}

A vegetação do Estado do Tocantins, segundo SEPLAN (2012) possui seis Regiões Fitoecológicas (Cerrado, Floresta Estacional, Floresta Ombrófila, Ecótono Floresta Estacional/Floresta Ombrófila, Encrave Cerrado/Floresta Ombrófila e Encrave Cerrado/Floresta Estacional), com a dominância do Cerrado.

Haidar et al. (2013) reconheceram apenas três regiões fitoecológicas para o Estado do Tocantins (Florestas, Savanas e Formações Pioneiras), com cerca de 20 tipos de vegetação (fitofisionomias), e destacam a dominância do Cerrado Stricto Sensu, além de encraves e ecótonos:

- Florestas (Floresta Estacional Semidecidual e Floresta Estacional Decidual), onde ocorrem Alismataceae, Gomphrena, Hippeastrum, Schinopsis brasiliensis, Spondias mombin, Tapirira guianensis, Annona crassiflora, Guatteria australis, Guatteria citriodora, Oxandra reticulata, Xylopia frutescens, Aspidosperma cuspa, Aspidosperma multiflorum, Aspidosperma pyrifolium, Himatanthus obovatus

- Savana (Cerrado) inclui:

Savana Florestada (Cerradão) com Curatella americana, Diospyros hispida, Machaerium acutifolium, Magonia pubescens, Protium heptaphyllum, Qualea grandiflora e Qualea parviflora.

Savana Arborizada com Bowdichia virgiloides, Byrsonima coccolobifolia, Byrsonima crassifolia, Connarus suberosus, Curatella americana, Lafoensia pacari, Qualea grandiflora,Qualea parviflora, Sclerolobium paniculatum, Vatairea macrocarpa, Salvertia convalariodora, Tabebuia áurea, Caryocar coriaceum, Dimorphandra gardineriana, Mouriri pusa, Mouriri elliptica, Kielmeyera lathophyton, Stryphnodendron coriaceum, 
Stryphnodendron obovatum, Buchenavia tomentosa, Diospyros coccolobifolia, Parkia platycephalla e Vochysia gardneri;

Savana Parque com Tabebuia aurea, Curatella americana, Byrsonima orbigniana, Annona coriacea, Tabebuia serratifolia, Erythroxylum suberosum, Acosmium dasycarpum, Andira cuyabensis, Dipteryx alata, Byrsonima sericea, Heteropterys byrsonimiifolia, Brosimum gaudichaudii, Myrcia multiflora, Myrcia rostrata, Ouratea castaneifolia, Simarouba versicolor, Qualea parviflora e Vochysia rufa, Justicia lanstyakii, Annona, Funastrum clausum, Mandevilla, Aspilia, Bauhinia acuruana-

Savana Gramíneo-lenhosa com Xanthosoma striatipes, Aeschynomene rostrata, Zornia latifolia

- Formação Pioneira (Formação Fluvial Lacustre), com Protium heptaphyllum, Tapirira guianensis, Licania apetala, Duguetia marcgraviana, Tabebuia serratifolia, Copaifera langsdorffii, Hymenaea courbaril, Physocalymma scaberimum, Himatanthus sucuuba. Brosimum lactescens, Caraipa densiflora, Ceiba penthandra, Cochlospermum orinocense, Diospyros poeppigiana, Cynometra marlenea, Mezilaurus itauba, Piranhea trifoliata, Pterocarpus santalinoides, Ruizteranea wittrockii, Sloanea eichleri, Terminalia lucida, Zygia inaequalis.

- Áreas de Contato (Encrave): Cerrado/ Floresta Estacional, com Aiouea macedoana, Ocotea aciphylla, Antonia ovata, Phthirusa, Banisteriopsis gardneriana, Byrsonima viminifolia, Pseudobombax longiflorum, Myrcia guianensis.

- Áreas de Contato (Ecótono): Floresta Estacional/Floresta Ombrófila, com Callisthene minor, Myrtaceae (Eugenia aff. patrissi e Eugenia cupulata), Martiodendron mediterraneum, Capaifera coriacea, Ephedranthus parviflorus, Aspidosperma discolor, Aspidosperma multiflorum; Manilkara salzmannii, Bocageopsis mattogrossensis, Chrysophyllum gonocarpum. Mouriri, Dipteryx, Vantanea cf. parviflora, Pagamea guianensis, Tabernaemontana, Sacoglottis guianensis, Brosimum rubescens, Sloanea guianensis, Crepidospermum rhoifolium, Thyrsodium spruceanum, Myrcia amazônica, Protium heptaphyllum, Tabebuia serratifolia, Apeiba tibourbou, Pseudobombax tomentosum, Astronium fraxinifolium e Guazuma ulmifolia, Aspidosperma subincanum, Hymenaea courbaril e Anadenanthera colubrina.

$\mathrm{Na}$ bacia hidrográfica do ribeirão Taquaruçu Grande, seguindo a classificação de Ribeiro e Walter (2008) ocorrem formações florestais (Mata Ciliar, Mata de Galeria, Mata 
Seca e Cerradão), formações savânicas (Cerrado Sentido Restrito, Palmeiral, Vereda) e formações campestres (Campo Sujo, Campo Limpo e Campo Rupestre).

\subsection{Procedimentos Metodológicos}

O desenvolvimento desta pesquisa tem seus procedimentos metodológicos baseados na proposta por Libault (1971) para a pesquisa geográfica, cujos procedimentos se enquadram em quatro níveis:

Nível 1 - Compilatório: refere-se à constatação de fatos e fenômenos a serem pesquisados. Compreende os levantamentos e coleta de dados de formatos diversos.

Nível 2 - Correlatório: trata da comparabilidade dos dados referentes a valores numéricos, localização e representação das variáveis utilizadas para caracterizar os elementos ou fenômenos geográficos.

Nível 3 - Semântico ou Interpretativo: representa a análise e a síntese, permitindo chegar aos resultados.

Nível 4 - Normativo: refere-se à tradução dos resultados em produtos que podem ter diferentes modos de codificação representativa dos resultados por meio de modelos numéricos, mapas temáticos, gráficos e tabelas.

Considerando isso, os níveis dos procedimentos metodológicos adotados são descritos a seguir.

\subsubsection{Primeira Etapa: Levantamento, Produção e Processamento dos Dados}

Compreendeu o levantamento de dados bibliográficos e cartográficos existentes, quando foi feita a seleção e compilação das informações coletadas. Esta etapa também se constituiu de levantamento e processamento de dados incluindo etapas de trabalho de campo e de laboratório.

\subsubsection{Levantamentos bibliográfico, cartográfico e de imagens de sensores orbitais}

O levantamento bibliográfico constituiu da seleção e leitura de bibliografias relacionadas à temática, assim como de trabalhos específicos a respeito da área de estudo e teve continuidade durante todo o tempo de execução da pesquisa. 
O levantamento cartográfico compreendeu de: cartas da Diretoria do Serviço Geográfico (DSG) do Ministério do Exército e do IBGE de 1979, na escala de 1:100.000; imagens de satélite LANDSAT TM5 (30 m de resolução), além de imagens do Google Earth e Atlas do Estado do Tocantins. Esses materiais possibilitaram o mapeamento da vegetação.

\subsubsection{Levantamento, produção e processamento de dados}

Esta fase teve início com o reconhecimento da área de estudo com base no material cartográfico e em imagens de sensores orbitais (LANDSAT e Google Earth) e definição dos pontos de amostragem. Incluiu a caracterização do meio físico com a produção e processamento de dados que se constituiu da etapa de mapeamento (caracterização topográfica, hidrográfica e vegetação), caracterização pedológica, vegetação (florística e fitossociológica) e análise da paisagem.

\subsection{Etapa de mapeamento}

Foram solicitadas ao Instituto de Pesquisas Espaciais (INPE) as Imagens LANDSAT da área de estudo, tendo em vista a seleção feita a partir do catálogo disponível no site do INPE (2010a). As imagens solicitadas foram: LANDSAT 5 TM - ORBITA 222 - PONTO 067 de 12 de maio de 2011. Optou-se por realizar o mapeamento a partir de imagens do mês de maio por ser transicional entre a estação úmida e seca e no qual há mais evidência na distinção dos padrões da vegetação de Cerrado sentido amplo (lato sensu) e quando ainda não se iniciou a época de queimadas na região, facilitando a interpretação das imagens no processo de mapeamento.

Para o geoprocessamento de imagens e o mapeamento da bacia do ribeirão Taquaruçu Grande, utilizou-se o Sistema de Processamento de Informações Georreferenciadas (SPRING), versão 5.1.8., software livre produzido pelo INPE (2010b) e seus aplicativos IMPIMA e SCARTA.

Para os mapas produzidos a partir da imagem do LANDSAT 5 TM, foram utilizadas as bandas 3, 4 e 5 para a composição da imagem colorida e processo de mapeamento devido as informações a serem coletadas e necessárias para este processo, tendo em vista as suas principais aplicações (Tabela 3.2), e resolução de $30 \mathrm{~m}$. A imagem LANDSAT com as respectivas bandas foi, primeiramente, convertida no IMPIMA, do modo "tiff" para o modo 
"grib", para posteriormente ser georreferenciada e processada no SPRING. Utilizou-se a Imagem LANDSAT do mosaico da NASA (2010) já georreferenciada disponível ${ }^{5}$ para georreferenciar as imagens LANDSAT a serem trabalhadas.

Tabela 3.2 - Principais aplicações potenciais das bandas espectrais do Landsat 5 TM. Fonte: SANO (1987)

\begin{tabular}{c|cclc}
\hline Banda & $\begin{array}{c}\text { Comprimento de } \\
\text { Onda }(\boldsymbol{\mu m})\end{array}$ & \multicolumn{1}{c}{$\begin{array}{c}\text { Faixa } \\
\text { espectral }\end{array}$} & \multicolumn{1}{c}{ Aplicações Principais } \\
$\mathbf{3}$ & $0,63-0,69$ & Vermelho & $\begin{array}{l}\text {-Absorção da clorofila, significativa na } \\
\text { diferenciação de espécies vegetais }\end{array}$ \\
$\mathbf{4}$ & $0,77-0,90$ & Infravermelho próximo & $\begin{array}{l}\text { Estudos de volume da biomassa e } \\
\text { delimitação de corpos d'água }\end{array}$ \\
$\mathbf{5}$ & $1,55-1,75$ & Infravermelho médio & $\begin{array}{l}\text { E-Estresse da vegetação por desequilíbrio de } \\
\text { água na cobertura foliar }\end{array}$ \\
\hline
\end{tabular}

Após obter o mosaico da NASA este foi corrigido pelo software GeoExpress View by ILS da LizardTech $(2010)^{6}$. O arquivo da NASA foi importado para o SPRING para a realização do registro da imagem LANDSAT, associando-se o azul (B) à banda 3 , o verde à banda $4(\mathrm{G})$ e o vermelho à banda $5(\mathrm{R})$, para a montagem da composição colorida RGB (do inglês: Red, Green, Blue), procedendo-se, posteriormente, as etapas seguintes para a realização do mapeamento: a) contraste linear; b) segmentação; c) classificação; d) pósclassificação; e) mapeamento; f) edição matricial. No SCARTA, foi feita a edição do mapa.

$\mathrm{Na}$ etapa de classificação, o processo utilizado foi de "pixel a pixel", que é definida como técnica de classificação multiespectral com treinamento supervisionado (utilizando-se pontos controle com coordenadas geográficas coletadas em campo) na qual o classificador utilizado foi o MAXVER-ICM (Interated Conditional Modes).

No "treinamento" (etapa da classificação), as classes temáticas que compuseram o mapa de unidades de paisagem foram:

a) Floresta, que incluiu Mata Ciliar, Mata de Galeria, Mata Seca, Vereda e Campo Limpo Úmido. A Vereda foi inserida nessa unidade da paisagem por constituir áreas úmidas, próximas à Matas Ciliares ou Matas de Galeria e o Campo Limpo Úmido por ocorrer associado à essas Matas e à Vereda.

b) Cerradão;

c) Cerrado Sentido Restrito;

\footnotetext{
${ }^{5}$ Disponível em: https://zulu.ssc.nasa.gov/mrsid. Acesso em 05/01/2011.

${ }^{6}$ Disponível em: http://www.lizardtech.com/solutions/geo. 05/01/2011.
} 
d) Campo Sujo Seco;

e) Área urbana e rural edificadas;

f) Agropecuária/Silvicultura;

g) Lago reservatório, ribeirões, córregos e brejos.

O Babaçual, por compor pequenas áreas, no mapeamento está representado tanto na unidade de paisagem Floresta, quanto em Cerradão e Cerrado Sentido Restrito, da mesma forma que o Campo Rupestre está inserido na classe temática Cerrado Sentido Restrito. O Lago reservatório da UHE Luís Eduardo Magalhães representa o curso superior do ribeirão Taquaruçu Grande inundado com o enchimento do referido Lago. A amplitude de determinadas classes temáticas foi em decorrência da resolução das imagens LANDSAT TM$5\left(30 \times 30 \mathrm{~m}=900 \mathrm{~m}^{2}\right)$.

Utilizou-se também a Folha de Vila Canela (DSG, 1979), na forma digital (formato “tiff'), para a composição do mapa base da área de estudo, passando pelas etapas do Módulo IMPIMA, com a seleção da banda monocromática e delimitação de uma área menor, na qual o retângulo envolvente do Projeto de Mapeamento esteja inserido. Em seguida, utilizou-se o SPRING para o processo de mapeamento por meio da vetorização da hidrografia e topografia da bacia hidrográfica do ribeirão Taquaruçu Grande.

A delimitação da bacia foi com base em critérios hidrográficos, divisores de água e cotas altimétricas. Utilizou-se a carta da Diretoria do Serviço Geográfico (DSG) do Ministério do Exército e do IBGE de 1979, na escala de 1:100.000, Folha de Vila Canela SC.22-Z-B-III MI-1644. Estes temas foram atualizados com vetorização complementar utilizando-se a imagem LANDSAT classificada, concluindo-se a edição do mapa no SCARTA. Foram produzidos os mapas de hidrografia (1977-2011), topográfico (1979) e de unidades de paisagem (2011).

Para a determinação da hierarquia fluvial foi utilizada a classificação de Strahler (1957 apud CHRISTOFOLETTI, 1980, p. 106) ${ }^{7}$ que considera que os menores canais sem tributários são de primeira ordem; os de segunda ordem se originam da confluência de dois canais de primeira ordem e só recebem afluentes de primeira ordem; os canais de terceira ordem surgem da confluência de dois canais de segunda ordem, podendo receber afluentes de segunda e primeira ordens; os canais de quarta ordem são resultantes da confluência de dois canais de terceira ordem, podendo receber canais de ordens inferiores, e assim sucessivamente.

\footnotetext{
${ }^{7}$ STRAHLER, A. N. Dimensional analysis of watershed Geomorphology. Amer. Geoph. Union Trans. 1957, 38, p. 913-920.
} 


\subsection{Caracterização pedológica}

A caracterização química e física do solo foi realizada em novembro de 2012 e a de umidade do solo, de fevereiro a agosto de 2013. Ambas incluíram etapas de campo e laboratório. Teve-se como base um delineamento experimental em blocos casualizados (5 blocos x 2 tratamentos) que corresponderam às áreas de estudo da vegetação de Campo Sujo Seco, com área total de $2000 \mathrm{~m}^{2}$ em cada bloco e os tratamentos à situação de disposição das parcelas de amostragem no tipo de relevo, ou seja: situação de topo de morro $\left(1000 \mathrm{~m}^{2}\right)$ e de vertente $\left(1000 \mathrm{~m}^{2}\right.$, na posição mediana).

As amostras de solo para análises químicas e físicas foram do tipo deformada, coletadas com Amostrador de Solo Semi-automático SACI Nº de série 090413, 12 Volts e 30 amperes (Figura 3.4), de forma aleatória a partir de caminhada em ziz-zag dentro das áreas das parcelas do inventário florístico (Figura 3.5), que correspondem aos blocos no estudo de solos.
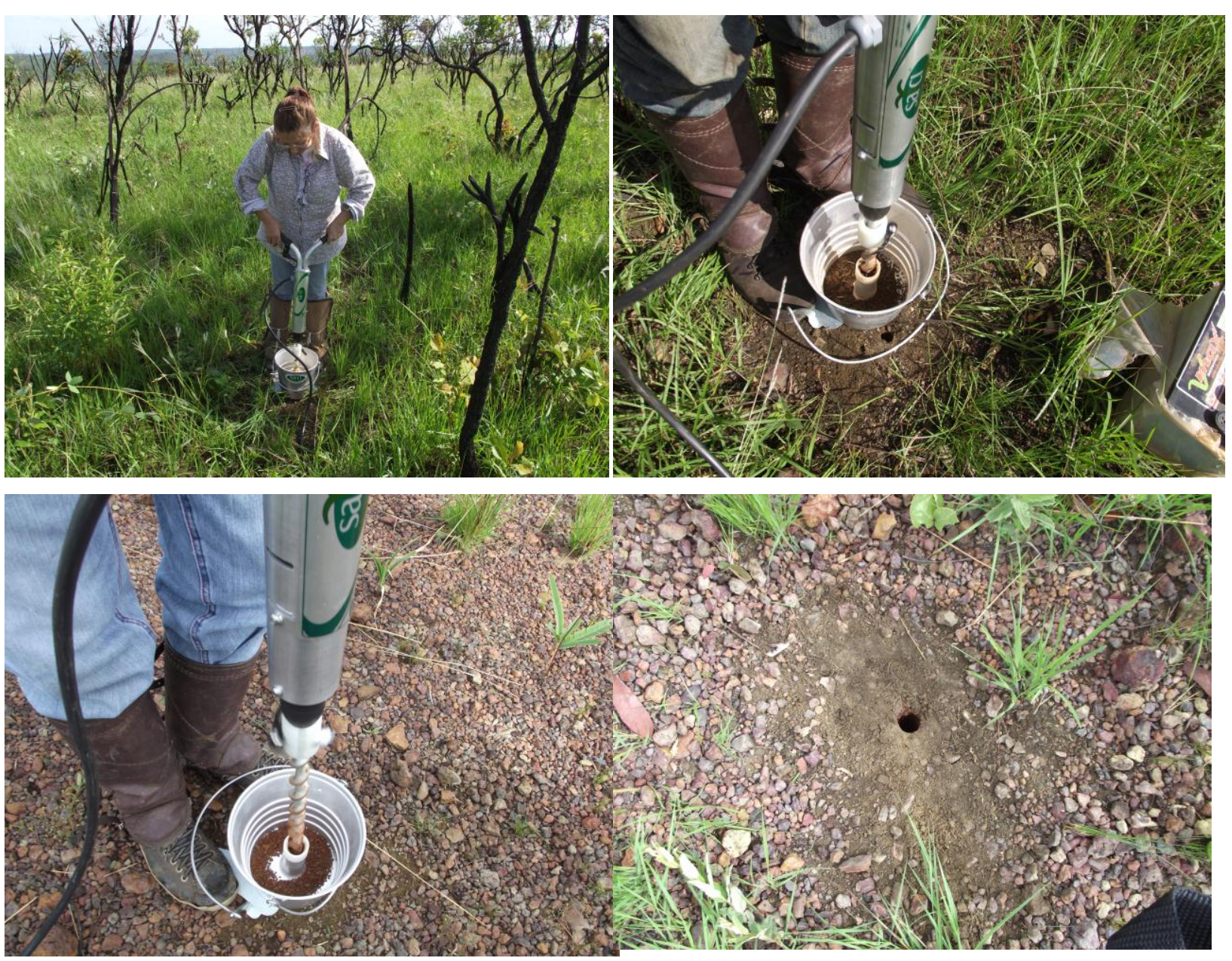

Figura 3.4 - Demonstração da coleta de solo sob vegetação de Campo Sujo Seco, na bacia hidrográfica do ribeirão Taquaruçu Grande, Palmas - TO (Fotografias por: T. C. C. Medeiros, 2012 
Foram coletadas 10 amostragens simples de solo a profundidade de 0-20 cm, para cada bloco (áreas), tendo-se o cuidado de remover folhas e outros detritos da superfície do solo a ser amostrado. As amostras foram colocadas juntas em saco plástico limpo, homogeneizadas, compondo uma amostra final, composta, de $500 \mathrm{~g}$, seguindo-se a metodologia da EMBRAPA $^{8}$. Foram devidamente lacradas, etiquetadas, transportadas ao Laboratório de Solos e Biogeografia (Geografia/UFT/Porto Nacional), e secas ao ar natural.

As análises químicas e físicas do solo foram realizadas pelo Laboratório Solo Fértil (Porto Nacional - TO). $\mathrm{Na}$ análise química foram obtidos dados analíticos de $\mathrm{pH}$ em $\mathrm{CaCl}_{3}$; Cálcio (Ca), Magnésio (Mg), Potássio (K), Alumínio (Al), Acidez Potencial (H+Al), Fósforo (P), Ferro (Fe) e Matéria Orgânica (M.O.), de acordo com a metodologia da EMBRAPA (1999). Em função dessas determinações, foram calculadas a Saturação por Bases (V\%), a Capacidade de Troca Catiônica (CTC), a Saturação de Al (m\%), a Saturação com H+Al. A análise física (textura) foi realizada por quantificação das frações areia, silte e argila dispersas em água tendo sido calculado o grau de floculação de acordo com EMBRAPA (1999).

Para a determinação da umidade dos solos as coletas foram realizadas no período de fevereiro a agosto de 2013, considerando-se a estacionalidade climática, seguindo-se a metodologia de Almeida (2005), com adaptações. Foram coletadas quatro amostras simples, deformadas de solo, em cada bloco (área), sendo duas amostras no topo e duas na vertente (posição mediana), na profundidade de 0-20 cm. As duas amostras do topo ou da vertente formaram uma amostra composta com cerca de $1 \mathrm{~kg}$ de solo para cada situação do relevo, totalizando $2 \mathrm{~kg}$ de solo por bloco. A coleta do solo foi feita manualmente, com pá e imediatamente acondicionada, sem peneiramento, em saco plástico, que foi envolvido com densa camada de filme plástico, para evitar a perda de umidade. As amostras foram devidamente etiquetadas, acomodadas em caixa plástica que foi mantida no interior do veículo, protegida do sol e transportada ao Laboratório de Solos e Biogeografia (Geografia/UFT/Porto Nacional).

Foi feito o peso úmido das amostras de solo, em balança digital de precisão, que foram secas em estufa a $65^{\circ} \mathrm{C}$, durante o período de três dias no Laboratório de Análise GeoAmbiental (Geografia/UFT/Porto Nacional). Após a secagem foi feito o peso seco e, a partir dos dados de peso seco e úmido, foi calculado o percentual de água presente no solo, de acordo com Troeh e Thompson (2007, p. 133), como no exemplo a seguir:

\footnotetext{
${ }^{8}$ http://www.cnps.embrapa.br/servicos/metodo_coleta.html > Acesso em 10 nov/2012.
} 
Massa do solo úmido $=75 \mathrm{~g}$

Massa do solo seco em estufa $=60 \mathrm{~g}$

Massa de água presente $=15 \mathrm{~g}$

Assim: $\%$ de água presente $=15 \mathrm{~g} / 60 \mathrm{~g}$ x $100=25 \%$

Para a análise estatística dos tratamentos (topo e vertente), foi realizado o teste " $T$ " não pareado (dados independentes) e teste " $T$ " pareado (cada topo com sua vertente). Para análise estatística entre áreas (blocos), foi realizada análise de variância (ANOVA) de um fator e a comparação das médias foi feita pelo teste de Tukey, usando o programa Bio Estat versão 5.0 de Ayres et al. (2007). Os parâmetros avaliados foram: pH, M.O., Ca, Mg, K, P, Fe, Al, H+Al, CTC Total, CTC Efetiva, Saturação de Al, Saturação com H+Al, Saturação por Bases, textura e água presente nos solos. Foram construídos gráficos e tabelas para representar os resultados das análises de solos.

\subsection{Caracterização da vegetação}

A caracterização da vegetação foi feita com base no mapeamento realizado da cobertura vegetal, considerando o geofácie Campo Sujo Seco, identificado em campo com a chave de identificação de fitofisionomias desenvolvida por Ribeiro e Walter (2008).

Com base no mapeamento e nos trabalhos de campo, foram selecionadas cinco áreas de estudo (Figura 3.5 e Tabela 3.3). A disposição das unidades amostrais dentro de cada uma das áreas obedeceu ao critério sistemático de acordo com Matteucci e Colma (1982). A amostragem foi pelo método de parcelas (MUELLER-DOMBOIS e ELLENBERG, 1974), por tratar-se de um método em estudos da vegetação de Cerrado bastante difundido (FIDELIS e GODOY, 2003; ASSUNÇÃO e FELFILI, 2004; FONSECA e SILVA JÚNIOR, 2004; FELFILI et al., 2007).

O total da área amostrada foi de um hectare, com o tamanho das parcelas de $10 \mathrm{~m}$ x $10 \mathrm{~m}$ $\left(100 \mathrm{~m}^{2}\right)$, totalizando 100 parcelas, sendo 50 parcelas em situação de relevo topo de morro e 50 parcelas em situação de relevo de vertente (posição mediana), totalizando 20 parcelas por área (10 parcelas no topo e 10 parcelas na vertente, Figura 3.6).

De acordo com Felfili et al. (2005), o número mínimo de parcelas para cálculos de variância em um inventário exploratório é dez, e para inventários florestais em florestas tropicais é desejável que a área da amostra (conjunto de parcelas ou unidades amostrais) seja 
de um hectare. Amostragens em áreas campestres do Cerrado, em geral, realizam inventários com áreas bem inferiores a um hectare (MUNHOZ; FELFILI, 2005; MUNHOZ; FELFILI, 2006; CONCEIÇÃO; PIRANI, 2006). 


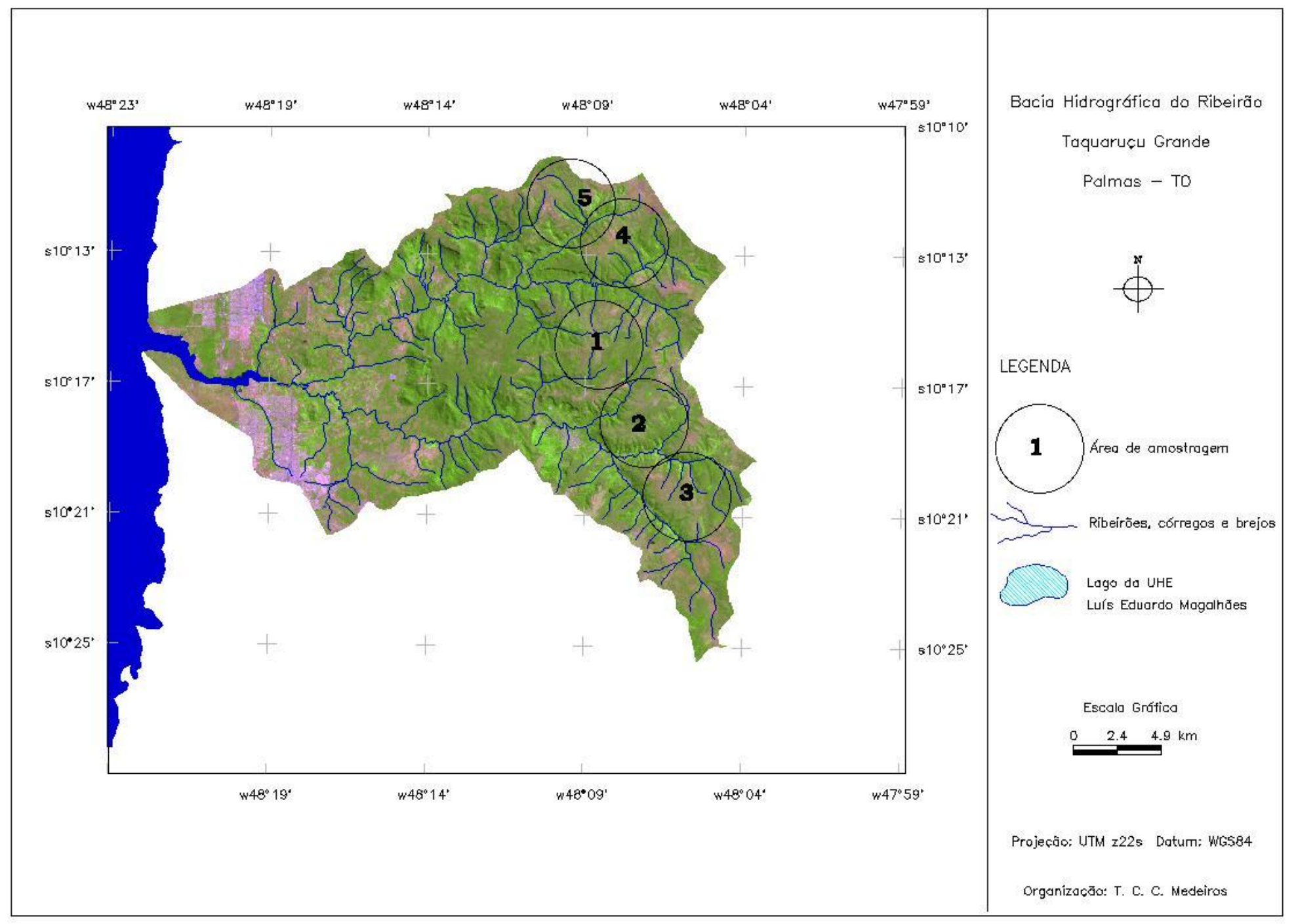

Figura 3.5 - Pontos de amostragem fitossociológica, florística e solos do Campo Sujo Seco, na bacia hidrográfica do ribeirão Taquaruçu Grande, Palmas - TO 
Tabela 3.3 - Coordenadas das áreas de amostragem no Campo Sujo da bacia hidrográfica do ribeirão Taquaruçu Grande, Palmas - TO (Organização: T. C. C. Medeiros)

\begin{tabular}{|c|c|c|}
\hline Área & Latitude Sul & Longitude Oeste \\
\hline Área 1 topo & $10^{\circ} 16^{\prime} 06,7^{\prime \prime}$ & $48^{\circ} 08^{\prime} 41,5^{\prime \prime}$ \\
\hline Área 1 vertente & $10^{\circ} 16^{\prime} 08,6^{\prime \prime}$ & $48^{\circ} 08^{\prime} 43,9^{\prime \prime}$ \\
\hline Área 2 topo & $10^{\circ} 18^{\prime} 41,7^{\prime \prime}$ & $48^{\circ} 07^{\prime} 21,3^{\prime \prime}$ \\
\hline Área 2 vertente & $10^{\circ} 18^{\prime} 37,2^{\prime \prime}$ & $48^{\circ} 07^{\prime} 20,1^{\prime \prime}$ \\
\hline Área 3 topo & $10^{\circ} 20^{\prime} 53,8^{\prime \prime}$ & $48^{\circ} 05^{\prime} 43,2^{\prime \prime}$ \\
\hline Área 3 vertente & $10^{\circ} 20^{\prime} 53,6^{\prime \prime}$ & $48^{\circ} 05^{\prime} 40,0^{\prime \prime}$ \\
\hline Área 4 topo & $10^{\circ} 12^{\prime} 41,9^{\prime \prime}$ & $48^{\circ} 07^{\prime} 27.8^{\prime \prime}$ \\
\hline Área 4 vertente & $10^{\circ} 12^{\prime} 48,6^{\prime \prime}$ & $48^{\circ} 07^{\prime} 50,6^{\prime \prime}$ \\
\hline Área 5 topo & $10^{\circ} 11^{\prime} 17,5^{\prime \prime}$ & $48^{\circ} 09^{\prime} 28,1^{\prime \prime}$ \\
\hline Área 5 vertente & $10^{\circ} 11^{\prime} 03,99^{\prime \prime}$ & $40^{\circ} 09^{\prime} 39,66^{\prime \prime}$ \\
\hline
\end{tabular}

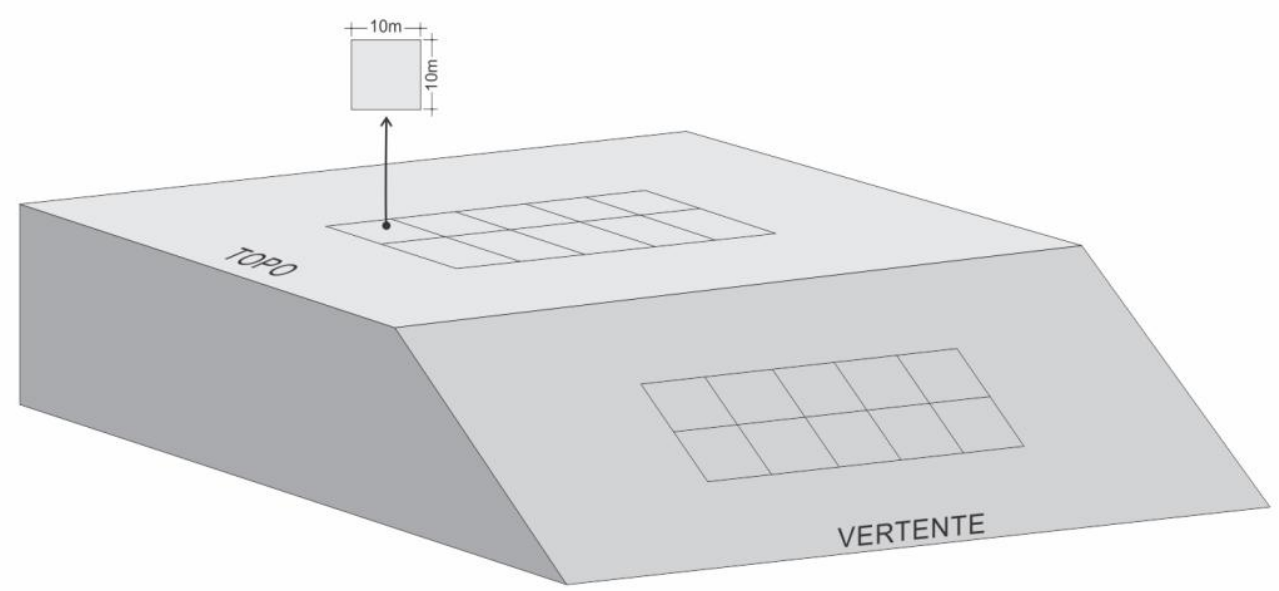

Figura 3.6 - Desenho esquemático da disposição das parcelas no relevo de topo e de vertente, no Campo Sujo Seco, na bacia hidrográfica do ribeirão Taquaruçu Grande, Palmas - TO

O critério de inclusão na medida da vegetação lenhosa foi de circunferência de caule $\geq$ $3,0 \mathrm{~cm}$ no nível do solo (livrando-se as imperfeições do caule). Esta circunferência de caule foi adotada tendo em vista a ocorrência de subarbustos e arbustos de algumas espécies com altura $\geq 1 \mathrm{~m}$ possuírem caules nessa medida de circunferência, a exemplo de espécies do gênero Bauhinia, Chamaecrista e Mimosa. A medida de circunferência ao nível do solo foi devido a própria estrutura de altura do Campo Sujo, e à abundância de ramificações de subarbustos, arbustos e árvores que dificultaram a medida de altura do peito. Os parâmetros biométricos medidos foram circunferência no nível do solo (com fita métrica) e altura de subarbustos, arbustos e árvores (com fita métrica, ou escala graduada, ou telêmetro com alcance de 4 a $30 \mathrm{~m}$ ), registrando-se a espécie medida (Figura 3.7). 
Para a amostragem da vegetação herbácea-subarbustiva, no centro de cada uma das 100 parcela de $100 \mathrm{~m}^{2}$, para amostragem da vegetação lenhosa, foram feitas duas sub-parcelas de $1 \mathrm{~m}^{2}$ para a caracterização do estrato herbáceo-subarbustivo, de acordo com Meira-Neto e Martins (2000), com adaptações. O critério de inclusão foi utilizado apenas para a vegetação subarbustiva, incluindo-se indivíduos com circunferência $\leq 3 \mathrm{~cm}$ de caule não incluídos na amostragem fitossociológica. Para a vegetação herbácea não houve critério de inclusão, tendo sido registrados todos os componentes inclusos na sub-parcela de $1 \mathrm{~m}^{2}$. A cobertura do solo pela vegetação herbácea-subarbustiva foi calculada da seguinte forma: foi medida a área ocupada pela espécie em $1 \mathrm{~m}^{2}$ (pelo fato de terem sido feitas duas parcelas de $1 \mathrm{~m}^{2}$ por parcela de $100 \mathrm{~m}^{2}$, foi feita a média da área da espécies nestas duas parcelas). Utilizou-se o valor médio da área ocupada pela espécie nas duas parcelas de $1 \mathrm{~m}^{2}$ e calculou-se a área da espécie, para $100 \mathrm{~m}^{2}$, por "Regra de Três" simples. A partir desse valor, foi calculado, também por "Regra de Três" simples, a cobertura do solo, em área de $10.000 \mathrm{~m}^{2}$, pela espécie.

Os parâmetros fitossociológicos (CURTIS; MCINTOSSH, 1950; 1951) analisados foram densidade, frequência, dominância absolutas e relativas e, a partir destas, o valor de importância específica (MUELLER-DOMBOIS; ELLENBERG, 1974).

Para avaliar a diversidade e similaridade, foram calculados o Índice de Similaridade de Sørensen e o Índice de Diversidade de Shannon-Wiener ( $\left.\mathrm{H}^{\prime}\right)$ e o Índice de Uniformidade de Pielou - equabilidade $\left(\mathrm{J}^{\prime}\right)$, como indicadores de heterogeneidade (PIELOU, 1975). A similaridade floristica entre as áreas foi calculada com base na presença e ausência de espécies, pelo índice de Jaccard e coeficiência de distância de Bray Curtis e, com base nestes, foi feita a analise de agrupamento por Unweighted Pair Groups Metod using Arithmetic Averanges (UPGMA) (MUELLER-DOMBOIS; ELLENBERG, 1974. Foi utilizado o método de ordenação Análise em Componentes Principais (ACP). Para análise dos referidos parâmetros, foi utilizado o software Fitopac 2 (SHEPHERD, 1995).

$\mathrm{Na}$ análise de agrupamento também foi utilizado o software WinTWINS (HILL,1979) para separar grupos florístico-estruturais de Campo Sujo Seco. Por ser um método sensível às características estruturais, a análise com o Twinspan não incluiu as espécies do estrato herbáceo-subarbustivo, nem as do estrato arbustivo-arbóreo com altura $\leq 0,4 \mathrm{~m} \mathrm{e} \leq 3,0 \mathrm{~cm}$. 

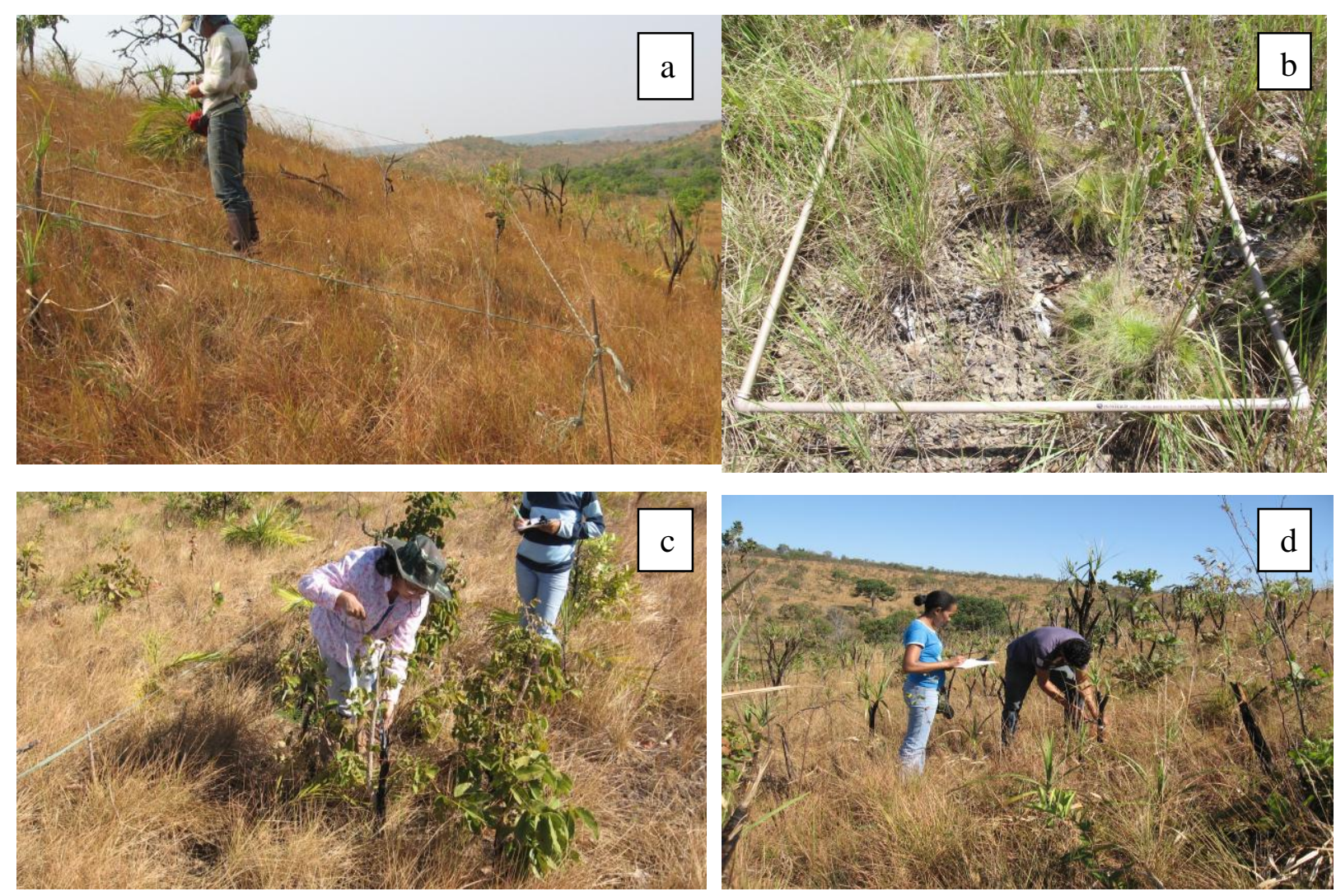

Figura 3.7 - Demonstração de aspectos da amostragem da caracterização florístico-estrutural com a disposição das parcelas de $100 \mathrm{~m}^{2}$ e sub-parcelas de $1 \mathrm{~m}^{2}$ na posição mediana da vertente (a); sub-parcela de $1 \mathrm{~m}^{2}$ para caracterização do estrato herbáceo-subarbustivo (b); medida de altura (c) e circunferência de base de plantas (d), da vegetação de Campo Sujo Seco, na bacia do ribeirão Taquaruçu Grande, Palmas TO. Fotografia de T.C.C. Medeiros em 2011)

Foram utilizadas as seguintes fórmulas:

1. Densidade

$\mathrm{DA}=$ número de árvores /hectare

DR de cada espécie $=$ DA da espécie/DA de todas as espécies $\mathrm{x} 100$

Onde:

$\mathrm{DA}=$ Densidade Absoluta

$\mathrm{DR}=$ Densidade Relativa

\section{Dominância}

DoA = Área basal de cada espécie/hectare

DoR = Área basal de cada espécie.ha ${ }^{-1} /$ Área basal total x100

Onde:

DoA = Dominância Absoluta

DoR $=$ Dominância Relativa 


\section{Frequência}

$\mathrm{FA}=\mathrm{n}^{\circ}$ de parcelas em que ocorre uma espécie/ $\mathrm{n}^{\circ}$ total de parcelas $\mathrm{x} 100$

FR da espécie $=$ FA da espécie/FT x 100

$$
\sum_{\mathrm{i}=1}^{\mathrm{n}} \text { FA da espécie }
$$

Onde:

FA $=$ Frequência Absoluta

$\mathrm{FR}=$ Frequência Relativa

$\mathrm{FT}=$ Frequência Total $\left(\sum\right.$ de todas as FA)

4. Índice de Valor de Importância (IVI)

IVI $=$ Densidade relativa + Frequência relativa + Dominância relativa

5. Índice de Shannon

$$
\begin{aligned}
& \mathrm{n} \\
& \mathrm{H}^{\prime}=-\sum \mathrm{pi} \cdot \mathrm{Ln}(\mathrm{pi}) \\
& \mathrm{i}=1 \\
& \mathrm{H} \max =\mathrm{Ln} \mathrm{S}
\end{aligned}
$$

Onde:

$\mathrm{H}^{\prime}$ = índice de diversidade de Shannon

$\mathrm{Ln}=$ logaritmo neperiano

$\mathrm{pi}=\mathrm{ni} / \mathrm{N}$

ni = números de indivíduos amostrados da espécie $\mathrm{i}$

$\mathrm{N}=$ número total de indivíduos amostrados

$\mathrm{H}$ max = entropia máxima (nats/ind.)

$\mathrm{S}=$ número total de espécies

6. Índice de uniformidade de Pielou

$\mathrm{J}^{\prime}=\mathrm{H}^{\prime} / \mathrm{H} \max$

Onde:

$\mathrm{J}^{\prime}$ = equabilidade

$\mathrm{H}^{\prime}$ = índice de diversidade de Shannon

H max = entropia máxima (nats/ind.)

7. Índice de $S_{\varnothing}$ rensen - varia de 0 a 1

$\mathrm{I}_{\mathrm{S}}=2 \mathrm{a} / 2 \mathrm{a}+\mathrm{b}+\mathrm{c}$

Onde:

$\mathrm{a}=$ número de espécies em comum às duas comunidades

$\mathrm{b}=$ número de espécies da comunidade 1

$\mathrm{c}=$ número de espécies da comunidade 2

8. Índice de Jaccard

$I_{J}=a / a+b+c$ 
Onde:

$\mathrm{a}=$ número de espécies em comum às duas comunidades

$\mathrm{b}=$ número de espécies da comunidade 1

$\mathrm{c}=$ número de espécies da comunidade 2

Em se tratando das espécies subarbustivao-arbustivo-arbóreas, a preferência das espécies pelo topo ou pela vertente foi caracterizada como: exclusiva - $100 \%$ de ocorrência; alta - de 66,6 a 99,9\% de ocorrência; média - 33,3 a 66,6\% de ocorrência; e, baixa - até 33,3\%.

O material botânico coletado foi identificado por meio de consulta a bibliografia específica, por comparação com exsicatas depositadas no Herbário HTO, do Núcleo de Estudos Ambientais (NEAMB)/UFT/Porto Nacional e, quando necessário, foi enviado a especialistas. O sistema taxonômico utilizado foi o APG III (2009) e o nome das categorias taxonômicas (ordem, família, gênero e espécie) foi confirmado em www.floradobrasil.jbri.gov.br (Acesso: 05 nov. 2013).

\subsection{Análise da Paisagem}

A análise da paisagem foi realizada com base na bibliografia, na interpretação visual da imagem LANDSAT/2011, com o auxílio da observação da imagem orbital Geoeye, disponível no Google Earth (2011) e visitas à área de estudo. O sistema de classificação para análise da paisagem baseou-se em Bertrand (2004), cujo sistema possui seis níveis temporoespaciais (Quadro 3.1), descritos a seguir:

1) Zona: unidade de $1^{a}$ grandeza, zonalidade planetária que se define primeiramente por seu clima e seus biomas.

2) Domínio: unidade de $2^{\mathrm{a}}$ grandeza, paisagens com dimensões subcontinentais e que são vigorosamente individualizadas podendo ser caracterizado por certa combinação de relevos e de climas.

3) Região Natural: unidade entre a $3^{\mathrm{a}}$ e $4^{\mathrm{a}}$ grandeza, compreende tanto conjuntos físicos, estruturais ou climáticos como domínios caracterizados pela sua vegetação, culturas humanas, dentre outros.

4) Geossistema: unidade entre a $4^{\mathrm{a}}$ e $5^{\mathrm{a}}$ grandeza temporo-espacial, unidade dimensional compreendida entre alguns quilômetros quadrados e algumas centenas de quilômetros quadrados. Em seu modelo teórico da paisagem ele se define pelo potencial ecológico (clima, hidrologia, geomorfologia), exploração biológica do espaço (vegetação, solos, fauna) e ação antrópica. 
5) Geofácies: unidade de $6^{\mathrm{a}}$ grandeza, corresponde a um setor fisionomicamente homogêneo onde se desenvolve a mesma fase de evolução geral do geossistema. Representa assim uma malha na cadeia das paisagens que se sucedem no tempo e no espaço no interior de um mesmo geossistema. Em relação à superfície coberta, corresponde a algumas centenas de quilômetros quadrados em média. Pode-se ter cadeias progressivas e cadeias regressivas de geofácies, como também um geofácie-clímax que constitui um estágio final da evolução natural do geossistema.

6) Geótopos: unidade de $7^{\mathrm{a}}$ grandeza, último nível de análise da escala espacial, representando sub-unidades do nível de análise Geofácies. Em Biogeografia (Unidades Elementares, Quadro 3.1) corresponde ao complexo biótopo-biocenose (menor unidade homogênea discernível no terreno). Em algumas vezes é indispensável conduzir a análise ao nível das micro-formas na escala do metro quadrado ou mesmo do decímetro quadrado, como por exemplo, uma diáclise alagada pela dissolução, uma cabeceira de nascente, um fundo de vale que o sol nunca atinge, uma face montanhosa, constituem igualmente biótopos. É o refúgio de biocenoses originais, às vezes relictuais ou endêmicas.

Quadro 3.1 - Esquematização da análise sintética da paisagem segundo Bertrand (2004)

\begin{tabular}{|c|c|c|c|c|c|c|c|}
\hline \multirow{2}{*}{$\begin{array}{c}\text { UNIDADES DA } \\
\text { PAISAGEM }\end{array}$} & \multirow{2}{*}{$\begin{array}{c}\text { ESCALA } \\
\text { TEMPORO- } \\
\text { ESPACIAL (A. } \\
\text { CAILEUX J. } \\
\text { TRICART) }\end{array}$} & \multirow{2}{*}{\begin{tabular}{|c|} 
EXEMPLO TOMADO NUMA \\
MESMA SÉRIE DE \\
PAISAGEM
\end{tabular}} & \multicolumn{5}{|c|}{ UNIDADES ELEMENTARES } \\
\hline & & & RELEVo (1) & Clima (2) & BOTÂNICA & BIOGEOGRAFIA & $\begin{array}{c}\text { UNIDADE } \\
\text { TRABALHADA } \\
\text { PELO HOMEM } \\
\text { (3) }\end{array}$ \\
\hline ZONA & $\begin{array}{c}\text { G I grandeza } \\
\text { G. I }\end{array}$ & Temperada & & Zonal & & Bioma & Zona \\
\hline DOMINIO & G. II & Cantábrico & $\begin{array}{l}\text { Domínio } \\
\text { estrutural }\end{array}$ & Regional & & & $\begin{array}{c}\text { Domínio } \\
\text { Região }\end{array}$ \\
\hline $\begin{array}{c}\text { REGIÃO } \\
\text { NATURAL }\end{array}$ & G. III-IV & Picos da Europa & $\begin{array}{l}\text { Região } \\
\text { estrutural }\end{array}$ & & $\begin{array}{l}\text { Andar } \\
\text { Série }\end{array}$ & & $\begin{array}{l}\text { Quarteirão rural } \\
\text { ou urbano }\end{array}$ \\
\hline GEOSSISTEMA & G. IV-V & $\begin{array}{c}\text { Atlântico Montanhês } \\
\text { (calcário sombreado com } \\
\text { faia higrófila a Asperula } \\
\text { odorata em "terra fusca") }\end{array}$ & $\begin{array}{l}\text { Unidade } \\
\text { estrutural }\end{array}$ & local & & $\begin{array}{c}\text { Zona } \\
\text { equipotencial }\end{array}$ & \\
\hline GEOFÁCIES & G. VI & $\begin{array}{c}\text { Prado de ceifa com } \\
\text { Molinio-Arrhenatheretea } \\
\text { em solo lixiviado } \\
\text { hidromórfico formado em } \\
\text { depósito morâinico }\end{array}$ & & & $\begin{array}{l}\text { Estádio } \\
\text { Agrupamen- } \\
\text { to }\end{array}$ & & $\begin{array}{l}\text { Exploração ou } \\
\text { quarteirão } \\
\text { parcelado } \\
\text { (pequena ilha } \\
\text { ou cidade) } \\
\end{array}$ \\
\hline GEÓTOPO & G. VII & $\begin{array}{l}\text { "Lapiés" de dissolução } \\
\text { com Aspidium lonchitis } \\
\text { em microsolo úmido } \\
\text { carbonatado em bolsas }\end{array}$ & & Microclima & & $\begin{array}{c}\text { Biótopo } \\
\text { Biocenose }\end{array}$ & $\begin{array}{l}\text { Parcela (casa } \\
\text { em cidade) }\end{array}$ \\
\hline
\end{tabular}

Nota: As correspondências entre as unidades são muito aproximadas e dadas somente a título de exemplo. 1 - conforme A. Cailleux, J. Tricart e G. Viers; 2 - conforme M. Sorre; 3 - conforme R. Brunet (Fonte: Bertrand, 2004). 


\subsection{Caracterização dos Geofácies}

O sistema de classificação adotado na análise da paisagem para a caracterização dos geofácies de vegetação natural foi o de Ribeiro e Walter (2008). Este sistema se baseia na fisionomia (forma) definida pela estrutura, pelas formas de crescimento dominantes e por possíveis mudanças estacionais, além de considerar aspectos do ambiente (fatores do solo) e da composição florística, adotando para as fitofisionomias uma nomenclatura regional de uso difundido.

Nesta proposta de classificação de vegetação do Cerrado Ribeiro e Walter (2008) descrevem 11 tipos principais de vegetação para o Cerrado, que estão enquadrados: em formações florestais (Mata ciliar, Mata de Galeria, Mata Seca e Cerradão), savânicas (Cerrado Sentido Restrito, Parque de Cerrado, Palmeiral e Vereda) e campestres (Campo Sujo, Campo Limpo e Campo Rupestre); também reconhece 25 fitofisionomias, incluídos os subtipos para algumas fitofiosionomias, como é o caso da Mata de Galeria (Mata Galeria Inundável e Mata de Galeria Não Inundável), Mata Seca (Mata Seca Sempre Verde, Mata Seca Semidecídua e Mata Seca Decídua), Cerrado Sentido Restrito (Cerrado Denso, Cerrado Típico, Cerrado Ralo e Cerrado Rupestre), Palmeiral (Macaubal, Guerobal, Babacual e Buritizal), Campo Sujo (Campo Sujo Seco, Campo Sujo Úmido e Campo Sujo com Murundus) e Campo Limpo (Campo Limpo Seco, Campo Limpo Úmido e Campo Limpo com Murundus).

As fitofisionomias dos geofácies da área de estudo, descritas com maior detalhe na sequência, segundo descrição feita por Ribeiro e Walter (2008), são: Mata Ciliar, Mata de Galeria, Mata Seca, Cerrado Sentido Restrito, Palmeiral, Vereda, Campo Sujo, Campo Limpo e Campo Rupestre.

Mata Ciliar: vegetação florestal que acompanha rios de médio e grande portes, não formando galerias. Diferencia-se da Mata de Galeria por apresentar certa deciduidade e pela composição florística, tendo em vista ser a Mata de Galeria considerada perenifólia (Figura 3.8). As árvores são predominantemente eretas com altura que variam de 20 a $25 \mathrm{~m}$ e com poucos indivíduos emergentes que chegam a $30 \mathrm{~m}$. A cobertura arbórea é variável entre as estações do ano, na estação chuvosa é de 50 a $90 \%$ e na estação seca pode chegar a ser inferior a 50\% (RIBEIRO; WALTER, 2008). 


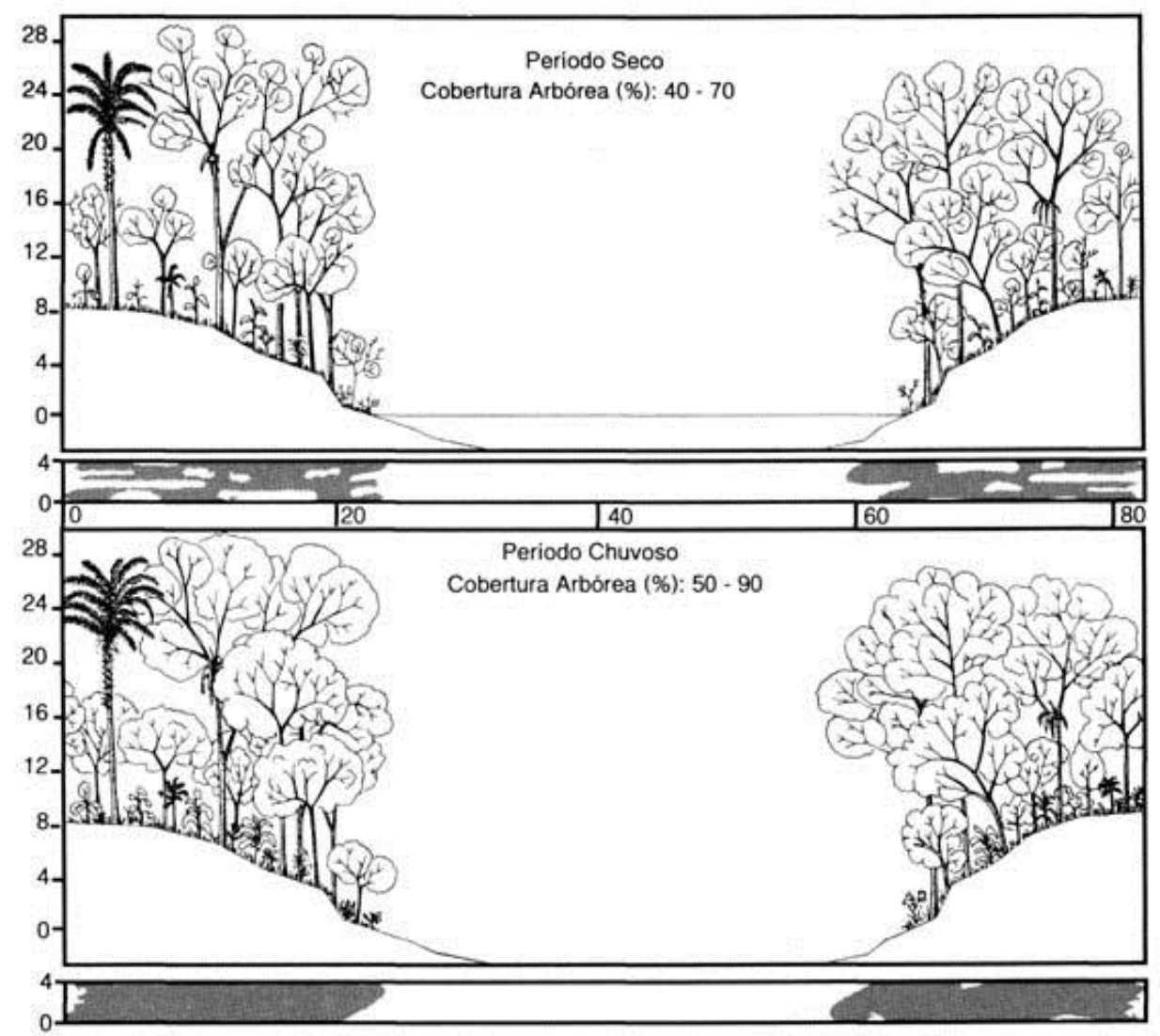

(1)

(2)

(1)

Figura 3.8 - Mata Ciliar representada em um diagrama de perfil (1) e cobertura arbórea (2) em uma faixa de $80 \mathrm{~m}$ de comprimento por $4 \mathrm{~m}$ de largura, nos períodos seco e chuvoso. Fonte: Ribeiro e Walter (2008)

Mata de Galeria: vegetação de tipo florestal que acompanha os rios de pequeno porte e córregos dos planaltos do Brasil Central formando corredores fechados (galerias) sobre os cursos de água (Figura 3.9). Em geral, essas matas localizam-se nos fundos dos vales ou nas cabeceiras de drenagem onde os cursos de água ainda não escavaram um curso definitivo e são perenifólias. São matas cujo estrato arbóreo varia de 20 a $30 \mathrm{~m}$ de altura e a superposição das copas fornece cobertura arbórea de 70 a 90\%. Pode ser ou não inundável (RIBEIRO; WALTER, 2008) (Figura 3.9). 


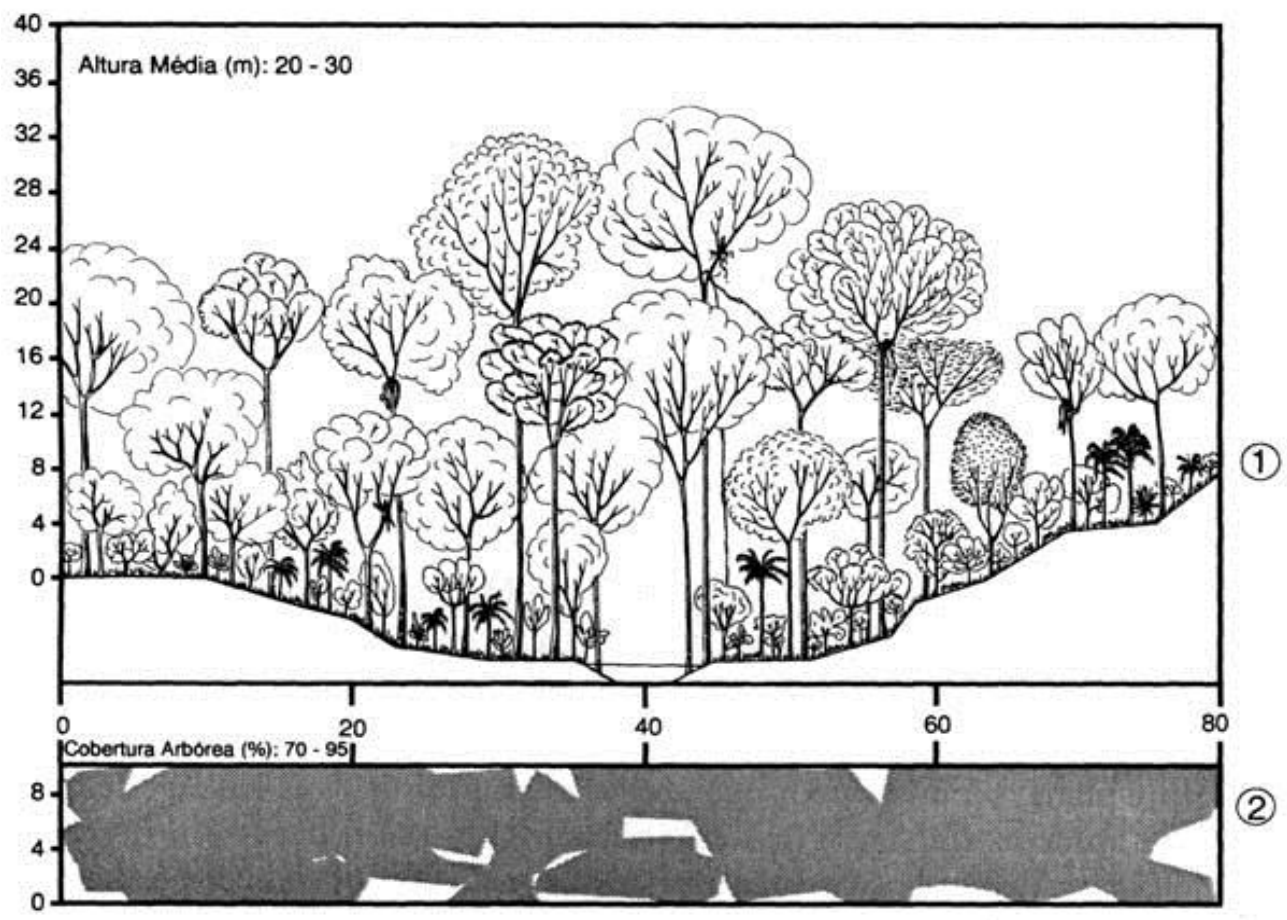

Figura 3.9 - Mata de Galeria não inundável representada pelo diagrama de perfil (1) e cobertura arbórea (2) em uma faixa de $80 \mathrm{~m}$ de comprimento por $10 \mathrm{~m}$ de largura. Fonte: Ribeiro e Walter (2008)

Mata Seca: caracterizada por diversos níveis de caducifolia durante a estação seca. Possuem estrato arbóreo médio de 15 a 25 m de altura. Ocorrem, geralmente, nos interflúvios e nos locais mais ricos em nutrientes, sendo dependentes das condições químicas e físicas do solo mesotrófico, principalmente da profundidade. Na estação chuvosa, a cobertura arbórea varia de 70 a 95\%. Conforme a Figura 3.10, pode ser sempre-verde, com cobertura arbórea de 60 a 90\%; semidecídua, com cobertura arbórea de 50 a 60\%); e, decídua, com cobertura arbórea de 30 a 50\% (RIBEIRO; WALTER, 2008).

Cerradão: formação florestal do Cerrado, que apresenta dossel contínuo e cobertura arbórea que varia de 50 a 90\%, sendo maior na estação chuvosa (Figura 3.11). A altura média do estrato arbóreo varia de 8 a $15 \mathrm{~m}$. Tais características proporcionam condições de luminosidade e favorecem a formação do estrato arbustivo e herbáceo diferenciados. Tem um padrão geral vegetal de semideciduidade, embora possa ser perenifólio (RIBEIRO; WALTER, 2008). 


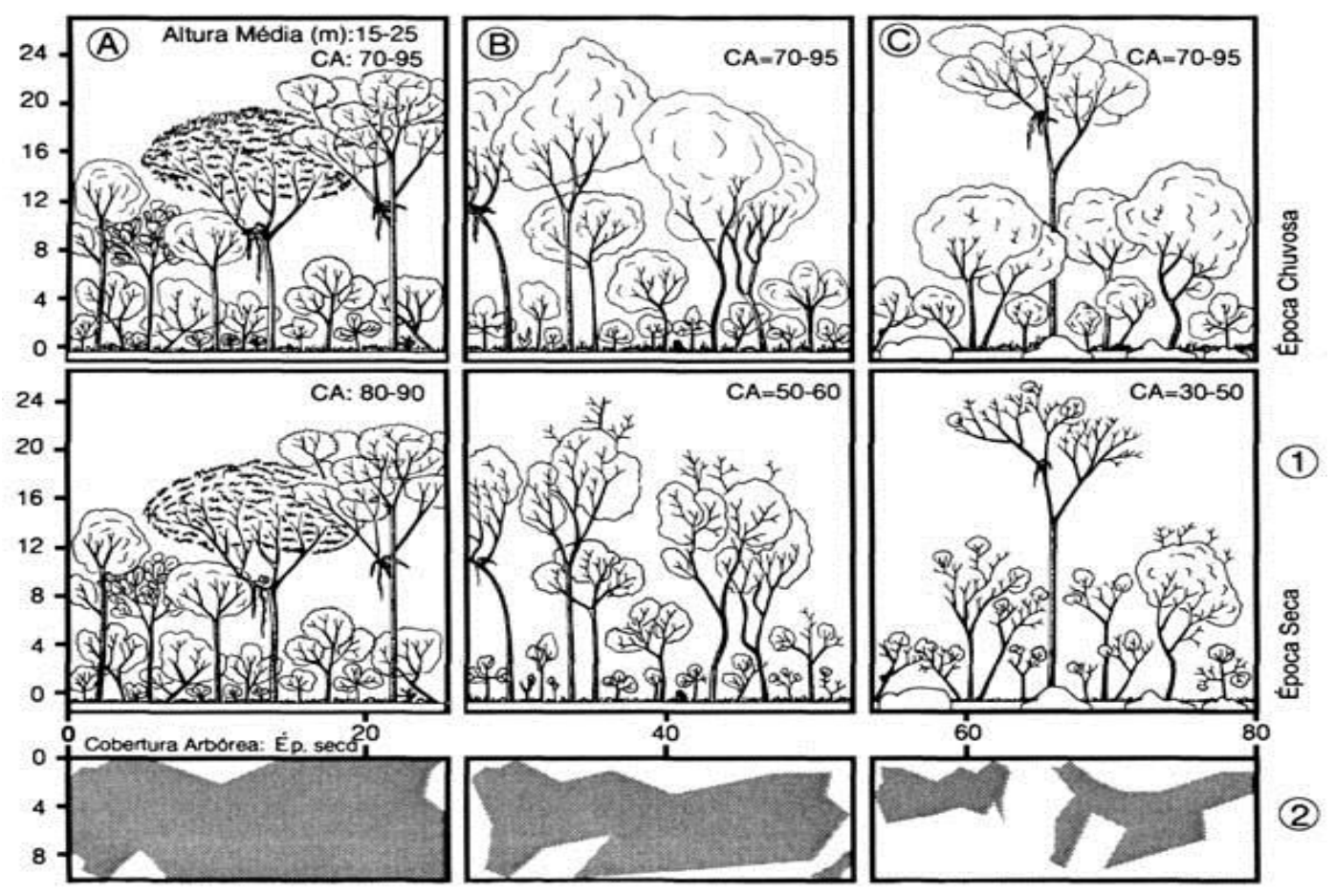

Figura 3.10 - Mata Seca representada pelo diagrama de perfil (1) e cobertura arbórea (2) em uma faixa de $80 \mathrm{~m}$ de comprimento por $10 \mathrm{~m}$ de largura, em diferentes épocas chuvosa e seca, onde: $\mathrm{Ca}=$ cobertura arbórea, $\mathrm{A}=$ Mata Seca Sempre-Verde, B = Mata Seca Semidecídua, C = Mata Seca Decídua com afloramento de rocha. Fonte: Ribeiro e Walter (2008)

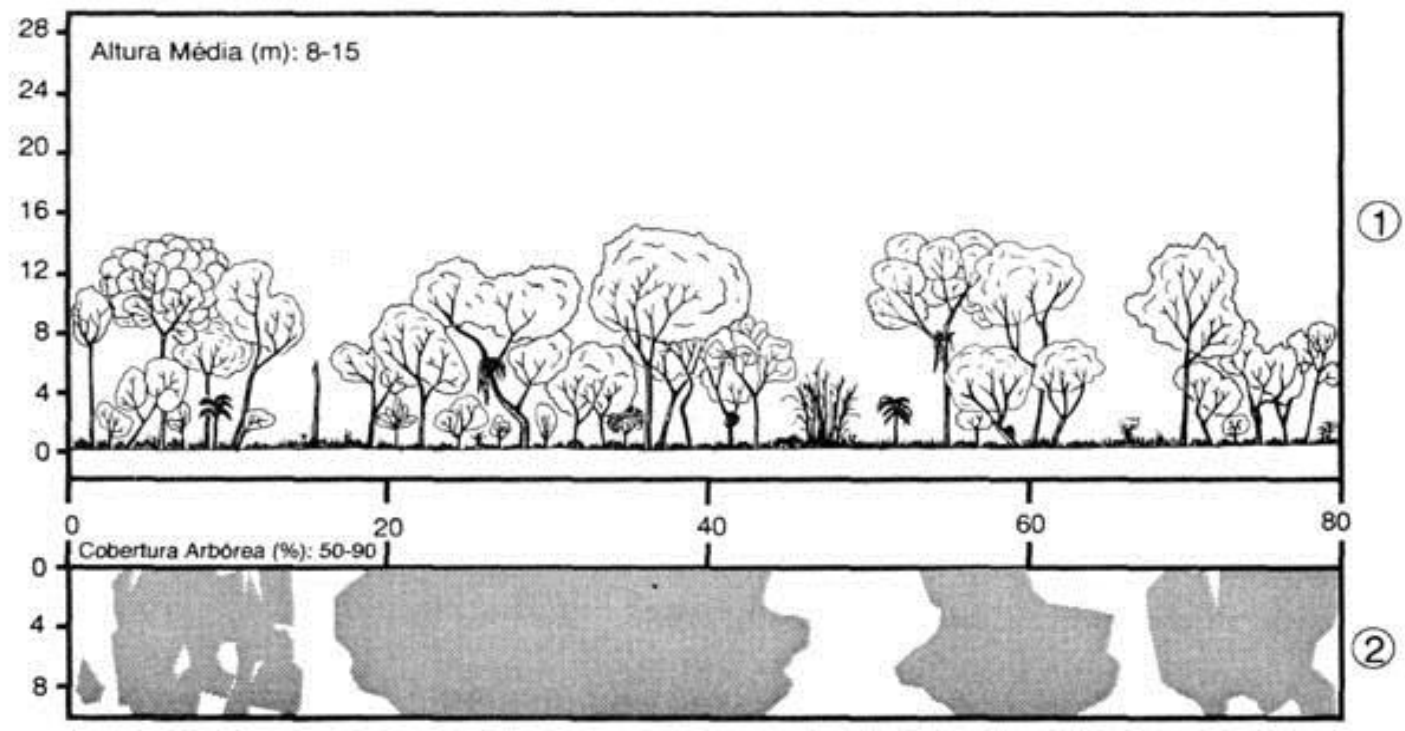

Figura 3.11 - Cerradão representado pelo diagrama de perfil (1) e cobertura arbórea (2) em uma faixa de $40 \mathrm{~m}$ de comprimento por $10 \mathrm{~m}$ de largura. Fonte: Ribeiro e Walter (2008) 
Cerrado Sentido Restrito: tem como características a presença de árvores baixas, inclinadas, tortuosas, com ramificações irregulares e retorcidas, geralmente com evidência de queimadas (RIBEIRO; WALTER, 2008). Possui 4 subtipos:

- Cerrado Denso - predominantemente arbóreo, forma mais densa e alta, com altura média de 5 a $8 \mathrm{~m}$ e cobertura arbórea de 50 a 70\%;

- Cerrado Típico - predominantemente arbóreo-arbustivo, é a forma comum e intermediária entre o Cerrado Denso e o Cerrado Ralo, tem altura média de 3 a $6 \mathrm{~m} \mathrm{e}$ cobertura arbórea de 20 a 50\% );

- Cerrado Ralo - predominantemente arbóreo-arbustivo, a forma mais baixa e menos densa, o estrato arbustivo-herbáceo é mais destacado em relação aos subtipos anteriores, tem altura média de 2 a 3 m e cobertura arbórea de 5 a 20\%;

- Cerrado Rupestre - vegetação arbóreo-arbustiva que ocorre em ambiente rupestre (rochosos), tem altura média de 2 a 4 m e cobertura arbórea de 5 a $20 \%$, podendo ocorrer em trechos contínuos, mas geralmente aparece em mosaicos, incluído em outros tipos de vegetação (Figura 3.12, respectivamente a, b, c).

Palmeiral: fitofisionomia da formação savânica caracterizada por uma única espécie de palmeira (Figura 3.13). Podem ser formados Attalea speciosa Mart. ex Spreng. (Babaçual), por Acrocomia aculeata (Macaubal), Syagrus oleraceae (Mart.) Becc (Guerobal) e Mauritia flexuosa L. F. (Buritizal). Ocorrem em terrenos bem drenados (interflúvios), exceto o Buritizal pelo fato de Mauritia flexuosa ser uma espécies de ambientes úmidos. Os palmeirais têm uma altura média de 8-15 m e cobertura arbórea de 30 a 60 \% (RIBEIRO; WALTER, 2008). 


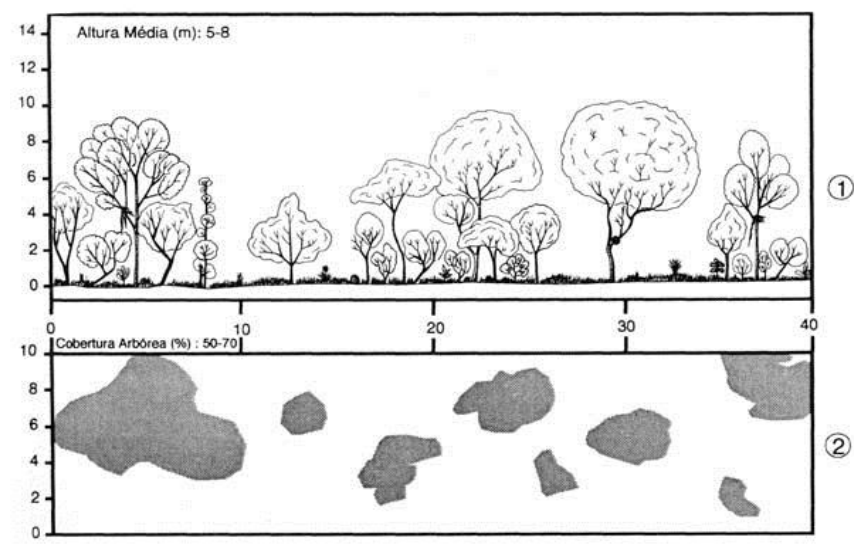

$\mathbf{a}$

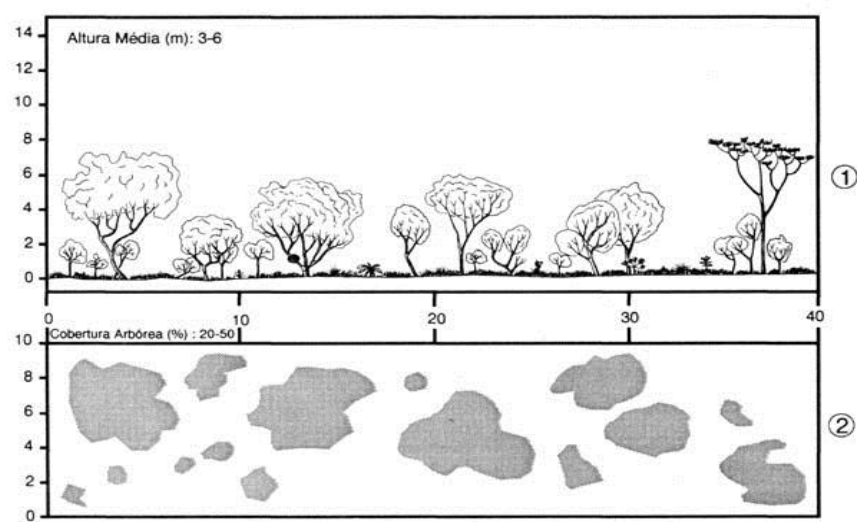

b

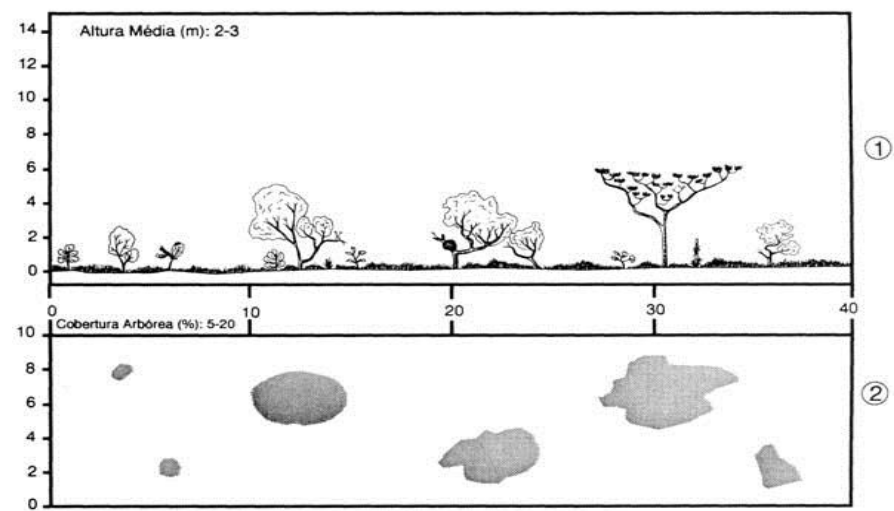

c

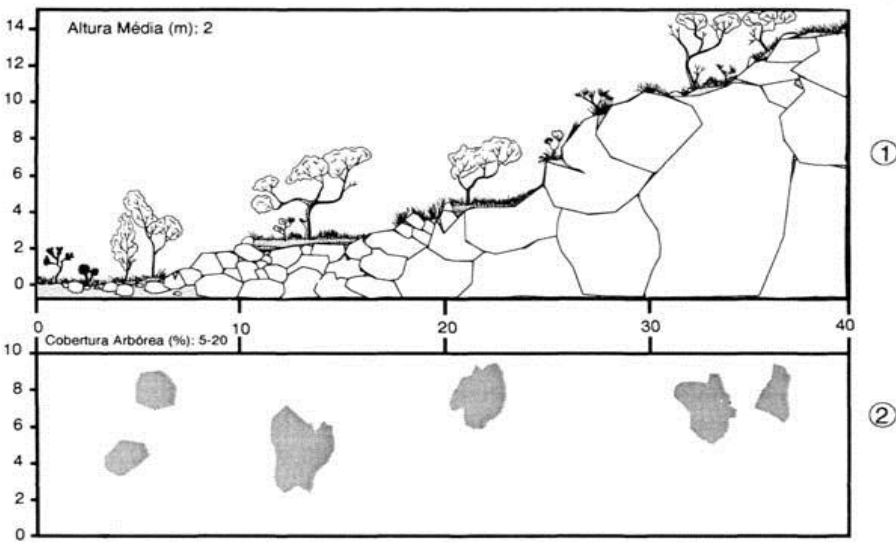

d

Figura 3.12 - Cerrado Denso (a), Típico (b), Ralo (c) e Rupestre (d), representados pelo diagrama de perfil (1) e cobertura arbórea (2) em uma faixa de $40 \mathrm{~m}$ de comprimento por $10 \mathrm{~m}$ de largura. Fonte: Ribeiro e Walter (2008) 


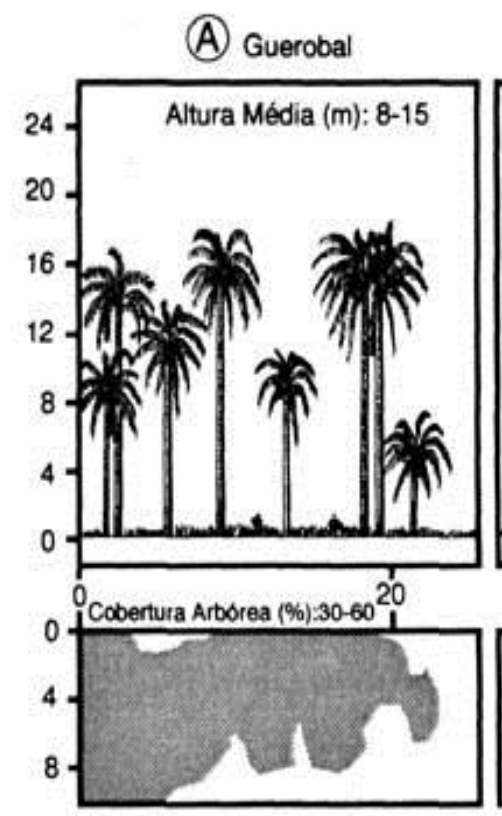

(B) Babaçual

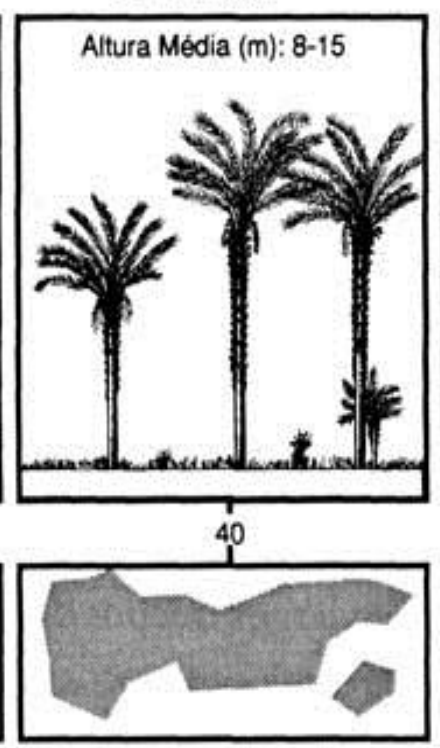

(C) Buritizal

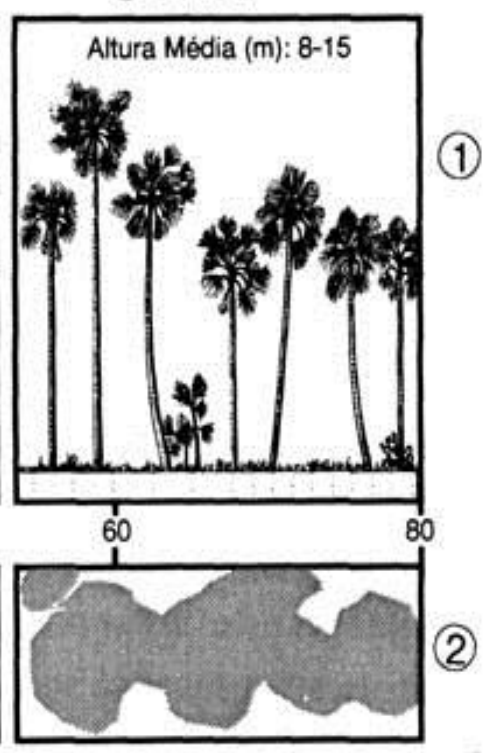

Figura 3.13 - Tipos de Palmeirais: Guerobal (A), Babaçual (B) e Buritizal (C) representados pelo diagrama de perfil (1) e cobertura arbórea (2) em uma faixa de $40 \mathrm{~m}$ de comprimento por $10 \mathrm{~m}$ de largura. Fonte: Ribeiro e Walter (2008)

Vereda: fitofisionomia com a palmeira Mauritia flexuosa L. F. (Buriti) emergente (Figura 3.14) que ocorre em agrupamentos mais ou menos densos de espécies arbustivoherbáceas. São circundadas por campos típicos, geralmente úmidos e os Buritis não formam dossel, como no tipo de Palmeiral chamado Buritizal (RIBEIRO; WALTER, 2008).

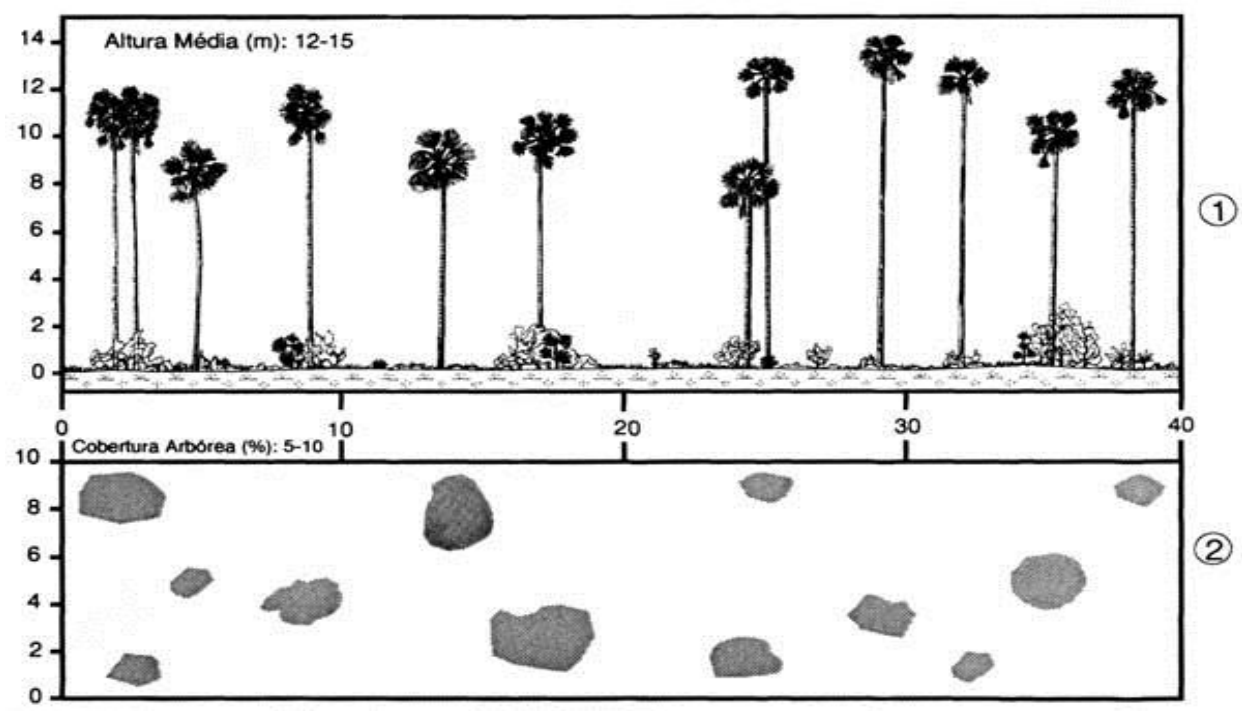

Figura 3.14 - Veredas representada pelo diagrama de perfil (1) e cobertura arbórea (2) em uma faixa de $40 \mathrm{~m}$ de comprimento por $10 \mathrm{~m}$ de largura. Fonte: Ribeiro e Walter (2008) 
As Veredas ocorrem em vales pouco íngremes ou áreas planas, acompanhando linhas de drenagem pouco definidas, sendo também comuns em posições intermediárias do terreno, próximas às nascentes (chamados de "olhos d'água") ou nas bordas das cabeceiras de Matas de Galeria. A altura média varia de 12 a 15 m e a cobertura arbórea de 5 a 10\%. O conjunto fitofisionômico caracteriza-se como uma savana.

Campo Sujo: tipo fisionômico exclusivamente herbáceo-arbustivo, com arbustos e subarbustos esparsos (Figura 3.15). Sua flora pode ser semelhante à do Cerrado Sentido Restrito, mas com indivíduos menos desenvolvidos. Devido às peculiaridades ambientais locais, pode haver três subtipos desta fisionomia: Campo Sujo Seco, Campo Sujo úmido e Campo Sujo com Murundus. Tem baixa cobertura arbórea, não ultrapassando $5 \%$ e a altura média de 2 m (RIBEIRO; WALTER, 2008).

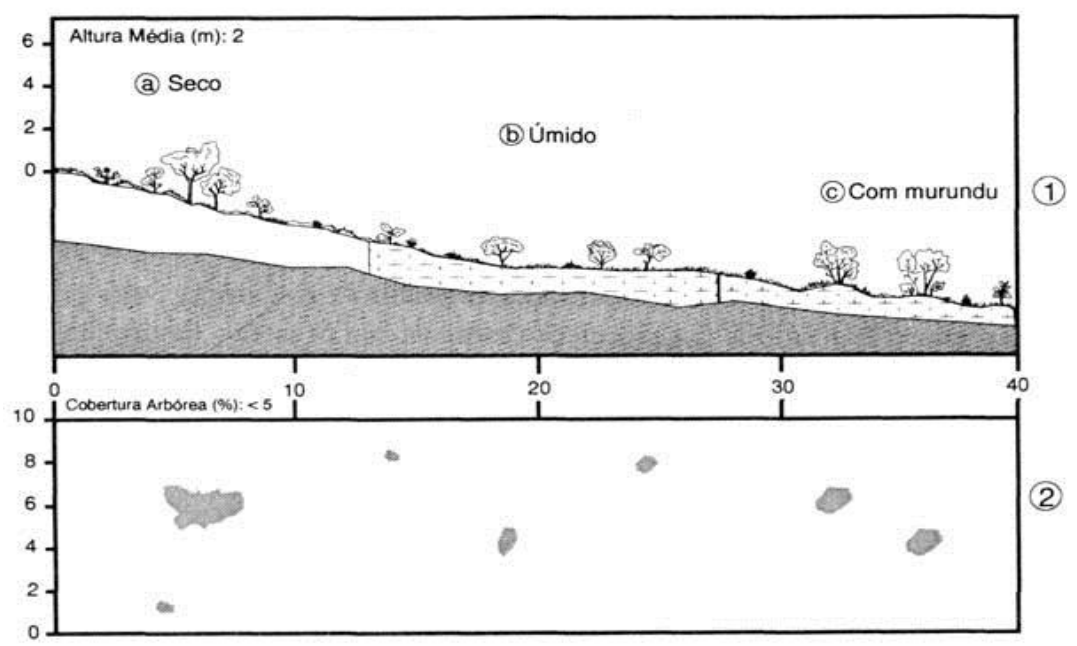

Figura 3.15 - Campo Sujo representado pelo diagrama de perfil (1) e cobertura arbórea (2) em uma faixa de $40 \mathrm{~m}$ de comprimento por $10 \mathrm{~m}$ de largura. Fonte: Ribeiro e Walter (2008)

Campo Limpo: é um tipo fisionômico exclusivamente herbáceo, sem árvores e com raros arbustos (Figura 3.16). Pode ser encontrado em diversas posições topográficas, com diferentes variações no grau de umidade, profundidade e fertilidade do solo. É encontrado mais frequentemente nas vertentes, nas chapadas, nos olhos d'água, circundando Veredas e nas bordas das matas de galeria. Devido às peculiaridades ambientais locais, pode haver três subtipos desta fisionomia: Campo Limpo Seco, Campo Limpo úmido e Campo Limpo com Murundus. Tem cobertura arbórea < 1\% e a altura média < 2 m (RIBEIRO; WALTER, 2008). 


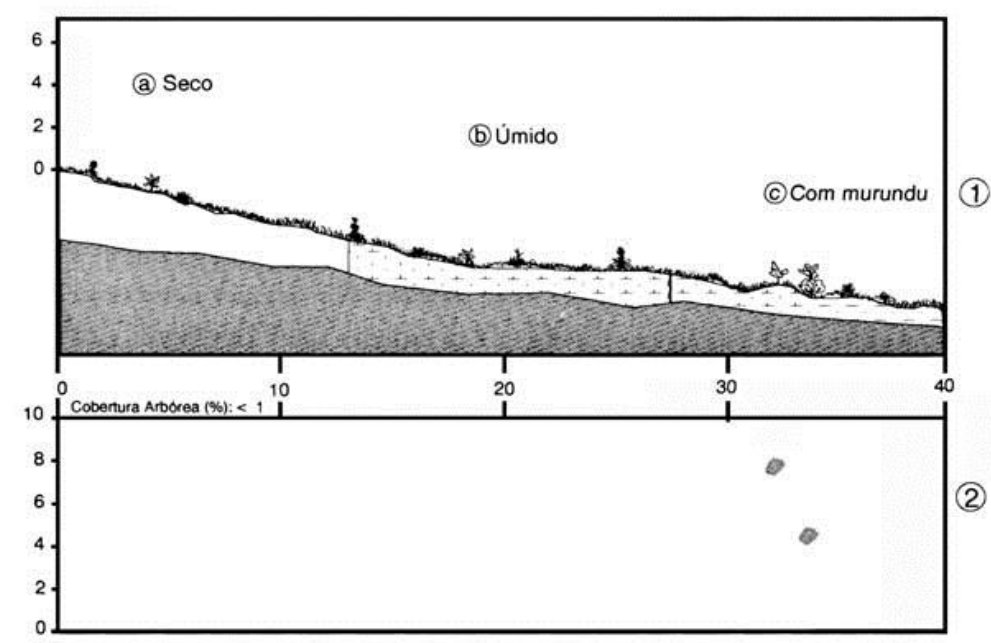

Figura 3.16 - Campo Limpo representado pelo diagrama de perfil (1) e cobertura arbórea (2) em uma faixa de $40 \mathrm{~m}$ de comprimento por $10 \mathrm{~m}$ de largura. Fonte: Ribeiro e Walter (2008)

Campo Rupestre: tipo fitofisionômico predominantemente herbáceo-arbustivo com a presença eventual de arvoretas de até $2 \mathrm{~m}$ de altura. Compreende um complexo de vegetação que agrupa paisagens em micro-relevos com espécies típicas, que ocupam trechos de afloramentos rochosos. Ocorre, geralmente, em altitudes superiores a $900 \mathrm{~m}$, ocasionalmente a partir de $700 \mathrm{~m}$, onde os ventos são constantes e há variações extremas de temperatura, com noites quentes e dias frios. Os indivíduos lenhosos concentram-se nas fendas das rochas (Figura 3.17). Há locais em que os arbustos dominam a paisagem, enquanto em outros predomina a flora herbácea. A cobertura arbórea < 5\% (RIBEIRO; WALTER, 2008).

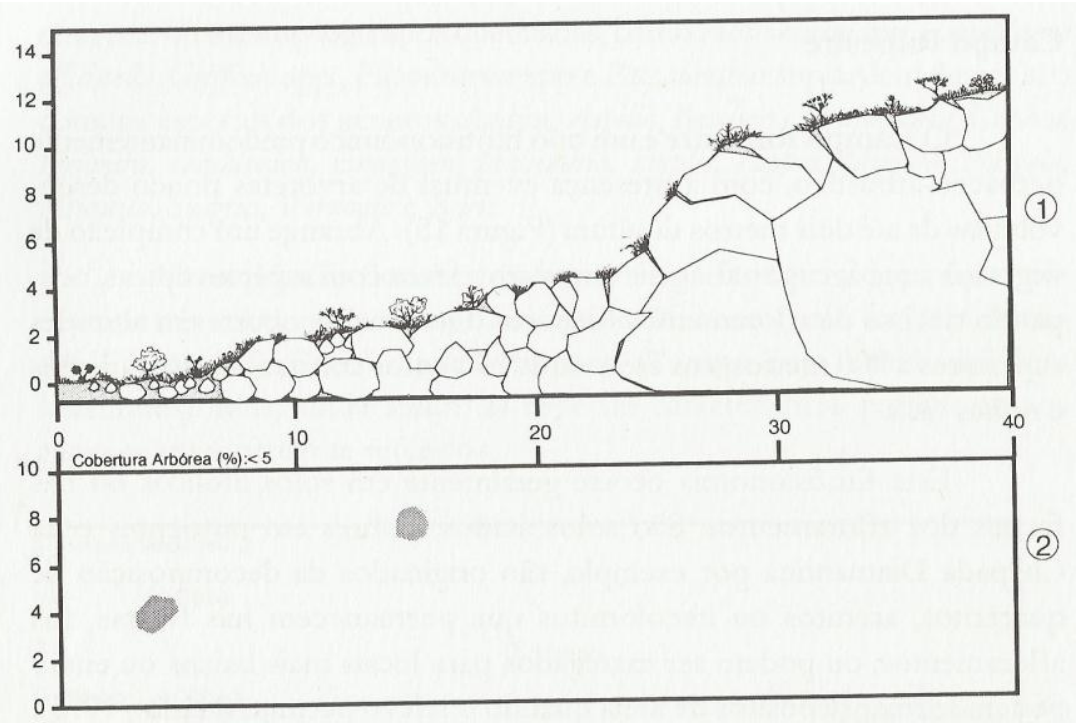

Figura 3.17 - Campo Rupestre representado pelo diagrama de perfil (1) e cobertura arbórea (2) em uma faixa de $40 \mathrm{~m}$ de comprimento por $10 \mathrm{~m}$ de largura. Fonte: Ribeiro e Walter (2008) 
3.3 Segunda Etapa: Correlações das Informações

Foram feitas as correlações entre todos os elementos do meio físico-biótico investigados a partir das informações dos mapas temáticos (topografia/hidrografia e vegetação), gráficos e tabelas dos dados de solos, florísticos e fitossociológicos.

\subsection{Terceira Etapa: Análise e Interpretação das Variáveis que Estruturam a Paisagem}

Constituiu-se da análise e interpretação de todas as informações coletadas, tabuladas e sintetizadas nos mapas, tabelas, gráficos e demais índices produzidos durante a pesquisa que caracterizam os geótopos integrantes da paisagem do Campo Sujo Seco, com a compreensão dos parâmetros ambientais e suas influências nos padrões florísticos e estrutiurais na bacia hidrográfica do ribeirão Taquaruçu Grande.

\subsection{Quarta Etapa: Concepção da Evolução da Paisagem}

Constituiu-se da síntese de todas as informações coletadas, correlacionadas, analisadas e interpretadas nas etapas anteriores, evidenciando as características dos padrões fitogeográficos de Campo Sujo Seco, com a produção de uma diagnose do espaço a partir do mapeamento de 2011, do inventário florístico e fitossociológico e da caracterização do meio físico, a partir da qual foram feitas conclusões e sugestões de usos para a paisagem do Campo Sujo Seco, na bacia hidrográfica do ribeirão Taquaruçu Grande. O Quadro 3.2 resume os procedimentos técnicos e metodológicos adotados nesta pesquisa. 
Quadro 3.2 - Síntese dos procedimentos técnicos e metodológicos utilizados na pesquisa

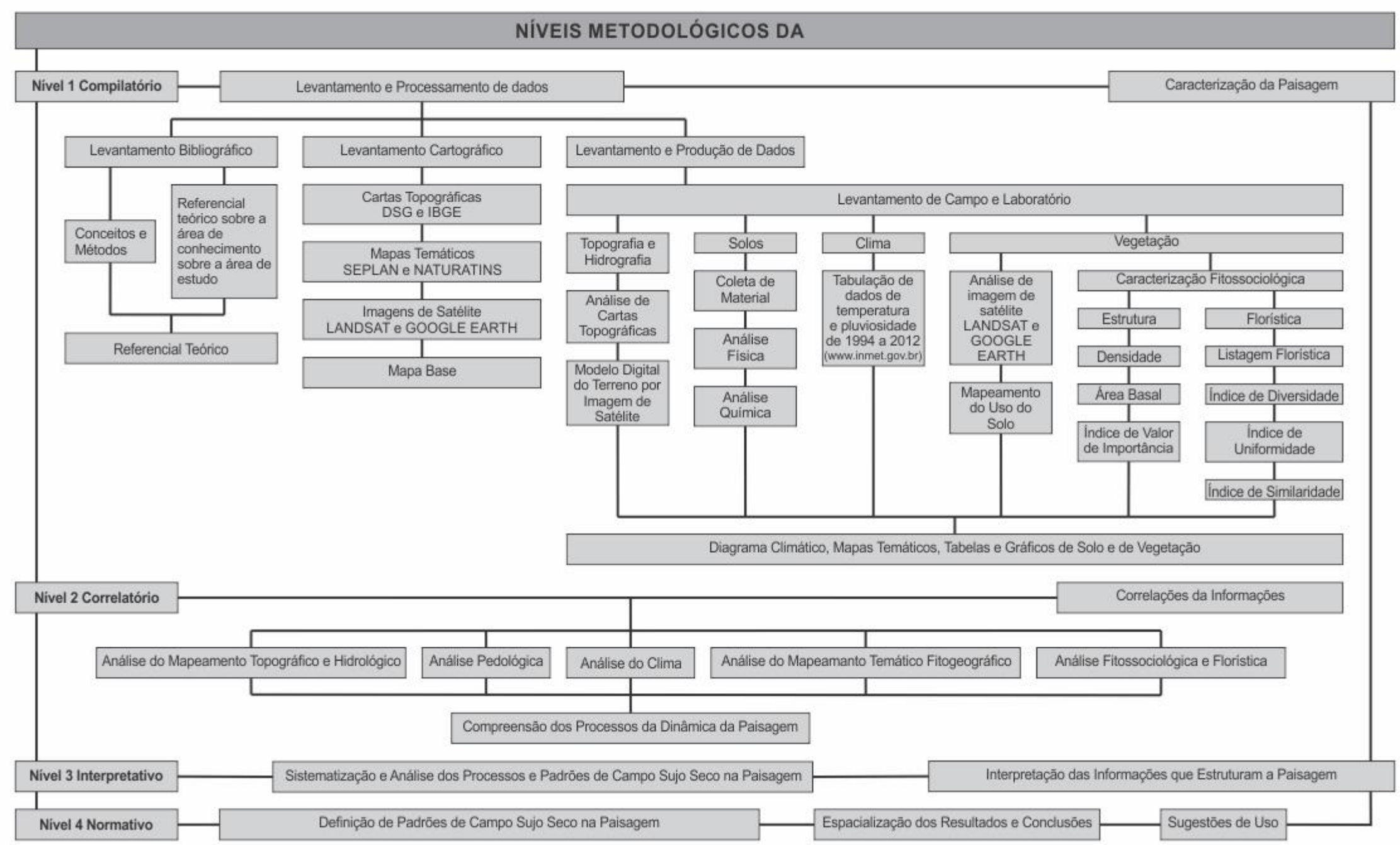




\section{RESULTADOS E DISCUSSÃO}

\subsection{Análise sintética da paisagem da bacia do ribeirão Taquaruçu Grande, Palmas (TO)}

A análise sintética da paisagem da bacia do ribeirão Taquaruçu Grande seguiu a hierarquia dos componentes geográficos de acordo com Bertrand (2004), estabelecendo a seguinte ordem: Zona, Domínio, Região Natural, Geossistema, Geofácies e Geótopos. (Quadro 4.1 e Figura 4.1).

\subsubsection{Zona: Zonobioma II - Florestas tropicais estacionais ou savanas}

A Terra possui zonas climáticas distintas, cujas extensões são determinadas pelos padrões de radiação solar e redistribuição do calor e umidade pelos ventos e correntes marinhas (RICKLEFS, 2010).

O Zonobioma II - Florestas tropicais estacionais ou savanas - constitui uma das zonas vegetacionais da geobiosfera estabelecidas por Walter (1986), com base na relação clima e vegetação e ocupa a faixa de clima tropical úmido-árido de chuvas estivais que, nas Américas, cobre uma grande área ao sul da bacia Amazônica e áreas menores que se estendem além dos $20^{\circ}$ norte na América Central e na Venezuela (WALTER, 1986), localizando-se, portanto, na Zona Intertropical, entre os trópicos de Câncer e de Capricórnio (RICKLEFS, 2010).

Caracteriza-se como sendo de baixa pressão em torno do Equador, essencialmente de origem térmica, ou seja, causada pelo aquecimento solar. É chamada de Zona Intertropical de Convergência, para a qual convergem os ventos predominantes de leste, que são os alísios de nordeste e os alísios de sudeste (AYOADE, 1998). Possui climas quentes que se distinguem pela variação da quantidade de chuvas e de temperaturas como os climas equatorial, tropical, subtropical, continental e temperado, predominando os climas equatorial e tropical (RICKLEFS, 2010).

A zona Intertropical, fitogeográficamente, abrange parte dos reinos florísticos Neotropical, Paleotropical, Australiano e pequena parte do reino Holártico, estabelecidos por Takhtajan (1986). Nestes reinos, pela influência climática, ocorrem biomas do tipo Floresta Pluvial Tropical, Floresta Sazonal Tropical Savana, Deserto Subtropical, Campo Temperado Deserto e Bosque/Arbusto (RICKLEFS, 2010). Dessa forma, possui a mais alta biodiversidade do Planeta. 
Quadro 4.1 - Unidades de paisagem da bacia do ribeirão Taquaruçu Grande, Palmas (TO)

\begin{tabular}{|c|c|}
\hline Zona & Florestas tropicais estacionais ou savanas \\
\hline Domínio & $\begin{array}{l}\text { Domínio dos chapadões tropicais interiores com cerrados e florestas-galeria - } \\
\text { Cerrado }\end{array}$ \\
\hline Região Natural & Ecorregião Araguaia Tocantins \\
\hline Geossistema & Bacia hidrográfica do ribeirão Taquaruçu Grande \\
\hline Geofácies & $\begin{array}{l}\text { 1. Mata Ciliar } \\
\text { 2. Mata de Galeria } \\
\text { 3. Mata Seca } \\
\text { 4. Cerradão } \\
\text { 5. Cerrado Sentido Restrito } \\
\text { 6. Babaçual } \\
\text { 7. Vereda } \\
\text { 8. Campo Sujo Seco } \\
\text { 9. Campo Limpo } \\
\text { 10. Campo Rupestre } \\
\text { 11. Área urbana } \\
\text { 12. Agropecuária/Silvicultura } \\
\text { 13. Lago reservatório, ribeirões, córregos e brejos }\end{array}$ \\
\hline $\begin{array}{c}\text { Geótopos } \\
\text { do } \\
\text { Campo Sujo } \\
\text { Seco }\end{array}$ & $\begin{array}{l}\text { 1. Campo Sujo Seco com Vochysia cinnamomea, Byrsonima coccobolifólia e } \\
\text { Vellozia seubertiana em topo e vertente de morro na área } 3 \\
\text { 2. Campo Sujo Seco com Vellozia seubertiana e Syagrus comosa em topo e } \\
\text { vertente de morro na área } 1 \text { e em vertente na área } 2 \\
\text { 3. Campo Sujo Seco com Byrsonima subterrânea em topo e vertente de morro na } \\
\text { área } 5 \\
\text { 4. Campo Sujo Seco Misto com Syagrus comosa, Vellozia seubertiana, } \\
\text { Erythroxylum suberosum, Ouratea spectabilis, Piptocarpha rotundifolia, } \\
\text { Dimorphandra mollis em topo de morro da área } 2 \\
\text { 5. Campo Sujo Seco com Vellozia seubertiana em topo de morro na área } 4\end{array}$ \\
\hline
\end{tabular}



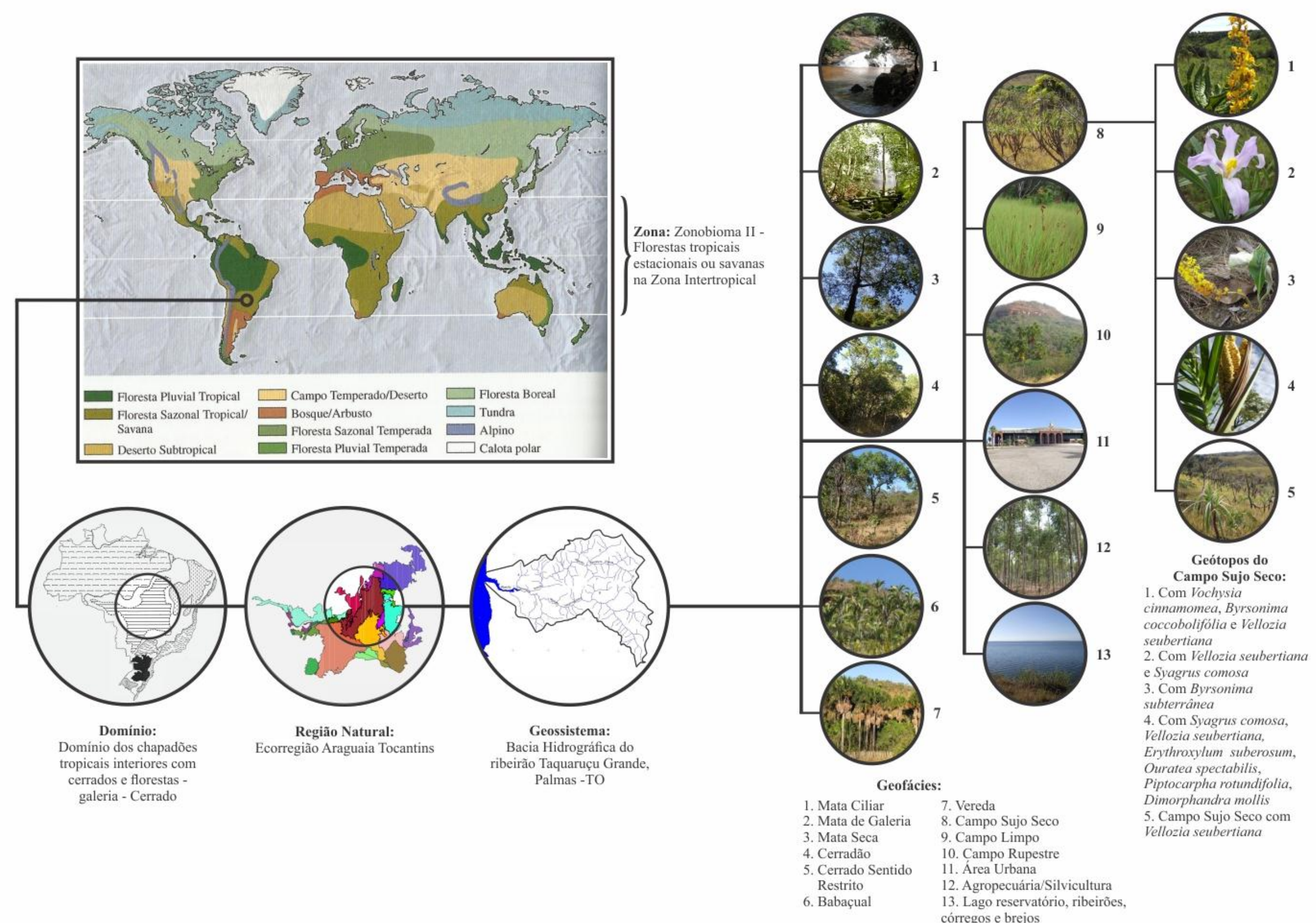

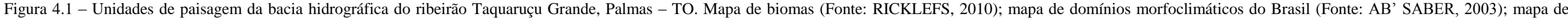
ecorregiões do Cerrado (Fonte: PINHEIRO et al, 2008 
Outra característica da Zona Intertropical é a falta da formação florestal, que é substituída pela vegetação do tipo savana ${ }^{1}$ (WALTER, 1986). No Brasil, o "Domínio dos chapadões tropicais, a duas estações, recobertos por cerrados e penetrados por florestasgalerias”, estabelecido por Ab'Saber (1967), faz parte do Zonobioma II.

\subsubsection{Domínio: Cerrado - Domínio dos chapadões tropicais interiores com cerrados e florestas-galeria}

O Cerrado, "Domínio dos chapadões tropicais interiores com cerrados e florestagaleria” constituem um dos grandes domínios paisagísticos do Brasil. Segundo Ab’Saber (1967), existe superposição muito expressiva entre os domínios morfoclimáticos e as províncias fitogeográficas brasileiras. Este autor estabeleceu seis grandes domínios paisagísticos: 1. Domínios dos chapadões tropicais interiores com cerrados e floresta-galeria; 2. Domínio das regiões serranas, tropicais úmidas, ou dos mares de morros; 3. Domínio das depressões intermontanas semiáridas, pontilhadas de inselbergs, dotadas de drenagem intermitente, e recobertas por caatingas extensivas; 4. Domínio de planaltos subtropicais, recobertos por araucárias e pradarias de altitude; 5. Domínio das coxilhas subtropicais uruguaio-sul-rio-grandenses; 6. Domínio das terras baixas equatoriais, extensivamente florestas, da Amazônia brasileira.

Cada domínio possui área core (área nuclear) e zonas ou faixas de transição, onde se interpenetram, se diferenciam e se misturam as vezes, formando mosaicos complexos resultantes de duas ou mais áreas de contato. As áreas core têm individualidade plena, não havendo qualquer relação destas com as províncias geológico-estruturais do país, pois dentro dos cores existem terrenos de idades diferentes e de litologia variada, estando estes profundamente amarrados aos quadros de superposição dos fatos geomórficos, hidrológicos e geopedológicos e possuem filiação evolutiva muito direta com a história paleoclimática quaternária das áreas ou zonas onde eles se expandiram e se fixaram (AB’SABER, 1967). Os "Domínios dos chapadões tropicais interiores com cerrados e floresta-galeria" são descritos por Ab’Sáber (1971) como:

\footnotetext{
${ }^{1}$ Savanas são sistemas ecológicos formados por pradarias tropicais, nas quais algumas espécies isoladas de lenhosas vivem em competição com gramíneas e outras herbáceas. São tipos vegetacionais antagônicos (um exclui o outro) e se mantêm em equilíbrio ecológico exclusivamente nas zonas tropicais. O antagonismo deve-se às diferenças relacionadas ao sistema radicular e ao balanço hídrico (WALTER, 1986).
} 
Área de primeira grandeza espacial avaliada entre 1,8 e 2 milhões de quilômetros quadrados. Posição geral da área: grosso-modo zonal, à semelhança das faixas de savanas na África. Região de maciços planaltos de estrutura complexa e planaltos sedimentares compartimentados; cerradões e cerrados nos interflúvios e florestasgalerias contínuas, ora mais largas ora mais estreitas; cabeceiras em "dales", ou seja, ligeiros anfiteatros pantanosos; solos de fraca fertilidade primária, em geral; drenagens perenes para os cursos d'água principais e secundários, com desaparecimento dos "caminhos d'água" das vertentes e dos interflúvios, na época das secas; interflúvios muito largos e vales bastante esgarçados entre si, com pouca ramificação geral da drenagem na área "core" dos cerrados; enclaves de matas em manchas de solos ricos, ou áreas de cais de nascentes ou olhos d'água perenes; ausência de mamelonização, calhas aluviais de tipo particularizados, em geral não meândricas nos planaltos; níveis de pediplanação nos compartimentos de planaltos, pedimentos escalonados e terraços com cascalhos; sinais de flutuações climáticas e paisagens vinculadas nas depressões intermontanas centrais ou periféricas da grande área dos cerrados; climas de tipo sudanês, com precipitações globais variando entre 1.300 e $1.800 \mathrm{~mm}$, concentradas no verão e relativamente baixas no inverno. Enclaves de matas, na forma de capões, de diferentes ordens de grandeza espacial." (AB'SABER, 1971, p. 2).

\subsubsection{Região Natural: Ecorregião Araguaia Tocantins}

Arruda et al. (2008) estabeleceram ecorregiões, unidades de conservação e representatividade ecológica do bioma Cerrado. A Ecorregião Araguaia Tocantins foi descrita por esses autores em abordagens geomorfológica, hidrográfica, pedológica e florística com a descrição do índice de raridade distribucional e endemismo (IRD, índice de representatividade ecológica por unidades de conservação de proteção integral (UCPI) e de unidades de conservação de uso sustentável (UCUS), como exposto a seguir.

A Ecorregião Araguaia Tocantins está localizada no noroeste do domínio do Cerrado, possui uma área de $244.598,1 \mathrm{~km}^{2}$, o que representa $12,2 \%$ do Cerrado. Faz parte da unidade geomorfológica regional de superfícies de aplanamentos que corresponde a extensa área com caimento regional em direção norte. Os relevos dominantes incluem-se em padrão de formas de topo convexo, medianamente extensas, e formas de topos tabulares amplas a medianamente extensas, com a presença de relevos residuais que constituem pequenas serras. $\mathrm{Na}$ porção norte, trunca sedimentos da bacia sedimentar do Parnaíba. As altitudes variam de 150 a 500 m e seus principais rios são o Araguaia e o Tocantins com muitos afluentes. Os solos predominantes são o Latossolo Vermelho-Amarelo, Argissolo Vermelho-Amarelo, Concrecionários, Neossolos Litólicos e Neossolos Quaetzarênicos (ARRUDA et al., 2008).

A flora caracteriza-se por dois complexos vegetacionais comuns no Cerrado: $3 \mathrm{~A} 2$ no norte da ecorregião e 3B2 no sul. As espécies indicadoras são: Cytropodium blanchetii, $C$. eugenii; Habenaria anisitsii, H. cryptophila, H. obtusa, H. pratensis, Jacaranda brasiliana, J. mutabilis, J. rufa, Mimosa brachycarpa, M. claussenii, M. distans, M. foliolosa, M. gracilis, 
M. hirsutissima, M. laticifera, M. nuda, M. polycephala, M. xanthocentra, M. xavantina, Phoradendron crassifolium, P. bathyoryctum, Psittacanthus biternatus, P. robustus, Tabebuia aurea, T. impetiginosa, T. ochracea e T. roseoalba (ARRUDA et al., 2008).

$\mathrm{O}$ índice de raridade distribucional e endemismo (IRD) dessa ecorregião apresentou valor médio de 0,068 , ocupando a $17^{a}$ posição entre as 22 ecorregiões do Cerrado, indicando que, as espécies presentes têm ampla distribuição. Entre os táxons indicadores foram registradas nove espécies endêmicas (Mimosa cyclophylla, M. densa, M. hypnodes, $M$. longepedunculata, M. manidea, M. rheiptera, M. somnambulans, M. vestita e Vernonia echinocephala) e nove não endêmicas (Dyckia racemosa, Habenaria goulieana, Miconia pileata, Phoradendron jenmani, P. multifoveolatum, Phthirusa theloneura, Struthanthuus uruguayensis, S. vulgaris e Vernonia eriolepis), exclusivas dessa ecorregião, o que leva a aumentar o IRD.

O índice de representatividade ecológica por unidades de conservação de proteção integral (UCPI) foi de 2,83\% e de 0,01\% de unidades de conservação de uso sustentável (UCUS). As unidades de conservação nessa ecorregião são: Parque Nacional da Chapada dos Veadeiros, Parque Nacional das Nascentes de Rio Parnaíba, Estação Ecológica Serra Geral do Tocantins, Parque Estadual do Cantão, Parque Estadual do Jalapão, Floresta Estadual do Araguaia e Área de Relevante Interesse Ecológico (ARIE) Águas de São João (ARRUDA et al., 2008).

Também fazem parte dessa ecorregião no Estado do Tocantins, de acordo com o Instituto Natureza do Tocantins (NATURATINS) ${ }^{2}$, o Parque Nacional do Araguaia, a Reserva Extrativista do Extremo Norte do Estado do Tocantins, Monumento Natural das Árvores Fossilizadas do Estado do Tocantins, Parque Estadual do Lageado, Monumento Natural Municipal Canyons e Corredeiras do rio Sono e as seguintes Áreas de Proteção Ambiental (APA): Serra da Tabatinga, Nascentes de Araguaína, Lago de Palmas, Serra do Lageado, Foz do rio Santa Teresa, Ilha do Bananal/Cantão, do Jalapão e Lago de Peixe/Angical, Lago de São Salvador do Tocantins, Paranã e Palmeirópolis, do Lago Santa Isabel. Além dessas unidades de conservação há Reserva Particular do Patrimônio Natural (RPPN): Fazenda Sonhada, Canguçu, Bela Vista, Reserva Sítio Ecológico Monte Santo, Catedral do Jalapão, Água Bonita, Fazenda Calixto, Reserva Minnehaha.

Estas unidades de conservação acima citadas para o Estado do Tocantins totalizaram $30.518,072 \mathrm{~km}^{2}$, não inclusos nos índices de representatividade ecológica por UCPI e UCUS

\footnotetext{
${ }^{2}$ Disponível em: <http://naturatins.to.gov.br/biodiversidade-e-reas-protegidas/> Acesso em 8 dez. 2013.
} 
calculado por Arruda et al. (2008), significando que a área de preservação dessa ecorregião é maior, o que contribui para elevar tais índices dessa ecorregião.

\subsubsection{Geossistema: Bacia hidrográfica do ribeirão Taquaruçu Grande}

A bacia hidrográfica do ribeirão Taquaruçu Grande localiza-se na parte centro sul do município de Palmas, entre as coordenadas geográficas de $10^{\circ} 10^{\prime} 33^{\prime \prime}$ e $10^{\circ} 25^{\prime} 18^{\prime \prime}$ de latitude sul e $48^{\circ} 03^{\prime} 57^{\prime \prime}$ a $48^{\circ} 23^{\prime} 03^{\prime \prime}$ de longitude oeste, estando totalmente inserida neste município que faz parte da IX Região Metropolitana de Palmas, na região norte do Brasil (SEPLAN, 2012).

Na hierarquia fluvial, o ribeirão Taquaruçu Grande constitui uma bacia de $5^{\mathrm{a}}$ ordem do rio Tocantins pela margem direita do seu curso médio (Figura 4.2). Tem como rio principal o próprio ribeirão Taquaruçu Grande, no qual se destacam, pela margem direita, os córregos Tiúba e Macacão e, pela margem esquerda, os córregos Machado, Buritizal e o ribeirão Taquaruçuzinho, seu principal tributário. O ribeirão Taquaruçu Grande tem parte de seu curso na unidade de relevo de Depressão do Tocantins e outra parte no Planalto Residual do Tocantins, mais especificamente, na serra do Lageado, onde tem suas nascentes.

Espacialmente, esta bacia hidrográfica se apresenta na forma triangular (CHRISTOFOLETTI, 1980), podendo-se considerar dois momentos distintos, ou seja, antes e depois da formação do lago reservatório da Usina Hidrelétrica Luís Eduardo Magalhães (UHE Luís Eduardo Magalhães). No primeiro momento, a bacia possuia área de 46.307,31 hectares, que correspondiam a aproximadamente $20 \%$ do município de Palmas (Figura 4.3). E, no segundo momento (Figura 4.4), com enchimento do referido lago, reduziu 129,84 hectares da área original ao atingir sua cota máxima de enchimento $(212 \mathrm{~m})$ em 2000 (INVESTICO) ${ }^{3}$, passando a $46.177,47$ hectares.

Geomorfologicamente, registram-se altitudes que variam de aproximadamente 200 a 700 m. Esta variação topográfica confere categorias geomorfológicas à área que incluem vales fluviais, planícies, planaltos e chapadas, que se interconectam por vertentes e cânions. Os vales constituem as cotas mais baixas com altitudes em torno de $200 \mathrm{~m}$, enquanto que os planaltos e chapadas, com topos aplainados ou suavemente ondulados, constituem as áreas de cimeira e chegam a cerca de $700 \mathrm{~m}$ de altitude (Figura 4.5). As planícies estendem-se entre a

\footnotetext{
${ }^{3}$ Disponível em: 〈http://www.divulgueja.com.br/investco/index.php?inv=ap/emp/historico.php >. Acesso em $15 / 10 / 2011$
} 


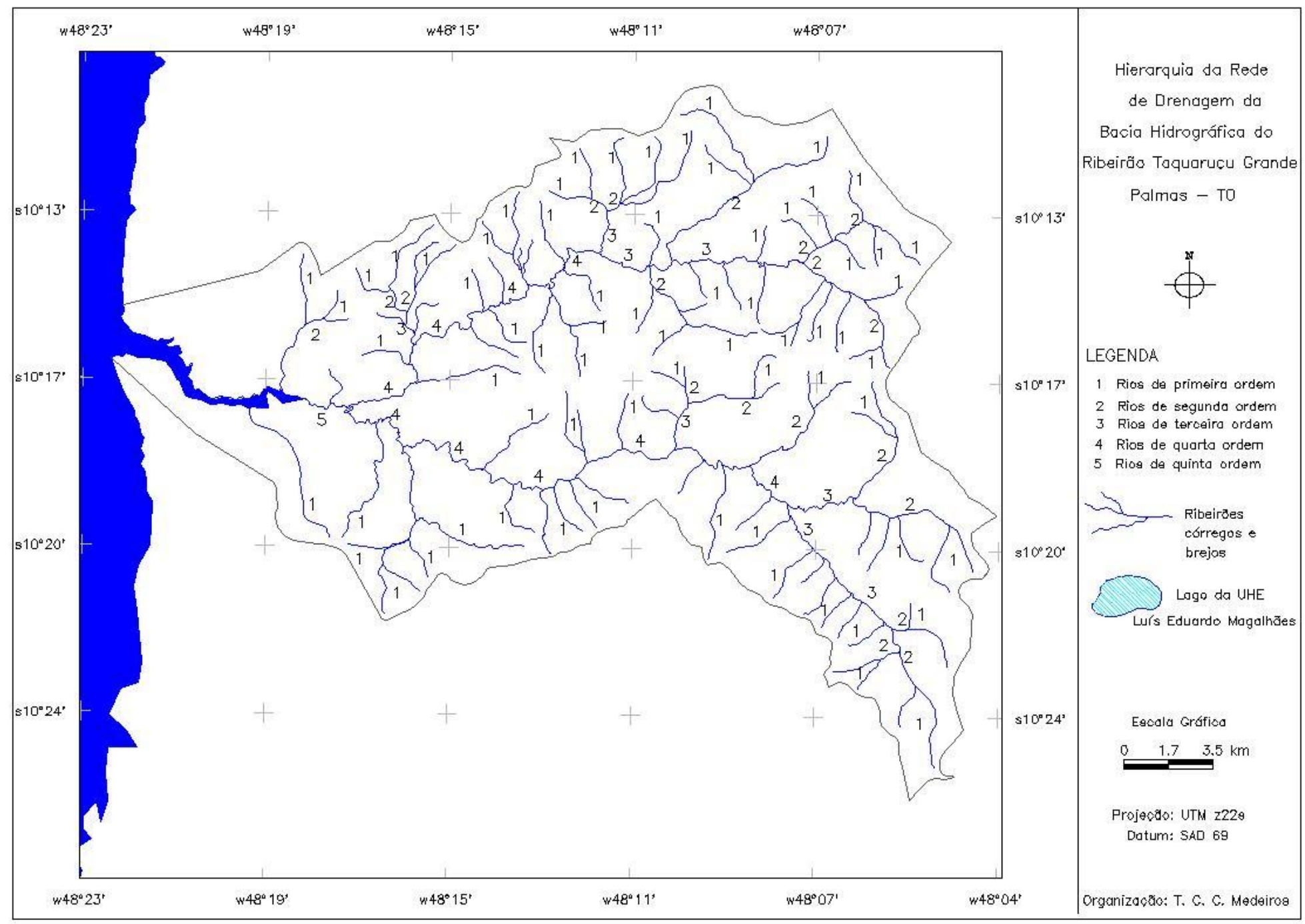

Figura 4.2 - Mapa da bacia hidrográfica do ribeirão Taquaruçu Grande, Palmas (TO), com base na Carta da Diretoria do Serviço Geográfico, Ministério do Exército e IBGE (1979) e imagem Landsat 2011 


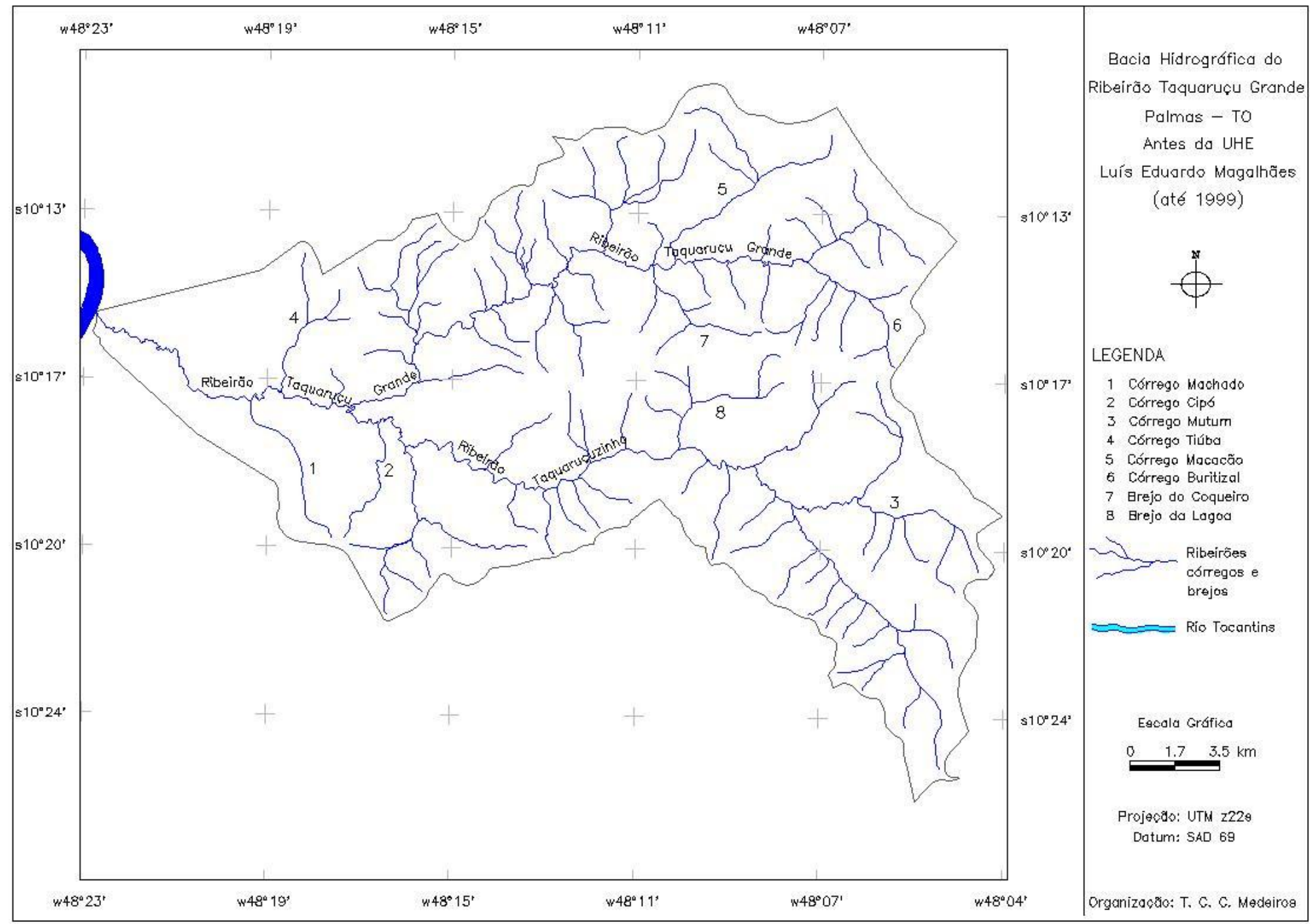

Figura 4.3 - Mapa da bacia hidrográfica do ribeirão Taquaruçu Grande, Palmas (TO), com base na Carta da Diretoria do Serviço Geográfico, Ministério do Exército e IBGE (1979) 


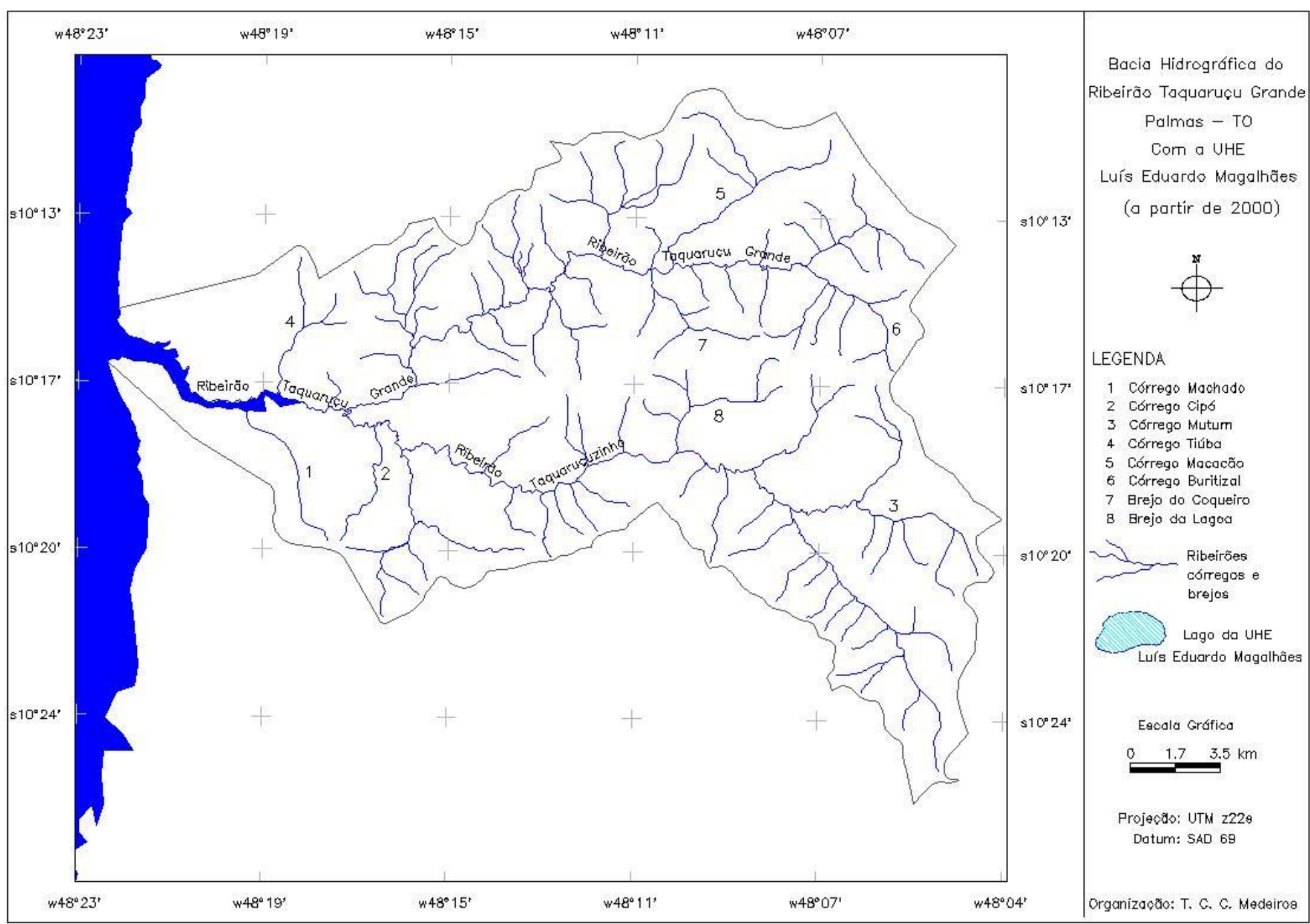

Figura 4.4 - Mapa da bacia hidrográfica do ribeirão Taquaruçu Grande, Palmas (TO), com base na Carta da Diretoria do Serviço Geográfico, Ministério do Exército e IBGE (1979) e imagem Landsat 2011 
serra do Lageado e o rio Tocantins, trecho hoje em parte transformado em lago reservatório da Usina Hidrelétrica Luís Eduardo Magalhães. Estas planícies são parte da feição geomorfológica Depressão do Tocantins, onde as altitudes estão entre 200 e 300 m (Figura 4.5).

Característica peculiar desta bacia é sua rede hidrográfica ser formada por córregos que correm, em geral, em vales fluviais estreitos e encaixados, formando cânions em meio aos planaltos e chapadas no centro, norte, nordeste, leste, sudeste e sul da bacia, ocupando grande parte de sua área, na serra do Lageado.

Neste cenário topográfico (Figur 4.6), há variada biota vegetal, onde ocorrem campos, cerrados e matas localizados nas áreas de chapadas e planaltos e descendo pelas vertentes pediplanadas e cânions, também ocorrem nas planícies secas. Já nas planícies ou vales úmidos, há Veredas, enquanto nos fundos dos vales fluviais há Matas de Galeria ou Ciliar, que formam um sistema conjunto com as Matas Secas, que sobem vertentes e cânions fazendo a conexão entre as geofácies na bacia.

A diversidade vegetal da bacia compõe-se de espécies que englobam fitofisionomias florestais, savânicas e campestres, incluindo Mata Ciliar, Mata de Galeria, Mata Seca, Cerradão, Vereda, Cerrado Sentido Restrito e Campo Sujo, que compõem os geofácies do ambiente natural na paisagem, como resultado da dinâmica histórica geológica, geomorfológica e climática à qual pertence esta bacia. 


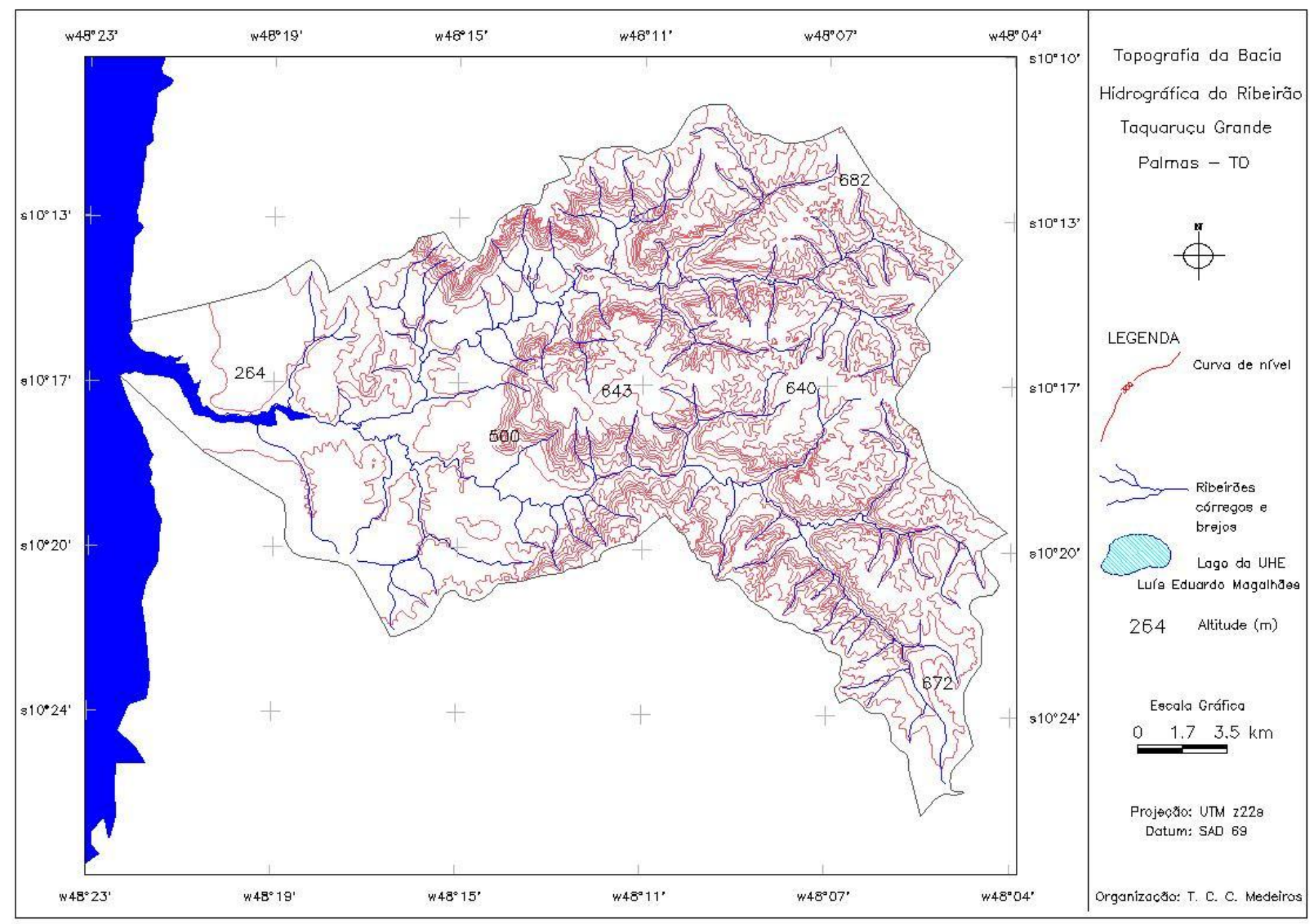

Figura 4.5 - Mapa Topográfico da bacia hidrográfica do ribeirão Taquaruçu Grande, Palmas (TO), com base Carta da Diretoria do Serviço Geográfico, Ministério do Exército e IBGE (1979) e imagem Landsat 2011 


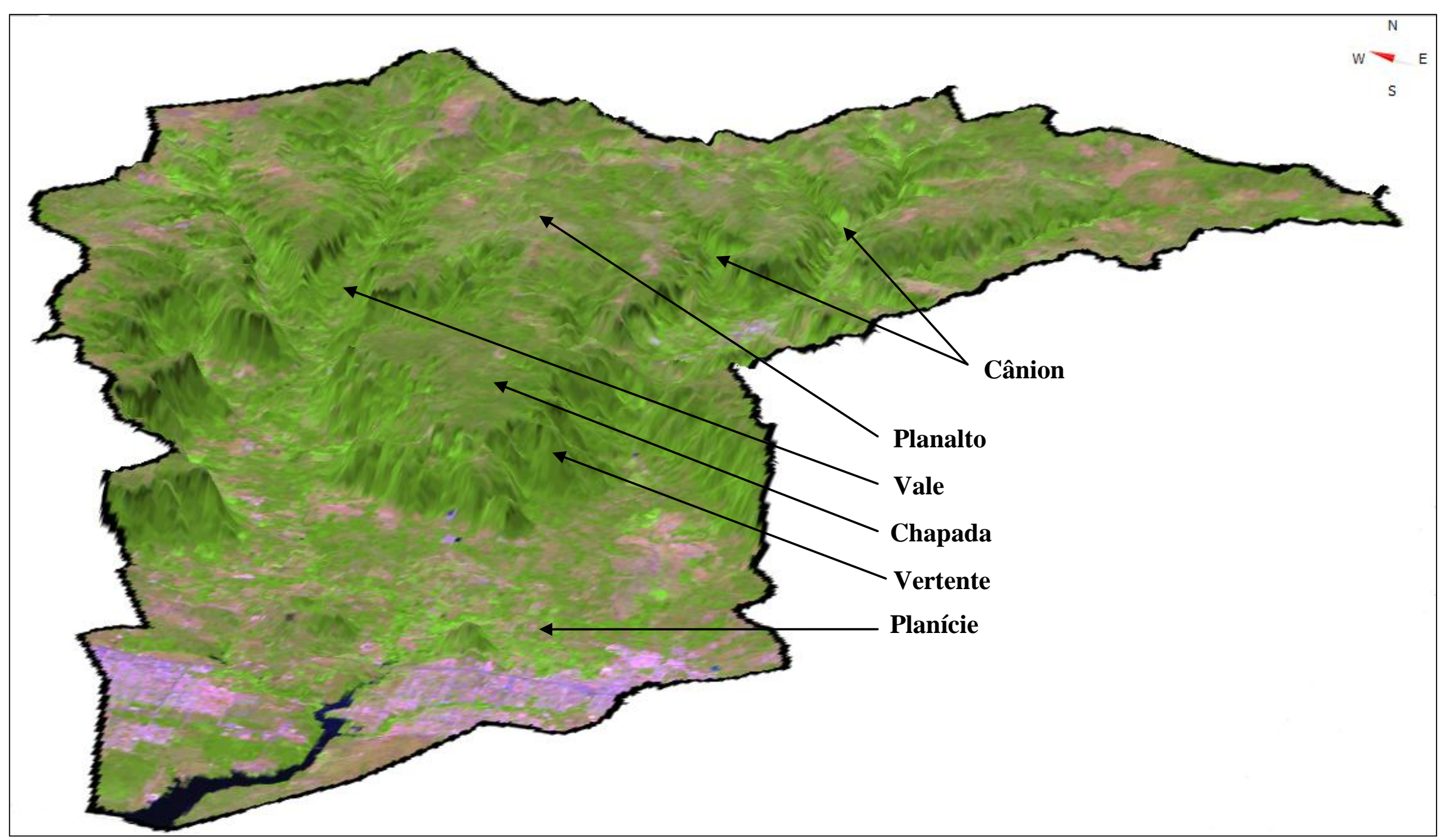

Figura 4.6 - Relevo com planícies, vales, vertentes, cânions, chapadas e planaltos na bacia hidrográfica do ribeirão Taquaruçu Grande, Palmas - TO, com base na imagem Landsat 2011 (Organização: T.C.C. Medeiros e S.S.V. de Cristo) 


\subsubsection{Geofácies e Geótopos}

A espacialização dos geofácies na paisagem na bacia do ribeirão Taquaruçu Grande está fortemente relacionada à geomorfologia e a disposição da rede de drenagem (Figura 4.7) e aos solos. Os geofácies Mata Ciliar, Mata de Galeria, Vereda, Campo Limpo e Lago reservatório, ribeirões, córregos e brejos estão associados às áreas dos vales e planícies fluviais. Já a Mata Seca, o Cerradão, o Cerrado Sentido Restrito e o Campo Sujo Seco, Campo Rupestre, Babaçual estão associados às vertentes e aos ambientes de topo (chapadas e planaltos ou a planícies secas). O geofácie Área Urbana localiza-se especificamente na planície seca e Agropecuária/Silvicultura ocorre nas várias formas do relevo.

Na classificação da paisagem a unidade de paisagem Floresta (Mata Ciliar, Mata de Galeria, Mata Seca, Vereda e Campo Limpo Úmido) tem dominância na bacia hidrográfica com uma área de 15.261,48 hectares, estando em segundo lugar o Cerradão, seguido pelo Campo Sujo Seco e Cerrado Sentido Restrito (Tabela 4.1).

Tabela 4.1 - Classificação da paisagem (com respectivas áreas), com base nas Geofácies na bacia hidrográfica do ribeirão Taquaruçu Grande, Palmas (TO), para o ano de 2011

\begin{tabular}{|c|c|c|}
\hline Unidades de Paisagem & Área (ha) & Área $(\%)$ \\
\hline Floresta & $15.763,32$ & 34,1 \\
\hline Cerradão & $12.850,92$ & 27,8 \\
\hline Campo Sujo & $7.478,82$ & 16,2 \\
\hline Cerrado Sentido Restrito & $4.964,31$ & 10,7 \\
\hline Área urbana ou rural edificadas & $2.844,09$ & 6,2 \\
\hline Agropecuária/Silvicultura & $1.872,81$ & 4,0 \\
\hline Lago Reservatório da UHE Luís Eduardo Magalhães & 403,20 & 1,0 \\
\hline Total & 46.177,47 & 100 \\
\hline
\end{tabular}




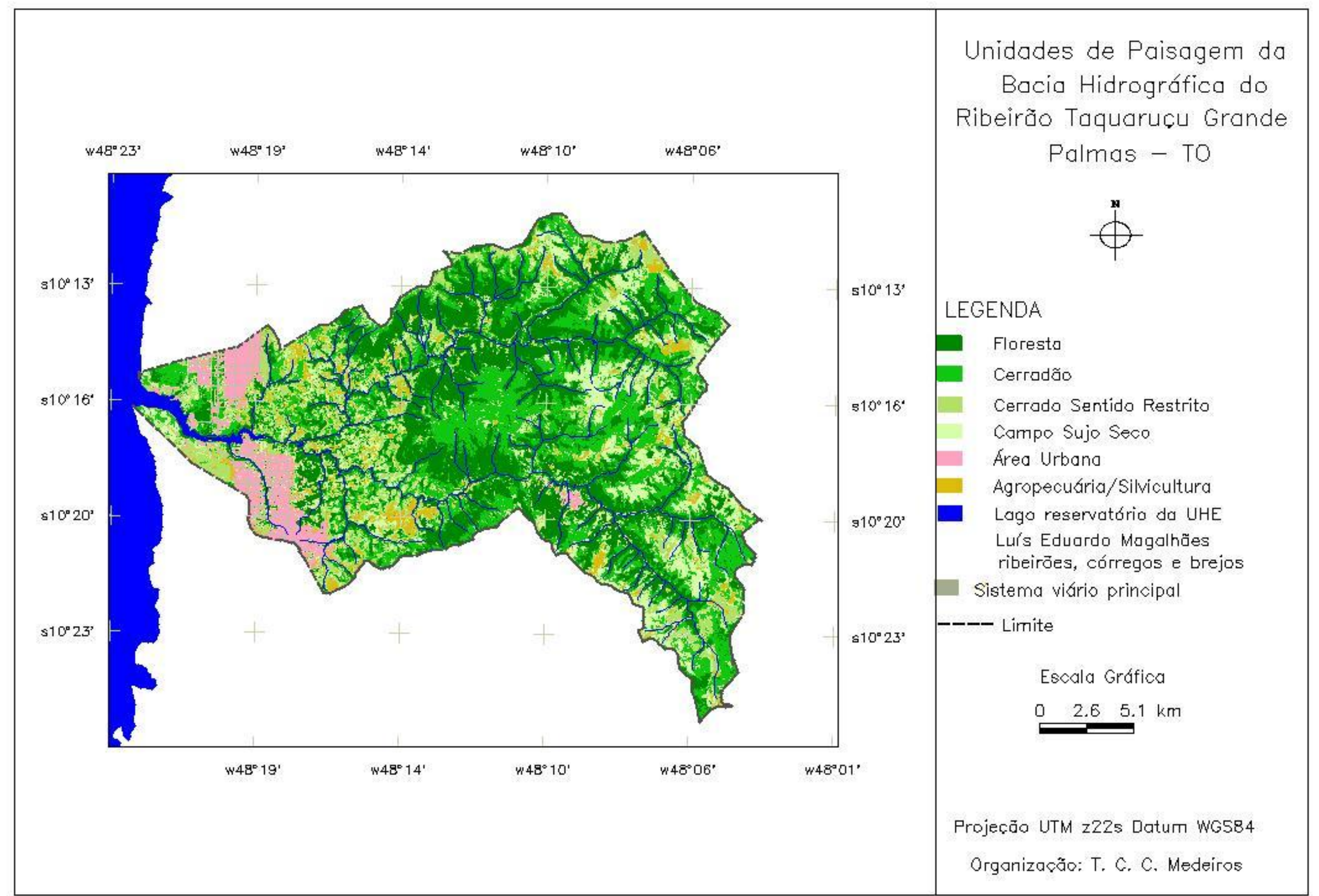

Figura 4.7 - Mapa de unidades de paisagem da bacia hidrográfica do ribeirão Taquaruçu Grande, Palmas - TO, com base na imagem Landsat 2011 
Outros estudos já mapearam a bacia hidrográfica do ribeirão Taquaruçu Grande. Comparando o mapeamento das unidades de paisagem com outros já realizados em datas anteriores (Tabela 4.2), verificou-se uma redução de 2,7\% nas áreas de Mata de Galeria, Mata Ciliar e Matas Secas entre 1998 (SOUZA, 2006) e 2011 e diminuição de 0,9\% entre 2006 (SOUZA, 2006) e 2011. Em relação aos dados apresentados por Martins e Monteiro (2013), a diferença foi de 5,4\% para o período entre 1998/2006 e 2011.

Em relação ao Campo Sujo e Cerrado Sentido Restrito, torna-se difícil estabelecer comparações tendo em vista que o sistema de classificação utilizado no mapeamento foi diferente entre os três trabalhos.

O Cerradão apresentou uma área bem mais elevada $(15,8 \%)$ que em Martins e Monteiro (2013), estando mais próxima da área estabelecida por Souza (2006), muito embora neste sistema de classificação o Cerradão esteja agrupado com cerrado e campo (Tabela 4.2). Porém, muitas áreas de Campo Sujo foram consideradas como pastagem por Souza (2006) em comparação com a área no presente mapeamento. Mas, se considerarmos as áreas de Cerradão, Cerrado e Campo, com parte da pastagem estabelecidas por Souza (2006), que é Campo, chega-se a valores semelhantes aos do mapeamento de 2011 (Tabela 4.2).

Quanto às áreas urbanizadas, há valores semelhantes com a área apresentada por Martins e Monteiro (2013), considerando o alto valor para pastagem em Souza (2006), A área ocupada pelo lago da UHE Luís Eduardo Magalhães foi semelhante entre 2006 e 2011.

As diferenças existentes os diferentes mapeamentos analisados podem estar relacionadas a questões metodológicas, assim como as características das imagens utilizadas no mapeamento. Souza (2006) e Martins e Monteiro (2013) utilizaram imagens LANDSAT no mapeamento de 1998 e no mapeamento de 2005 (SOUZA, 2006) e de 2006 (MARTINS; MONTEIRO, 2013), utilizaram imagens CBERS-2. Estas imagens possuem resolução de $20 \mathrm{x}$ 20 m, enquanto a imagem LANDSAT TM 5 utilizada no presente estudo tem resolução de 30 x $30 \mathrm{~m}$. Um outro fator a considerar é que tais imagens possuem sistemas sensores com imageadores diferenciados: no LANDSAT, o Thematic Mapper e no CBERS o Imageador por Varredura de Média (IRMSS), Imageador de Amplo Campo de Visada (WFI) e a Câmera Imageadora de Alta Resolução (CCD).

Além desses aspectos, os sistemas de classificação utilizados nos mapeamentos também foram diferentes e, no processo de classificação da imagem, optou-se pela classificação supervisionada a partir de pontos controle e realização de checagem de campo, usando-se a chave de identificação de fitofisionomias produzidas por Ribeiro e Walter (2008) 
para a identificação das fitofisionomias no ambiente natural. Souza (2006) fez trabalho de campo, enquanto Martins e Monteiro (2013) realizaram a classificação em tela do computador. 
Tabela 4.2 - Índices das unidades de paisagem de diversos mapeamentos da bacia hidrográfica do ribeirão Taquaruçu Grande, Palmas (TO)

\begin{tabular}{|c|c|c|c|c|c|}
\hline Unidades de Paisagem & $\begin{array}{c}\text { Imagem } \\
\text { de } 2011 \\
\text { Este } \\
\text { Trabalho }\end{array}$ & $\begin{array}{c}\text { Imagem } \\
\text { de } 1998 \\
\text { Sousa } \\
(2006)\end{array}$ & $\begin{array}{c}\text { Imagem } \\
\text { de } 2005 \\
\text { Sousa } \\
(2006)\end{array}$ & $\begin{array}{c}\text { Imagem } \\
\text { de } 1998 \\
\text { Martins e } \\
\text { Monteiro } \\
(2013)\end{array}$ & $\begin{array}{c}\text { Imagem } \\
\text { de } 2006 \\
\text { Martins e } \\
\text { Monteiro } \\
\text { (2013) }\end{array}$ \\
\hline Floresta & $34,1 \%$ & & & & \\
\hline Floresta de Galeria/ Vertente & & $36,8 \%$ & $35,0 \%$ & & \\
\hline Mata de Galeria + Floresta Estacional Semidecidual + Mata Ciliar & & & & $39,07 \%$ & $39,05 \%$ \\
\hline Cerradão & $27,8 \%$ & & & $14,0 \%$ & $12,0 \%$ \\
\hline Campo Sujo Seco & $16,2 \%$ & & & & \\
\hline Cerrado Sentido Restrito & $10,7 \%$ & & & $30,0 \%$ & $29,0 \%$ \\
\hline Cerrado (Cerrado + Cerradão + Campo) & & $38,9 \%$ & $37,0 \%$ & & \\
\hline Agropecuária/Silvicultura & $6,2 \%$ & & & & \\
\hline Áreas urbanizadas/antropizadas & & $3,9 \%$ & $10,0 \%$ & & \\
\hline Área Urbana & & & & $4,0 \%$ & $8,0 \%$ \\
\hline Agropecuária/Silvicultura & $4,0 \%$ & & & & \\
\hline Lago Reservatório da UHE Luís Eduardo Magalhães & $1,0 \%$ & & & & $1,0 \%$ \\
\hline Pastagem & & $16,6 \%$ & $18,0 \%$ & $2,0 \%$ & $4,0 \%$ \\
\hline Queimadas & & $3,8 \%$ & - & & \\
\hline Culturas perenes & & & & $3,0 \%$ & $0 \%$ \\
\hline Cerrado Campestre & & & & $8,0 \%$ & $7,0 \%$ \\
\hline TOTAL & $100 \%$ & $100 \%$ & $100 \%$ & $100 \%$ & $100 \%$ \\
\hline
\end{tabular}




\subsubsection{Geofácie Mata Ciliar}

A Mata Ciliar está presente principalmente no curso inferior dos ribeirões Taquaruçuzinho e Taquruçu Grande, quando estes ficam mais largos (Figura 4.8). Ocorrem as espécies Inga sp. (ingás), Tabebuia sp. (ipês), Mauritia flexuosa L. f. (Buriti), Xylopia ermaginata Mart. (Pindaíba-d'água), Vochysia haenkeana Mart, Physocalymma sp, Hymenaea stignocarpa Mart. Ex Hayne (Jatobá) e Cecropia sp. (Embaúba) Jacaranda cuspidifolia (Caroba), Cuspidaria sp.,

Este geofácie apresentou uma dinâmica espacial, tendo-se como base a tipologia dinâmica de geossistemas estabelecida por Bertrand (2004), que corresponde à geofácies em "resistasia" do tipo "resistasia verdadeira", pela destruição total da vegetação e do solo (nos trechos inundados com o enchimento do Lago Reservatório da UHE Luís Eduardo Magalhães), dando lugar a um novo geofácie na paisagem (área inundada pelo Lago), no curso inferior do ribeirão Taquaruçu Grande. A Mata Ciliar original foi submersa pelo Lago e muitos trechos da paisagem, atualmente, apresentam-se fortemente humanizados com práticas agropecuárias (Figura 4.8)..

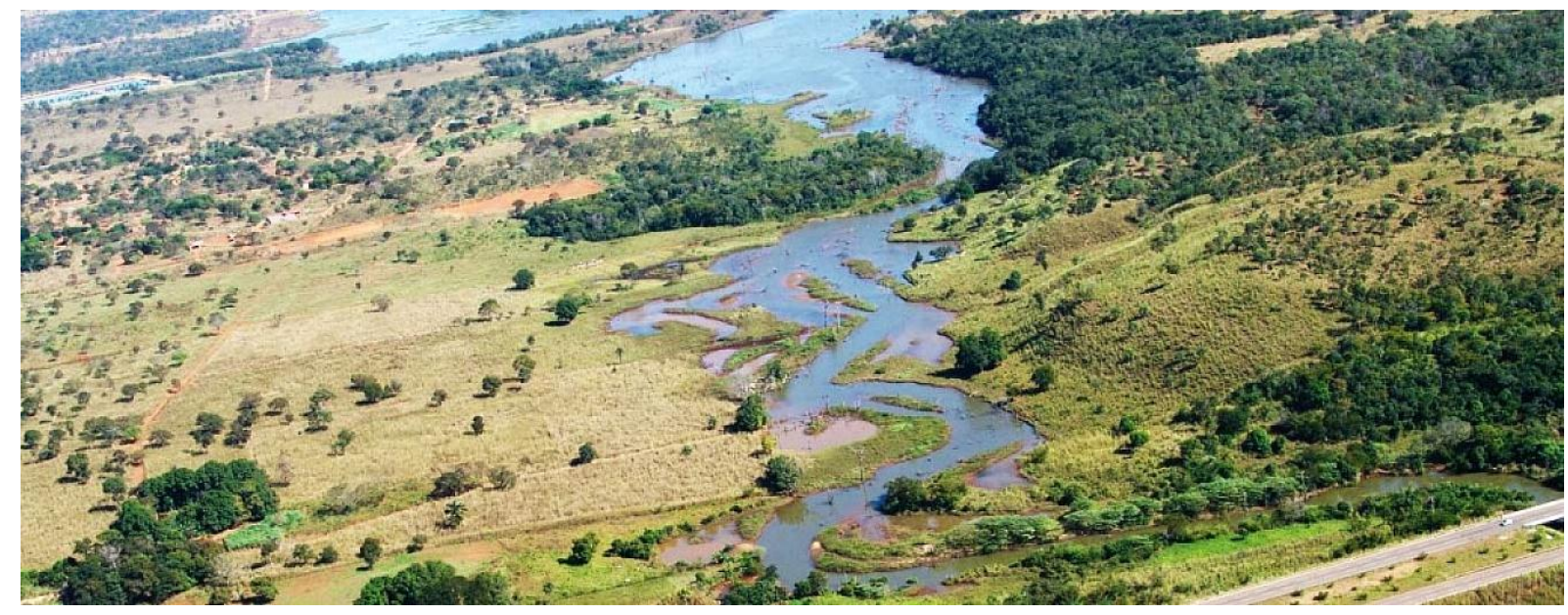

Figura 4.8 - Mata Ciliar no ribeirão Taquaruçuzinho, na bacia hidrográfica do ribeirão Taquaruçu Grande, Palmas (TO). Fonte: Projeto Taquaruçu. Disponível em:

< www.projetotaquarussu.com.br > Acesso em 08 dez. 2013 


\subsubsection{Geofácie Matas de Galeria}

As Matas de Galeria ocorrem nos vales encaixados entre os chapadões e planaltos, com margens com topografia acidentada. São encontradas ao longo dos ribeirões ${ }^{4}$ Taquaruçu Grande e Taquaruçuzinho e córregos ${ }^{5}$ Tiúba, Macacão, Machado e Buritizal e Brejo da Lagoa. As espécies que ocorrem nessas matas são: Inga edulis Mart., Inga sp. (Ingás), Tabebuia spp. (Ipês), Mauritia flexuosa L. f. (Buriti), Xylopia ermaginata Mart. (Pindaíbad'água), Xylopia sp., Mandevilla spp. e Vochysia haenkeana (Spreng.) Mart., Tabebuia roseoalba (Ridl.) Sandwith, entre outras.

Este geofácie apresentou subtipos, podendo-se observar Mata de Galeria não inundável e Mata de Galeria inundável (Figura 4.9; 4.10), seguindo-se a classificação fitofisionômica de Ribeiro e Walter (2008). A transição com as matas de vertente (Cerradão ou Matas Secas) ocorre de forma imperceptível, como comentado por Ribeiro e Walter (2008).

A Mata de Galeria na tipologia dinâmica de geossistemas (BERTRAND, 2004), enquadra-se em mais de uma tipologia. Em determinadas áreas observou-se o tipo "biostasia”, onde a atividade geomorfológica é fraca ou nula. O potencial ecológico é mais ou menos estável. O sistema de evolução é dominado pela pedogêneses, competição entre espécies vegetais, etc... A intervenção antrópica pode provocar dinâmica regressiva da vegetação e dos solos, mas, não compromete gravemente o equilíbrio entre o potencial ecológico e a exploração biológica. Correponde a geofácies "climácicos”, "plesioclimácicos" ou "subclimácicos", paisagens onde o clímax é mais ou menos conservado, a intervenção humana é de caráter limitado, sem comprometer o equilíbrio de conjunto. Em caso de ocorrência de desmatamento ou eventos de ordem natural a reconstrução da cobertura vegetal e dos solos ocorre bem rapidamente; o potencial ecológico não parece modificado.

Por outro lado, há setores onde se observa o tipo "biostasia" com dinâmica regressiva sem modificação importante do potencial ecológico, mas a vegetação foi modificada ou destruída e os solos transformados pelas atividades antrópicas.

\footnotetext{
${ }^{4}$ Ribeirão: curso de água maior do que u regato, mas menor que um rio (KOOGAN: HOUAISS, 2000).

${ }^{5}$ Córrego: Riacho, robeiro, regato (KOOGAN: HOUAISS, 2000).
} 

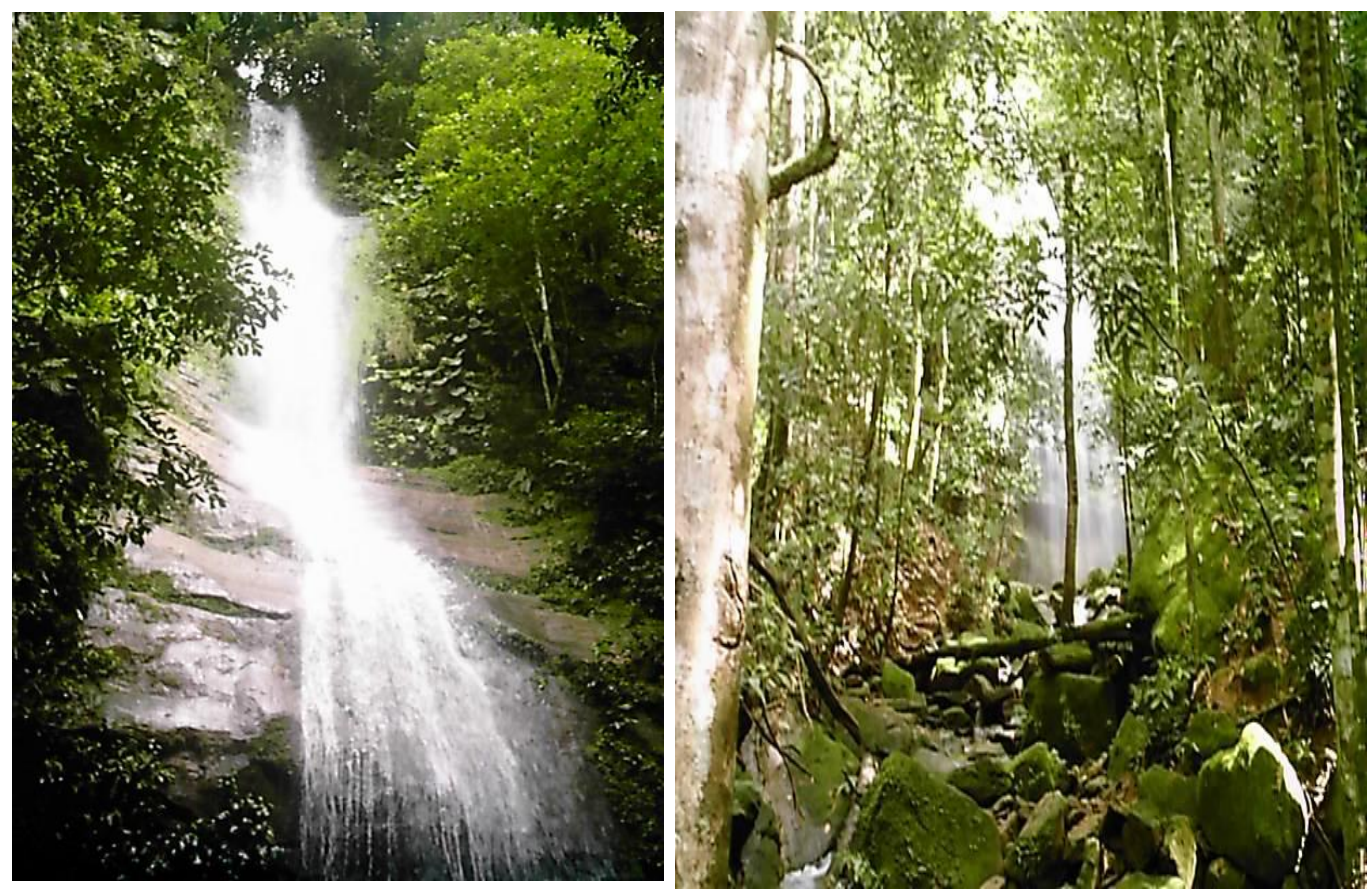

Figura 4.9 - Matas de Galeria do Brejo da Lagoa, na bacia hidrográfica do ribeirão Taquaruçu Grande, Palmas (TO). Fotografia: T. C. C. Medeiros, 2010

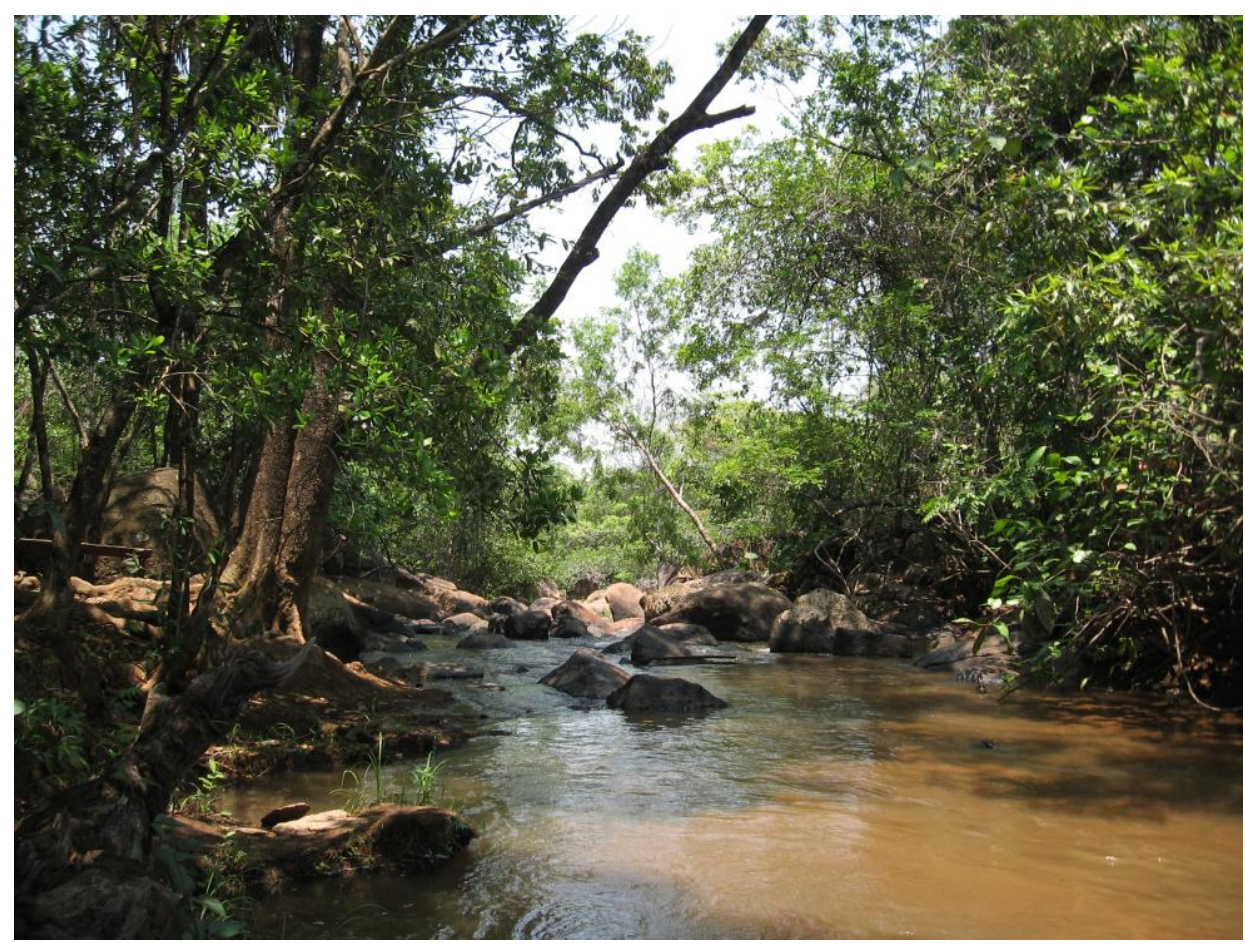

Figura 4.10 - Matas de Galeria inundável do ribeirão Taquaruçuzinho, na bacia hidrográfica do ribeirão Taquaruçu Grande, Palmas (TO). Fotografia: T. C. C. Medeiros, 2010 


\subsubsection{Geofácie Mata Seca}

As Matas Secas ocorrem nos topos ou nas vertentes dos interflúvios e planícies secas (Figura 4.11). Neste geofácie foram observadas Mata Seca Sempre Verde, Mata Seca Semidecídua, Mata Seca Decídua (subtipos de Mata Seca de acordo com a classificação de RIBEIRO; WALTER, 2008).

Algumas espécies ocorrentes são: Handroanthus ochraceus (Cham.) Standley (Ipê do Cerrado), Tabebuia spp. (ipês), Caryocar brasiliense Camb. (Pequi), Anadenantera spp. (Angicos), Vatairea macrocarpa (Benth.) (Angelim-do-Cerrado), Maximiliana maripa (Aubl.) Drude, (Inajá) Vochysia tucanorum Mart. (Pau-Tucano), Vochysia spp., Bowdichia virgilioides H. B. K., Pterodon ermaginatus Vog., e Acrocomia aculeata (Jacq.) Lodd. ex Mart. (Macaúba).

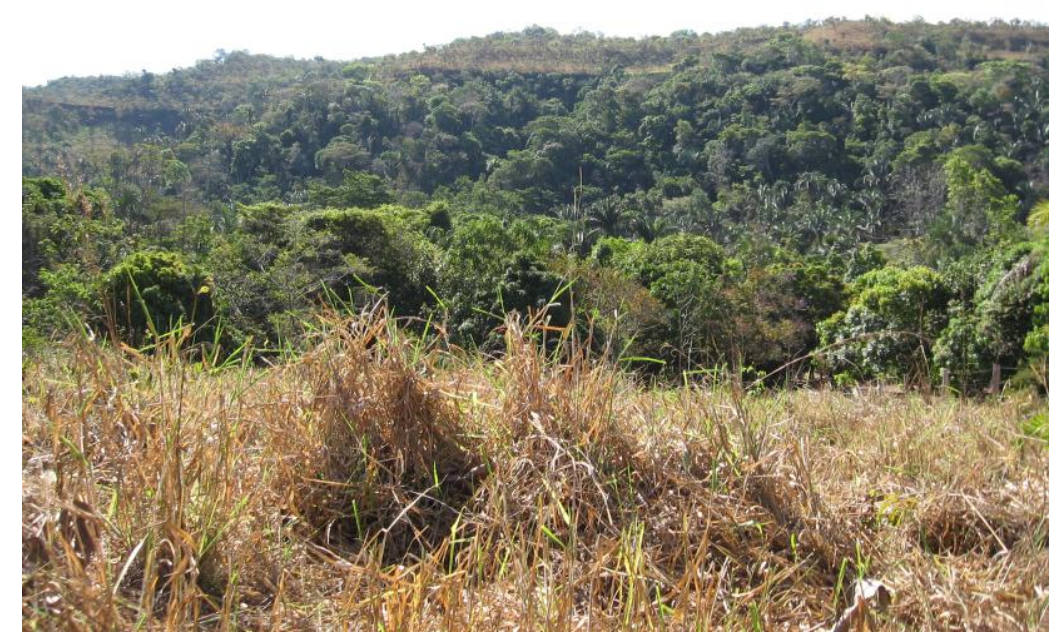

Figura 4.11 - Mata Seca em vertentes à margem direita do córrego Mutum, na bacia hidrográfica do ribeirão Taquaruçu Grande, Palmas (TO). Fotografia: T. C. C. Medeiros, 2011

Quanto à tipologia dinâmica de geossistema (BERTRAND, 2008) há setores mais preservados que se enquadram como do tipo "biostasia", correspondendo a geofácies “climácicos", "plesioclimácicos” ou "subclimácicos”, como já descrito para o geofácie Mata de Galeria. E há setores do tipo "biostasia” com dinâmica regressiva sem modificação importante do potencial ecológico, mas fortemente humanizados, onde a vegetação foi modificada ou destruída e os solo transformados pelas atividades agropecuárias, porém, sem haver o rompimento do equilíbrio ecológico, em chapadas, planaltos e vertentes da serra do Lageado. Já nas planícies secas (Depressão do Tocantins), a dinâmica corresponde ao tipo 
geofácies em "resitasia" com "resistasia verdadeira", pela destruição total da vegetação e do solo (nos trechos urbanizados), dando lugar a um novo geofácie, o urbano, a cidade de Palmas.

A Mata Ciliar, a Mata de Galeria e a Mata Seca constituem formações florestais (RIBEIRO; WALTER, 2008) e na classificação da paisagem, esses geofácies compuseram a unidade "Floresta", que totalizou $15.763,32$ ha $(34,1 \%)$ da bacia hidrográfica do ribeirão Taquaruçu Grande (Tabela 4.1; Figura 4.7).

\subsubsection{Geofácie Cerradão}

Assim como as Matas Secas, o Cerradão (Figura 4.12) ocorre nos topos ou nas vertentes dos interflúvios, ou nas planícies secas. Ocupa uma área de $12.850,92$ ha $(27,8 \%)$ na bacia hidrográfica do ribeirão Taquaruçu Grande (Tabela 4.1; Figura 4.7). Sua flora constitui um misto de espécies de mata e de cerrado com Curatela americana Lin. (Sambaíba), Caryocar brasiliense Camb. (Pequi), Bowdichya virgilioides H. B. K. (Sucupira preta), Piterodon ermaginatus Vog. (Sucupira branca), Vatairea macrocarpa (Benth.) (Angelim-docerrado), Kielmeyera coriacea (Spreng.) Mart. (Pau-santo), Hymenaea stignocarpa Mart. Ex Hayne (Jatobá), Qualea parviflora Mart. (Pau-terra-de-folha-grande), Qualea grandiflora Mart. (Pau-terra-de-folha-pequena) e Vochysia tucanorum Mart. (Pau-tucano), entre outras.

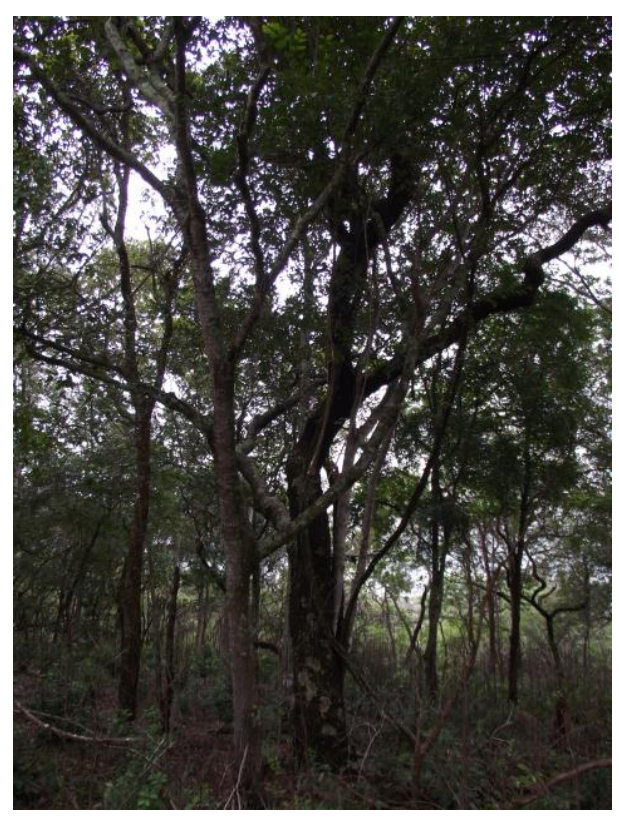

Figura 4.12 - Cerradão em área de chapada entre o vale do ribeirão Taquaruçuzinho e o ribeirão Taquaruçu Grande, na bacia hidrográfica do ribeirão Taquaruçu Grande, Palmas (TO). Fotografia: T. C. C. Medeiros, 2011 
Assim como na Mata Seca, enquadra-se na tipologia dinâmica de geossistemas (BERTRAND, 2004), como do tipo "biostasia”, correpondendo a geofácies "climácicos", "plesioclimácicos" ou "subclimácicos", bem como do tipo "biostasia" com dinâmica regressiva, além de se observar também o tipo "resistasia" com "resistasia verdadeira", como já comentado para a Mata Seca.

\subsubsection{Geofácie Cerrado Sentido Restrito}

Este geofácie Ocorre nos topos, nas vertentes dos interflúvios ou nas planícies secas, assim como a Mata Ciliar, Mata de Galeria e Mata Seca. Ocupa uma área de 4.964,31 ha $(10,7 \%)$ da bacia do ribeirão Taquaruçu Grande (Tabela 4.1; Figura 4.7), onde ocorrem as espécies Caryocar brasiliense (Pequi), Anacardium microcarpum Ducke (Cajuí), Astronium fraxifolium Schott., Aspidosperma tomentosa Mart., Hancornia speciosa Gomez (Mangaba), Tabebuia spp., (Ipês), Piptocarpa rotundifolia (Less.) Baker (Cabelo de negro), Bulbostylis paradoxa Ness (Capim barba-de-bode), Rincosphora sp., Curatela americana Linn. (Sambaíba), Bauhinia spp. (Pata de vaca) e Byrsonima spp. (Muricis), entre outras.

Assim como a Mata Seca e o Cerradão, enquadra-se na tipologia dinâmica de geossistemas (BERTRAND, 2004), do tipo "biostasia", correspondendo a geofácies "climácicos", "plesioclimácicos" ou "subclimácicos"; do tipo "biostasia" com dinâmica regressiva; e do tipo "resistasia" com "resistasia verdadeira", como já comentado para a Mata Seca. O geofácie Cerrado Sentido Restrito apresentou os seguintes subtipos: Cerrado Denso, Cerrado Típico, Cerrado Ralo (Figura 4.13), Cerrado Rupestre (Figura 4.14), fitofisionomias descritas por Ribeiro e Walter (2008).

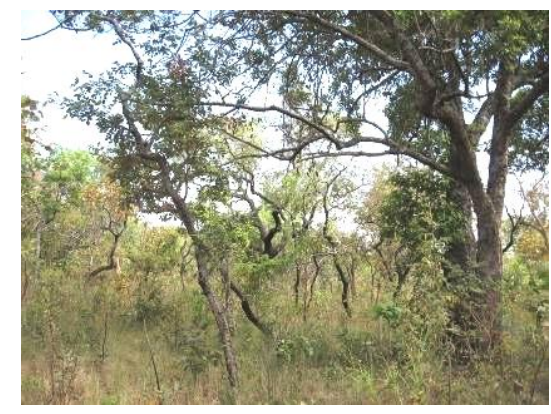

Cerrado Denso

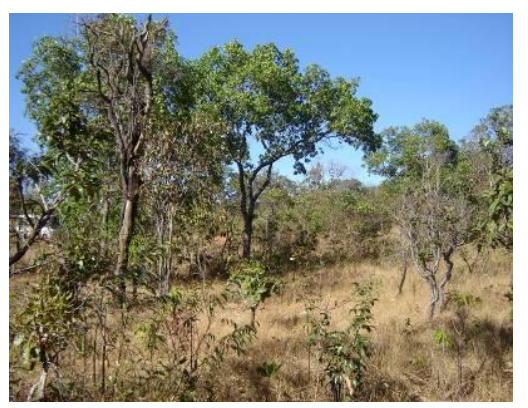

Cerrado Típico

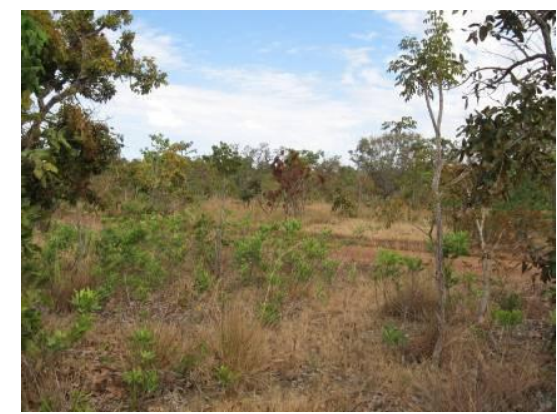

Cerrado Ralo

Figura 4.13 - Cerrado Sentido Restrito em área de chapada entre o vale do ribeirão Taquaruçuzinho e o ribeirão Taquaruçu Grande, na bacia hidrográfica do ribeirão Taquaruçu Grande, Palmas (TO). Fotografia: T. C. C. Medeiros, 2011 


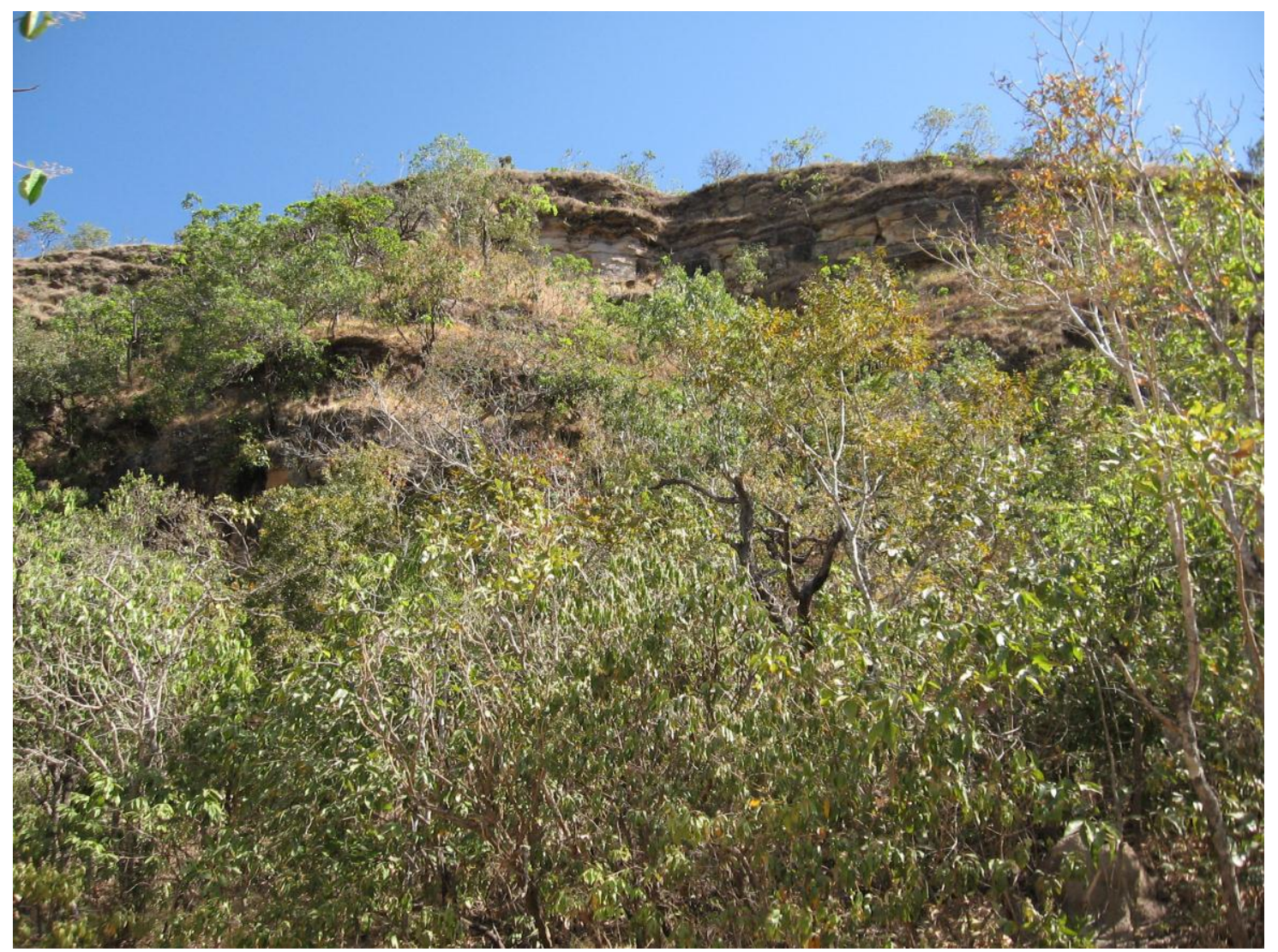

Figura 4.14 - Cerrado Rupestre, no vale do Vai Quem Quer, na bacia hidrográfica do ribeirão Taquaruçu Grande, Palmas (TO). Fotografia: T. C. C. Medeiros, 2011

\subsubsection{Geofácie Vereda}

A Vereda (Figura 4.15) ocorre em vales mais amplos na planície da Depressão do Tocantins, bem como nas áreas de topo no interior de planaltos ou chapadas da Serra do Lageado (Planalto Residual do Tocantins). A ocorrência de Vereda está condicionada à presença de afloramento ou proximidade com a superfície do lençol freático, em áreas de solos Glei (hidromórficos). É, geralmente, circundada por Campo Limpo Úmido.

Outra característica da Vereda é a presença da palmeira Mauritia flexuosa L.f. (Buriti), que ocorre com espécies dicotiledôneas com altura e adensamentos variados como, Miconia albicans (Sw.) Triana, Myrcia splendens (Sw.) DC., Vochysia tucanorum Mart. (Pau tucano), Jacaranda spp. Mandevilla sp., dentre outras.

A Vereda enquadra-se na tipologia dinâmica de geossistemas (BERTRAND, 2004), do tipo "biostasia", correspondendo a geofácies "climácicos", "plesioclimácicos" ou "subclimácicos", mas também do tipo "resentasia" com "resistasia verdadeira", correspondendo aos trechos em que as Veredas foram substituídas pelas estradas. 


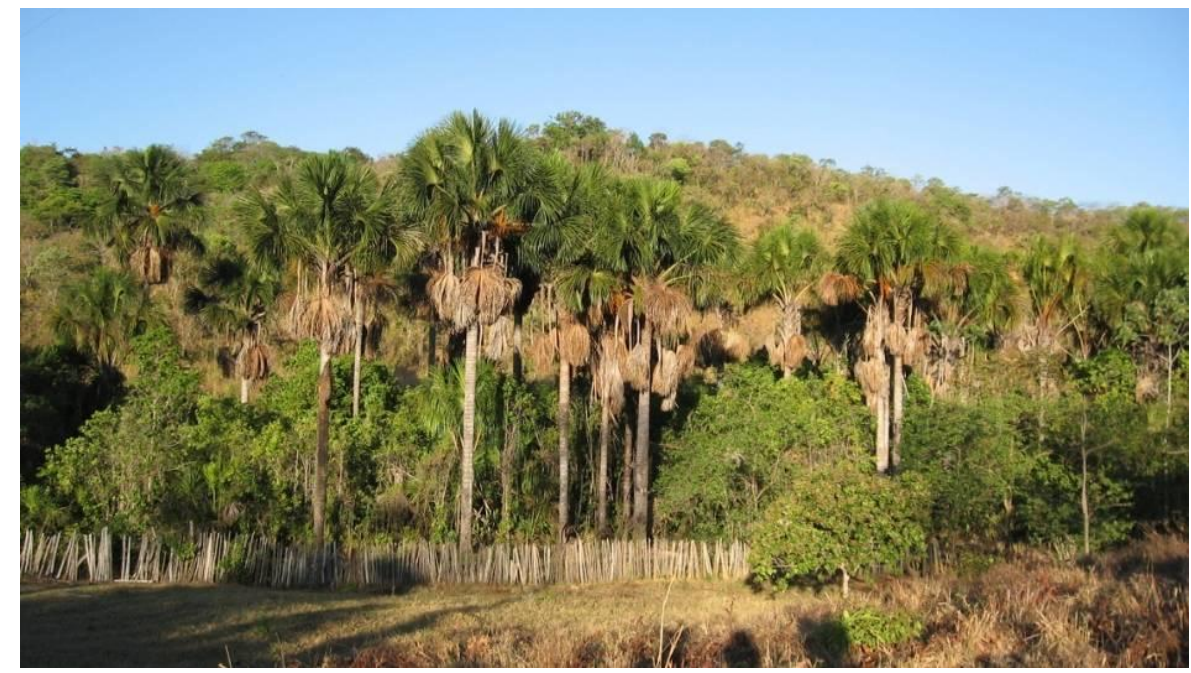

Figura 4.15 - Vereda em área adjacente ao vale de tributário do córrego Mutum, na bacia hidrográfica do ribeirão Taquaruçu Grande, Palmas (TO). Fotografia: T. C. C. Medeiros, 2011

\subsubsection{Geofácie Campo Sujo Seco}

O Campo Sujo Seco (subtipo de Campo Sujo na classificação fitofisionômica do Cerrado de RIBEIRO; WALTER, 1998; 2008), é caracteristicamente herbáceo-arbustivo, ocorrendo predominantemente, nos topos da serra do Lageado (chapadas e planaltos), em altitudes elevadas em torno de 600 a quase $700 \mathrm{~m}$, em relevo suavemente ondulado, mas também em áreas de planícies secas, porém, com baixa expressividade (Figura 4.16). Ocupa uma área de 7.478,82 ha (16,2\%) da bacia do ribeirão Taquaruçu Grande (Tabela 4.1; Figura 4.7).

No Campo Sujo Seco ocorrem Anacardium humile A.St.-Hil (Cajuí), Annona macrocarpa Barb. Rodr. (Bruto), Himatanthus obovatus (M. Arg.) Woods. (Pau de leite), Trimezia juncifolia (Klatt.) Benth., Connarus suberosus Planch., Piptocarpa rotundifolia (Less.) Baker (Cabelo de negro), Bulbostylis paradoxa Ness. (Capim barba de bode), Rhyncosphora consanguinea (Kunth.) Böeckeler, Panuicum maximum Hochst. Ex Rich (Capim colonião), Davilla elliptica St. Hill, Manihot violacea Pohl e Kilmeyera coriacea (Spr.) Mart., Velozia seubertiana Goethart \& Henrard (Canela de ema), dentre outras.

Na tipologia dinâmica de geossistemas (BERTRAND , 2004), este geofácie enquadrase como do tipo "biostasia", correpondendo a geofácies "climácicos”, "plesioclimácicos” ou "subclimácicos". 


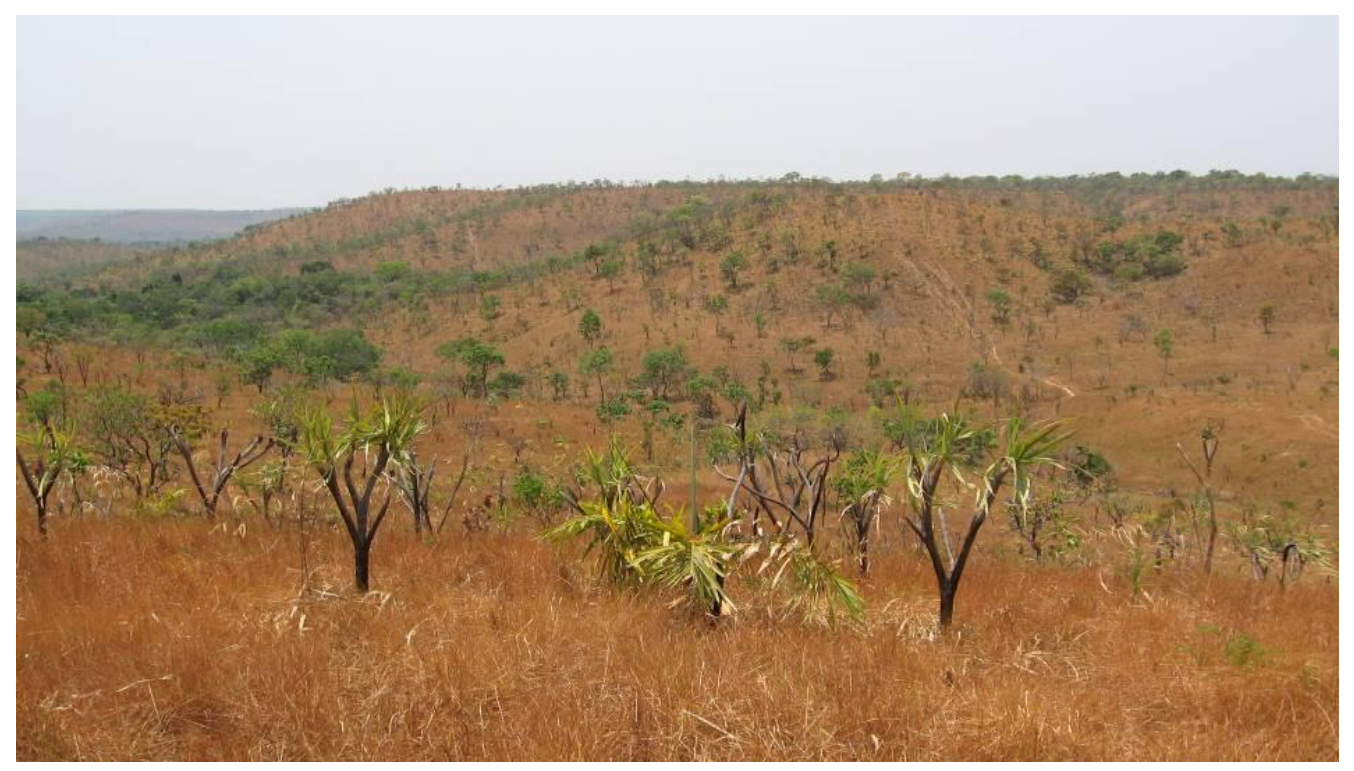

Figura 4.16 - Campo Sujo Seco em área de topo e vertentes suavemente onduladas de chapadas, na bacia hidrográfica do ribeirão Taquaruçu Grande, Palmas (TO). Fotografia: T. C. C. Medeiros, 2011

No geofácie Campo Sujo Seco pode-se observar trechos em que a exploração biológica (vegetação) tem composição florística bem específica, constituindo-se em geótopos deste geofácie:

a) Campo Sujo Seco com Vochysia cinnamomea, Byrsonima coccobolifólia e Vellozia seubertiana em topo e vertente na área 3;

b) Campo Sujo Seco com Vellozia seubertiana e Syagrus comosa em topo e vertente na área 1 e em vertente na área 2;

c) Campo Sujo Seco com Byrsonima subterrânea em topo e vertente na área 5;

d) Campo Sujo Seco Misto com Syagrus comosa, Vellozia seubertiana, Erythroxylum suberosum, Ouratea spectabilis, Piptocarpha rotundifolia, Dimorphandra mollis em topo da área 2;

e) Campo Sujo Seco com Vellozia seubertiana em topo na área 4

O geofácie Campo Sujo Seco foi estudado de forma individualizada a partir do item 4.2.

Na área de ocorrência de Campo Sujo Seco, ocorrem afloramentos da Formação Pimenteiras, com ocorrência de fósseis de Crinóides (animais marinhos), indicando a invasão do mar em épocas pretéritas na região central do Brasil, devido a processos de subsidência que acometeram a Plataforma Sul-Americana em épocas geológicas passadas, a partir do Siluriano/Devoniano Inferior e que ocasionou a formação da Bacia sedimentar do Parnaíba, posteriormente soerguida por processo decorrentes da orogênese andina (SCHOBBENHAUS; NEES,2003) (Figura 4.17). 


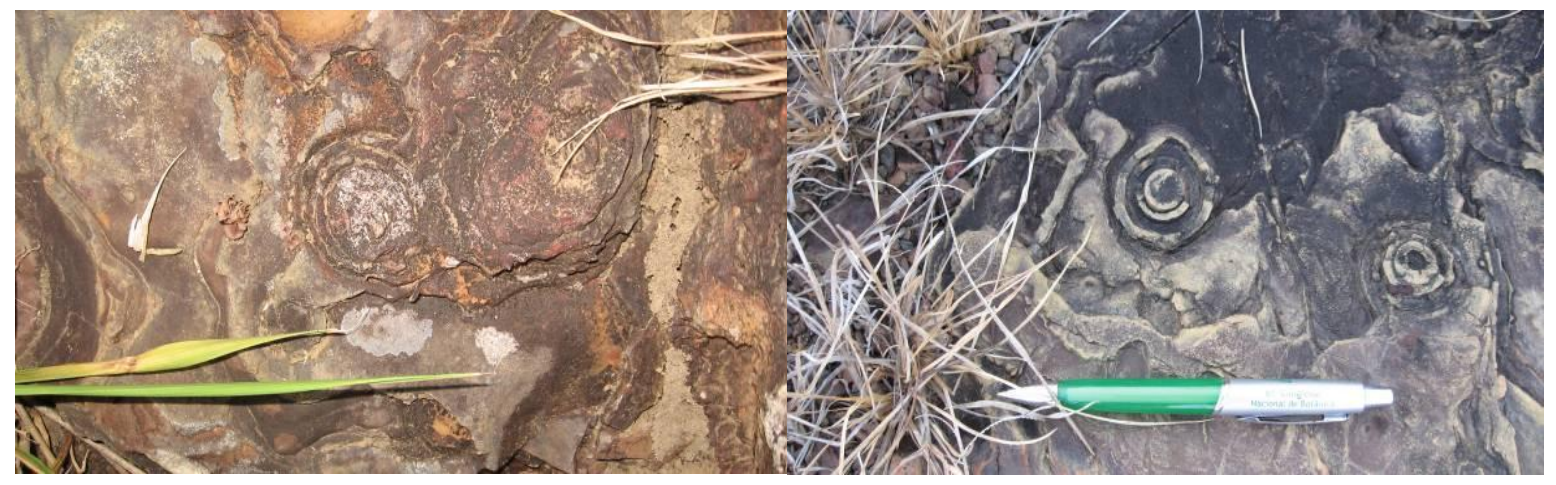

Figura 4.17 - Fósseis de Crinóides em Campo Sujo Seco em chapada, na bacia hidrográfica do ribeirão Taquaruçu Grande, Palmas (TO). Fotografia: T. C. C. Medeiros, 2011

\subsubsection{Geofácie Campo Limpo}

O Campo Limpo (uma das fitofisionomias do Cerrado estabelecidas por RIBEIRO; WALTER, 1998; 2008), é predominantemente herbáceo, possui poucos arbustos e não tem árvores (Figura 4.18). Ocorre, geralmente, associado às Matas Ciliares e de Galeria ou Veredas, onde o terreno não é acidentado, caracterizando-se como Campos Limpos Úmidos, embora que sazonalmente em alguns trechos. Por ocorrer em pequenas áreas associadas às Matas Ciliares e de Galeria e Veredas, na classificação da paisagem foi incluso na unidade Floresta.

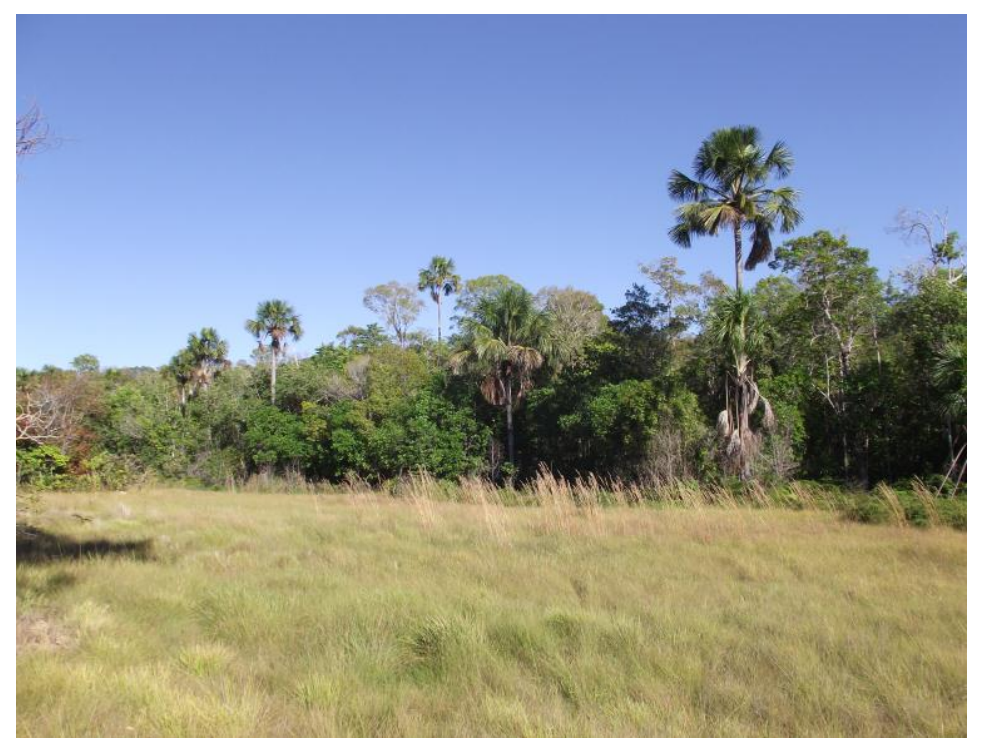

Figura 4.18 - Campo Limpo úmido em área de Vereda, na bacia hidrográfica do ribeirão Taquaruçu Grande, Palmas (TO). Fotografia: T. C. C. Medeiros, 2013 
Apresenta uma grande ocorrência do Gênero Rhynchospora Vahl da família Cyperaceae. Outros gêneros ocorrentes são Eleocharis sp., também da família Cyperaceae e Pteridium sp. (Samambaia). Assim como o Campo Sujo Seco enquadra-se na tipologia dinâmica de geossistemas (BERTRAND, 2004), como do tipo "biostasia", correpondendo a geofácies “climácicos”, "plesioclimácicos” ou "subclimácicos”.

\subsubsection{Geofácie Campo Rupestre}

O Campo Rupestre (uma das fitofisionomias do Cerrado estabelecidas por RIBEIRO; WALTER, 1998; 2008), é característicamnte herbáceo-arbustivo e com pouca presença de arvoretas. Ocorre em vertentes íngrimes das bordas dos chapadões e planaltos com altitudes em torno de $700 \mathrm{~m}$, onde há afloramentos rochosos e geralmente, associado ao Cerrado Sentido Restrito (Figura 4.19). Por ocorrer em áreas mais restritas, na classificação da paisagem foi incluso na unidade Cerrado Sentido Restrito.

Ocorrem espécies como: Schefflera macrocarpa (Cham. \& Schltdl.) Frodin (Manfdiocão), Ananas ananassoides (Baker) 1. B Sm. (Abacaxi do Cerrado), Bulbostylis paradoxa Ness. (Capim barba de bode), Bulbostylis sp. e espécies dos gêneros Miconia, Rhynchospora, Trimezia, Calliandra, Chamaecrista, Mimosa, Diplusodon, Axonopus, Panicum, Trachypogon, Manihot e Vellozia.

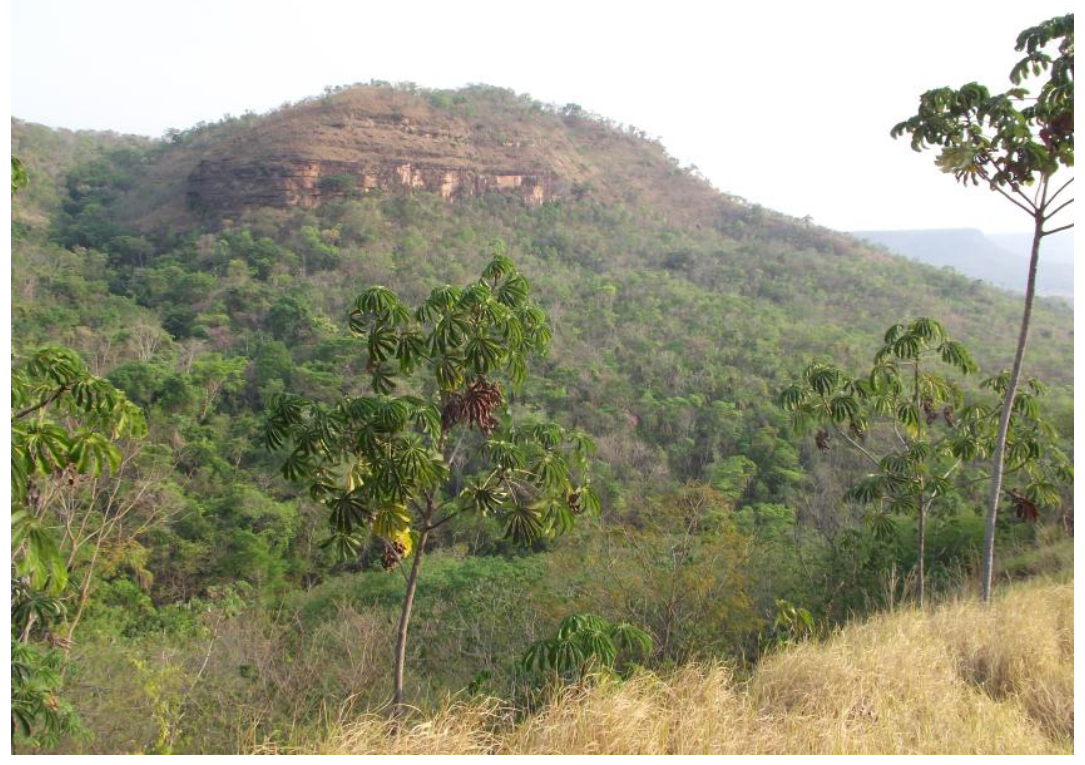

Figura 4.19 - Campo Rupestre em vertente íngreme de morro à margem esquerda do Brejo da Lagoa, na bacia hidrográfica do ribeirão Taquaruçu Grande, Palmas (TO). Fotografia: T. C. C. Medeiros, 2011 
Com relação à tipologia dinâmica de geossistemas (BERTRAND, 2004), este geofácie enquadra-se no tipo em "resistasia" com "geomorfogênese natural", comum em regiões mais secas e em altitudes elevadas, onde a erosão faz parte do "clímax", contribuindo para limitar naturalmente o desenvolvimento da vegetação e dos solos.

\subsubsection{Geofácie Babaçual}

O Babaçual é um palmeiral de babaçu (Attalea speciosa Mart. ex Spreng.), um subtipo de Palmeiral na classificação fitofisionômica do Cerrado de Ribeiro e Walter (1998; 2008). Ocorre nos planaltos, planícies ou encostas, sem associação com os ribeirões e córregos (Figura 4.20). Geralmente está associado às atividades antrópicas como ações de desmatamentos e queimadas, ocorrendo em áreas desmatadas nos geofácies Cerrado Sentido Restrito, Cerradão e Matas Secas. Juntamente com o Babaçu também ocorrem gramíneas, ciperáceas e outras plantas herbáceas.

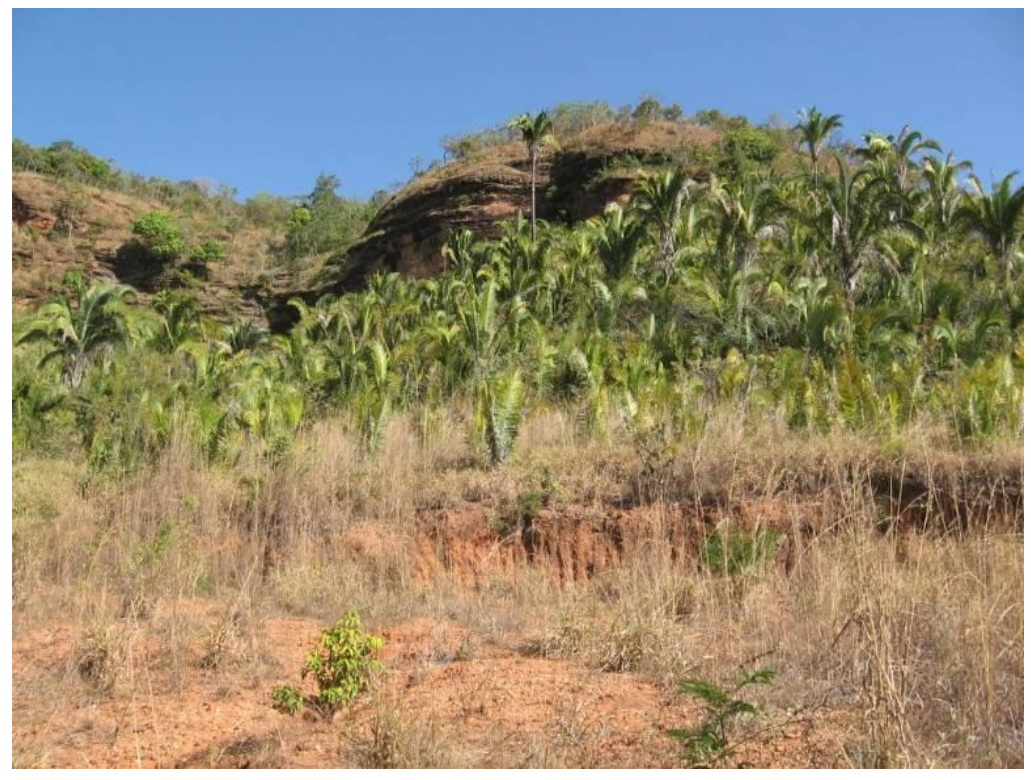

Figura 4.20 - Babaçual em área de chapada entre o vale do ribeirão Taquaruçuzinho e o córrego Mutum, na bacia hidrográfica do ribeirão Taquaruçu Grande, Palmas (TO). Fotografia: T. C. C. Medeiros, 2011

Este geofácie substituiu os geofácies naturais em decorrência do processo de "resistasia verdadeira" (Bertrand (2004), provocada pela ação antrópica (desmatamentos e queimadas) em trechos de Mata Seca, Cerradão e Cerrado Sentido Restrito. Na classificação da paisagem foi inserido nas unidades Floresta, Cerradão e Cerrado Sentido Restrito. 


\subsubsection{Geofácie Área Urbana}

A Área Urbana compreende a cidade de Palmas e a sede do Distrito de Taquaruçu, no município de Palmas (TO). A cidade de Palmas localiza-se na área de planície fluvial do rio Tocantins (Depressão do Tocantins) e o distrito de Taquaruçu na serra do Lageado. Este geofácie ocupa uma área de 2.844,09 ha $(6,2 \%)$ da bacia hidrográfica do ribeirão Taquaruçu Grande (Tabela 4.1; Figura 4.7) e expressa a ação antrópica que se caracteriza por meio das edificações e equipamentos urbanos destinados às funções de habitação, trabalho, serviços, recreação e circulação, entre outros (Figura 4.21 e 4.22).
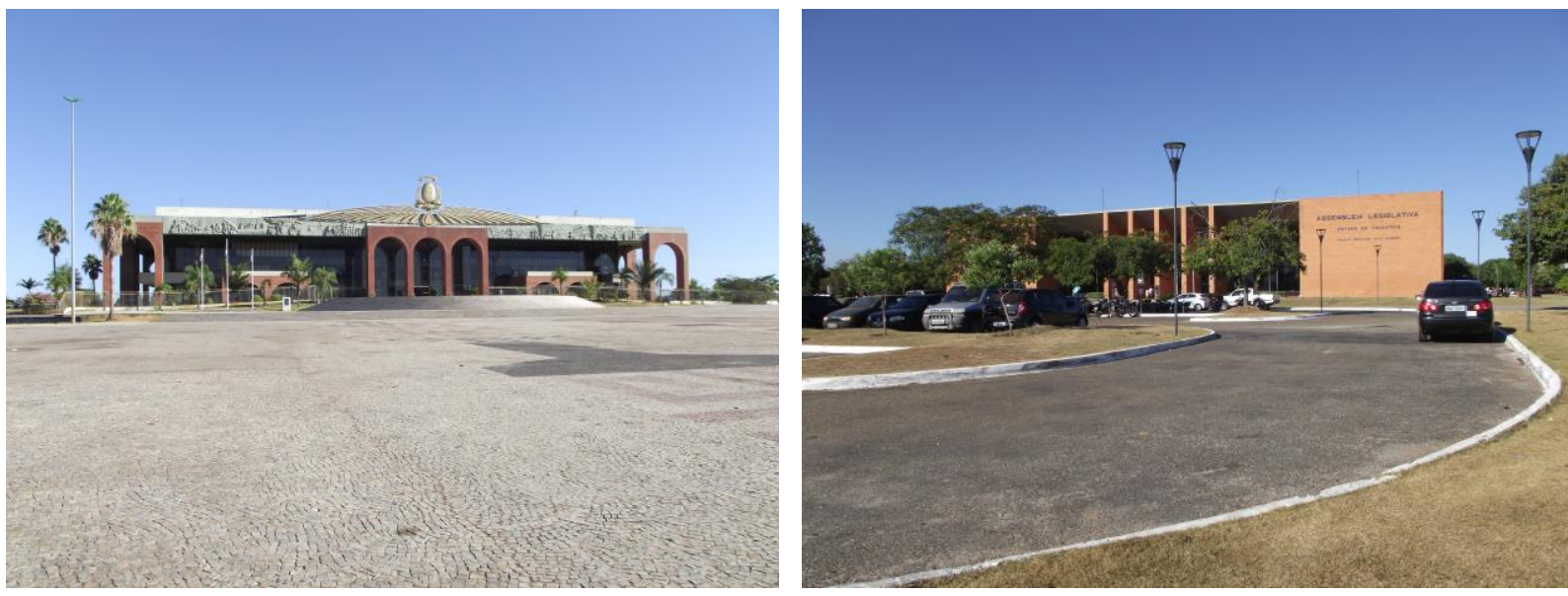

Figura 4.21 - Aspecto da área urbana da cidade de Palmas (Palácio dos Girassóis e Assembléia Legislativa), município de Palmas (TO). Fotografia: T. C. C. Medeiros, 2013

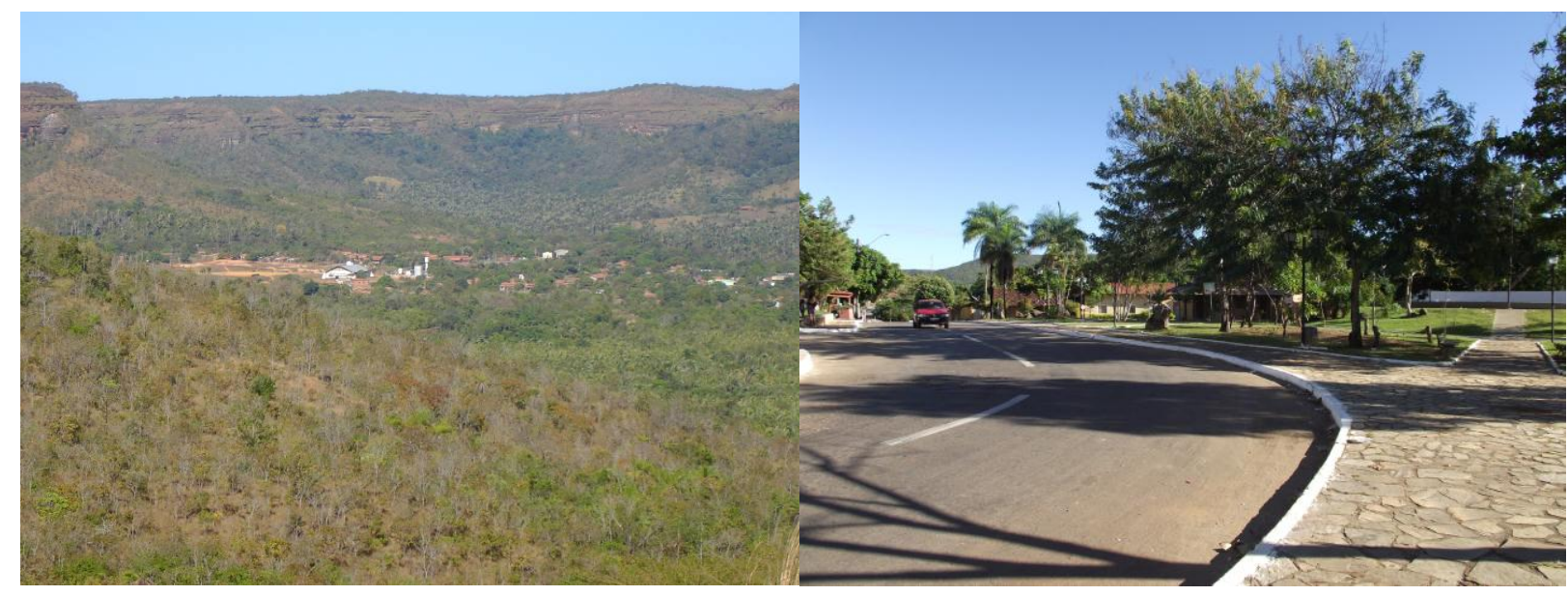

Figura 4.22 - Aspecto da área urbana do distrito de Taquaruçu, na bacia hidrográfica do ribeirão Taquaruçu Grande, município de Palmas (TO). Fotografia: T. C. C. Medeiros, 2013 
O geofácie Área Urbana na dinâmica da paisagem substituiu o ambiente natural em decorrência do processo de "resistasia verdadeira" (BERTRAND, 2004), provocada pela ação antrópica (total remoção) em trechos de Mata Seca, Cerradão e Cerrado Sentido Restrito, para instalação dos equipamentos urbanos, cujo processo de transformação é progressivo pela expansão das cidades de Palmas e Taquaruçu. Em meio à área urbana de Palmas pode-se ainda observar fragmentos florestais e savânicos (Figura 4.23).

O município de Palmas possuía uma população de 228.332 habitantes em 2010, estimada para o ano de 2013 em 257.904 habitantes $^{6}$, a população de Taquaruçu, entretanto, foi de 4.739 habitantes em 2010, correspondendo a apenas 2,1\% da população de Palmas .

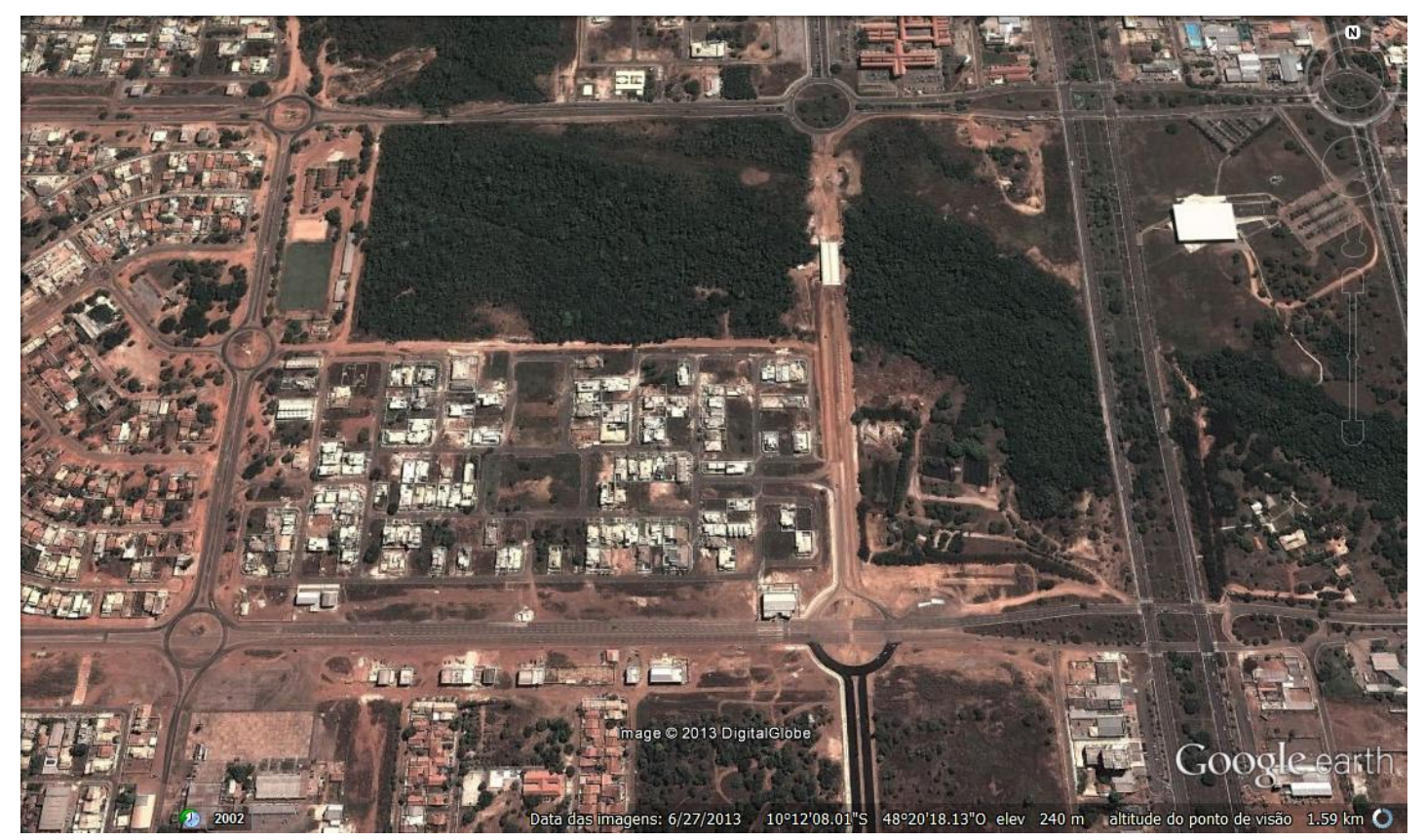

Figura 4.23 - Aspecto da área urbana de Palmas (TO), onde se observa fragmentos florestais e savânicos, na bacia hidrográfica do ribeirão Taquaruçu Grande, município de Palmas (TO). Fotografia: Google Earth, $2013^{7}$

\subsubsection{Geofácie Agricultura/Silvicultura}

Compreende áreas de usos antrópicos diversos fora da área urbana como os usos agropecuários (arroz, feijão, mandioca e milho, dentre outras culturas, pastagens e criações de

\footnotetext{
${ }^{6}$ Disponível em:

<http://cidades.ibge.gov.br/xtras/perfil.php?lang=\&codmun=172100\&search=tocantins/palmas $>$ Acesso em 09 dez.2013.

${ }^{7}$ Google Earth. Imagens de Palmas (TO).Disponível em: 〈http://www.google earth.com.br/ >. Acesso em: 08 dez. 2013.
} 
animais), áreas de reflorestamento com Eucalyptus sp. e solo exposto (Figura 4.24 e 25) e ocupam uma área de 1.872,81 ha $(4,0 \%)$ da bacia do ribeirão Taquaruçu Grande (Tabela 4.1; Figura 4.7).

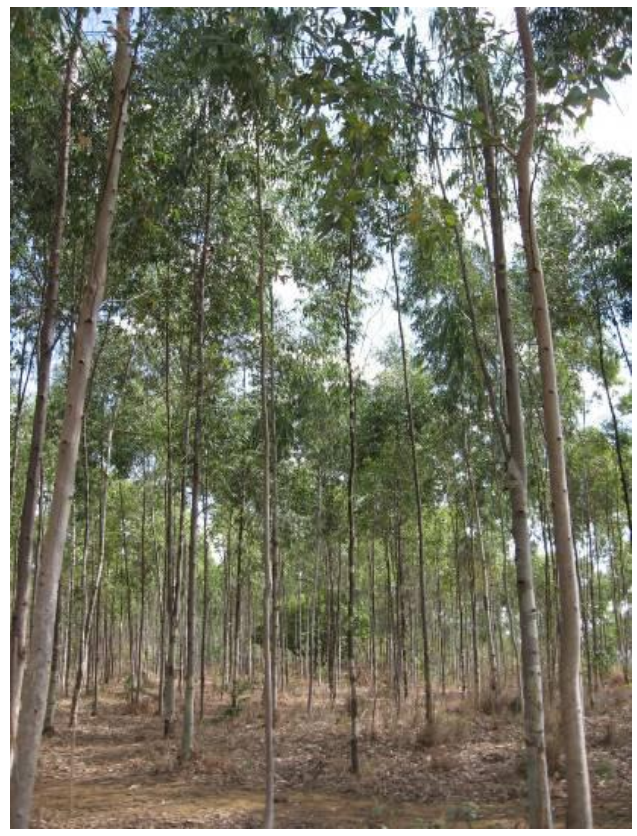

a

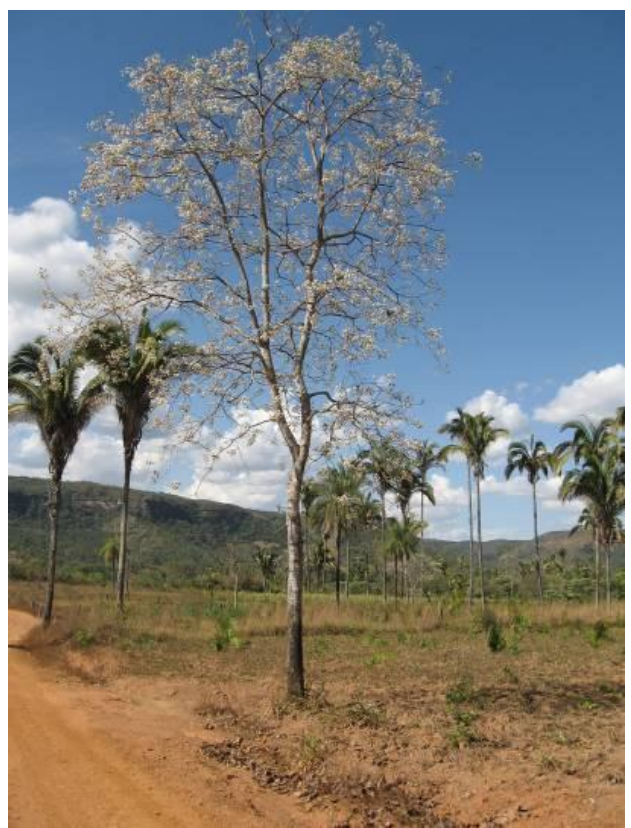

$\mathrm{b}$

Figura 4.24 - Atividades Agropecuárias/Silvicultura como reflorestamento de Eucalyptus sp. (a), e desmatamento (b), na bacia do ribeirão Taquaruçu Grande, município de Palmas (TO). Fotografia: T. C. C. Medeiros, 2011/2013

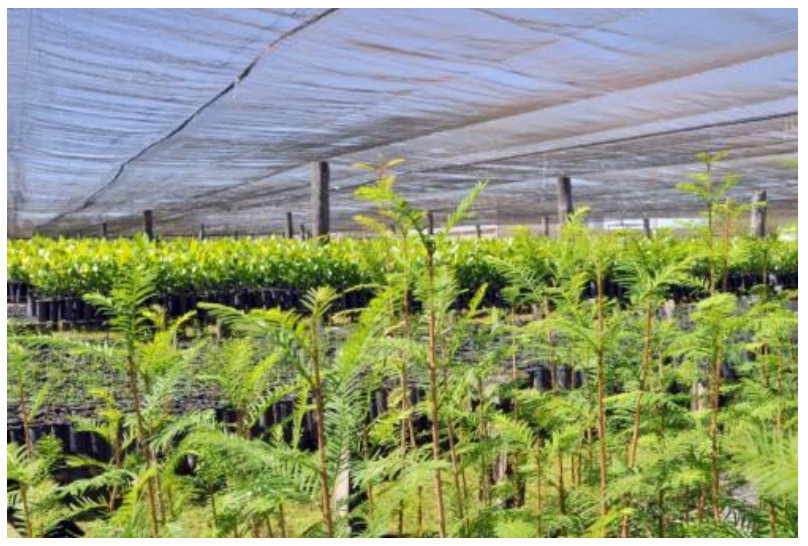

a

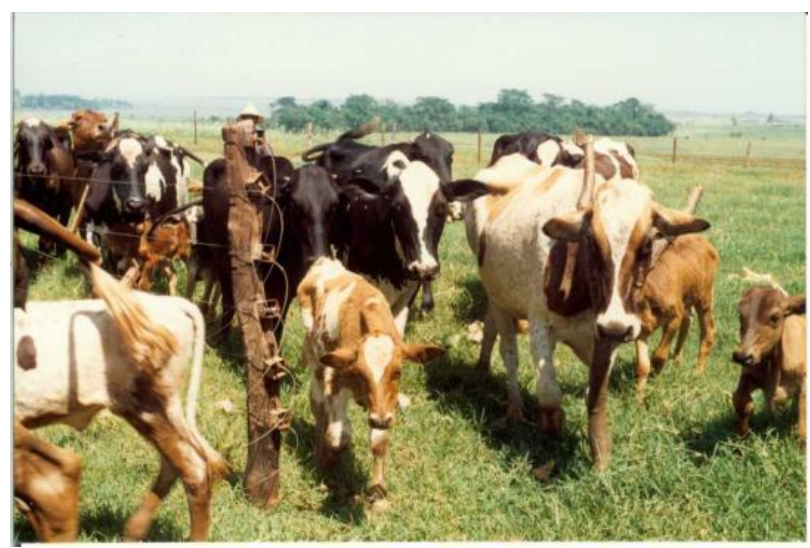

b

Figura 4.25 - Atividades Agropecuárias/Silvicultura, com aspectos da agricultura (a) e da pecuária (b), na bacia do ribeirão Taquaruçu Grande, município de Palmas (TO). Fotografia disponível em: <www.portalnorte.com.br $>$; <www.memorialduke.com.br $>$. Acesso em 08 dez. 2013 
Este geofácie na dinâmica da paisagem substituiu o ambiente natural em decorrência do processo de "resistasia verdadeira" (Bertrand (2004), provocada pela ação antrópica (desmatamentos e queimadas) em trechos de Mata Seca, Cerradão e Cerrado Sentido Restrito, para instalação das áreas agrícolas, pastagens e criação de animais.

\subsubsection{Geofácie Lago Reservatório, Ribeirões, Córregos e Brejos}

Corresponde à rede de drenagem da bacia hidrográfica do ribeirão Taquaruçu Grande, em geral formada por córregos, sendo os principais: Tiúba, Macacão Machado, Buritizal e o ribeirão Taquaruçuzinho, principal tributário do ribeirão Taquaruçu Grande, além Lago Reservatório da UHE Luís Eduardo Magalhães (Figura 4.26), com área de 403,20 ha, correspondendo a $1 \%$ da área da bacia hidrográfica (Tabela 4.1, Figura 4.7), no curso inferior do ribeirão Taquaruçu Grande.

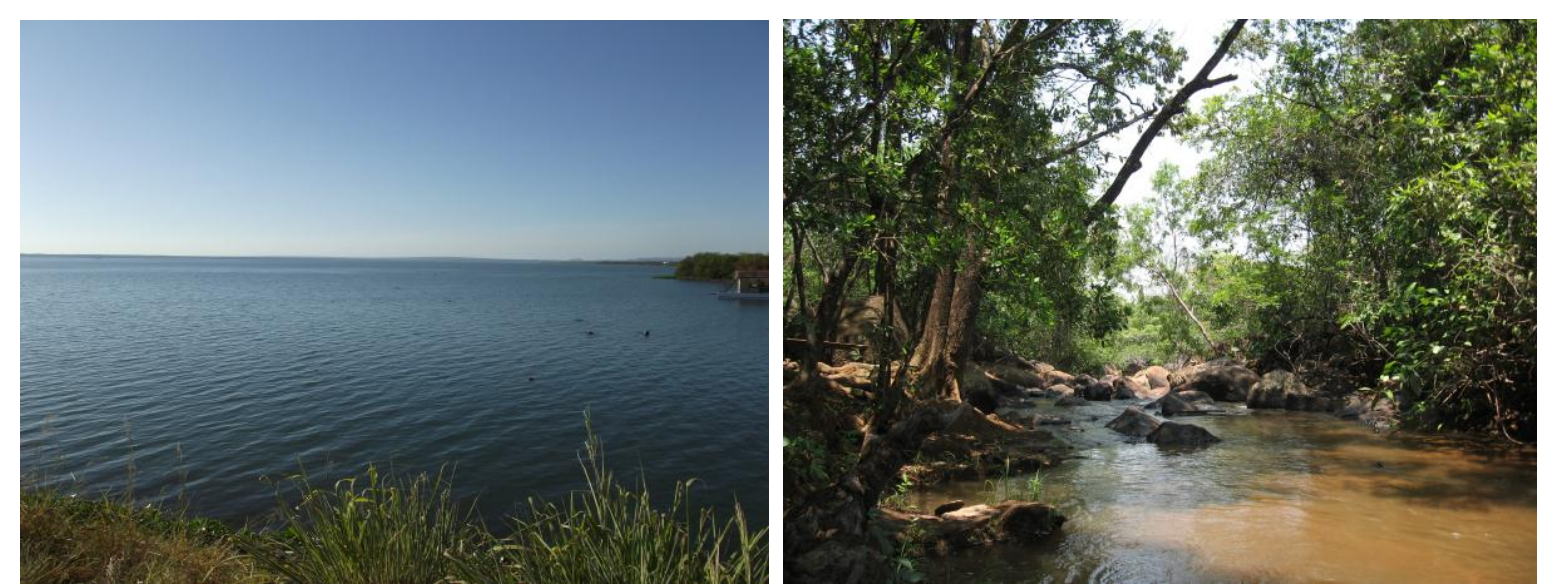

Figura 4.26 - Lago e ribeirão Taquaruçuzinho, na bacia hidrográfica do ribeirão Taquaruçu Grande, município de Palmas (TO). Fotografia: T. C. C. Medeiros, 2013

Uma característica peculiar da hidrografia da bacia do ribeirão Taquruçu Grande são as cabeceiras de drenagem em anfiteatro devido à geomorfologia e a geologia da área. Vários córregos são originados e alimentados pela drenagem que devido à erosão do terreno, formam cachoeiras nas bordas dos chapadões (Figura 4.27).

A dinâmica da paisagem hídrica mostra transformações do ambiente natural em decorrência de alterações, já comentadas, nos diversos geofácies da bacia hidrográfica, contribuindo para a degradação dos corpos d' água.

A paisagem da bacia hidrográfica do ribeirão Taquaruçu Grande apresentou níveis diferenciados na sua dinâmica geossitêmica. Na área de planície (Depressão do 
Tocantins), principalmente, a transformação geossitêmica foi drástica em virtude da implantação da capital do Estado, Palmas. Também houve mudanças hidrológicas drásticas no curso inferior do Ribeirão Taquaruçu Grande com o enchimento do Lago Reservatório da UHE Luís Eduardo Magalhães. Dessa forma, na Depressão do Tocantins a dinâmica geossistêmica dos geofácies foi mais rápida e em maior escala para "resistasia verdadeira". $\mathrm{Na}$ serra do Lageado (Planalto Residual do Tocantins), entretanto, a dinâmica geossistêmica para "resistasia verdadeira" tem sido mais lenta e em menor escala, embora também ocorram mudanças drásticas na paisagem.
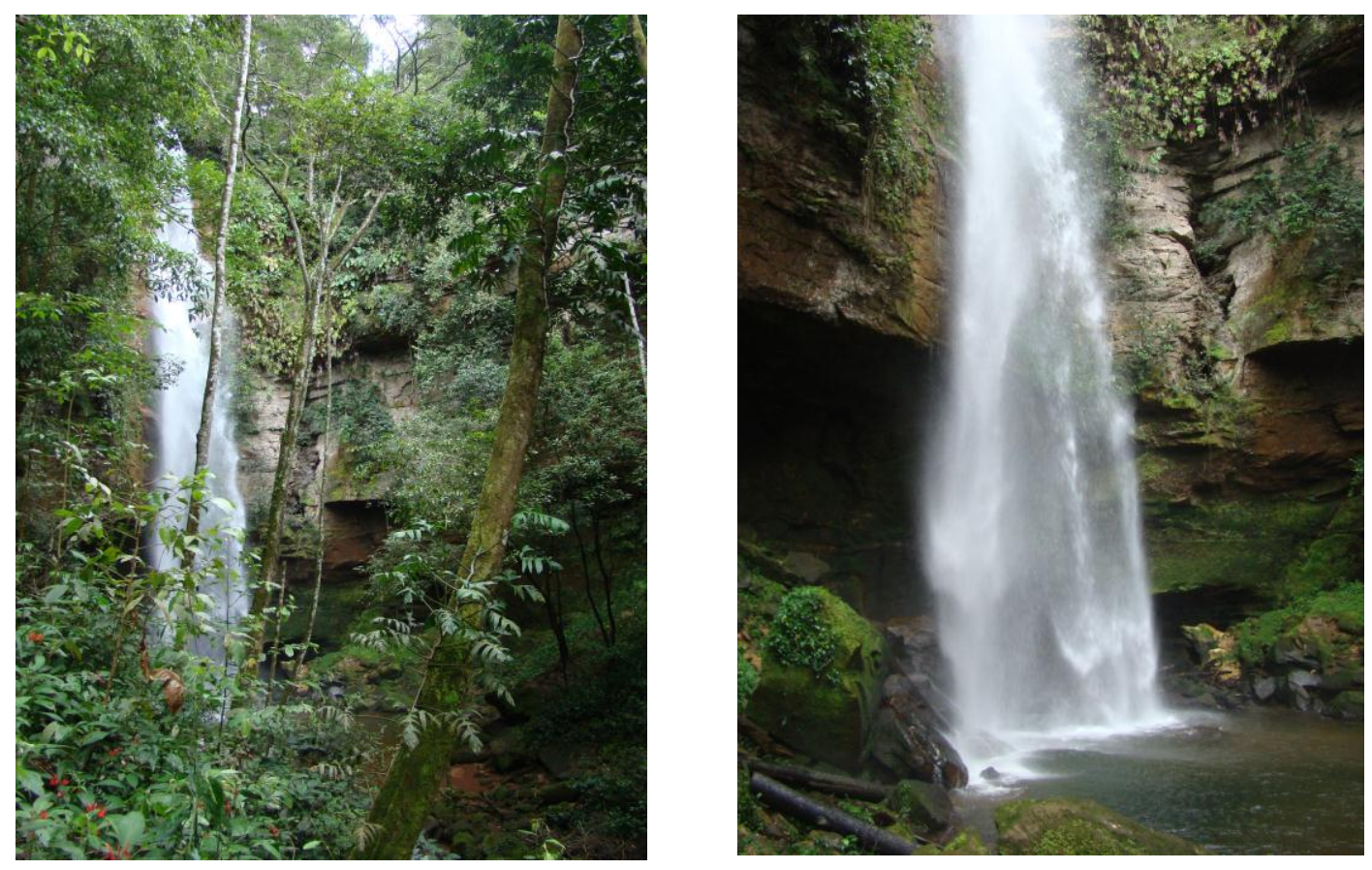

Figura 4.27 - Cachoeira da Roncadeira, na borda de chapadão, no Brejo da Lagoa, na bacia hidrográfica do ribeirão Taquaruçu Grande, município de Palmas (TO). Fotografia: Y. T. Rocha, 2012

Em se tratando da hidrografia, segundo Guarda (2006) o ribeirão Taquaruçuzinho tem quase toda sua extensão formada por fazendas e chácaras, com ocorrências de diversas cachoeiras que são visitadas e muito freqüentadas. O ribeirão Taquaruçu Grande tem seu percurso natural dentro de chácaras e fazendas onde é notado o assoreamento anualmente no período chuvoso, quando na época de plantio os agricultores fazem o preparo do solo sem práticas de conservação. Destaca impactos negativos, principalmente, para a captação de água, nas estações de tratamento, com finalidade de abastecimento da população da cidade de Palmas, que recebem os sedimentos carreados pelos corpos hídricos que se encontram desprotegidos pelo desmatamento de suas matas. 


\subsection{Geofácie Campo Sujo Seco}

\subsubsection{Aspectos do Meio Físico}

\subsubsection{Altitude}

As áreas de Campos Sujos Secos da bacia hidrográfica do ribeirão Taquaruçu Grande variaram pouco em termos de altitude. No relevo do tipo topo, estiveram entre $674 \mathrm{~m}$ e 636 m. Os topos mais altos foram na Área 4, Área 1 e Área 5; nas Áreas 2 e 3 foram mais baixos. Já nas vertentes, variou de $660 \mathrm{~m}$ a 617 m, onde a Área 2 apresentou menor altitude (Figura 4.28), podendo-se observar que as altitudes dos topos e vertentes foram variáveis, há vertentes mais altas que topos e vice-versa.

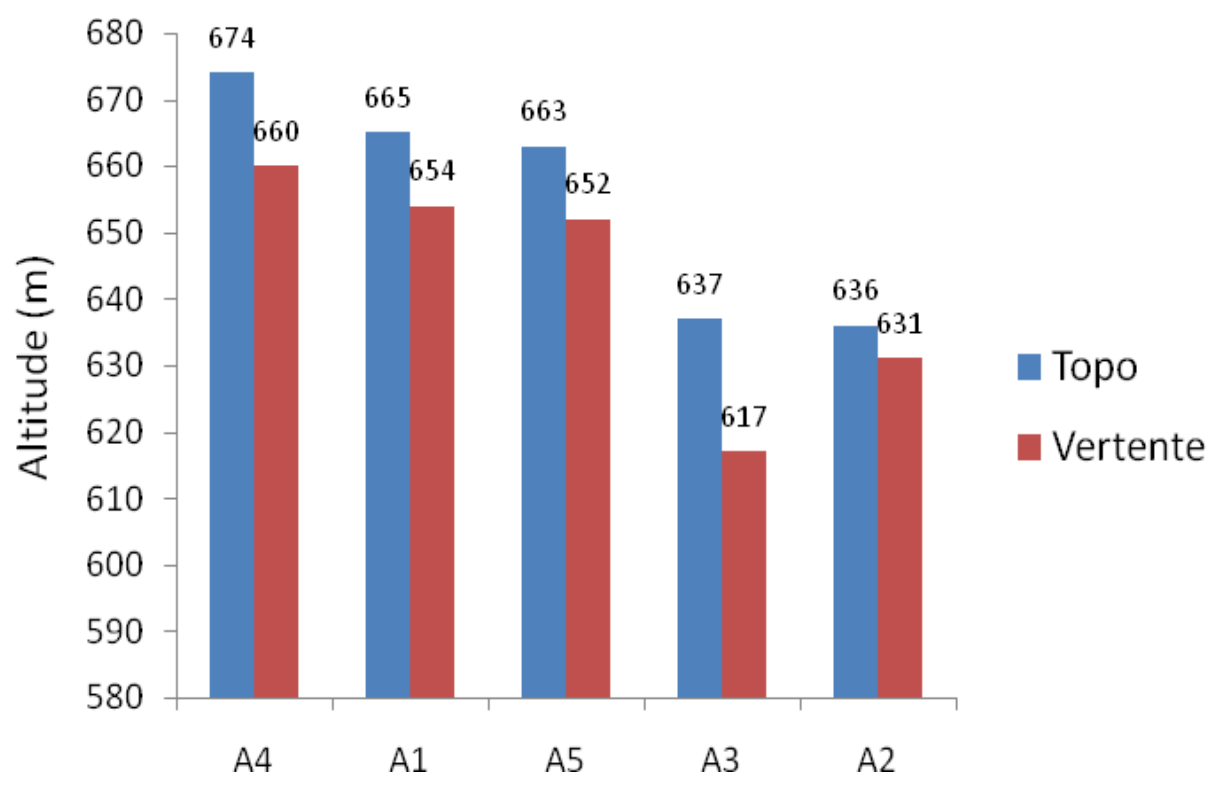

Figura 4.28 - Altitude dos Campos Sujos Secos em relevos de topo e vertente, na bacia hidrográfica do ribeirão Taquaruçu Grande, Palmas (TO)

A Figura 4.5 mostra a topografia da paisagem da bacia hidrografia em estudo, onde os planaltos e chapadas, em uma escala ampla, apresentam altitudes variadas com $640 \mathrm{~m}$ a 682 m. A Figura 4.28, que mostra altitudes em uma escala restrita, pontual, indicou haver vertentes com altitudes superiores ao topo de $640 \mathrm{~m}$. Isto indica que há situações no relevo em que a altitude de topo pode ser mais baixa ou semelhante à de vertente em planalto com relevo ondulado (Figura 4.29). 


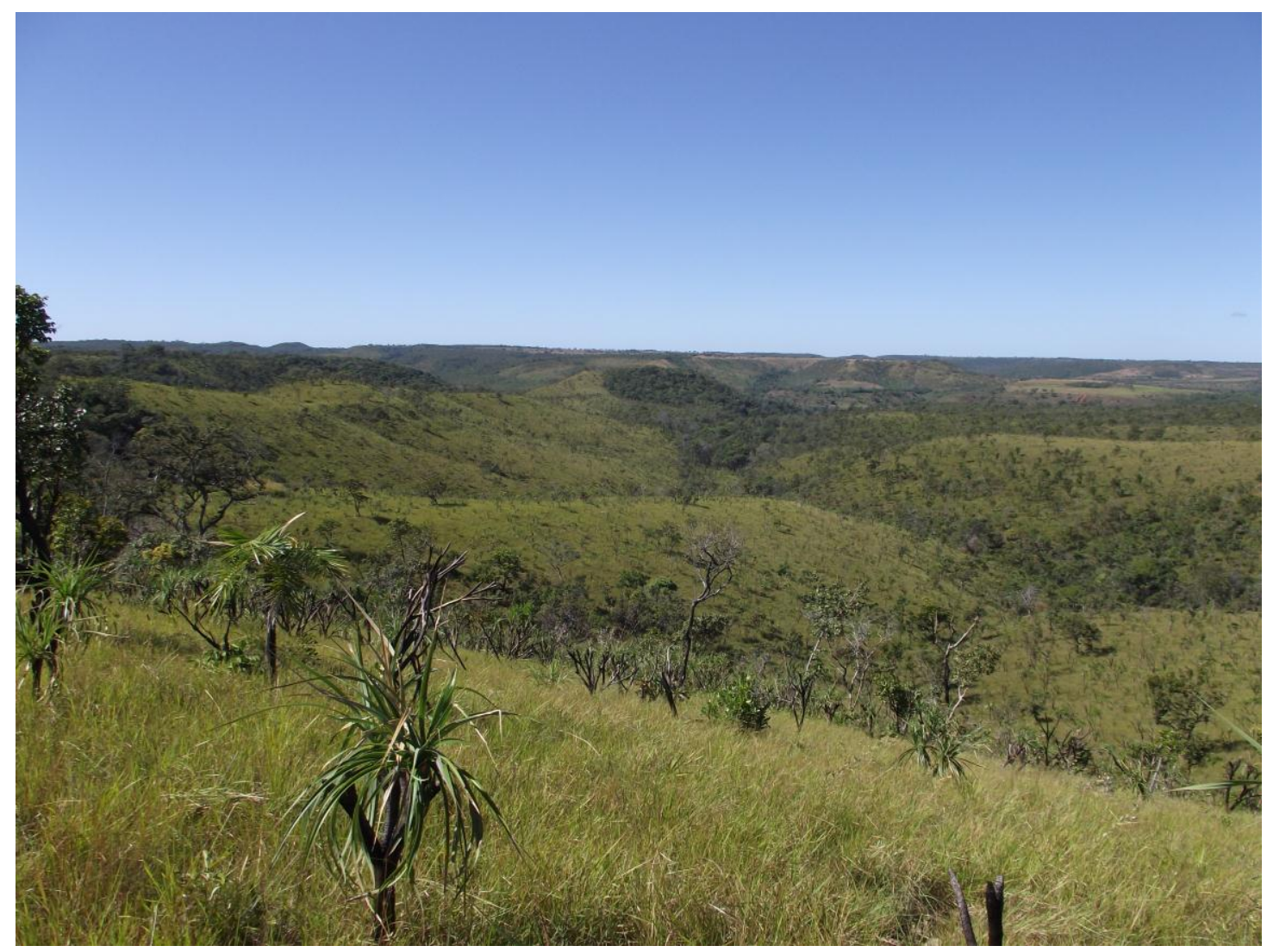

Figura 4.29 - Aspectos da paisagem mostrando a variação de altitude de topos em relação a vertentes, em área de Campo Sujo Seco (A4), em planalto com relevo ondulado, na bacia hidrográfica do ribeirão Taquaruçu Grande, Palmas (TO)

$\mathrm{Na}$ bacia do ribeirão Taquaruçu Grande (serra do Lageado) os níveis topográficos superiores são inferiores a $900 \mathrm{~m}$. No Brasil os campos rupestres, geralmente, ocorrem acima desta altitude (RIBEIRO; WALTER, 2008; VASCONCELOS, 2011). A altitude em torno de 700 m do Campo Sujo Seco do ribeirão Taquaruçu Grande é transicional, em escala regional, para a de $900 \mathrm{~m}$ do campo rupestre, o que leva a existência de uma flora com elementos do cerrado e de campo rupestre, onde a Vellozia seubertiana é a espécie dominante.

Alguns pesquisadores discutem o caráter de altitude dos campos, já abordado desde o início do século XIX, como por exemplo, Martius (1943 apud WALTER, 2006, p.59) ${ }^{1}$ referiu-se aos campos rupestres como "campos mais altos" ou "campos altos"... muitas vezes compráveis aos campos alpinos", e faz comentários específicos relatando a presença de algumas espécies como Liliáceas e os gêneros de Vellozia e Barbacenia. Langsdorff em seus diários em 1820 se referiu aos campos rupestres como "Vegetação alpina", "regiões elevadas

\footnotetext{
${ }^{1}$ MARTIUS, C. P. Ph. von. A fisionomia do reino vetgetal no Brasil. Arquivos do Museu Paraense, Curitiba. V. 3, n. 1, p. 239-271, 1943. (Tradução de E. Niemeyer e C. Stellfeld. Die Physiognomie dês pflanzenreiches in Brasilien. Rede zur oeffentl. Sitz. Akad. Wiss. München, 1824).
} 
alpinas" ou "campos alpinos" (SILVA, 1997 apud WALTER, 2006, p.59)².

Campos (1912) em seu sistema de classificação para a fitogeografia brasileira, ao descrever uma das grandes divisões do seu sistema de classificação, os "campos alpinos", citou as serras do Espinhaço, Canastra e os Gerais da Bahia como exemplos de locais de ocorrência deste tipo de campo e fez referência às Vellozias como plantas que dão esse cunho alpino. Este autor também tratou da ocorrência desses campos em Goiás, nas chapadas divisoras das bacias do Parnaíba e do Tocantins onde, segundo ele, existe uma verdadeira transição de campos cerrados para os campos alpinos, citando a "canela d'ema" de Bomfim a Pirenópolis. De onde se depreende que a serra do Lageado, em uma escala regional, é parte desse conjunto físico transicional da biodiversidade dos campos cerrados, do relevo residual do Tocantins (setor norte do Planalto Central), para os campos rupestres de Goiás, da serra do Espinhaço, Canastra e dos Gerais da Bahia.

Também Stannard et al. (1998) comentaram que os cerrados de altitude, assim como os campos rupestres, ocorrem em regiões serranas brasileiras seguindo uma continuidade na serra do Espinhaço (da Bahia a Minas Gerais) e em manchas nas áreas montanhosas, como na serra da Mantiqueira e da Canastra; também citaram as espécies do gênero Vellozia como "marcadoras desse tipo de vegetação".

O termo "campos alpinos" foi posteriormente substituído por "campo rupestre" e utilizado primeiramente por Magalhães (1966) ao se referir à vegetação dos topos de montanha da Cadeia do Espinhaço.

Vasconcelos (2011), entretanto, estabeleceu diferenciações entre campos rupestres e campos de altitude, estando os primeiros distribuídos em altitudes acima de $900 \mathrm{~m}$, em montanhas de origem pé-cambriana que foram remodeladas por movimentos tectônicos a partir do Paleógeno, estando associados a afloramentos de quartzito, arenito e minério de ferro, principalmente, ao longo da Cadeia do Espinhaço, embora possam ser encontrados nas serras do Brasil Central (chapada dos Veadeiros, e serra dos Pirineus, ambas em Goiás, e serra da Canastra, no sudoeste de Minas Gerais) ou montanhas da região de São João Del Rei (serra do Lenheiro), Tiradentes (serra de São José) e Iputinga (MG), sendo as três últimas consideradas como pertencentes a serra da Mantiqueira.

Já os campos de altitude são típicos dos pontos mais elevados de montanhas que se soergueram durante o Terciário (serra do Mar e Mantiqueira), geralmente situados acima de

\footnotetext{
${ }^{2}$ SILVA, D. G. B. (Ed.). Os diários de Langsdorff: Rio de Janeiro e Minas Gerais. Campinas: Associação Internacional de Estudos Langsdorff: Rio de Janeiro: Fiocruz, 1997.v.1 400p. (Tradução: Márcia Lyra Nascimento Egg e outros).
} 
$1.500 \mathrm{~m}$ de altitude, associados a rochas ígneas e metamórficas como granito, gnaisse, e nefelino-sienito, como no caso de Itatiaia. Em termos de domínios vegetacionais, em geral, os campus rupestres da cadeia do Espinhaço estão situados em áreas de transição entre o Cerrado, a Caatinga e a Mata Atlântica, enquanto os campos de altitude das serras do Mar e Mantiqueira estão totalmente inseridos na região da Mata Atlântica (VASCONCELOS, 2011).

\subsubsection{Relevo}

Os campos encontram-se nas áreas mais altas, nas "cimeiras", da bacia hidrográfica do ribeirão Taquaruçu Grande, em alguns locais descem as vertentes, mas também ocorrem nas áreas secas de baixa altitude, como a depressão do Tocantins (com cerca de $200 \mathrm{~m}$ de altitude, segundo RADAMBRASIL, 1981).

Nas cinco áreas de estudo, o relevo variou de plano a levemente ondulado. As vertentes apresentaram graus de inclinação variados, de ondulados $\left(8\right.$ a $\left.20^{\circ}\right)$ a fortemente ondulados $\left(20 \mathrm{a} 45^{\circ}\right)$ com formas côncavas e convexas. As vertentes com menor inclinação foram encontradas nas Área $2\left(12^{\circ}\right)$, Área $3\left(21^{\circ}\right)$ e Área $5\left(17^{\circ}\right)$. As Áreas 1 e 4 apresentaram maior inclinação, sendo que na Área 1 o grau de inclinação da vertente foi de $26^{\circ}$, enquanto na Área 4 foi de $40^{\circ}$. Em escala regional, enquadra-se no domínio dos chapadões com superfícies aplainadas, seguindo as descrições de Ab’Saber (1963) e Christofoletti (1966) ao se referirem a respeito da geomorfologia do Cerrado.

\subsubsection{Solos}

Os solos sob a vegetação de Campos Sujos Secos nas áreas cinco estudadas são do tipo Plintossolos (SEPLAN, 2012) (Figura 4.30). No atual Sistema Brasileiro de Classificação de Solos a classe dos Plintossolos, caracteriza-se por ser constituída de material com horizonte plíntico ou litoplíntico ou concrecionário (SANTOS et al., 2006). São, portanto, solos minerais que se formam sob condições de restrição à percolação da água, sujeitos ao efeito temporário do excesso de umidade, considerados, de forma geral, como imperfeitamente ou mal drenados, que têm como característica fundamental a expressiva plintização com ou sem petroplintita. 


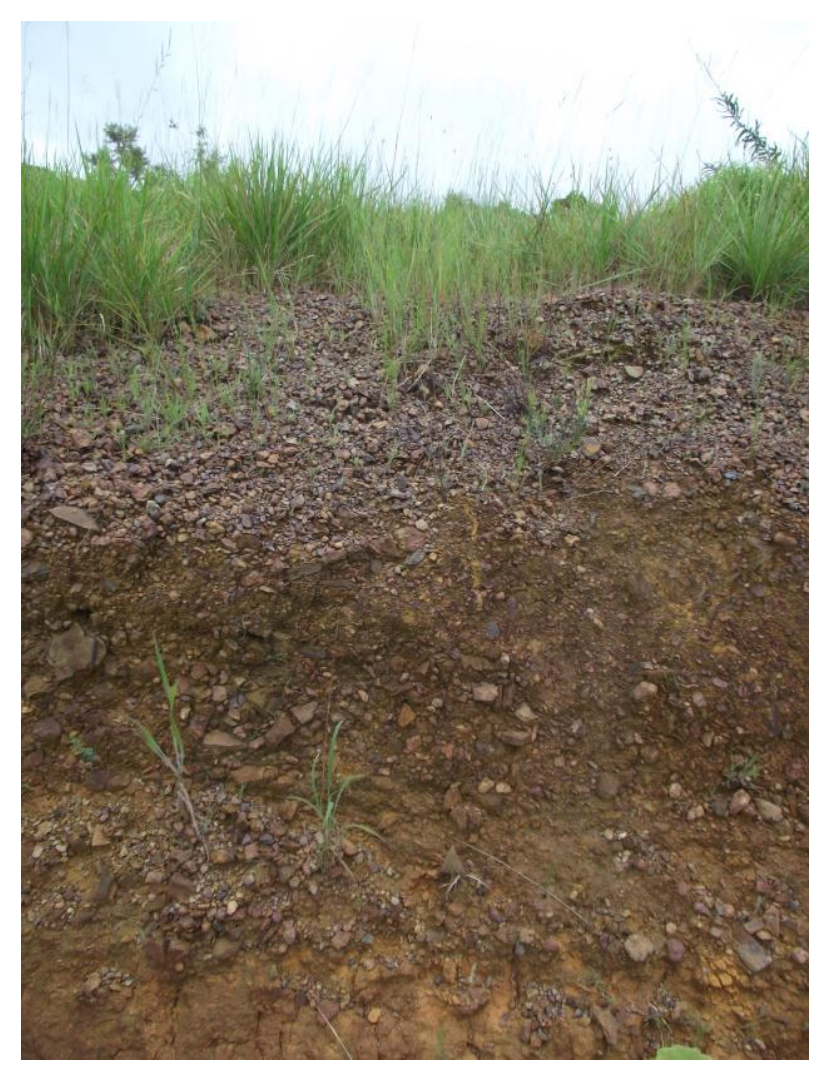

a

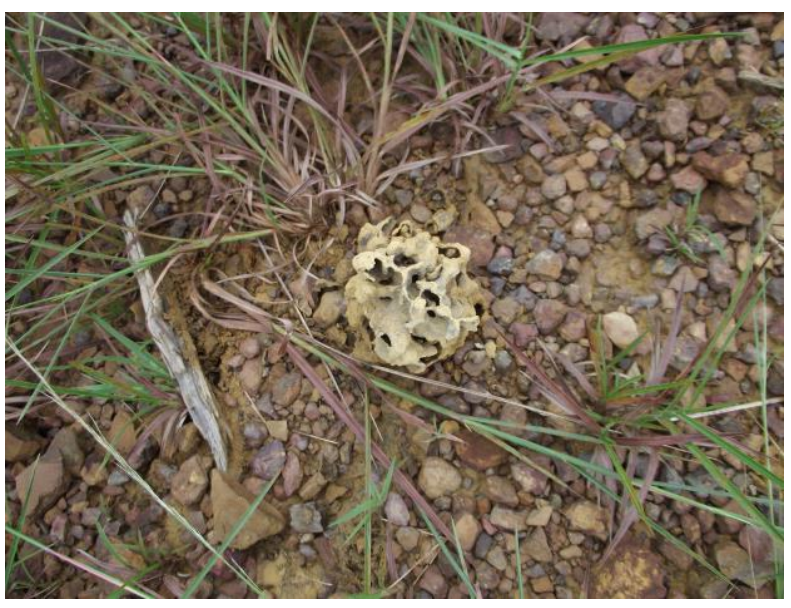

c

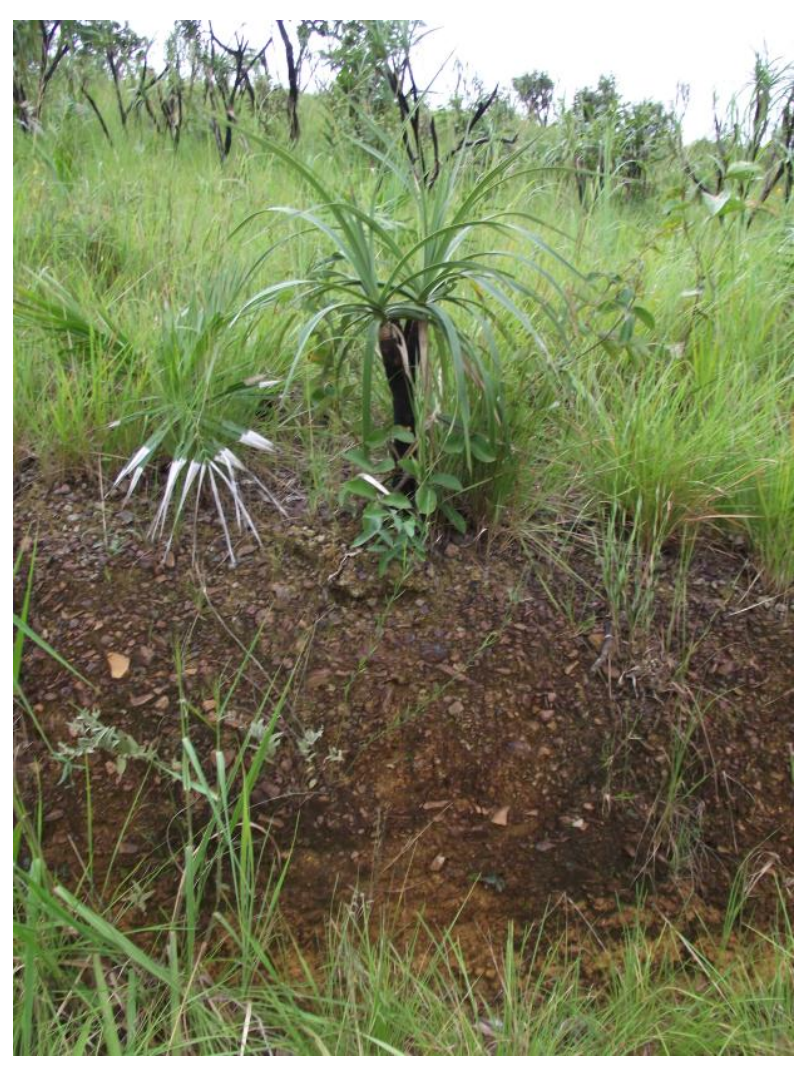

$\mathbf{b}$

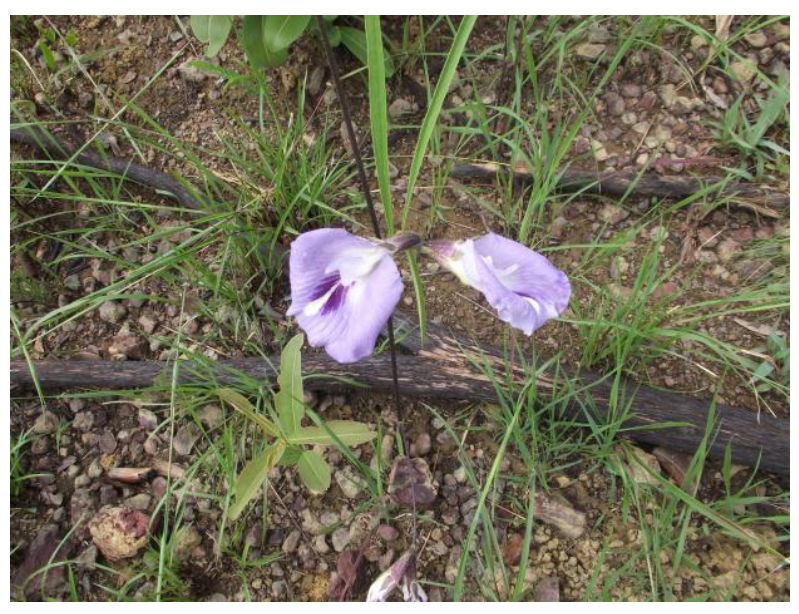

d

Figura 4.30 - Aspectos do Plintossolo sob vegetação de Campo Sujo Seco em corte vertical de topo (a), em corte vertical em vertente (b), em superficie de topo (c) e em superfície de vertente (d), na bacia hidrográfica do ribeirão Taquaruçu Grande, Palmas ( TO)

O Plintossolo possui uma parte de solos que ocorre em terrenos de várzeas em áreas geomórficas de depressão e outra parte (com horizonte concrecionário, principalmente), que possui melhor drenagem e ocupa posições mais elevadas em relação aos primeiros (SANTOS et al., 2006). 
Em mapa de solos do Estado do Tocantins (REATTO et al., 2008), no ambiente de cerrado, o Plintossolo ocupa uma área correspondente a 1,69\% e o Plintossolo Pétrico, 0,89\%. Estes solos apresentam, em índice de ocorrência, menores percentuais apenas que o Latossolo (2,89\%), o Argissolo (2,33\%) e o Neossolo Quartzarênico (1,97\%), entretanto, a classe de Plintossolo (2,58\%) é menor apenas que a ocorrência de Latossolo.

\subsection{Umidade}

A água presente no solo, no período de fevereiro a agosto de 2013, variou de 9 a $28 \%$ (Tabela 4.3). O maior índice de umidade nos solos foi registrado no mês de abril; em março, apenas algumas áreas apresentaram maiores teores de água. O ano de 2013 caracterizou-se como um ano atípico no que tange à periodicidade das chuvas, que se prolongaram até meados de junho.

Tabela 4.3 - Água (\% de água/1 kg de solo) presente em solos nas áreas de topo (T) e vertente (V) do Campo Sujo Seco, na bacia hidrográfica do ribeirão Taquaruçu Grande, Palmas (TO)

\begin{tabular}{ccccccc}
\hline \multirow{2}{*}{ Áreas } & \multicolumn{5}{c}{ Meses de 2013 } & \multirow{2}{*}{ Média } \\
\cline { 2 - 6 } & Fevereiro & Março & Abril & Junho & Agosto & \\
\hline A1T & 9,6 & 15,7 & 20,4 & 8,4 & 7,7 & 12,4 \\
A2T & 13,0 & 28,7 & 27,4 & 15,0 & 11,6 & 19,1 \\
A3T & 11,7 & 10,6 & 19,7 & 8,3 & 9,1 & 11,9 \\
A4T & 9,5 & 10,6 & 12,9 & 10,2 & 12,7 & 11,2 \\
A5T & 9,4 & 9,1 & 15,8 & 9,6 & 10.3 & 10,4 \\
\hline A1V & 12,2 & 17,4 & 26,9 & 8,3 & 12,2 & 15,4 \\
A2V & 11,1 & 13,2 & 22,1 & 12,9 & 11,1 & 14,8 \\
A3V & 12,2 & 10,3 & 19,0 & 10,5 & 10,6 & 12,5 \\
A4V & 9,1 & 13,3 & 15,2 & 9,0 & 8,0 & 10,9 \\
A5V & 10,0 & 11,1 & 19,4 & 8,9 & 9,9 & 11,9 \\
\hline Média & $\mathbf{1 0 , 8}$ & $\mathbf{1 4 , 0}$ & $\mathbf{1 9 , 9}$ & $\mathbf{1 0 , 1}$ & $\mathbf{1 0 , 3}$ & $\mathbf{1 3 , 0}$ \\
\hline
\end{tabular}

Segundo Brady (1989), os teores de água no solo são extremamente variáveis, mas o solo com percentual de água entre 20 e 30\% apresenta boas condições de crescimento para as plantas. Lepsch (2002) indica que uma boa condição para as plantas é quando a água ocupa $25 \%$ dos componentes do solo. Observou-se que esses índices foram atingidos por algumas áreas na estação chuvosa.

Os solos são bem drenados e, ao longo do período de observação, a Área 2 (topo) manteve um índice de água no solo superior às demais Áreas (Figuras 4.31 e 4.32). Um fator a considerar em relação ao maior teor de água no solo da Área 2, é a inclinação da vertente, 
tendo sido a área com menor grau de inclinação $\left(12^{\circ}\right)$. Nesta condição a água das chuvas tem maior infiltração (LEPSCH, 2002). Os meses com maior quantidade de água nos solos foram março e abril (Figuras 4.31).

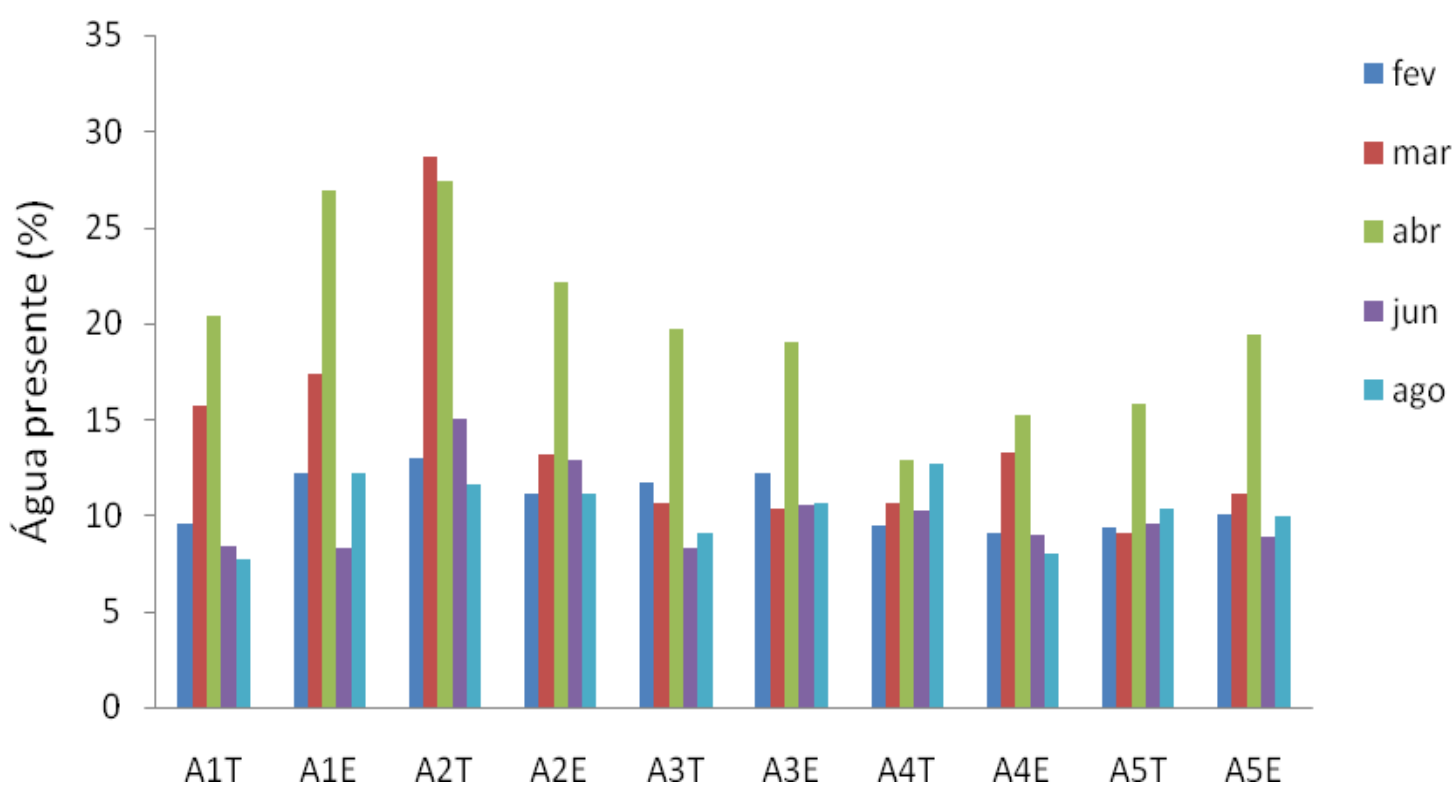

Figura 4.31 - Água presente no solo do Campo Sujo Seco nos meses de fevereiro (fev), março (mar), abril (abr), junho (jun) e agosto (ago) de 2013, em áreas de topo e vertente, na bacia hidrográfica do ribeirão Taquaruçu Grande, Palmas (TO)

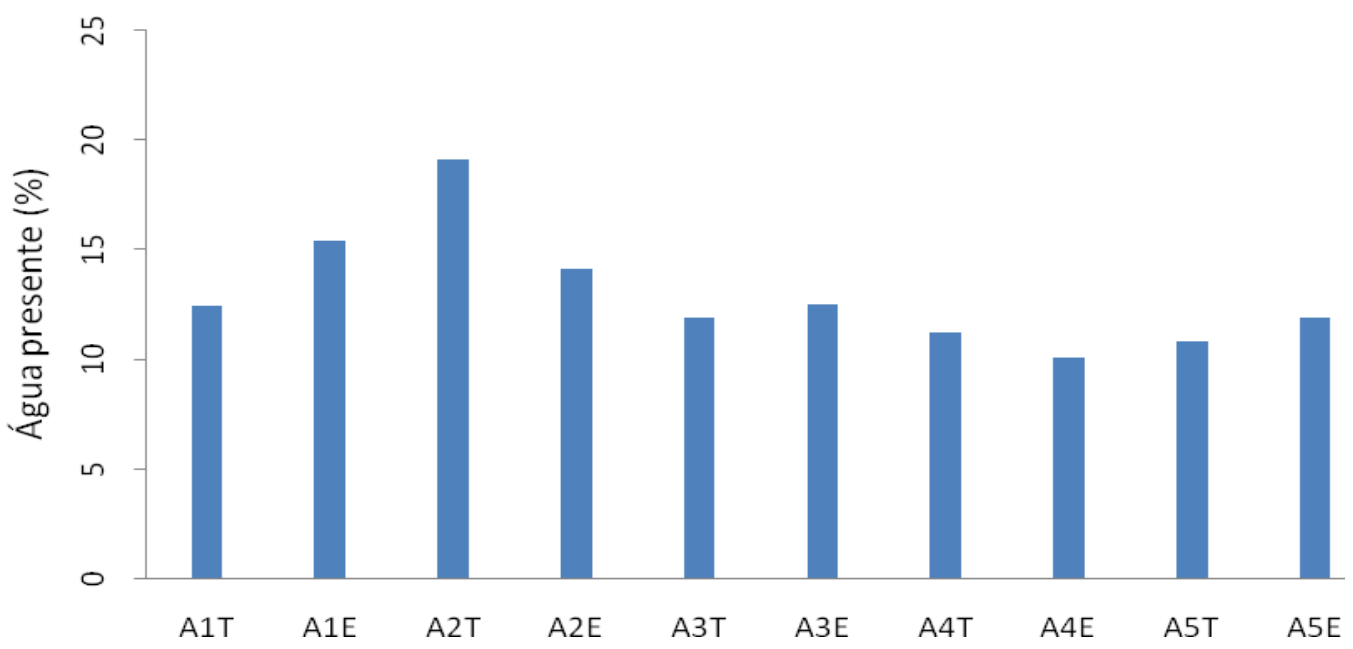

Figura 4.32 - Percentuais médios de água presente no solo do Campo Sujo Seco, relativos aos meses de fevereiro, março, abril, junho e agosto de 2013, em áreas de topo e vertente, na bacia hidrográfica do ribeirão Taquaruçu Grande, Palmas ( TO) 
Mas, apesar dessas variações quanto ao teor de água nos solos, estatisticamente as médias da água presente no solo não diferiram entre si entre topo e vertente (tratamento). Entre áreas (blocos), só houve diferença no mês de junho, na Área 2, quando o teor de água foi maior em relação a todas as demais áreas, que não diferiram entre si (Tabela 4.4).

Tabela 4.4 - Teores médios de água (\% de água/1 kg de solo) presente em áreas de solos de Campo Sujo Seco, na bacia hidrográfica do ribeirão Taquaruçu Grande, Palmas (TO) ao longo do período de fevereiro a agosto de 2013

\begin{tabular}{cccccc}
\hline Áreas & Fevereiro & Março & Abril & Junho & Agosto \\
\hline A1 & $10,9 \mathrm{~b}$ & $16,5 \mathrm{~b}$ & $23,6 \mathrm{~b}$ & $8,3 \mathrm{~b}$ & $9.9 \mathrm{~b}$ \\
A2 & $12,0 \mathrm{~b}$ & $20.9 \mathrm{~b}$ & $24,7 \mathrm{~b}$ & $13,9 \mathrm{a}^{*}$ & $11.3 \mathrm{~b}$ \\
A3 & $11,9 \mathrm{~b}$ & $10.4 \mathrm{~b}$ & $19,3 \mathrm{~b}$ & $9,4 \mathrm{~b}$ & $9.8 \mathrm{~b}$ \\
A4 & $9,3 \mathrm{~b}$ & $11,9 \mathrm{~b}$ & $14,0 \mathrm{~b}$ & $9,6 \mathrm{~b}$ & $10.3 \mathrm{~b}$ \\
A5 & $9,7 \mathrm{~b}$ & $10,1 \mathrm{~b}$ & $17,6 \mathrm{~b}$ & $9,2 \mathrm{~b}$ & $10.1 \mathrm{~b}$ \\
\hline \multicolumn{7}{l}{ Médias seguidas por letras iguais não diferem entre si. } \\
*: significativo pelo teste de Tukey a 5\% de probabilidade.
\end{tabular}

\subsection{Atributos químicos do solo}

\subsection{1 pH e Acidez Potencial}

Os valores de $\mathrm{pH}$ no solo ou acidez ativa variaram de 4,0 na A5V a 4,59 na A2T (Tabela 4.3). Os solos, com base em Tomé-Júnior (1997), apresentaram níveis de acidez ativa muito alta $(\mathrm{pH} \leq 4,3)$; isso correspondeu a $90 \%$ dos solos amostrados. Na A2T a acidez foi considerada alta, pH entre 4,0 a 4,59 (Tabela 4.5). Segundo Tomé-Júnior (1997), a acidez é considerada alta quando o pH é da ordem de 4,4 a 5,0. Lopes e Guilherme (1994) também consideraram alta a acidez de $\mathrm{pH}<5,0$. Para Tomé-Júnior (1997), valores de $\mathrm{pH}$ abaixo de 4,5 ou acima de 7,5 restringem bastante o crescimento, pois esses valores indicam a existência de várias condições desfavoráveis às plantas, como pobreza de cálcio e magnésio, e altos teores de alumínio. $\mathrm{O}$ pH é um índice que fornece o grau de acidez ou alcalinidade de um extrato aquoso do solo, é utilizado como indicativo das condições gerais de fertilidade do solo (TOMÉ-JÚNIOR, 1997).

Os valores de pH do solo, entre áreas (blocos), não diferiram estatisticamente entre si. Mas, diferiram entre topo e vertente (tratamentos). As médias entre topo $(4,3)$ e vertente $(4,1)$ foram significativamente diferentes ao nível de $2 \%$ de probabilidade pelo teste " $T$ " $(p=0,02)$. 
Tabela 4.5 - Propriedades químicas do solo sob vegetação de Campo Sujo Seco, em área de topo (T) e de vertente (V), na bacia hidrográfica do ribeirão Taquaruçu Grande, Palmas (TO)

\begin{tabular}{|c|c|c|c|c|c|c|c|c|c|c|c|c|c|c|}
\hline \multirow{2}{*}{ Área } & \multirow{2}{*}{$\underset{\mathrm{CH}}{\mathrm{pH} 2}$} & \multicolumn{5}{|c|}{$\mathrm{cmol}_{\mathrm{c}} / \mathrm{dm}^{3}(\mathrm{meq} / 100 \mathrm{ml})$} & \multicolumn{3}{|c|}{$\mathrm{mg} / \mathrm{dm} 3(\mathrm{ppm})$} & \multirow{2}{*}{$\begin{array}{l}\text { CTC } \\
\text { Total }\end{array}$} & \multirow{2}{*}{$\begin{array}{l}\text { CTC } \\
\text { Efetiva }\end{array}$} & \multirow{2}{*}{$\begin{array}{c}\text { Saturação } \\
\text { por Bases } \\
(\mathrm{V} \%)\end{array}$} & \multirow{2}{*}{$\begin{array}{c}\text { Saturação } \\
\text { por Al } \\
(\mathrm{m} \%)\end{array}$} & \multirow{2}{*}{$\begin{array}{c}\% \text { na } \\
\text { CTC } \\
\mathrm{H}+\mathrm{Al}\end{array}$} \\
\hline & & $\mathrm{Ca}$ & $\mathrm{Mg}$ & $\mathrm{Al}$ & $\mathrm{H}+\mathrm{Al}$ & $\mathrm{K}$ & P Mehlich & $\mathrm{Fe}$ & M.O. & & & & & \\
\hline $\mathrm{A} 1 \mathrm{~T}$ & 4,30 & 0,23 & 0,18 & 0,4 & 6,93 & 0,09 & 4,2 & 101,0 & 23,3 & 7,4 & 0,90 & 6,7 & 44,4 & 93,6 \\
\hline $\mathrm{A} 2 \mathrm{~T}$ & 4,59 & 0,45 & 0,37 & 0,2 & 6,10 & 0,10 & 5,6 & 156,0 & 15,7 & 7,0 & 1,12 & 13,1 & 14,0 & 87,1 \\
\hline A3T & 4,20 & 0,20 & 0,16 & 0,3 & 6,35 & 0,07 & 3,6 & 41,0 & 18,9 & 6,8 & 0,73 & 6,3 & 44,9 & 93,4 \\
\hline $\mathrm{A} 4 \mathrm{~T}$ & 4.15 & 0,22 & 0,18 & 0,4 & 8,91 & 0,15 & 13 & 43,0 & 32,7 & 9,5 & 0,95 & 5,8 & 45,0 & 93,8 \\
\hline A5T & 4,32 & 0,18 & 0,07 & 0,2 & 5,19 & 0,05 & 4,8 & 78,0 & 8,0 & 5,5 & 0,5 & 5,5 & 40,0 & 94,4 \\
\hline A1V & 4,23 & 0,15 & 0,13 & 0,4 & 6,84 & 0,07 & 5,0 & 186,0 & 13,7 & 7,2 & 0,75 & 4,9 & 53,3 & 95,0 \\
\hline $\mathrm{A} 2 \mathrm{~V}$ & 4,00 & 0,40 & 0,37 & 0,6 & 8,41 & 0,17 & 3,4 & 44,0 & 35,0 & 9,3 & 1,54 & 10,1 & 39,0 & 90,4 \\
\hline A3V & 4,10 & 0,15 & 0,16 & 0,5 & 6,93 & 0,08 & 4,5 & 65,0 & 21,0 & 7,3 & 0,83 & 4,5 & 60,2 & 94,9 \\
\hline $\mathrm{A} 4 \mathrm{~V}$ & 4,00 & 0,19 & 0,14 & 0,8 & 9,48 & 0,15 & 4,7 & 53,0 & 31,0 & 10,0 & 1,28 & 4,8 & 61,0 & 94,8 \\
\hline $\mathrm{A} 5 \mathrm{~V}$ & 4,00 & 0,19 & 0,13 & 1,0 & 9,65 & 0,16 & 6,0 & 52,0 & 35,0 & 10,1 & 1,48 & 4,7 & 67,6 & 95,5 \\
\hline
\end{tabular}


A acidez dos solos é também medida pela Acidez Potencial $(\mathrm{H}+\mathrm{Al})$, que variou de $5,19 \mathrm{cmol}_{\mathrm{c}} / \mathrm{dm}^{3}$ (A5T) a 9,65 $\mathrm{cmol}_{\mathrm{c}} / \mathrm{dm}^{3}$ (A5V), Tabela 4.5. Os teores da Acidez Potencial não diferiram entre áreas, nem entre topo e vertente. Esse tipo de acidez foi considerada por Lopes et al. (1990) como a mais prejudicial ao crescimento da maioria das plantas.

\subsection{Macronutrientes}

\subsection{1 Cálcio}

O teor de cálcio $(\mathrm{Ca})$ trocável foi baixo em todas as áreas, variou de $0,15 \mathrm{cmol}_{\mathrm{c}} / \mathrm{dm}^{3}$ (A1V) a $0,45 \mathrm{cmol}_{\mathrm{c}} / \mathrm{dm}^{3}$ (A2T), Tabela 4.5. O teor de Ca é considerado baixo quando $<2,0$ $\mathrm{cmol}_{\mathrm{c}} / \mathrm{dm}^{3}$ (Tomé-Júnior, 1997). Lopes (1984) e Souza e Lobato (2004), em relação ao cerrado, consideraram baixos os teores de Ca trocável em solos com menos de $1,5 \mathrm{cmol}_{\mathrm{c}} / \mathrm{dm}^{3}$. Segundo Lopes (1984), o que está abaixo de $0,4 \mathrm{cmol}_{\mathrm{c}} / \mathrm{dm}^{3}$ indica uma extrema deficiência. A extrema deficiência de Ca foi observada em $80 \%$ das amostras, exceto para A2T E A2V (Tabela 4.5).

Os teores de $\mathrm{Ca}$ dos solos, para tratamento (relevo de topo e vertente), não diferiram entre si. Mas, houve diferença significativa ao nível de $1 \%$ de probabilidade, pelo teste de Tukey, para os teores de $\mathrm{Ca}$ dos solos entre áreas (blocos). Os solos da A2 apresentaram teores de Ca significativamente mais elevados em relação os demais (Tabela 4.6).

Tabela 4.6 - Teores médios de $\mathrm{Ca}\left(\mathrm{cmol}_{\mathrm{d}} / \mathrm{dm}^{3}\right)$, para áreas (blocos), em solos de Campo Sujo Seco, na bacia hidrográfica do ribeirão Taquaruçu Grande, Palmas (TO)

\begin{tabular}{cl}
\hline Áreas (blocos) & Médias \\
\hline $\mathrm{A} 1$ & $0,19 \mathrm{~b}$ \\
$\mathrm{~A} 2$ & $0,42 \mathrm{a} * *$ \\
$\mathrm{~A} 3$ & $0,17 \mathrm{~b}$ \\
$\mathrm{~A} 4$ & $0,20 \mathrm{~b}$ \\
$\mathrm{~A} 5$ & $0,18 \mathrm{~b}$ \\
\hline Médias seguidas por letras iguais não diferem entre si. \\
**: significativo pelo teste de Tukey a $1 \%$ de probabilidade.
\end{tabular}

\subsection{2 Magnésio}

Os teores de magnésio $(\mathrm{Mg})$ variaram de $0,07 \mathrm{cmolc} / \mathrm{dm}^{3}$ (A5T) a $0,37 \mathrm{cmolc} / \mathrm{dm}^{3}$ (A2T e A2V). Foram baixos em todas as áreas, inferiores a $0,4 \mathrm{cmolc} / \mathrm{dm}^{3}$, sendo que os solos da A5T e da A3V apresentaram os menores teores (Tabela 4.5). 
Teores de Mg são considerados baixos quando < 0,4 cmolc/dm ${ }^{3}$ (Tomé-Júnior, 1997). Souza e Lobato (2004) consideraram baixos os teores de $\mathrm{Mg}<0,5 \mathrm{cmolc} / \mathrm{dm}^{3}$. De acordo com Lopes (1984), deficiências de Mg trocável são também uma tônica marcante nos solos do Cerrado. Este autor classificou como baixos os teores $\leq 0,5 \mathrm{cmol}_{\mathrm{c}} / \mathrm{dm}^{3}$ e considerou que valores $\leq 0,1 \mathrm{cmol}_{\mathrm{c}} / \mathrm{dm}^{3}$ indicam extrema deficiência deste nutriente, situação da A3V e A5T, que corresponde a $20 \%$ das amostras.

Os teores de $\mathrm{Mg}$ nos solos não diferiram estatisticamente para os tratamentos (relevo tipo topo e tipo vertente). Para o $\mathrm{Mg}$, assim como para $\mathrm{Ca}$, houve diferença significativa a $1 \%$ de probabilidade entre médias das áreas (blocos) pelo teste de Tukey. Os solos da A2 possuem teores de Mg significativamente mais altos que os demais (Tabela 4.7).

Tabela 4.7 - Teores médios de $\mathrm{Mg}\left(\mathrm{cmol}_{\mathrm{c}} / \mathrm{dm}^{3}\right)$, para áreas (blocos), em solos de Campo Sujo Seco, na bacia hidrográfica do ribeirão Taquaruçu Grande, Palmas (TO)

\begin{tabular}{cl}
\hline \multicolumn{1}{c}{ Áreas (blocos) } & Médias \\
\hline $\mathrm{A} 1$ & $0,15 \mathrm{~b}$ \\
$\mathrm{~A} 2$ & $0,37 \mathrm{a}^{* *}$ \\
$\mathrm{~A} 3$ & $0,13 \mathrm{~b}$ \\
$\mathrm{~A} 4$ & $0,16 \mathrm{~b}$ \\
$\mathrm{~A} 5$ & $0,10 \mathrm{~b}$ \\
\hline Médias seguidas por letras iguais não diferem entre si. \\
**: significativo pelo teste de Tukey a 1\% de probabilidade.
\end{tabular}

\subsection{3 Fósforo}

Os teores de P variaram de $3,4 \mathrm{cmol}_{\mathrm{c}} / \mathrm{dm}^{3}(\mathrm{~A} 2 \mathrm{~V})$ a $13,0 \mathrm{cmol}_{\mathrm{c}} / \mathrm{dm}^{3}$ (A5T), Tabela 4.5. A classificação do teor de fósforo (P) disponível, em solos, depende do extrator e da textura (TOMÉ-JÚNIOR, 1997). De acordo com o teor de argila na classe 210-400 g/kg para a região do Cerrado, pelo extrator Mehlich, considerando a textura dos solos da área de estudo, o teor de fósforo variou de muito baixo com teores $<5 \mathrm{mgP} / \mathrm{dm}^{3}$ (A1T; A2V; A3T; A3V; A4V; e A5V), a baixo (A2T e A5V) com 5,6-6,0 $\mathrm{mgP} / \mathrm{dm}^{3}$ (Tabela 4.3). Apenas a A4T apresentou teor considerado médio $\left(13,0 \mathrm{mgP} / \mathrm{dm}^{3}\right)$, tomando-se como referência Tomé-Júnior (1997). Apesar da variação dos dados, estatisticamente, os teores de $\mathrm{P}$ não diferiram entre os tratamentos, nem entre blocos. 


\subsection{4 Potássio}

Os teores de potássio $(\mathrm{K})$ trocável variaram de baixo $\left(\leq 0,10 \mathrm{cmol}_{\mathrm{c}} / \mathrm{dm}^{3}\right)$ a médios $\left(0,11-0,30 \mathrm{cmol}_{\mathcal{C}} / \mathrm{dm}^{3}\right)$ de acordo com a classificação de Tomé-Júnior (1997). A5T apresentou o menor teor $\left(0,05 \mathrm{cmol}_{\mathrm{c}} / \mathrm{dm}^{3}\right)$ e $\mathrm{A} 2 \mathrm{~V}$, o maior teor $\left(0,17 \mathrm{cmol}_{\mathrm{c}} / \mathrm{dm}^{3}\right.$, Tabela 4.5). Lopes (1984) considerou solos com $<0,15 \mathrm{cmol}_{\mathrm{c}} / \mathrm{dm}^{3}$ como deficientes em K. Dos solos amostrados, $60 \%$ estão dentro dessa faixa (deficientes) e os demais valores são próximos a esse valor. Estatisticamente, os teores de $\mathrm{K}$ não diferiram entre tratamentos, e nem entre blocos.

\subsection{Micronutriente Ferro}

Os teores de ferro (Fe) variaram de $41,0 \mathrm{mg} / \mathrm{dm}^{3}$ (ppm) na A3T a $186,0 \mathrm{mg} / \mathrm{dm}^{3}$ (ppm) na A1V (Tabela 4.5). Estes teores foram considerados muito altos, principalmente nas A1T e A1V e A2T. Segundo Tomé-Júnior (1997), os valores de Fe são considerados altos quando >12 $\mathrm{mg} / \mathrm{dm}^{3}$. Estatisticamente não houve diferença significativa entre os teores de topo e de vertente (tratamentos), nem entre áreas (blocos).

\subsection{Alumínio}

Os teores de alumínio (Al) trocável variaram de baixos $\left(0,2 \mathrm{cmol}_{\mathrm{c}} / \mathrm{dm}^{3}\right)$ nas $\mathrm{A} 2 \mathrm{~T}$ e A5T a médios $\left(1,0 \mathrm{cmol}_{\mathcal{C}} / \mathrm{dm}^{3}\right)$ na A5V (Tabela 4.5). Apesar da acidez dos solos, os teores de Al não são extremamente altos, mas como os teores de cálcio, magnésio e potássio são muito baixos (Tabela 4.8) e têm pouca contribuição no balanço de troca catiônica, os teores de $\mathrm{Al}$ com muito baixos teores de bases trocáveis se constituem em importantes limitações destes solos.

Para as plantas nativas, especialmente as do cerrado, o alumínio pode até ser essencial (JANSEN et al., 2003). O óxido de Al é um agente que contribui de maneira eficaz na estrutura do solo tropical, sendo, portanto, altamente benéfico. Se o Al trocável não ultrapassar determinada porcentagem dos cátions existentes na CTC efetiva, dependendo da textura do solo, possivelmente não será maléfico (JANSEN et al., 2003).

De acordo com Osaki (1991), teores menores que $5 \mathrm{mmol}_{\mathrm{c}} / \mathrm{dm}^{3}$ (muito baixos) não são prejudiciais, de 5-10 (baixos) são pouco prejudiciais e de $10,1-1,20 \mathrm{mmol}_{\mathrm{c}} / \mathrm{dm}^{3}$ são medianamente prejudiciais. Segundo Malavolta (1989), solos com mais que $0,3 \mathrm{cmol}_{\mathrm{d}} / \mathrm{dm}^{3} \mathrm{de}$ 
$\mathrm{Al}$ são chamados de álicos. $\mathrm{Na}$ área de estudo, em $80 \%$ dos solos estudados, os teores de $\mathrm{Al}$ foram $\geq 0,3 \mathrm{cmol}_{\mathcal{C}} / \mathrm{dm}^{3}$, exceto nas áreas 2 e 5 (topo), nas quais os teores foram de 0,2 $\mathrm{cmol}_{\mathrm{C}} / \mathrm{dm}^{3}$.

A saturação de Al foi alta, acima de $30 \mathrm{~m} \%$ e chegando a muito alta (> $50 \mathrm{~m} \%$ ), portanto, muito prejudicial, situação encontrada nos solos das vertentes das A1, A3, A4, e A5, exceto na $\mathrm{A} 2 \mathrm{~T}$, na qual a saturação de $\mathrm{Al}$ foi baixa, não prejudicial $(14,0 \mathrm{~m} \%)$.

Os teores de Al não foram diferentes entre áreas (blocos), mas, foram diferentes entre topo e vertente (tratamento). Os teores médios do topo $\left(0,30 \mathrm{cmol}_{\mathrm{c}} / \mathrm{dm}^{3}\right)$ diferiram dos da vertente $\left(0,66 \mathrm{cmol}_{\mathrm{c}} / \mathrm{dm}^{3}\right)$ ao nível de $2 \%$ de probabilidade pelo teste de Tukey. Os topos apresentaram menores teores de $\mathrm{Al}$ que as vertentes.

\subsection{Matéria Orgânica}

Os teores de matéria orgânica (M.O.) variaram de baixos a médios (Tabela 4.5), sendo que A5T apresentou o menor teor $\left(8,0 \mathrm{~g} / \mathrm{dm}^{3}\right)$ e A2E o maior teor $\left(35,0 \mathrm{~g} / \mathrm{dm}^{3}\right)$. Lopes (1984) e Tomé-Júnior (1997) consideraram como baixos os teores de M.O. < 15 g/dm3 e como altos os teores > $50 \mathrm{~g} / \mathrm{dm} 3$. Segundo Tomé-Júnior (1997), altos teores de M.O., dentre outros aspectos, significa alta Capacidade de Troca Catiônica (CTC) Total, o que representa maior capacidade de retenção de cátions e também maior resistência à variação de pH (alto poder tampão). Já no tocante a baixos teores de M.O., estes indicam solos arenosos, baixa CTC Total e CTC Efetiva, portanto, baixo poder tampão e alta possibilidade de lixiviação de bases ( $\mathrm{Ca}, \mathrm{Mg}$ e K). Estatisticamente, os valores de M.O. não diferiram entre topo e vertente (tratamentos), nem entre áreas (blocos).

\subsection{Capacidade de Troca Catiônica}

Os teores da capacidade de troca catiônica (CTC) foram calculados para a CTC Total e para a CTC Efetiva (Tabela 4.5). Os teores de CTC Total (soma de bases $+\mathrm{H}+\mathrm{Al}$ ) variaram de $5,5 \mathrm{cmol}_{\mathrm{c}} / \mathrm{dm}^{3}(\mathrm{~A} 5 \mathrm{~T})$ a $10,1 \mathrm{cmol}_{\mathrm{c}} / \mathrm{dm}^{3}(\mathrm{~A} 5 \mathrm{~V})$. Foram baixos $\left(\leq 15 \mathrm{cmol}_{\mathrm{c}} / \mathrm{dm}^{3}\right)$, de acordo com Sousa e Lobato (2004). Mas, apesar dos baixos valores, as maiores contribuições para os teores da CTC Total foram de Acidez Potencial $(\mathrm{H}+\mathrm{Al})$, cátions potencialmente tóxicos, segundo Tomé-Júnior (1997), cujos índices, geralmente, estiveram acima de 90\% (Tabela 4.5). 
Analisando a participação da Acidez Potencial na CTC Total, os teores foram diferentes entre áreas. $\mathrm{Na} \mathrm{A} 2$ a Acidez Potencial foi significativamente diferente ao nível de probabilidade de $2 \%$ pelo teste de Tukey, apresentando-se com menor participação na CTC Total que nas demais áreas (Tabela 4.8). Houve também diferença entre topo vertente ao nível de $2 \%$ de probabilidade pelo teste " $T$ " pareado, sendo que o topo apresentou menor Acidez Potencial na CTC $(92,5 \%$ b) que a vertente $(94,1 \% a)$.

Tabela 4.8 - Teores médios de H+Al (\%), para áreas, em solos de Campo Sujo Seco, na bacia hidrográfica do ribeirão Taquaruçu Grande, Palmas (TO)

\begin{tabular}{cc}
\hline Áreas (blocos) & H+Al (\% na CTC) \\
\hline A1 & $94,3 \mathrm{a}$ \\
A2 & $88,7 \mathrm{~b}^{*}$ \\
A3 & $94,1 \mathrm{a}$ \\
A4 & $94,3 \mathrm{a}$ \\
A5 & $94,9 \mathrm{a}$ \\
\hline *édias seguidas por letras iguais não diferem entre si. \\
*: significativo pelo teste de Tukey a 2\% de probabilidade
\end{tabular}

A CTC Efetiva $(\mathrm{Ca}+\mathrm{Mg}+\mathrm{K}+\mathrm{Al})$ apresentou teores variando de 0,5 a 1,5 $\mathrm{cmol}_{\mathrm{c}} / \mathrm{dm}^{3}$. Em $60 \%$ das amostras, os teores foram extremamente baixos, $<1 \mathrm{cmol}_{\mathrm{c}} / \mathrm{dm}^{3}$. A Saturação de Al também representou altos índices na CTC Efetiva (Tabela 4.5). Lopes e Guilherme (1994) consideraram teores de CTC baixos quando são da ordem de 0-2,5 $\mathrm{cmol}_{\mathrm{c}} / \mathrm{dm}^{3}$ para a região do Cerrado. Lopes e Guilherme (2004) consideraram que o valor de CTC Efetiva de 2,05 $\mathrm{cmol}_{\mathrm{c}} / \mathrm{dm}^{3}$ é extremamente baixo e indica que o solo apresenta baixa capacidade de reter cátions.

Analisando a participação dos teores de Saturação de Al na CTC Efetiva, estes não diferiram entre áreas (blocos), mas, diferiram entre topo e vertente (tratamentos). A média dos teores do topo $\left(37,7 \mathrm{cmol}_{\mathrm{c}} / \mathrm{dm}^{3}\right)$ foi significativamente menor que da vertente $(56,2$ $\mathrm{cmol}_{\mathrm{c}} / \mathrm{dm}^{3}$ ) a $5 \%$ de probabilidade pelo teste de "T" não pareado.

Os teores de CTC Total e CTC Efetiva, não diferiram estatisticamente entre topo e vertente (tratamentos), nem entre áreas (blocos).

Os teores da CTC Total e CTC Efetiva foram altamente correlacionados, positivamente, com os teores de M.O. de acordo com o Coeficiente de Determinação $\left(\mathrm{R}^{2}\right)=$ 0.9153 e 0,6885 para CTC Total e CTC Efetiva, respectivamente (Figura 4.33). 

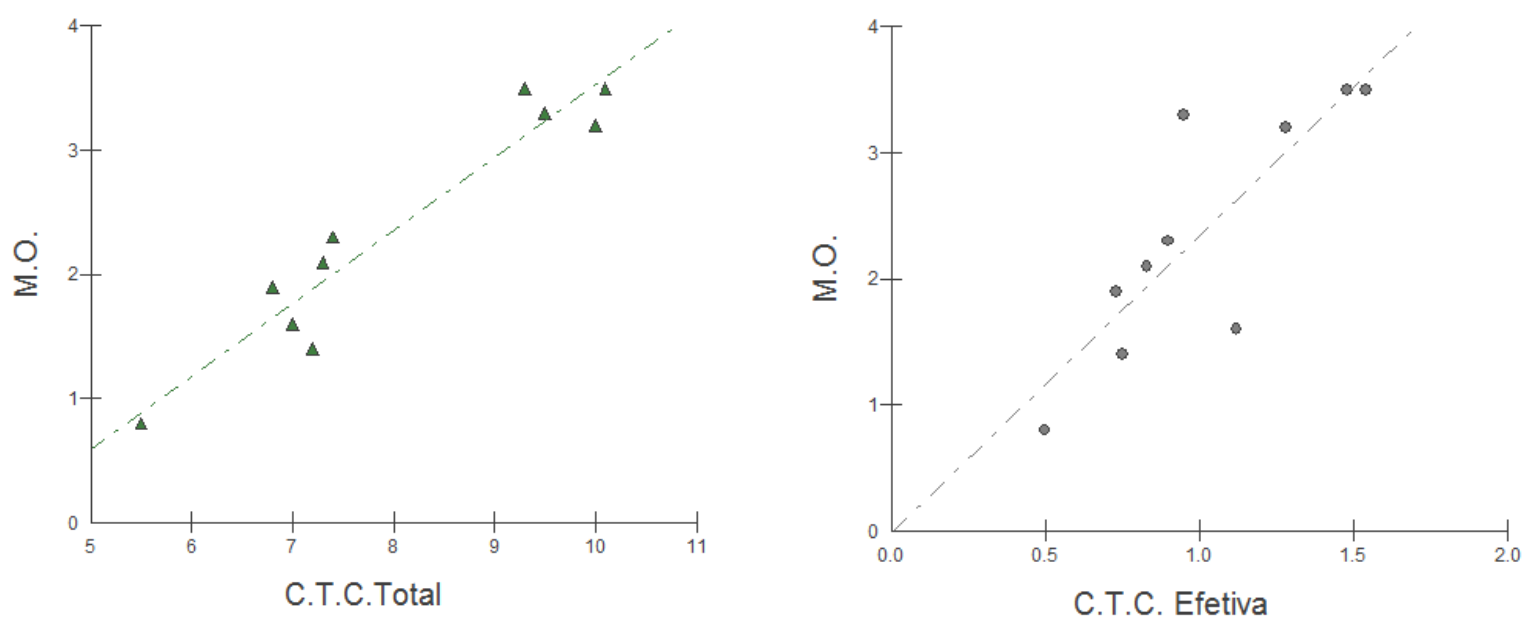

Figura 4.33 - Relações entre teores de M.O. (\%) com CTC Total e CTC Efetiva $\left(\mathrm{cmol}_{\mathrm{c}} / \mathrm{dm}^{3}\right.$ ) em solos de Campo Sujo Seco, em 2012, na bacia hidrográfica do ribeirão Taquaruçu Grande, Palmas (TO)

Neto et al. (2009), estudando os solos do cerrado, encontraram valores de M.O. coincidentes com os valores médios de CTC e, segundo estes autores, essa coincidência indica a importância da M.O. como condicionadora de cargas em solos de clima tropical. Por ser, o Campo Sujo Seco do ribeirão Taquaruçu Grande, uma fisionomia de vegetação mais baixa e esparsa e o solo de textura média, a M.O., evidenciou essa relação. A área mais arenosa (área 5 topo) apresentou menor valor de M.O. e consequentemente menor CTC (Tabela 4.5).

Lopes (1984), em estudos dos solos do cerrado, encontrou teores de M.O. variando de médios a altos. $\mathrm{O}$ autor concluiu que apesar dos solos apresentarem, na sua maioria, níveis de médios a altos de M.O., indicando que esta é a principal fração envolvida na formação de cargas negativas e troca de cátions, os valores de CTC Efetiva, apresentaram-se muito baixos $\left(97 \%<4 \mathrm{cmol}_{\mathrm{c}} / \mathrm{dm}^{3}\right)$.

As explicações dadas por Lopes (1984) para a pequena contribuição da fração orgânica, medido pela baixa CTC Efetiva desses solos são de que esse pequeno efetivo é devido à abundância de óxidos, hidróxidos e óxidos-hidróxidos de Fe e Al na fração argila de solos intemperizados, ocorrendo em partículas discretas e/ou em camadas revestindo as partículas de argila. Esses materiais podem desenvolver cargas positivas sob condições de baixo $\mathrm{pH}$, fazendo com que haja interação entre os efeitos dos compostos orgânicos e inorgânicos nestes solos, diminuindo as cargas negativas líquidas quando esses componentes se encontram associados. Outro aspecto é que, sob condições edáfico-biótico-climáticas que ocorrem na área de Cerrado, haveria menor formação de grupos funcionais efetivos no processo de troca de cátions como resultado da composição da M.O.. Neste caso, a maior ou menor formação de grupos funcionais depende não somente da natureza da M.O., como 
também das condições associadas ao meio ambiente.

Sob condições de pH ácido como é o caso dos solos do Cerrado, há uma diminuição da atividade microbiana e, consequentemente, menor formação de grupos funcionais efetivos no processo de troca catiônica. Na amplitude de $\mathrm{pH}$ 4,8-5,2 nos solos do Cerrado, possivelmente não ocorreria suficiente ionização dos grupos funcionais da M.O. (carboxílicos, fenólicos, enólicos e imídicos), para produzir a formação de grande número de cargas negativas (LOPES, 1984). Esta situação se aplica aos solos dos Campos Sujos Secos da bacia hidrográfica do ribeirão Taquaruçu Grande, tendo em vista que eles apresentaram níveis de $\mathrm{pH}<5,0$ (Tabela 4.5).

\subsection{Saturação por Bases}

A Saturação por Bases variou de 4,5\% (A3E) a 13,1\% (A2T) (Tabela 4.3). Os maiores índices de saturação de bases foram para os solos da A2T e A2V, como reflexo dos maiores teores de Ca, Mg e K (Tabela 4.5). Para Tomé-Júnior (1997), a saturação por bases fornece uma ideia do estado de ocupação das cargas da CTC Total, ou seja, qual a proporção ocupada pelos cátoins úteis $(\mathrm{Ca}, \mathrm{Mg}$ e $\mathrm{K})$ do total das cargas negativas existentes no solo. Assim, a Saturação por Bases é excelente indicativo das condições gerais da fertilidade do solo, que de acordo com a Saturação por Bases (V\%) e Saturação por Alumínio (m\%) podem ser divididos em três grupos: solos eutróficos ou férteis $(\mathrm{V} \% \geq 50 \%)$, solos distróficos ou pouco férteis (V\% $<50 \%$ ), e solos álicos ou muito pobres ( $\mathrm{Al}$ trocável $\geq 0,3 \mathrm{cmolc} / \mathrm{dm} 3 \mathrm{e} \mathrm{m} \% \geq 50 \%$ ).

Os solos em todas as áreas apresentaram teores de Saturação por Bases inferiores a $50 \%$ (Tabela 4.5), sendo que $80 \%$ das amostras apresentaram Al trocável $\geq 0,3\left(\mathrm{cmol}_{\mathrm{c}} / \mathrm{dm}^{3}\right)$ e $40 \%$ das amostras apresentaram m\% > 50\%. Segundo Haridasan (2007), o critério mínimo de 2,0 cmol (+)/kg de Ca e Mg trocáveis tem sido utilizado para separar solos mesotróficos de solos distróficos, desta forma, os solos dos Campos Sujos Secos estudados caracterizam-se como distróficos e álicos

Os valores de Saturação por Bases (V\%) foram significativamente diferentes para tratamento (topo e vertente). Os solos dos topos $(\mathrm{V} \%=7,48)$ apresentaram maiores índices de Saturação por Bases que os das vertentes (V\% = 5,8\%), a $2 \%$ de probabilidade pelo teste "T" pareado, indicando que são menos distróficos que os da vertente.

Para os blocos (áreas), também houve diferença entre os teores de Saturação por Bases. Pois, A2 é significativamente diferente das demais ao nível de $2 \%$ de probabilidade pelo teste de Tukey (Tabela 4.9). Essa diferença significativa, assim como ocorreu para os 
relevos de topo e vertente, é devido os teores de $\mathrm{Ca}, \mathrm{Mg}$ e $\mathrm{K}$, que foram maiores na $\mathrm{A} 2 \mathrm{~T}$ e A2V em relação às demais áreas e que influenciaram os resultados da Saturação por Bases.

Tabela 4.9 - Teores médios de Saturação por Bases (V\%) para áreas (blocos), em solos de Campo Sujo Seco, na bacia hidrográfica do ribeirão Taquaruçu Grande, Palmas (TO)

\begin{tabular}{cc}
\hline Áreas (blocos) & $\mathbf{V \%}$ \\
\hline A1 & $5,8 \mathrm{~b}$ \\
A2 & $11,6 \mathrm{a}^{*}$ \\
$\mathrm{~A} 3$ & $5,4 \mathrm{~b}$ \\
$\mathrm{~A} 4$ & $5,3 \mathrm{~b}$ \\
$\mathrm{~A} 5$ & $5,1 \mathrm{~b}$ \\
\hline Médias seguidas por letras iguais não diferem entre si. \\
*: significativo pelo teste de Tukey a 2\% de probabilidade
\end{tabular}

\subsection{Atributos físicos do solo}

A textura dos solos foi considerada média com percentuais: de argila, variando de $20 \%$ a 33\%; silte, variando de $13 \%$ a $23 \%$; e areia variando de $51 \%$ a $64 \%$ (Tabela 4.5 ). A textura média significa teor de argila + silte $>150 \mathrm{~g} / \mathrm{kg}$ e $\operatorname{argila}<350 \mathrm{~g} / \mathrm{kg}$. Os solos com esse tipo de textura apresentam: baixo-moderada susceptibilidade à erosão; médios a baixos valores de retenção de água; e, densidade pode ser elevada, próxima a $1,4 \mathrm{~g} / \mathrm{cm}^{3}$, sem que isso signifique que ele está compactado (TOMÉ-JÚNIOR, 1997).

Em estudos de densidade de solos de fitofisionomias do Cerrado mato-grossense, Souza et al. (2010) apresentaram resultados que indicaram valores mais elevados de densidade de solos de campo sujo em relação ao cerradão, mata ciliar e pastagens, em decorrência do campo sujo ter textura mais arenosa e baixa quantidade de serapilheira sobre o solo, encontrando-se abaixo do índice crítico ao desenvolvimento radicular.

Os percentuais de argila e de areia não diferiram, estatisticamente, entre topo e vertente (tratamento), nem entre áreas (blocos). Já os percentuais de silte não foram diferentes entre áreas, mas, foram diferentes entre topo e vertente ao nível de probabilidade de $1 \%$ pelo teste "T" pareado, sendo que os solos da vertente $(18,8 \%$ a) tiveram maiores teores de silte que os solos do topo $(15,8 \% \mathrm{~b})$.

Verificou-se uma característica muito expressiva quanto à pedregosidade, que variou de muito pedregosa (15 - 50\%) nas áreas 2 e 3, a extremamente pedregosa (> 50\%), nas áreas 1,4 e 5, tanto no topo quanto na vertente. Em relação à presença de matacões, foi variável 
entre as áreas, não ultrapassando 15\%, sendo as áreas de topo (áreas 2, 3 e 5) apresentaram menores índices de ocorrência de matacões $(0,1-3,0 \%)$ e as demais ficaram na faixa de 3$15 \%$.

Quanto à rochosidade que se caracteriza, segundo Santos et al. (2005), pela exposição de rochas do embasamento na superfície ou presença de matacões com mais de $1 \mathrm{~m}$ de diâmetro, tanto as áreas de topo como as de vertente, caracterizaram-se pela condição de serem não rochosas.

\subsection{Caracterização geral dos solos}

No que se refere à erosão dos solos, não foi constatado nenhum processo erosivo aparente na área. Há indícios de rolamentos de materiais nodulares da parte alta e média das vertentes para a região da base, principalmente nas Áreas 1 e 4, cujas vertentes possuem maior grau de inclinação.

Os solos dos Campos Sujos Secos na bacia hidrográfica do ribeirão Taquaruçu Grande caracterizaram-se como solos:

- com baixo teor de água disponível, mesmo durante a estação chuvosa;

- ácidos, pelos baixos valores de $\mathrm{pH}$, distróficos pelos baixos teores de bases, em que $\mathrm{Ca}$ e $\mathrm{Mg}$ apresentaram valores inferiores a $2,0 \mathrm{cmol}_{\mathrm{c}} / \mathrm{dm}^{3}$;

- álicos, pelos altos teores de Al trocável e saturação de Al, e de textura média com mais alta fração de areia que de argila e silte.

- altos teores de Fe;

- e, pela própria característica dos Plintossolos pétricos, pela presença de concreções ferruginosas, foram extremamente pedregosos.

Quanto ao relevo, as condições de topo e vertente não influenciaram nos teores de umidade, matéria orgânica e dos nutrientes, quando analisados isoladamente, $\mathrm{Ca}, \mathrm{Mg}, \mathrm{P}, \mathrm{K}$, e Fe, não havendo diferença significativa entre os teores de topo e vertente. O mesmo não foi constatado em relação ao $\mathrm{pH}, \mathrm{Al}$ e Saturação por Bases, que apresentaram teores diferentes entre topo e vertente. Os solos do topo foram menos ácidos e menos distróficos que os da vertente. Já as vertentes tiveram maiores teores de $\mathrm{Al}$

Em se tratando da comparação entre áreas, apenas Ca e Mg apresentaram diferenças e em conseqüência disso, a Saturação por Bases apresentou diferenças significativas. Além desses nutrientes, também houve diferença entre os teores de água presente no solo. Área 2 se 
distinguiu das demais por ter mais $\mathrm{Ca}$ e $\mathrm{Mg}$ e menor saturação com $\mathrm{H}+\mathrm{Al}$ e, portanto, maior Saturação por Bases, bem como maior quantidade de água nos solos no mês de junho (quase metade do período seco).

Dessa forma, Saturação por Bases mostrou haver diferença significativa na fertilidade dos solos entre topo e vertente, em que os solos dos topos indicaram ser menos distróficos que os da vertente. Também entre as áreas, houve diferença significativa: a área 2 indicou ter solos menos distróficos e ter mais água no período seco que as demais áreas.

Quanto à textura, não houve diferença significativa para os teores de argila e de areia entre topo e vertente nem entre as áreas. Mas, para o silte houve diferença significativa entre topo e vertente, em que a vertente apresentou maiores teores que o topo. 


\subsubsection{Aspectos Fitogeográficos}

\subsubsection{Sistemática e distribuição geográfica}

A flora da comunidade de plantas do Campo Sujo Seco, amostrada nas parcelas A1V ${ }^{1}$, $\mathrm{A}^{\mathrm{T}} \mathrm{T}^{2}, \mathrm{~A} 2 \mathrm{~V}, \mathrm{~A} 2 \mathrm{~T}, \mathrm{~A} 3 \mathrm{~V}, \mathrm{~A} 3 \mathrm{~T}, \mathrm{~A} 4 \mathrm{~V}, \mathrm{~A} 4 \mathrm{~T}, \mathrm{~A} 5 \mathrm{~V}$ e A5T, da bacia hidrográfica do ribeirão Taquaruçu Grande (Palmas - TO) pertence à divisão Magnoliophyta (Angiospermas) e é composta de plantas vasculares, com espécies monocotiledôneas (classe Liliopsida) e dicotiledôneas (classe Magnoliopsida), que se distribuem em ordens, famílias, gêneros e espécies (Figura 4.34).

Do ponto de vista taxonômico a flora é predominantemente da classe Magnoliopsida, com a presença de 17 ordens, 33 famílias, 71 gêneros e 100 espécies. As ordens com maiores números de famílias foram Malpighiales (7) e Myrtales (5); as demais tiveram de 1 a 3 famílias (Figura 4.26). A ordem Fabales, embora com apenas uma família, teve 20 gêneros e 25 espécies. Além de Fabales, as ordens com maiores números de espécies foram: Malpighiales (18) e Myrtales (17). A classe Liliopsida foi composta por 4 ordens, 6 famílias, 10 gêneros e 21 espécies. A ordem Poales teve mais famílias (3), gêneros (7) e espécies (18) que as demais (Figura 4.27; Quadros 4.2 e 4.3).

\footnotetext{
${ }^{1} \mathrm{~V}$ (vertente)

${ }^{2} \mathrm{~T}$ (topo)
} 


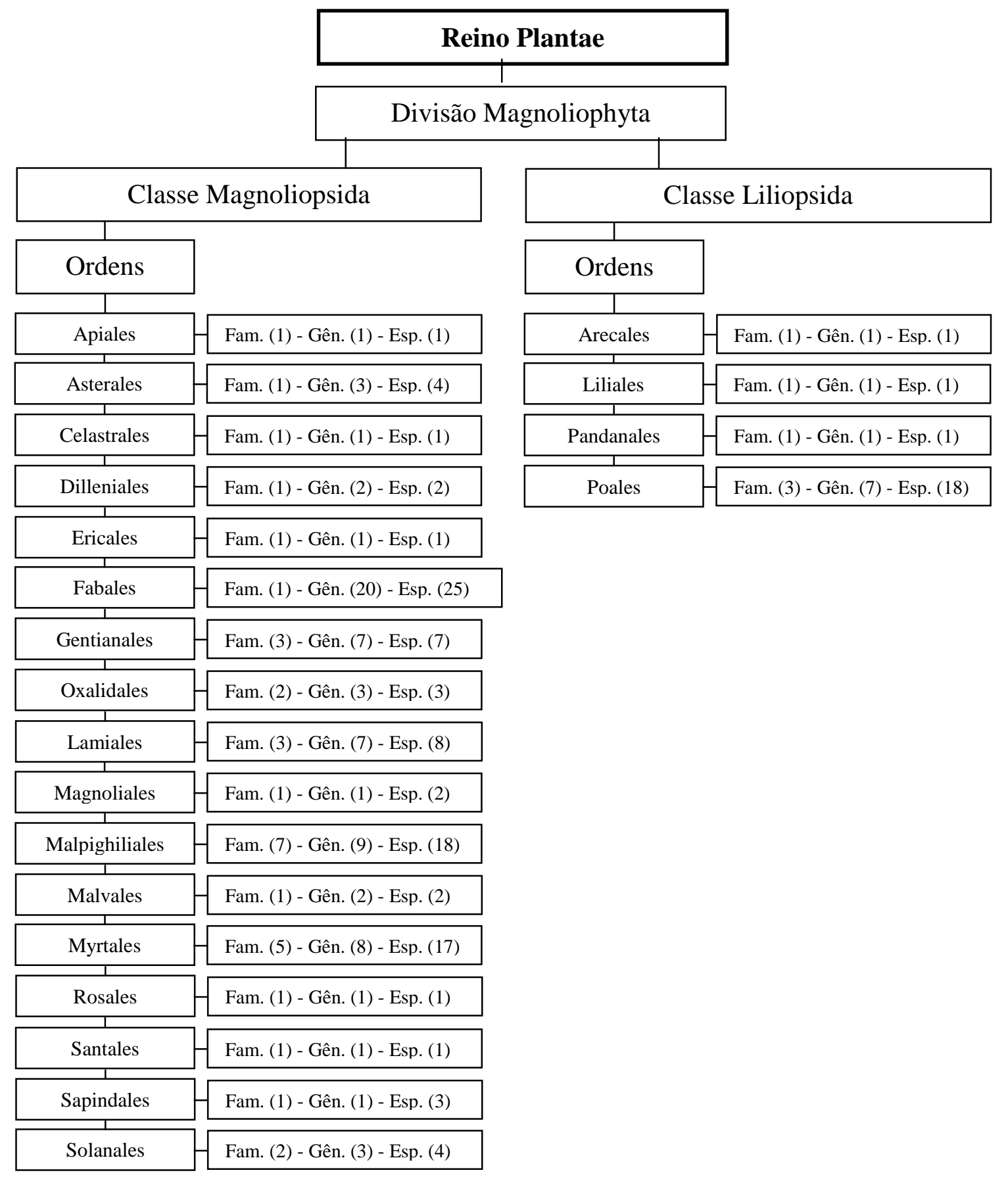

Figura 4.34 - Síntese da sistemática da comunidade de plantas do Campo Sujo Seco, da bacia hidrográfica do ribeirão Taquaruçu Grande, Palmas (TO), com base no APG III (2009) 
Quadro 4.2 - Florística da comunidade de plantas do Campo Sujo Seco, na bacia hidrográfica do ribeirão Taquaruçu Grande, Palmas (TO), com espécies da classe Magnoliopsida, segundo a ordem, família, gênero, ambiente de ocorrência e distribuição geográfica (continua)

\begin{tabular}{|c|c|c|c|c|c|}
\hline Ordem & Família & Gênero & Espécie & Domínio/Bioma & Distribuição geográfica \\
\hline Apiales & Araliaceae & Schefflera & $\begin{array}{l}\text { Schefflera macrocarpa (Cham. \& } \\
\text { Schltdl.) Frodin }\end{array}$ & $\begin{array}{l}\text { Caatinga } \\
\text { Mata Atlântica } \\
\text { Cerrado }\end{array}$ & $\begin{array}{l}\text { Nativa; endêmica; BA, MT, GO, DF, MG, SP (FORZZA, et al., 2010); e } \\
\text { em Mato Grosso do Sul (ALMEIDA et al., 1998). }\end{array}$ \\
\hline \multirow[t]{4}{*}{ Asterales } & \multirow[t]{4}{*}{ Asteraceae } & \multirow[t]{2}{*}{ Aspilia } & Aspilia foliacea (Spreng.) Baker & $\begin{array}{c}\text { Cerrado } \\
\text { Pampa }\end{array}$ & $\begin{array}{l}\text { Nativa; endêmica; Norte (RO), Centro-Oeste (MT, GO, DF, MS), } \\
\text { Sudeste (MG, SP), Sul (PR, RS) (FORZZA et al., 2010). } \\
\text { Bolívia (www.cerradosdebolivia.org). }\end{array}$ \\
\hline & & & Aspilia leucoglossa Malme & Cerrado & $\begin{array}{l}\text { Nativa; endêmica; Norte (RO), Nordeste (PI), Centro-Oeste (MT, GO, } \\
\text { MS), (FORZZA et al., 2010). } \\
\text { Bolívia (www.cerradosdebolivia.org). }\end{array}$ \\
\hline & & Lessingianthus & $\begin{array}{l}\text { Lessingianthus obtusatus (Less.) } \\
\text { H.Rob. }\end{array}$ & Cerrado & $\begin{array}{l}\text { Nativa; não endêmica; Centro-Oeste (MT, GO, DF), Sudeste (MG, SP) } \\
\text { (FORZZA et al., 2010). }\end{array}$ \\
\hline & & Piptocarpha & $\begin{array}{lll}\text { Piptocarpha } & \text { rotundifolia } & \text { (Less.) } \\
\text { Baker } & & \end{array}$ & $\begin{array}{l}\text { Mata Atlântica } \\
\text { Cerrado }\end{array}$ & $\begin{array}{l}\text { Nativa; não endêmica (FORZZA et al., 2010). BA. DF, ES, GO, MA, } \\
\text { MT, MS, MG, RJ, SP, TO (ALMEIDA et all., 1998). }\end{array}$ \\
\hline Celastrales & Celastraceae & Salacia & $\begin{array}{l}\text { Salacia crassifolia (Mart. ex Schult.) } \\
\text { G.Don }\end{array}$ & $\begin{array}{l}\text { Caatinga } \\
\text { Cerrado }\end{array}$ & $\begin{array}{l}\text { Nativa; não endêmica; Norte (TO, RO), Nordeste (PI, BA), Centro-Oeste } \\
\text { (MT, GO, DF, MS), Sudeste (MG, SP, RJ) (FORZZA et al., 2010). } \\
\text { Maranhão (ALMEIDA et al., 1998). }\end{array}$ \\
\hline \multirow[t]{2}{*}{ Dilleniales } & \multirow[t]{2}{*}{ Dilleniaceae } & Curatella & Curatella americana $\mathrm{L}$. & $\begin{array}{l}\text { Amazônia } \\
\text { Caatinga } \\
\text { Cerrado } \\
\text { Mata Atlântica }\end{array}$ & $\begin{array}{l}\text { Nativa; não endêmica; Norte (RR, AP, PA, AM, TO, RO), Nordeste } \\
\text { (MA, PI, CE, RN, PB, PE, BA, AL, SE), Centro-Oeste (MT, GO, DF, } \\
\text { MS), Sudeste (MG) (FORZZA et al., 2010; ALMEIDA et al., 1998). } \\
\text { Bolívia (www.cerradosdebolivia.org). }\end{array}$ \\
\hline & & Davilla & Davilla elliptica A.St.-Hil. & $\begin{array}{l}\text { Amazônia } \\
\text { Caatinga } \\
\text { Cerrado }\end{array}$ & $\begin{array}{l}\text { Nativa; não endêmica; Norte (PA, TO, RO), Nordeste (MA, PI, BA), } \\
\text { Centro-Oeste (MT, GO, DF, MS), Sudeste (MG, SP) (FORZZA et al., } \\
\text { 2010; MEDEIROS, 2011). } \\
\text { Bolívia (www.cerradosdebolivia.org) }\end{array}$ \\
\hline Ericales & Ebenaceae & Diospyros & Diospyros hispida A. DC. & $\begin{array}{l}\text { Amazônia } \\
\text { Caatinga } \\
\text { Cerrado } \\
\text { Mata Atlântica }\end{array}$ & $\begin{array}{l}\text { Nativa; não endêmica; Norte (PA, TO, RO), Nordeste (MA, PI, CE, PB, } \\
\text { PE, BA, AL), Centro-Oeste (MT, GO, DF, MS), Sudeste (MG, ES, SP, } \\
\text { RJ), Sul (PR) (FORZZA et al., 2010; MEDEIROS, 2011). }\end{array}$ \\
\hline \multirow[t]{3}{*}{ Fabales } & \multirow[t]{3}{*}{ Fabaceae } & Leptolobium & Leptolobium dasycarpum Vogel & $\begin{array}{l}\text { Amazônia } \\
\text { Cerrado }\end{array}$ & $\begin{array}{l}\text { Nativa; não endêmica; TO, RO, MA, PI, CE, BA, MT, GO, DF, MS, } \\
\text { MG, SP (FORZZA et al., 2010; MEDEIROS, 2011). } \\
\text { Bolívia (www.cerradosdebolivia.org) }\end{array}$ \\
\hline & & Andira & Andira humilis Mart. ex Benth. & $\begin{array}{l}\text { Amazônia } \\
\text { Caatinga } \\
\text { Cerrado }\end{array}$ & $\begin{array}{l}\text { Nativa; endêmica; Norte (PA, RO), Nordeste (MA, RN, PE, BA), } \\
\text { Centro-Oeste (MT, DF, MS), Sudeste (MG, SP), Sul (PR) (FORZZA et } \\
\text { al., 2010). Paraíba (ALMEIDA et al., 1998). }\end{array}$ \\
\hline & & Bauhinia & Bauhinia curvula Benth. & $\begin{array}{l}\text { Amazônia } \\
\text { Cerrado }\end{array}$ & $\begin{array}{l}\text { Nativa; endêmica; Norte (PA), Centro-Oeste (MT, GO, DF, MS), } \\
\text { Sudeste (MG) (FORZZA et al., 2010; MEDEIROS, 2011). }\end{array}$ \\
\hline
\end{tabular}


Quadro 4.2 - Florística da comunidade de plantas do Campo Sujo Seco, na bacia hidrográfica do ribeirão Taquaruçu Grande, Palmas (TO), com espécies da classe Magnoliopsida, segundo a ordem, família, gênero, ambiente de ocorrência e distribuição geográfica (continuação)

\begin{tabular}{|c|c|c|c|c|c|}
\hline Ordem & Família & Gênero & Espécie & Domínio/Bioma & Distribuição geográfica \\
\hline \multirow[t]{10}{*}{ Fabales } & \multirow[t]{10}{*}{ Fabaceae } & Bauhinia & Bauhinia rufa (Bong.) Steud. & Cerrado & $\begin{array}{l}\text { Nativa; não endêmica; Norte, Nordeste, Centro-Oeste (GO, DF), Sudeste } \\
\text { (MG), Sul (FORZZA et al., 2010; MEDEIROS, 2011). }\end{array}$ \\
\hline & & Bowdichia & Bowdichia virgiloides Kunth & $\begin{array}{l}\text { Amazônia } \\
\text { Caatinga } \\
\text { Cerrado } \\
\text { Mata Atlântica } \\
\text { Pantanal }\end{array}$ & $\begin{array}{l}\text { Nativa; não endêmica; Norte (RR, AP, PA, AM, TO, RO), Nordeste } \\
\text { (MA, PI, CE, RN, PB, PE, BA, AL, SE), Centro-Oeste (MT, GO, DF, } \\
\text { MS), Sudeste (MG, ES, SP), Sul (PR) (FORZZA et al., 2010). Acre, Rio } \\
\text { de Janeiro (ALMEIDA et al., 1998). Bolívia, Colômbia, Guiana, } \\
\text { Paraguai, Suriname, Venezuela (FILARDI et al., 2007). Bolívia } \\
\text { (www.cerradosdebolivia.org) }\end{array}$ \\
\hline & & Camptosema & $\begin{array}{l}\text { Camptosema scarlatium (Mart. Ex } \\
\text { Benth.) Burkart }\end{array}$ & Cerrado & $\begin{array}{l}\text { Nativa; não endêmica (FORZZA et al., 2010). Paraguai, Argentina e no } \\
\text { Brasil (FILARDI et al., 2007). No Brasil (CE, BA, GO, DF, MG, ES, SP, } \\
\text { RJ, PR, RS) (ANDRADE et al., 2009; MEDEIROS, 2011). }\end{array}$ \\
\hline & & Centrosema & Centrosema virginianum (L.) Benth. & $\begin{array}{l}\text { Amazônia } \\
\text { Caatinga } \\
\text { Mata Atlântica } \\
\text { Cerrado }\end{array}$ & $\begin{array}{l}\text { Nativa; não endêmica; AC, PI, CE, PB, PE, BA, MT, MS, MG, ES, SP, } \\
\text { RJ, PR, SC, RS (FORZZA et al., 2010;. Em Minas Gerais, nos campos } \\
\text { rupestres da Cadeia do Espinhaço (Brandão et al. 1995, Lewis 1995, } \\
\text { Zappi et al. 2005). Bolívia (www.cerradosdebolivia.org) }\end{array}$ \\
\hline & & Calliandra & Calliandra dysantha Benth. & Cerrado & $\begin{array}{l}\text { Nativa; não endêmica (FORZZA et al., 2010). BA, CE, DF, GO, MT, } \\
\text { MS, MG, SP, TO (ALMEIDA et al., 1998). }\end{array}$ \\
\hline & & \multirow[t]{3}{*}{ Chamaecrista } & Chamaecrista diphylla (L.) Greene. & $\begin{array}{c}\text { Amazônia } \\
\text { Caatinga } \\
\text { Cerrado } \\
\text { Mata Atlântica } \\
\end{array}$ & $\begin{array}{l}\text { Nativa; não endêmica; Norte (RR, AP, PA, AM, TO, RO), Nordeste } \\
\text { (MA, PI, CE, RN, PB, PE, AL, SE), Centro-Oeste (MT, GO, MS), } \\
\text { Sudeste (MG, RJ) (FORZZA et al., 2010). México, Caribe e América } \\
\text { Central até a América do Sul (QUEIROZ; LOIOLA, 2009). }\end{array}$ \\
\hline & & & $\begin{array}{l}\text { Chamaecrista orbiculata (Benth.) } \\
\text { H.S.Irwin \& Barneby }\end{array}$ & Cerrado & $\begin{array}{l}\text { Nativa; endêmica (FORZZA et al., 2010). BA,DF, GO, MG, MS } \\
\text { (Proença et al., 2006) }\end{array}$ \\
\hline & & & Chamaecrista serpens (L.) Greene & $\begin{array}{l}\text { Cerrado } \\
\text { Caatinga }\end{array}$ & $\begin{array}{l}\text { Nativa; não endêmica (FORZZA et al., 2010). BA, PI (www.cnip.org.br), } \\
\text { América Central e América do Sul. Brasil (PA, RR, MA, RN, PE, BA, } \\
\text { MT, GO, MG e SP (QUEIROZ; LOIOLA,2009). }\end{array}$ \\
\hline & & Clitoria & Clitoria guianensis (Aubl.) Benth. & Cerrado & $\begin{array}{l}\text { Nativa; não endêmica (FORZZA et al., 2010). RR, AM, PA, AM, TO, } \\
\text { MA, PI, CE, PE, BA, MT, GO, DF, MS, MG, ES, SP, PR (MEDEIROS, } \\
\text { 2011). México, Caribe, América Central e América do Sul (ILDIS, } \\
\text { 2005). No Brasil, em MG na Cadeia do Espinhaço (FILARDI et al., } \\
\text { 2007). } \\
\text { Bolívia (www.cerradosdebolivia.org) }\end{array}$ \\
\hline & & Crotalaria & Crotalaria unifoliolata Benth. & Cerrado & $\begin{array}{l}\text { Nativa; endêmica; Centro-Oeste (GO, DF), Sudeste (MG, SP) (FORZZA } \\
\text { et al., 2010). Minas Gerais na Cadeia do Espinhaço (FILARDI et al., } \\
\text { 2007). São Paulo, Bolívia (www.efloras.org/florataxon.aspx?flora_id ) }\end{array}$ \\
\hline
\end{tabular}


Quadro 4.2 - Florística da comunidade de plantas do Campo Sujo Seco, na bacia hidrográfica do ribeirão Taquaruçu Grande, Palmas (TO), com espécies da classe Magnoliopsida, segundo a ordem, família, gênero, ambiente de ocorrência e distribuição geográfica (continuação)

\begin{tabular}{|c|c|c|c|c|c|}
\hline Ordem & Família & Gênero & Espécie & Domínio/Bioma & Distribuição geográfica \\
\hline \multirow[t]{12}{*}{ Fabales } & \multirow[t]{12}{*}{ Fabaceae } & Dimorphandra & Dimorphandra mollis Benth. & $\begin{array}{l}\text { Amazônia } \\
\text { Cerrado }\end{array}$ & $\begin{array}{l}\text { Nativa; não endêmica; Norte (TO, RO), Nordeste (MA, PI, CE, BA), } \\
\text { Centro-Oeste (MT, GO, DF, MS), Sudeste (MG, SP) (FORZZA et al., } \\
\text { 2010). Pará (ALMEIDA et al., 1998). }\end{array}$ \\
\hline & & Dipteryx & Dipteryx alata Vogel & $\begin{array}{l}\text { Caatinga } \\
\text { Cerrado }\end{array}$ & $\begin{array}{l}\text { Nativa; não endêmica; Norte (TO), Nordeste (MA, PI, CE, BA), Centro- } \\
\text { Oeste (MT, GO, DF, MS), Sudeste (MG, SP) (FORZZA et al., 2010). } \\
\text { Bolívia (www.cerradosdebolivia.org) }\end{array}$ \\
\hline & & Hymenaea & $\begin{array}{l}\text { Hymenaea stigonocarpa Mart. ex } \\
\text { Hayne }\end{array}$ & Cerrado & $\begin{array}{l}\text { Nativa; não endêmica (FORZZA et al., 2010). AM, BA, CE, DF, GO, } \\
\text { MA, MT, MS, MG, PA, PI, SP, TO (ALMEIDA et al., 1998). } \\
\text { Bolívia (www.cerradosdebolivia.org) }\end{array}$ \\
\hline & & \multirow[t]{2}{*}{ Mimosa } & $\begin{array}{l}\text { Mimosa albolanata var. } \\
\text { brasiliana Barneby }\end{array}$ & Cerrado & $\begin{array}{l}\text { Nativa; endêmica; Centro-Oeste (GO, DF), Sudeste (MG) (FORZZA et } \\
\text { al., 2010). Restrita ao Brasil Central, Distrito Federal, Goiás, Minas } \\
\text { Gerais (DUTRA, 2009). }\end{array}$ \\
\hline & & & $\begin{array}{l}\text { Mimosa radula var. imbricata } \\
\text { (Benth.) Barneby }\end{array}$ & Cerrado & $\begin{array}{l}\text { Nativa; endêmica; Centro-Oeste (GO), Sudeste (MG) (FORZZA et al., } \\
\text { 2010). Endêmica do Brasil Central (GO, DF, MT, MS, MG na serra de } \\
\text { Canastra e Cadeia do espinhaço), SP (DUTRA, 2009). }\end{array}$ \\
\hline & & Platypodium & Platypodium elegans Vogel & Cerrado & Nativa; não endêmica (FORZZA et al., 2010) \\
\hline & & Pterodon & Pterodon emarginatus Vogel & $\begin{array}{l}\text { Caatinga } \\
\text { Cerrado }\end{array}$ & $\begin{array}{l}\text { Nativa; não endêmica; Norte (TO, RO), Nordeste (MA, PI, CE, BA), } \\
\text { Centro-Oeste (MT, GO, DF, MS), Sudeste (MG, SP) ( FORZZA et al., } \\
\text { 2010; ALMEIDA et al., 1998). Bolívia (www.cerradosdebolivia.org) }\end{array}$ \\
\hline & & Tachigali & $\begin{array}{l}\text { Tachigali rugosa (Mart. ex } \\
\text { Benth.) Zarucchi \& Puipoly }\end{array}$ & Mata Atlântica & $\begin{array}{l}\text { Nativa; endêmica; BA, MG, ES, SP, RJ (FORZZA et al, 2010). Ocorre } \\
\text { também em Goiás, (LORENZI, 2009; MEDEIROS,2011). }\end{array}$ \\
\hline & & Senna & $\begin{array}{l}\text { Senna velutina (Vogel) H.S.Irwin } \\
\& \text { Barneby }\end{array}$ & $\begin{array}{l}\text { Amazônia } \\
\text { Caatinga } \\
\text { Cerrado }\end{array}$ & $\begin{array}{l}\text { Nativa; não endêmica; Norte (TO), Nordeste (MA, PI, CE, BA), Centro- } \\
\text { Oeste (MT, GO, DF, MS), Sudeste (MG, SP) (FORZZA et al.,2010). }\end{array}$ \\
\hline & & Stryphnodendron & $\begin{array}{l}\text { Stryphnodendron adstringens } \\
\text { (Mart.) Coville }\end{array}$ & $\begin{array}{l}\text { Caatinga } \\
\text { Cerrado }\end{array}$ & $\begin{array}{l}\text { Nativa; endêmica; Norte (TO), Nordeste (BA), Centro-Oeste (MT, GO, } \\
\text { DF, MS), Sudeste (MG, SP), Sul (PR) (FORZZA et al., 2010). MA, PI, } \\
\text { TO (ALMEIDA et al., 1998). }\end{array}$ \\
\hline & & \multirow[t]{2}{*}{ Vigna } & $\begin{array}{l}\text { Vigna firmula (Benth.) Maréchal, } \\
\text { Mascherpa \& Stainier }\end{array}$ & $\begin{array}{l}\text { Amazônia } \\
\text { Caatinga } \\
\text { Cerrado } \\
\text { Mata Atlântica }\end{array}$ & $\begin{array}{l}\text { Nativa; não endêmica; Norte (PA, TO), Nordeste (MA, PI, BA), Centro- } \\
\text { Oeste (MT, GO, DF, MS), Sudeste (MG, SP) (FORZZA et al., 2010). } \\
\text { Paraguai e Brasil (Cadeia do Espinhaço, Minas Gerais, FILARDI et al., } \\
\text { 2007). Bolívia (www.cerradosdebolivia.org) }\end{array}$ \\
\hline & & & Vigna speciosa (Kunth) Verdc. & $\begin{array}{c}\text { Cerrado } \\
\text { Mata Atlântica }\end{array}$ & $\begin{array}{l}\text { Nativa; não endêmica; Centro-Oeste (MT, GO, DF, MS), Sudeste (MG, } \\
\text { ES, SP, RJ), Sul (PR) (FORZZA et al., 2010). América Central até a } \\
\text { Colômbia, Equador e Venezuela Piper (1926) e Maréchal et al. (1978) } \\
\text { apud Snak (2011). }\end{array}$ \\
\hline
\end{tabular}


Quadro 4.2 - Florística da comunidade de plantas do Campo Sujo Seco, na bacia hidrográfica do ribeirão Taquaruçu Grande, Palmas (TO), com espécies da classe Magnoliopsida, segundo a ordem, família, gênero, ambiente de ocorrência e distribuição geográfica (continuação)

\begin{tabular}{|c|c|c|c|c|c|}
\hline Ordem & Família & Gênero & Espécie & Domínio/Bioma & Distribuição geográfica \\
\hline \multirow[t]{7}{*}{ Gentianales } & \multirow[t]{2}{*}{ Apocynaceae } & Hancornia & Hancornia speciosa Gomes & $\begin{array}{l}\text { Cerrado } \\
\text { Caatinga } \\
\text { Pantanal }\end{array}$ & $\begin{array}{l}\text { Nativa; não endêmica (FORZZA et al., 2010). AL, AP, AM, BA, DF, ES, } \\
\text { GO, MA, MT, MS, MG, PA, PB, PE, PI, SP, TO) (ALMEIDA et al., } \\
\text { 1998) e em outros países da América do Sul (POTT; POTT, 1994). } \\
\text { Bolívia (www.cerradosdebolivia.org). }\end{array}$ \\
\hline & & Himatanthus & $\begin{array}{l}\text { Himatanthus obovatus (Mull. Arg.) } \\
\text { Woodson }\end{array}$ & $\begin{array}{l}\text { Cerrado } \\
\text { Pantanal }\end{array}$ & $\begin{array}{l}\text { Nativa; endêmica (FORZZA et al., 2010) Cerrados do Brasil Central } \\
\text { (POTT; POTT, 1994). Bolívia (www.cerradosdebolivia.org). }\end{array}$ \\
\hline & Gentianaceae & Deianira & Deianira chiquitana Herzog & $\begin{array}{c}\text { Cerrado } \\
\text { Mata Atlântica }\end{array}$ & $\begin{array}{l}\text { Nativa; não endêmica; Nordeste (MA), Centro-Oeste (MT, GO), Sudeste } \\
\text { (MG, SP) (FORZZA et al., 2010). } \\
\text { Bolívia (www.cerradosdebolivia.org). }\end{array}$ \\
\hline & \multirow[t]{4}{*}{ Rubiaceae } & Borreria & $\begin{array}{l}\text { Borreria eryngioides } \text { Cham.\& } \\
\text { Schltdl. }\end{array}$ & $\begin{array}{c}\text { Caatinga } \\
\text { Cerrado } \\
\text { Mata Atlântica } \\
\text { Pantanal, Pampa } \\
\end{array}$ & $\begin{array}{l}\text { Nativa; não endêmica (FORZZA et al., 2010). Brasil (BA, DF, GO, MT, } \\
\text { MS, MG, PR, RS, SP e SC), Argentina, Bolívia, Paraguai, Uruguai, } \\
\text { inclusive no Chaco (POTT; POTT, 1994). }\end{array}$ \\
\hline & & Tocoyena & $\begin{array}{l}\text { Tocoyena formosa (Cham. \& Schltdl.) } \\
\text { K.Schum. }\end{array}$ & $\begin{array}{l}\text { Amazônia } \\
\text { Caatinga } \\
\text { Cerrado } \\
\text { Mata Atlântica } \\
\text { Pantanal }\end{array}$ & $\begin{array}{l}\text { Nativa; não endêmica; Norte (AP, PA, AM), Nordeste (MA, CE, PE, } \\
\text { BA), Centro-Oeste (MT, GO, DF, MS), Sudeste (MG, SP), Sul (PR) } \\
\text { (FORZZA et al., 2010). Ampla distribuição Neotropical, América } \\
\text { Central e do Sul, do México a Argentina, de Marajó a São Paulo, Mato } \\
\text { Grosso do Sul (POTT; POTT, 1994). } \\
\text { Bolívia (www.cerradosdebolivia.org). }\end{array}$ \\
\hline & & Mitracarpus & $\begin{array}{l}\text { Mitracarpus frigidus (Willd. ex } \\
\text { Roem. \& Schult.) K. Schum. }\end{array}$ & $\begin{array}{c}\text { Amazônia } \\
\text { Caatinga } \\
\text { Cerrado } \\
\text { Mata Atlântica } \\
\end{array}$ & $\begin{array}{l}\text { Nativa; não endêmica; Norte (RR, AM), Nordeste (PI, PB, PE, BA), } \\
\text { Sudeste (MG, ES, RJ), Sul (SC) (FORZZA et al., 2010). Ampla } \\
\text { distribuição, ocorrendo na Colômbia, Venezuela, Guiana Francesa e } \\
\text { Brasil, de Roraima até o de Santa Catarina (Delprete et al., 2005). }\end{array}$ \\
\hline & & Palicourea & Palicourea rigida Kunth & $\begin{array}{l}\text { Amazônia } \\
\text { Caatinga } \\
\text { Cerrado } \\
\text { Mata Atlântica } \\
\end{array}$ & $\begin{array}{l}\text { Nativa; não endêmica. AC, AM, PA,RO, BA, ES, MG, SP, PR } \\
\text { (FORZZA et al., 2010). Brasil Central, nos cerrados brasileiros e em } \\
\text { outras savanas neotropicais (MACHADO et al., 2010). Bolivia } \\
\text { (www.cerradosdebolivia.org). }\end{array}$ \\
\hline \multirow[t]{2}{*}{ Lamiales } & \multirow[t]{2}{*}{ Lamiaceae } & Amasonia & $\begin{array}{l}\text { Amasonia campestris (Aubl.) } \\
\text { Moldenke }\end{array}$ & $\begin{array}{l}\text { Amazônia } \\
\text { Caatinga } \\
\text { Cerrado }\end{array}$ & $\begin{array}{l}\text { Nativa; não endêmica; Norte (PA, AM, AC), Nordeste (MA, PI, CE, } \\
\text { BA), Centro-Oeste (MT, GO), Sudeste (ES) (FORZZA et al., 2010). }\end{array}$ \\
\hline & & Hyptis & Hyptis peduncularis Benth. & Cerrado & Nativa; endêmica; DF, GO e MG (FORZZA, et al., 2010) \\
\hline
\end{tabular}


Quadro 4.2 - Florística da comunidade de plantas do Campo Sujo Seco, na bacia hidrográfica do ribeirão Taquaruçu Grande, Palmas (TO), com espécies da classe Magnoliopsida, segundo a ordem, família, gênero, ambiente de ocorrência e distribuição geográfica (continuação)

\begin{tabular}{|c|c|c|c|c|c|}
\hline Ordem & Família & Gênero & Espécie & Domínio/Bioma & Distribuição geográfica \\
\hline \multirow[t]{6}{*}{ Lamiales } & Lamiaceae & Peltodon & Peltodon tomentosus Pohl & $\begin{array}{l}\text { Amazônia } \\
\text { Caatinga } \\
\text { Mata Atlântica } \\
\text { Cerrado } \\
\end{array}$ & $\begin{array}{l}\text { Nativa; não endêmica; No Norte (RO), Nordeste (BA), Centro Oeste } \\
\text { (MT, GO, MS), Sudeste (MG, SP), Sul ( PA), (FORZZA, et al., 2010; } \\
\text { TANUS; ASSIS, 2004). } \\
\text { Bolívia (www.cerradosdebolivia.org). }\end{array}$ \\
\hline & \multirow[t]{2}{*}{ Verbenaceae } & Casselia & Casselia Nees \& Mart. & Cerrado & $\begin{array}{l}6 \text { espécies (4 endêmicas), } 1 \text { variedade ( } 1 \text { endêmica) (FORZZA et al., } \\
\text { 2010). Bolívia (www.cerradosdebolivia.org). }\end{array}$ \\
\hline & & Lippia & Lippia florida Cham. & Cerrado & Nativa; endêmica; Sudeste (MG) (FORZZA et al., 2010). \\
\hline & \multirow[t]{3}{*}{ Bignoniaceae } & Tabebuia & $\begin{array}{l}\text { Tabebuia aurea (Manso) Benth. \& } \\
\text { Hook.f. ex S. Moore }\end{array}$ & $\begin{array}{l}\text { Amazônia } \\
\text { Caatinga } \\
\text { Cerrado } \\
\text { Mata Atlântica } \\
\text { Pantanal } \\
\end{array}$ & $\begin{array}{l}\text { Nativa; não endêmica; Norte (AP, PA, AM, TO), Nordeste (MA, PI, CE, } \\
\text { RN, PB, PE, BA, AL, SE), Centro-Oeste (MT, GO, DF, MS), Sudeste } \\
\text { (MG, SP), Sul (PR) (FORZZA et al., 2010). Também em Roraima } \\
\text { (ALMEIDA et al., 1998). } \\
\text { Bolívia (www.cerradosdebolivia.org) }\end{array}$ \\
\hline & & & Tabebuia roseoalba (Ridl.) Sandwith & $\begin{array}{l}\text { Amazônia } \\
\text { Caatinga Cerrado } \\
\text { Mata Atlântica } \\
\text { Pantanal } \\
\end{array}$ & $\begin{array}{l}\text { Nativa; não endêmica; Norte (PA, TO), Nordeste (MA, PI, CE, RN, PB, } \\
\text { PE, BA, AL, SE), Centro-Oeste (MT, GO, DF, MS), Sudeste (MG, ES, } \\
\text { SP, RJ) (FORZZA et al., 2010; LORENZI, 2008). } \\
\text { Bolívia (www.cerradosdebolivia.org). }\end{array}$ \\
\hline & & Zeyheria & $\begin{array}{l}\text { Zeyheria tuberculosa (Vell.) Bur. ex } \\
\text { Verlot }\end{array}$ & $\begin{array}{c}\text { Cerrado } \\
\text { Mata Atlântica }\end{array}$ & $\begin{array}{l}\text { Nativa; não endêmica; Nordeste (MA, PI, CE, RN, PB, PE, BA, AL, SE), } \\
\text { Sudeste (MG, ES, SP, RJ) (FORZZA et al., 2010). De Minas Gerais até o } \\
\text { norte do Paraná (Lorenzi, 2008). }\end{array}$ \\
\hline \multirow[t]{2}{*}{ Magnoliales } & \multirow[t]{2}{*}{ Annonaceae } & \multirow[t]{2}{*}{ Annona } & Annona coriacea Mart & $\begin{array}{l}\text { Cerrado } \\
\text { Pantanal }\end{array}$ & $\begin{array}{l}\text { Nativa; não endêmica; Norte (PA, TO, RO), Nordeste (MA, PI, CE, PB, } \\
\text { PE, BA), Centro-Oeste (MT, GO, DF, MS), Sudeste (MG, SP), Sul (PR) } \\
\text { (FORZZA et al., 2010; LORENZI, 2008). }\end{array}$ \\
\hline & & & Annona crassiflora Mart. & $\begin{array}{l}\text { Cerrado } \\
\text { Pantanal }\end{array}$ & $\begin{array}{l}\text { Nativa; não endêmica; Norte (PA, TO), Nordeste (MA, BA), Centro- } \\
\text { Oeste (MT, GO, DF, MS), Sudeste (MG, SP), Sul (PR) (FORZZA et al., } \\
\text { 2010). Piauí (ALMEIDA et al., 1998). }\end{array}$ \\
\hline \multirow[t]{3}{*}{ Malpighiales } & \multirow[t]{3}{*}{ Erythroxylaceae } & \multirow[t]{3}{*}{ Erythroxylum } & $\begin{array}{l}\text { Erythroxylum cf. citrifolium A.St.- } \\
\text { Hil. }\end{array}$ & $\begin{array}{l}\text { Amazônia } \\
\text { Cerrado } \\
\text { Mata Atlântica }\end{array}$ & $\begin{array}{l}\text { Nativa; não endêmica; Norte (RR, AP, PA, AM, RO), Nordeste (MA, } \\
\text { CE, PB, PE, BA, AL), Centro-Oeste (MT, GO, MS), Sudeste (MG, ES, } \\
\text { SP, RJ), Sul (FORZZA et al., 2010; MEDEIROS, 2011). }\end{array}$ \\
\hline & & & Erythroxylum suberosum A.St. Hil. & $\begin{array}{l}\text { Amazônia } \\
\text { Cerrado } \\
\text { Mata Atlântica }\end{array}$ & $\begin{array}{l}\text { Nativa; não endêmica (FORZZA et al., 2010). RO, AP, PA, AM, TO, } \\
\text { RR, MA, PI, CE, PB, PE, BA, AL, MT, GO, DF, MS, MG, ES, SP, RJ, } \\
\text { PR (MEDEIROS, 2011). Bolívia (www.cerradosdebolivia.org) }\end{array}$ \\
\hline & & & Erythroxylum tortuosum Mart. & $\begin{array}{l}\text { Amazônia } \\
\text { Caatinga } \\
\text { Cerrado }\end{array}$ & $\begin{array}{l}\text { Nativa; não endêmica; Norte (RO), Centro-Oeste (MT, GO, DF, MS), } \\
\text { Sudeste (MG, SP), Sul (FORZZA et al., 2010). }\end{array}$ \\
\hline
\end{tabular}


Quadro 4.2 - Florística da comunidade de plantas do Campo Sujo Seco, na bacia hidrográfica do ribeirão Taquaruçu Grande, Palmas (TO), com espécies da classe Magnoliopsida, segundo a ordem, família, gênero, ambiente de ocorrência e distribuição geográfica (continuação)

\begin{tabular}{|c|c|c|c|c|c|}
\hline Ordem & Família & Gênero & Espécie & Domínio/Bioma & Distribuição geográfica \\
\hline \multirow[t]{12}{*}{ Malpighiales } & \multirow[t]{3}{*}{ Euphorbiaceae } & Croton & Croton goyazensis Mull. Arg. & Cerrado & $\begin{array}{l}\text { Nativa; não endêmica; Norte (PA), Nordeste (PI, BA), Centro-Oeste } \\
\text { (GO, DF) (FORZZA et al., 2010; ALMEIDA et al., 1998). }\end{array}$ \\
\hline & & \multirow[t]{2}{*}{ Manihot } & Manihot acuminatissima Mull.Arg. & $\begin{array}{l}\text { Caatinga } \\
\text { Cerrado }\end{array}$ & $\begin{array}{l}\text { Nativa; endêmica; Nordeste (BA), Centro-Oeste (GO) (FORZZA et al., } \\
\text { 2010). Também no Distrito Federal (RODRIGUES, 2007). }\end{array}$ \\
\hline & & & Manihot sparsifolia Pohl & Cerrado & $\begin{array}{l}\text { Nativa; endêmica; Centro-Oeste (GO) (FORZZA et al., 2010). Distrito } \\
\text { Federal (RODRIGUES, 2007) }\end{array}$ \\
\hline & \multirow[t]{4}{*}{ Malpighiaceae } & \multirow[t]{4}{*}{ Byrsonima } & Byrsonima coccolobifolia Kunth & $\begin{array}{l}\text { Amazônia } \\
\text { Cerrado }\end{array}$ & $\begin{array}{l}\text { Nativa; não endêmica; Norte (RR, AM, TO), Nordeste (BA, SE), } \\
\text { Centro-Oeste (MT, GO, DF, MS), Sudeste (MG, SP), Sul (PR), } \\
\text { (FORZZA et al., 2010; LORENZI, 2008; MEDEIROS, 2011). } \\
\text { Bolívia (www.cerradosdebolivia.org). }\end{array}$ \\
\hline & & & Byrsonima pachyphylla A.Juss. & $\begin{array}{l}\text { Amazônia, } \\
\text { Cerrado }\end{array}$ & $\begin{array}{l}\text { Nativa; endêmica(?); Norte (PA, TO, RO), Nordeste (MA, RN, BA), } \\
\text { Centro-Oeste (MT, GO, DF, MS) (FORZZA et al., 2010). }\end{array}$ \\
\hline & & & $\begin{array}{l}\text { Byrsonima subterranea } \text { Brade \& } \\
\text { Marckgr. }\end{array}$ & $\begin{array}{l}\text { Amazonia } \\
\text { Cerrado } \\
\text { Pantanal }\end{array}$ & $\begin{array}{l}\text { Nativa; endêmica(?); Norte (RR, TO, AC), Nordeste (BA), Centro- } \\
\text { Oeste (MT, GO, DF), Sudeste (MG, SP), Sul (PR) (FORZZA et al., } \\
\text { 2010). Mato Grosso do Sul (MARIMON et al., 2012). }\end{array}$ \\
\hline & & & Byrsonima verbascifolia (L.) DC. & $\begin{array}{l}\text { Amazônia } \\
\text { Caatinga } \\
\text { Cerrado }\end{array}$ & $\begin{array}{l}\text { Nativa; não endêmica; Norte (RR), Nordeste (BA, AL), Centro-Oeste } \\
\text { (MT, GO, DF, MS), Sudeste (MG, SP), Sul (PR) (FORZZA et al., } \\
\text { 2010). Também no Amazonas, Pará, Tocantins (ALMEIDA et al., } \\
\text { 1998; LORENZI, 2008). Bolívia (www.cerradosdebolivia.org) }\end{array}$ \\
\hline & Caryocaraceae & Caryocar & Caryocar brasiliense Cambess. & Cerrado & $\begin{array}{l}\text { Nativa; não endêmica (FORZZA et al., 2010). BA, CE, DF, GO, MA, } \\
\text { MT, MS, MG, PA, PI, RJ, SP, TO (ALMEIDA et al., 1998). Bolívia } \\
\text { (www.cerradosdebolivia.org). }\end{array}$ \\
\hline & \multirow[t]{3}{*}{ Calophyllaceae } & \multirow[t]{3}{*}{ Kielmeyera } & Kielmeyera coriacea Mart. \& Zucc. & $\begin{array}{l}\text { Amazônia } \\
\text { Caatinga } \\
\text { Cerrado } \\
\text { Mata Atlântica } \\
\end{array}$ & $\begin{array}{l}\text { Nativa; endêmica; Norte (PA, AM, RO), Nordeste (BA), Centro-Oeste } \\
\text { (MT, GO, DF, MS), Sudeste (MG, SP), Sul (PR) (FORZZA et al., } \\
\text { 2010). CE, DF, GO, MA, MT, MS, MG, PA, PI, SP, TO (ALMEIDA } \\
\text { et al., 1998). Bolívia (www.cerradosdebolivia.org). }\end{array}$ \\
\hline & & & Kielmeyera lathrophyton Saddi & $\begin{array}{c}\text { Caatinga } \\
\text { Cerrado } \\
\text { Mata Atlântica }\end{array}$ & $\begin{array}{l}\text { Nativa; endêmica; Nordeste (BA), Centro-Oeste (GO, DF), Sudeste } \\
\text { (MG, SP) (FORZZA et al., 2010; LORENZI, 2009). }\end{array}$ \\
\hline & & & Kielmeyera rosea Mart. \& Zucc. & Cerrado & $\begin{array}{l}\text { Nativa; endêmica; Norte, Nordeste, Centro-Oeste, Sudeste (MG) } \\
\text { (FORZZA, et al., 2010). Bolívia (www.cerradosdebolivia.org) }\end{array}$ \\
\hline & Clusiaceae & Platonia & Platonia insignis Mart. & $\begin{array}{l}\text { Amazônia } \\
\text { Cerrado }\end{array}$ & $\begin{array}{l}\text { Nativa; endêmica; Norte (PA), Nordeste (MA) (FORZZA et al., 2010; } \\
\text { LORENZI, 2008). }\end{array}$ \\
\hline
\end{tabular}


Quadro 4.2 - Florística da comunidade de plantas do Campo Sujo Seco, na bacia hidrográfica do ribeirão Taquaruçu Grande, Palmas (TO), com espécies da classe Magnoliopsida, segundo a ordem, família, gênero, ambiente de ocorrência e distribuição geográfica (continuação)

\begin{tabular}{|c|c|c|c|c|c|}
\hline Ordem & Família & Gênero & Espécie & Domínio/Bioma & Distribuição geográfica \\
\hline \multirow[t]{3}{*}{ Malpighiales } & \multirow[t]{2}{*}{ Ochnaceae } & \multirow[t]{2}{*}{ Ouratea } & Ouratea hexasperma (A.St.-Hil.) Baill. & $\begin{array}{l}\text { Amazônia } \\
\text { Cerrado }\end{array}$ & $\begin{array}{l}\text { Nativa; não endêmica; Norte (AP, TO), Nordeste (MA, PI, CE, RN, } \\
\text { PB, PE, BA), Centro-Oeste (MT, GO, DF), Sudeste (MG, SP) } \\
\text { (FORZZA et al., 2010; MEDEIROS, 2011). }\end{array}$ \\
\hline & & & Ouratea spectabilis (Mart.) Engl. & Cerrado & $\begin{array}{l}\text { Nativa; endêmica; Nordeste, Centro-Oeste (MT, GO, MS), Sudeste } \\
\text { (MG, SP), Sul (PR) (FORZZA et al., 2010). Também na Bahia, } \\
\text { (ALMEIDA et al., 1998). }\end{array}$ \\
\hline & Salicaceae & Casearia & Casearia sylvestris $\mathrm{Sw}$. & $\begin{array}{l}\text { Amazônia } \\
\text { Caatinga } \\
\text { Cerrado } \\
\text { Mata Atlântica } \\
\text { Pampa } \\
\text { Pantanal }\end{array}$ & $\begin{array}{l}\text { Nativa; não endêmica; Norte (RR, AP, PA, AM, TO, AC, RO), } \\
\text { Nordeste (MA, PI, CE, RN, PB, PE, BA, AL, SE), Centro-Oeste (MT, } \\
\text { GO, DF, MS), Sudeste (MG, ES, SP, RJ), Sul (PR, SC, RS) (FORZZA } \\
\text { et al., 2010). Do México às Antilhas, das Guianas ao Rio Grande do } \\
\text { Sul e Tocantins, Paraguai, Uruguai e Argentina (ALMEIDA et al., } \\
\text { 1998). }\end{array}$ \\
\hline \multirow[t]{2}{*}{ Malvales } & \multirow[t]{2}{*}{ Malvaceae } & Eriotheca & $\begin{array}{l}\text { Eriotheca pubescens (Mart. \& Zucc.) } \\
\text { Schott. \& Endl. }\end{array}$ & Cerrado & $\begin{array}{l}\text { Nativa; não endêmica; Norte (TO), Nordeste (BA), Centro-Oeste (MT, } \\
\text { GO, DF, MS), Sudeste (MG, SP) (FORZZA et al., 2010). }\end{array}$ \\
\hline & & Peltaea & $\begin{array}{l}\text { Peltaea edouardii (Hochr.) Krapov. \& } \\
\text { Cristobal }\end{array}$ & $\begin{array}{c}\text { Cerrado } \\
\text { Mata Atlântica }\end{array}$ & $\begin{array}{l}\text { Nativa; não endêmica; Centro-Oeste (MT, GO, MS), Sudeste (MG, } \\
\text { SP), Sul (PR, SC, RS) (FORZZA et al., 2010). }\end{array}$ \\
\hline \multirow[t]{2}{*}{ Myrtales } & \multirow[t]{2}{*}{ Lythraceae } & \multirow[t]{2}{*}{ Diplusodon } & Diplusodon microphyllus Pohl & Cerrado & Nativa; endêmica; Sudeste (MG) (FORZZA, et al., 2010). \\
\hline & & & Diplusodon sessiliflorus Koehne & Cerrado & Nativa; endêmica; Centro-Oeste (GO, DF) (FORZZA et al., 2010) \\
\hline \multirow[t]{5}{*}{ Myrtales } & \multirow[t]{3}{*}{ Melastomataceae } & \multirow[t]{2}{*}{ Miconia } & Miconia albicans (Sw.) Triana & $\begin{array}{l}\text { Amazônia } \\
\text { Caatinga } \\
\text { Cerrado } \\
\text { Mata Atlântica }\end{array}$ & $\begin{array}{l}\text { Nativa; não endêmica; Norte (RR, AP, PA, AM, TO, AC, RO), } \\
\text { Nordeste (MA, PI, CE, RN, PB, PE, BA, AL, SE), Centro-Oeste (MT, } \\
\text { GO, DF, MS), Sudeste (MG, ES, SP, RJ), Sul (PR); (FORZZA et al., } \\
\text { 2010). }\end{array}$ \\
\hline & & & Miconia ferruginata DC. & $\begin{array}{l}\text { Amazônia } \\
\text { Caatinga } \\
\text { Cerrado }\end{array}$ & $\begin{array}{l}\text { Nativa; não endêmica; Norte (PA, TO), Nordeste (BA, SE), Centro- } \\
\text { Oeste (MT, GO, DF, MS), Sudeste (MG, SP) (FORZZA et al., 2010; } \\
\text { MEDEIROS, 2011). }\end{array}$ \\
\hline & & Tibouchina & Tibouchina aegopogon (Naudin) Cogn. & Cerrado & $\begin{array}{l}\text { Nativa; endêmica; Norte (TO), Centro-Oeste (MT, GO, DF), Sudeste } \\
\text { (MG) (FORZZA et al., 2010). Bolívia (www.cerradosdebolivia.org) }\end{array}$ \\
\hline & Myrtaceae & Myrcia & Myrcia splendens (Sw.) DC. & $\begin{array}{l}\text { Amazônia } \\
\text { Caatinga } \\
\text { Cerrado } \\
\text { MataAtlântica } \\
\text { Pantanal } \\
\end{array}$ & $\begin{array}{l}\text { Nativa; não endêmica; Norte (RR, AP, PA, AM, TO, AC, RO), } \\
\text { Nordeste (CE, RN, PB, PE, BA, AL, SE), Centro-Oeste (MT, GO, } \\
\text { MS), Sudeste (MG, ES, SP, RJ), Sul (PR, SC, RS) (FORZZA et al., } \\
\text { 2010). Distrito Federal, Goiás ao Rio Grande do Sul (SILVA JUNIOR, } \\
\text { 2009). }\end{array}$ \\
\hline & Myrtaceae & Psidium & Psidium firmum O.Berg & $\begin{array}{c}\text { Caatinga } \\
\text { Cerrado } \\
\text { Mata Atlântica }\end{array}$ & $\begin{array}{l}\text { Nativa; endêmica; Nordeste (BA), Centro-Oeste (GO, DF), Sudeste } \\
\text { (MG, SP); (FORZZA et al., 2012; ALMEIDA et al., 1998). }\end{array}$ \\
\hline
\end{tabular}


Quadro 4.2 - Florística da comunidade de plantas do Campo Sujo Seco, na bacia hidrográfica do ribeirão Taquaruçu Grande, Palmas (TO), com espécies da classe Magnoliopsida, segundo a ordem, família, gênero, ambiente de ocorrência e distribuição geográfica (continuação)

\begin{tabular}{|c|c|c|c|c|c|}
\hline Ordem & Família & Gênero & Espécie & Domínio/Bioma & Distribuição geográfica \\
\hline \multirow[t]{10}{*}{ Myrtales } & Myrtaceae & Psidium & Pisidium L. & $\begin{array}{c}\text { Amazônia } \\
\text { Caatinga } \\
\text { Cerrado } \\
\text { Mata Atlântica } \\
\text { Pantanal } \\
\end{array}$ & $\begin{array}{l}\text { Nativa; endêmica. Norte (AC, AM, PA, RO, TO), Nordeste ( AL, BA, } \\
\text { CE, MA, PB, PE, PI RN SE), Centro Oeste (DF, GO, MS, MT), } \\
\text { Sudeste (ES, MG, RJ, SP), Sul (PR, RS, SC) (FORZZA et al., 2010) }\end{array}$ \\
\hline & \multirow[t]{9}{*}{ Vochysiaceae } & \multirow[t]{2}{*}{ Qualea } & Qualea grandiflora Mart. & $\begin{array}{l}\text { Amazônia } \\
\text { Caatinga } \\
\text { Cerrado } \\
\text { Mata Atlântica }\end{array}$ & $\begin{array}{l}\text { Nativa; não endêmica; Norte (PA, AM, AC), Nordeste (MA, PI, CE, } \\
\text { BA), Centro-Oeste (MT, GO), Sudeste (MG, SP), Sul (PR) (FORZZA } \\
\text { et al., 2010). MS, TO (ALMEIDA et al., 1998). } \\
\text { Bolívia (www.cerradosdebolivia.org). }\end{array}$ \\
\hline & & & Qualea parviflora Mart. & $\begin{array}{l}\text { Amazônia } \\
\text { Caatinga } \\
\text { Cerrado } \\
\text { Mata Atlântica } \\
\end{array}$ & $\begin{array}{l}\text { Nativa; não endêmica; Norte (PA, AM), Nordeste (MA, PI, CE, BA), } \\
\text { Centro-Oeste (MT, GO), Sudeste (MG, SP) (FORZZA et al., 2010; } \\
\text { MEDEIROS, 2011). } \\
\text { Bolívia (www.cerradosdebolivia.org). }\end{array}$ \\
\hline & & Salvertia & Salvertia convallariodora A.St.-Hil. & $\begin{array}{l}\text { Caatinga } \\
\text { Cerrado }\end{array}$ & $\begin{array}{l}\text { Nativa; não endêmica; Norte (PA, AM, TO), Nordeste (MA, PI, BA), } \\
\text { Centro-Oeste (MT, GO, DF), Sudeste (MG, SP) (FORZZA et al., } \\
\text { 2010). MS, TO (ALMEIDA et al., 1998). }\end{array}$ \\
\hline & & \multirow[t]{6}{*}{ Vochysia } & Vochysia cinnamomea Pohl & $\begin{array}{c}\text { Cerrado } \\
\text { Mata Atlântica }\end{array}$ & $\begin{array}{l}\text { Nativa; endêmica; Norte, Centro-Oeste (MT, GO), Sudeste (MG, SP) } \\
\text { (FORZZA et al., 2010). Paraguai (POTT; POTT, 1994). }\end{array}$ \\
\hline & & & Vochysia divergens Pohl & Cerrado & $\begin{array}{l}\text { Nativa; não endêmica; Centro-Oeste (MT, GO) (FORZZA et al., 2010). } \\
\text { Também em Mato Grosso do Sul e na Bolívia (LORENZI, 2009). }\end{array}$ \\
\hline & & & Vochysia rufa Mart. & Cerrado & $\begin{array}{l}\text { Nativa; endêmica (FORZZA et al., 2010). BA, DF, GO, MA, MG, MT } \\
\text { (PROENÇA et al., 2006). Bolívia (www.cerradosdebolivia.org). }\end{array}$ \\
\hline & & & Vochysia cf. thyrsoidea Pohl & $\begin{array}{c}\text { Cerrado } \\
\text { Mata Atlântica }\end{array}$ & $\begin{array}{l}\text { Nativa; endêmica; Nordeste (CE, BA), Centro-Oeste (GO, DF), } \\
\text { Sudeste (MG, SP) (FORZZA et al., 2010). Mato Grosso, Mato Grosso } \\
\text { do Sul, (ALMEIDA et al., 1998). }\end{array}$ \\
\hline & & & Vochysia tucanorum Mart. & $\begin{array}{c}\text { Cerrado } \\
\text { Mata Atlântica }\end{array}$ & $\begin{array}{l}\text { Nativa; não endêmica (FORZZA et al., 2010). BA, MT, GO, DF, MG, } \\
\text { SP, RJ, PR, SC (MEDEIROS, 2011). } \\
\text { Bolívia (www.cerradosdebolivia.org). }\end{array}$ \\
\hline & & & Vochysia elliptica Mart. & $\begin{array}{c}\text { Cerrado } \\
\text { Mata Atlântica }\end{array}$ & $\begin{array}{l}\text { Nativa; endêmica. Nordeste (PE, BA), Centro-Oeste (GO, DF), Sudeste } \\
\text { (MG, RJ) (FORZZA et al., 2010) }\end{array}$ \\
\hline \multirow[t]{2}{*}{ Oxalidades } & \multirow[t]{2}{*}{ Connaraceae } & Connarus & Connarus suberosus Planch. & Cerrado & $\begin{array}{l}\text { Nativa; endêmica (FORZZA et al, 2010). Norte (PA), Planalto Central } \\
\text { ( BA, PI, MA, MS) e Sul (PR), (LORENZI, 2009). Bolívia } \\
\text { (www.cerradosdebolivia.org). }\end{array}$ \\
\hline & & Rourea & Rourea induta Planch. & $\begin{array}{l}\text { Cerrado } \\
\text { Amazônia }\end{array}$ & $\begin{array}{l}\text { Nativa; não endêmica (PA, RO, PI, BA, MG, GO, MA, CE, PE, MT, } \\
\text { MS, TO, SP (FORZZA et al., 2010). }\end{array}$ \\
\hline
\end{tabular}


Quadro 4.2 - Florística da comunidade de plantas do Campo Sujo Seco, na bacia hidrográfica do ribeirão Taquaruçu Grande, Palmas (TO), com espécies da classe Magnoliopsida, segundo a ordem, família, gênero, ambiente de ocorrência e distribuição geográfica (continuação)

\begin{tabular}{|c|c|c|c|c|c|}
\hline Ordem & Família & Gênero & Espécie & Domínio/Bioma & Distribuição geográfica \\
\hline Oxalidales & Oxalidaceae & Oxalis & $\begin{array}{l}\text { Oxalis densifolia Mart. \& Zucc. ex } \\
\text { Zucc. }\end{array}$ & Cerrado & $\begin{array}{l}\text { Nativa; endêmica; Centro-Oeste (MT, GO, DF), Sudeste (MG, SP, RJ) } \\
\text { (FORZZA et al., 2010; MEDEIROS, 2011). }\end{array}$ \\
\hline Rosales & Moraceae & Brosimum & Brosimum gaudichaudii Trécul & $\begin{array}{l}\text { Amazônia } \\
\text { Caatinga } \\
\text { Cerrado } \\
\text { Mata Atlântica }\end{array}$ & $\begin{array}{l}\text { Nativa; não endêmica; Norte (AM, RO), Nordeste (MA, CE, PB, PE, } \\
\text { BA, AL), Centro-Oeste (MT, GO, DF, MS), Sudeste (MG, ES, SP, RJ), } \\
\text { Sul (PR) (FORZZA et al., 2010). PA, PI, TO (ALMEIDA et al., 1998). } \\
\text { Bolívia (www.cerradosdebolivia.org). }\end{array}$ \\
\hline Santalales & Opiliaceae & Agonandra & $\begin{array}{l}\text { Agonandra brasiliensis Miers ex Benth. } \\
\text { \& Hook.f. }\end{array}$ & $\begin{array}{l}\text { Amazônia } \\
\text { Caatinga } \\
\text { Cerrado } \\
\text { Mata Atlântica }\end{array}$ & $\begin{array}{l}\text { Nativa; não endêmica (FORZZA et al., 2010). BA, DF, CE, ES, GO, } \\
\text { MA, MT, MS, MG, PA, PI, SP, TO (ALMEIDA et al., 1998). Bolívia } \\
\text { (www.cerradosdebolivia.org). }\end{array}$ \\
\hline \multirow[t]{3}{*}{ Sapindales } & \multirow[t]{3}{*}{ Anacardiaceae } & \multirow[t]{3}{*}{ Anacardium } & Anacardium humile A.St.-Hil. & $\begin{array}{l}\text { Caatinga } \\
\text { Cerrado }\end{array}$ & $\begin{array}{l}\text { Nativa; não endêmica; Norte (TO, RO), Nordeste (PI, BA), Centro- } \\
\text { Oeste (MT, GO, DF, MS), Sudeste (MG, SP), Sul (PR) (FORZZA et } \\
\text { al., 2010; Bolívia (www.cerradosdebolivia.org). }\end{array}$ \\
\hline & & & Anacardium occidentale L. & $\begin{array}{c}\text { Amazônia, } \\
\text { Caatinga } \\
\text { Cerrado } \\
\text { Mata Atlântica } \\
\text { Pampa } \\
\text { Pantanal } \\
\end{array}$ & $\begin{array}{l}\text { Nativa; não endêmica; Norte (RR, AP, PA, AM, TO, AC), Nordeste } \\
\text { (MA, PI, CE, RN, PB, PE, BA, AL, SE), Centro-Oeste (MT, GO, DF), } \\
\text { Sudeste (MG, ES, SP, RJ), Sul (PR, SC); BA, DF, GO, MT, MS, MG, } \\
\text { SP (ALMEIDA et al., 1998). }\end{array}$ \\
\hline & & & Anacardium nanum A. St. Hil. & Cerrado & Nativa; endêmica. DF, MT, GO, MG \\
\hline \multirow[t]{4}{*}{ Solanales } & \multirow[t]{3}{*}{ Convolvulaceae } & \multirow[t]{2}{*}{ Merremia } & Merremia tomentosa (Choisy) Hallier & Cerrado & $\begin{array}{l}\text { Nativa; endêmica; Centro-Oeste (MT, GO, DF, MS), Sudeste (MG, } \\
\text { SP), Sul (PR) (FORZZA et al., 2010; MEDEIROS, 2011) }\end{array}$ \\
\hline & & & $\begin{array}{l}\text { Merremia flagellaris (Choisy) } \\
\text { O'Donnell }\end{array}$ & $\begin{array}{l}\text { Caatinga } \\
\text { Cerrado }\end{array}$ & $\begin{array}{l}\text { Nativa; endêmica; Nordeste (PB, BA), Centro-Oeste (GO), Sudeste } \\
\text { (MG) (FORZZA et al., 2010; MEDEIROS, 2011) }\end{array}$ \\
\hline & & Ipomoea & Ipomoea procumbens Mart. ex. Choisy & $\begin{array}{c}\text { Caatinga } \\
\text { Cerrado } \\
\text { Mata Atlântica }\end{array}$ & $\begin{array}{l}\text { Nativa; endêmica; Nordeste (BA), Centro-Oeste (GO, DF), Sudeste } \\
\text { (MG, SP), Sul (PR) (FORZZA et al., 2010; MEDEIROS, 2011). }\end{array}$ \\
\hline & Solanaceae & Solanum & Solanum lycocarpum A.St.-Hil. & $\begin{array}{c}\text { Cerrado } \\
\text { Mata Atlântica }\end{array}$ & $\begin{array}{l}\text { Nativa; não endêmica; Nordeste (BA), Centro-Oeste (MT, GO, DF, } \\
\text { MS), Sudeste (MG, ES, SP, RJ), Sul (PR) (FORZZA et al., 2010). AM, } \\
\text { MA, PA, TO (ALMEIDA et al., 1998, MEDEIROS, 2011). }\end{array}$ \\
\hline
\end{tabular}


Quadro 4.3 - Florística da comunidade de plantas do Campo Sujo Seco, na bacia hidrográfica do ribeirão Taquaruçu Grande, Palmas (TO), com espécies da classe Liliopsida, segundo a ordem, família, gênero, ambiente de ocorrência e distribuição geográfica (continua)

\begin{tabular}{|c|c|c|c|c|c|}
\hline Ordem & Família & Gênero & Espécie & Domínio/Bioma & Distribuição geográfica \\
\hline Arecales & Arecaceae & $\overline{\text { Syagrus }}$ & Syagrus comosa (Mart.) Mart. & $\begin{array}{l}\text { Amazônia } \\
\text { Cerrado }\end{array}$ & $\begin{array}{l}\text { Nativa; endêmica; Norte (PA, TO), Nordeste (PI, BA), Centro-Oeste } \\
\text { (MT, GO), Sudeste (MG) (FORZZA et al., 2010). }\end{array}$ \\
\hline Asparagales & Iridaceae & Trimezia & $\begin{array}{l}\text { Trimezia juncifolia (Klatt.) Benth. \& } \\
\text { Hook. }\end{array}$ & $\begin{array}{l}\text { Amazônia } \\
\text { Cerrado } \\
\text { Mata Atlântica }\end{array}$ & $\begin{array}{l}\text { Nativa; não endêmica; Centro-Oeste (MT, GO, DF, MS), Sudeste (MG, } \\
\text { SP), Sul (PR) (FOORZA et al., 2010; MEDEIROS, 2011) }\end{array}$ \\
\hline Pandanales & Velloziaceae & Vellozia & $\begin{array}{l}\text { Vellozia seubertiana Goethart \& } \\
\text { Henrard }\end{array}$ & $\begin{array}{c}\text { Caatinga } \\
\text { Cerrado }\end{array}$ & $\begin{array}{l}\text { Nativa; endêmica; Nordeste (BA), Centro-Oeste (MT, GO); MT no } \\
\text { Parque Estadual do Cristalino (SMITH; AYENS, 1976; NEVES, } 2009 ; \\
\text { FUNDAÇAO ECOLÒGICA DO CRISTALINO -WEB 2013). }\end{array}$ \\
\hline \multirow[t]{8}{*}{ Poales } & Bromeliaceae & Ananas & $\begin{array}{l}\text { Ananas ananassoides (Baker) L. B. } \\
\text { Sm. }\end{array}$ & $\begin{array}{l}\text { Amazônia, } \\
\text { Caatinga, } \\
\text { Cerrado } \\
\text { Mata Atlântica }\end{array}$ & $\begin{array}{l}\text { Nativa; não endêmica; Norte (AP, PA, AM, TO, RO), Nordeste (CE, } \\
\text { PB), Centro-Oeste (MT, GO, DF, MS), Sudeste (MG, ES, SP, RJ), Sul } \\
\text { (PR) (FORZZA et al., 2010; ALMEIDA et al., 1998). } \\
\text { Bolívia (www.cerradosdebolivia.org). }\end{array}$ \\
\hline & \multirow[t]{5}{*}{ Cyperaceae } & Bulbostylis & $\begin{array}{l}\text { Bulbostylis paradoxa } \quad \text { (Spreng.) } \\
\text { Lindm. }\end{array}$ & $\begin{array}{l}\text { Amazônia } \\
\text { Caatinga } \\
\text { Cerrado }\end{array}$ & $\begin{array}{l}\text { Nativa; não endêmica; Norte, Nordeste, Centro-Oeste, Sudeste, Sul } \\
\text { (FORZZA et al., 2010; MEDEIROS, 2011). Bolívia } \\
\text { (www.cerradosdebolivia.org). }\end{array}$ \\
\hline & & Eleocharis & Eleocharis R. Br. & $\begin{array}{l}\text { Amazônia } \\
\text { Caatinga, Cerrado } \\
\text { Mata Atlântica } \\
\text { Pampa, Pantanal }\end{array}$ & $\begin{array}{l}\text { Nativa; não endêmica; Norte, Nordeste, Centro-Oeste, Sudeste, Sul } \\
\text { (FORZZA et al., 2010). }\end{array}$ \\
\hline & & Fimbristylis & Fimbristylis Vahl. & $\begin{array}{c}\text { Amazônia } \\
\text { Caatinga, Cerrado } \\
\text { Mata Atlântica } \\
\text { Pampa, Pantanal }\end{array}$ & $\begin{array}{l}\text { Nativa; não endêmica; Norte, Nordeste, Centro-Oeste, Sudeste, Sul } \\
\text { (FORZZA et al., 2010). }\end{array}$ \\
\hline & & \multirow[t]{2}{*}{ Rhynchospora } & Rhynchospora brasiliensis Boeckeler & $\begin{array}{l}\text { Amazônia } \\
\text { Cerrado } \\
\text { Mata Atlântica }\end{array}$ & $\begin{array}{l}\text { Nativa; não endêmica; Norte, Nordeste, Centro-Oeste, Sudeste, Sul } \\
\text { (FORZZA et al., 2010). }\end{array}$ \\
\hline & & & $\begin{array}{l}\text { Rhynchospora consanguinea (Kunth.) } \\
\text { Böeckeler }\end{array}$ & $\begin{array}{l}\text { Amazônia } \\
\text { Caatinga } \\
\text { Cerrado }\end{array}$ & $\begin{array}{l}\text { Nativa; não endêmica; Norte, Nordeste, Centro-Oeste, Sudeste, Sul } \\
\text { (FORZZA et al., 2010; PROENÇA et al., 2006). Bolívia } \\
\text { (www.cerradosdebolivia.org). }\end{array}$ \\
\hline & \multirow[t]{2}{*}{ Poaceae } & Axonopus & $\begin{array}{l}\text { Axonopus brasiliensis } \quad \text { (Spreng.) } \\
\text { Kuhlm. }\end{array}$ & $\begin{array}{l}\text { Amazônia } \\
\text { Caatinga } \\
\text { Cerrado } \\
\text { Mata Atlântica }\end{array}$ & $\begin{array}{l}\text { Nativa; não endêmica; Nordeste, Centro-Oeste (MT, GO, DF, MS), } \\
\text { Sudeste (MG, SP), Sul (PR) (FORZZA et al., 2010). Bolívia } \\
\text { (www.cerradosdebolivia.org). }\end{array}$ \\
\hline & & Panicum & Panicum maximum $\mathrm{L}$. & $\begin{array}{c}\text { Amazônia } \\
\text { Cerrado }\end{array}$ & $\begin{array}{l}\text { Amazônia Oriental (DIAS-FILHO; SERRÃO, 1995), Brasil Central } \\
\text { (ANJOS et al., 2009). }\end{array}$ \\
\hline
\end{tabular}


Quadro 4.3 - Florística da comunidade de plantas do Campo Sujo Seco, na bacia hidrográfica do ribeirão Taquaruçu Grande, Palmas (TO), com espécies da classe Liliopsida, segundo a ordem, família, gênero, ambiente de ocorrência e distribuição geográfica (conclusão)

\begin{tabular}{|c|c|c|c|c|c|}
\hline Ordem & Família & Gênero & Espécie & Domínio/Bioma & Distribuição geográfica \\
\hline \multirow[t]{10}{*}{ Poales } & Indeterminada 1 & Indeterminada 1 & Indeterminada 1 & - & - \\
\hline & Indeterminada 2 & Indeterminada 2 & Indeterminada 2 & - & - \\
\hline & Indeterminada 3 & Indeterminada 3 & Indeterminada 3 & - & - \\
\hline & Indeterminada 4 & Indeterminada 4 & Indeterminada 4 & - & - \\
\hline & Indeterminada 5 & Indeterminada 5 & Indeterminada 5 & - & - \\
\hline & Indeterminada 6 & Indeterminada 6 & Indeterminada 6 & - & - \\
\hline & Indeterminada 7 & Indeterminada 7 & Indeterminada 7 & - & - \\
\hline & Indeterminada 8 & Indeterminada 8 & Indeterminada 8 & - & - \\
\hline & Indeterminada 9 & Indeterminada 9 & Indeterminada 9 & - & - \\
\hline & Indeterminada 10 & Indeterminada 10 & Indeterminada 10 & - & - \\
\hline
\end{tabular}


Ainda há poucos registro a respeito da flora tocantinense (FELFILI; FAGG, 2007; CARAÍBA; MEDEIROS, 2009; LIRA; MEDEIROS, 2009; HAIDAR et al., 2011; MEDEIROS et al., 2012; LEMOS, 2013). Das 121 espécies ocorrentes no Campo Sujo Seco da bacia hidrográfica do ribeirão Taquaruçu Grande, apenas 42 (34,7\%) são citadas como ocorrentes no Estado do Tocantins (Quadros 4.2 e 4.3) em publicações científicas como Almeida et al. (1998), Lorenzi (2002; 2008; 2009), Forzza et al. (2010) e Medeiros (2011), que têm uma aboradagem de distribuição geográfica de espécies vegetais no Brasil. A flora dos campos é bem diversificada, pois $74,4 \%$ dos gêneros são compostos por apenas uma espécie. A sua distribuição geográfica é, por vezes, ampla, ocorrendo não apenas no Cerrado brasileiro; algumas espécies ocorrem em outros Domínios/Biomas brasileiros, nos cerrados bolivianos e em outras localidades da América do Sul e América Central (Quadros 4.2 e 4.3).

Um total de 30 espécies (27\%), das 111 ocorrentes nas comunidadedes de plantas dos Campos Sujos estudados, identificadas, é citado na literatura científica como de ocorrência exclusiva no Cerrado; 17 espécies $(15,3 \%)$ ocorrem no Cerrado, Amazônia, Caatinga e Mata Atlântica; 10 espécies (9\%) no Cerrado e na Caatinga; assim como no Cerrado e Amazônia, e também no Cerrado e Mata Atlântica, 9 espécies $(8,1 \%)$ no Cerrado, Amazônia e Caatinga; 3 espécies $(2,7 \%)$ no Cerrado e Pantanal, 6 espécies (5,4\%) no Cerrado, Amazônia, Caatinga, Mata Atlântica e Pantanal; 4 espécies (3,6\%) no Cerrado, Caatinga e Mata Atlântica, como também no Cerrado, Amazônia e Mata Atlântica, e no Cerrado, Amazônia, Caatinga, Mata Atlântica, Pantanal e Pampa; e, uma espécie $(0,9 \%)$ no Cerrado e Pampa, no Cerrado, na Caatinga e Pantanal, no Cerrado, Caatinga, Mata Atlântica e Pantanal, e na Mata Atlântica.

Essa análise indica haver, em se tratando de domínios morfoclimáticos e fitogeográficos brasileiros, um trânsito maior destas espécies entre Cerrado, Caatinga, Amazônia e Mata Atlântica. Essa complexa conexão do Cerrado com os domínios fitogeográficos circundantes tem sido abordada por Oliveira-Filho e Ratter (2000), que mostraram que a interação de fatores, tais como a precipitação sazonal, a baixa fertilidade dos solos, drenagem moderada a alta, incêndios e as flutuações climáticas do quaternário, influenciam a distribuição da vegetação do Cerrado. Estes autores ainda afirmaram que este domínio fitogeográfico, embora visto como corredor seco, não constitui essencialmente uma barreira, pois constitui um corredor para muitas espécies da Amazônia e Mata Atlântica, da mesma forma em relação à Caatinga e ao Chaco.

Entretanto, nem todas as espécies foram exclusivas do território brasileiro; das 111, identificadas, um total de 37 (33,3\%) ocorrem nos cerrados da Bolívia oriental. Em se 
tratando das 30 espécies que são reconhecidas como ocorrentes só no Cerrado (Quadro 4.2; 4.3), 10 espécies (Vochysia rufa, Connarus suberosus, Tibouchina aeopogon, Caryocar brasiliense, Aspilia leucoglossa, Kielmeyera rosea, Clitoria guianensis, Crotalaria unifoliata, Hymenaea stignocarpa, Casselia sp.) também são referidas como de ocorrência nos cerrados da Bolívia oriental (WOOD, 2011), da mesma forma que das 17 espécies que ocorreram no Cerrado, Amazônia, Caatinga e Mata Atlântica, 11 espécies (Ananas ananassoides, Qualea grandiflora, Qualea parviflora, Peltodon tomentosum, Curatella americana, Vigna firmula, Palicourea rígida, Kielmeyera coriacea, Brosimum gawdichaudii e Agonandra brasiliensis) são referidas como de ocorrência nos cerrados da Bolívia pela mesma publicação e assim como todas que as seguem.

Das 10 espécies que ocorreram no Cerrado e Caatinga, Dipteryx alata e Peltodon emerginatus, também têm ocorrência na Bolívia; das 9 espécies que ocorreram no Cerrado, Amazônia e Caatinga, três espécies (Byrsonima verbascifolia, Rhyncosphora consanguinea e Davila eliptica) têm ocorrência na Bolívia; bem como das 10 espécies que ocorreram no Cerrado e Mata Atlântica apenas Deianira cf. chiquitana tem ocorrência na Bolívia; das 10 espécies ocorrentes no Cerrado e Amazônia, duas (Byrsonima coccobolifolia e Leptolobium dasycarpum) têm ocorrência na Bolívia; das 3 espécies que ocorreram no Cerrado e Pantanal, Himatanthus obovatus, também tem ocorrência na Bolívia; das 6 espécies que ocorreram no Cerrado, Amazônia, Caatinga, Mata Atlântica e Pantanal, quatro (Bowdichia virgilioides, Tocoyena formosa, Tabebuia aurea e Tabebuia roseoalba) ocorreram na Bolívia; a espécie Hancornia speciosa, que ocorreu no Cerrado, Caatinga e Pantanal, também tem ocorrência na Bolívia, da mesma forma que a espécie Aspilia foliaceae, que ocorreu no Cerrado e no Pampa.

Isso evidencia que a flora do Campo Sujo Seco da bacia hirográfica do ribeirão Taquaruçu Grande, na serra do Lageado, tem conexões geográficas diversas, parecendo haver grande afinidade florística com a flora do cerrado oriental boliviano, fato que ocorre porque os cerrados bolivianos são uma extensão territorial dos cerrados brasileiros, do qual ainda se tem pouco conhecimento, como mostram os estudos de Segarra (2011) e Wood (2011).

Poucas espécies que ocorreram no Campo Sujo Seco da bacia hidrográfica do ribeirão Taquaruçu Grande têm uma área de distribuição geográfica de ampla distribuição Neotropical, como é o caso da Tocoyena formosa (jenipapo) com ocorrência desde o México, Brasil, Argentina (FORZZA et al., 2010) e Bolívia (WOOD, 2011). Da mesma forma que a Casearia sylvestris, do México às Antilhas, Brasil, Paraguai, Uruguai e Argentina (FORZZA 
et al., 2010); e, Bowdichia virgilioides, que ocorre desde a Guiana, Suriname, Venezuela, Colômbia, Bolívia, Paraguai e Brasil, onde só não tem ocorrência registrada para o Domínio Pampa (FORZZA, et al., 2010).

Do ponto de vista da importância da biodiversidade, o Campo Sujo Seco da bacia hidrográfica do ribeirão Taquaruçu Grande abriga espécies que apresentam distribuição geográfica de certa forma restrita no Cerrado brasileiro, como:

- Vellozia seubertiana, que tem ocorrência citada apenas para Mato Grosso, no Parque Estadual do Cristalino (SEMA/MT, 2009), Mato Grosso e Goiás (SMITH; AYENSU, 1976) e Chapada Diamantina - BA (NEVES, 2009);

- Byrsonima subterranea que foi considerada presumivelmente extinta no estado de São Paulo (SMA-SP, 1998);

- espécies do gênero Mimosa como Mimosa albolanata cf. var. brasiliana de ocorrência restrita no Brasil Central (GO, MG e DF); nos campos rupestres de Minas é restrita ao Espinhaço Central (DUTRA, 2009;

- Mimosa radula cf. var. imbricata, ocorre em pequenas populações isoladas em poucas localidades. Sua ocorrência é restrita aos campos rupestre de Minas Gerais (serra da Canastra, área disjunta da Cadeia do Espinhaço) e às serras de Goiás entre 990-1.370 m de altitude (DUTRA, 2009).

\subsubsection{Formas de vida vegetal}

Outro aspecto importante que se deve considerar a respeito da flora da comunidade de plantas do Campo Sujo, uma vez que este tem em destaque o componente herbáceosubarbustivo-arbustivo, é a influência do clima na dinâmica anual da vida de tais plantas. Sendo o Cerrado um Domínio de clima tropical sujeito à estacionalidade climática, este tem efeitos determinantes na composição florística do estrato herbáceo e subarbustivo, com mudanças na paisagem entre as estações seca e chuvosa. Segundo Muller-Dombois e Ellemberg (1974) o caráter da paisagem é fortemente influenciado pelos tipos de vegetação e formas de vida que evidenciam mudanças sazonais.

Nas áreas de Campo Sujo Seco na bacia hidrográfica do ribeirão Taquaruçu Grande. ocorreram as formas de vida tipo Fanerófitas (árvores, arbustos e lianas, cujas gemas localizam-se a cima de $30 \mathrm{~cm}$ do nível do solo), Caméfitas (plantas perenes com base lenhosa nas quais as gemas estão a menos de $30 \mathrm{~cm}$ do solo), Hemicriptófitas (plantas escondidas ou 
semi-escondidas durante a estação do ano desfavorável, com gemas ao nível do solo), Terófitas (plantas anuais) e Geófitas (plantas perenes com gemas subterrâneas contidas em bulbo ou rizoma), porém com predomínio de Fanerófitas, Hemicriptófitas e de Caméfitas (Quadro 4.4; Figura 4.35), de acordo com a classificação de formas de vida das plantas de Raunkiaër (1934), segundo o seu comportamento na estação mais desfavorável do ano. As famílias mais expressivas quanto à forma de vida foram Fabaceae e Vochysiaceae, que são do tipo fanerófita (Quadro 4.4).

Quadro 4.4 - Espécies da comunidade de plantas do Campo Sujo Seco (topo e vertente), na bacia hidrográfica do ribeirão Taquaruçu Grande, Palmas (TO), com formas de vida (Fan = Fanerófitas; Hem $=$ Hemicriptófitas; Cam = Caméfitas; Ter $=$ Terófitas; Geo = Geófitas) $($ continua)

\begin{tabular}{|c|c|c|c|}
\hline Família/ Espécie & Topo & Vertente & Forma de vida \\
\hline \multicolumn{4}{|l|}{ ANACARDIACEAE } \\
\hline Anacardium humile & $\mathrm{x}$ & $\mathrm{x}$ & Fan \\
\hline Anacardium nanum & $\mathrm{x}$ & $\mathrm{x}$ & Cam \\
\hline Anacardium occidentale & $\mathrm{x}$ & $\mathrm{x}$ & Fan \\
\hline \multicolumn{4}{|l|}{ ANNONACEAE } \\
\hline Annona coriacea & $\mathrm{x}$ & $\mathrm{x}$ & Fan \\
\hline Annona crassiflora & $\mathrm{x}$ & $\mathrm{x}$ & Fan \\
\hline \multicolumn{4}{|l|}{ APOCYNACEAE } \\
\hline Hancornia speciosa & $\mathrm{x}$ & $\mathrm{x}$ & Fan \\
\hline Himatanthus obovatus & $\mathrm{x}$ & $\mathrm{x}$ & Fan \\
\hline \multicolumn{4}{|l|}{ ARALIACEAE } \\
\hline Schefflera macrocarpa & $\mathrm{x}$ & $\mathrm{x}$ & Fan \\
\hline \multicolumn{4}{|l|}{ ARECACEAE } \\
\hline Syagrus comosa & $\mathrm{x}$ & $\mathrm{x}$ & Fan \\
\hline \multicolumn{4}{|l|}{ ASTERACEAE } \\
\hline Aspilia foliacea & $\mathrm{x}$ & & Geo \\
\hline Aspilia leucoglossa & $\mathrm{x}$ & & Geo \\
\hline Piptocarpha rotundifolia & $\mathrm{x}$ & $\mathrm{x}$ & Fan \\
\hline Lessigianthus obtusatus & $\mathrm{x}$ & $\mathrm{x}$ & Can \\
\hline \multicolumn{4}{|l|}{ BIGNONIACEAE } \\
\hline Tabebuia aurea & & $\mathrm{x}$ & Fan \\
\hline Tabebuia roseoalba & $\mathrm{x}$ & & Fan \\
\hline Zeyhera tuberculosa & $\mathrm{x}$ & $\mathrm{x}$ & Fan \\
\hline \multicolumn{4}{|l|}{ BROMELAACEAE } \\
\hline Ananas ananassoides & & $\mathrm{x}$ & Hem \\
\hline \multicolumn{4}{|l|}{ CARYOCARACEAE } \\
\hline Caryocar brasiliense & $\mathrm{x}$ & & Fan \\
\hline \multicolumn{4}{|l|}{ CELASTRACEAE } \\
\hline Salacia crassifolia & $\mathrm{x}$ & $\mathrm{x}$ & Fan \\
\hline \multicolumn{4}{|l|}{ CALOPHYLLACEAE } \\
\hline Kielmeyera coriacea & $\mathrm{x}$ & $\mathrm{x}$ & Fan \\
\hline Kielmeyera lanthrophyton & & $\mathrm{x}$ & Fan \\
\hline Kielmeyera rosea & $\mathrm{x}$ & & Fan \\
\hline
\end{tabular}


Quadro 4.4 - Espécies da comunidade de plantas do Campo Sujo Seco (topo e vertente), na bacia hidrográfica do ribeirão Taquaruçu Grande, Palmas (TO), com formas de vida (Fan = Fanerófitas; Hem = Hemicriptófitas; Cam = Caméfitas; Ter = Terófitas; Geo = Geófitas) (continuação)

\begin{tabular}{|c|c|c|c|}
\hline Família/ Espécie & Topo & Vertente & Forma de vida \\
\hline \multicolumn{4}{|l|}{ CLUSIACEAE } \\
\hline Platonia insignis & & $\mathrm{x}$ & Fan \\
\hline \multicolumn{4}{|l|}{ CONNARACEAE } \\
\hline Connarus suberosus & $\mathrm{x}$ & $\mathrm{x}$ & Fan \\
\hline Rourea induta & $\mathrm{x}$ & $\mathrm{x}$ & Fan \\
\hline \multicolumn{4}{|l|}{ CONVOLVULACEAE } \\
\hline Ipomoea procumbens & $\mathrm{x}$ & $\mathrm{x}$ & Hem \\
\hline Merremia flagellaris & $\mathrm{x}$ & $\mathrm{x}$ & Hem \\
\hline Merremia tomentosa & & $\mathrm{x}$ & Hem \\
\hline \multicolumn{4}{|l|}{ CYPERACEAE } \\
\hline Bulbostylis pradoxa & $\mathrm{x}$ & $\mathrm{x}$ & Cam \\
\hline Eleocharis $\mathrm{sp}$ & $\mathrm{x}$ & $\mathrm{x}$ & Geo \\
\hline Fimbristylis sp & $\mathrm{x}$ & $\mathrm{x}$ & Hem \\
\hline Rhynchospora brasiliensis & $\mathrm{x}$ & $\mathrm{x}$ & Hem \\
\hline Rhynchospora consanguinea & $\mathrm{x}$ & $\mathrm{x}$ & Hem \\
\hline \multicolumn{4}{|l|}{ DILLENIACEAE } \\
\hline Curatella americana & $\mathrm{x}$ & $\mathrm{x}$ & Fan \\
\hline Davilla elliptica & $\mathrm{x}$ & $\mathrm{x}$ & Fan \\
\hline \multicolumn{4}{|l|}{ EBENACEAE } \\
\hline Diospyros hispida & $\mathrm{x}$ & $\mathrm{x}$ & Fan \\
\hline \multicolumn{4}{|l|}{ ERYTHROXYLACEAE } \\
\hline Erythroxylum cf. citrifolium & $\mathrm{x}$ & & Fan \\
\hline Erythroxylum suberosum & $\mathrm{x}$ & $\mathrm{x}$ & Fan \\
\hline Erythroxylum tortuosum & & $\mathrm{x}$ & Fan \\
\hline \multicolumn{4}{|l|}{ EUPHORBIACEAE } \\
\hline Manihot acuminatissima & & $\mathrm{x}$ & Cam \\
\hline Manihot sparsifolia & $\mathrm{x}$ & $\mathrm{x}$ & Cam \\
\hline Croton goyazensis & $\mathrm{x}$ & $\mathrm{x}$ & Cam \\
\hline \multicolumn{4}{|l|}{ FABACEAE } \\
\hline Andira humilis & $\mathrm{x}$ & $\mathrm{x}$ & Fan \\
\hline Bauhinia curvula & $\mathrm{x}$ & $\mathrm{x}$ & Fan \\
\hline Bauhinia rufa & $\mathrm{x}$ & $\mathrm{x}$ & Fan \\
\hline Bowdichia virgilioides & $\mathrm{x}$ & $\mathrm{x}$ & Fan \\
\hline Calliandra dysantha & $\mathrm{x}$ & $\mathrm{x}$ & Fan \\
\hline Chamaecrista orbiculata & $\mathrm{x}$ & $\mathrm{x}$ & Fan \\
\hline Dimorphandra mollis & $\mathrm{x}$ & $\mathrm{x}$ & Fan \\
\hline Dipteryx alata & $\mathrm{x}$ & $\mathrm{x}$ & Fan \\
\hline Hymenaea stigonocarpa & $\mathrm{x}$ & $\mathrm{x}$ & Fan \\
\hline Leptolobium dasycarpum & $\mathrm{x}$ & $\mathrm{x}$ & Fan \\
\hline Mimosa albolanata cf. var. brasiliana & $\mathrm{x}$ & $\mathrm{x}$ & Fan \\
\hline Mimosa radula cf. var. imbricata & $\mathrm{x}$ & $\mathrm{x}$ & Cam \\
\hline Platypodium elegans & $\mathrm{x}$ & & Fan \\
\hline Pterodon emarginatus & $\mathrm{x}$ & & Fan \\
\hline Senna velutina & & $\mathrm{x}$ & Fan \\
\hline Stryphnodendron adstringens & $\mathrm{x}$ & $\mathrm{x}$ & Fan \\
\hline Tachigali rugosa & $\mathrm{x}$ & $\mathrm{x}$ & Fan \\
\hline Captosema scarlatium & $\mathrm{x}$ & $\mathrm{x}$ & Hem \\
\hline
\end{tabular}


Quadro 4.4 - Espécies da comunidade de plantas do Campo Sujo Seco (topo e vertente), na bacia hidrográfica do ribeirão Taquaruçu Grande, Palmas (TO), com formas de vida (Fan = Fanerófitas; Hem = Hemicriptófitas; Cam = Caméfitas; Ter = Terófitas; Geo = Geófitas) (continuação)

\begin{tabular}{|c|c|c|c|}
\hline Família/ Espécie & Topo & Vertente & Forma de vida \\
\hline \multicolumn{4}{|l|}{ FABACEAE } \\
\hline Centrosema virginianum & $\mathrm{x}$ & & Hem \\
\hline Chamaecrista diphylla & $\mathrm{x}$ & & Cam \\
\hline Chamaecrista serpens & $\mathrm{x}$ & $\mathrm{x}$ & Cam \\
\hline Clitória guianensis & $\mathrm{x}$ & $\mathrm{x}$ & Hem \\
\hline Crotalaria unifoliolata & $\mathrm{x}$ & $\mathrm{x}$ & Cam \\
\hline Vignia firmula & $\mathrm{x}$ & $\mathrm{x}$ & Cam \\
\hline Vignia speciosa & $\mathrm{x}$ & & Cam \\
\hline \multicolumn{4}{|l|}{ GENTIANACEAE } \\
\hline Deianira cf. chiquitana & $\mathrm{x}$ & & Cam \\
\hline \multicolumn{4}{|l|}{ IRIDACEAE } \\
\hline Trimezia juncifolia & $\mathrm{x}$ & $\mathrm{x}$ & Geo \\
\hline \multicolumn{4}{|l|}{ LAMIACEAE } \\
\hline Amasonia campestris & $\mathrm{x}$ & $\mathrm{x}$ & Hem \\
\hline Hyptis peduncularis & $\mathrm{x}$ & & Hem \\
\hline Peltodon tomentosus & $\mathrm{x}$ & & Hem \\
\hline \multicolumn{4}{|l|}{ LYTHRACEAE } \\
\hline Diplusodon microphyllus & $\mathrm{x}$ & & Cam \\
\hline Diplusodon sessiliflorus & $\mathrm{x}$ & & Cam \\
\hline \multicolumn{4}{|l|}{ MALPIGHIACEAE } \\
\hline Byrsonima coccobolifolia & $\mathrm{x}$ & $\mathrm{x}$ & Fan \\
\hline Byrsonima pachyphylla & $\mathrm{x}$ & $\mathrm{x}$ & Fan \\
\hline Byrsonima subterrânea & $\mathrm{x}$ & $\mathrm{x}$ & Fan \\
\hline Byrsonima verbascifolia & $\mathrm{x}$ & $\mathrm{x}$ & Fan \\
\hline \multicolumn{4}{|l|}{ MALVACEAE } \\
\hline Eriotheca pubescens & $\mathrm{x}$ & & Fan \\
\hline Peltaea edouardii & $\mathrm{x}$ & $\mathrm{x}$ & Hem \\
\hline \multicolumn{4}{|l|}{ MELASTOMATACEAE } \\
\hline Miconia albicans & & $\mathrm{x}$ & Fan \\
\hline Miconia ferruginata & $\mathrm{x}$ & & Fan \\
\hline Tibouchina aegopogon & $\mathrm{x}$ & $\mathrm{x}$ & Cam \\
\hline \multicolumn{4}{|l|}{ MORACEAE } \\
\hline Brosimum gaudichaudii & $\mathrm{x}$ & $\mathrm{x}$ & Fan \\
\hline \multicolumn{4}{|l|}{ MYRTACEAE } \\
\hline Myrcia splendens & $\mathrm{x}$ & $\mathrm{x}$ & Fan \\
\hline Psidium firmum & $\mathrm{x}$ & $\mathrm{x}$ & Fan \\
\hline Psidium sp. & $\mathrm{x}$ & & Fan \\
\hline \multicolumn{4}{|l|}{ OCHNACEAE } \\
\hline Ouratea hexasperma & $\mathrm{x}$ & $\mathrm{x}$ & Fan \\
\hline Ouratea spectabilis & $\mathrm{x}$ & $\mathrm{x}$ & Fan \\
\hline \multicolumn{4}{|l|}{ OPILIACEAE } \\
\hline Agonandra brasiliensis & & $\mathrm{x}$ & Fan \\
\hline \multicolumn{4}{|l|}{ OXALIDACEAE } \\
\hline Oxalis densifolia & $\mathrm{x}$ & $\mathrm{x}$ & Cam \\
\hline \multicolumn{4}{|l|}{ POACEAE } \\
\hline Axonopus brasiliensis & $\mathrm{x}$ & $\mathrm{x}$ & Hem \\
\hline Indeterminada 1 & & $\mathrm{x}$ & Hem \\
\hline Indeterminada 2 & $\mathrm{x}$ & $\mathrm{x}$ & Hem \\
\hline Indeterminada 3 & $\mathrm{x}$ & $\mathrm{x}$ & Hem \\
\hline Indeterminada 4 & $\mathrm{x}$ & $\mathrm{x}$ & Hem \\
\hline
\end{tabular}


Quadro 4.4 - Espécies da comunidade de plantas do Campo Sujo Seco (topo e vertente), na bacia hidrográfica do ribeirão Taquaruçu Grande, Palmas (TO), com formas de vida (Fan = Fanerófitas; Hem $=$ Hemicriptófitas; Cam $=$ Caméfitas; Ter $=$ Terófitas; Geo $=$ Geófitas $)$ (conclusão)

\begin{tabular}{|c|c|c|c|}
\hline Família/ Espécie & Topo & Vertente & Forma de vida \\
\hline \multicolumn{4}{|l|}{ POACEAE } \\
\hline Indeterminada 5 & $\mathrm{x}$ & $\mathrm{x}$ & Hem \\
\hline Indeterminada 6 & $\mathrm{x}$ & $\mathrm{x}$ & Hem \\
\hline Indeterminada 7 & $\mathrm{x}$ & $\mathrm{x}$ & Hem \\
\hline Indeterminada 8 & $\mathrm{x}$ & $\mathrm{x}$ & Hem \\
\hline Indeterminada 9 & $\mathrm{x}$ & & Hem \\
\hline Indeterminada10 & $\mathrm{x}$ & $\mathrm{x}$ & Hem \\
\hline Panicum maximum & & $\mathrm{x}$ & Hem \\
\hline \multicolumn{4}{|l|}{ RUBIACEAE } \\
\hline Palicourea rigida & & $\mathrm{x}$ & Fan \\
\hline Tocoyena formosa & $\mathrm{x}$ & & Fan \\
\hline Borreria eryngioides & & $\mathrm{x}$ & Ter \\
\hline Mitracarpus frigidus & $\mathrm{x}$ & $\mathrm{x}$ & Ter \\
\hline \multicolumn{4}{|l|}{ SALICACEAE } \\
\hline Casearia sylvestris & $\mathrm{x}$ & $\mathrm{x}$ & Fan \\
\hline \multicolumn{4}{|l|}{ SOLANACEAE } \\
\hline Solanum lycocarpum & $\mathrm{x}$ & & Fan \\
\hline \multicolumn{4}{|l|}{ VELLOZIACEAE } \\
\hline Vellozia seubertiana & $\mathrm{x}$ & $\mathrm{x}$ & Fan \\
\hline \multicolumn{4}{|l|}{ VERBENACEAE } \\
\hline Casselia sp. & $\mathrm{x}$ & & Hem \\
\hline Lippia florida & $\mathrm{x}$ & & Hem \\
\hline \multicolumn{4}{|l|}{ VOCHYSIACEAE } \\
\hline Qualea grandiflora & $\mathrm{x}$ & $\mathrm{x}$ & Fan \\
\hline Qualea parviflora & $\mathrm{x}$ & $\mathrm{x}$ & Fan \\
\hline Salvertia convallariodora & $\mathrm{x}$ & $\mathrm{x}$ & Fan \\
\hline Vochysia cf. divergens & & $\mathrm{x}$ & Fan \\
\hline Vochysia rufa & $\mathrm{x}$ & $\mathrm{x}$ & Fan \\
\hline Vochysia cf. thyrsoidea & & $\mathrm{x}$ & Fan \\
\hline Vochysia cinnamomea & $\mathrm{x}$ & $\mathrm{x}$ & Fan \\
\hline Vochysia elliptica & $\mathrm{x}$ & & Fan \\
\hline Vochysia tucanorum & $\mathrm{x}$ & $\mathrm{x}$ & Fan \\
\hline
\end{tabular}

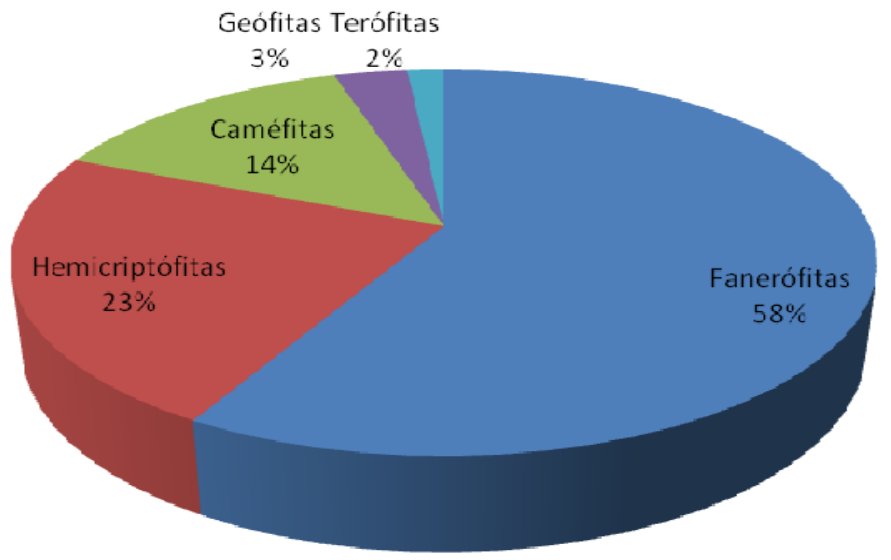

Figura 4.35 - Contribuição das formas de vida das espécies da comunidade de plantas do Campo Sujo Seco, na bacia hidrográfica do ribeirão Taquaruçu Grande, Palmas (TO) 


\subsubsection{Florística e fitossociologia}

O Campo Sujo Seco da bacia hidrográfica do ribeirão Taquaruçu Grande, cujas parcelas de amostragem foram A1V; A1T; A2V; A2T; A3V; A3T; 4E; A4T; A5V; A5T, teve um total de 39 famílias, 82 gêneros e 121 espécies, sendo 77 espécies componentes do estrato subarbustivo-arbustivo-arbóreo e 44 do estrato herbáceo-subarbustivo (Quadro 4.2; 4.3).

A família Fabaceae destacou-se entre as demais com 25 espécies, seguida pela Poaceae com 12 e Vochysiaceae com 9 (Figura 4.36). Em levantamentos fitossociológicos do Cerrado, essas famílias estão sempre entre as que apresentam maiores números de espécies. A maioria das famílias $(92,3 \%)$ teve um número de espécies inferior a 9 (Figura 4.36) e, deste percentual, as famílias Velloziaceae, Arecaceae, Araliaceae, Ebenaceae, Celastraceae, Moraceae, Salicaceae, Oxalidaceae, Iridiaceae, Clusiaceae, Opiliaceae, Bromeliaceae, Solanaceae, Caryocaraceae e Gentianaceae foram representadas apenas por uma espécie.

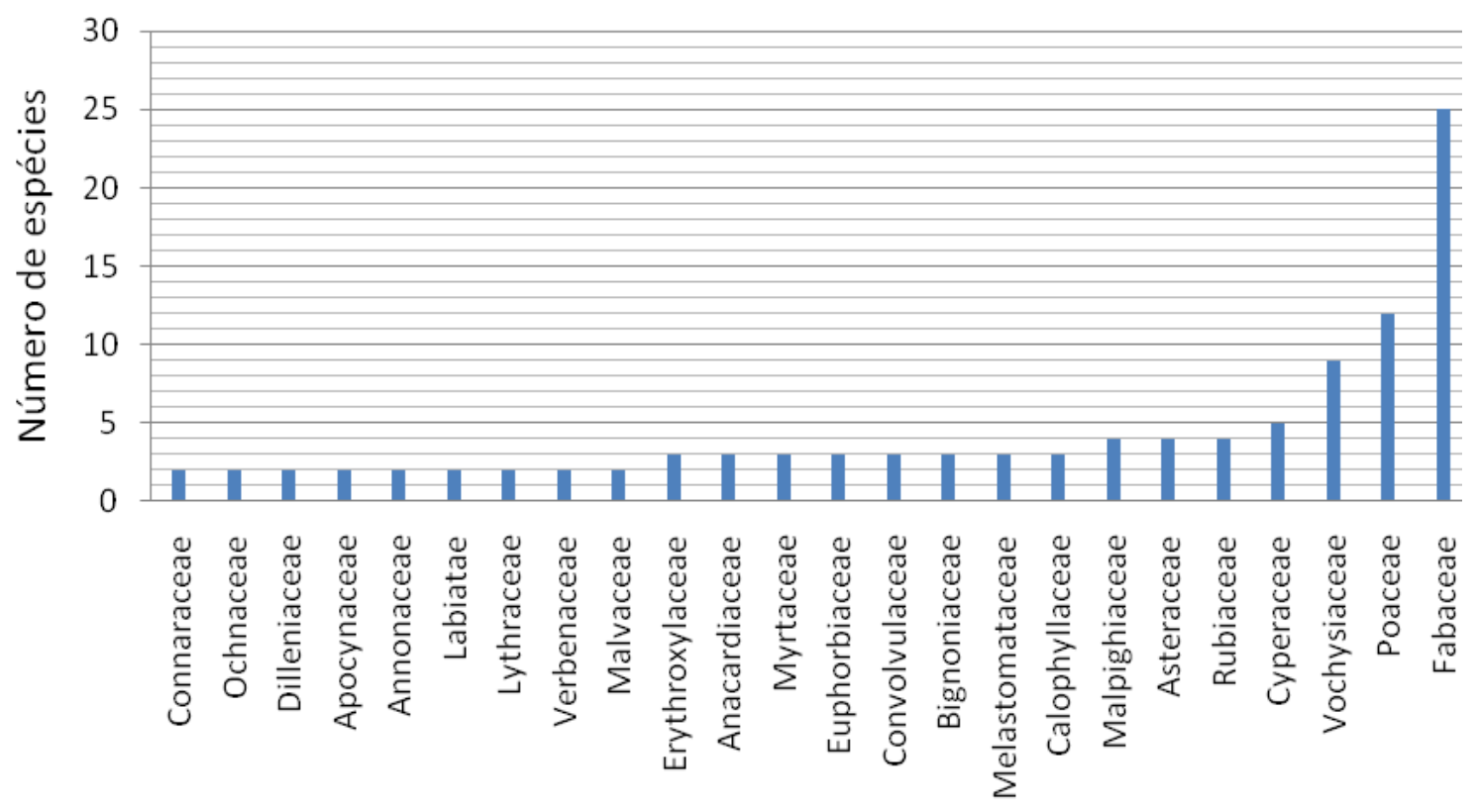

Famílias

Figura 4.36 - Distribuição do número de espécies, por famílias com $\geq 2$ espécies, da comunidade de plantas do Campo Sujo Seco, na bacia hidrográfica do ribeirão Taquaruçu Grande, Palmas (TO)

Comparando a flora do Campo Sujo Seco da bacia hidrográfica do ribeirão Taquaruçu Grande com a de outros Campos Sujos em número de espécies, gêneros e famílias, o Campo Sujo Seco desta pesquisa apresentou maior semelhança com o Campo Sujo da Fazenda Água Limpa (DF) estudado por Munhoz e Felfili (2006). Outros Campos Sujos também foram 
estudados: da fazenda Água Limpa (DF) estudados por Amaral (2008); de Itirapina (SP), por Tanus e Assis (2004); da Estação Ecológica do Panga (MG), por Moreno et al. (2008); da Floresta Nacional de Silvânia (GO), por Araújo et al. (2012); e, da Estação Ecológica de Pirapitinga (MG), estudados por Giácomo et al. (2013) (Figura 4.37).

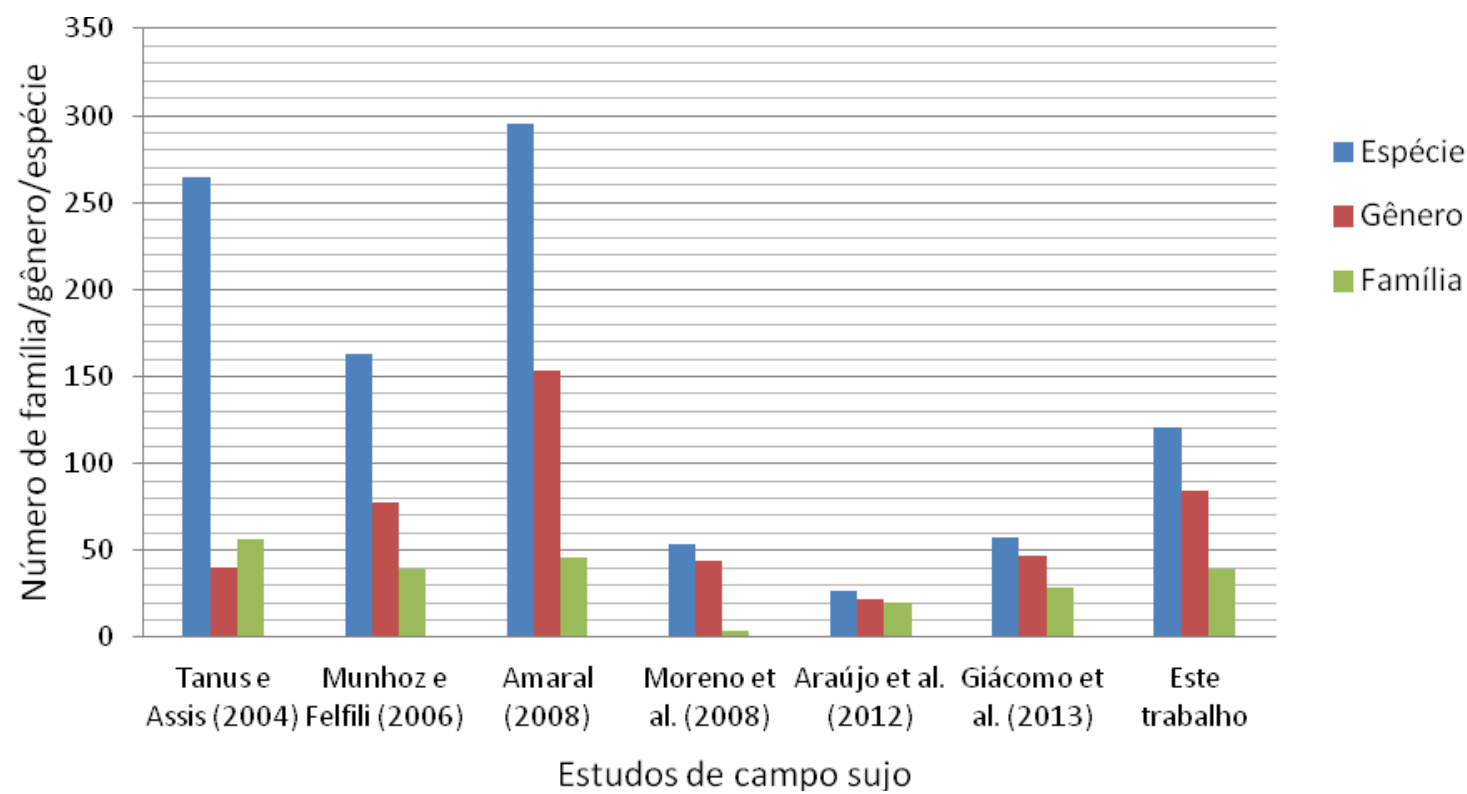

Figura 4.37 - Número de espécies, gêneros e famílias de alguns estudos em áreas de Campo Sujo do Cerrado brasileiro e do Campo Sujo Seco, na bacia hidrográfica do ribeirão Taquaruçu Grande, Palmas (TO)

Quanto aos Campos Sujos de Itirapina, é preciso que se considere a sua localização geográfica. Segundo Durigan et al. (2004), os cerrados de São Paulo possuem características peculiares, formando um bloco particular, por se situarem no limite sul do Cerrado e estarem sujeitos a geadas e a períodos de seca menos prolongados que os do Brasil Central.

Por outro lado, o Campo Sujo da Fazenda Água Limpa estudado por Amaral (2008), estava a sete anos sem ocorrência de queimadas e isso é um fator que deve ser considerado, pois a autora comentou ter havido decréscimo de $9 \%$ das plantas herbáceas, mas também aumento de $16 \%$ de subarbustos nesses campos.

A área de Campos Sujos da Estação Ecológica do Panga (MG) era uma fazenda que possuía como atividade principal a agropecuária até 1984, que foi comprada em 1985 pela Universidade Federal de Uberlândia e se tornou uma área de preservação ambiental e a partir de então a vegetação vem se reconstituíndo naturalmente, além de ocorrem em altitudes mais elevadas (MORENO et al., 2008) que os Campos Sujos Secos do ribeirão Taquaruçu Grande. 
Da mesma forma, os Campos Sujos da Floresta Nacional de Silvânia (GO) estão em altitudes bem mais elevadas, 900 m em média (ARAÚJO et al., 2012).

Os Campos Sujos da Estação Ecológica de Pirapitinga na ilhas das Três Marias (MG) estão localizados nas margens do Reservatório da Usina Hidrelétrica de Três Marias, sujeito à oscilação do nível da barragem entre a cota máxima de $568 \mathrm{~m}$ até a mínima de $559 \mathrm{~m}$ acima do nível do mar, sendo que em sua cota máxima, a Estação assume feição de ilha. Pode ser que essa condição ambiental tenha influências sobre a flora dos campos desta localidade, pois em termos de altitude são semelhantes ao da bacia do Taquaruçu Grande.

\subsection{Estrato subarbustivo-arbustivo-arbóreo do Campo Sujo Seco}

A vegetação do estrato subarbustivo-arbustivo-arbóreo do Campo Sujo Seco da bacia hidrográfica do ribeirão Taquaruçu Grande foi composta por 31 famílias, 53 gêneros, 77 espécies. As famílias Fabaceae e Vochysiaceae tiveram maiores números de espécies e 97,4\% das famílias tiveram menos que cinco espécies, sendo que deste percentual, 14 famílias tiveram apenas uma espécie (Figura 4.38).

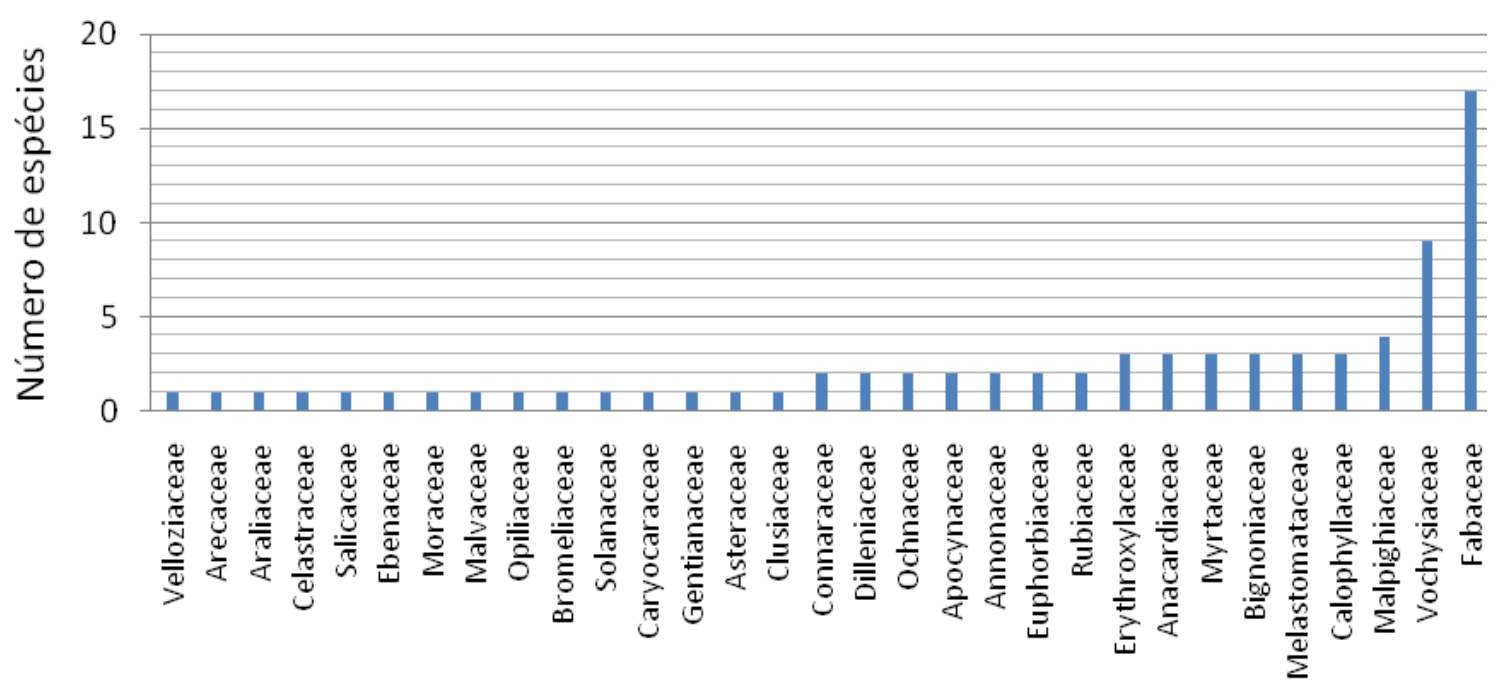

Famílias

Figura 4.38 - Distribuição do número de espécies, por famílias do estrato subarbustivo-arbustivoarbóreo, da comunidade de plantas do Campo Sujo Seco, na bacia hidrográfica do ribeirão Taquaruçu Grande, Palmas (TO)

Do total de 77 espécies, 48,1\% tiveram $\geq 10$ plantas (Figura 4.39) e 51,9\% tiveram menos que 10 plantas (espécies que apresentaram densidade absoluta $\leq 9,0$ indivíduos.ha $^{-1}$, 
Tabela 4.10). A densidade total foi 2.761,47 indivíduos.ha ${ }^{-1}$, a dominância foi 5,64 $\mathrm{m}^{2}$. ha ${ }^{-1}$, o diâmetro médio foi 4,61 cm e a altura média de 1,118 m (Tabela 4.11). Estes valores incluem plantas vivas e seus galhos mortos e plantas mortas registradas em condições de relevo dos tipos topo e vertente.

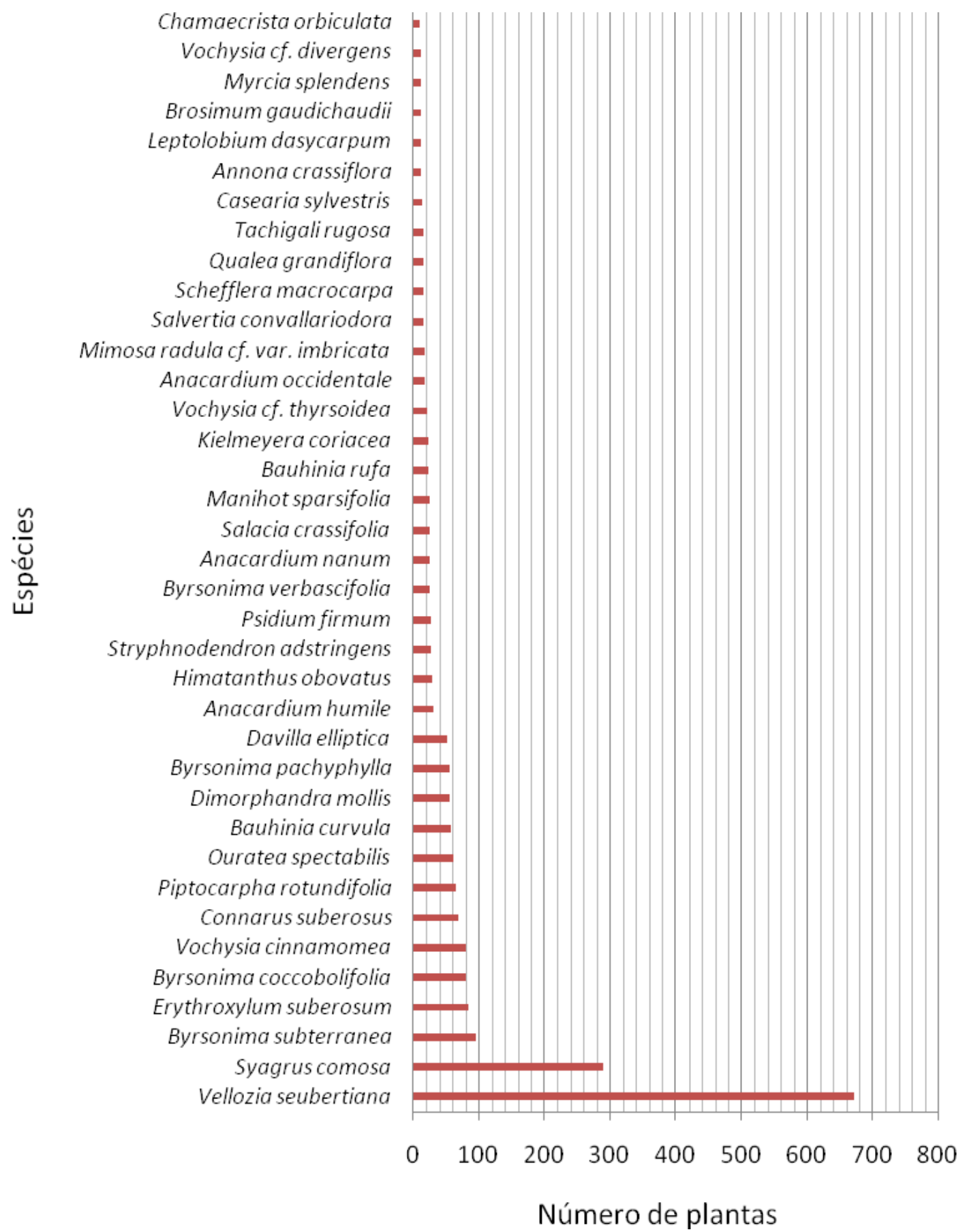

Figura 4.39 - Distribuição do número de plantas, por espécie com $\geq 10$ indíviduos.ha $^{-1}$, no Campo Sujo Seco, na bacia hidrográfica do ribeirão Taquaruçu Grande, Palmas (TO) 
Tabela 4.10 - Espécies vivas do Campo Sujo Seco (A1V; A1T; A2V; A2T; A3V; A3T; A4V; A4T; A5V; A5T), na bacia hidrográfica do ribeirão Taquaruçu Grande, Palmas (TO), com densidade absoluta (AbsDe); densidade relativa (RelDe); frequência absoluta (AbsFr); frequência relativa (RelFr); dominância absoluta (AbsDo); dominância relativa (RelDo); em ordem decrescente de índice de valor de importância (IVI) (continua)

\begin{tabular}{|c|c|c|c|c|c|c|c|}
\hline Espécies & $\begin{array}{c}\text { AbsDe } \\
\text { (ind/ha) }\end{array}$ & $\begin{array}{c}\text { RelDe } \\
(\%)\end{array}$ & $\begin{array}{c}\text { AbsFr } \\
(\%)\end{array}$ & $\begin{array}{c}\text { RelFr } \\
(\%)\end{array}$ & $\begin{array}{l}\text { AbsDo } \\
\left(\mathbf{m}^{2} / \mathbf{h a}\right)\end{array}$ & $\begin{array}{c}\text { RelDo } \\
(\%)\end{array}$ & $\begin{array}{l}\text { IVI } \\
(\%)\end{array}$ \\
\hline Vellozia seubertiana & 671.0 & 29.20 & 78.00 & 8.20 & 1.97 & 34.98 & 72.38 \\
\hline Syagrus comosa & 289.0 & 12.58 & 71.00 & 7.47 & 0.50 & 8.78 & 28.82 \\
\hline Erythroxylum suberosum & 83.0 & 3.61 & 44.00 & 4.63 & 0.22 & 3.88 & 12.12 \\
\hline Piptocarpha rotundifolia & 64.0 & 2.79 & 40.00 & 4.21 & 0.25 & 4.50 & 11.49 \\
\hline Connarus suberosus & 68.0 & 2.96 & 38.00 & 4.00 & 0.20 & 3.61 & 10.57 \\
\hline Byrsonima coccobolifolia & 80.0 & 3.48 & 34.00 & 3.58 & 0.16 & 2.86 & 9.92 \\
\hline Dimorphandra mollis & 56.0 & 2.44 & 33.00 & 3.47 & 0.18 & 3.22 & 9.13 \\
\hline Ouratea spectabilis & 60.0 & 2.61 & 36.00 & 3.79 & 0.11 & 1.96 & 8.35 \\
\hline Byrsonima pachyphylla & 55.0 & 2.39 & 33.00 & 3.47 & 0.13 & 2.30 & 8.17 \\
\hline Davilla elliptica & 52.0 & 2.26 & 37.00 & 3.89 & 0.10 & 1.80 & 7.96 \\
\hline Byrsonima subterranea & 95.0 & 4.13 & 24.00 & 2.52 & 0.07 & 1.30 & 7.95 \\
\hline Vochysia cinnamomea & 80.0 & 3.48 & 16.00 & 1.68 & 0.15 & 2.59 & 7.75 \\
\hline Salvertia convallariodora & 16.0 & 0.70 & 14.00 & 1.47 & 0.25 & 4.48 & 6.64 \\
\hline Bauhinia curvula & 57.0 & 2.48 & 38.00 & 4.00 & 0.01 & 0.11 & 6.59 \\
\hline Stryphnodendron adstringens & 26.0 & 1.13 & 23.00 & 2.42 & 0.09 & 1.67 & 5.22 \\
\hline Byrsonima verbascifolia & 25.0 & 1.09 & 21.00 & 2.21 & 0.09 & 1.65 & 4.94 \\
\hline Psidium firmum & 26.0 & 1.13 & 18.00 & 1.89 & 0.08 & 1.40 & 4.42 \\
\hline Anacardium occidentale & 18.0 & 0.78 & 13.00 & 1.37 & 0.11 & 2.01 & 4.16 \\
\hline Anacardium humile & 30.0 & 1.31 & 19.00 & 2.00 & 0.04 & 0.72 & 4.03 \\
\hline Anacardium nanum & 25.0 & 1.09 & 16.00 & 1.68 & 0.05 & 0.90 & 3.67 \\
\hline Himatanthus obovatus & 29.0 & 1.26 & 17.00 & 1.79 & 0.03 & 0.59 & 3.64 \\
\hline Kielmeyera coriacea & 22.0 & 0.96 & 20.00 & 2.10 & 0.03 & 0.45 & 3.51 \\
\hline Schefflera macrocarpa & 16.0 & 0.70 & 10.00 & 1.05 & 0.08 & 1.45 & 3.20 \\
\hline Qualea grandiflora & 16.0 & 0.70 & 11.00 & 1.16 & 0.07 & 1.20 & 3.05 \\
\hline Salacia crassifólia & 25.0 & 1.09 & 13.00 & 1.37 & 0.02 & 0.42 & 2.87 \\
\hline Bauhinia rufa & 23.0 & 1.00 & 17.00 & 1.79 & 0.00 & 0.06 & 2.85 \\
\hline Manihot sparsifolia & 25.0 & 1.09 & 15.00 & 1.58 & 0.01 & 0.15 & 2.82 \\
\hline Vochysia cf. thyrsoidea & 20.0 & 0.87 & 13.00 & 1.37 & 0.02 & 0.42 & 2.66 \\
\hline Tachigali rugosa & 15.0 & 0.65 & 12.00 & 1.26 & 0.04 & 0.74 & 2.65 \\
\hline Annona crassiflora & 12.0 & 0.52 & 11.00 & 1.16 & 0.04 & 0.79 & 2.47 \\
\hline Diospyros hispida & 8.0 & 0.35 & 8.00 & 0.84 & 0.05 & 0.93 & 2.12 \\
\hline Casearia sylvestris & 14.0 & 0.61 & 13.00 & 1.37 & 0.01 & 0.11 & 2.08 \\
\hline Brosimum gaudichaudii & 11.0 & 0.48 & 9.00 & 0.95 & 0.04 & 0.64 & 2.06 \\
\hline Leptolobium dasycarpum & 12.0 & 0.52 & 10.00 & 1.05 & 0.02 & 0.34 & 1.92 \\
\hline Bowdichia virgilioides & 7.0 & 0.30 & 6.00 & 0.63 & 0.05 & 0.92 & 1.86 \\
\hline Andira humilis & 6.0 & 0.26 & 3.00 & 0.32 & 0.07 & 1.17 & 1.75 \\
\hline Mimosa radula cf. var. imbricata & 17.0 & 0.74 & 9.00 & 0.95 & 0.00 & 0.05 & 1.74 \\
\hline Myrcia splendens & 11.0 & 0.48 & 9.00 & 0.95 & 0.01 & 0.17 & 1.59 \\
\hline Qualea parviflora & 5.0 & 0.22 & 5.00 & 0.53 & 0.05 & 0.80 & 1.55 \\
\hline Vochysia rufa & 8.0 & 0.35 & 8.00 & 0.84 & 0.02 & 0.33 & 1.52 \\
\hline Chamaecrista orbiculata & 10.0 & 0.44 & 6.00 & 0.63 & 0.00 & 0.07 & 1.14 \\
\hline
\end{tabular}


Tabela 4.10 - Espécies vivas do Campo Sujo Seco (A1V; A1T; A2V; A2T; A3V; A3T; A4V; A4T; A5V; A5T), na bacia hidrográfica do ribeirão Taquaruçu Grande, Palmas (TO), com densidade absoluta (AbsDe); densidade relativa (RelDe); frequência absoluta (AbsFr); frequência relativa (RelFr); dominância absoluta (AbsDo); dominância relativa (RelDo); em ordem decrescente de índice de valor de importância (IVI) (conclusão)

\begin{tabular}{|c|c|c|c|c|c|c|c|}
\hline Espécies & $\begin{array}{l}\text { AbsDe } \\
\text { (ind/ha) }\end{array}$ & $\begin{array}{c}\text { RelDe } \\
(\%)\end{array}$ & $\begin{array}{c}\text { AbsFr } \\
(\%)\end{array}$ & $\begin{array}{c}\text { RelFr } \\
(\%)\end{array}$ & $\begin{array}{l}\text { AbsDo } \\
\left(\mathrm{m}^{2} / \mathrm{ha}\right)\end{array}$ & $\begin{array}{c}\text { RelDo } \\
(\%)\end{array}$ & $\begin{array}{l}\text { IVI } \\
(\%)\end{array}$ \\
\hline Manihot acuminatissima & 8.0 & 0.35 & 7.00 & 0.74 & 0.00 & 0.01 & 1.09 \\
\hline Dipteryx alata & 5.0 & 0.22 & 3.00 & 0.32 & 0.03 & 0.51 & 1.05 \\
\hline Calliandra dysantha & 9.0 & 0.39 & 6.00 & 0.63 & 0.00 & 0.02 & 1.04 \\
\hline Vochysia cf. divergens & 11.0 & 0.48 & 2.00 & 0.21 & 0.02 & 0.28 & 0.97 \\
\hline Curatella americana & 4.0 & 0.17 & 3.00 & 0.32 & 0.03 & 0.45 & 0.94 \\
\hline Tabebuia aurea & 5.0 & 0.22 & 5.00 & 0.53 & 0.01 & 0.14 & 0.88 \\
\hline Annona coriacea & 4.0 & 0.17 & 4.00 & 0.42 & 0.02 & 0.27 & 0.87 \\
\hline Mimosa albolanata cf. var. brasiliana & 7.0 & 0.30 & 2.00 & 0.21 & 0.01 & 0.25 & 0.77 \\
\hline Senna velutina & 4.0 & 0.17 & 4.00 & 0.42 & 0.00 & 0.01 & 0.60 \\
\hline Hymenaea stigonocarpa & 4.0 & 0.17 & 3.00 & 0.32 & 0.00 & 0.08 & 0.57 \\
\hline Pterodon emarginatus & 5.0 & 0.22 & 3.00 & 0.32 & 0.00 & 0.03 & 0.56 \\
\hline Rourea induta & 4.0 & 0.17 & 3.00 & 0.32 & 0.00 & 0.06 & 0.55 \\
\hline Ouratea hexasperma & 2.0 & 0.09 & 2.00 & 0.21 & 0.01 & 0.23 & 0.53 \\
\hline Zeyhera tuberculosa & 2.0 & 0.09 & 2.00 & 0.21 & 0.01 & 0.21 & 0.51 \\
\hline Kielmeyera rosea & 3.0 & 0.13 & 3.00 & 0.32 & 0.00 & 0.06 & 0.51 \\
\hline Vochysia tucanorum & 3.0 & 0.13 & 3.00 & 0.32 & 0.00 & 0.05 & 0.49 \\
\hline Erythroxilum cf. citrifolium & 5.0 & 0.22 & 2.00 & 0.21 & 0.00 & 0.02 & 0.45 \\
\hline Tocoyena formosa & 2.0 & 0.09 & 2.00 & 0.21 & 0.01 & 0.14 & 0.44 \\
\hline Hancornia speciosa & 3.0 & 0.13 & 2.00 & 0.21 & 0.00 & 0.08 & 0.42 \\
\hline Miconia ferruginata & 1.0 & 0.04 & 1.00 & 0.11 & 0.01 & 0.21 & 0.36 \\
\hline Eriotheca pubescens & 2.0 & 0.09 & 2.00 & 0.21 & 0.00 & 0.03 & 0.33 \\
\hline Tibouchina aegopogon & 2.0 & 0.09 & 2.00 & 0.21 & 0.00 & 0.00 & 0.30 \\
\hline Agonandra brasiliensis & 1.0 & 0.04 & 1.00 & 0.11 & 0.00 & 0.08 & 0.23 \\
\hline Erythroxylum tortuosum & 2.0 & 0.09 & 1.00 & 0.11 & 0.00 & 0.03 & 0.22 \\
\hline Tabebuia roseoalba & 1.0 & 0.04 & 1.00 & 0.11 & 0.00 & 0.07 & 0.22 \\
\hline Palicourea rigida & 1.0 & 0.04 & 1.00 & 0.11 & 0.00 & 0.05 & 0.20 \\
\hline Ananas ananassoides & 1.0 & 0.04 & 1.00 & 0.11 & 0.00 & 0.04 & 0.18 \\
\hline Psidium sp. & 1.0 & 0.04 & 1.00 & 0.11 & 0.00 & 0.01 & 0.16 \\
\hline Solanum lycocarpum & 1.0 & 0.04 & 1.00 & 0.11 & 0.00 & 0.01 & 0.16 \\
\hline Vochysia elliptica & 1.0 & 0.04 & 1.00 & 0.11 & 0.00 & 0.01 & 0.16 \\
\hline Platypodium elegans & 1.0 & 0.04 & 1.00 & 0.11 & 0.00 & 0.01 & 0.16 \\
\hline Caryocar brasiliense & 1.0 & 0.04 & 1.00 & 0.11 & 0.00 & 0.01 & 0.16 \\
\hline Kielmeyera lanthrophyton & 1.0 & 0.04 & 1.00 & 0.11 & 0.00 & 0.01 & 0.16 \\
\hline Deianira cf. chiquitana & 1.0 & 0.04 & 1.00 & 0.11 & 0.00 & 0.00 & 0.15 \\
\hline Miconia albicans & 1.0 & 0.04 & 1.00 & 0.11 & 0.00 & 0.00 & 0.15 \\
\hline Platonia insignis & 1.0 & 0.04 & 1.00 & 0.11 & 0.00 & 0.00 & 0.15 \\
\hline
\end{tabular}


Tabela 4.11 - Parâmetros fitossociológicos da comunidade subarbustiva-arbustivo-arbórea do Campo Sujo Seco, na bacia hidrográfica do ribeirão Taquaruçu Grande, Palmas (TO), com informações de densidade, dominância, diâmetro (média) e altura (média) relacionados às parcelas de amostragem de topo e de Vertente, com respectivos percentuais totais de plantas vivas e mortas

\begin{tabular}{|c|c|c|c|c|c|c|c|c|c|c|c|c|c|c|}
\hline \multirow{2}{*}{$\begin{array}{c}\text { Tipo } \\
\text { de } \\
\text { relevo }\end{array}$} & \multicolumn{5}{|c|}{ Densidade (indivíduos.ha ${ }^{-1}$ ) } & \multicolumn{5}{|c|}{ Dominância $\left(\mathrm{m}^{2} \cdot \mathrm{ha}^{-1}\right)$} & \multicolumn{3}{|c|}{$\begin{array}{c}\text { Diâmetro } \\
\text { Média }(\mathrm{cm})\end{array}$} & \multirow{2}{*}{$\begin{array}{c}\text { Altura } \\
\text { Média } \\
\text { (m) }\end{array}$} \\
\hline & Vivas & $(\%)$ & Mortas & $(\%)$ & Total & Viva & $(\%)$ & Morta & $(\%)$ & Total & Vivas & Mortas & Total & \\
\hline Topo & $2.242,0$ & 91,8 & 200,22 & 8,2 & $2.442,22$ & 5,78 & 77,4 & 1,69 & 22,6 & 7,47 & 4,56 & 5,24 & 4,9 & 1,23 \\
\hline Vertente & $2.354,0$ & 90,0 & 263,25 & 10,0 & $2.617,25$ & 5,50 & 74,7 & 1,86 & 25,3 & 7,36 & 4,66 & 5,18 & 4,92 & 1,09 \\
\hline Total & $2.298,0$ & 83,2 & 463,47 & 16,8 & $2.761,47$ & 5,64 & 76 & 1,78 & 24,0 & 7,41 & 4,61 & 5,21 & 4,91 & 1,12 \\
\hline
\end{tabular}


Para as plantas vivas, a densidade foi 2.298,0 indivíduos.ha ${ }^{-1}$, a dominância 5,64 $\mathrm{m}^{2} \cdot \mathrm{ha}^{-1}$ e o diâmetro (média) de 4,61 cm; para as plantas mortas, a densidade foi 463,47 indivíduos.ha ${ }^{-1}$, a dominância $1,78 \mathrm{~m}^{2} \cdot \mathrm{ha}^{-1}$ e o diâmetro (média) de $5,21 \mathrm{~cm}$. Os percentuais relativos a esses parâmetros sempre foram altos para as plantas vivas, porém o diâmetro (média) foi mais elevado nas mortas devido a mais baixa densidade e mais alta área basal destas plantas em relação às vivas (Tabela 4.11). Nos valores de dominância relativos à plantas mortas estão incluídas biomassa de tronco (indivíduos mortos) e de galhos mortos das plantas vivas, estes últimos representam $38,1 \%$ da dominância de biomassa morta. Em termos de desenvolvimento estrutural a vegetação de topo e Vertente é semelhante por apresentarem valores muito próximos de diâmetro (média) e altura (Tabela 4.11).

As espécies vivas que tiveram maiores biomassas mortas de galhos foram Vellozia seubertiana e Connarus suberosus $\left(0,05 \mathrm{~m}^{2} \cdot \mathrm{ha}^{-1}\right)$, Dimorphandra mollis $\left(0,04 \mathrm{~m}^{2} \cdot \mathrm{ha}^{-1}\right)$, Anacardium humile, Manihot sparsifolia, Piptocarpha rotundifolia e Erythroxylum suberosum $\left(0,02 \mathrm{~m}^{2} \cdot \mathrm{ha}^{-1}\right)$, Davilla elliptica, Stryphnodendron adstringens, Byrsonima coccobolifolia, Kielmeyera coriacea, Leptolobium dasycarpum, Vochysia rufa e Tachigali rugosa $\left(0,01 \mathrm{~m}^{2} \cdot \mathrm{ha}^{-1}\right)$.

Em relação às plantas mortas, constatou atividades de corte seletivo de Vellozia seubertiana em duas áreas de amostragem e se associou essa atividade ao uso desta planta como lenha pela sua característica potencial de combustível. Em geral foram observadas evidências de queimadas e, em algumas vezes, a presença de cupim, o que levou a associar a causa da mortalidade também a esses fatores.

As espécies vivas com maior índice de valor de importância (IVI) foram Vellozia seubertiana, Syagrus comosa, Erythroxylum suberosum, Piptocarpha rotundifolia, Connarus suberosus, Byrsonima coccobolifolia, Dimorphandra mollis, Ouratea spectabilis, Byrsonima pachyphylla, Davilla elliptica, Byrsonima subterranea e Vochysia cinnamomea (Tabela 4.10), em que a espécie Vellozia seubertiana se destacou das demais, seguida por Syagrus comosa, refletindo suas maiores densidades, frequências e dominâncias (Figura 4.40).

Tratando-se das plantas mortas, os maiores valores de IVI também foram para as plantas de $V$. seubertiana $(232,43 \%)$, enquanto para as outras espécies mortas não identificáveis foi $67,57 \%$. V. seubertiana teve densidade de 397,5 indivíduos.ha $^{-1}$ mortos e as outras mortas 80 indivíduos.ha ${ }^{-1}$. Em relação a dominância, esta foi também maior para $V$. seubertiana $\left(1,31 \mathrm{~m}^{2} \cdot \mathrm{ha}^{-1}\right)$ que para as outras plantas mortas $\left(0,22 \mathrm{~m}^{2} \cdot \mathrm{ha}^{-1}\right)$. 


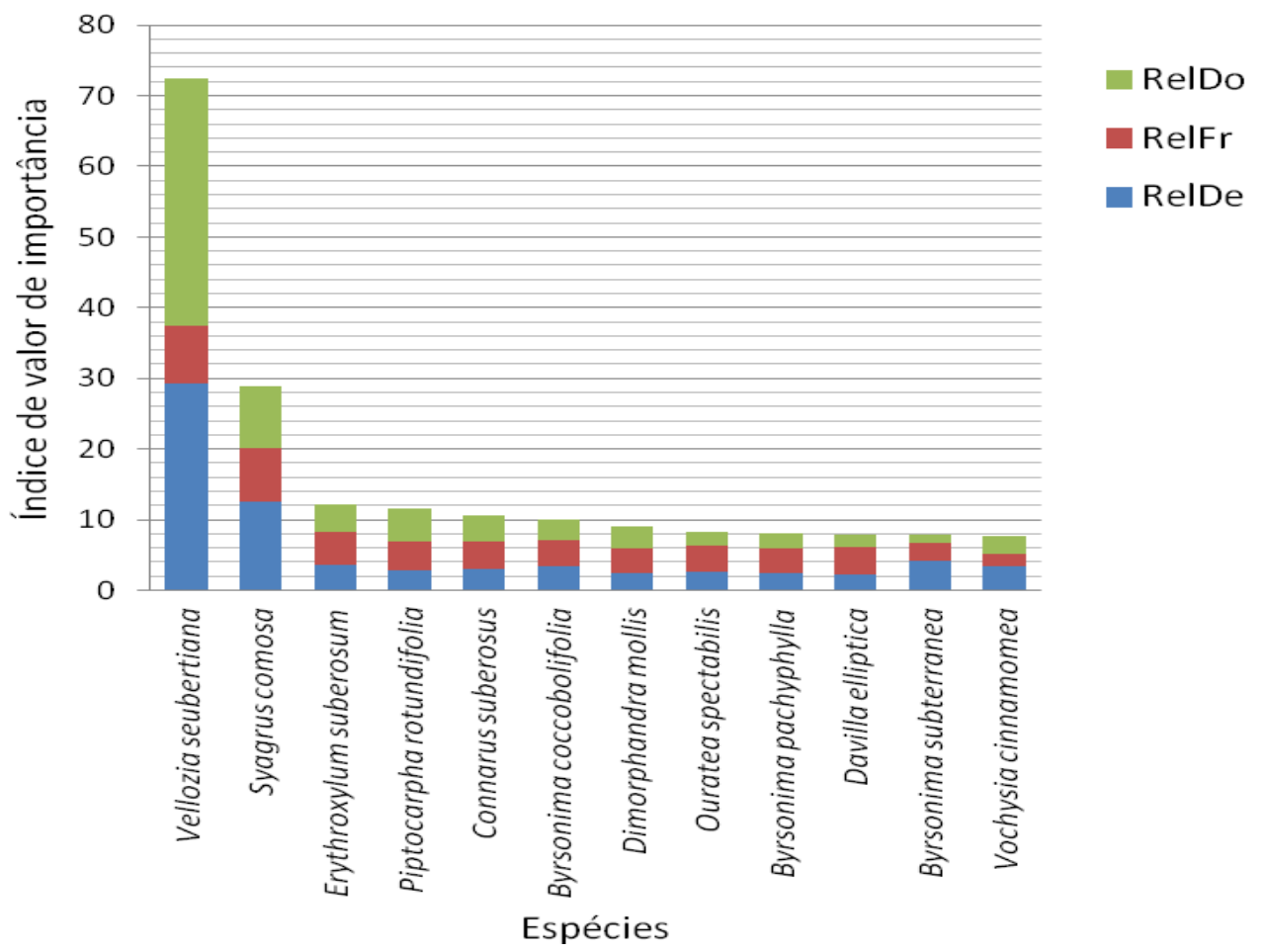

Figura 4.40 - Distribuição das espécies com índice de valor de importância (IVI) acima de 7\%, da comunidade de plantas do Campo Sujo Seco (A1V; A1T; A2V; A2T; A3V; A3T; 4E; A4T; A5V; A5T), na bacia hidrográfica do ribeirão Taquaruçu Grande, Palmas (TO)

Estudos fitossociológicos em Campo Sujo são escassos em se tratando dos parâmetros de densidade, área basal e altura, podendo-se citar: Moreno et al. (2008), com estudos na Estação Ecológica do Panga (MG); Araújo et al. (2012), na Floresta Nacional de Silvânia (GO); e, Giácomo (2013) na Estação Ecológica de Pirapitinga (MG).

Observou-se que os dados relacionados a estes parâmetros são variados entre os Campos Sujos. Em termos comparativos, o Campo Sujo estudado da bacia hidrográfica do ribeirão Taquaruçu Grande, apresentou densidade mais elevada, área basal mediana e menor altura em relação aos demais (Tabela 4.12). Estas variações podem estar ligadas aos gradientes ambientais de cada localidade, como também a diferenças metodológicas. No presente trabalho o sistema de inclusão dos indivíduos foi de circunferência $\geq 3 \mathrm{~cm}$ à altura do solo, enquanto os outros estudos incluiram apenas indivíduos com caules mais grossos: Moreno et al. (2008) adotou sistema de inclusão $\geq 10 \mathrm{~cm}$ de circunferência à altura do solo, Araújo et al. (2012), $\geq 5 \mathrm{~cm}$ de diâmetro $(15,7 \mathrm{~cm}$ de circunferência) à altura do solo e Giácomo et al. (2013) $\geq 16 \mathrm{~cm}$ de circunferência à altura do solo. 
Tabela 4.12 - Parâmetros fitossociológicos (densidade, área basal e altura média) para Campo Sujo de diversas localidades do Cerrado brasileiro e da bacia hidrográfiaca do ribeirão Taquaruçu Grande, Palmas (TO)

\begin{tabular}{lcccl}
\hline \multicolumn{1}{c}{ Localidade } & $\begin{array}{c}\text { Densidade } \\
\left(\mathbf{i n d . h a}^{-1}\right)\end{array}$ & $\begin{array}{c}\text { Área Basal } \\
\left(\mathbf{m}^{2} \cdot \mathbf{. h a}^{-\mathbf{1}}\right)\end{array}$ & $\begin{array}{c}\text { Altura } \\
\text { média (m) }^{(\mathbf{m})}\end{array}$ & \multicolumn{1}{c}{ Fonte } \\
\hline Bacia do Taquaruçu Grande, Palmas (TO) & $2.298,0$ & 5,64 & 1,12 & Este trabalho \\
E. E. Panga, Uberlândia (MG) & $1.850,0$ & 8,7 & 3,5 & Moreno et al.(2008) \\
FLONA de Silvânia (GO) & 730,0 & 1,96 & 2,47 & Araújo et al. (2012) \\
E. E. Pirapitinga (MG) & 926,0 & 6,72 & 2,7 & Giácomo et al. (2013) \\
\hline
\end{tabular}

\subsection{Estrato subarbustiva-arbustivo-arbórea do Campo Sujo Seco: topo}

Analisando o estrato subarbustivo-arbustivo-arbóreo sob a perspectiva do relevo, na situação de relevo do tipo topo, a vegetação subarbustiva-arbustivo-arbórea do Campo Sujo Seco do ribeirão Taquaruçu Grande, amostrada nas parcelas A1T; A2T; A3T; A4T; A5T, foi composta por 28 famílias, 49 gêneros e 66 espécies. As famílias com maior número de espécies foram Fabaceae e Vochysiaceae, representando 24,2\% e 12,1\%, respectivamente, do total de espécies nesse tipo de relevo, enquanto alto percentual de famílias $(63,7 \%)$ teve número de espécies inferior a cinco (Figura 4.41).

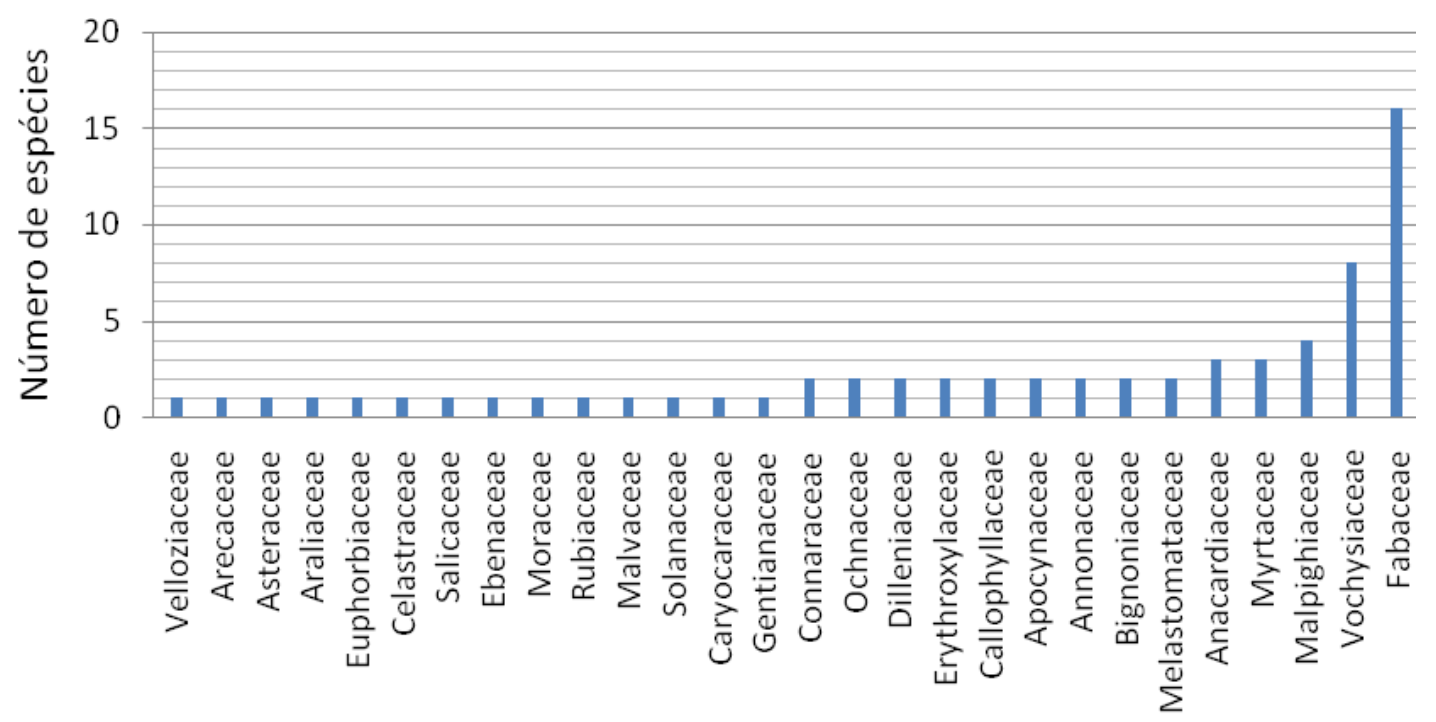

Famílias

Figura 4.41 - Distribuição do número de espécies, por famílias do estrato subarbustivo-arbustivoarbóreo, da comunidade de plantas do Campo Sujo Seco (topo), na bacia hidrográfica do ribeirão Taquaruçu Grande, Palmas (TO) 
As espécies com maior número de plantas (Figura 4.42) foram Vellozia seubertiana (259), Syagrus comosa (151) e Byrsonima subterranea (81). Alto percentual de espécies $(60,6 \%)$ teve menos que 10 plantas (espécies que apresentaram densidade absoluta $\leq 18$

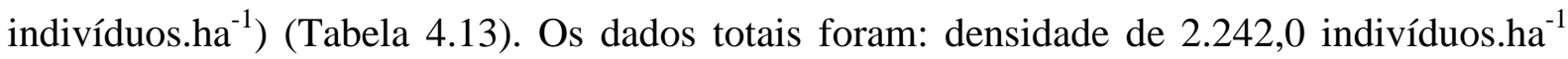
(91,8\% de plantas vivas e 8,2\% de plantas mortas); dominância foi 5,782 $\mathrm{m}^{2}$. ha ${ }^{-1}$ (77,4\% de plantas vivas e 22,6\% de plantas mortas); o diâmetro (média) 4,5 cm, sendo 4,56 m para as plantas vivas e 5,24 $\mathrm{cm}$ para as mortas e a altura (média) foi 1,15 m (Tabela 4.11).

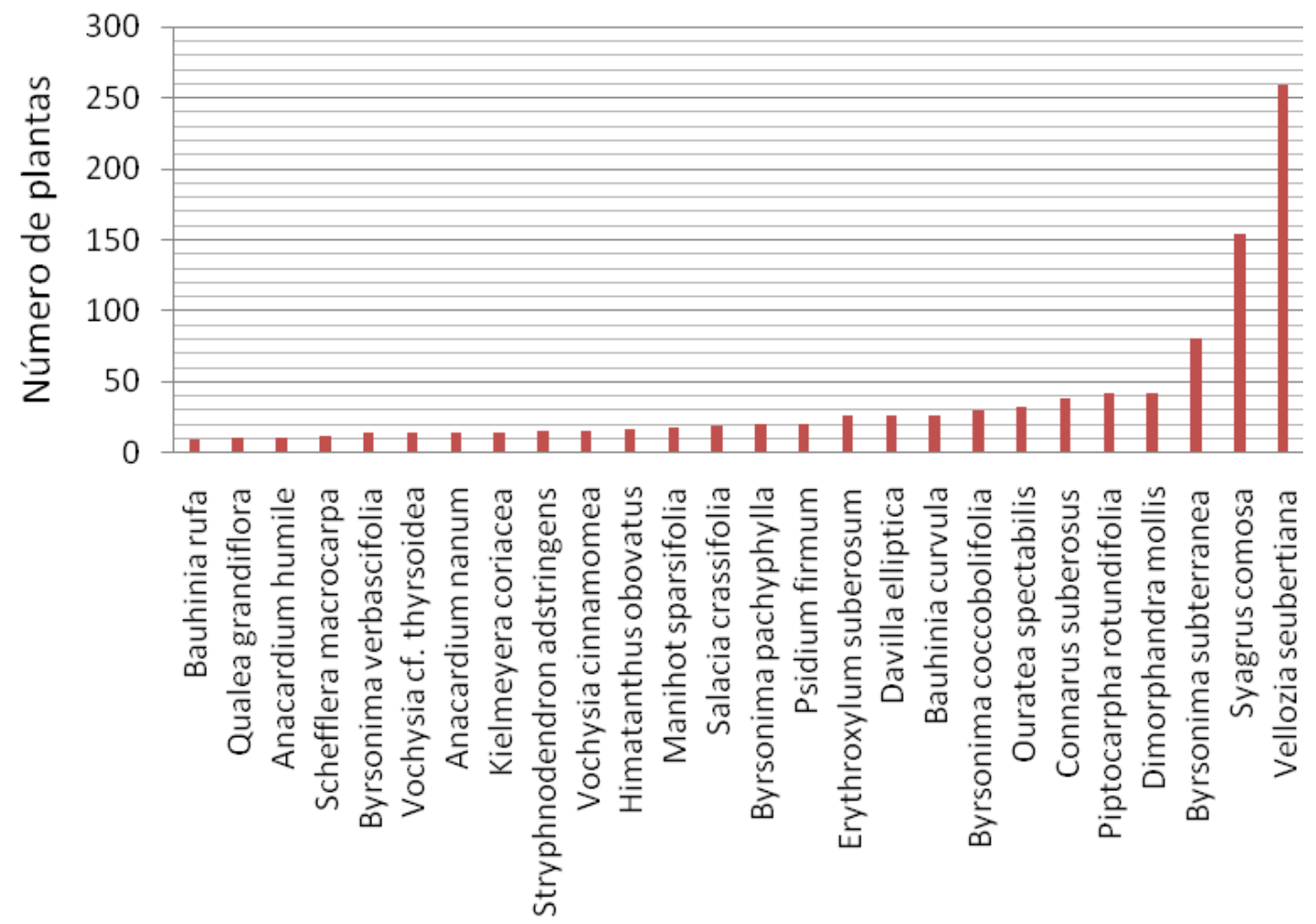

Espécies

Figura 4.42 - Distribuição do número de plantas, por espécie com $\geq 10$ indíviduos, no Campo Sujo Seco (topo), na bacia hidrográfica do ribeirão Taquaruçu Grande, Palmas (TO) 
Tabela 4.13 - Espécies do Campo Sujo Seco (topo), na bacia hidrográfica do ribeirão Taquaruçu Grande, Palmas (TO), com área de ocorrência, densidade absoluta (AbsDe); densidade relativa (RelDe); frequência absoluta (AbsFr); frequência relativa (RelFr); dominância absoluta (AbsDo); dominância relativa (RelDo); em ordem decrescente de índice de valor de importância (IVI) (continua)

\begin{tabular}{|c|c|c|c|c|c|c|c|}
\hline Espécies & $\begin{array}{c}\text { AbsDe } \\
\text { (ind./ha) }\end{array}$ & $\begin{array}{c}\text { RelDe } \\
(\%)\end{array}$ & $\begin{array}{c}\text { AbsFr } \\
(\%)\end{array}$ & $\begin{array}{c}\text { RelFr } \\
(\%)\end{array}$ & $\begin{array}{l}\text { AbsDo } \\
\left(\mathrm{m}^{2} / \mathrm{ha}\right)\end{array}$ & $\begin{array}{c}\text { RelDo } \\
(\%)\end{array}$ & $\begin{array}{l}\text { IVI } \\
(\%)\end{array}$ \\
\hline Vellozia seubertiana & 518.0 & 23.10 & 66.00 & 6.68 & 1.72 & 29.82 & 59.60 \\
\hline Syagrus comosa & 308.0 & 13.74 & 70.00 & 7.09 & 0.44 & 7.61 & 28.43 \\
\hline Piptocarpha rotundifolia & 84.0 & 3.75 & 48.00 & 4.86 & 0.37 & 6.40 & 15.00 \\
\hline Dimorphandra mollis & 84.0 & 3.75 & 48.00 & 4.86 & 0.29 & 4.93 & 13.54 \\
\hline Byrsonima subterranea & 162.0 & 7.23 & 34.00 & 3.44 & 0.13 & 2.23 & 12.90 \\
\hline Connarus suberosus & 76.0 & 3.39 & 38.00 & 3.85 & 0.22 & 3.84 & 11.08 \\
\hline Ouratea spectabilis & 66.0 & 2.94 & 40.00 & 4.05 & 0.10 & 1.73 & 8.72 \\
\hline Byrsonima coccobolifolia & 60.0 & 2.68 & 34.00 & 3.44 & 0.14 & 2.44 & 8.56 \\
\hline Erythroxylum suberosum & 52.0 & 2.32 & 30.00 & 3.04 & 0.13 & 2.31 & 7.67 \\
\hline Davilla elliptica & 52.0 & 2.32 & 40.00 & 4.05 & 0.07 & 1.16 & 7.52 \\
\hline Psidium firmum & 42.0 & 1.87 & 26.00 & 2.63 & 0.13 & 2.28 & 6.78 \\
\hline Stryphnodendron adstringens & 32.0 & 1.43 & 30.00 & 3.04 & 0.13 & 2.30 & 6.77 \\
\hline Byrsonima pachyphylla & 40.0 & 1.78 & 26.00 & 2.63 & 0.11 & 1.96 & 6.37 \\
\hline Bauhinia curvula & 54.0 & 2.41 & 38.00 & 3.85 & 0.01 & 0.11 & 6.37 \\
\hline Salvertia convallariodora & 6.0 & 0.27 & 6.00 & 0.61 & 0.30 & 5.23 & 6.11 \\
\hline Byrsonima verbascifolia & 28.0 & 1.25 & 22.00 & 2.23 & 0.11 & 1.93 & 5.41 \\
\hline Schefflera macrocarpa & 24.0 & 1.07 & 12.00 & 1.21 & 0.16 & 2.69 & 4.98 \\
\hline Anacardium nanum & 30.0 & 1.34 & 20.00 & 2.02 & 0.09 & 1.55 & 4.92 \\
\hline Kielmeyera coriacea & 30.0 & 1.34 & 26.00 & 2.63 & 0.04 & 0.72 & 4.69 \\
\hline Anacardium occidentale & 18.0 & 0.80 & 16.00 & 1.62 & 0.12 & 2.16 & 4.58 \\
\hline Qualea grandiflora & 22.0 & 0.98 & 12.00 & 1.21 & 0.12 & 2.15 & 4.35 \\
\hline Manihot sparsifolia & 36.0 & 1.61 & 22.00 & 2.23 & 0.01 & 0.21 & 4.04 \\
\hline Anacardium humile & 22.0 & 0.98 & 20.00 & 2.02 & 0.04 & 0.70 & 3.71 \\
\hline Himatanthus obovatus & 34.0 & 1.52 & 14.00 & 1.42 & 0.03 & 0.58 & 3.51 \\
\hline Salacia crassifolia & 38.0 & 1.69 & 14.00 & 1.42 & 0.02 & 0.33 & 3.44 \\
\hline Vochysia cinnamomea & 32.0 & 1.43 & 12.00 & 1.21 & 0.05 & 0.79 & 3.43 \\
\hline Vochysia cf. thyrsoidea & 28.0 & 1.25 & 16.00 & 1.62 & 0.03 & 0.54 & 3.41 \\
\hline Andira humilis & 10.0 & 0.45 & 4.00 & 0.40 & 0.13 & 2.17 & 3.03 \\
\hline Bauhinia rufa & 20.0 & 0.89 & 18.00 & 1.82 & 0.00 & 0.03 & 2.74 \\
\hline Annona crassiflora & 14.0 & 0.62 & 12.00 & 1.21 & 0.04 & 0.73 & 2.57 \\
\hline Casearia sylvestris & 16.0 & 0.71 & 16.00 & 1.62 & 0.01 & 0.18 & 2.51 \\
\hline Tachigali rugosa & 10.0 & 0.45 & 10.00 & 1.01 & 0.04 & 0.72 & 2.18 \\
\hline Mimosa radula cf. var. imbricata & 16.0 & 0.71 & 12.00 & 1.21 & 0.00 & 0.07 & 1.99 \\
\hline Myrcia splendens & 14.0 & 0.62 & 10.00 & 1.01 & 0.02 & 0.32 & 1.95 \\
\hline Chamaecrista orbiculata & 18.0 & 0.80 & 10.00 & 1.01 & 0.01 & 0.13 & 1.95 \\
\hline Diospyros híspida & 10.0 & 0.45 & 10.00 & 1.01 & 0.03 & 0.48 & 1.93 \\
\hline Bowdichia virgilioides & 10.0 & 0.45 & 8.00 & 0.81 & 0.03 & 0.45 & 1.70 \\
\hline Vochysia rufa & 8.0 & 0.36 & 8.00 & 0.81 & 0.03 & 0.49 & 1.66 \\
\hline Qualea parviflora & 4.0 & 0.18 & 4.00 & 0.40 & 0.06 & 1.06 & 1.64 \\
\hline Dipteryx alata & 8.0 & 0.36 & 4.00 & 0.40 & 0.05 & 0.88 & 1.64 \\
\hline Curatella americana & 2.0 & 0.09 & 2.00 & 0.20 & 0.05 & 0.83 & 1.12 \\
\hline Pterodon emarginatus & 10.0 & 0.45 & 6.00 & 0.61 & 0.00 & 0.06 & 1.11 \\
\hline Brosimum gaudichaudii & 8.0 & 0.36 & 6.00 & 0.61 & 0.01 & 0.10 & 1.06 \\
\hline Annona coriacea & 4.0 & 0.18 & 4.00 & 0.40 & 0.03 & 0.44 & 1.02 \\
\hline Kielmeyera rosea & 6.0 & 0.27 & 6.00 & 0.61 & 0.01 & 0.12 & 1.00 \\
\hline
\end{tabular}


Tabela 4.13 - Espécies do Campo Sujo Seco (topo), na bacia hidrográfica do ribeirão Taquaruçu Grande, Palmas (TO), com densidade absoluta (AbsDe); densidade relativa (RelDe); frequência absoluta (AbsFr); frequência relativa (RelFr); dominância absoluta (AbsDo); dominância relativa (RelDo); em ordem decrescente de índice de valor de importância (IVI) (conclusão)

\begin{tabular}{lccccccc}
\hline \multicolumn{1}{c}{ Espécies } & $\begin{array}{c}\text { AbsDe } \\
\text { (ind./ha) }\end{array}$ & $\begin{array}{c}\text { RelDe } \\
(\boldsymbol{\%})\end{array}$ & $\begin{array}{c}\text { AbsFr } \\
(\boldsymbol{\%})\end{array}$ & $\begin{array}{c}\text { RelFr } \\
(\boldsymbol{\%})\end{array}$ & $\begin{array}{c}\text { AbsDo } \\
\left(\mathbf{m}^{2} / \mathbf{h a}\right)\end{array}$ & $\begin{array}{c}\text { RelDo } \\
(\boldsymbol{\%})\end{array}$ & $\begin{array}{c}\text { IVI } \\
(\boldsymbol{\%})\end{array}$ \\
\hline Leptolobium dasycarpum & 6.0 & 0.27 & 6.00 & 0.61 & 0.01 & 0.12 & 1.00 \\
Erythroxilum cf. citrifolium & 10.0 & 0.45 & 4.00 & 0.40 & 0.00 & 0.04 & 0.89 \\
Calliandra dysanta & 10.0 & 0.45 & 4.00 & 0.40 & 0.00 & 0.02 & 0.87 \\
Tocoyena formosa & 4.0 & 0.18 & 4.00 & 0.40 & 0.02 & 0.28 & 0.86 \\
Hymenaea stigonocarpa & 6.0 & 0.27 & 4.00 & 0.40 & 0.01 & 0.15 & 0.83 \\
Miconia ferruginata & 2.0 & 0.09 & 2.00 & 0.20 & 0.02 & 0.42 & 0.71 \\
Zeyhera tuberculosa & 2.0 & 0.09 & 2.00 & 0.20 & 0.02 & 0.36 & 0.65 \\
Eriotheca pubescens & 4.0 & 0.18 & 4.00 & 0.40 & 0.00 & 0.06 & 0.65 \\
Vochysia tucanorum & 4.0 & 0.18 & 4.00 & 0.40 & 0.00 & 0.06 & 0.64 \\
Hancornia speciosa & 4.0 & 0.18 & 2.00 & 0.20 & 0.01 & 0.15 & 0.54 \\
Mimosa albolanata cf. var. brasiliana & 4.0 & 0.18 & 2.00 & 0.20 & 0.01 & 0.11 & 0.49 \\
Tabebuia roseoalba & 2.0 & 0.09 & 2.00 & 0.20 & 0.01 & 0.14 & 0.43 \\
Rourea induta & 2.0 & 0.09 & 2.00 & 0.20 & 0.00 & 0.02 & 0.31 \\
Psidium sp & 2.0 & 0.09 & 2.00 & 0.20 & 0.00 & 0.02 & 0.31 \\
Solanum lycocarpum & 2.0 & 0.09 & 2.00 & 0.20 & 0.00 & 0.02 & 0.31 \\
Vochysia elliptica & 2.0 & 0.09 & 2.00 & 0.20 & 0.00 & 0.02 & 0.31 \\
Platypodium elegans & 2.0 & 0.09 & 2.00 & 0.20 & 0.00 & 0.02 & 0.31 \\
Caryocar brasiliense & 2.0 & 0.09 & 2.00 & 0.20 & 0.00 & 0.02 & 0.31 \\
Tibouchina aegopogon & 2.0 & 0.09 & 2.00 & 0.20 & 0.00 & 0.00 & 0.30 \\
Deianira cf. chiquitana & 2.0 & 0.09 & 2.00 & 0.20 & 0.00 & 0.00 & 0.29 \\
Ouratea hexasperma & 2.0 & 0.09 & 2.00 & 0.20 & 0.00 & 0.00 & 0.29 \\
\hline
\end{tabular}

As espécies de plantas vivas com maior Índice de Valor de Importância (IVI) foram Vellozia seubertiana, Syagrus comosa, Piptocarpha rotundifolia, Dimorphandra mollis, Byrsonima subterranea, Connarus suberosus, Ouratea spectabilis, Byrsonima coccobolifolia, Erythroxylum suberosum, Davilla elliptica, (Tabela 4.13), com maiores densidade, frequência e dominância relativas (Figura 4.43).

Vellozia seubertiana também teve maior densidade dentre a população de plantas mortas com (347,6 indivíduos.ha $\left.{ }^{-1}\right)$, maior dominância $\left(1,15 \mathrm{~m}^{2} \cdot \mathrm{ha}^{-1}\right)$ e IVI $(228,03 \%)$. Já as outras mortas tiveram 76,2 plantas.ha ${ }^{-1} ; 0,25 \mathrm{~m}^{2} \cdot \mathrm{ha}^{-1} ; 71,97 \%$ para densidade, dominância e IVI, respectivamente. Os galhos mortos das plantas vivas representam $23,3 \%$ do total de dominância morta. As espécies vivas que tiveram maiores biomassas de galhos mortos foram Connarus suberosus $\left(0.08 \mathrm{~m}^{2} \cdot \mathrm{ha}^{-1}\right)$, Dimorphandra mollis $\left(0,06 \mathrm{~m}^{2} \cdot \mathrm{ha}^{-1}\right)$, Vellozia seubertiana (0.04 $\left.\mathrm{m}^{2} \cdot \mathrm{ha}^{-1}\right)$, Manihot sparsifolia $\left(0.03 \mathrm{~m}^{2} \cdot \mathrm{ha}^{-1}\right)$, Anacardium humile, Piptocarpha rotundifolia $\left(0.02 \mathrm{~m}^{2} \cdot \mathrm{ha}^{-1}\right)$, Davilla elliptica, Kielmeyera coriacea e Hymenaea stignocarpa $\left(0.01 \mathrm{~m}^{2} \cdot \mathrm{ha}^{-1}\right)$. 


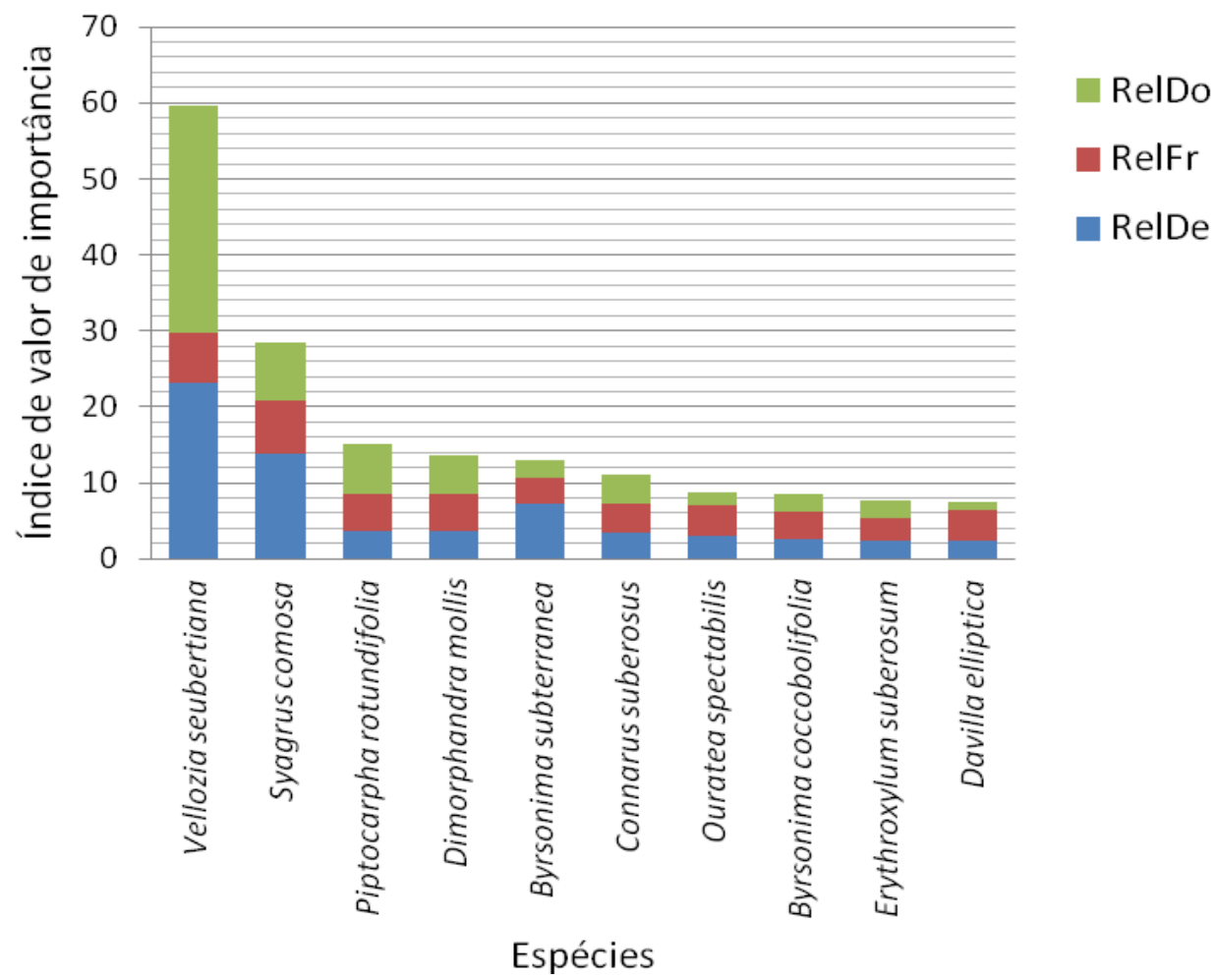

Figura 4.43 - Distribuição das espécies com índice de valor de importância (IVI) acima de 7\%, da comunidade de plantas do Campo Sujo Seco, na bacia hidrográfica do ribeirão Taquaruçu Grande, Palmas (TO)

Em termos de áreas geográficas, a comunidade de plantas da área 1 teve mais famílias, gêneros e espécies, enquanto que a área 5 apresentou os menores números (Tabela 4.14). A área 1 também apresentou maiores densidade e dominância, porém, o menor diâmetro (média) devido à grande densidade de plantas, principalmente de Vellozia seubertiana $(1.180,0$ indivíduos.ha $\left.{ }^{-1}\right)$ e Syagrus comosa (1.080,0 indivíduos.ha $\left.{ }^{-1}\right)$. Os campos com vegetação mais desenvolvida foram os das áreas 2; 3 e 4, que também apresentaram maiores alturas (Tabela 4.15).

Tabela 4.14 - Número de famílias, gêneros e espécies, da comunidade de plantas do Campo Sujo Seco, por área, na bacia hidrográfica do ribeirão Taquaruçu Grande, Palmas (TO)

\begin{tabular}{cccc}
\hline Área & Famílias & Gêneros & Espécies \\
\hline A1T & 22 & 32 & 41 \\
A2T & 19 & 29 & 31 \\
A3T & 20 & 29 & 34 \\
A4T & 18 & 29 & 32 \\
A5T & 16 & 22 & 26 \\
\hline
\end{tabular}


Tabela 4.15- Densidade absoluta (AbsDe), dominância absoluta (AbsDo), diâmetro (média) e altura (média) da comunidade de plantas do Campo Sujo Seco, por área, na bacia hidrográfica do ribeirão Taquaruçu Grande, Palmas (TO)

\begin{tabular}{ccccc}
\hline Áreas & $\begin{array}{c}\text { AbsDe } \\
\text { (ind./ha) }\end{array}$ & $\begin{array}{c}\text { AbsDo } \\
\left(\mathbf{m}^{\mathbf{2}} / \mathbf{h a}\right)\end{array}$ & $\begin{array}{c}\text { Diâmetro } \\
(\mathbf{c m})\end{array}$ & $\begin{array}{c}\text { Altura } \\
(\mathbf{m})\end{array}$ \\
\hline A1T & $4.390,0$ & 7,595 & 3,848 & 0,89 \\
A2T & $1.340,0$ & 4,695 & 5,708 & 1,62 \\
A3T & $1.460,0$ & 5,29 & 5,173 & 1,18 \\
A4T & $2.230,0$ & 6,996 & 5,396 & 1,54 \\
A5T & $1.790,0$ & 4,329 & 3,939 & 0,93 \\
\hline
\end{tabular}

\subsection{Estrato subarbustivo-arbustivo-arbóreo do Campo Sujo Seco: Vertente}

A vegetação do estrato subarbustivo-arbustivo-arbóreo do Campo Sujo Seco do ribeirão Taquaruçu Grande foi composta por 26 famílias, 44 gêneros e 64 espécies. As famílias com maior número de espécies foram Fabaceae (15) e Vochysiaceae (8), sendo que 92,3\% das famílias possuem menos que cinco espécies (Figura 4.44).

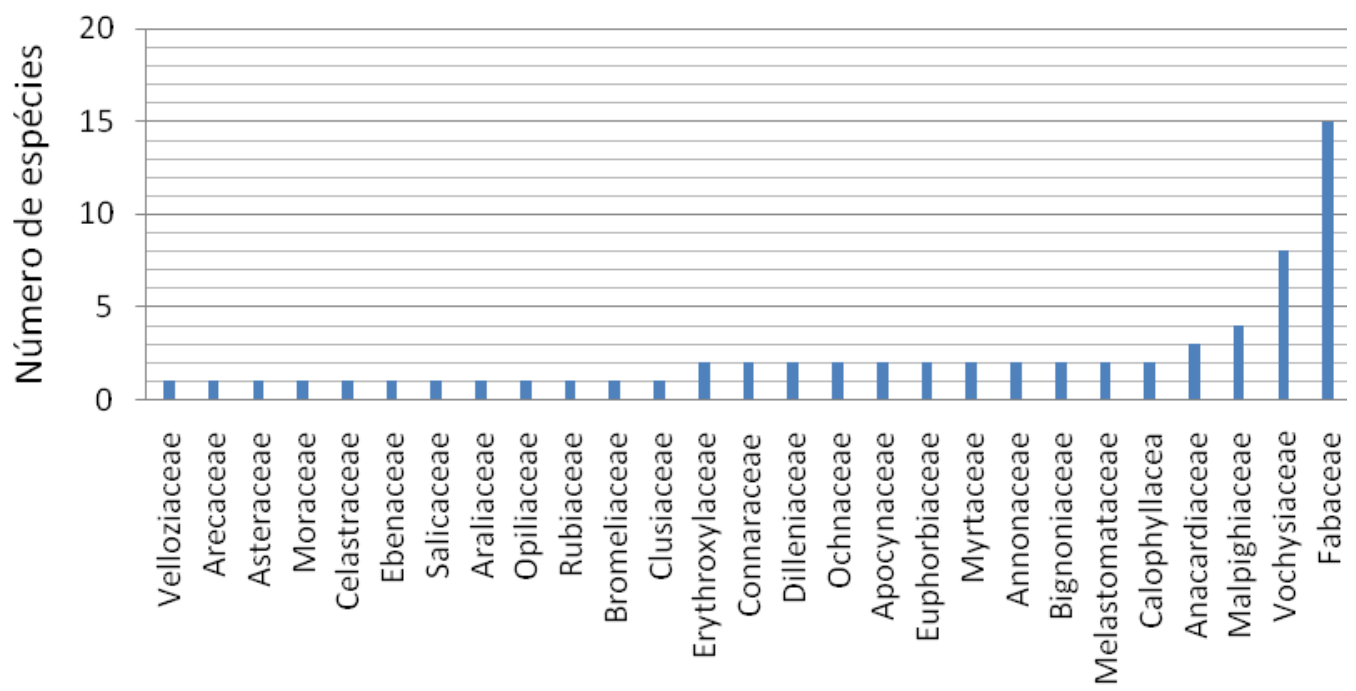

Famílias

Figura 4.44 - Distribuição do número de espécies, por famílias do estrato subarbustivo-arbustivoarbóreo, da comunidade de plantas do Campo Sujo Seco (vertente), na bacia hidrográfica do ribeirão Taquaruçu Grande, Palmas (TO)

As espécies com maior número de plantas (Figura 4.45) foram, principalmente, Vellozia sebertiana (412) e Syagrus comosa (135) e 65,6\% tiveram número menor que 10 plantas (espécies que apresentaram densidade $\leq 18,0$ indivíduos.ha $^{-1}$, Tabela 4.16). A 
densidade foi 2.354,0 indivíduos.ha ${ }^{-1}$ (90\% de plantas vivas e $10 \%$ de plantas mortas), a dominância $5,497 \mathrm{~m}^{2} / \mathrm{ha}^{-1}(74,7 \%$ de plantas vivas e $25,3 \%$ de plantas mortas), o diâmetro (média) 4,659 $\mathrm{cm}(4,66 \mathrm{~cm}$ para plantas vivas e $5,18 \mathrm{~cm}$ para plantas mortas) e a altura (média) de 1,09 m (Tabela 4.11).

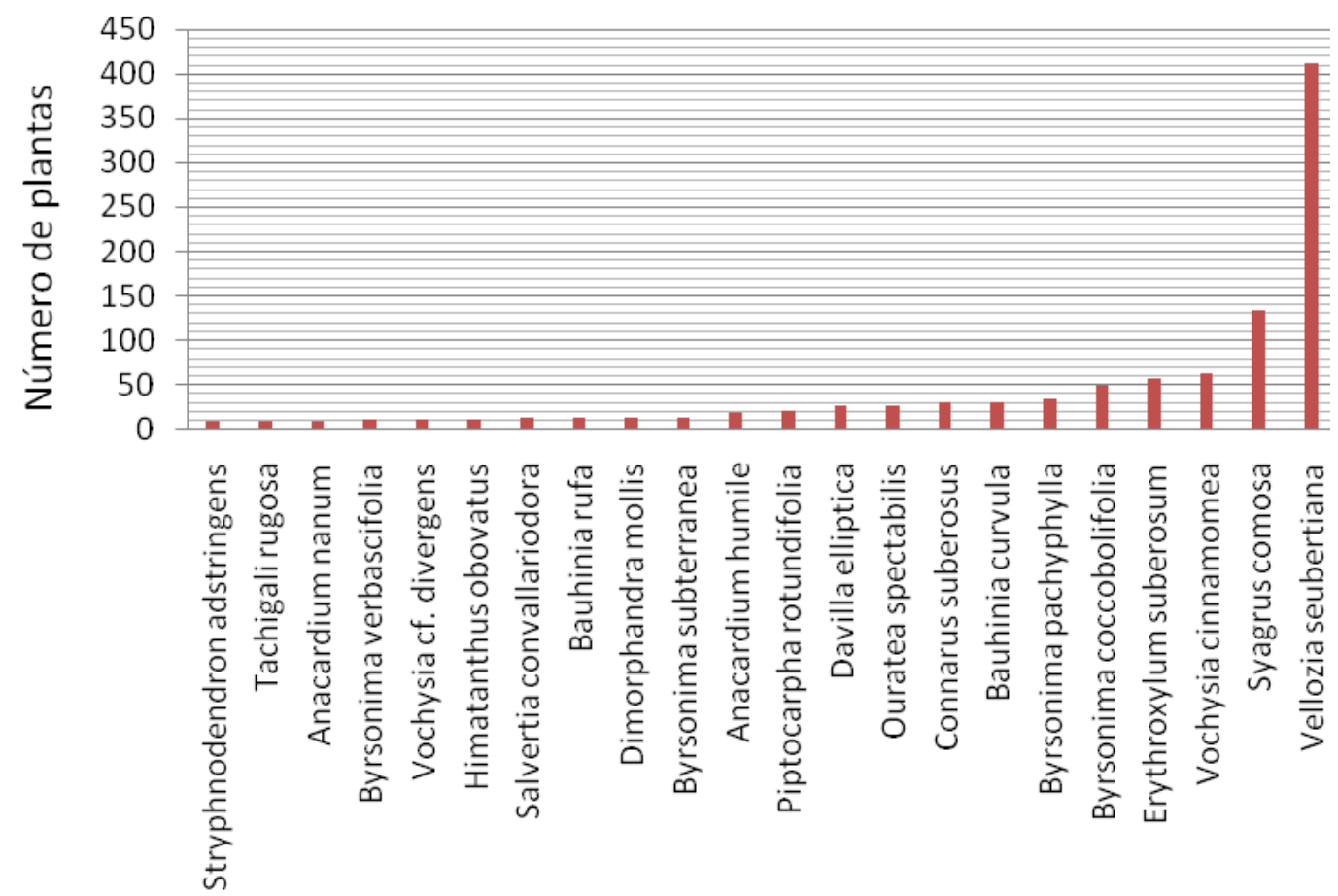

\section{Espécies}

Figura 4.45 - Distribuição do número de plantas, por espécie com $\geq 10$ indíviduos, no Campo Sujo Seco (vertente), na bacia hidrográfica do ribeirão Taquaruçu Grande, Palmas (TO)

As espécies com maior índice de valor de importância (IVI) foram Vellozia seubertiana, Syagrus comosa, Erythroxylum suberosum, Vochysia cinnamomea, Byrsonima coccobolifolia, Connarus suberosus, Byrsonima pachyphylla, Davilla elliptica, Ouratea spectabilis, Piptocarpha rotundifolia, Salvertia convallariodora, (Tabela 4.16), mas, principalmente $V$. seubertiana, devido às mais altas densidade, dominância e frequência relativas (Figura 4.46).

A espécie Vellozia seubertiana teve maior IVI $(233,3 \%)$ em relação às plantas mortas $(66,7 \%)$ pelas suas maiores densidade $\left(452,6\right.$ indivíduos.ha $\left.{ }^{-1}\right)$ e dominância $\left(1,48 \mathrm{~m}^{2} \cdot \mathrm{ha}^{-1}\right)$. As outras espécies mortas tiveram 84,2 plantas.ha ${ }^{-1} ; 0,19 \mathrm{~m}^{2} \cdot \mathrm{ha}^{-1}$ de densidade e dominância, respectivamente. No que se refere à biomassa morta de galhos, esta corresponde a $14,8 \%$ da dominância mortas e as espécies vivas com maior biomassa morta de galhos foram $V$. seubertiana $\left(0.06 \mathrm{~m}^{2} \cdot \mathrm{ha}^{-1}\right)$, Erythroxylum suberosum $\left(0.04 \mathrm{~m}^{2} \cdot \mathrm{ha}^{-1}\right)$, Vochysia rufa $(0.03$ 
$\mathrm{m}^{2} \cdot \mathrm{ha}^{-1}$ ), Byrsonima coccobolifolia, Tachigali rugosa, Leptolobium dasycarpum e Stryphnodendron adstringens $\left(0,02 \mathrm{~m}^{2} \cdot \mathrm{ha}^{1}\right)$, Anacardium nanum, Dimorphandra mollis, Connarus suberosus e Kielmeyera coriacea $\left(0,01 \mathrm{~m}^{2} \cdot \mathrm{ha}^{-1}\right)$.

Tabela 4.16 - Espécies do Campo Sujo Seco (vertente), na bacia hidrográfica do ribeirão Taquaruçu Grande, Palmas (TO), com densidade absoluta (AbsDe); densidade relativa (RelDe); frequência absoluta (AbsFr); frequência relativa (RelFr); dominância absoluta (AbsDo); dominância relativa (RelDo); em ordem decrescente de índice de valor de importância (IVI) (continua)

\begin{tabular}{|c|c|c|c|c|c|c|c|}
\hline Espécies & $\begin{array}{c}\text { AbsDe } \\
\text { (ind./ha) }\end{array}$ & $\begin{array}{c}\text { RelDe } \\
(\%)\end{array}$ & $\begin{array}{c}\operatorname{AbsFr} \\
(\%)\end{array}$ & $\begin{array}{c}\text { RelFr } \\
(\%)\end{array}$ & $\begin{array}{l}\text { AbsDo } \\
\left(\mathrm{m}^{2} / \mathrm{ha}\right)\end{array}$ & $\begin{array}{c}\text { RelDo } \\
(\%)\end{array}$ & $\begin{array}{l}\text { IVI } \\
(\%)\end{array}$ \\
\hline Vellozia seubertiana & 824.0 & 35.00 & 90.00 & 9.85 & 2.22 & 40.41 & 85.26 \\
\hline Syagrus comosa & 270.0 & 11.47 & 72.00 & 7.88 & 0.55 & 10.02 & 29.36 \\
\hline Erythroxylum suberosum & 114.0 & 4.84 & 58.00 & 6.35 & 0.30 & 5.53 & 16.72 \\
\hline Vochysia cinnamomea & 128.0 & 5.44 & 20.00 & 2.19 & 0.25 & 4.49 & 12.11 \\
\hline Byrsonima coccobolifolia & 100.0 & 4.25 & 34.00 & 3.72 & 0.18 & 3.31 & 11.28 \\
\hline Connarus suberosus & 60.0 & 2.55 & 38.00 & 4.16 & 0.19 & 3.38 & 10.08 \\
\hline Byrsonima pachyphylla & 70.0 & 2.97 & 40.00 & 4.38 & 0.15 & 2.67 & 10.02 \\
\hline Davilla elliptica & 52.0 & 2.21 & 34.00 & 3.72 & 0.14 & 2.48 & 8.41 \\
\hline Ouratea spectabilis & 54.0 & 2.29 & 32.00 & 3.50 & 0.12 & 2.20 & 7.99 \\
\hline Piptocarpha rotundifolia & 44.0 & 1.87 & 32.00 & 3.50 & 0.14 & 2.50 & 7.87 \\
\hline Salvertia convallariodora & 26.0 & 1.10 & 22.00 & 2.41 & 0.20 & 3.68 & 7.19 \\
\hline Bauhinia curvula & 60.0 & 2.55 & 38.00 & 4.16 & 0.01 & 0.12 & 6.82 \\
\hline Dimorphandra mollis & 28.0 & 1.19 & 18.00 & 1.97 & 0.08 & 1.42 & 4.58 \\
\hline Byrsonima verbascifolia & 22.0 & 0.93 & 20.00 & 2.19 & 0.07 & 1.34 & 4.47 \\
\hline Anacardium humile & 38.0 & 1.61 & 18.00 & 1.97 & 0.04 & 0.74 & 4.33 \\
\hline Himatanthus obovatus & 24.0 & 1.02 & 20.00 & 2.19 & 0.03 & 0.60 & 3.81 \\
\hline Anacardium occidentale & 18.0 & 0.76 & 10.00 & 1.09 & 0.10 & 1.86 & 3.72 \\
\hline Stryphnodendron adstringens & 20.0 & 0.85 & 16.00 & 1.75 & 0.05 & 1.00 & 3.60 \\
\hline Tachigali rugosa & 20.0 & 0.85 & 14.00 & 1.53 & 0.04 & 0.75 & 3.13 \\
\hline Brosimum gaudichaudii & 14.0 & 0.59 & 12.00 & 1.31 & 0.07 & 1.20 & 3.11 \\
\hline Byrsonima subterranea & 28.0 & 1.19 & 14.00 & 1.53 & 0.02 & 0.31 & 3.03 \\
\hline Bauhinia rufa & 26.0 & 1.10 & 16.00 & 1.75 & 0.00 & 0.09 & 2.94 \\
\hline Leptolobium dasycarpum & 18.0 & 0.76 & 14.00 & 1.53 & 0.03 & 0.58 & 2.87 \\
\hline Annona crassiflora & 10.0 & 0.42 & 10.00 & 1.09 & 0.05 & 0.85 & 2.37 \\
\hline Anacardium nanum & 20.0 & 0.85 & 12.00 & 1.31 & 0.01 & 0.20 & 2.37 \\
\hline Salacia crassifolia & 12.0 & 0.51 & 12.00 & 1.31 & 0.03 & 0.52 & 2.34 \\
\hline Diospyros hispida & 6.0 & 0.25 & 6.00 & 0.66 & 0.08 & 1.41 & 2.32 \\
\hline Kielmeyera coriacea & 14.0 & 0.59 & 14.00 & 1.53 & 0.01 & 0.17 & 2.29 \\
\hline Manihot acuminatissima & 16.0 & 0.68 & 14.00 & 1.53 & 0.00 & 0.02 & 2.23 \\
\hline Bowdichia virgilioides & 4.0 & 0.17 & 4.00 & 0.44 & 0.08 & 1.42 & 2.03 \\
\hline Psidium firmum & 10.0 & 0.42 & 10.00 & 1.09 & 0.03 & 0.47 & 1.99 \\
\hline Vochysia cf. divergens & 22.0 & 0.93 & 4.00 & 0.44 & 0.03 & 0.57 & 1.95 \\
\hline Vochysia cf. thyrsoidea & 12.0 & 0.51 & 10.00 & 1.09 & 0.02 & 0.29 & 1.90 \\
\hline Tabebuia aurea & 10.0 & 0.42 & 10.00 & 1.09 & 0.02 & 0.28 & 1.80 \\
\hline Qualea grandiflora & 10.0 & 0.42 & 10.00 & 1.09 & 0.01 & 0.20 & 1.72 \\
\hline Casearia sylvestris & 12.0 & 0.51 & 10.00 & 1.09 & 0.00 & 0.03 & 1.64 \\
\hline Manihot sparsifolia & 14.0 & 0.59 & 8.00 & 0.88 & 0.01 & 0.09 & 1.56 \\
\hline Mimosa radula cf. var. imbricata & 18.0 & 0.76 & 6.00 & 0.66 & 0.00 & 0.04 & 1.46 \\
\hline Qualea parviflora & 6.0 & 0.25 & 6.00 & 0.66 & 0.03 & 0.53 & 1.44 \\
\hline Vochysia rufa & 8.0 & 0.34 & 8.00 & 0.88 & 0.01 & 0.15 & 1.37 \\
\hline Schefflera macrocarpa & 8.0 & 0.34 & 8.00 & 0.88 & 0.01 & 0.14 & 1.36 \\
\hline Caliandra dysantha & 8.0 & 0.34 & 8.00 & 0.88 & 0.00 & 0.01 & 1.23 \\
\hline
\end{tabular}


Tabela 4.16 - Espécies do Campo Sujo Seco (vertente), na bacia hidrográfica do ribeirão Taquaruçu Grande, Palmas (TO), com densidade absoluta (AbsDe); densidade relativa (RelDe); frequência absoluta (AbsFr); frequência relativa (RelFr); dominância absoluta (AbsDo); dominância relativa (RelDo); em ordem decrescente de índice de valor de importância (IVI) (conclusão)

\begin{tabular}{lccccccc}
\hline \multicolumn{1}{c}{ Espécies } & $\begin{array}{c}\text { AbsDe } \\
\text { (ind./ha) }\end{array}$ & $\begin{array}{c}\text { RelDe } \\
(\boldsymbol{\%})\end{array}$ & $\begin{array}{c}\text { AbsFr } \\
(\boldsymbol{\%})\end{array}$ & $\begin{array}{c}\text { RelFr } \\
(\boldsymbol{\%})\end{array}$ & $\begin{array}{c}\text { AbsDo } \\
\left(\mathbf{m}^{\mathbf{2}} / \mathbf{h a}\right)\end{array}$ & $\begin{array}{c}\text { RelDo } \\
(\boldsymbol{\%})\end{array}$ & $\begin{array}{c}\text { IVI } \\
(\boldsymbol{\%})\end{array}$ \\
\hline Senna velutina & 8.0 & 0.34 & 8.00 & 0.88 & 0.00 & 0.01 & 1.23 \\
Myrcia splendens & 8.0 & 0.34 & 8.00 & 0.88 & 0.00 & 0.01 & 1.23 \\
Mimosa albolanata cf. var. brasiliana & 10.0 & 0.42 & 2.00 & 0.22 & 0.02 & 0.40 & 1.05 \\
Rourea induta & 6.0 & 0.25 & 4.00 & 0.44 & 0.01 & 0.10 & 0.79 \\
Ouratea hexasperma & 2.0 & 0.08 & 2.00 & 0.22 & 0.03 & 0.47 & 0.78 \\
Curatella americana & 6.0 & 0.25 & 4.00 & 0.44 & 0.00 & 0.05 & 0.74 \\
Annona coriacea & 4.0 & 0.17 & 4.00 & 0.44 & 0.01 & 0.10 & 0.70 \\
Agonandra brasiliensis & 2.0 & 0.08 & 2.00 & 0.22 & 0.01 & 0.17 & 0.47 \\
Erythroxylum tortuosum & 4.0 & 0.17 & 2.00 & 0.22 & 0.00 & 0.06 & 0.45 \\
Dipteryx alata & 2.0 & 0.08 & 2.00 & 0.22 & 0.01 & 0.13 & 0.44 \\
Andira humilis & 2.0 & 0.08 & 2.00 & 0.22 & 0.01 & 0.12 & 0.42 \\
Palicourea rigida & 2.0 & 0.08 & 2.00 & 0.22 & 0.01 & 0.10 & 0.41 \\
Ananas ananassoides & 2.0 & 0.08 & 2.00 & 0.22 & 0.00 & 0.07 & 0.38 \\
Zeyhera tuberculosa & 2.0 & 0.08 & 2.00 & 0.22 & 0.00 & 0.07 & 0.37 \\
Vochysia tucanorum & 2.0 & 0.08 & 2.00 & 0.22 & 0.00 & 0.04 & 0.34 \\
Kielmeyera lanthrophyton & 2.0 & 0.08 & 2.00 & 0.22 & 0.00 & 0.01 & 0.32 \\
Chamaecrista orbiculata & 2.0 & 0.08 & 2.00 & 0.22 & 0.00 & 0.01 & 0.31 \\
Tibouchina aegopogon & 2.0 & 0.08 & 2.00 & 0.22 & 0.00 & 0.00 & 0.31 \\
Miconia albicans & 2.0 & 0.08 & 2.00 & 0.22 & 0.00 & 0.00 & 0.31 \\
Platonia insignis & 2.0 & 0.08 & 2.00 & 0.22 & 0.00 & 0.00 & 0.31 \\
Hymenaea stigonocarpa & 2.0 & 0.08 & 2.00 & 0.22 & 0.00 & 0.00 & 0.31 \\
Hancornia speciosa & 2.0 & 0.08 & 2.00 & 0.22 & 0.00 & 0.00 & 0.31 \\
\hline
\end{tabular}

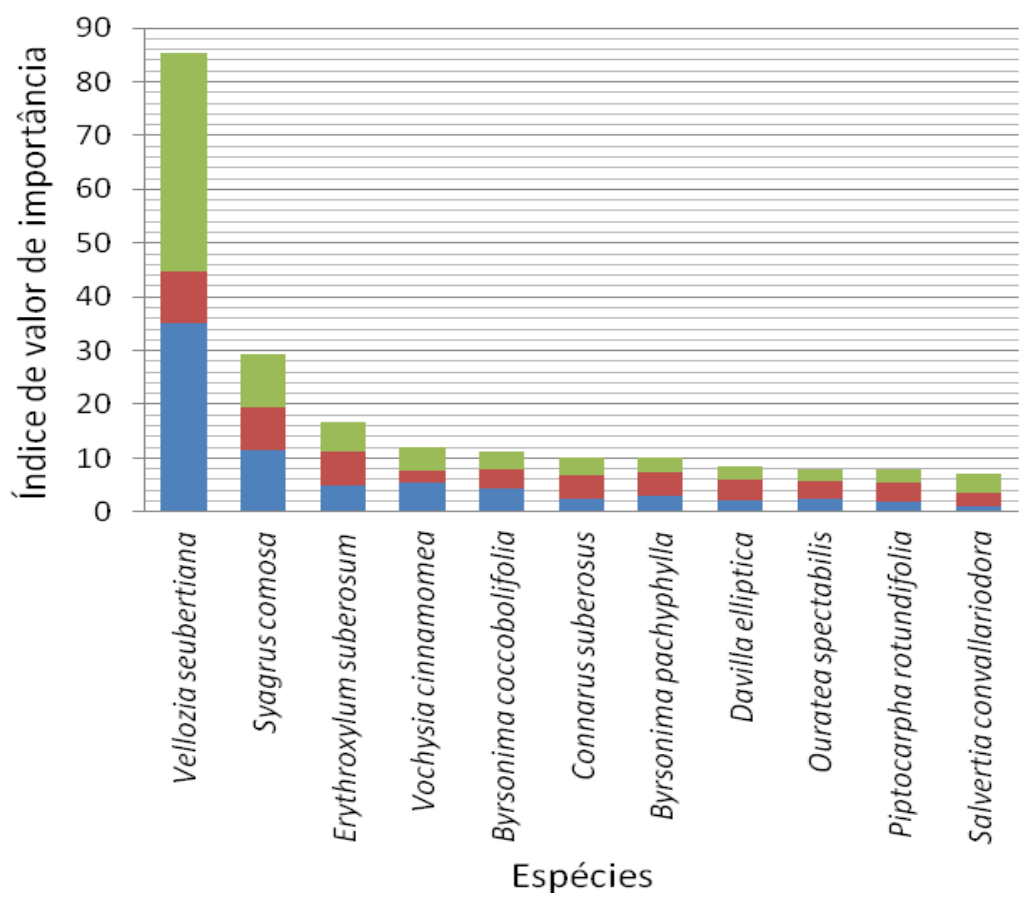

RelDo

RelFr

RelDe

Figura 4.46 - Distribuição das espécies com índice de valor de importância (IVI) acima de 7, da comunidade de plantas do Campo Sujo Seco (A1V; A2V; A3V; A4V; A5V), na bacia hidrográfica do ribeirão Taquaruçu Grande, Palmas (TO) 
Comparando-se as áreas de amostragem (A1V; A2V; A3V; A4V; A5V), houve uma variação em número de famílias, gêneros e espécies entre as áreas. A comunidade de plantas da área 2 teve mais famílias e espécies, enquanto que a área 3 teve mais gêneros e a área 1 teve menos famílias (Tabela 4.17). A área 1 também apresentou maiores densidades, já a maior dominância ficou com a área 2. Houve menor amplitude de variação dos diâmetros (média) entre as áreas na vertente que no topo, porém, as áreas 2 e 4 apresentaram-se com vegetação mais desenvolvida em diâmetro de caule e altura. $\mathrm{O}$ menor diâmetro (média) ficou com a área 1 (Tabela 4.18), devido à grande densidade de Vellozia seubertianan (2.350,0 indivíduos.ha ${ }^{-1}$ ).

Tabela 4.17 - Número de famílias, gêneros e espécies, da comunidade de plantas do Campo Sujo Seco, por área, na bacia hidrográfica do ribeirão Taquaruçu Grande, Palmas (TO)

\begin{tabular}{cccc}
\hline Área & Famílias & Gêneros & Espécies \\
\hline A1V & 16 & 24 & 28 \\
A2V & 22 & 28 & 34 \\
A3V & 19 & 29 & 34 \\
A4V & 19 & 21 & 25 \\
A5V & 17 & 22 & 29 \\
\hline
\end{tabular}

Tabela 4.18 - Densidade absoluta (AbsDe), dominância absoluta (AbsDo), diâmetro (média) e altura (média) da comunidade de plantas do Campo Sujo Seco, por área, na bacia hidrográfica do ribeirão Taquaruçu Grande, Palmas (TO)

\begin{tabular}{ccccc}
\hline Área & AbsDe & AbsDo & $\begin{array}{c}\text { Diâmetro } \\
\text { (média) }\end{array}$ & Altura (média) \\
\hline A1V & $4.140,0$ & 6,51 & 4,07 & 0,98 \\
A2V & $2.080,0$ & 7,05 & 5,53 & 1,40 \\
A3V & $2.400,0$ & 4,67 & 4,43 & 0,88 \\
A4V & $1.800,0$ & 5,76 & 5,71 & 1,25 \\
A5V & $1.350,0$ & 3,27 & 4,12 & 1,05 \\
\hline
\end{tabular}

\subsection{Estrato herbáceo-subarbustivo do Campo Sujo Seco}

Uma característica dos Campos Sujos Secos é a expressiva presença do estrato herbáceo-subarbustivo. Na bacia hidrográfica do ribeirão Taquaruçu Grande, 36,4\% do total de 121 de espécies das comunidades de plantas ocorrentes no Campo Sujo Seco são deste estrato. 
As famílias com maior número de espécies foram Poaceae, Fabaceae e Cyperaceae (Figura 4.47). As espécies que tiveram maiores coberturas de solo foram Indeterminada 5, Rhynchospora brasiliensis, Axonopus brasiliensis, Bulbostylis pradoxa, Indeterminada 2, Indeterminada 4 e Indeterminada 6 (Tabela 4.19). Tanto no topo quanto na vertente, ocorreram altos índices de solo exposto com dados semelhantes entre os dois tipos de relevo ( $22,6 \%$ na vertente e $21,1 \%$ no topo).

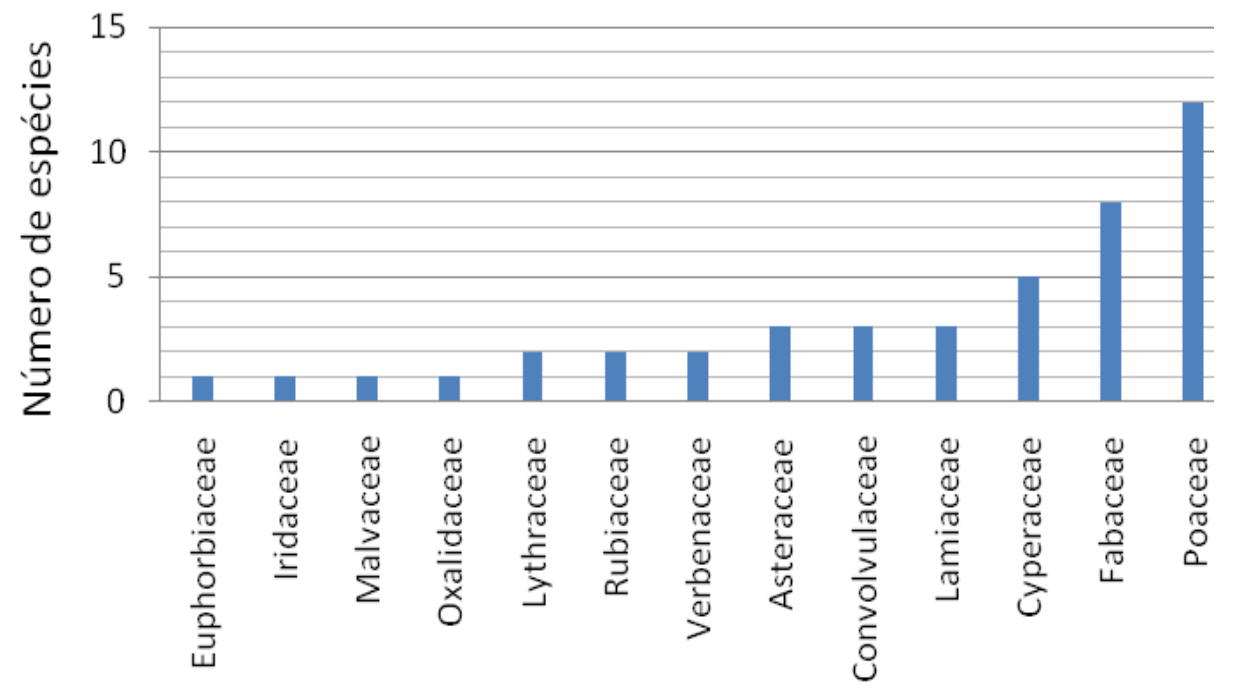

Famílias

Figura 4.47 - Distribuição do número de espécies, por famílias do estrato hebáceo-subarbustivo, da comunidade de plantas do Campo Sujo Seco, na bacia hidrográfica do ribeirão Taquaruçu Grande, Palmas (TO) 
Tabela 4.19 - Espécies do Campo Sujo Seco (topo e vertente), do estrato herbáceo-subarbustivo, na bacia hidrográfica do ribeirão Taquaruçu Grande, Palmas (TO), em ordem alfabética, com respectivos índices de cobertura do solo

\begin{tabular}{|c|c|c|}
\hline Espécies & Topo $(\%)$ & Vertente $(\%)$ \\
\hline Amasonia campestris & 0,5 & 0 \\
\hline Aspilia foliacea & 0,4 & 0 \\
\hline Aspilia leucoglossa & 0,3 & 0 \\
\hline Axonopus brasiliensis & 13,64 & 13,67 \\
\hline Borreria eryngioides & 0 & 0,1 \\
\hline Bulbostylis pradoxa & 5,5 & 11,16 \\
\hline Indeterminada 5 & 28,32 & 22,64 \\
\hline Indeterminada 2 & 3,36 & 3,2 \\
\hline Indeterminada 3 & 0,6 & 1,7 \\
\hline Indeterminada 6 & 1,5 & 3,4 \\
\hline Indeterminada 7 & 0 & 0,18 \\
\hline Indeterminada 8 & 1,4 & 1,8 \\
\hline Indeterminada 10 & 0,2 & 0,06 \\
\hline Indeterminada 1 & 1,22 & 2,3 \\
\hline Indeterminada 4 & 0,4 & 6,14 \\
\hline Indeterminada 9 & 0,2 & 0,12 \\
\hline Captosema scarlatium & 0,42 & 0,46 \\
\hline Casselia $\mathrm{sp}$ & 0,1 & 0 \\
\hline Centrosema virginianum & 0,24 & 0 \\
\hline Chamaecrista diphylla & 0,04 & 0 \\
\hline Chamaecrista serpens & 0,3 & 0,22 \\
\hline Clitoria guianensis & 0,2 & 0,08 \\
\hline Crotalaria unifoliolata & 0,34 & 0,3 \\
\hline Diplusodon microphyllus & 0,18 & 0 \\
\hline Diplusodon sessiliflorus & 0,22 & 0 \\
\hline Eleocharis sp. & 0,92 & 0,38 \\
\hline Croton goyazensis & 1.02 & 1.4 \\
\hline Fimbristylis sp. & 0,06 & 0,18 \\
\hline Hyptis peduncularis & 0,08 & 0 \\
\hline Ipomoea procumbens & 0,9 & 0,14 \\
\hline Lippia florida & 0 & 0,06 \\
\hline Merremia flagellaris & 0,06 & 0,27 \\
\hline Merremia tomentosa & 0 & 0,22 \\
\hline Mitracarpus frigidus & 0,16 & 0,32 \\
\hline Oxalis densifolia & 0,38 & 0,04 \\
\hline Panicum maximum & 0 & 0,8 \\
\hline Peltaea edouardii & 0,02 & 0,1 \\
\hline Peltodon tomentosus & 0 & 0,06 \\
\hline Rhynchospora brasiliensis & 14,34 & 5,16 \\
\hline Rhynchospora consanguinea & 0,26 & 0,1 \\
\hline Trimezia juncifolia & 0,04 & 0,1 \\
\hline Lessigianthus obtusatus & 0,24 & 0 \\
\hline Vigna firmula & 0,3 & 0,22 \\
\hline Vigna speciosa & 0,32 & 0,26 \\
\hline
\end{tabular}

Em se tratando da cobertura do solo por área geográfica, considerando o relevo de topo, Rhynchospora brasiliensis teve ampla ocorrência na área 3 (A3T), Indeterminada 5 nas áreas 2 e 5 (A2T; A5T) e Axonopus brasiliensis na área 4 (A4T) (Figura 4.48). 


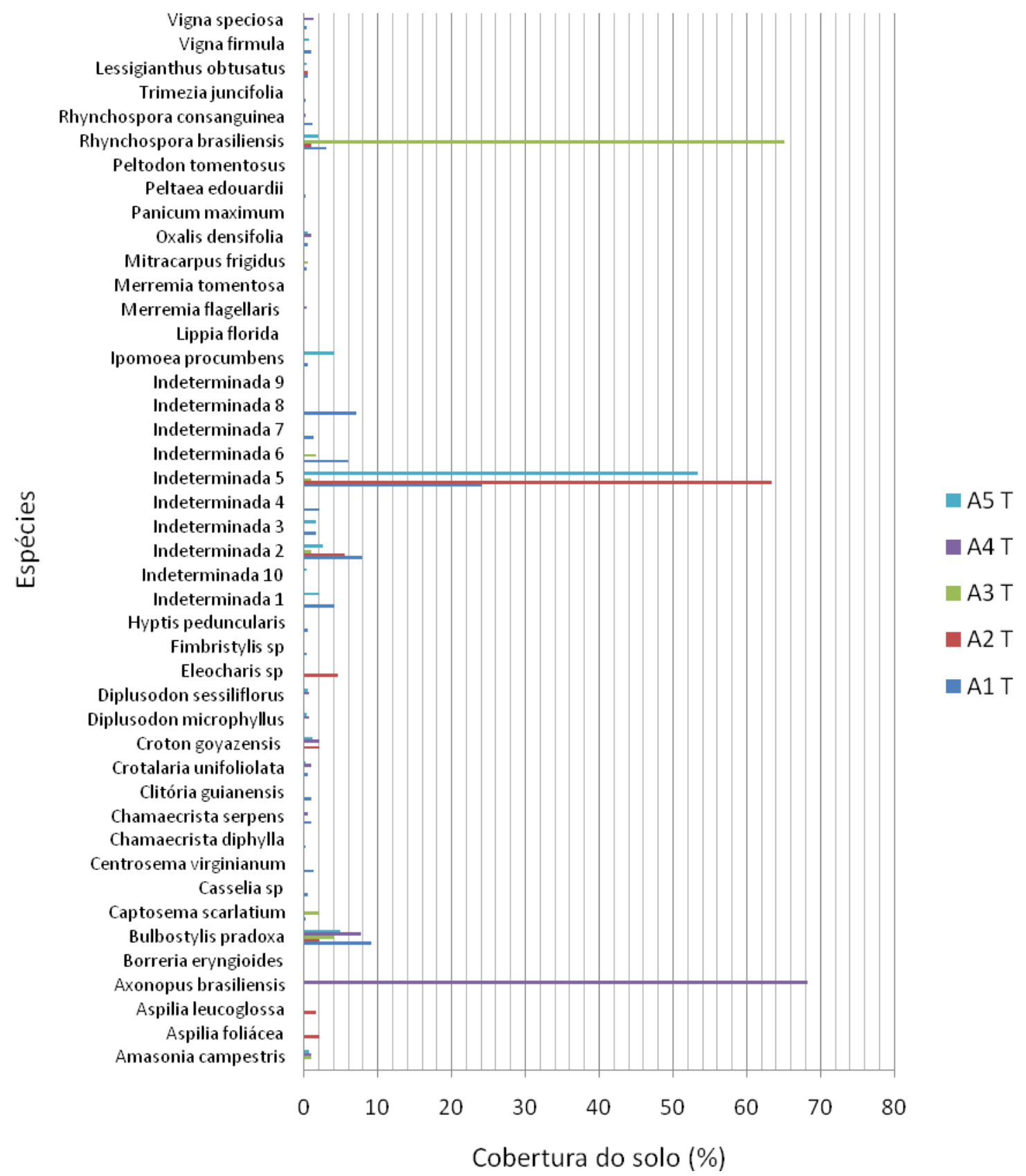

Figura 4.48 - Índice de cobertura do solo das espécies do estrato herbáceo-subarbustivo do Campo Sujo Seco, por áreas do topo (A1T; A2T; A3T; A4T; A5T), na bacia hidrográfica do ribeirão Taquaruçu Grande, Palmas (TO)

No relevo de vertente, também Rhynchospora brasiliensis teve ocorrência na área 3 (A3V), menos expressiva que no topo, Indeterminada 5 manteve ampla ocorrência nas áreas 2 e 5 (A2V; A5V) assim com Axonopus brasiliensis na área 4 (A4T) e Bulbostylis paradoxa teve mais expressiva ocorrência em todas as áreas que no topo (Figura 4.49). 


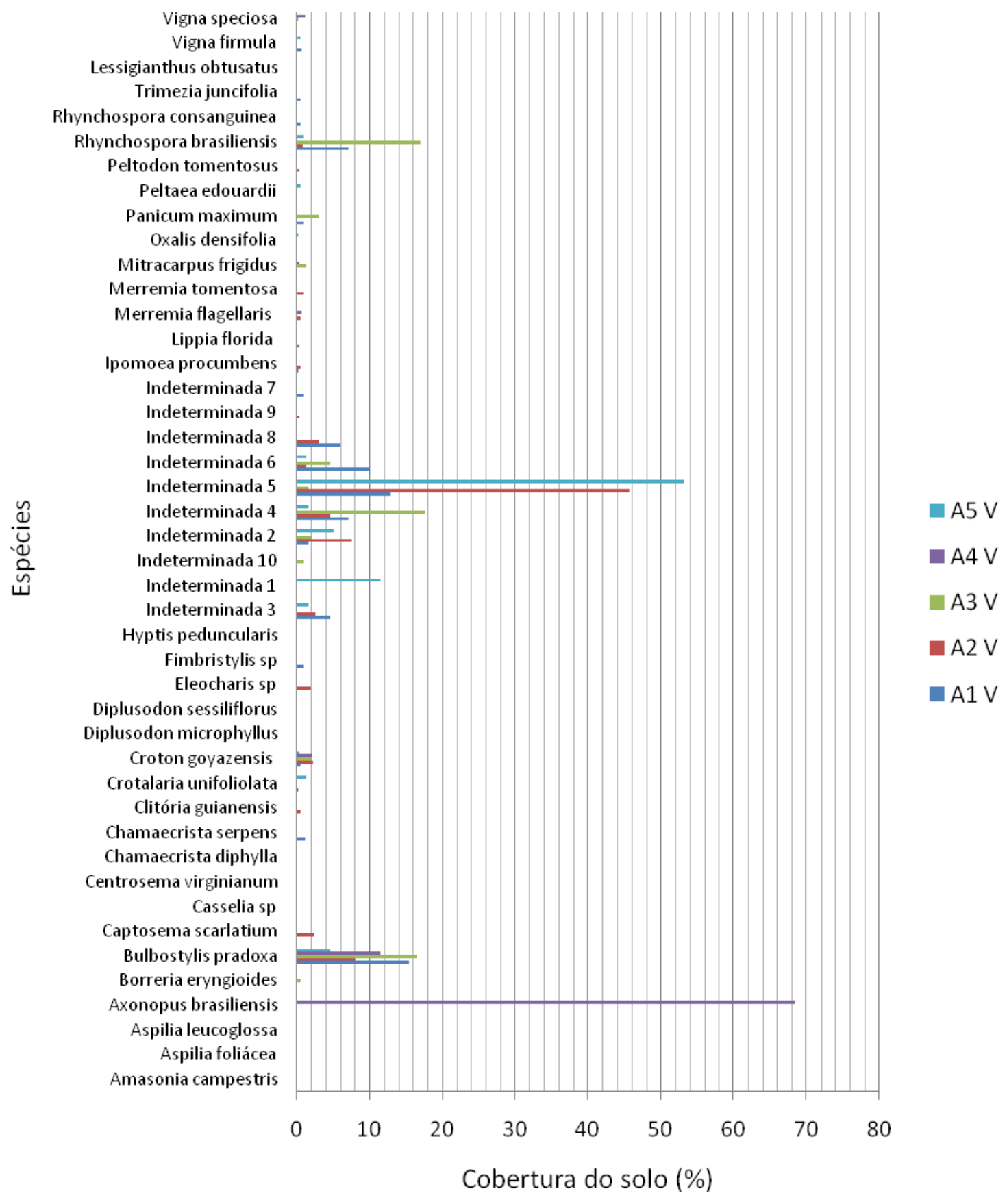

Figura 4.49 - Índice de cobertura do solo das espécies do estrato herbáceo-subarbustivo do Campo Sujo Seco, por áreas da vertente (A1V; A2V; A3V; A4V; A5V), na bacia hidrográfica do ribeirão Taquaruçu Grande, Palmas (TO) 


\subsection{Diversidade e similaridade florística do Campo Sujo Seco}

\subsection{1 Índice de Diversidade de Shannon-Wiener}

A diversidade da comunidade do Campo Sujo Seco da bacia hidrográfica do ribeirão Taquaruçu Grande, pelo índice de diversidade de Shannon-Wiener foi $H^{\prime}=3,065$ nats.indivíduo ${ }^{-1}$ e o índice de uniformidade de equitabilidade ou uniformidade de Pielou foi $\mathrm{J}^{\prime}=0,706$, calculados para todo o bosque sem vegetação herbáceo-subarbustiva. Com a vegetação herbáceo-subarbustiva, o índice de Shannon-Wiener foi H'= 3,533 nats.indivíduo-1 e a equitabilidade de Pielou, J'=0,737. Em se tratando de áreas de amostragem, as maiores diversidades de espécies, foram da área 3 (topo) e da área 5 (vertente), ambas apresentaram as maiores equitabilidades em relação às demais áreas (Tabela 4.20).

Tabela 4.20 - Diversidade de espécies pelo índice de Shannon-Wiener ( $\left.\mathrm{H}^{\prime}\right)$ e equitabilidade de Pielou (J'), em relevo de topo (A1T; A2T; A3T; A4T; A5T), e Vertente (A1V; A2V; A3V; A4V; A5V), da comunidade de plantas do Campo Sujo Seco, na bacia hidrográfica do ribeirão Taquaruçu Grande, Palmas (TO)

\begin{tabular}{cccccc}
\hline Áreas & $\begin{array}{c}\text { Topo } \\
\text { H' }\end{array}$ & J' & Áreas & Vertente & J' \\
\hline A1T & 2,66 & 0,72 & A1V & 1,84 & 0,55 \\
A2T & 2,94 & 0,86 & A2V & 2,75 & 0,78 \\
A3T & 3,05 & 0,87 & A3V & 2,64 & 0,75 \\
A4T & 2,57 & 0,74 & A4V & 1,95 & 0,61 \\
A5T & 2,39 & 0,73 & A5V & 2,95 & 0,88 \\
\hline
\end{tabular}

O valor de $\mathrm{H}^{\prime}=3,533$ nats.indivíduo ${ }^{-1}$ para o Campo Sujo estudado é um valor considerado alto, geralmente acima dos valores registrados para Campos Sujos, estando mais semelhante ao Campo Sujo da Estação Ecológica Pirapitinga (MG) e na faixa de cerrado stricto sensu (Tabela 4.21). Felfili et al. (1992) consideram altos os valores do índice de Shannon-Wiener acima de 3,0 nats.indivíduo ${ }^{-1}$, indicando cerrados bem preservados. Segundo Felfili e Felfili (2001), no Cerrado Stricto Sensu, a diversidade alfa, está na faixa de 3,0 a 3,5 nats/indivíduo, sendo portanto, elevada.

Quanto à equitabilidade, que mede a uniformidade de distribuição dos indivíduos nas espécies, o valor de $\mathrm{J}^{\prime}=0,737$, indica certa desigualdade na distribuição do número de indivíduos nas espécies. Como se pôde constatar, as espécies Vellozia seubertiana, principalmente, Syagrus comosa, Erythroxylum suberosum, Byrsonima subterranea e Vochysia cinnamomea ocorreram em grandes densidades (Tabela 4.10), enquanto que 18,2\% 
das espécies lenhosas foram representadas por apenas um indivíduo. Segundo Felfili e Felfli (2001), em ambientes tropicais, o número de espécies é elevado e a distribuição desigual, ou seja, com poucas espécies contendo muitos indivíduos e um grande número de espécies com um número reduzido de indivíduos Neste último caso podem ser consideradas raras localmente.

Tabela 4.21 - Índices de diversidade de Shannon $\left(\mathrm{H}^{\prime}\right)$ nats.indivíduo ${ }^{-1}$ e equitabilidade de Pielou (J') em diversas fitofisionomias no Campo Sujo e no Campo Sujo Seco da bacia hidrográfica do ribeirão Taquaruçu Grande, Palmas (TO)

\begin{tabular}{lcccl}
\hline \multicolumn{1}{c}{ Localidade } & H' & J' & Fitofisionomia & \multicolumn{1}{c}{ Fonte } \\
\hline Bacia do Taquaruçu Grande, Palmas (TO) & 3,50 & 0,74 & Campo Sujo & Este trabalho \\
Fazenda Água Limpa (DF) & 3,20 & - & Campo Sujo & Munhoz e Felfili (2006) \\
E. E. Panga (MG) & 3,00 & 0,80 & Campo Sujo & Moreno et al. (2008) \\
Silvânia (GO) & 2,92 & 0,87 & Campo Sujo & Araújo et al. (2012) \\
E. E. Pirapitinga (MG) & 3,43 & 0,85 & Campo Sujo & Giácomo et al. (2013) \\
E. E. Águas Emendadas ( DF) & 3,62 & - & Cerrado SS* & Felfili et al. (1992) \\
A.P.A Gama Cabeça de Veado (DF) & 3,56 & - & Cerrado SS & Felfili et al. (1992) \\
Parque Nacional de Brasília (DF) & 3,34 & - & Cerrado SS & Felfili et al. (1992) \\
Fazenda Água Limpa (DF) & 3,42 & - & Cerrado SS & Felfili e Silva-Júnior (1992) \\
PEN & 3,24 & - & Cerrado SS & Rossi et al. (1998) \\
Abaeté (MG) & 3,59 & 0,80 & Cerrado SS & Saporetti et al. (2003) \\
Pé-de-Gigante (SP) & 3,62 & 0,84 & Cerrado SS & Fidelis e Godoy (2003) \\
Silvânia (GO) & 3,48 & - & Cerrado SS & Araújo. Et al. (2012) \\
Patrocínio (MG) & 3,53 & - & Cerradão & Felfili et al. (1992) \\
APA (DF) & 3,17 & - & Cerradão & Felfili et al. (1994) \\
Silvânia (GO) & 3,31 & - & Cerrado SS/Cerradão & Felfili et al. (1992) \\
AÇUD & 4,25 & - & Mata de Galeria & Sampaio et al. (1997) \\
Paracatu (MG) & 3,11 & - & & Felfili et al. (1992)
\end{tabular}

*Cerrado SS = Cerrado Stricto Sensu

\subsection{Análise de Agrupamento}

A análise de agrupamento da comunidade de plantas do Campo Sujo Seco utilizando o método UPGMA (Unweighted Pair-Group Metod using Arithmetc Averanges), pelo coeficiente de semelhança de Jaccard, teve Correlação Cofenética significativa, com valor de 0.876. Esta análise indicou a existência de grupos florísticos individualizados, onde as comunidades da área 1 (topo) com área 1 (vertente) apresentaram maior similaridade florística entre si, seguidas pela área 5 (vertente) com área 5 (topo) e área 3 (vertente) com área 3 (topo). A Área 2 (vertente) apresentou-se mais similar ao grupo da área 3, enquanto que as áreas 2 (topo) e área 4 (topo e vertente) foram as mais diferentes. Portanto, a um corte de 46\% (metade entre a menor e a maior similaridade), tem-se a composição de seis grupos florísticos individualizados (Figura 4.50). 


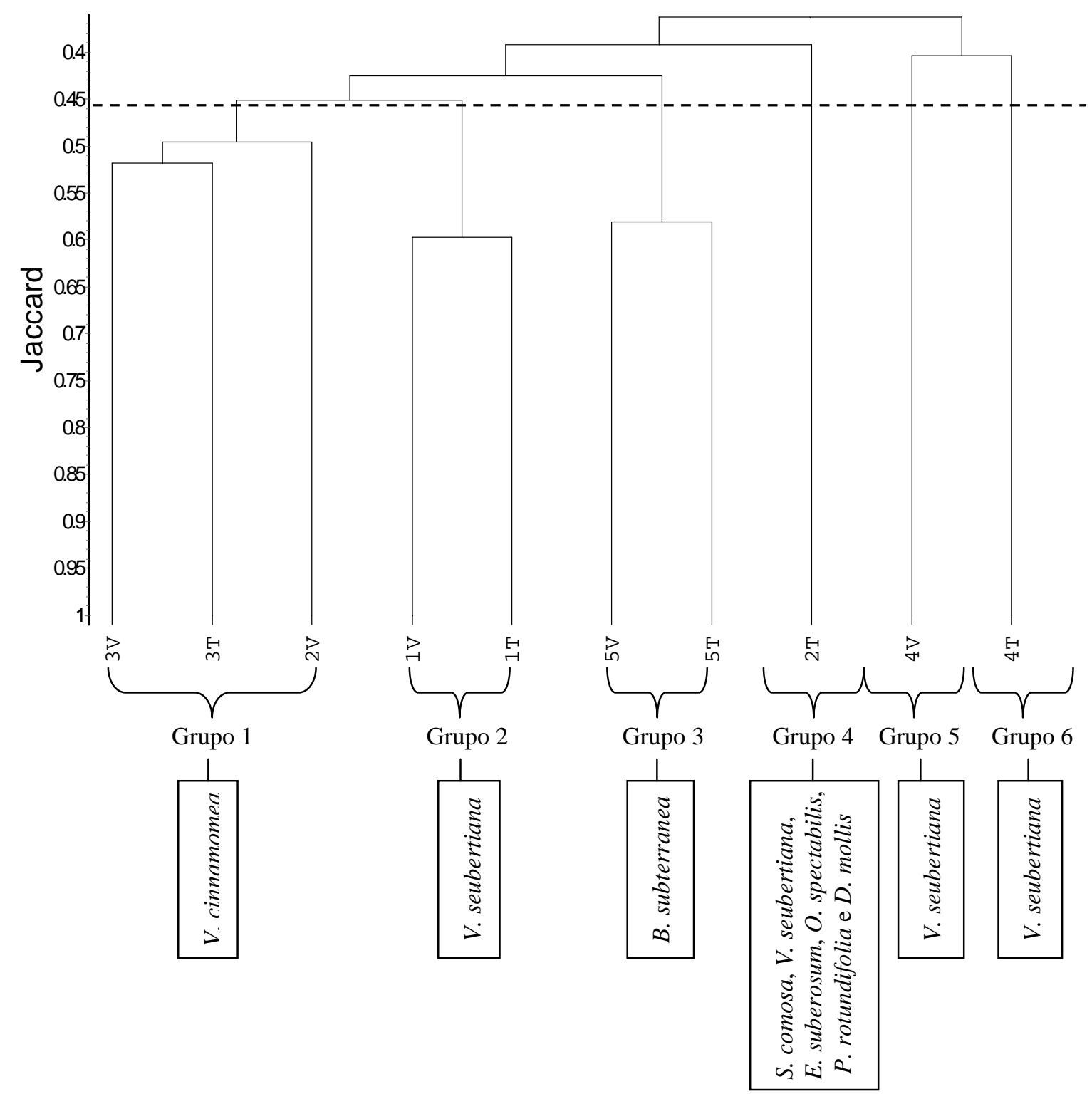

Figura 4.50 - Dendograma de similaridade de Jaccard das comunidades de plantas do Campo Sujo Seco, em cinco áreas de relevo de topo $(\mathrm{T})$ e vertente $(\mathrm{V})$, na bacia hidrográfica do ribeirão Taquaruçu Grande, Palmas (TO), com ligação dos grupos pela média não ponderada (UPGMA)

O Grupo 1 (Figura 4.50) foi formado pelas comunidades de plantas do Campo Sujo Seco da área 3 (topo e vertente) com a área 2 (vertente). $\mathrm{Na}$ área 3, as espécies com maior número de ocorrência foram Vochysia cinnamomea, Byrsonima coccobolifolia e Vellozia seubertiana (Figura 4.51). A área 2 (vertente) apresentou maior similaridade florística com a área 3 que, com nível de corte de $46 \%$, formaram um único grupo.

As espécies que contribuíram para essa similaridade foram Vellozia seubertiana, Connarus suberosus, Piptocarpha rotundifolia, Dimorphandra mollis, Bauhinia rufa, Myrcia 
splendens, Davilla elliptica, Byrsonima verbascifolia, Qualea grandiflora, Erythroxylum suberosum, Ouratea spectabilis, Anacardium occidentale, Byrsonima pachyphylla, Syagrus comosa, Himatanthus obovatus, Bulbostylis paradoxa, Rhynchosphora brasiliensis, Indeterminada 2, Indeterminada 4, Indeterminada 5 e Indeterminada 6; pela expressiva presença de $V$. cinnamomea na área 3, sobretudo na Vertente, esses são Campos Sujos Secos de $V$. cinnamomea (Figuar 4.52).

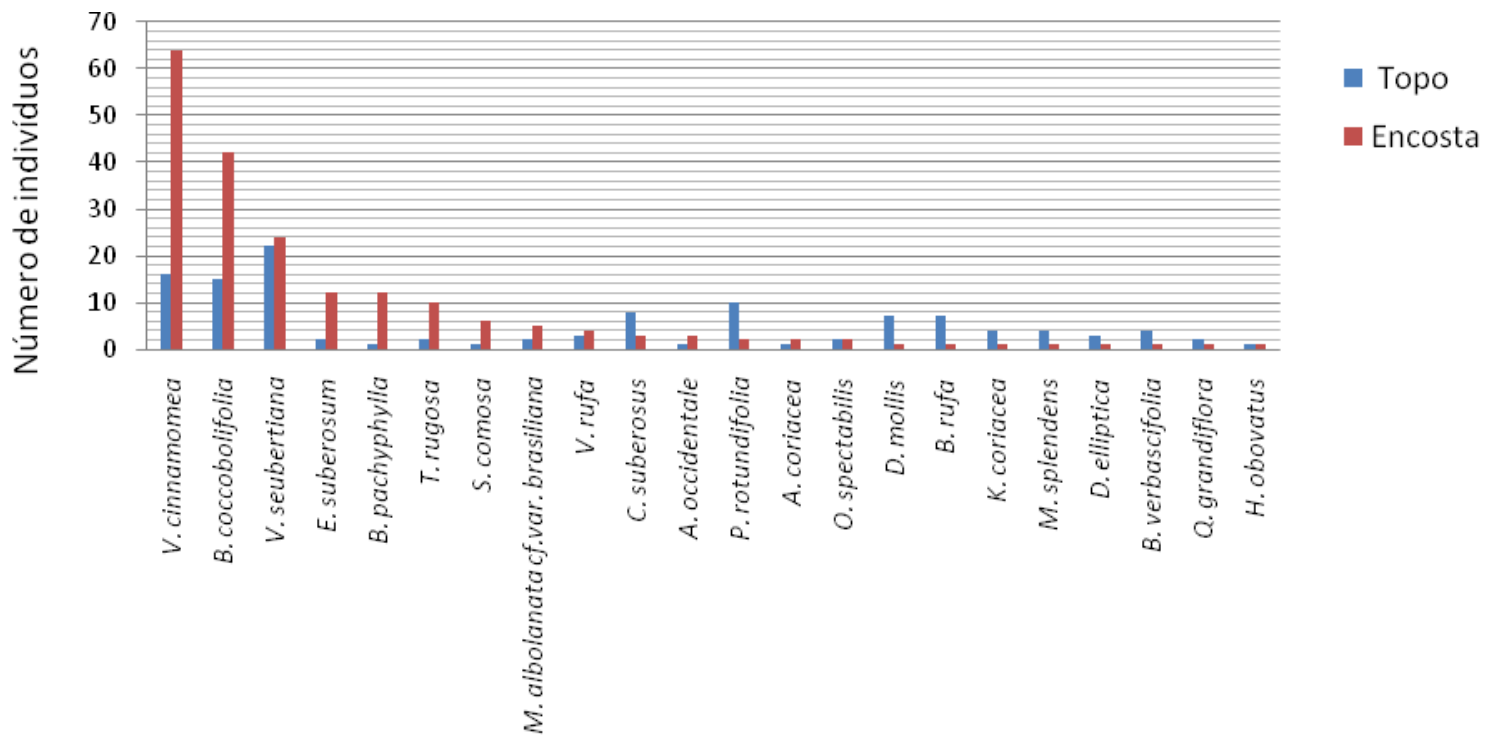

Espécies

Figura 4.51 - Grupo 1 (área 3 - topo e vertente), por número de indivíduos das espécies, das comunidades de plantas do Campo Sujo Seco, na bacia hidrográfica do ribeirão Taquaruçu Grande, Palmas (TO)
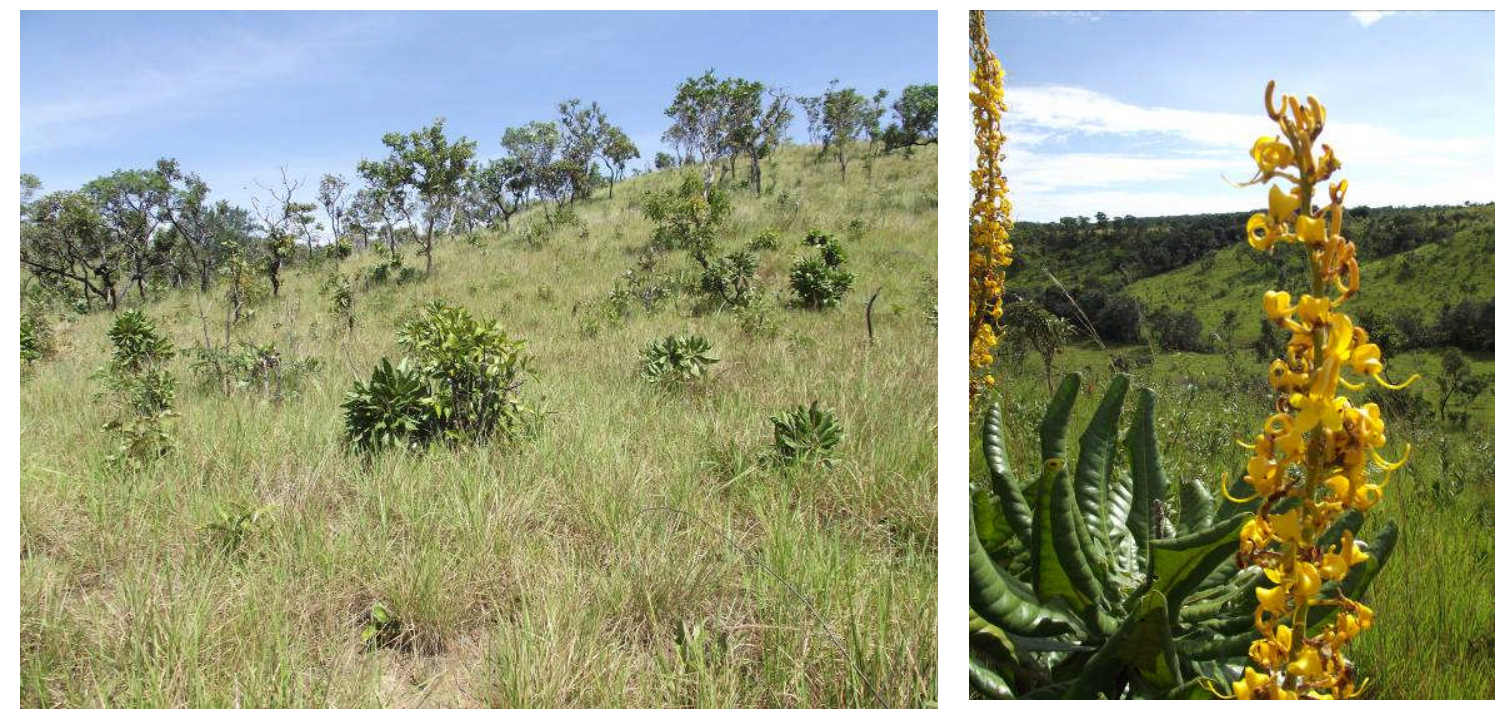

Figura 4.52 - Grupo 1 (área 3 - vertente), com Vochysia cinnamomea, em Campo Sujo Seco, na bacia hidrográfica do ribeirão Taquaruçu Grande, Palmas (TO). Fotografia: T.C.C. Medeiros (2012) 
O Grupo 2 (Figura 4.50), formado pelas comunidades de plantas dos Campos Sujos Secos da área 1 (topo e vertente), foi o que apresentou maior similaridade florística entre as comunidades de topo e vertente, $56 \%$ e as espécies que tiveram maior número de plantas nesta similaridade florística foram Vellozia seubertiana e Syagrus comosa (Figura 4.53), podendo ser caracterizado como Campos Sujos Secos de Vellozia pela sua expressiva ocorrência (Figura 4.54).

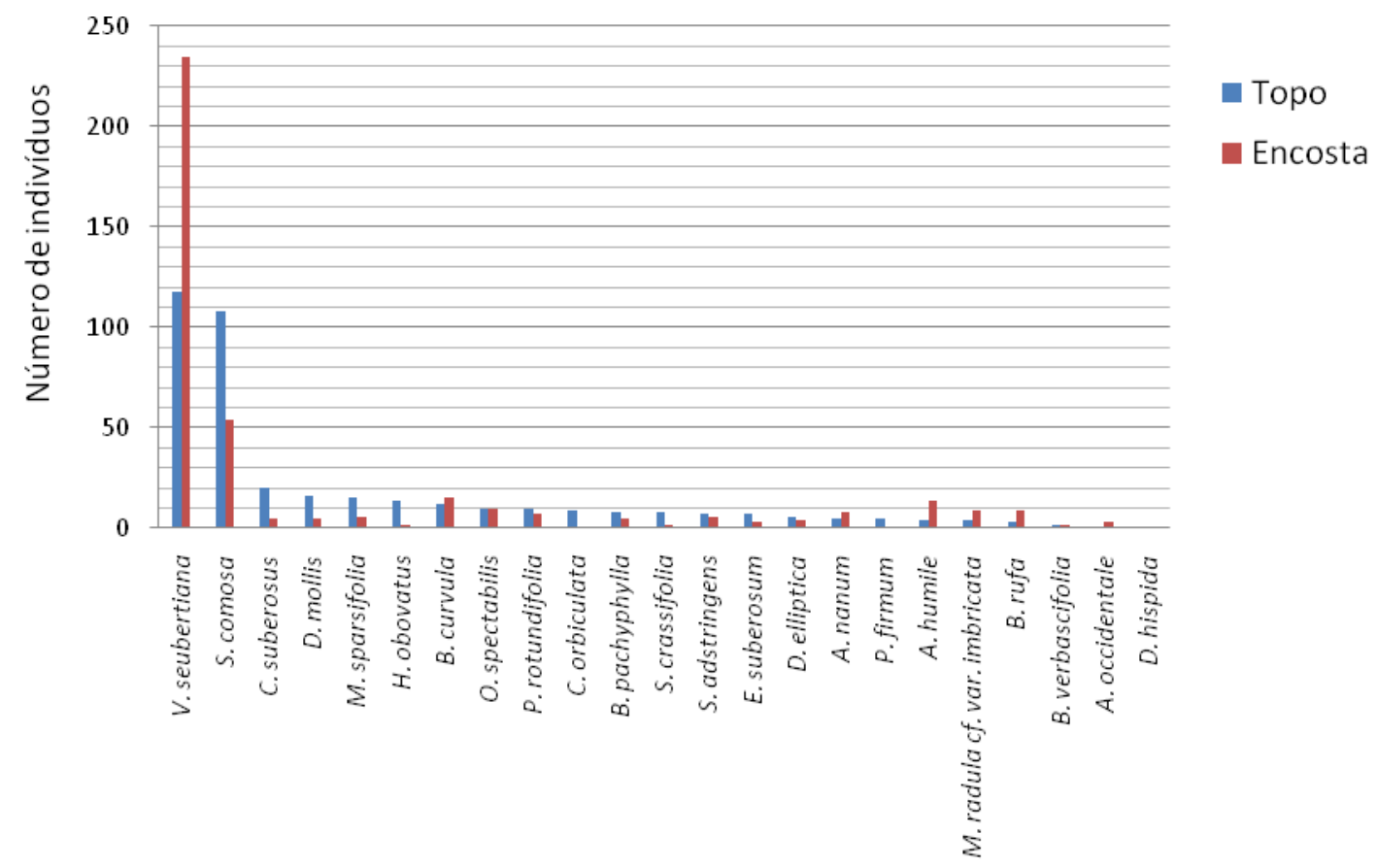

Espécies

Figura 4.53 - Grupo 2 (área 1 - topo e Vertente), por número de espécies, das comunidades de plantas do Campo Sujo Seco, na bacia hidrográfica do ribeirão Taquaruçu Grande, Palmas (TO)
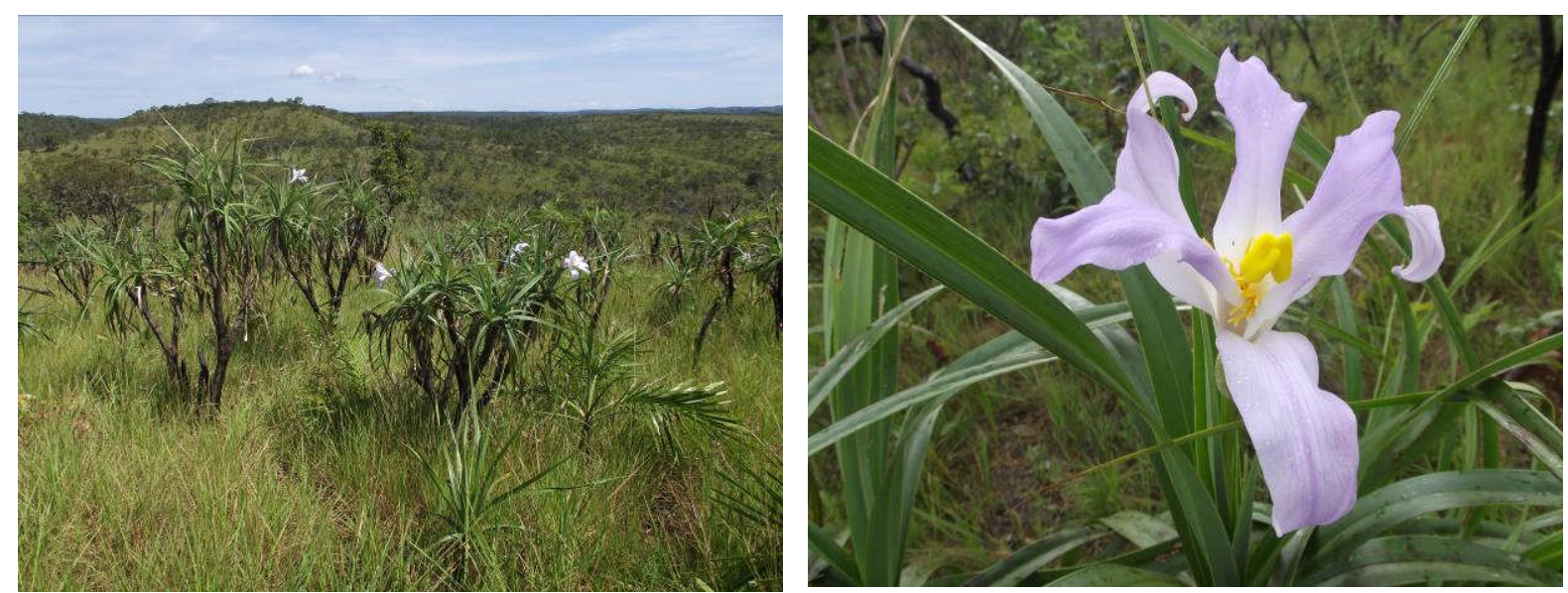

Figura 4.54 - Grupo 2 (área 1- topo), com Vellozia seubertiana, em Campo Sujo, na bacia hidrográfica do ribeirão Taquaruçu Grande, Palmas (TO). Fotografia: T.C.C. Medeiros (2012) 
O Grupo 3 (Figura 4.50), composto pelas comunidades de plantas dos Campos Sujos Secos da área 5, apresentou uma similaridade de 58\% entre as comunidades de topo e Vertente, sendo o segundo em maior similaridade. As principais espécies comuns entre topo e Vertente, em número de plantas, foram Byrsonima subterranea, Vellozia seubertiana, Vochysia thyrsoidea, Davila elliptica e Erythroxylum suberosum (Figura 4.55). Pela expressiva ocorrência de Byrsonima subterranea, foram denominados de Campos Sujos Secos de Byrsonima subterranea (Figura 4.56).

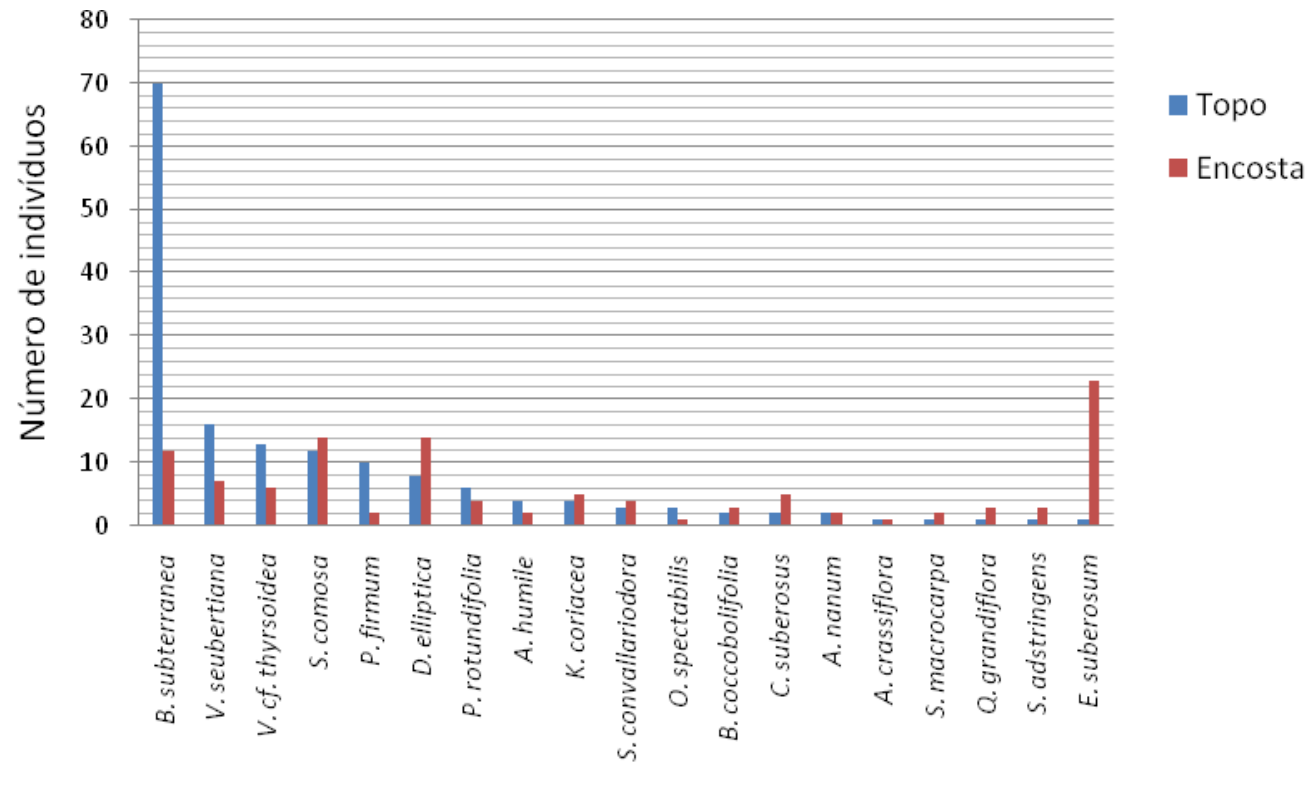

Espécies

Figura 4.55 - Grupo 3 (área 5 - topo e Vertente), por número de espécies, das comunidades de plantas do Campo Sujo Seco, na bacia hidrográfica do ribeirão Taquaruçu Grande, Palmas (TO)
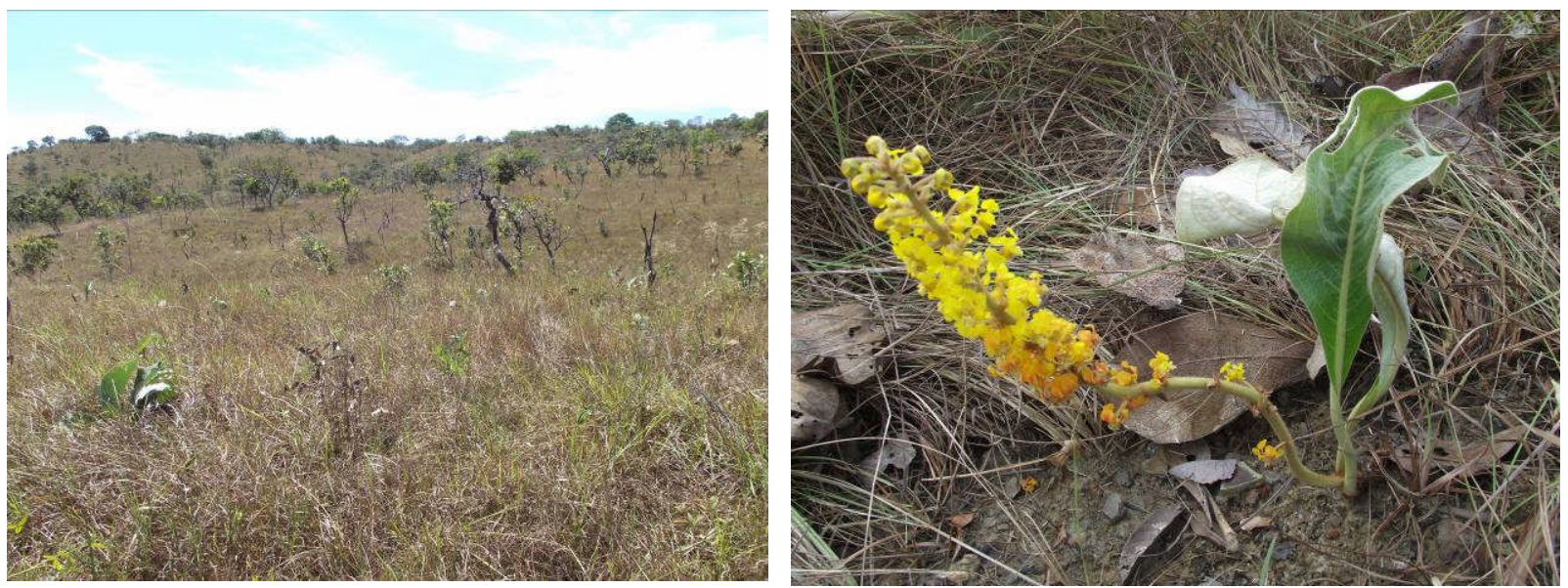

Figura 4.56 - Grupo 3 (área 5 - topo), com Byrsonima subterranea, em Campo Sujo Seco, na bacia hidrográfica do ribeirão Taquaruçu Grande, Palmas (TO). Fotografia: T.C.C. Medeiros (2012) 
O Grupo 4 (Figura 4.50), formado pelas comunidades de plantas do Campo Sujo Seco da área 2 (topo), diferenciou-se dos demais, principalmente, pelas espécies Vochysia cf. thyrsoidea, Aspilia foliacea, A. leucoglossa e Eleocharis sp., sendo as três últimas do estrato herbáceo, que ocorreram apenas nessa área. Visualmente, apresenta-se como Campo Sujo Seco misto por não haver uma única espécies arbustiva de maior destaque em número de plantas, mas Syagrus comosa, Vellozia seubertiana, Erythroxylum suberosum, Ouratea spectabilis, Piptocarpha rotundifolia e Dimorphandra mollis, dentre outras espécies, ocorreram com elevado e variado número de plantas (Figuras 4.57 e 4.58 ).

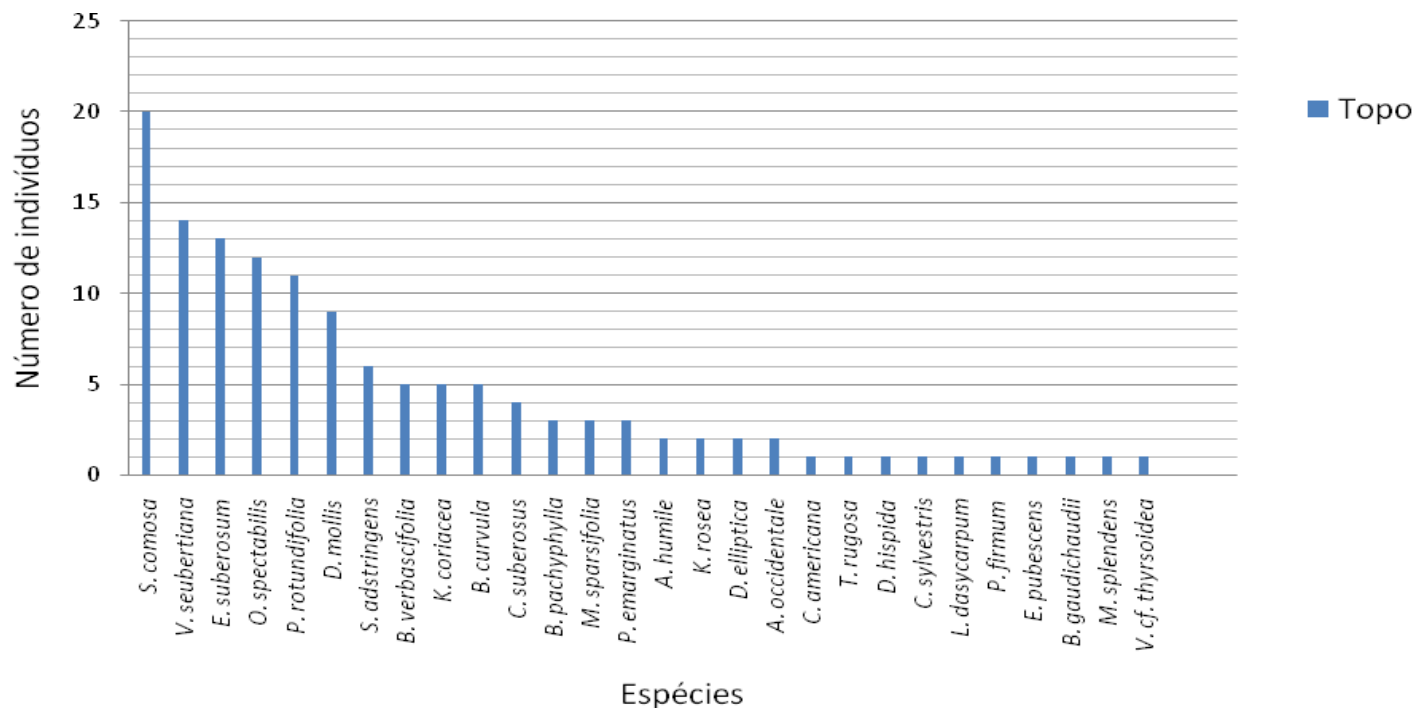

Figura 4.57 - Grupo 4 (área 2 - topo), por número de plantas das comunidades do Campo Sujo Seco, na bacia hidrográfica do ribeirão Taquaruçu Grande, Palmas (TO)
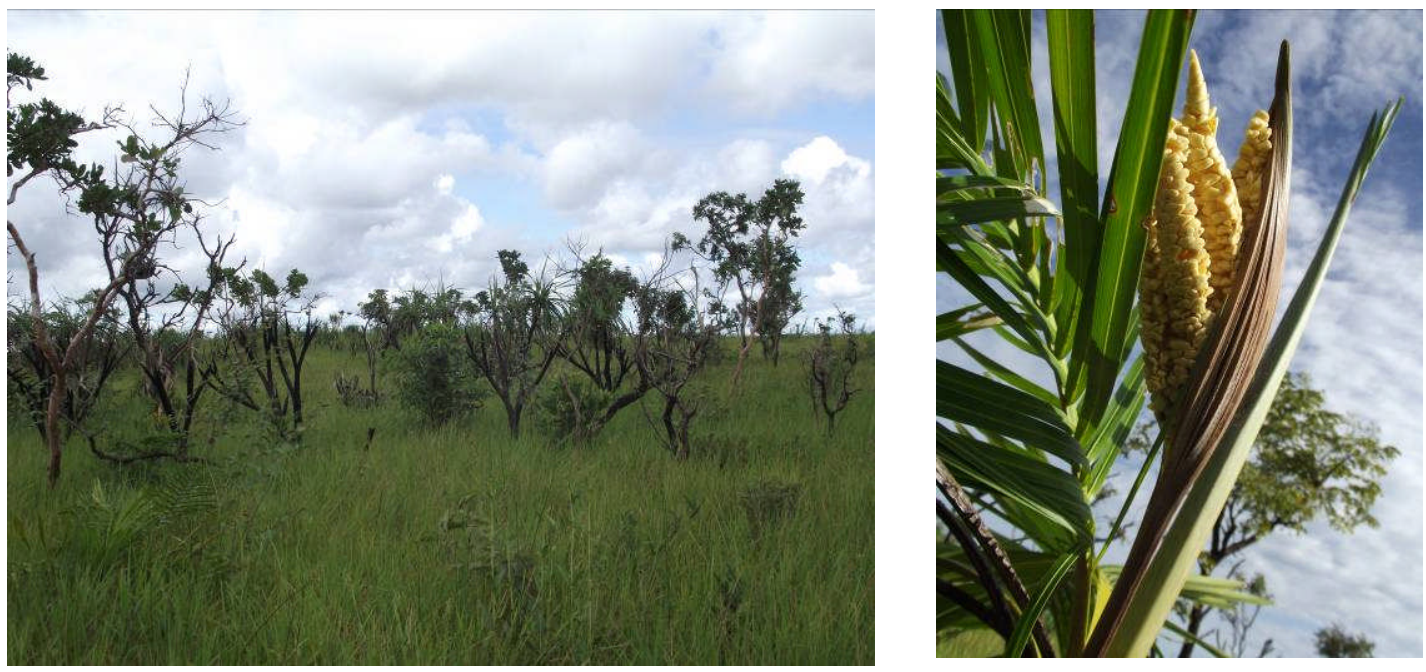

Figura 4.58 - Grupo 4 (área 2 - topo), com V. seubertiana, S. comosa e outras espécies, em Campo Sujo Seco, na bacia hidrográfica do ribeirão Taquaruçu Grande, Palmas (TO). Fotografia: T.C.C. Medeiros (2012) 
Os Grupos 5 e 6 (Figura 4.50) foram formados pelas comunidades de plantas da área 4. Esta área apresentou baixa similaridade florística entre as comunidades de topo e vertente. As espécies que compuseram essa similaridade foram, sobretudo, Vellozia seubertiana e Suyagrus comosa com maior número de plantas. Ao nível de corte de $46 \%$, a área 4 (topo) diferenciou-se da área 4 (vertente), formando cada uma delas um grupo florístico diferente (Figuras 4.59 e 4.60 ).

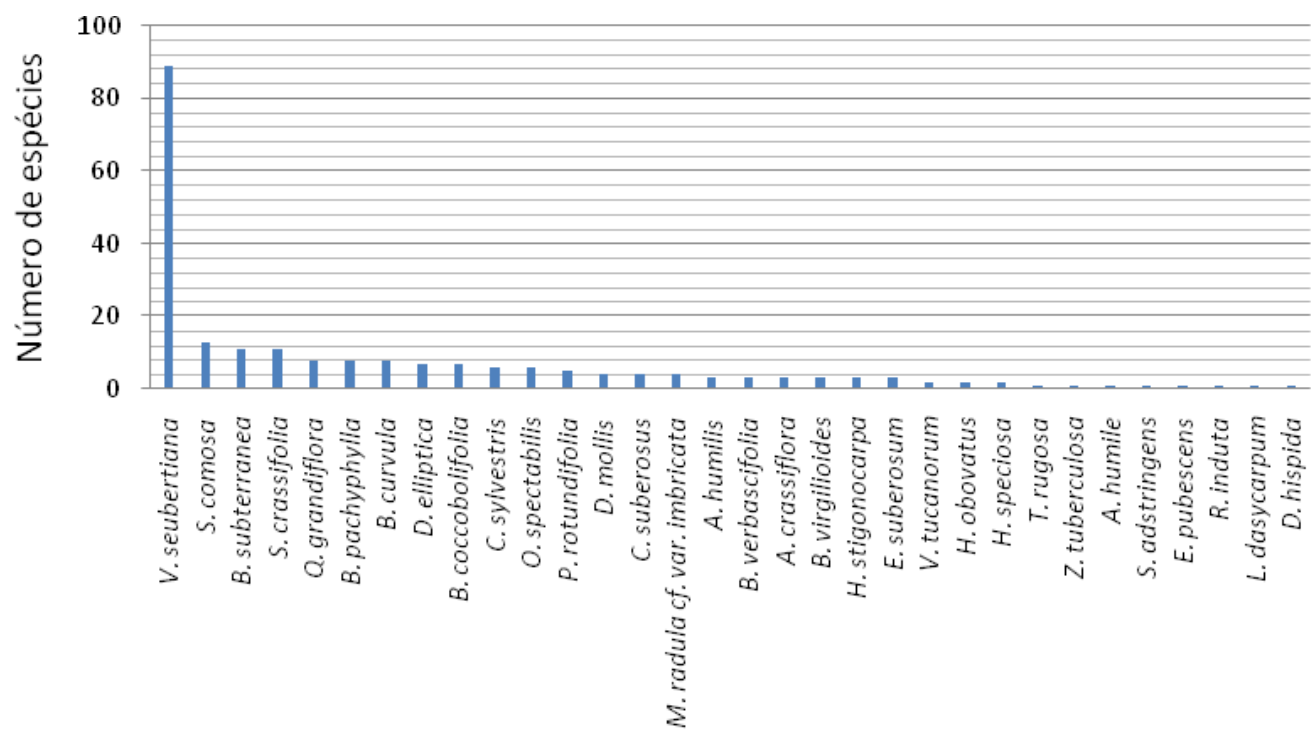

Topo

Figura 4.59 - Grupos 5 (área 4 - topo) por número de plantas da comunidade do Campo Sujo Seco, na bacia hidrográfica do ribeirão Taquaruçu Grande, Palmas (TO)

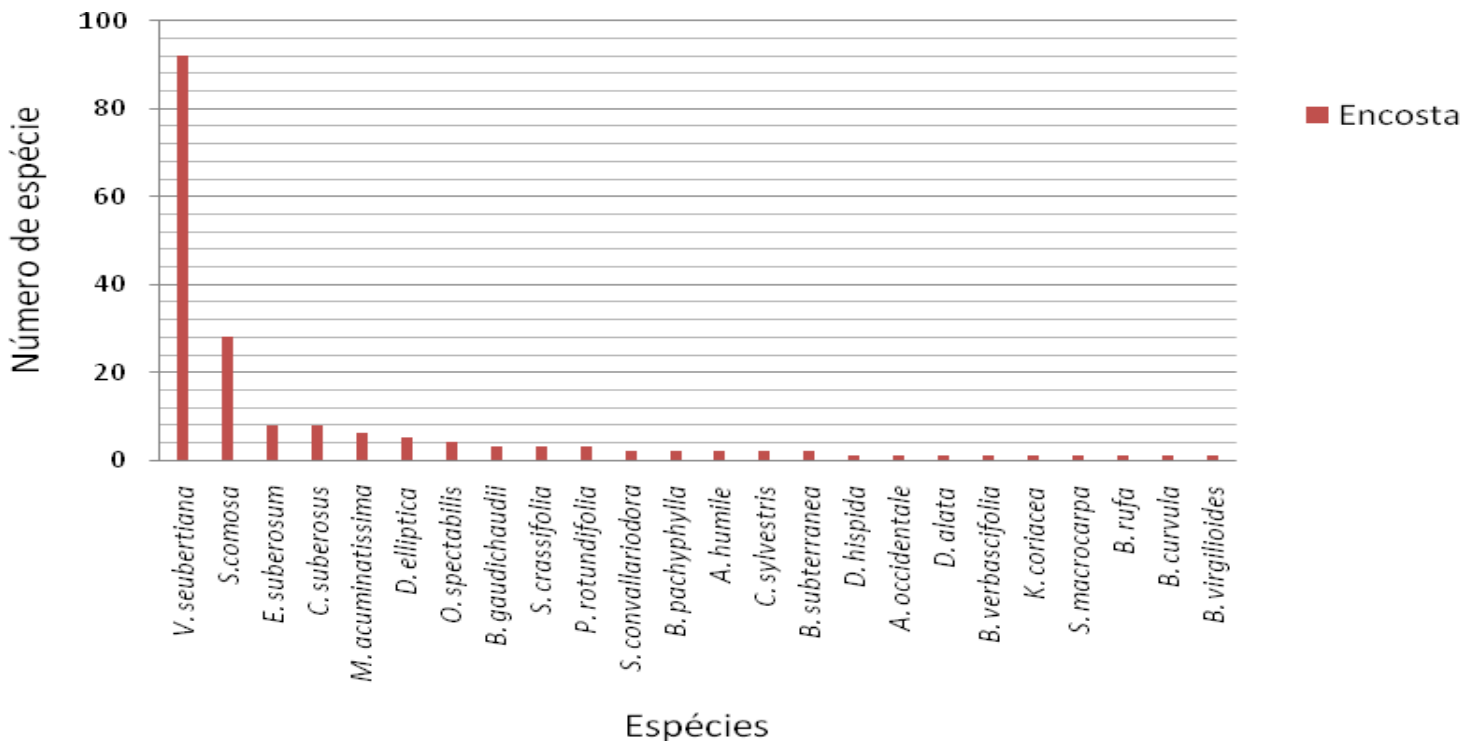

Figura 4.60 - Grupos 6 (área 5 - vertente), por número de plantas da comunidades do Campo Sujo Seco, na bacia hidrográfica do ribeirão Taquaruçu Grande, Palmas (TO) 
As espécies que levaram a essa diferenciação florística entre topo e vertente na área 4 foram: Annona crassiflora, Andira humilis, Byrsonima coccobolifolia, Dimorphandra mollis, Eriotheca pubescens, Hancornia speciosa, Himatanthus obovatus, Hymenaea stigonocarpa, Leptolobium dasycarpum, Mimosa radula cf. var. imbricata, Qualea grandiflora, Rourea induta, Stryphnodendron adstringens, Vochysia tucanorum e Zeyera tuberculosa, Amasonia campestris, Oxalis densifolia, Chamaecrista serpens, Crotalaria unifoliata, Diphusodon microphyllus, D. sessiliflorus e Rhynchospora consanguinea, ocorreram só no topo. Ao passo Bauhinia rufa, Brosimum gaudichaudii, Dipteryx alata, Salvertia convallariodora e Scheflera macrocarpa ocorreram só na vertente. Estes também são Campos Sujos Secos de Vellozia seubertiana pela abundância dessa espécie (Figura 4.61).

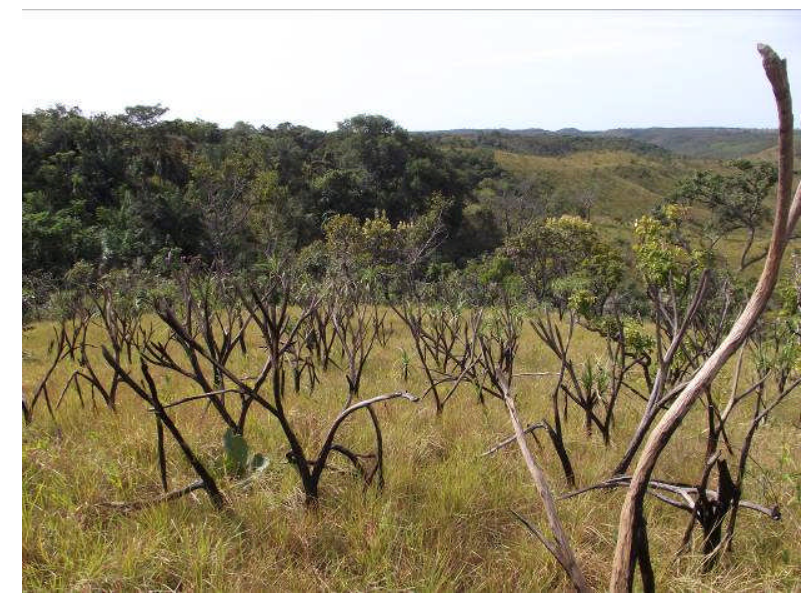

A

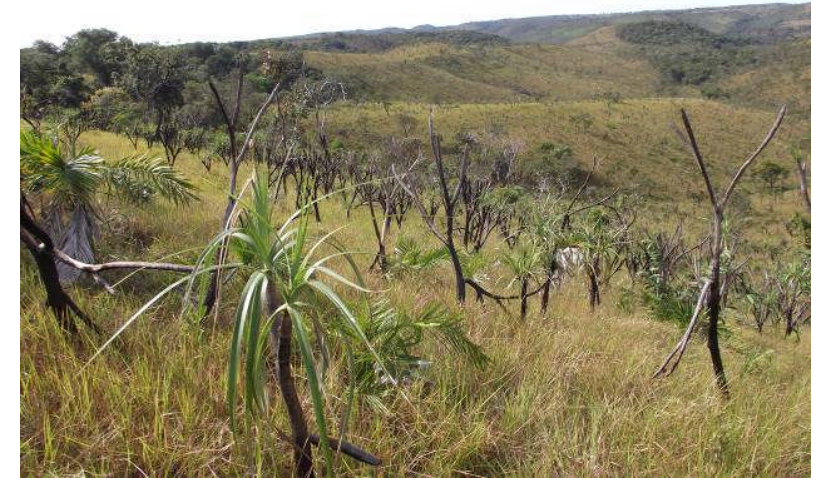

B

Figura 4.61 - Grupos 5 (A - topo) e Grupo 6 (B - vertente) representados pela área 4, com Vellozia seubertiana, em Campo Sujo Seco, na bacia hidrográfica do ribeirão Taquaruçu Grande, Palmas (TO). Fotografia: T.C.C. Medeiros (2012)

Os Campos Sujos Secos de Vellozia têm distribuição espacial ampla na bacia hidrográfica do ribeirão Taquaruçu Grande e os campos estudados, com predominância de Vellozia seubertiana, situam-se na área central da serra do Lageado. Os Campos Sujos Secos de Vochysia cinnamomea situam-se na área sul da mesma serra e os Campos Sujos Secos de Byrsonima subterranea localizam-se no extremo norte. Espacialmente, os Campos Sujos Secos, ocupam os topos dos morros, como se constituíssem ilhas isoladas pelos sistemas de matas de galeria e matas secas. A espécie $B$. subterranea parece ter ocorrência exclusiva nos Campos Sujos Secos do extremo norte da bacia. 


\subsection{1 Método Twinspan}

A análise florística pelo método Twinspan (Two-Way Indicator Species Analysis) também mostrou a existência de diferenças florística das comunidades de plantas, no Campo Sujo estudado, pela individualização de várias grupos, cujos reultados apresentaram semelhanças com a análise do índice de Jaccard pelo método UPGMA, muito embora nesta análise não tenham sido incluídas as espécies do estrato herbáceo-subarbustivo, nem as do estrato arbustivo-arbóreo com altura inferior a $0,4 \mathrm{~m}$ e diâmetro menor que $3,0 \mathrm{~cm}$, uma vez que o método Twinspan é muito sensível às características estruturais. Ao final da análise, foi formado um total de 12 grupos florísticos (Figura 4.62).

Por ser o Twinspan um método divisivo, a primeira divisão foi feita com todo o conjunto de parcelas $(\mathrm{N}=100)$. Foram individualizados dois subgrupos, onde parcelas da área 3 (topo e vertente) formaram um subgrupo separado das demais parcelas que compuseram um subgrupo maior com espécie preferenciais e não preferenciais (Quadro 4.5); a espécie Vochyia cinnamomea foi a espécie indicadora na divisão desses dois subgrupos (Figura 4.62). 


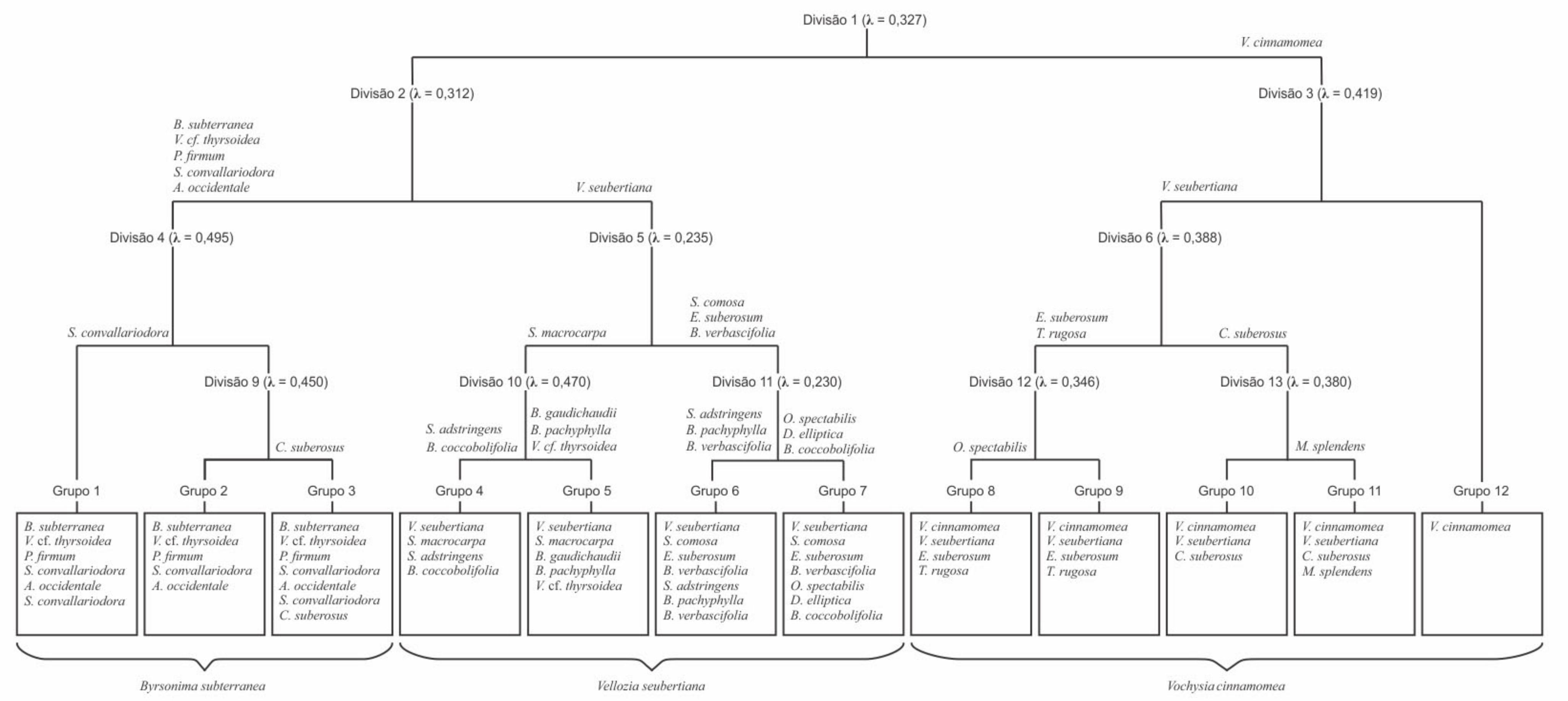

Figura 4.62 - Dendograma da classificação Twinspan (até o $4^{\circ}$ nível de divisão) das comunidades de plantas do campo sujo seco, na bacia hidrográfica do ribeirão Taquaruçu Grande, Palmas (TO) 
Quadro 4.5 - Espécies preferenciais e não preferenciais das divisões estabelecidadas pelo método Twinspan, das comunidades de plantas do Campo Sujo Seco, na bacia hidrográfica do ribeirão Taquaruçu Grande, Palmas (TO)

\begin{tabular}{|c|c|c|c|c|}
\hline & Divisão 1 & Divisão 2 & Divisão 3 & Divisão 4 \\
\hline 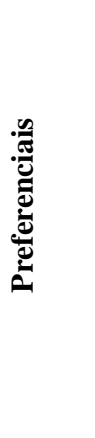 & $\begin{array}{l}\text { S. comosa } \\
\text { D. mollis } \\
\text { P. rotundifolia } \\
\text { S. adstringens } \\
\text { D. elliptica } \\
\text { L. dasycarpum } \\
\text { B. coccobolifolia } \\
\text { S. convallariodora } \\
\text { V. cinnamomea } \\
\text { T. rugosa }\end{array}$ & $\begin{array}{l}\text { P. firmum } \\
\text { A. occidentale } \\
\text { S. convallariodora } \\
\text { B. subterranea } \\
\text { V. cf. thyrsoidea } \\
\text { V. seubertiana } \\
\text { O. spectabilis } \\
\text { S. adstringens } \\
\text { D. elliptica } \\
\text { B. pachyphylla } \\
\text { B. verbascifolia }\end{array}$ & $\begin{array}{l}\text { V. seubertiana } \\
\text { O. spectabilis } \\
\text { C. suberosus } \\
\text { E. suberosum } \\
\text { B. verbascifolia } \\
\text { T. rugosa } \\
\text { V. rufa } \\
\text { P. firmum } \\
\text { M. splendens } \\
\text { S. convallariodora } \\
\text { K. coriacea } \\
\text { M. albolanata }\end{array}$ & $\begin{array}{l}\text { O. spectabilis } \\
\text { P. rotundifolia } \\
\text { D. elliptica } \\
\text { Q. grandiflora } \\
\text { S. convallariodora } \\
\text { D. alata } \\
\text { V. seubertiana } \\
\text { A. humile } \\
\text { A. occidentale } \\
\text { C. suberosus }\end{array}$ \\
\hline 晃 & $\begin{array}{l}\text { V. seubertiana } \\
\text { O. spectabilis } \\
\text { B. pachyphylla } \\
\text { C. suberosum } \\
\text { E. suberosus } \\
\text { B. verbascifolia }\end{array}$ & $\begin{array}{l}\text { S. comosa } \\
\text { A. humile } \\
\text { D. mollis } \\
\text { P. rotundifolia } \\
\text { C. suberosum } \\
\text { E. suberosus }\end{array}$ & $\begin{array}{l}\text { B. pachyphylla } \\
\text { L. dasycarpum } \\
\text { B. coccobolifolia } \\
\text { V. cinnamomea }\end{array}$ & $\begin{array}{l}\text { D. mollis } \\
\text { P. firmum } \\
\text { E. suberosum } \\
\text { V. cf. thyrsoidea }\end{array}$ \\
\hline & Divisão 5 & Divisão 6 & Divisão 9 & Divisão 10 \\
\hline 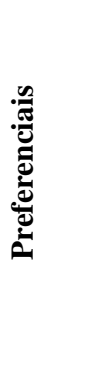 & $\begin{array}{l}\text { A. humile } \\
\text { B. gaudichaudii } \\
\text { S. macrocarpa } \\
\text { S. comosa } \\
\text { O. spectabilis } \\
\text { P. rotundifolia } \\
\text { B. pachyphylla } \\
\text { E. suberosum } \\
\text { B. verbascifolia }\end{array}$ & $\begin{array}{l}\text { E. suberosus } \\
\text { S. convallariodora } \\
\text { T. rugosa } \\
\text { V. rufa } \\
\text { R. induta } \\
\text { V. cf. divergens } \\
\text { D. elliptica } \\
\text { C. suberosum } \\
\text { B. verbascifolia }\end{array}$ & $\begin{array}{l}\text { A. humile } \\
\text { D. mollis } \\
\text { A. nanum } \\
\text { P. firmum } \\
\text { A. crassiflora } \\
\text { B. coccobolifolia } \\
\text { C. suberosum } \\
\text { E. suberosum } \\
\text { V. rufa } \\
\text { C. suberosum }\end{array}$ & $\begin{array}{l}\text { D. mollis } \\
\text { A. nanum } \\
\text { S. adstringens } \\
\text { B. coccobolifolia } \\
\text { S. comosa } \\
\text { B. pachyphylla } \\
\text { H. obovatus } \\
\text { B. gaudichaudii } \\
\text { V. cf. thyrsoidea }\end{array}$ \\
\hline & $\begin{array}{l}\text { V. seubertiana } \\
\text { D. mollis } \\
\text { S. adstringens } \\
\text { D. elliptica } \\
\text { C. suberosus } \\
\text { B. coccobolifolia }\end{array}$ & $\begin{array}{l}\text { V. seubertiana } \\
\text { O. spectabilis } \\
\text { B. pachyphylla } \\
\text { L. dasycarpum } \\
\text { B. coccobolifolia } \\
\text { V. cinnamomea }\end{array}$ & $\begin{array}{l}\text { V. seubertiana } \\
\text { S. comosa } \\
\text { A. occidentale } \\
\text { B. subterranea } \\
\text { V. cf. thyrsoidea }\end{array}$ & $\begin{array}{l}\text { V. seubertiana } \\
\text { A. humile } \\
\text { D. elliptica } \\
\text { C. suberosum } \\
\text { S. macrocarpa }\end{array}$ \\
\hline & Divisão 11 & Divisão 12 & Divisão 13 & \\
\hline 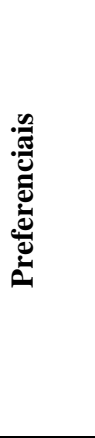 & $\begin{array}{l}\text { S. adstringens } \\
\text { B. pachyphylla } \\
\text { B. verbascifolia } \\
\text { O. spectabilis } \\
\text { D. elliptica } \\
\text { B. coccobolifolia }\end{array}$ & $\begin{array}{l}\text { S. comosa } \\
\text { P. firmum } \\
\text { A. occidentale } \\
\text { O. spectabilis } \\
\text { P. rotundifolia } \\
\text { V. rufa } \\
\text { R. induta } \\
\text { B. pachyphylla } \\
\text { L. dasycarpum } \\
\text { S. convallariodora } \\
\text { T. rugosa } \\
\text { V. cf. divergens }\end{array}$ & $\begin{array}{l}\text { O. spectabilis } \\
\text { D. elliptica } \\
\text { B. pachyphylla } \\
\text { B. verbascifolia } \\
\text { L. dasycarpum } \\
\text { B. coccobolifolia } \\
\text { M. splendes } \\
\text { T. rugosa }\end{array}$ & \\
\hline 疍 & $\begin{array}{l}\text { V. seubertiana } \\
\text { S. comosa } \\
\text { D. mollis } \\
\text { P. rotundifolia } \\
\text { C. suberosum } \\
\text { E. suberosus }\end{array}$ & $\begin{array}{l}\text { V. seubertiana } \\
\text { E. suberosus } \\
\text { B. coccobolifolia } \\
\text { V. cinnamomea }\end{array}$ & $\begin{array}{l}\text { V. seubertiana } \\
\text { C. suberosum } \\
\text { V. cinnamomea }\end{array}$ & \\
\hline
\end{tabular}


A divisão $2(\mathrm{~N}=84)$, parcelas da área 5 (topo e vertente) foram individualizadas das demais, formando um subgrupo. As espécies indicadoras foram Byrsonima subterranea, Vochysia cf. thyrsoidea, Psidium firmum, Salvertia convallariodora, Anacardium occidentale e Vellozia seubertiana (espécies preferenciais e não preferenciais no Quadro 4.5; Figura 4.62).

$\mathrm{Na}$ divisão $3(\mathrm{~N}=16)$, parcelas da área 3 (Vertente e topo) foram separadas, mostrando que dentro dessa área há padrões florísticos também distintos. A espécie indicadora foi Vellozia seubertiana (espécies preferenciais e não preferenciais no Quadro 4.5; Figura 4.62).

Na divisão $4(\mathrm{~N}=9)$, parcelas da área 5 formaram subgrupos diferentes e a espécie indicadora foi Salvertia convallariodora, significando diferenças entre topo e Vertente (espécies preferenciais e não preferenciais no Quadro 4.5; Figura 4.62).

A divisão $5(\mathrm{~N}=75)$ apresentou autovalor abaixo $(\lambda=0,235)$. As espécies indicadoras foram Schefflera macrocarpa, Syagrus comosa, Erythroxylum suberosum e Byrsonima verbascifolia (espécies preferenciais e não preferenciais no Quadro 4.5; Figura 4.62).

A divisão $6(\mathrm{~N}=14)$ novamente mostrou diferenças florísticas dentro da área 3 (topo e vertente). As espécies indicadoras foram Erythroxylum suberosum, Tachigali rugosa e Connarus suberosus (espécies preferenciais e não preferenciais no Quadro 4.5; Figura 4.62).

As divisões 7 e 8 falharam.

A divisão $9(\mathrm{~N}=5)$ também foi referente à área 5, na qual a espécie Connarus suberosus foi a espécie indicadora (espécies preferenciais e não preferenciais no Quadro 4.5; Figura 4.62).

A divisão $10(\mathrm{~N}=16)$ foi mais ampla que as demais pelo fato dos subgrupos formados serem compostos por parcelas da área 1 (topo e vertente), área 2 (topo e vertente), área 4 (topo e vertente) e algumas parcelas da área 5 (topo). As espécies indicadoras foram Brosimum gaudichaudii, Stryphnodendron adstringens, Byrsonima pachyphylla e Vochysia thyrsoidea (espécies preferenciais e não preferenciais no Quadro 4.5; Figura 4.62).

A divisão $11(\mathrm{~N}=59)$ também apresentou autovalor baixo $(\lambda=0,230)$ e as espécies indicadoras foram Davilla elliptica, Stryphnodendron adstringens, Byrsonima verbascifolia, Byrsonima pachyphylla, Ouratea spectabilis e Dimorphandra mollis (espécies preferenciais e não preferenciais no Quadro 4.5; Figura 4.62). Assim como a divisão 10, foi bem ampla por agrupar parcelas de todas as áreas (área 1, topo e Vertente; área 2, topo e Vertente; área 3, topo; área 4, topo e Vertente; e área 5, topo e Vertente).

A divisão $12(\mathrm{~N}=7)$ foi representada pelas parcelas da área 3 (topo e vertente), onde a 
espécie indicadora foi Ouratea spectabilis (espécies preferenciais e não preferenciais no Quadro 4.5; Figura 4.62).

A divisão $13(\mathrm{~N}=7)$ consta de parcelas da área 3 (topo e vertente) com área 4 (topo), cuja espécie indicadora foi Myrcia splendens (espécies preferenciais e não preferenciais no Quadro 4.5; Figura 4.62).

Dos 12 grupos formados (Figura 4.62), os grupos 1; 2 e 3 tiveram como indicadora principal a espécie Byrsonima subterranea, representando as parcelas da área 5 (topo e vertente). Assim, os campos sujo secos da área 5 são campos de B. subterranea. Esta espécie caracteriza-se por ocorrer nos cerrados e campos rupestres (MAMEDE, 1993) e também tem ocorrência em campos com murundus (MARION et al., 2012). Apresenta estômatos em ambas as faces das folhas (GIULIETTI, 1971), característica que parece ser mais comum em plantas de regiões secas e bastante frequente em espécies típicas do Cerrado (MAMEDE, 1993).

$\mathrm{Na}$ área de estudo, B. subterranea foi indicadora de solos com mais altos teores de areia, embora os solos estudados sejam de textura média; os solos da área 5 apresentaram maiores percentuais de areia em relação aos demais e estivarm entre os mais secos. Outras características destes solos foram os baixos teores de matéria orgânica, mais baixa saturação de bases (V\%) e capacidade de troca catiônica (C.T.C.), alta saturação de alumínio e a espécie foi preferencial de topo. Parece ser uma espécie de ocorrência restrita no Cerrado e foi considerada presumivelmente extinta no estado de São Paulo (SMA-SP, 1998).

As outras espécies que, juntamente com Byrsonima subterranea formaram os grupos florísticos 1; 2 e 3 (Figura 4.62) foram:

- Vochysia cf. thyrsoidea, planta perenifólia, heliófita, seletiva xerófita, característica exclusiva dos cerrados e campos cerrados de altitude. Ocorre preferencialmente em terrenos secos e pedregosos de Vertente (LORENZI, 2002); é uma espécie tombada pelo Decreto $\mathrm{n}^{\circ}$ 14.783/93, do Distrito Federal;

- Psidium firmum, arbusto de ocorrência no Cerrado Sentido Restrito e em Campo Sujo (FRAZON, et al.,2009);

- Salvertia convallariodora, planta decídua, heliófila, seletiva xerófita, característica dos cerrados. Ocorre preferencialmente em terrenos altos de solos bem drenados, tanto nas formações primárias como secundárias (LORENZI, 2008);

- Anacardium occidentale, planta de porte arbóreo (SILVA et al., 2001), apresenta uma distribuição restrita, com maior presença no cerrado e menor no cerradão, ocorrendo 
principalmente em Neossolos Litólicos, e ou em solos com concreções ou cascalho (SOUZA et al., 2010);

- Connarus suberosus, planta decídua, heliófila, seletiva xerófita, secundária, característica exclusiva dos cerrados e campos cerrados secos do Brasil Central. Ocorre preferencialmente em formações pioneiras e secundárias abertas de locais acima de $700 \mathrm{~m}$ de altitude, em terrenos arenosos de baixa fertilidade e bem drenados (LORENZI, 2002).

Os grupos 4; 5; 6 e 7 (Figura 4.62), cuja indicadora principal foi a espécie Vellozia seubertiana, são representados pelas parcelas da área 1 (topo e vertente), área 2 (topo e vertente) e área 4 (topo e vertente), principalmente; constituem os campos de Vellozia seubertiana (Figura 4.62). É importante destacar que as áreas 2 e 4 apresentaram uma flora herbácea-subarbustiva bem peculiar, somente registrada nessas localidades, que não fez parte da análise pelo Twinspan por suas características estruturais, o que fez esta análise agrupá-las com a área 1, pois excluindo essas espécies não lenhosas e pouco desenvolvidas, essas áreas têm em comum a ampla ocorrência de $V$. seubertiana.

A espécie $V$. seubertiana ocorre em Neossolos Litólicos e Neossolos Quartzarênicos, sendo que a maioria das espécies de Velloziaceae é rupícula e cresce em ambientes xéricos, em solos argilosos ou em fendas de rochas (AYENSU, 1973). É uma família muito citada como de ocorrência nos campos ferruginosos de Minas Gerais e na serra do Espinhaço (MELLO-SILVA，1995; MELLO-SILVA; MENEZES，1998; RODELA,1998; VIANA; LOMBARDI, 2007; ATAIDE, et al., 2011). Parece ser uma espécie de ocorrência restrita no Cerrado brasileiro, sendo citada apenas para a Chapada Diamantina - BA (NEVES, 2009), Mato Grosso (Parque Estadual do Cristalino, SEMA/MT, 2009), Mato Grosso e Goiás (SMITH; AYENSU, 1976). Sobretudo na área de estudo, V. seubertiana foi indicadora dos solos mais ricos em ferro; também se fez mais presente nas áreas de maior altitude, e nas Vertentes com maior grau de inclinação.

As outras espécies indicadoras que ocorreram com $V$. seubertiana nos grupos 4; 5; 6 e 7 foram:

- Schefflera macrocarpa que é uma planta perenifólia, cuja ocorrência é citada para o Cerradão, e Cerrado Sentido Restrito (ALMEIDA et al., 1998);

- Stryphnodendron adstringens, planta decídua, heliófila, pioneira, seletiva xerófita, característica de formações abertas como cerrados e campos cerrados. Apresenta nítida preferência por solos arenosos e de drenagem rápida como os situados em Vertentes suaves e topos de morros. Ocorre tanto em formações primárias como secundárias (LORENZI, 2008); 
- Byrsonima coccobolifolia, planta decídua, heliófila, seletiva xerófita secundária, característica e exclusiva dos cerrados e campos cerrados, onde tem ampla dispersão em todo o país (do Amazonas ao Paraná e Mato Grosso do Sul). Ocorre preferencialmente em terrenos elevados com solos bem drenados. É capaz de resistente ao fogo por possui casca muito grossa e suberosa (LORENZI, 2002);

- Byrsonima pachyphylla, arbusto com ocorrência em borda de mata e em Campo Sujo (MEDEIROS, 2011);

- Byrsonima verbascifolia, planta decídua, heliófila, seletiva xerófita, característica e exclusiva dos cerrados e campos cerrados. Ocorre preferencialmente em terrenos secos e elevados de solos arenosos e pobres (LORENZI, 2002);

- Brosimum gaudichaudii, planta decídua, heliófila, seletiva xerófita, característica e exclusiva dos cerrados e campos cerrados, onde apresenta frequência esparsa a elevada com dispersão descontínua. É particularmente frequente nos terrenos arenosos e bem drenados (LORENZI, 2002);

- Erythroxylum suberosum, arvoreta de ocorrência no cerrado (stricto sensu), vereda, Campo Sujo, campo rupestre (lato sensu), savanas amazônicas, carrasco (MEDEIROS, 2011);

- Ouratea spectabilis, árvore ou arbusto endêmico do Cerrado, facilmente reconhecida por apresentar caule e ramos com epiderme com textura escamosa e esfoliante (SALVADOR et al., 2010);

- Syagrus comosa: arbusto com ocorrência em borda de Mata de Galeria, Cerradão, Cerrado (ralo rupestre) e Campo Sujo (MEDEIROS, 2011); ocorre em áreas abertas do Cerrado, principalmente sobre terrenos pedregosos de até $1.200 \mathrm{~m}$ de altitude (LORENZI, 2004);

- Vochysia thyrsoidea: árvore típica do cerrado do Brasil Central, que pode chegar a $12 \mathrm{~m}$ de altura e é muito comum no cerrado do Distrito Federal (PAVIANI; JERONYMO, 1992).

Os grupos 8; 9; 10; 11 e 12 (Figura 4.62) representam as parcelas da área 3 (topo Vertente), onde a principal indicadora das divisões dos grupos formados foi a espécie Vochysia cinnamomea, caracterizando estes campos como de V. cinnamomea (Figura 4.62). Esta espécie é uma planta decídua, heliófila, seletiva xerófita, pioneira, característica exclusiva dos cerrados e campos cerrados. Ocorre preferencialmente em terrenos bem drenados e acima de $800 \mathrm{~m}$ de altitude, onde chega a formar populações puras. Em regiões muito elevadas de campos, pode se apresentar como simples arbusto de menos de 1,5 m (LORENZI, 2002). Na área de estudo, esta espécie foi indicadora de solos de textura média que tenderam a maiores percentuais de areia e altas saturações de alumínio e ocuparam áreas 
principalmente de Vertente com mais baixas altitudes.

As espécies que ocorreram com Vochysia cinnamomea na formação dos grupos 8; 9; 10, 11 e 12 foram: Vellozia seubertiana; Erythroxylum suberosum; Connarus suberosus; Myrcia splendens e Thachigali rugosa. A espécie Myrcia splendens, perenifólia e no Brasil Central ocorre associada à matas de galeria e cerradão (SILVA-JÚNIOR; PEREIRA, 2009) e Thachigali rugosa é semidecídua, heliófila, seletiva xerófita, secundária, característica e exclusiva das matas semidecíduas de altitude, que corre preferencialmente em formações secundárias localizadas em altitudes superiore a $1.000 \mathrm{~m}$ sobre terrenos argilosos e bem drenados (LORENZI, 2002). Tendo em vista os Campos Sujos ocorrerem muitas vezes próximos a matas secas e matas de galeria, sua flora é influenciada pela flora desses ambientes com algumas plantas, apesar de poucas, ocorrendo na área campestre.

A flora das comunidades de plantas dos Campos Sujos estudados representa bem as condições edáficas neles presentes: bem drenados, ácidos, distróficos e álicos. Segundo Goodland (1971), o planalto central brasileiro, onde ocorre o cerrado, é uma região edafologicamente antiga. Os solos do planalto, entre os mais velhos do mundo, estão sendo intemperizados desde o Cretáceo, há 100 milhões de anos; são solos senis e por isso enriquecidos de alumínio.

Para Goodland (1971), como os solos do Cerrado contém muito Alumínio trocável, as plantas devem ser tolerantes a altos teores de Alumínio e várias espécies, ocorrentes no Campos Sujos de Taquaruçu, são citadas por ele como tolerantes ou acumuladoras de alumínio: Piptocarpha rotundifolia (Asteraceae); Qualea grandiflora, Qualea parviflora, Vochysia rufa, V. thyrsoidea (Vochysiaceae); Palicourea rigida (Rubraceae); e, Vellozia glauca (=Vellozia seubertiana), Velloziaceae.

Haridasan (1982) citou como acumuladoras de alumínio, além das espécies já citadas para a família Vochysiaceae, a espécie Vochysia elliptica e fez referência a espécies de Melastomataceae (Miconia ferruginata) e a Palicourea rigida (Rubiaceae). As espécies acumuladoras de alumínio apresentam altos valores de IVI nas comunidades nativas em solos distróficos talvez devido a uma vantagem competitiva. Algumas acumuladoras são restritas a solos distróficos, outras são indiferentes como Qualea grandiflora, já as espécies $V$. thyrsoidea e Miconia albicans não crescem em solos calcários na ausência de alumínio (HARIDASAN, 2000). 


\subsection{Análise de Ordenação}

A Análise em Coordenadas Principais (ACP) indicou a formação de dois grupos, sendo um formado pelas áreas de topo A3, A4 e A5, que teve uma forte correlação florística $\left(\mathrm{r}^{2}=0,9187\right)$, e outro grupo formado por áreas de topo e vertente, A1T, A1V, A2T, A2V, A3V, A4V E A5V, cuja correlação entre tais áreas foi baixa $\left(r^{2}=0,1533\right)$, indicando haver diferenças florísticas entre elas (Figura 4.63).

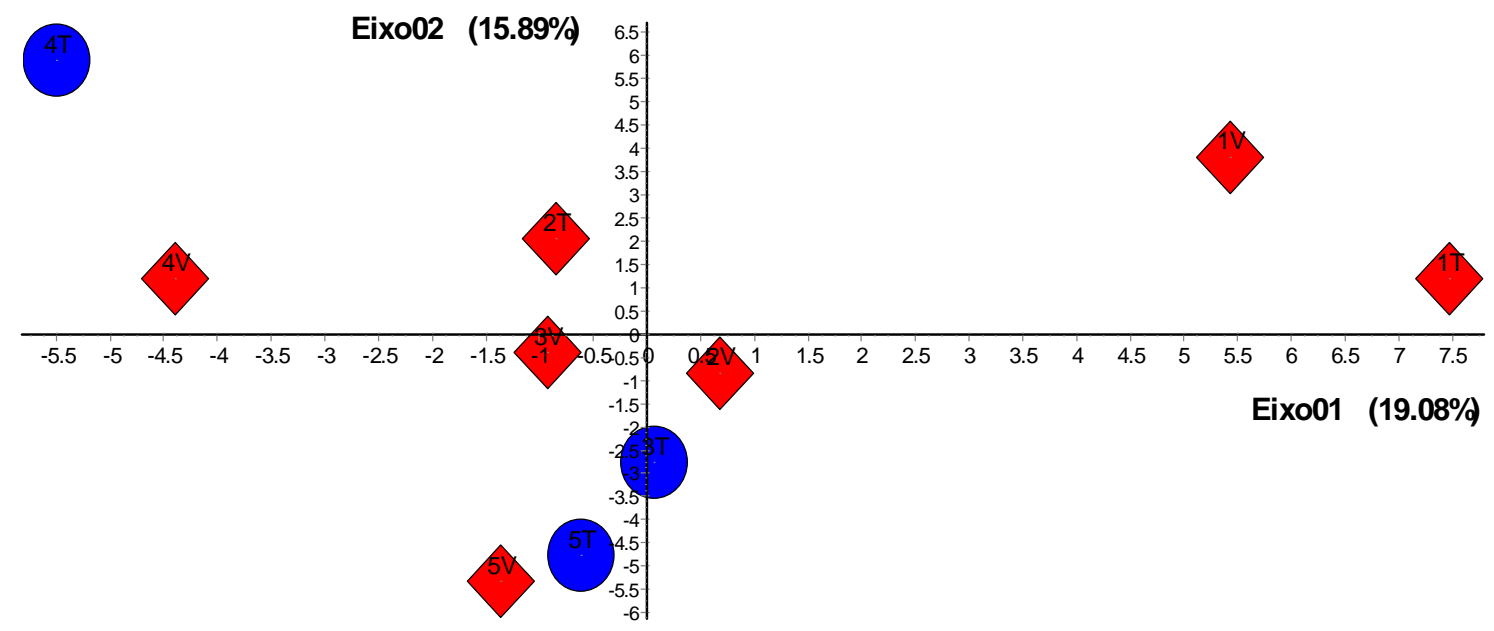

Figura 4.63 - Análise em Componentes Principais (PCO) das comunidades de plantas do Campo Sujo Seco, na bacia hidrográfica do ribeirão Taquaruçu Grande, Palmas (TO)

As espécies comuns no grupo com alta correlação florística (A3T, A4T e A5T) foram, principalmente, $V$. seubertiana, S. comosa e B. coccobolifolia. Além da abundância dessas espécies, essas áreas tiveram afinidades florísticas específicas. $\mathrm{Na}$ A3T e A4T também ocorreu B. pachyphylla; na A3T e A5T, V. cinnamomea; e na A4T e A5T houve abundância de B. subterrânea.

A análise florística pelo método ACP teve certa concordância com a análise feita pelo método UPGMA em relação à A4, separando $\mathrm{A} 4 \mathrm{~T}$ da $\mathrm{A} 4 \mathrm{~V}$, assim como também teve concordância com a análise pelo método Twinspan, que separou a A3T da A3V e a A5T da $\mathrm{A} 5 \mathrm{~V}$, evidenciando a existência de grupos florísticos diferenciados entre topo e vertente em algumas áreas. 


\subsection{Análise de variações estruturais}

O Campo Sujo Seco estudado não apresentou apenas variações florísticas, mas também variações estruturais. Quanto à distribuição espacial da densidade das plantas, observou-se que variações, podendo-se visualisar três tipos ou padrões de Campo Sujo Seco: Campo Sujo Seco denso, Campo Sujo Seco típico e Campo Sujo Seco ralo, seguindo-se a nomenclatura de Ribeiro e Walter (1998; 2008), que adotaram os termos denso, ralo e típico para demonstrar variações de cobertura arbórea das fitofisionomias do Cerrado Sentido Restrito. Quanto ao Campo Sujo, estes autores, ao estabelecerem o sistema de classificação de fitofisionomias para o Cerrado, considerando variações ambientais, distinguiram três subtipos: Campo Sujo Seco, Campo Sujo Úmido e Campo Sujo com Murundus.

Os Campos Sujos da bacia do ribeirão Taquaruçu Grande, são Campos Sujos Secos que, por sua vez apresentaram padrões diferenciados de densidade podendo-se classificá-los como Campos Sujos Secos Densos, Campos Sujos Secos Típicos e Campos Sujos Secos Ralos. Ressalta-se, assim, que os termos denso, ralo e típico estão sendo utilizados para demonstrar variações de densidade de plantas e não cobertura arbórea.

Os Campos Sujos Secos Ralos (Figura 4.64), foram campos com densidade $\leq 1.500$ indivíduos.ha ${ }^{-1}$ (parcelas $10 \mathrm{~m}$ x $10 \mathrm{~m}$ com número de plantas $\leq 15$ ), ocorreram nos topos das áreas 2 e 3 e na área 5 (vertente); os Campos Sujos Secos Típicos foram campos com

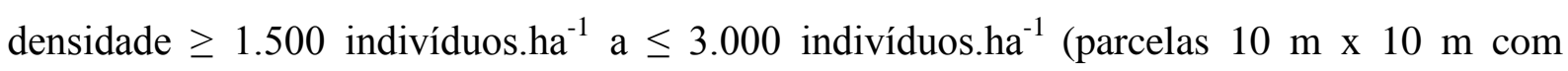
número de plantas $\geq 15 \mathrm{e} \leq 30$ ), foram os das áreas 2 e 3 (vertente), área 4 (topo e vertente) e área 5 (topo); e os Campos Sujos Secos Densos foram os campos com densidade $\geq 3.000$ indivíduos.ha ${ }^{-1}$ (parcelas com número de plantas $\geq 30$ ) e foram característicos da área 1 (topo e vertente).

Tem-se, portanto, quanto à densidade, Campos Sujos Secos densos de Vellozia seubertiana no topo e na Vertente da área 1; Campos Sujos Secos Típicos de V. seubertiana e Syagrus comosa na Vertente da área 2; Campos Sujos Secos Típicos de Vochysia cinnamomea na Vertente da área 3; Campos Sujos Secos Típicos de V. seubertiana no topo e na vertente da área 4; Campos Sujos Secos típicos de Byrsonima subterranea no topo da área 5; Campos Sujos Secos Ralos de S. comosa com V. seubertiana, Erythroxylum suberosum, Ouratea spectabilis e Piptpcarpha rotundifolia no topo da área 2; Campos Sujos Secos Ralos de V. seubertiana e V. cinnamomea no topo da área 3; e Campos Sujos Secos ralos de E. suberosum, S. comosa, Davilla elliptica e B. subterranea na vertente da área 5. 


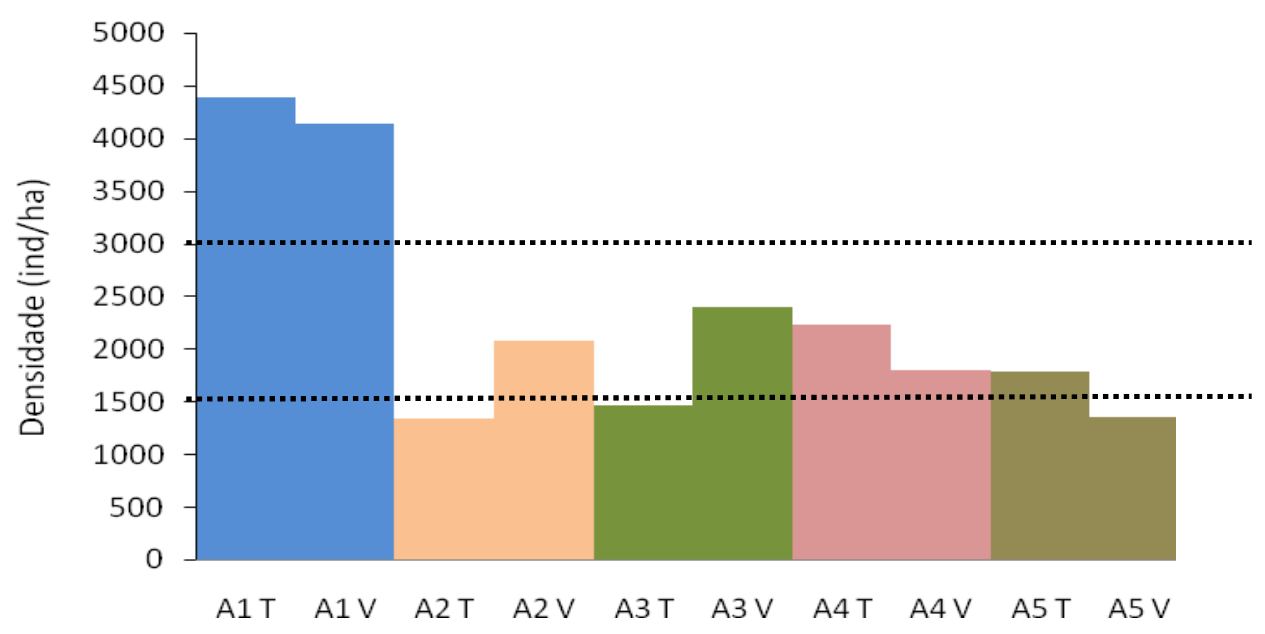

Figura 4.64 - Densidade de plantas registrada no Campo Sujo Seco, por área de topo (T) e de vertente $(\mathrm{V})$, na bacia hidrográfica do ribeirão Taquaruçu Grande, Palmas (TO)

Isto deixa evidente que o Campo Sujo tem uma diversidade fitofisionômica não apenas em relação às variações das condições ambientais já demonstrada por Ribeiro e Walter (1998; 2008), mas também em relação à florística e densidade de plantas lenhosas, formando padrões diferenciados florísticos e estruturais.

\subsection{Similaridade florística com outros Campos Sujos}

A similaridade florística das comunidades de plantas dos Campos Sujos Secos da bacia hidrográfica do ribeirão Taquaruçu Grande com a de outros Campos Sujos, de acordo com o índice de Sørensen, foi baixa (Quadro 4.6).

Quadro 4.6 - Similaridade florística entre Campos Sujos de várias localidades do Cerrado e o Campo Sujo Seco da bacia hidrográfica do ribeirão Taquaruçu Grande, Palmas (TO)

\begin{tabular}{|l|c|l|}
\hline \multicolumn{1}{|c|}{ Localidade } & Índice de Sørensen & \multicolumn{1}{c|}{ Fonte } \\
\hline Itirapina (SP) & 0,18 & Tannus e Assis (2004) \\
Fazenda Água Limpa (DF) & 0,09 & Munhoz e Felfili (2006) \\
Fazenda Água Limpa (DF) & 0,12 & Amaral (2008) \\
Estação Ecológica do Panga (MG) & 0,27 & Moreno et al. (2008) \\
Floresta Nacional de Silvania (GO) & 0,15 & Araújo et al. (2012) \\
Estação Ecológica do Pirapitinga (MG) & 0,34 & Giácomo et al. (2013) \\
\hline
\end{tabular}

O Cerrado ocupa uma grande área no Brasil Central e apresenta gradiente ambiental muito diversificado; o clima, por exemplo, exerce grande influência sobre a vegetação. Os Campos Sujos de Itirapina (SP) estão sob regime climático do tipo Cwa (clima mesotérmico), de acordo com a classificação de Köopen, com temperaturas mínimas de $17^{\circ} \mathrm{C}$ e máximas de 
$23,5^{\circ} \mathrm{C}$ e a uma altitude de aproximadamente $700 \mathrm{~m}$ (TANNUS; ASSIS, 2004).

Os Campos Sujos da Fazenda Água Limpa (DF) estão sob o regime climático Aw Megatérmico, que apresenta temperatura média anual máxima de $28,5^{\circ} \mathrm{C}$ e mínima de $12^{\circ} \mathrm{C}$; o solo é fortemente ácido - $\mathrm{pH} 4,02$, com níveis de alumínio elevados $-0,35 \mathrm{cmol}_{\mathrm{c}} / \mathrm{dm}^{3}-\mathrm{e}$ baixos teores de cálcio - $0,35 \mathrm{cmol}_{\mathrm{c}} / \mathrm{dm}^{3}$, magnésio - $0,12 \mathrm{cmol}_{\mathrm{c}} / \mathrm{dm}^{3}$ - e fósforo - 1,14 $\mathrm{cmol}_{\mathrm{c}} / \mathrm{dm}^{3}$ (MUNHOZ; FELFILI, 2006; AMARAL, 2008).

Os campos estudados por Moreno et al. (2008), em clima também Aw Megatérmico, estão em altitudes variando de 740 a $830 \mathrm{~m}$ e os solos onde se encontram apresentaram acidez média $\left(\mathrm{pH}\right.$ de 5,5), Al trocável médio $\left(0,72 \mathrm{cmol}(+) \cdot \mathrm{kg}^{-1}\right)$, e baixa C.T.C. Efetiva $(0,13$ $\left.\operatorname{cmol}(+) \cdot \mathrm{kg}^{-1}\right)$.

Os Campos Sujos estudados por Araújo et al. (2012), na Floresta Nacional de Silvânia (GO), são campos de clima Aw Megatérmico em altitudes médias de 900 m.

Os Campos Sujos da Estação Ecológica de Pirapitinga (MG), em clima Aw Megatérmico, estão a 570-630 m de altitude (GIÁCOMO et al., 2013).

Os Campos Sujos Secos da bacia hidrográfca do ribeirão Taquaruçu Grande estão sob regime climático Aw Megatérmico com temperatura anual máxima foi de $33^{\circ} \mathrm{C}$ e a mínima de $21,1^{\circ} \mathrm{C}$ e a uma altitude entre 600 a $700 \mathrm{~m}$ e ocorrem em solos ácidos, distróficos e álicos.

Como se pôde observar, o clima e a altitude semelhantes foram fatores que contribuíram para maior afinidade entre os campos estudados e os de Pirapitinga (MG) e, em relação aos demais, em similaridade florística, muito embora outros parâmetros físico-bióticos devam ser levados em conta. A proximidade geográfica com os campos do Distrito Federal não foi um fator, por si só, que resultasse em maior similaridade florística. O Campo Sujo apresenta características peculiares de cada área, como Felfili et al. (2008) afirmaram, a resposta das espécies aos diversos fatores físicos e bióticos, assim como aos resultantes da interação entre esses fatores, evidencia que cada local tem características próprias e outras que são comuns a outros locais possíveis de serem identificadas.

\subsubsection{Relevo e vegetação}

A respeito da relação entre o relevo e a vegetação, constatou-se que, em geral, há diferenças entre topo e vertente para alguns parâmetros e índices fitossociológicos, porém não são muito expressivas (Tabela 4.22). 
Tabela 4.22 -Parâmetros fitossociológicos e de diversidade florística para o Campo Sujo Seco (topo e vertente), na bacia hidrográfica do ribeirão Taquaruçu Grande, Palmas (TO)

\begin{tabular}{lcccc}
\multicolumn{1}{c}{ Categorias } & Topo & $(\boldsymbol{\%})$ & Vertente & $(\boldsymbol{\%})$ \\
\hline $\mathrm{N}^{\text {o de famílias }}$ & 28 & 51,9 & 26 & 48,1 \\
$\mathrm{~N}^{\text {o de gêneros }}$ & 76 & 52,8 & 68 & 47,2 \\
$\mathrm{~N}^{\text {o de espécies }}$ & 104 & 52 & 96 & 48 \\
Densidade (ind./ha) & $2.242,0$ & 48,8 & $2.354,0$ & 51,2 \\
Dominância (m $\left.{ }^{2} / \mathrm{ha}\right)$ & 5,78 & 51,3 & 5,5 & 48,7 \\
\% de indivíduos mortos & 8,2 & 45 & 10 & 55 \\
DAP - média & 4,5 & - & 4,6 & - \\
Índice de Shannon-Wiener & 3,16 & - & 2,8 & - \\
Equabilidade & 0,75 & - & 0,68 & - \\
\hline
\end{tabular}

Quanto ao número de famílias, a diferença entre topo e vertente foi de 3,8\%, de 5,6\% para gêneros, $4 \%$ para espécies, 2,4\% para densidade, de 2,6\% para dominância (Tabela 4.22). Do ponto de vista da diversidade florística, considerando-se que o índice de ShannonWiener é de 0 a 5, a diversidade foi relativamente alta, principalmente no topo, e a equitabilidade (índice de uniformidade de Pielou) foi também maior no topo, indicando haver uma pequena diferença em relação à uniformidade na distribuição dos indivíduos nas espécies no topo que na vertente. A densidade foi mais baixa no topo, enquanto que a dominância foi mais alta. Verificou-se o inverso na vertente e devido, a essa inversão de valores de densidade e dominância entre topo e vertente, o diâmetro (média) foi praticamente igual. O índice de mortalidade de plantas foi mais baixo no topo, com $10 \%$ de diferença entre topo e vertente, sendo mais alto na vertente (Tabela 4.22).

O índice de Sørensen entre as duas situações de relevo foi alto $(0,79)$, o que sugere que há alta similaridade florística entre topo e vertente que, apesar de alta ,indica que $21 \%$ são diferentes, ou seja, nem todas as vertentes possuem alta similariade com os topos.

Considerando-se a disposição no relevo, 80 espécies $(66,1 \%)$ ocorreram em ambas as situações de relevo, topo e vertente, ao passo que poucas espécies ocorreram só na vertente ou só no topo. Embora exista ampla plasticidade das espécies em ocorrerem em ambos os tipos de relevo, o maior número de indivíduos em uma situação ou em outra indicou preferência de ocorrência em um desses ambientes. Houve preferência mais alta das espécies pelo relevo tipo topo $(20,7 \%)$, que pelo relevo tipo vertente $(13,2 \%)$ (Quadros 4.7 e 4.8$)$. 
Quadro 4.7 - Distribuição de espécies no topo em grupos de predominância baixa, média, alta, e exclusivas, de acordo com a sua respectiva densidade em relevo de topo ou vertente no Campo Sujo Seco, na bacia hidrográfica do ribeirão Taquaruçu Grande, Palmas (TO)

\begin{tabular}{|c|c|c|c|c|c|}
\hline Grupos & Espécies do topo & Topo & $(\%)$ & Vertente & $(\%)$ \\
\hline Exclusivas de topo & $\begin{array}{l}\text { Pterodon emarginatus } \\
\text { Erythroxilum cf. citrifolium } \\
\text { Kielmeyera rosea } \\
\text { Tocoyena formosa } \\
\text { Eriotheca pubescens }\end{array}$ & $\begin{array}{c}10.0 \\
10.0 \\
6.0 \\
4.0 \\
4.0\end{array}$ & $\begin{array}{l}100 \\
100 \\
100 \\
100 \\
100\end{array}$ & $\begin{array}{l}0 \\
0 \\
0 \\
0 \\
0\end{array}$ & $\begin{array}{l}0 \\
0 \\
0 \\
0 \\
0\end{array}$ \\
\hline Predominâcia alta & $\begin{array}{l}\text { Vochysia cf. thyrsoidea } \\
\text { Chamaecrista orbiculata } \\
\text { Byrsonima subterranea } \\
\text { Andira humilis }\end{array}$ & $\begin{array}{c}28.0 \\
18.0 \\
162.0 \\
10.0\end{array}$ & $\begin{array}{l}93 \\
90 \\
85 \\
83\end{array}$ & $\begin{array}{c}12.0 \\
2.0 \\
28.0 \\
2.0\end{array}$ & $\begin{array}{c}7 \\
10 \\
15 \\
17\end{array}$ \\
\hline Predominâcia média & $\begin{array}{l}\text { Psidium firmum } \\
\text { Dipteryx alata } \\
\text { Salacia crassifolia } \\
\text { Dimorphandra mollis } \\
\text { Hymenaea stigonocarpa } \\
\text { Schefflera macrocarpa } \\
\text { Manihot sparsifolia } \\
\text { Bowdichia virgilioides } \\
\text { Qualea grandiflora } \\
\text { Kielmeyera coriacea }\end{array}$ & $\begin{array}{c}42.0 \\
8.0 \\
38.0 \\
84.0 \\
6.0 \\
24.0 \\
36.0 \\
10.0 \\
22.0 \\
30.0\end{array}$ & $\begin{array}{l}81 \\
80 \\
76 \\
75 \\
75 \\
75 \\
72 \\
71 \\
69 \\
68\end{array}$ & $\begin{array}{c}10.0 \\
2.0 \\
12.0 \\
28.0 \\
2.0 \\
8.0 \\
14.0 \\
4.0 \\
10.0 \\
14.0\end{array}$ & $\begin{array}{l}19 \\
20 \\
24 \\
15 \\
25 \\
25 \\
28 \\
29 \\
31 \\
32\end{array}$ \\
\hline Predominâcia baixa & $\begin{array}{l}\text { Hancornia speciosa } \\
\text { Vochysia tucanorum } \\
\text { Piptocarpha rotundifolia } \\
\text { Myrcia splendens } \\
\text { Diospyros hispida } \\
\text { Stryphnodendron adstringens } \\
\text { Anacardium nanum } \\
\text { Himatanthus obovatus } \\
\text { Annona crassiflora } \\
\text { Casearia sylvestris } \\
\text { Calliandra dysanta } \\
\text { Connarus suberosus } \\
\text { Byrsonima verbascifolia } \\
\text { Ouratea spectabilis } \\
\text { Syagrus comosa }\end{array}$ & $\begin{array}{c}4.0 \\
4.0 \\
84.0 \\
14.0 \\
10.0 \\
32.0 \\
30.0 \\
34.0 \\
14.0 \\
16.0 \\
10.0 \\
76.0 \\
28.0 \\
66.0 \\
308.0\end{array}$ & $\begin{array}{l}67 \\
67 \\
66 \\
64 \\
62 \\
61 \\
60 \\
59 \\
58 \\
57 \\
56 \\
56 \\
56 \\
55 \\
53\end{array}$ & $\begin{array}{c}2.0 \\
2.0 \\
44.0 \\
8.0 \\
6.0 \\
20.0 \\
20.0 \\
24.0 \\
10.0 \\
12.0 \\
8.0 \\
60.0 \\
22.0 \\
54.0 \\
270.0\end{array}$ & $\begin{array}{l}33 \\
33 \\
34 \\
36 \\
38 \\
39 \\
40 \\
41 \\
42 \\
43 \\
44 \\
44 \\
44 \\
45 \\
47\end{array}$ \\
\hline
\end{tabular}


Quadro 4.8 - Distribuição de espécies na vertente em grupos de predominância baixa, média, alta, e exclusivas, de acordo com a sua respectiva densidade em relevo de topo ou vertente no Campo Sujo Seco, na bacia hidrográfica do ribeirão Taquaruçu Grande, Palmas (TO)

\begin{tabular}{|c|l|c|c|c|c|}
\hline \multicolumn{1}{|c|}{ Grupos } & \multicolumn{1}{|c|}{ Espécies da Vertente } & Topo & $(\%)$ & Vertente & (\%) \\
\hline \hline Exclusivas de Vertente & Manihot acuminatissima & 0 & 0 & 16.0 & 100 \\
& Tabebuia aurea & 0 & 0 & 10.0 & 100 \\
& Senna velutina & 0 & 0 & 8.0 & 100 \\
& Erythroxylum tortuosum & 0 & 0 & 4.0 & 100 \\
\hline Predominância média & Salvertia convallariodora & 6.0 & 19 & 26.0 & 81 \\
& Vochysia cinnamomea & 32.0 & 20 & 128.0 & 80 \\
& Curatella americana & 2.0 & 25 & 6.0 & 75 \\
& Leptolobium dasycarpum & 6.0 & 25 & 18.0 & 75 \\
& Mimosa albolanata cf. var. brasiliana & 4.0 & 29 & 10.0 & 71 \\
& Erythroxylum suberosum & 52.0 & 31 & 114.0 & 69 \\
\hline Predominância baixa & Tachigali rugosa & 10.0 & 33 & 20.0 & 67 \\
& Byrsonima pachyphylla & 40.0 & 36 & 70.0 & 64 \\
& Brosimum gaudichaudii & 8.0 & 36 & 14.0 & 64 \\
& Anacardium humile & 22.0 & 37 & 38.0 & 63 \\
& Byrsonima coccobolifolia & 60.0 & 38 & 100.0 & 62 \\
& Vellozia seubertiana & 518.0 & 39 & 824.0 & 61 \\
& Qualea parviflora & 4.0 & 40 & 6.0 & 60 \\
& Bauhinia rufa & 20.0 & 44 & 26.0 & 56 \\
& Bauhinia curvula & 54.0 & 47 & 60.0 & 53 \\
& Mimosa radula cf. var. imbricata & 16.0 & 47 & 18.0 & 53 \\
\hline
\end{tabular}

Das espécies de distribuição exclusiva, algumas foram de ocorrência rara por ocorrer apenas um indivíduo. No topo, as espécies Miconia ferruginata, Deianira cf. chiquitana, Psidium sp, Solanum lycocarpum, Vochysia elliptica, Platypodium elegans, Caryocar brasiliense, Tabebuia roseoalba apresentaram distribuição rara. Na vertente foram Agonandra brasiliensis, Palicourea rigida, Ananas ananassoides, Kielmeyera lanthrophyton, Miconia albican, Platonia insignis. Porém, as espécies Davilla elliptica, Anacardium occidentale, Vochysia rufa, Annona coriacea, Zeyhera tuberculosa, Rourea induta, Tibouchina aegopogon e Ouratea hexasperma por ter os mesmos percentuais (50\%) de ocorrência tanto no topo quanto na vertente, foram consideradas de distribuição não preferencial.

As espécies de mais ampla ocorrência, isto é, que ocorreram em todas as áreas de amostragem, tanto no topo quanto na Vertente foram: Vellozia seubertiana, Syagrus comosa, Connarus suberosus, Davilla elliptica, Erythroxylum suberosum, Ouratea spectabilis e Piptocarpha rotundifolia. No estrato herbáceo, foi a espécie Bulbostylis paradoxa.

No que se refere à influência do grau de inclinação do relevo em relação ao número de espécies, existe uma correlação negativa, ou seja, quanto mais alto o grau de inclinação, menor o número de espécies. $\mathrm{O}$ coeficiente de correlação $\mathrm{R}^{2}=0.6475$ indicou haver correlação negativa moderada entre o grau de inclinação e o número de espécies (Figura 
4.65).

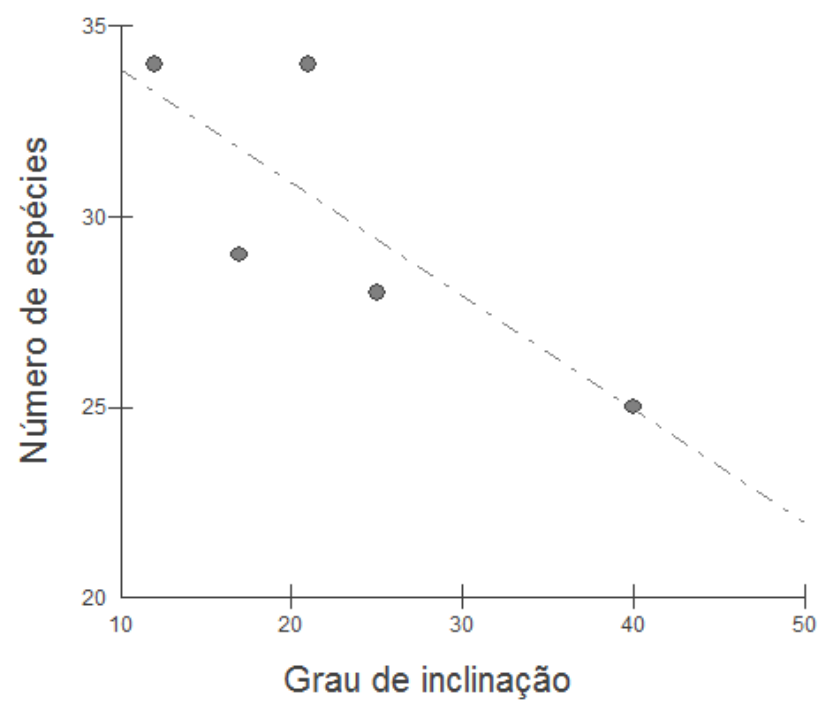

Figura 4.65 - Relação entre grau de inclinação da Vertente e número de espécie (número de espécies/ha), das comuniddes de plantas do Campo Sujo Seco, na bacia hidrográfica do ribeirão Taquaruçu Grande, Palmas (TO)

Em relação ao número de indivíduos, a correlação foi baixa com Coeficiente de Determinação $\left(\mathrm{R}^{2}\right)=0.0046$ (Figura 4.66), devido a grande variação do número de espécies em relação à inclinação do relevo. Da mesma forma, também não houve correlação entre inclinação do relevo com a dominância absoluta, cujo Coeficiente de Determinação $\left(\mathrm{R}^{2}\right)=$ 0.0032 (Figura 4.67).

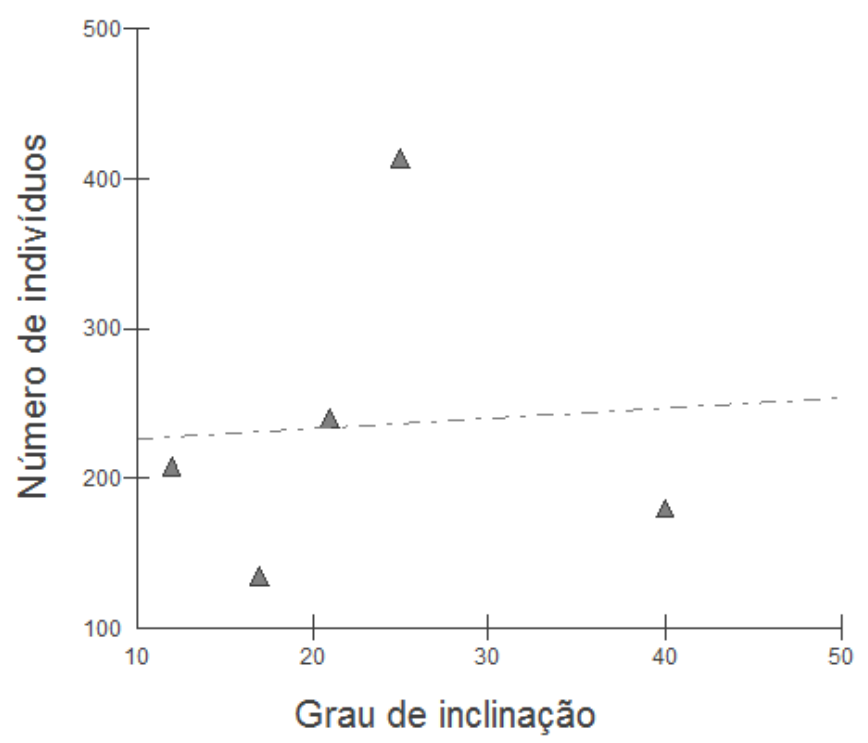

Figura 4.66 - Relação entre grau de inclinação da Vertente e número de indivíduos ( número de ind./ha), das comunidades de plantas do Campo Sujo Seco, na bacia hidrográfica do ribeirão Taquaruçu Grande, Palmas (TO) 


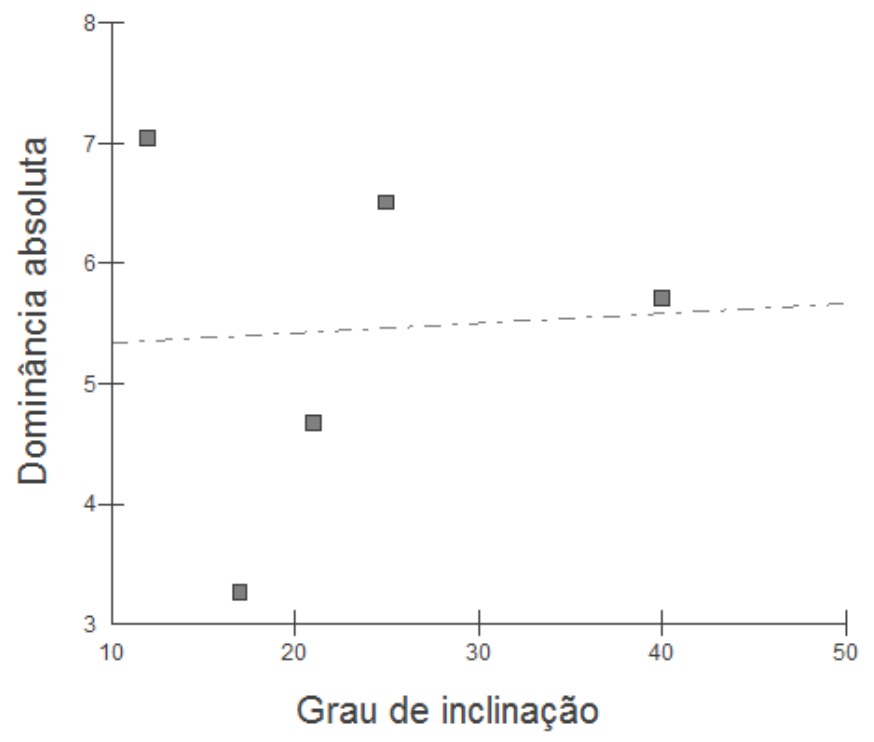

Figura 4.67 - Relação entre grau de inclinação da Vertente e dominância absoluta das espécies $\left(\mathrm{m}^{2} / \mathrm{ha}\right)$, das comunidades de plantas do Campo Sujo Seco, na bacia hidrográfica do ribeirão Taquaruçu Grande, Palmas (TO)

No estrato herbáceo-subarbustivo, 10 espécies foram exclusivas do topo, como Amasonia campestris, Aspilia foliacea e Aspilia leucoglossa, entre outras (Tabela 4.18); sete foram exclusivas da vertente (Centrosema virginianum, Chamaecrista diphylla, Diplusodon microphyllus e Diplusodon sessiliflorus, entre outras), embora com poucos percentuais de cobertura; 27 espécies ocorreram em ambos os tipos de relevo.

As espécies de ampla ocorrência, em geral, apresentaram baixos percentuais de diferenças entre a ocorrência no relevo de topo ou de vertente (Tabela 4.19). Outras espécies, em número reduzido, apresentaram índices preferenciais mais definidos por um tipo ou outro de relevo, como o Bulbostylis pradoxa e Indeterminada 4 com ocorrência preferencial na Vertente e Rhynchospora brasiliensis e indeterminada 5 no topo (Tabela 4.19).

A similaridade florística pelo índice de Sørensen, entre as duas situações de relevo, foi baixa $(0,27)$, significando que há uma baixa semelhança florística entre topo e vertente das espécies do estrato herbáceo-subarbustivo, diferentemente das espécies subarbustivasabustivo-arbóreas, que registraram índice de similaridade alto entre topo e vertente. Isso significa que o relevo de topo e vertente teve influência maior na distribuição de espécies do estrato herbácio-subarbustivo do que no estrato subarbustivo-arbustivo-arbóreo.

O Coeficiente de Determinação $\left(\mathrm{R}^{2}\right)=0.5140$ entre grau de inclinação da vertente e número de espécies foi médio no estrato herbáceo-subarbustivo, ou seja, a mudança por si só 
do tipo de relevo (se de topo ou de vertente) tem certa influência na distribuição das espécies do estrato herbáceo-subarbustivo, indicando que as espécies desse estrato são sensíveis a essa mudança, uma vez que seu sistema radicular é pouco profundo e as vertentes são ambientes mais instáveis (Figura 4.68).

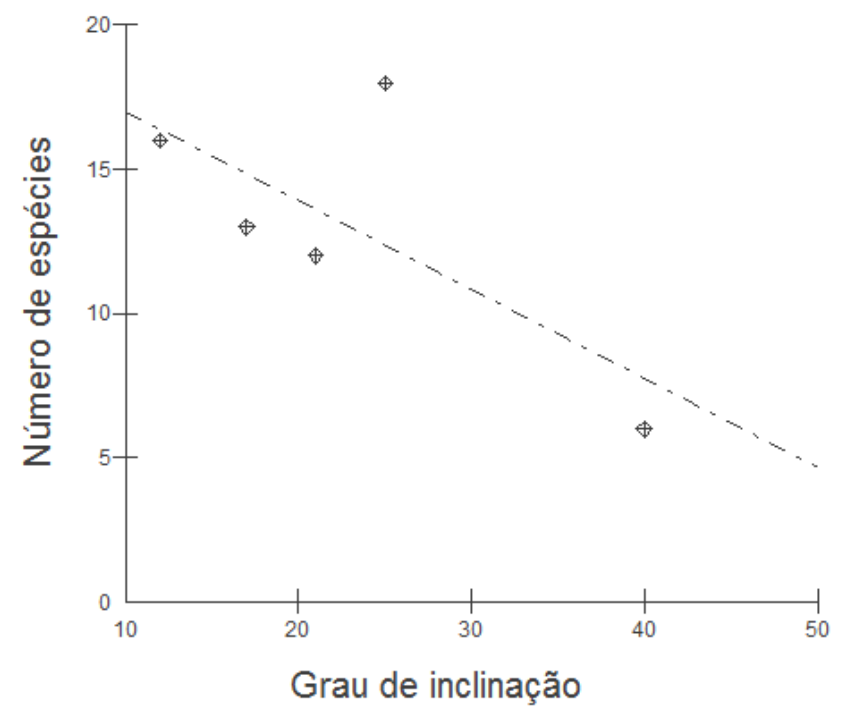

Figura 4.68 - Correlação entre grau de inclinação da vertente e número de espécies herbáceassubarbustivas, das comuniddes de plantas do Campo Sujo Seco, na bacia hidrográfica do ribeirão Taquaruçu Grande, Palmas (TO)

Apesar da alta similaridade florística entre topo e vertente, diferenças foram mostradas na formação de grupos florísticos resultante das análises de agrupamento (UPGMA e Twinspan) e de ordenação (PCA), quando alguns grupos foram constituídos pela vegetação de topo e vertente, evidenciando essa similaridade. Porém, outros grupos foram formados com a separação de uma mesma área, como é o caso da área 2, em que o topo constituiu um grupo separado do da vertente e da área 4; esta última, quando feito o corte ao nível de similaridade de $46 \%$ no agrupamento UPGMA, a vertente foi separada do topo. Assim como também a análise pelo Twinspan e PCA indicaram a separação entre topo e vertente das áreas 3; 4 e 5.

As diferenças entre os parâmetros fitossociológicos e a variedade de padrões florísticos existentes são reflexo das condiçõe físico-ambientais. Os parâmetros analisados (inclinação de vertentes, altitude, fertilidade e umidade dos solos) também evidenciaram diferenças entre relevo de topo e de vertente e também entre áreas geográficas distintas de Campo Sujo, dentro da bacia hidrográfica do ribeirão Taquaruçu Grande.

O solo, embora distrófico, apresentou maior fertilidade (maior saturação de bases) no topo que na vertente, favorecendo maior diversidade de espécies vegetais neste tipos de relevo. Em termos de áreas geográficas distintas, área 2 foi a de solo com maior fertilidade e 
no topo; embora álico, o solo apresentou menores teores de saturação de Alumínio e, embora ácido, o maior $\mathrm{pH}$ e maior umidade, que proporcionou maior equitabilidade da flora lá existente e também uma flora do estrato herbáceo-subarbustiva bem específica, o que a fez diferente de outras áreas, mostrando a influência do relevo e das condições edáficas locais na diversidade de espécies e na formação de padrões florísticos diferentes. 


\section{CONCLUSÕES}

A bacia hidrográfica do ribeirão Taquaruçu Grande é uma bacia de $5^{\mathrm{a}}$ ordem que atualmente tem uma área de 46.177,47 ha e, com base na análise da paisagem, é composta pelos geofácies: Mata Ciliar, Mata de Galeria, Mata Seca, Cerradão, Cerrados Sentido Restrito, Babaçual, Veredas, Campo Sujo Seco, Campo Limpo, Campo Rupestre, Lago reservatório, ribeirões, córregos e brejos, Área Urbana, confirmando a primeira hipótese deste trabalho, que afirma que esta bacia hidrográfica tem uma diversidade de fitofisionomias do Cerrado.

A unidade Floresta ocupou a maior área da bacia hidrográfica (28.614.24 ha), sendo que a Mata Ciliar, Mata de Galeria, Vereda e Campo Limpo e Mata Seca representaram juntas $15.763,32$ ha $(34,1 \%$ da bacia) e o Cerradão $12.850,92$ ha $(27,8 \%)$, seguidos pelos Campos Sujos Secos (7.478,82 ha ou 16.2\%), pelas formas savânicas do Cerrado Sentido Restrito (4.964,31 ha ou 10,7\%), Área Urbana (2.844,09 ha ou 6,2 \%), Agropecuária/Silvicultura $(1.872,81$ ha ou 4,0\%) e pela área do Lago reservatório da UHE Luís Eduardo Magalhães dentro da bacia (403,20 ha ou 1,0\%).

Os Campos Sujos Secos localizam-se, predominantemente, nos planaltos e chapadas da serra do Lageado, cujos topos, por vezes, são suavemente ondulados, mas também ocorrem nas planícies secas da depressão do Tocantins de forma pouco expressiva, confirmando em parte a hipótese 2 que afirma que os Campos Sujos ocorrem nos planaltos e chapadas.

Os solos dos Campos Sujos Secos são do tipo Plintossolos Pétricos e se caracterizaram como de baixo teor de água, ácidos, distróficos, álicos com altos teores de ferro, e de textura média.

As condições de relevo de topo e vertente influenciaram nos teores de $\mathrm{pH}, \mathrm{Al}$, Saturação de Al, Saturação com H+Al e Saturação por Bases, havendo diferença significativa entre topo e vertente. Mas, não influenciaram nos teores de M.O., Umidade dos solos, nem dos nutrientes $\mathrm{Ca}, \mathrm{Mg}, \mathrm{P}, \mathrm{K}$, e Fe, quando analisados isoladamente, não havendo diferença significativa entre os teores de topo e vertente. Porém, a saturação por bases mostrou haver diferença significativa na fertilidade dos solos entre topo e vertente, sendo que os solos dos topos indicaram ser menos distróficos que os da vertente. Também entre as áreas de estudo, houve diferença significativa para os teores de $\mathrm{Ca}, \mathrm{Mg}$, Acidez Potencial (H+Al), Saturação Por Bases e Umidade. A área 2 indicou ter solos menos distróficos que as demais áreas e maior umidade em meados da estação 
seca.

A textura dos solos não apresentou diferença significativa para os teores de argila e de areia entre topo e vertente, nem entre as áreas. Apenas para o silte houve diferença significativa entre topo e vertente.

A flora do Campo Sujo Seco da bacia hidrográfica do ribeirão Taquaruçu Grande tem as seguintes características:

- apresentou 39 famílias, 82 gêneros e 121 espécies, sendo 77 espécies componentes do estrato subarbustivo-arbustivo-arbóreo e 44 do estrato herbáceo-subarbustivo. A família Fabaceae destacou-se entre as demais, com 25 espécies, seguida por Poaceae, com 12, e Vochysiaceae, com nove espécies.

- nem todas as espécies foram exclusivas do território brasileiro. Das 111 espécies identificadas, 37 espécies (33,3\%) também ocorrem no Cerrado da Bolívia oriental.

- poucas espécies têm uma área de distribuição geográfica de ampla distribuição Neotropical, como Tocoyena formosa, Casearia sylvestris e Bowdichia virgilioides.

- das 121 espécies, 58\% são fanerófitas, 23\% hemicriptófitas, 14\% caméfitas, 3\% geófitas e $2 \%$ terófitas.

- os Campos Sujos da bacia do ribeirão Taquaruçu Grande apresentaram densidade mais elevada, área basal mediana e menor altura em relação a outros Campos Sujos já estudados no Domínio do Cerrado.

- o número de famílias, de gêneros e de espécies foi mais alto no topo, levando à maior diversidade $\left(\mathrm{H}^{\prime}=3,16\right.$ nats.indivíduo $\left.{ }^{-1}\right)$ que na vertente $\left(\mathrm{H}^{\prime}=2,8\right.$ nats.indivíduo $\left.{ }^{-1}\right)$.

- a densidade de plantas vivas e mortas foi mais alta na vertente.

- existe alta similaridade florística, pelo índice de Sørensen, entre topo e vertente $(0,79)$ e isso ficou evidente na formação de grupos florísticos, em que alguns foram formados por topos e vertentes nas mesmas áreas de amostragem. Mas, em relação a outros Campos Sujos já estudados, a similaridade florística foi baixa.

- a diversidade alfa pelo índice de Shannon-Wiener $\left(H^{\prime}=3,533\right.$ nats.indivíduo $\left.{ }^{-1}\right)$, foi alta, geralmente acima da diversidade para Campos Sujos, e na faixa de Cerrado Sentido Restrito, indicando boa preservação.

- os Campos Sujos Secos da bacia do ribeirão Taquaruçu Grande, de acordo com a densidade de plantas têm padrões de Campos Sujos Secos Densos, Campos Sujos Secos Típicos e Campos Sujos Secos Ralos, tanto em relevos de topo e de vertente, confirmando a hipótese 4 que afirma que existe mais de um tipo de Campo Sujo.

Existem padrões estruturais e florísticos diversos de Campo Sujo Seco na bacia 
hidrográfica do ribeirão Taquaruçu Grande e as condições ambientais de relevo e edáficas tiveram influência na formação de tais padrões, confirmando a hipótese 3 de que o solo e o relevo são fatores ambientais que influenciam a diversidade dos tipos de Campo Sujo; também confirma a hipótese 5, porém a hipótese 5 que afirma que a diversidade florística é o fator de diferenciação entre tipos de Campos Sujos foi parcialmente confirmada, uma vez que além dos padrões florísticos há padrões estruturais:

- Vellozia seubertiana forma Campos Sujos Secos Densos e Típicos no topo e na vertente, mais concentrados no centro-norte da bacia;

- Byrsonima subterranea forma Campos Sujos Secos Típicos no topo, mais concentrados no norte da bacia;

- Vochysia cinnamomea forma Campos Sujos Secos Típicos na vertente, mais concentrados no sul da bacia.

Os padrões florísticos constituíram os geótopos do geofácie Campo Sujo Seco:

1. Campo Sujo Seco com Vochysia cinnamomea, Byrsonima coccobolifólia e Vellozia seubertiana em topo e vertente de morro na área 3

2. Campo Sujo Seco com Vellozia seubertiana e Syagrus comosa em topo e vertente de morro na área 1 e em vertente na área 2

3. Campo Sujo Seco com Byrsonima subterrânea em topo e vertente de morro na área 5

4. Campo Sujo Seco Misto com Syagrus comosa, Vellozia seubertiana, Erythroxylum suberosum, Ouratea spectabilis, Piptocarpha rotundifolia, Dimorphandra mollis em topo de morro da área 2

5. Campo Sujo Seco com Vellozia seubertiana em topo de morro na área 4

Do ponto de vista da importância da biodiversidade vegetal, os Campos Sujos Secos da bacia do ribeirão Taquaruçu Grande abrigam espécies que parecem ter distribuição geográfica restrita, como Vellozia seubertiana e Byrsonima subterranea, Mimosa albolanata cf. var. brasiliana e Mimosa radula cf. var. imbricata.

\section{SUGESTÕES DE USOS}

As sugestões de uso baseiam-se em usos que visem o desenvolvimento da pesquisa científica, de manejo ecológico e de uso sustentável do geossistema da bacia hidrográfica do ribeirão Taquaruçu Grande, de modo a compreender melhor a sua funcionalidade, por tratar-se de um ambiente com grandes responsabilidades sócioeconômicas (agropecuária/silvicultura, turismo e abastecimento de água da capital 
Palmas), mas também ambientais (conservação da biodiversidade), por apresentar alta biodiversidade vegetal, mas está em acelerado ritmo de ocupação. Assim, sugere-se:

- Estudos da dinâmica de populações de espécies herbáceas, subarbustivas, arbustivas e arbóreas no Campo Sujo para compreender a paisagem campestre do Cerrado.

- Estudos biológicos das espécies para compreender sua maior preferência pelo relevo de topo ou de vertente.

- Estudos sobre a ocorrência e dinâmica das térmitas na área de Campo Sujo e de que forma elas podem estar contribuindo na manutenção da paisagem campestre no Cerrado.

- Estudos biológicos associados à pratica de queimadas para entender a resposta das espécies a esses eventos e de que forma eles têm contribuído para a manutenção da paisagem campestre no Cerrado.

- Estudos paleontológicos de modo a documentar a grande ocorrência de fósseis, muitos deles expostos, e cuja informação, em parte, está se perdendo devido a ação do intemperismo.

- Estudos climáticos mais localizados, havendo a necessidade da existência de uma estação meteorológica na bacia do ribeirão Taquaruçu Grande de modo a ter dados mais condizentes com a realidade e que favorecerão a compreensão não apenas de dados biológicos, mas também da dinâmica físico-ambiental.

- Estudos geomorfológicos mais específicos como, por exemplo, da dinâmica do relevo

- Estudos hidrológicos mais específicos de forma a caracterizar todos os tributários da rede hidrográfica, tendo em vista a importância desta bacia no abastecimento de água do município de Palmas e na manutenção da biodiversidade.

- Estudos geográficos de dinâmica populacional, anseios e tendências de uso do espaço, de impactos e riscos ambientais.

- Estudos biogeográficos da Mata Ciliar, Mata de Galeria, Mata Seca, Cerrado Sentido Restrito, Palmeiral, Veredas, Campo Limpo e Campos Rupestres.

- Estudos sócio-econômicos e turísticos no sentido de compreender a importância da manutenção paisagística do Campo Sujo Seco em favorecimento da renda da população local, como por exemplo, a larga ocorrência de Vellozia nos Campos Sujos de Taquaruçu poderia ser aproveitada pelo turismo local, principalmente na época de floração que ocorre de forma sincronizada e os campos tornam-se floridos.

- Zoneamento ambiental para o estabelecimento de diretrizes no sentido de estabelecer políticas de manejo ecológico que visem a recuperação, conservação e o uso sustentável. 


\section{REFERÊNCIAS BIBLIOGRÁFICAS}

AB' SABER, A. N. Cerrados e Mandacarus. Scientific American Brasil. São Paulo, ano 1, n. 4, p. 98, 2002.

Contribuição a geomorfologia da área do Cerrado. Simpósio sobre o Cerrado. São Paulo, USP, 1982, p. 117-124.

O Pantanal Matogrossesse e a teoria dos refúgios. Revista Brasileira de Geografia. Rio de Janeiro: IBGE-CNG. 1988, p. 9-57.

, Os domínios morfoclimáticos da América do Sul. Primeira aproximação. Geomorfologia. São Paulo, USP-IGEOG, n. 52, p. 1-22, 1977.

A. N. Contribuição à geomorfologia dos cerrados. In: SIMPÓSIO SOBRE O CERRADO, 3, 1963, São Paulo. Anais... São Paulo: Edusp, 1963. p. 15-50.

A. N. A organização natural das paisagens inter e subtropicais brasileiras. In: SIMPÓSIO SOBRE CERRADO, 3., 1971, São Paulo, Anais... São Paulo: Editora Edgard Blücher LTDA/Editora Universidade de Sâo Paulo, 1971, p. 1-14.

, Domínios morfoclimáticos e províncias fitogeográficas no Brasil. Orientação. São Paulo, USP-IGEOG, n. 3, p. 45-48, 1967.

O relevo brasileiro e seus problemas. In: AZEVEDO, A. (Org.). Brasil as fases físicas. São Paulo: Nacional, v;1, p. 135-250, 1964.

Os domínios da natureza no Brasil: potencialidades paisagísticas. São Paulo: Ateliê Editorial, 2003.

AGOSTINHO, S.; VIANA, M. S. S.; FERNANDES, A. C. S. Duas novas icnoesoécies de Bifungites Desio, 1940 na Formação Pimenteiras, Devoniano da Bacia do Parnaíba, Brasil. Arquivos do Museu Nacional, Rio de Janeiro, v.62, n.4, p.519-530, 2004.

ALHO, C. J. R.; MARTINS, E. S. (Orgs.). De grão em grão o Cerrado perde espaço. Brasília: WWF, 1995.

ALMEIDA, R. S. A Geografia física no IBGE 1938-1998. Revista de Ciências Humanas, v. 9, n. 1, p. 55-66, 2009.

ALMEIDA, S. P.; PROENÇA, C. E.B.; SANO, S. M.; RIBEIRO, J. F. Cerrado: espécies vegetais úteis. Planaltina: Embrapa-CPAC. 1998. 464 p.

ALMEIDA, G. C. P. Caracterização física e classificação dos solos. Universidade federal de Juiz de Fora/ Faculdade de Engenharia/ Departamento de Transportes. 2005. 145 p. 
AMARAL, A. G. Mudanças estruturais eflorísticas do estrato herbáceo-arbustivo em campo sujo limpo úmido na Fazenda Água Limpa - DF após um período de sete anos. 2008. 180 f. Dissertação (Mestrado). Instituto de Biologia, Departamento de Botânica da Universidade de Brasília, 2008.

ANDRADE, L. A. Z.; FELFILI, J. M.; Violatti, L. Fitossociologia de uma área de cerrado na RECOR-IBGE, Brasíia-DF. Acta Botanica Brasilica, 16(2): 225-240, 2002.

APG III. An update of the Angiosperm Phylogeny Group classification for the orders and families of flowering plants: APG. Botanical Journal of the Linnean Society, p 105-121. 2009.

ARAÚJO, W. S.; PORFÍRIO JÚNIOR, E. D.; FRANCENER, A.; HALL, C. F. Composição florística e estrutura fitossociológica de áreas de campo sujo e cerrado sentido restrito na Floresta Nacional de Silvânia, Goiás, Brasil. INSULA Revista de Botânica Florianópolis, n. 41, p.42-58, 2012.

ARGENTO, M. S. F.; CRUZ, C. B. M. Mapemaneto Geomorfológico. In CUNHA,S.B.; GUERRA, A. J. T. (Orgs.) Geomorfologia - Exercícios,Técnicas e Aplicações. Rio de Janeiro: Bertrand Brasil SA, 1996, p. 239-249.

ARRUDA, M. B. et al. Ecorregiões, unidades de conservação e representatividade ecológica do Bioma Cerrado. In: SANO, S. M.; ALMEIDA, S. P.; RIBEIRO, J. F. (Eds.). Cerrado: Ecologia e Flora. Embrapa Cerrados. Brasília: DF: Embrapa Informações Tecnológicas, v. 1, p. 229-272. 2008.

ASSUNÇÃO, S. L.; FELFILI, J. M. Fitossociologia de um fragmeto de cerrado sensu stricto na APA do Paranoá, DF, Brasil. Acta Botânica Brasilica. v. 18, n. 4, p.903-909, 2004.

ATAIDE, E. S.; CASTRO, P. T. A.; FERNANDES, G. W. Florística e caracterização de uma área de campo ferruginoso no complexo minerário Alegria, serra de Antônio Pereira, Ouro Preto, Minas Gerais, Brasil. Revista Árvore, Viçosa-MG, v. 35, n. 6, p. 1265-1275, 2011.

AYOADE, J.O. Introdução à Climatologia para os trópicos. 4a ed. Rio de Janeiro: Bertrand do Brasil, 1996.

AYRES, M., AYRES JÚNIOR, M., AYRES, D.L. \& SANTOS, A.A. 2007. BIOESTAT Aplicações estatísticas nas áreas das ciências bio-médicas. Ong Mamiraua. Belém, PA.

BARBOSA,A. S.; RIBEIRO, M. B.; SCHMITZ, P. I. Cultura e ambiente em áreas de cerrado do sudoeste de Goiás. In: PINTO, M. N. (Org.). Cerrado: caracterização, ocupação e perspectiva. Brasília: Ed. UNB; SEMATEC, p. 75-107, 1993.

BERNALDEZ,F. G. Ecology y Paisage. Madrid. H. Blume, 1981.

BERTALANFFY, L. VON. Teoria general de los sistemas: Fundamentos, Desarrollo, aplicaciones. Mexico: Fondo de Cultura Econômica, 2003.

BERTRAND, G. Paisagem e Geografia Física Global. Esboço Metodológico. R. RA' E GA, Curitiba, n. 8, p. 141-152, 2004. Editora UFPR. 
BÓLOS I CAPDEVILA, M. Manual de ciência del paisaje. Barcelona: Masson, 1992.

BOSCH, H.; CAROL, H. Princípios do conceito da paisagem. Boletim Geográfico, v. 27, n. 202, p. 26-29, 1968.

BRADY, N. C. Natureza e propriedade dos solos. Tradução Antônio B. Neiva Figueiredo. Rio de Janeiro: Freitas Bastos, 1989. 878 p.

BRASIL. Constituição da República Federativa do Brasil. EDIOURO, 1988.128 p.

BRASIL. Lei $\mathrm{n}^{\mathrm{o}}$. 9.985, de 18 de julho de 2000. Institui o Sistema Nacional de Unidades de Conservação da Natureza - SNUC. Estabelece critérios e normas para a criação, implantação e gestão das unidades de conservação. Disponível em:www.mma.gov.br/port/sbf/dap/doc/snuc.pdf. Acesso em 04/11/2009.

BRASIL. Ministério de Minas e Energia, Secretaria Geral. Projeto RADAMBRASIL Folha SC. 22 Tocantins: geologia, geomorfologia, pedologia, vegetação e uso potencial da terra. Rio de Janeiro, Levantamento de recursos naturais, v. 22, 524 p. 1981.

BROWN, E. H. Geografia Física, seu conteúdo e suas relações. Bol. Geogr. Rio de Janeiro, 35 (254): 14-21, 1977.

CABRERA, A. L.; WILlinK, A. Biogeografia de América Latina. Monografia n. 13. Washington: Secretaría General de La Organizción de Estado Americanos, 1973. 120 p.

CAILlEUX, A. Biogéographie mondiale. Paris: Presses Universitaires de France. 1953. 126.

CAMARGO, M. C. R. Aplicações de indicadores perceptivos para análise das paisagens cênicas do trajeto entre o distrito de Taquaruçu e Palmas/TO. 2005, 196 f. Dissertação (Mestrado em Ciências do Ambiente). Universidade Federal do Tocantins, Palmas, 2005.

CAMARGO, O.; MONIZ, A.C.; JORGE, J.A.; VALADARES, J.M. Métodos de analise química, mineralógica e física do solo do Instituto Agronômico de Campinas. Campinas. Instituto Agronômico, 90p. 1996, (Boletim Técnico 106).

CAMPOS , G. Mapa florestal. Ministério da agricultura , Indústria e Commercio/Serviço Geológico e Mineralógico do Brasil. Rio de Janeiro: Typ. Da Diretoria do Serviço de Estatística, 1912. 116 p.

CARAÍBA, M. O. S. B.; MEDEIROS, T. C. C. Caracterização fitofisionômica e levantamento florístico de uma sequência de solo na "propriedade 1", na Serra de Monte do Carmo - Tocantins. V SEMINÁRIO DE INICIAÇÃO CIENTÍFICA DA UFT 2009. Anais... PDF. 118.

CAVAlCANTE, M. E. S. O discurso autonomista do Tocantins. Goiânia: Edtora UCG, 2003.240 p.

CHRISTOFOLETTI, A. Considerações a propósito da geografia física dos cerrados. Notícia Geomorfológica, n. 11, p. 5-32, 1966. 
CHRISTOFOLETTI, A. Geomorfologia. São Paulo: Edgard Blucher. 1980.

CHRISTOFOLETTI, A. Geografia Física. Bol. Geog. Teorética, 11(21 e 22): 5-8, 1981.

CONCEIÇÃO, A. A.; PIRANI, J. R. Diversidade em quatro áreas de campo rupestres na Chapada Diamantina, Brasil: espécies distintas, mas riquezas similares. Rodriguésia, v. 58, n.1, p. 193-206. 2007.

CONTI, J. B. Geografia, zonalidade e paisagem. In: Anais do III Encontro Interdisciplinar sobre o estudo da paisagem. UNESP, Rio Claro, 1998.

CONTI, J. B.. Os Geógrafos e a Paisagem: algumas considerações. Revista Território Geográfico, v. 06, p. 01-05, 2011.

COUTINHO, L. M. O conceito de Cerrado. Revista Brasileira de Botânica, v. 1, p. 17-23, 1978.

COUTINHO, L. M. O bioma do Cerrado. In: Klein, a. 1. (Org.). Eugene Warming e o cerrado brasileiro: um século depois. São Paulo: Editora UNESP; Imprensa Oficial do Estado, p. 77-91, 2002.

COUTINHO, L. M. O conceito de bioma. Acta Botanica Brasilica, v. 20, n. 1, p. 13-23. 2006.

COX, C. B.; MOORE, PD. Biogeografia: uma abordagem ecológica e evolucionária. Tradução de Luís Felipe Coutinho Ferreira da Silva-Rio de Janeiro: LTC, 2009. 398 p.

CRUZ, O. A Geografia Física, o geossistema, a paisagem e os estudos dos processos geomórficos. Boletim de Geografia Teorética, 15 (29-30): p. 53-62, 1985.

CURTIS, J. T.; McINTOSH, R. P. An upland forest continum in the prairie-forest borde region of Wisconsin. Ecology, 32, p. 476-496,1951.

CURTIS, J. T.; McINTOSH, R. P. The interrelations of certain analytic and syntetic phytosociological characters. Ecology, 31, p. 434-455, 1950.

DAJOZ, R. Ecologia de Paisagem e metapopulações.In: DAJOZ, R. Princípios de ecologia. Tradução Fátima Murad. Porto Alegre: Artmed, 2005. p. 344-369, 2005.

DASMANN, R. E. Asystem for defining and classifying natural regions for purposes of conservation. Morges (Switzerland): International Union of Conservation of Nature Resource, IUCN Occasional Paper no.7, 1973.

DE CANDOLLE, A. Essai élémentaire de géographie botanique. In: LOMOLINO, M. V.; SAX, D. F. BROW, J. H. Foundations of Biogeography: classic paper with commentaries. Chicago: The University Of Chicago Press, p.28-48. 2004.

DELPOUX, M. Ecossistema e Paisagem. Métodos em Questão, São Paulo: USP - Instituto de Geografia, 1974. 
DINERSTEIN, E. et al, Una evaluación del estado de conservación de lãs ecoregiones terrestres de América Latina y El Caribe. Washington, DC: WWF, 1995. 135 p.

DSG. Diretoria do Serviço Geográfico - Brasil. Ministério do Exército. Folha Vila Canela SC.22-Z-B-III/MI-1544. Escala1:100.000. 1979.

DURIGAN, G. Métodos para análise de vegetação arbórea. In: CULLEN JÚNIOR, L.; RUDRAN, R.; VALADARES-PADUA, C. (Orgs.). Métodos de estudo em Biología da Conservação \& Manejo da Vida Silvestre. Editora UFPR, v. 88, p. 455-479, 2

DUTRA, V. F. Diversidade de Mimosa L. (Leguminosae) nos campos rupestres de Minas Gerais: taxonomia, distribuição geográfica e filogeografia. 2009, 294 f. Tese (doutorado). Universidade Federal de Viçosa. 2009.

EMPRESA BRASILEIRA DE PESQUISA AGROPECUARIA - EMBRAPA. Centro Nacional de Pesquisa de solos. Manual de Análises Químicas de Solos, Plantas e Fertilizantes. Brasília, 1999. 370p.

EITEN, G. The Cerrado vegetation of Brazil. Botânical Review, v. 38, n. 2, p. 201-341, 1972.

EITEN,G. Vegetação do Cerrado. In: PINTO, M. N. (Org.). Cerrado: caracterização, ocupação e perspectiva. Brasília: Ed. UNB; SEMATEC, p. 17-73, 1993.

FELFILI, J. M. et al. Fitossocilogia da vegetação arbórea.. In: FELFILI, J.M.; RESENDE, A. V.; SILVA JÚNIOR, M. C. (Orgs.). Biogeografia do Bioma Cerrado: vegetação e solos da Chapada dos Veadeiros. Brasília: Editora Universidade de Brasília: Finatec, 2007. cap. 3.

FELFILI, J. M. Floristic composition and phytosociology of the gallery forest alongside the Gama stream in Brasília, DF, Brazil. Revista Brasileira de Botânica. 17(1):1-11. 1994.

FELFILI, J. M.; CARVALHO, F. A.; RICARDO, F. H. Manual para o monitoramento de parcelas permanentes nos biomas Cerrado e Pantanal. Brasília: Universidade de Brasília, Departamento de Engenharia Florestal. 2005..

FELFILI, J. M.; FAGG1, C. W. Floristic composition, diversity and structure of the "cerrado" sensu strict on rocky soils in northern Goiás and southern Tocantins, Brazil. Revista Brasileira de Botânica, v.30, n.3, p.375-385, 2007.

FELFILI, J. M.; FILGUEIRAS, T. S.; HARIDASAN, M.; SILVA JÚNIOR, M. C.; MENDONÇA, R. C.; REZENDE, A. V. Projeto biogeografia do bioma cerrado: vegetação e solos. Cadernos de Geociências, v. 12, n. 4, p. 75-166, 1994.

FELFILI, J. M.; SILVA JÚNIOR, M. C. A comparative study of cerrado (sensu stricto) vegetation in central Brazil. Journal of Tropical Ecology, v.9, n.3, p.277-289, 1993.

FELFILI, J. M.; SILVA JÚNIOR, M. C.; RESENDE, A. V.; MACHADO, J. W.; WALTER, B.M. T.; SILVA, P. E.; HAY, J. D. Análise comparativa da florística e fitosociologia da vegetação arbórea do cerrado sensu stricto na Chapada Pratinha, DF Brasil. Acta Botanica Brasilica, 6(2): 1992. 
FELFILI, M. C.; FELFILI, J. M. Biodiversidade alfa e beta no cerrado sensu stricto da Chapada da Pratinha, Brasil. Acta Botanica Brasilica, v. 15, n. 2, p. 243-254. 2001.

FELFILI, J. M. et al. Diversidade florística das áreas nucleares da Reserva da Biosfera do Cerrado - Fase I. In: ORGANIZAÇÃO DAS NAÇÕES UNIDAS PARA A EDUCAÇÃO, A CIÊNCIA E A CULTURA/BRASIL/Ministério do Meio Ambiente, dos Recursos Hídricos e da Amazônia Legal. Vegetação no Distrito Federal: - tempo e espaço: uma avaliação multitemporal da perda da cobertura vegetal no DF e da diversidade florística das áreas nucleares da Reserva da Biosfera do Cerrado - Fase I. Brasília: UNESCO, 2000. p.29-74.

FERREIRA, M. N. Planejamento sistemático das unidades de conservação do Estado do Tocantins. 2011,168 f. Tese (Doutorado). Instituto de Biociências. Universidade de São Paluo. 2011.

FERRI, M. G. Ecologia dos Cerrados. In: SIMPÓSIO SOBRE CERRADO, 4., 1977, São Paulo, Anais... São Paulo: Editora Universidade de Sâo Paulo/ Editora Itatiaia, 1977, p. 1533.

FIDELIS, A. T.; GODOY, S. A. P. Estrutura de um cerrado stricto sensu at the Glebe Cerrado Pé-de-Gigante, Snta Rita do Passa Quatro, SP. Acta Botânica Brasilica. v. 17, n. 4, p. 531539, 2003.

FIEDLER, N. C.; AZEVEDO, I. N. C.; RESENDE, A. V.; MEDEIROS, M. B.; VENTUROILI, F. Efeitos de incêndios florestais na estrutura e composição florística de uma área de cerrado sensu estrito na Fazenda Água Limpa-DF. Revista Árvore. V. 28, p. 129138. 2004.

FLORENZANO, G. T. Iniciação em sensoriamento remoto. São Paulo: Oficina de Texto, 2007.

FONSECA, M. S.; SILVA JÚNIOR, M. C. Fitossociologia e similaridade florística entre trechos de Cerrado Sentido Restrito em interflúvio e em vale no Jardim Botânico de Brasília, DF. Acta Botanica Brasílica. v.18, n. 1. 2004.

FORZZA, R. C. et al. (Org.). Catálogo de plantas e fungos do Brasil, volume 1, Rio de Janeiro : Andrea Jakobsson Estúdio : Instituto de Pesquisas Jardim Botânico do Rio de Janeiro, 2010. 875 p.

FORZZA, R. C. et al. (Org.). Catálogo de plantas e fungos do Brasil, volume 2, Rio de Janeiro : Andrea Jakobsson Estúdio : Instituto de Pesquisas Jardim Botânico do Rio de Janeiro, 2010. 873 p.

FRAZON, R. C.; CAMPOS, L. Z. O.; PROENÇA, C. E. B.; SOUZA-SILVA, J. C. Araças do gênero Psidium: principais espécies, ocorrências, descrição e usos. Planaltina, DF: Embrapa Cerrados, 2009.

FRÓVOLA. M. A paisagem dos geógrafos russos: a evolução do olhar geográfico entre o século XI e o XX. The landscape of the russian geographers: the evolution of the 
geographical perspective between the nineteenth and the twentieth centuries. R. RA'E GA, Curitiba, n. 13, p. 159-170, 2007.

GAMA JÚNIOR, J. M. Braquiópodes da Formação Pimenteiras(Devoniano médio/superior), na região sudoeste da bacia do Parnaíba, município de Palmas, Estado do Tocantins, Brasil. Dissertação (Mestrado), 2008, 74 f. Instituto de Geociências, Universidade d Brasília. 2008.

GENTRY, A.H. Tropical forest biodiversity: distributional patterns and their conservational significance. Oikos, n. 63, p. 19-82, 1992.

GIÁCOMO, R. G.; CARVALHO, D. C.; PEREIRA, M. G.; SOUZA, A. B.; GAUI, T. D. Florística e fitossociologia em áreas de campo sujo e cerrado sensu stricto na Estação Ecológica de Pirapitinga - MG. Ciência Florestal, Santa Maria, v. 23, n. 1, p. 29-43, 2013.

GIULIE'ITI, A.M. Byrsonima do Distrito Federal. In (FERRI, M. G., coord.). III SIMPÓSIO DO CERRADO. São Paulo: Edgar Blücher. p. 113-49. 1917.

GODROM, M.; FORMAN, R. T. T. Landscape modification and changing ecological characteristics. In: MOONEY, H. A.; GODRON, M. (Eds.), Disturbance and ecosystems, p. 13-28. Ecological studies nº4, 1983.

GOMES, B. Z.; MARTINS, F. R.; TAMASHIRO, J. Y. Estrutura do cerradão e da transição entre cerrado e floresta paludícola num fragmento da International Paper do Brasil Ltda., em Brotas, São Paulo. Revista Brasileira de Botânica. v. 27, n. 2, p. 249-262. 2004.

GOODLAND, R. Oligotrofismo e alumínio no Cerrado. In: SIMPÓSIO SOBRE CERRADO, 3., 1971, São Paulo, Anais... São Paulo: Editora Edgard Blücher LTDA/Editora Universidade de Sâo Paulo, 1971, p. 44-59.

GOOGLE EARTH. Imagem Geoeye. Disponível em:< http://earth.google.com/ >.Acesso em: 2010/2011.

GRESSLER,E.; PIZO, M. A.; MORELLATO, L. P. C. Polinização e dispersão de sementes em Myrtaceae do Brasil. Revista Brasil. Bot., v.29, n.4, p.509-530, out.-dez. 2006.

GUARDA, S. D. M. Expansão Urbana do Entorno do Lago do Município de Palmas TO (1990, 1993, 1999, 2002, 2005): acompanhamento por dados de sensoriamento remoto. 2006, 129 f. Dissertação (Mestrado em Ciências do Ambiente). Universidade Federal do Tocantins, Palmas, 2006.

GUERRA, A. T. Dicionário geológico-geomorfológico. Rio de Janeiro: IBGE, 1987.

HAIDAR, R. F.; DIAS, R. R.; PEREIRA, E. Q.; SANTANA, I. T.; REIS, J. S. Mapeamento e reconstituição dos ambientes fitoecológicos para o sul do estado do Tocantins por meio de imagens Landsat MSS e TM, e dados geoambientais. XV Simpósio Brasileiro de Sensoriamento Remoto - SBSR. Anais... Curitiba, PR, Brasil, 30 de abril a 05 de maio de 2011, INPE, p.2059-2066.

HARIDASAN, M. Aluminium accumulation by some cerrado native species of central Brazil. Plant and Soil, n. 65, p.265-273, 1982. 
HARIDASAN, M. Performance of Miconia albicans (Sw.) Triana, an aluminium accumulating species in acidic and calcareous soils. Communications in Soil Science and Plant Analysis, n. 19, p.1091-1103, 1988.

HARIDASAN, M. Solos. In: FELFILI, J. M.; RESENDE, A. V.; SILVS JÚNIOR, M. C. Biogeografia do bioma cerrado: vegetação e solos da Chapada dos Veadeiros. Brasília: Editora Universidade de Brasília: Finatec, 2007. 256 p.

HARIDASAN, M. Nutrição mineral de plantas nativas do cerrado. Revista Brasileira de Fisiologia Vegetal, v. 12, n. 1, p. 54-64, 2000.

HENRIQUES, R. P. B. A viagem que revelou a biodiversidade do Brasil ao Mundo. Ciência Hoje, V. 42, N. 252, p. 24-29, 2008.

HILL, M. O. TWINSPAN: a FORTRAN program for arranging multivariate data in an ordered two way table by classification of individual and attributes. Ithaca: Cornell University, $1979.60 \mathrm{p}$.

HUBBELL, S.P.; FOSTER, R.B. Commonness and rarity in a neotropical forest: implications for tropical tree conservation. In Conservation Biology: the science of scarcity and diversity (M. Soulé, ed.). Sunderland, Massachusetts, p. 205-231. 1986.

HUMBOLDT, A. Essay on the geography of plants. In: LOMOLINO, M. V.; SAX, D. F. BROW, J. H. Foundations of Biogeography: classic paper with commentaries. Chicago: The University Of Chicago Press, p. 49-57. 2004.

IBGE, Fundação Instituto Brasileiro de Geografia e Estatística. Manual técnico da vegetação brasileira. Rio de Janeiro: IBGE. 1992.

INPE. Instituto Nacional de Pesquisas Espaciais. Dados de satélites. Catálogo de imagens LANDSAT (Land Remote Sensing Satellite). Disponível em: 〈http://www.dpi.inpe.br/spring/ $>$.Acesso em: 30 de Jul; 15 de Set.; 10 de Dez. 2010a.

INPE. Instituto Nacional de Pesquisas Espaciais. Softwares livres. SPRING (Sistema de Processamento de Informações Geográficas). Disponível em: <http://www.dpi.inpe.br/spring/>.Acesso em: 30 de Jul. 2010 b.

INSTITUTO BRASILEIRO DO MEIO AMBIENTE E DOS RECURSOS NATURAIS RENOVÁVEIS (IBAMA). Biomas. Brasília, DF, 2012. Disponível em: $<$ http://siscom.ibama.gov.br/>Acesso em 26/07/2012.

INSTITUTO NACIONAL DE METEOROLOGIA (INMET). Dados Históricos. Banco de Dados Meteorológicos para Ensino e Pesquisa (BDMEP). Disponível em: <www.inmet.gov.br $>$ Acesso em 20/12/2012.

INVESTCO. INVESTMENT \& CONSTRUCTION DEVELOPMENT CORPORATION. Histórico, ano $2001 . \quad$ Disponível em: $<$ http://www.investco.com.br/dados_usina/caracteristicas_tecnicas/caracteristicas_tecnica s.asp.>Acesso em 23 de Ago. 2011. 
JANSEN, S.; SMETS, E.; HARIDASAN, M. Aluminum accumulation in flowering plants. In: BLUMEL, D. D.; RAPPAPORT, A. (Ed). Mc-Graw Hill Yearbook of Science and Technology. New York: McGraw-Hill, 2003. p. 11-13.

KENT, M.; COKER, P. Vegetation description analyses. London: Behaven Press, 1992. 363 p.

KLEIN, A. L. (Org.). Eugene Warming e o cerrado brasileiro: um século depois. São Paulo: Editora UNESP; Imprensa Oficial do Estado, p. 77-91, 2002.

KOOGAN, A.; HOUAISS, A. (Ed.). Enciclopédia e dicionário digital 98. Direção geral de André Koogan Breikmam. São Paulo: Delta: Estadão, 1998.

LEPSCH, I. F. Formação e conservação dos solos. São Paulo: Oficina de Textos, 2002. 178 p.

LEMOS, H. L. Vegetação arbustivo-arbórea em áreas de Cerrado Típico e Cerrado Rupestre no Estado do Tocantins. 2013, 82 f. Dissertação (Mestrado),Universidade de Brasília. Faculdade de Tecnologia, Departamento de Engenharia Florestal. 2013.

LÍBANO, A. M.; FELFILI, J. M. Mudanças temporais na composição florística e na diversidade de um cerrado sensu estricto do Brasil Central em um período de 18 anos (19852003). Acta Botanica Brasilica. v. 20, n. 4. p. 927-936. 2006.

LIBAULT, A. Os quatro níveis da pesquisa geográfica. Métodos em Questão. São Paulo: IGEOG-USP, p. 1-13, 1971.

LIMA, D. A. Atlas geográfico do Brasil. IBGE, Rio de Janeiro, 1966.

LIRA, D. C.; MEDEIROS, T. C. C. Caracterização fitofisionômica e levantamento florístico de uma sequência de solos na "propriedade 2", na serra do Monte do Carmo - Tocantins. V SEMINÁRIO DE INICIAÇÃO CIENTÍFICA DA UFT 2009. Anais... PDF. 120.

LIZARDTECH. GeoExpress View by ILS. Disponível em:http://www.lizardtech.com/solutions/geo.Acesso em: 31 de Jul. 2010.

LOPES, A. S. Solos sob "Cerrado": características, propriedades e manejo. Piracicaba: Associação Brasileira para Pesquisa da Potassa e da Fosfato. $2^{a}$ Ed. !984. 162 p.

LOPES, A. S.; GUILHERME, L. R. G. Interpretação da análise de solo: conceitos e aplicações. São Paulo, ANDA 2004. 22 p. (Boletim Técnico, 2).

LOPES, A. S.; GUILHERME, L. R. G. Solos sob cerrado: manejo da fertilidade para a produção agropecuária. São Paulo, ANDA, 1994 (2a edição). 62p. (boletim técnico, 5).

LOPES, A. S.; SILVA, M. C.; GUILHERME, L. R. G. Acidez do solo e calagem. 3 a ed. Ver. / São Paulo, ANDA 1990. 22 p. (Boletim Técnico, 1).

LORENZI, H. Árvores brasileiras: manual de identificação e cultivo de plantas arbóreas do Brasil, vol. 2. 2a Ed. Nova Odessa, SP: Instituto Plantarum, 2002. 384 p. 
LORENZI, H. Árvores brasileiras: manual de identificação e cultivo de plantas arbóreas do Brasil, vol. 1. 2a Ed. Nova Odessa, SP: Instituto Plantarum, 2008. 384 p.

LORENZI, H. Árvores brasileiras: manual de identificação e cultivo de plantas arbóreas do Brasil, vol. 3. 1 ${ }^{\text {a }}$. Ed. Nova Odessa, SP: Instituto Plantarum, 2008. 384 p.

MACHADO, R. B.; AGUIAR, L. M. S.; CASTRO, A. A. J. F.; NOGUEIRA, C. C.; NETO, M. B. R. Caracterização da fauna e flora do Cerrado. In: IX SIMPÓSIO NACIONAL CERRADO II SIMPÓSIO INTERNACIONAL SAVANAS TROPICAIS. IX SIMPÓSIO NACIONAL CERRADO II SIMPÓSIO INTERNACIONAL SAVANAS TROPICAIS, 2008, Brasilia DF. Anais... Brasília, 2008. Capítulo 9.

MACHADO, R. B.; RAMOS NETO, P. PEREIRA, E., CALDAS, E., GONÇALVES, N.; SANTOS, K.; TABOR, K. STEININGER, M. Estimativas de perda da área do Cerrado brasileiro. Conservação Internacional do Brasil, Brasília, 2004.

MAGAlHÃES, G. M. Sobre os cerrados de Minas Gerais. Anais da Academia Brasileira de Ciências, v.38, (Supl.) p.59-70, 1966.

MAMEDE, M. C. H. Anatomia dos órgãos vegetativos de Camarea (Malpichiaceae). Acta Botânica Brasilica, v. 7, n. 1, p. 3-19, 1993.

MARION, B. S.; MARIMON-JUNIOR, B. H.; MEWS, H. A.; JANCOSKI, H. S.; FRANCZAK, D. D.; LIMA, H. S.; LENZA, E.; ROSSETE, A. N.; MORESCO, M. C. Florística dos campos de murundus do Pantanal do Araguaia, Mato Grosso, Brasil. Acta Botanica Brasilica, v. 26, n. 1, p. 181-196, 2012.

MARQUES, A. K. Avaliação da qualidade da água da bacia do Ribeirão Taquaruçu Grande e da área de sua influência no reservatório da Usina Hidroelétrica Luis Eduardo Magalhães, TO. 2011, 229 f. Tese (Doutorado em Ciências na Área de Tecnologia NuclearMateriais. Instituto de Pesquisas Energéticas. SÃO PAULO, 2011.

MARTINEZ, F. R. Em torno al valor atual Del paisaje em geografia. Cadernos Geográficos, Granada, n. 9, p. 23-42. 1079.

MARTINS, A. K. E.; MONTEIRO, C. B. Uso de geotecnologia para análise de fragmentação do cerrado na paisagem da bacia do ribeirão Taquaruçu Grande, Palmas - TO. In: XVI Simpósio Brasileiro de Sensoriamento Remoto - SBSR/INPE. Anais... Foz do Iguaçu, PR, Brasil, p. 3763-3770, 2013.

MARTINS, D. D. S.; MARTINS, I. C. M. Quantificação e qualificação dos problemas ambientais por atores sociais do ribeirão Taquaruçu Grande, Palmas - TO. Revista de Ciências Ambientais, Canoas, v.2, n.2, p. 25-42, 2008.

MARTINS, F. R. Fitossociologia de florestas no Brasil: um histórico bibliográfico. Pesquisa série Botânica, São Leopoldo, n. 40, 1989.

MEDEIROS, J. D. Guia de campo: vegetação do Cerrado 500 espécies. Brasília: MMA/SBF, $2011.534 \mathrm{p}$. 
MEDEIROS, M. B.; MIRANDA, H. S. Mortalidade pós-fogo em espécies lenhosas de campo sujo submetido a três queimadas prescritas anuais. Acta Botanica Brasilica. 19(3): 493-500. 2005.

MEDEIROS, M. B.; WALTER, B. M. T.; SILVA, G. P.; GOMES, B. M.; LIMA, I. L. P.; SILVA, S. R.; MOSER, P.; OLIVEIRA, W. L.; CAVALCANTI, T. B. Vascular Flora of the Tocantins River Middle Basin, Brazil. Check List, v. 8, n.5, p. 852-885, 2012. Disponívelem:<www.checklist.org.br>.Acesso em 10/01/2013.

MEIRA-NETO, J. A. A.; MARTINS, F. R. Composição florística do estrato herbáceoarbustivo de uma floresta estacional semidecidual em Viçosa - MG. Revista Árvore, v. 24, n. 4, p. 407-416. 2000.

MELLO-SILVA, R. Aspectos taxonômicos, biogeográficos, morfológicos e biológicos das Velloziaceae de Grão-Mogol, Minas Gerais, Brasil. Boletim de Botânica da Universidade de São Paulo, n. 14, p. 49-79, 1995.

MELLO-SILVA, R.; MENEZES, N. L. Duas espécies novas de Velloziaceae de Minas Gerais. Acta Botanica Brasilica, v.1, n.2, p.195-207, 1988.

MENDONÇA, F. Geografia Física: ciência humana? São Paulo: Contexto, 1991. 72 p.

METZGER, J. P. O que é ecologia de paisagens? Biota Neotrop. 1(1/2): 2001. http://www.biotaneotropica.org.br/v1n12. Acesso em 20 out.2013.

MORENO, M. I. C.; SCHIAVINI, I.; HARIDASAN, M. Fatores edáficos influenciando na estrutura de fitofisionomias do Cerado. Caminhos de Geografia, v. 9, n. 25, p. 173-194. 2008.

MILAGRES. V. R. Percepção das paisagens do distrito Taquaruçu: ouvindo a comunidade local sobre a representatividade, agradabilidade e desagradabilidade de suas paisagens. Ateliê Geográfico, v. 3, n. 8, p.130-151, 2009.

MINISTÉRIO DO MEIO AMBIENTE (MMA); INSTITUTO BRASILEIRO DO MEIO AMBIENTE E DOS RECURSOS NATURAIS RENOVÁVEIS (IBAMA). Monitoramento do bioma Cerrado 2009-2010. Brasília, DF, 2011. Disponível em: 〈http://siscom.ibama.gov.br/monitorabiomas/cerrado/APRESENTACAO_cerrado_2010.pdf $>$ Acesso em 26/07/2013.

MIRANDA, J. C. Agricultura familiar e desenvolvimento rural: um olhar sobre a experiência do Assentamento Coqueirinho - Palmas/TO. 2007. 128f. Dissertação (Mestrado). Universidade Federal do Mato Grosso do Sul. 2007.

MOREIRA, R. O que é geografia. São Pulo: Editora Brasiliense S.A. 1981. 113 p.

MORRONE, J. J. Biogeografía de América Latina y el Caribe. Manuales y Tesis SEA 3, Zaragoza (España). 2001. 148 p.

MULLER-DOMBOIS, D.; ELLEMBERG, H. Aims and methods of vegetation ecology. New york: Willey and Sons, 1974. 
MUNHOZ, C. B. R.; FELFILI, J. M. Fenologia do estrato herbéceo-subarbutivo de uma comunidade de campo sujo na Fazenda Água Limpa no Distrito Federal, Brasil. Acta Botanica Brasilica, v. 19, n. 4, p. 979-988. 2005.

MUNHOZ, C.B.R. Padrões de distribuição sazonal e espacial das espéciees do estrato herbáceo-subarbustivo em comunidades de campo limpo úmido e de campo sujo. 2003. 290 f. Tese (Doutorado). Instituto de Ciências Biológicas. Universidade de Brasília. 2003.

MUNHOZ, C.B.R.; FELFILI, J. M. Fitosociologia do estrato herbéceo-subarbutivo de uma área de campo sujo no Distrito Federal, Brasil. Acta Botanica Brasilica, v. 20, n. 3, p. 671685. 2006.

MYERS, N.; MITTERMEIER, R. A.; MITTERMEIER, C. G.; DA FONSECA, G. A. B., KENT, J. Biodiverty hotspots for conservation priorities. Nature, n. 403, p. 853-858, 2002.

NASA. National Aeronautics and Space Administration. GeoCover. 2000. Earth Science Applications Directorate-MrSid Image Server. Disponível em: < https://zulu.ssc.nasa.gov/mrsid >.Acesso em: 31 de Jul. 2010.

NETO, M. B. R. Caracterização da fauna e flora do Cerrado. In: IX SIMPÓSIO NACIONAL CERRADO II SIMPÓSIO INTERNACIONAL SAVANAS TROPICAIS. IX SIMPÓSIO NACIONAL CERRADO II SIMPÓSIO INTERNACIONAL SAVANAS TROPICAIS, 2008, Brasilia DF. Anais... Brasília, 2008. Capítulo 9.

NEVES, S. P. S. Fenologia, biologia floral e polinização de espécies de Velloziaceae Endl. em área de campo rupestre na chapada Diamantina, Bahia, Brasil. 2009. 67 f. Dissertação (Mestrado). Universidade Estadual de Feira de Santana. 2009.

ODUM, E. P.; BARRETT, G. W. Fundamentos de ecologia. São Paulo: Cengage Learning, 2008.

OLIVEIRA, P. S.; R. J. MARQUIS (Eds.). The Cerrados of Brazil. Ecology and natural history of a neotropical savanna. Columbia University Press, New York. 2002.

OLIVEIRA-FILHO, A. T.; FLUMINHAN-FILHO, M. Vegetation ecology of the Parque Florestal Quedas Rio Bonito, Brazil. CERNE, v.5, n.2, p.051-064, 1999.

OLIVEIRA-FILHO, A. T.; RATTER, J. A.; SHEPHERD, G. J. F. Floristic composition and community structureof a Central Brasilian gallery forest. Flora, n. 184, p. 103-117, 1990.

OLIVEIRA-FILHO, A. T.; MARTINS, F. R. A comparative study of five cerrado areas in southern Mato Grosso, Brazil. Edinburgh Journal of Botany, v. 48, n. 3, p. 307-332, 1991.

OLIVEIRA-FILHO, A. T.; RATTER, J. A. A study of the oringin of Central Brasilian forests by the analisis of plant species distribution patterns. Edinburgh Journal of Botany, v.52, n. 2, p.141-194, 1995.

OLSON, D. M. et al. Terrestrial ecoregions of the World: a new map of life on Earth. BioScience, v. 1, n. 11, p. 933-938. 2001. 
OSAKI, F. Calagem e adubação. Campinas: Instituto Brasileiro de Ensino Agrícola, 1991. $503 \mathrm{p}$.

PADILHA, D. R. C.; SALIS, S. M.; CRISPIM, S. M. A. Fitossociologia das Espécies Lenhosas em Campo Cerrado no Pantanal de Poconé e Paiaguás. Boletim de Pesquisa e Desenvolvimento / Embrapa Pantanal. Corumbá: Embrapa Pantanal, 2008. Disponível em: $<$ http://www.cpap.embrapa.br/publicacoes/download.php?arq_pdf=BP81>.Acesso em 27 de fev 2009.

PAVIANI, T. I.; JERONYMO, A. S. Canais secretores em Vochysia thyrsoidea Pohl (Vochysiaceae). Acta Botanica Brasilica, Feira de Santana, v. 6, n. 1, p. 88-105, 1992.

PINTO, J. R. R.; OLIVEIRA-FILHO, A. T.; HAY, J. D.V. Influences of soil and topography on the composition of a tree community in a Central Brasilian gallery forests. Edinburgh Journal of Botany, v. 62,n. 1\&2, p.69-90, 2005.

PIELOU, E. C. The interpretation of ecological data: a primer on classification and ordnation. New York: John Wiley \& Sons, 1987.163p.

PINHEIRO, L. C. S. J.; CASTRO, A. S.; MARTINS, E. S. Levantamento das classes de solo existentes nas Ecorregiões inseridas no limite do Cerrado contínuo. In: IX SIMPÓSIO NACIONAL SOBRE O CERRADO E II SIMPÓSIO INTERNACIONAL SOBRE SAVANAS TROPICAIS, 2008, Brasília. Simpósio Nacional sobre o Cerrado. Planaltina: Embrapa Cerrados, 2008. v. 1. p. 1-5.

PONCIANO, L. C. M. O.; FONSECA, V. M. M.; FERNANDES,A. C. S.; MACHADO, D. M. C.; SOUZA, A. R. Afloramento Fossilífero de Oiti, Bacia do Parnaíba, PI - Registro de um mar devoniano no Nordeste do Brasil. In: SCHOBBENHAUS, W. M.; C.; SOUZA, C. R. G.; FERNANDES, A. C. S.; BERBERT-BORN, M.; SALLUN FILHO, W.; QUEIROZ ,E. T.; (Eds.) Sítios Geológicos e Paleontológicos do Brasil. Disponível em: <http://www.unb.br/ig/sigep/sitio051/sitio051.pdf.>. Acesso em: 10 Jul.2011.

Projeto de Monitormento do Desmatamento dos Biomas Brasileiros/Monitoramento do Cerrado. Disponível em: $<$ http://siscom.ibama.gov.br/monitorabiomas/cerrado/. $>$ Acesso em: 22/07/2013.

RAUNKIAER, C. Life forms of plants and statistical plant Geography, Clarendon Press, Oxford. 1934. $632 \mathrm{p}$.

RATTER, J. A.; ASKEW, G. P.; MONTGOMERY, R. F. GIFFORD, D.R. Observações adicionais sobre o cerradão de solos mesotróficos no Brasil Central. In: SIMPÓSIO SOBRE O CERRADO, 4., 1977, São Paulo, Anais... São Paulo: Editora Edgard Blücher LTDA/Editora Universidade de Sâo Paulo, 1977, p. 303-316.

REATTO, A.; COREIA, J.R.; SPERA, S.T.; MARTINS, E.S. Solos do bioma cerrado: aspectos. In: SANO, S.M. (ORG.). Cerrado: ecologia e flora. Brasília: Embrapa Informaçõe Tecnológicas, 2008, p. 107-149. 
RIBEIRO, J. F.; SANO, S. M.; MACÊDO, J.; SILVA,J. A. Os principais tipos fitofisionômicos da região dos Cerrados. Planaltina: EMBRAPA-CPAC, 1983. 28p. (EMBRAPA-CPAC. Boletim de Pesquis, 21).

RIBEIRO, J. F.; WALTER, B. M. T. Fitofisionomias do Bioma Cerrado. In: SANO, S. M.; ALMEIDA, S. P. (Org.). Cerrado: ambiente e flora. Planaltina: EMBRAPA-CPAC, 1998, p. 89-166.

RIBEIRO, J. F.; WALTER, B. M. T. Fitofisionomias do bioma Cerrado. In: SANO, S. M.;

ALMEIDA, S. P.; RIBEIRO, J. F. (Eds.). Cerrado: Ecologia e Flora. Embrapa Cerrados. Brasília: DF: Embrapa Informações Tecnológicas, v. 1, p. 151-212, 2008.

RIBEIRO, J.F.; WALTER, B.M.T. Fitofisionomias do Bioma Cerrado. In: SANO, S.M.; ALMEIDA, S.P. Cerrado: ambiente e flora. Planaltina. EMBRAPA-CPAC, p.89-166, 1998.

RICKLEFS, R. E. A economia da natureza. Rio de Janeiro: Guanabara Koogan, 2010.

RIZZINI, C. T. 1997. Tratado de Fitogeografia do Brasil: aspectos ecológicos, sociológicos e florísticos. Rio de Janeiro: Âmbito Cultural Edições LTDA, 1997.

RIZZINI, C. T. Nota prévia sobre a divisão fitogeográfica do Brasil. Revista Brasileira de Geografia, Ano XXV, n. 1, p. 3-64, 1963.

RIZZINI, C. T. Tratado de fitogeografia do Brasil. São Paulo: Hucitec; EDUSP, v. 2, 1979. $794 \mathrm{p}$.

RODEL, L. G. Cerrados de altitude e campos rupestres do Parque Estadual do Ibitipoca, sudeste de Minas Gerais: distribuição florística por subfisionomias da vegetação. Revista do Departamento de Geografia, n. 12, p. 163-189, 1998.

RODRIGUES, E.; CAINZOS, R. L. P.; QUEIROGA, J.; HERRMANN, B. C. Conservação em paisagens fragmentadas. In: CULLEN JR. L.; RUDRAN, R.; VALLADARES-PADUA, C. (Orgs.). Métodos de estudos em Biología da Conservação \& Manejo da Vida Silvestre. Curitiba: Ed. UFPR; Fundação O Boticário, p. 481-511, 2004.

ROMARIZ, D.A. Aspectos da vegetação do Brasil. 2 ed. São Paulo: Edição da Autora, 1996. $60 \mathrm{p}$.

ROSSI, C. V.; SILVA JÚNIOR, M. C.; SANTOS, C. E. N. Fitossociologia do estrato arbóreo do Cerrado (sensu stricto) no Parque Ecológico Norte, Brasília-DF. Boletim do Herbário Ezechias Paulo Heringer, n. 2, p.49-56. 1998.

ROUGERIE, G. Geografia das paisagens. Tradução de Heloysa de Lima Dantas. São Paulo: Difusão Européia do Livro. 1969. 133 p.

SALVADOR, G. S.; CERVI, A. C.; BROTTO, M. L.; SANTOS, E. P. A família Ochnaceae DC. no estado do Paraná, Brasil1. Acta Botanica Brasilica, v. 24, n. 2, p. 423-434. 2010. 
SAMPAIO, A. B.; NUNES, R. V.; WALTER, B. M. T. Fitossociologia de uma mata de galeria na Fazenda Sucupira do CENARGEN, Brasília-DF. In: L. L. Leite, C. H. Saito (Eds.). Contribuição ao Conhecimento Ecológico do Cerrado. Dept. Ecologia-Universidade de Brasília. Brasília, p. 29-37. 1997.

SAMPAIO, A. J. Phytogeographia Pedagogica Brasileira. Biblioteca Padagogica Brasileira. Rio de Janeiro: Companhia Editora Nacional. $2^{\text {a }}$ Ed. Série $5^{\mathrm{a}}$ Brasiliana, v. 35. 1938. 334 p.

SANO, E. E. (Coord.) Mapeamento de cobertura vegetal do bioma Cerrado (Relatório Final). Brasília, $\quad$ DF, 2007. 93p. Disponível em:<http://mapas.mma.gov.br/geodados/brasil/vegetacao/vegetacao2002//cerrado/documento s/relatorio_final.>.Acesso em 10 set. 2011.

SANO, E. E. Treinamento e seleção em sensoriamento remoto. Belém: SUDAM/OEA, 1987.

SANTOS, H. G.; JACOMINE, P. K. T.; ANJOS, L. H. C. ; OLIVEIRA, V. A. OLIVEIRA, J. B. ; COELHO, M. R. ; LUMBRERAS, J. F.; CUNHA, T J F ; GOMES, J. B. V. ; et al. . Sistema Brasileiro de Classificação de Solos. 2. ed. Rio de Janeiro: Embrapa Solos, v. 1, 2006.

SANTOS, L. B. Aspecto geral da vegetação do Brasil. Boletim Geográfico, Rio de janeiro, ano 1, n. 5 , p. 68-73, 1943.

SAnTOS, M. E. C. M.; CARVAlHO, M. S. S. Paleontologia das Bacias do Parnaíba, Grajaú e São Luís. Rio de Janeiro, Programa Levantamentos Geológicos Básicos do Brasil PLGB. CPRM-Serviço Geológico do Brasil/DIEDIG/DEPAT, 2004. livro eletrônico em formato pdf.

SANTOS, R. D.; LEMOS, R. C.; SANTOS, H. G.; KER, J. C.; ANJOS, L. H. C. Manual de descrição e coleta de solo no campo. Viçosa, Sociedade Brasileira de Ciência de Solo, 2005. $100 \mathrm{p}$.

SANTOS, T. R. R. Fitogeografia da vegetação arbustivo-arbóreaem áreas de cerrado rupestre no Estado de Goiás. 2011. 110 f. Dissertação (Mestrado). Faculdade de Tecnologia do Departamento de Engenharia Florestal da Universidade de Brasília. 2011.

SAPORETTI JÚNIOR, A. W.; MEIRA NETO, J. A. A.; ALMADO, R. P. Fitosociologia de cerrado sensu stricto no município de Abaeté-MG. Revista Árvore, v.27, n.3, p.413-419, 2003.

SCHOBBENHAUS, C.; NEVES, B. B. B. In: BIZZI, L. A. SCHOBBENHAUS, C.; VIDOTTI, R. M.; GONÇALVES, J. H. (Eds.). Geologia, Tectônica e Recursos Minerais do Brasil. Brasília: CPRM - Serviço Geológico do Brasil, 2003. cap. 1, p. 5-25.

SECRETARIA DE DESENVOLVIMENTO URBANO E HABITAÇÃO (SEDUH). Microbacias do município de Palmas. Secretária do Desenvolvimento Urbano e Habitação/Gerência de Informações urbanísticas e Georreferenciamento. Prefeitura Municipal de Palmas. Palmas: SEDUH. Disponível 
$<$ http://201.90.134.51/portalprefeitura/servicos/seduh/dados/mapastematicos/m013a2007_mic robacias_municipio_palmas_a3_arcgis92.pdf>.Acesso em: 06 de Jun. 2011.

SECRETARIA DE PLANEJAMENTO E MEIO AMBIENTE (SEPLAN). Atlas do Tocantins: Subsídios ao planejamento da gestão territorial. Secretária do planejamento e Meio Ambiente, Superintendência de Pesquisa e Zoneamento Ecológico Econômico, Diretoria de Zoneamento Ecológico-Econômico. $3^{\text {a }}$ ed. Palmas: SEPLAN, 2008.

SECRETARIA DE PLANEJAMENTO E MEIO AMBIENTE (SEPLAN). Atlas do Tocantins: Subsídios ao planejamento da gestão territorial. Secretária do planejamento e Meio Ambiente, Superintendência de Pesquisa e Zoneamento Ecológico Econômico, Diretoria de Zoneamento Ecológico-Econômico. 6ª ed. Palmas: SEPLAN, 2012.

SECRETARIA DE ESTADO DO MEIO AMBIENTE - SEMA/MT. Plano de manejo do Parque Estadual do Cristalino. Vol. I: Diagnóstico Ambiental e Sócioeconômico. Cuiabá, 2009.

SECRETARIA DO MEIO AMBIENTE DO ESTADO DE SÃO PAULO (SMA). RESOLUÇÃO SMA 20, DE 09-03-98. D.O.E /DATA PUB. 10/03/1998. SEÇÃO I /VOLUME 109. PÁGINA 20 /FASC. 08. 12 p. Acesso em 15/07/2013 www. ambiente.sp.gov.br

SEGARRA, V. D. Aportes ao conhecimento da flora e diversidade do bioma Cerrado do Brasil e da Bolívia. 2011. 98 f. Dissertação (Mestrado). Instituto de Ciências Biológicas. Universidade de Brasília. 2011.

SHEPHERD, G. J. Fitopac 2. Manual do usuário. Campinas: Universidade Estadual de Campinas, 1995.

SILVA, D. B. ; SILVA, J. A.; JUNQUEIRA,N. T. V.; ANDRADE, L. R. M. Frutas do cerrado. Brasília: Embrapa Informações Tecnológicas, 2001. 178 p.

SILVA, A. J. P.; LOPES, R. C.; VASCONCELOS, A. M.; BAHIA, R. B. C. In: BIZZI, L. A. SCHOBBENHAUS, C.; VIDOTTI, R. M.; GONÇALVES, J. H. (Eds.). Geologia, Tectônica e Recursos Minerais do Brasil. Brasília: CPRM - Serviço Geológico do Brasil, 2003. cap. 2, p. 55-85.

SILVA, J. M. C.; BATES, J. M. Biogeographic patterns and conservation in the South American Cerrado: a tropical savanna hotspot. BioScience, n. 52, p. 225-233, 2002.

SILVA, W. M.; ALVES, Y. M. CANDEIRO, R. A. Coleção de icnofósseis da Bacia do Parnaíba depositada no Laboratório de Paleobiologia da Universidade Federal do Tocantins. Revista de Biologia e Ciências da Terra, v. 10, n. 1, p.67-77, 2010.

SILVA-JÚNIOR, M. C.; PEREIRA, B. A. S. + 100 árvores do cerrado - Matas de Galeria: guia de campo. Brasília, Ed. Rede de Sementes do Cerrado, 2009. 288 p.

SIQUEIRA NETO, M.; PICCOLO, M. C.; SCOPEL, ERIC.; COSTA JUNIOR, C.; CERRI, C. C.; BERNOUX, M. Carbono total e atributos químicos com diferentes usos do solo no Cerrado. Acta Scientiarum. Agronomy Maringá, v. 31, n. 4, p. 709-717, 2009. 
SMITH, L. B.; AYENSU, E. S. A Revision of American Velloziaceae. Smithsonian Contributions to Botany 30: i-viii + 1-172. 1976.

SOARES JÚNIOR. F. J.; SILVEIRA, C. L. Diagnóstico da composição, estrutura e conservação da vegetação da região de Liberdade, sul de Minas Gerais, Brasil. SaBios: Revista Saúde e Biologia, v.5, n.2, p.43-59, jan./abr, 2011.

SOARES, J. J.; SOUZA, M. H. A.; LIMA, M. I. S. Twenty yars of post-fire plant succession in a "Cerrado", São Carlos, SP, Brazil. Brazil Journal Biology, v. 66, n. 2B, p. 587-602, 2006.

SOUSA, D. M. G.; LOBATO, E. Cerrado: correção do solo e adubação. Brasília, DF: Embrapa Informação Tecnológica, 2004. 416 p.

SOUZA, F. N. S.; CREMON, C.; MAPELI, N. C.; SENA, C. G.; CARVALHO, J. M. Atributos físicos do solo em fitofisionomias do cerrado mato-grossense e em pastagem degradada. In: CONGRESSO DE INICIAÇÃO CIENTÍFICA, 3., 2010, Cáceres/MT. Anais... Cáceres/MT: Pró-Reitoria de Pesquisa e Pós-Graduação - PRPPG. Vol. 6. Cód. 1561. CDROM 2178-7492.

SOUZA, M. A. V. Dinâmica da paisagem na bacia do Ribeirão Taquaruçu Grande no município de Palmas-TO. 2006. 90 f. Dissertação (Mestrado). Universidade Federal do Tocantins. Palmas. 2006.

STANNARD, B. L.; HARLEY, R. M.; HARVEY, Y. B. Flona of the Pico das Almas, Chapada Diamantina - Bahia, Brasil. Surrey, Great Britain; Royal Botanic Gardens, Kew; Ed. Whitstable Litho Ttd. 1995.

TAKHTAJAN, A. Floristic Regions of the World. University of California Press, Berkeley, 1986.

TANNUS, J. L. S.; ASSIS, M. A. Composição de espécies vasculares de campo sujo e campo úmido em área de cerrado, Itirapina - SP, Brasil1. Revista Brasileira de Botânica, v.27, n.3, p.489-506, 2004.

TANNUS, J.L.S.; ASSIS, M.A.; MORELLATO, L.P.C. Fenologia reprodutiva em campo sujo e campo úmido numa área de Cerrado no sudeste do Brasil, Itirapina - SP. Biota Neotropica. Sep/Dec 2006 vol. 6, no. 3 Disponível em: $<$ http://www.biotaneotropica.org.br/>Acesso em 20 de abr 2010.

THE NATURE CONSERVANCY. Conservation Action Planning: Developing Strategies, Taking Action, and Measuring Success at Any Scale. Overview of Basic Practices Version: February 2007.

TOME JÚNIOR. B. Manual para interpretação de análise de solo. Guaíba: Agropecuária, 1997. 247p.

THOEH, F. R.; THOMPSON, L. M. Solos e fertilidades do solo. São Paulo: Organização Andrec. 2007. 
TURNER, M. G. Ecologia da paisagem: o efeito dos padrões nos processos. Annual Review of Ecology and Systematics, n. 20, p. 171-197, 1089.

UDVARDY, M. D. F. A classification of the biogeographical provinces of the world. Morges (Switzerland): International Union of Conservation of Nature Resource, IUCN Occasional Paper no.18, 1975. 48 p.

Universidade do Tocantins (UNITINS); Fundo Nacional do Meio Ambiente (FNMA). Plano de Manejo da Sub-bacia do Ribeirão Taquaruçu Grande - (S.O.S TAQUARUÇU). Palmas, 1999.

VALE, C.C. Teoria geral do sistema: histórico e correlações com a geografia e com o estudo da paisagem. Entre-Lugar, n. 6, p. 58-108, 2012.

VASCONCELOS, M. F. O que são campos rupestres e campos de altitude nos topos de montanha do Leste do Brasil? Revista Brasil. Bot., V.34, n.2, p.241-246, 2011.

VELOSO, H. P. Atlas florestal do Brasil, Rio de Janeiro, Ministério da Agricultura, Serviço de Informação, 82 p. 1966.

VELOSO, H. P.; GÓES FILHO, L. Fitogeografia Brasileira - classificação fisionômica ecológica da vegetação neotropical. Boletim Técnico. Projeto RADAMBRAILl, Série vegetação, Salvadpr, n. 1, P. 1-80. 1982.

VELOSO, H. P.; RANGEL FILHO, A. L. R.; LIMA, J. C. A. Classificação da vegetação brasileira, adaptada a um sistema universal. Rio de Janeiro: IBGE, Departamento de Recursos Naturais e Estudos Ambientais, 1991. 124 p.

VIANA, P. L.; LOMBARDI, J. A. Florística e caracterização dos campos rupestres sobre cangana Serra da Calçada, Minas Gerais, Brasil. Rodriguesia, v. 58, n.1, p. 159-177, 2007. VICENTE, L.E.; PEREZ FILHO, A. Abordagem Sistêmica e Geografia. Rio Claro: Revista Geografia, v. 28, n.3, p. 323-344, 2003.

VILLARROEL, S. D. Aportes ao conhecimento da flora e diversidade do bioma Cerrado do Brasil e da Bolívia. 2011. 98 f. Dissertação (Mestrado). Instituto de ciências Biológicas, Departamento de Botânica, Programa de Pós-Grauação em Botânica. 2011.

WALTER, B. M. T. Fitofisionomias do bioma Cerrado: síntese terminológica e relações florísticas. 2006. 389 f. Tese (Doutorado). Instituto de Ciências Biológicas da Universidade e Brasília. 2006.

WALTER, H. Vegetação e zonas climáticas: tratado de ecologia global. Tradutoras Anna Terzi Giova, Hildegard T. Buchup; revisão técnica e notas Antôonio Lambert. São Paulo: EPU, 1986.

WALTER, H.; HARNICKELL, E.; MULLER-DOMBOIS, D. Climate diagram maps of the individual continents and the ecological climatic regions of the earth. Suplement to: The Vegetation Monographs. Springer-Verlarg. New York. 1975.

WALTER, H.; LIETH, H. Klimadiagramamm-Weltatlos. Jena: Pusl. Gustav Fischer, 1967. 
WARMING, E. Lagoa Santa. São Paulo: EDUSP/Belo Horizonte: Itatiaia, 1973. 284p. Original de 1892. Inclui “A vegetação de cerrados brasileiros” por M.G.Ferri.

WOOD, J. R. I (Ed.). Guia Darwing de las plantas de lós cerrados de La Chiquitania. Santa Cruz, Bolivia, 2011. 214 p.

ZUNINO, M.; ZULLINI, A. Biogeografía: la dimensión espacial de la evolución. Ciudad de México: FCE, 2003. 